Historic, Archive Document

Do not assume content reflects current scientific knowledge, policies, or practices. 

BUCKBEE'SEARLIEST MARKET OTMARKET) GARDENERS AND LARGE PLANTERS EDITION 1 T. Her

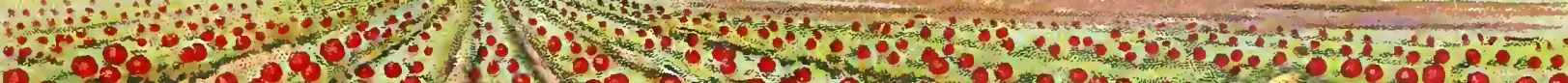

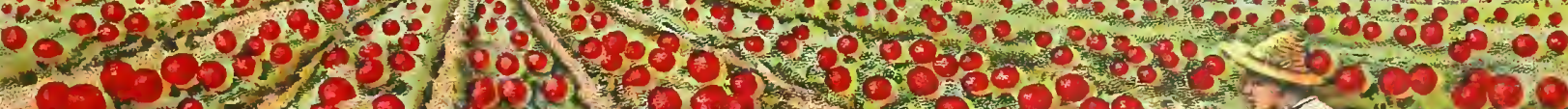

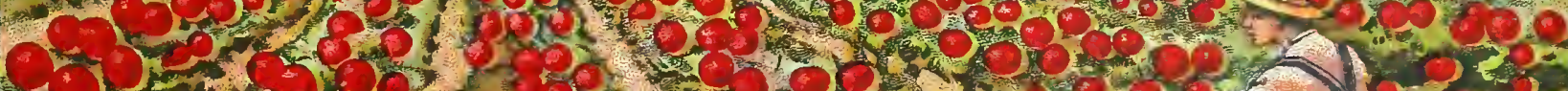

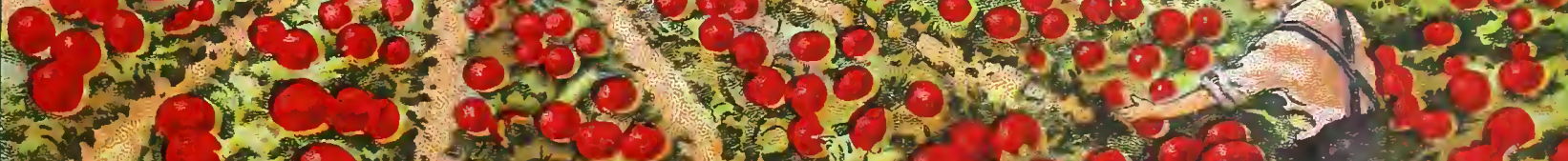

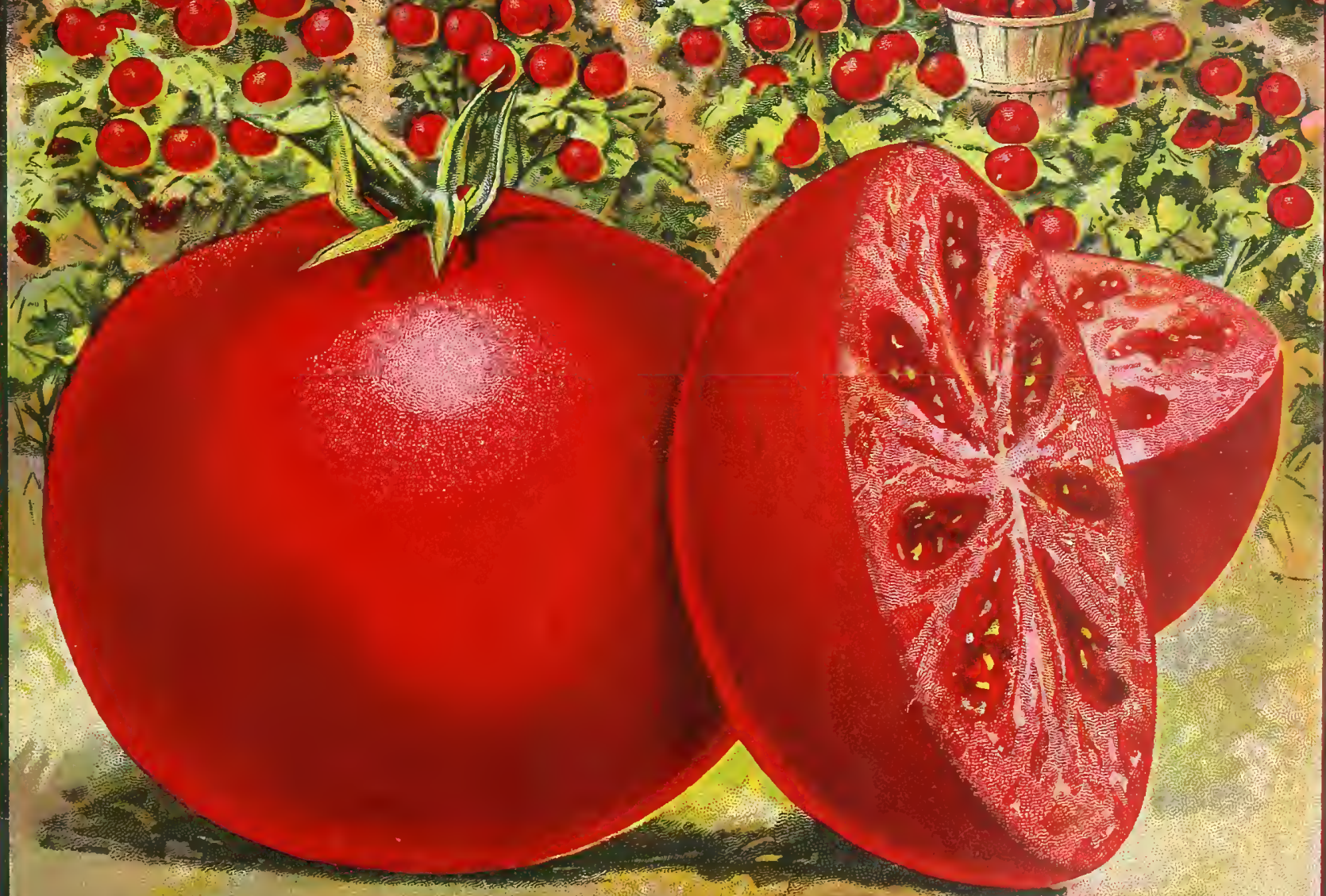

BUCKBEE'S EARLIEST MARKET TOMATO THE WORLD BEATING-PRIZE WINNING-MONEY MAKING TOMATO

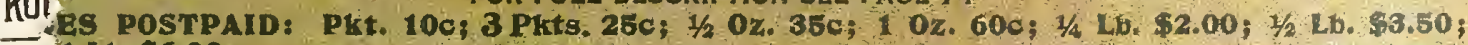
L.10. \$6.00. 


\section{Buckbee's Collections of Vegetable Seeds}

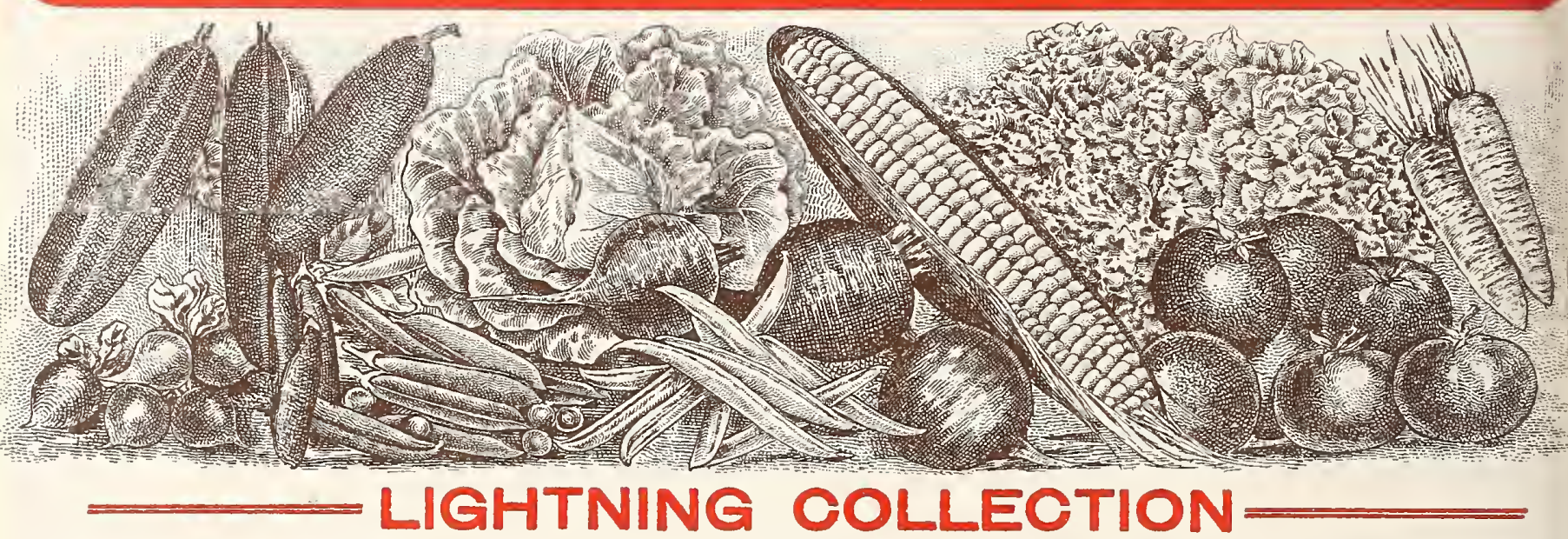

10 PACKAGES OF EXTRA EARLY VARIETIES OF VEGETABLES, POSTPAID $50 C$

If you want to be ahead of your neighbors 10 to 20 days. then plant the varieties in this collection; they are the fintest and earliest strains of their class and can only be obtained from me. They should be in every garden and are all of great value to the market gardener.

Beans-Buckbee's Earliest Brittle Wax.

Beets_Buckbee's New Early Model.

Cabbage-Buckbee's 60 Day.

Carrot-Buckbee's Early Amsterdam.
Corn_Sweet_Buckbee's Perfected Early Bantam.

Cucumber-Buckbee's Earliest of All.

Lettuce-Buckbee's Early Rockford Market.
Peas_Buckbee's New Early Laxtonian.

Radis h-Buckbee's Earliest Crisp as Ice.

Tomato-Buckbee's Great 80 Day.

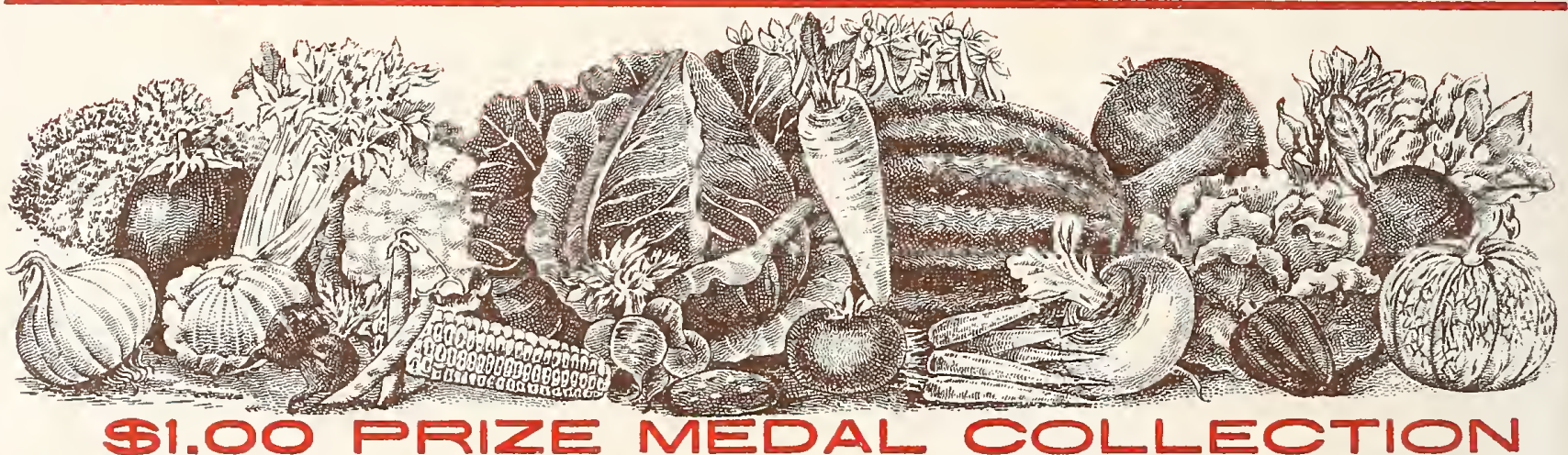

33 PACKAGES OF THE EEST VEGETAELES, SUFFICIENT FOR A FAMILY GARDEN, POSTPAID FOR ONLY SI.OO

Asparagus-Standerd variety:

Beet-Select Eerly Sort.

Beet-Buokbee's Improved Long Smooth Blood.

Beans-Buokbee's Rust Proof.

Cabbage-Slandard Eerly.

Carrot-Best Long Variety.
Caullfiower-Buokbee's Early Fevorite.

Celery-Buckbeo's Improved Golden Heert.

Corn-Swget, Best Early Veriety.

Corn-Salad. (Fotticus or Lemb', Lettuce.)
Cress-Fine Curled or Pcpper Crass.

Cucumber-Fine Teble Veriety.

Cucumber-Early Cluster. $\quad$ Peas-Earliest Variety.

Melon-Musk, True Osege.

Melon-Musk, Select Early Sort

Melon-Water. Now Dixie.

Melon-Weter, Fine Variety.

Onion-Buckbee's Denvers.
Onlon-Fine Pickling Veriety.

Parsnlp-Long Sugar.

\begin{abstract}
Parsley-Curled.
Pepper-Mountain Swcet.

Radish-Eerly Long Scerlet.

Sage-For seesoning end dress

Spinach-New Round Leaf.

Squash-Select Winter V
Squash-New Crookneck.

Turnlp-Buckbee's Purple Top.

Turnlp-Rute Bege.
\end{abstract}

Comato-rine Rod Variety.

Tomato-Best Fency Sort.

10 Cholce Flowerlng Bulbs Pree with Every Order for the Prlze with Every Or

NOTICE-The Prize Medel Collection is sold et the extre low price because mede up before the busy seeson begins. It cennot be broken.

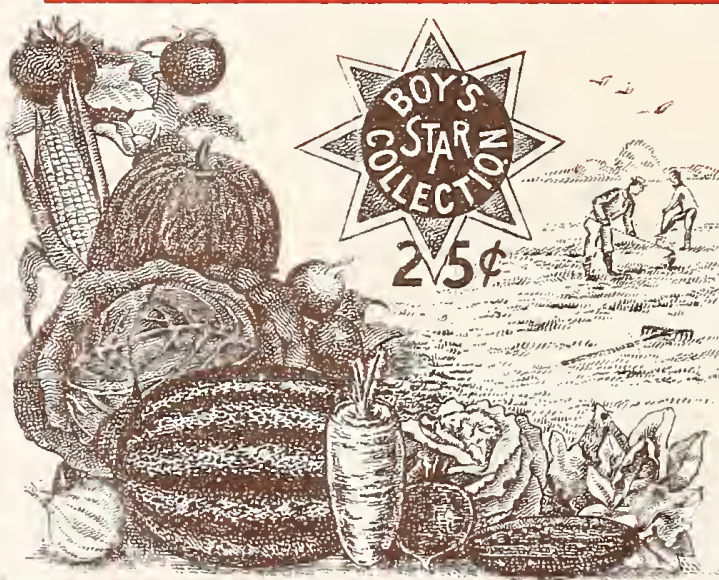

Boy's Star Collection

Comprising liberal packages of the following 12 Varieties:

Beet-The Bismarck.

Cabbage-Eerly Wokefield.

Pop Corn-Buokbee's Snowball:

Cress-Or Pepper Cress.

Cucumber-Buckbee's Monarch White

Spine.

Lettuce-Eerly.

Also Ten Fine Flowering Bulbs.

PREPAID BY MAIL FOR $25 \mathrm{C}$ GIVE YOUR BOYS A GARDEN

To encourage gardening for the young I offer at reduced rates this $\mathrm{c}^{\mathrm{t}}$ collection, composed of varieties sure to please, and at the same "; likely to succeed with indifferent care. With each collection $I$ w:" number of choice novelties.

NOTICE.

None of the Collectlons offered on this page can be bro circumintances, Please don't ask it.
Melon-Musk, Heckensaok.

Melon-Weter, lce Greem.

Onlon-Buckbee's Denvers

Radish-Now Rosy Gem.

plrach-Exira Round Leaf.

Tomato-Plum. 


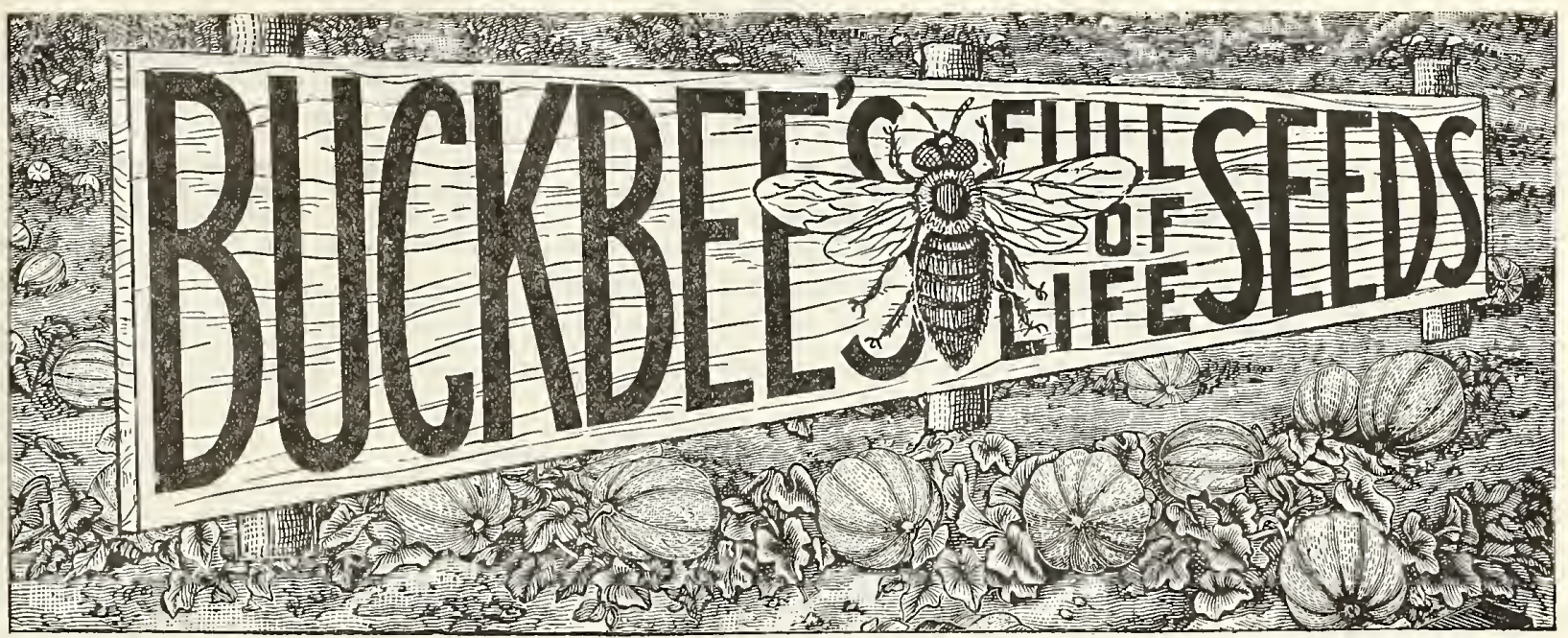

\section{DIRECT FROM THE GROWER TO THE PLANTER}

They are Tested, Reliable Seeds for all Soils and all Climates

They Have Satisfied Every Buyer for 45 Years

No Book Accounts TERMS CASH WITH ORDER

USE ORDER BLANK AND ENVELOPE WHICH YOU WILL FIND INCLOSED WITH THIS CA'TALOGUE IN MAKING OUT YOUR ORDER

Customers from Canada and Foreign Countries Must Send Twenty-five Cents Additional for Postage and Packing on Each Dollar's Worth of Seeds ordered. REMEMRER-We cannot accept Canadian Postage Stamps Plant Shipments We always recommend having plants (bent express, when there is an exand do not have to wash the soil off the roots (as in the case when ent by mail). We always try to add enough extra plants of our Kindly write your list of plants all together (not mixed up with the seeds) so as to prevent any mistake upon the part of our clerks in plants are to go at purchaser's risk.

\section{READ THESE FEW WORDS ABOUT RELIABLE SEEDS}

From good seeds only can good crops be grown. Yet a great many contingencies may arise to prevent the hest seeds from giving satisfaction, and for all these reasons we cannot, of course, guarantee or be responsible for a crop, as success is dependent
upon natural causes, which are beyond human control. Therefore, we do not warrant in any way, express or implied, the contents, or seeds, bulbs, or plants sold by us, and we will not be in any way responsible for the crop. If the purchaser does not accept these goorls on once, and money will be refunded. Subject to above conditions we

\section{FAIR PLAY GUARANTEE}

First-We guarantee that all seeds sold shall reach customers in good condition.

aveond-We guarantee to hold ourselyes responsible for the safe arrival of all remittances sent us by P. O. Order, Bank Draft, Expres Order, or Registered Letter.

Third-We guarantee to deliver free of charge in the United States all garden and flower seeds listed in this catalogue, except those quoted Potatoes and such other items that are plainly marked to be shipped Ey Express or Freight at purchaser's expense. (he order free or charge, or refund the money paid us for same.

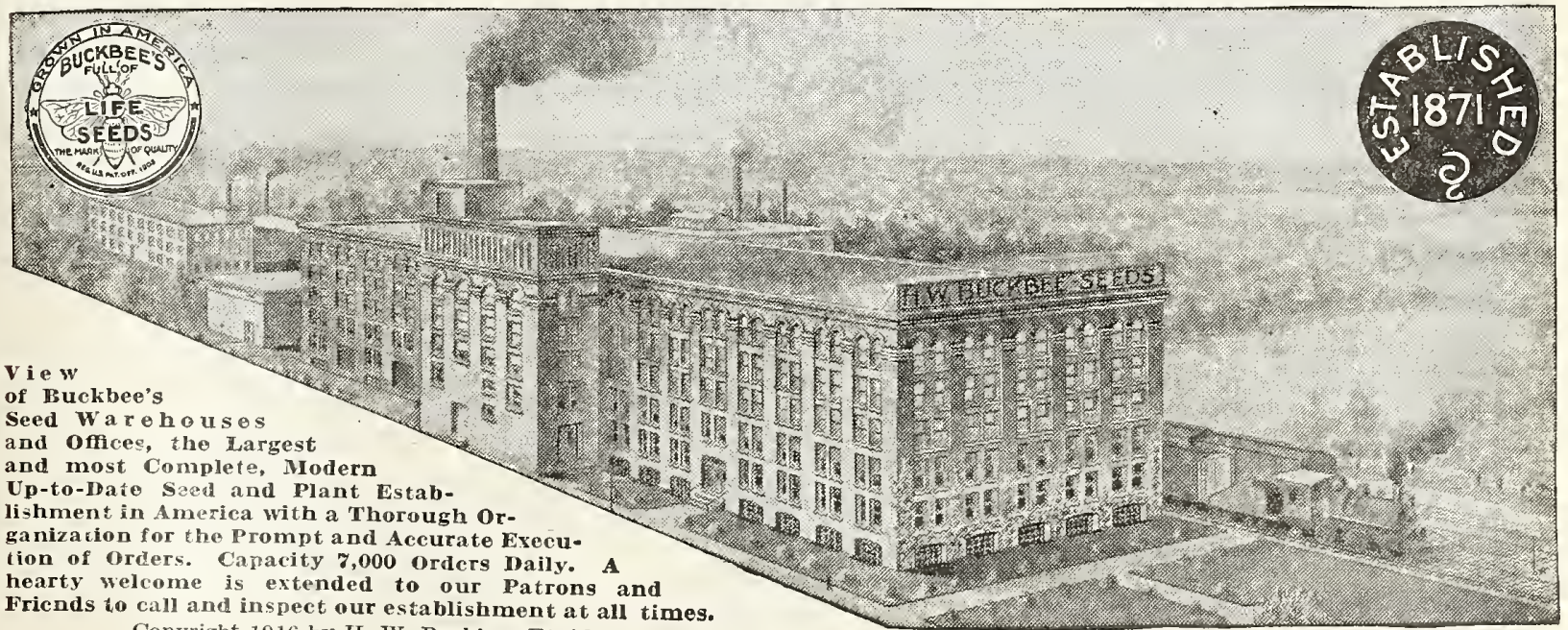
Copyright 1916 by H. W. Buckbee, Et Al

ROCKFORD SEED FARMST.H.W.BDCIRBEE, ROCKFORD.ILIINOIS. FOREST CTYYREEMHOUSES. 


\section{SPECIAL WHOLESALE BULK PRICE LIST OF BUCKBEE'S "FULL OF LIFE" SEEDS}

NoTICE-All Seeds listed on Pages 2 and 3 of this Catalogue are shipped by Express or Freight at purchaser's expense. No extra charge is mado for paeking, boxes or bags.

SEEDS BY PARCEL POST - If any items are wanted is Y PARCEL POST add additional for postage and packing at tho rate of

10 cents a pound and 15 cents per quart, to Wholesale Prices quoted on Pages 2 and 3 of this Catalogue.
SEVERAL VARIETIES OF SEEDS WERE SIORT CROP THE PAST SEASON-CRDER EARLY T On a number of varieties, such as Beans, we can aceept orders only in connection with other Seeds. For instance, we reserve the privilege of declln-
ing orders for beans alone, but we will ship reasonable quantities of Beans when included along with a good general order for Vegetable Seeds; as it is our purpose to protect, as usual, our thousands of custoniers who annually look to us for a general supply of Bueklore's "IFull of Life" Seeds.

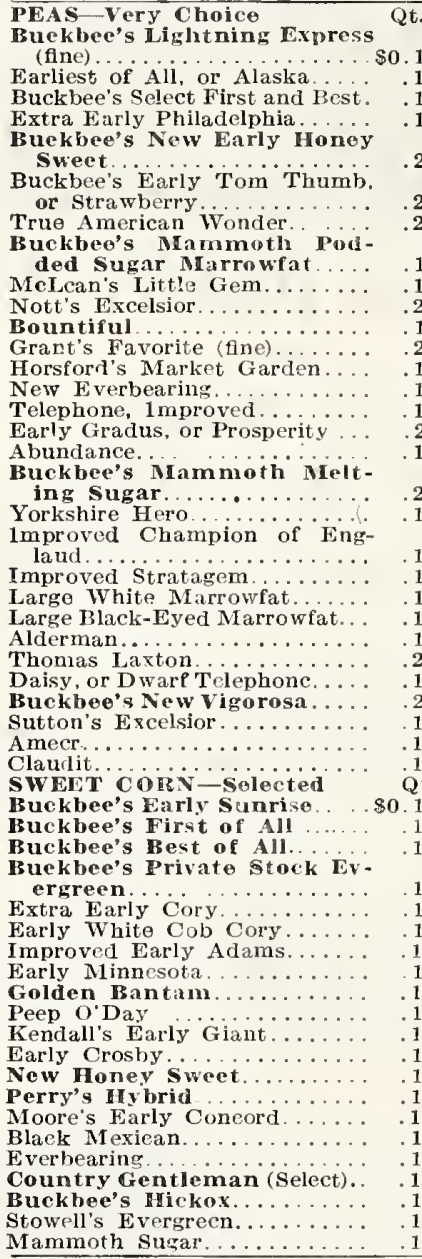

Conover's Colossal APAGUS Barr's liammoth.

Buckbee's Perfection.

New Palmetto.

Columbian Mammoth white.

Columbian Mammoth

Dewing's Imp. Blood Turnip

Buckbee's Long Blood.

Imp. Extra Early Eclipse.....

Buckbee's Sunset (the best)

Imp. Early Blood Turnip...

Early Yellow Turnip ......

Detroit Dark Red Turnip.

Market Gardener's ... Tü Turnip.

Buckbee's Half Long Blood.

Buckbee's Egyptian Turnip.

Columbia

The Bismarck

Black Queen.

New True Darls Stinson.

Buckbee's Earliest of All

Swiss Chard, Lucullus

BEET-Mangel

Buckbee's Mastodon......
Buckbee's Mam. Lon

New Golden Tankard..

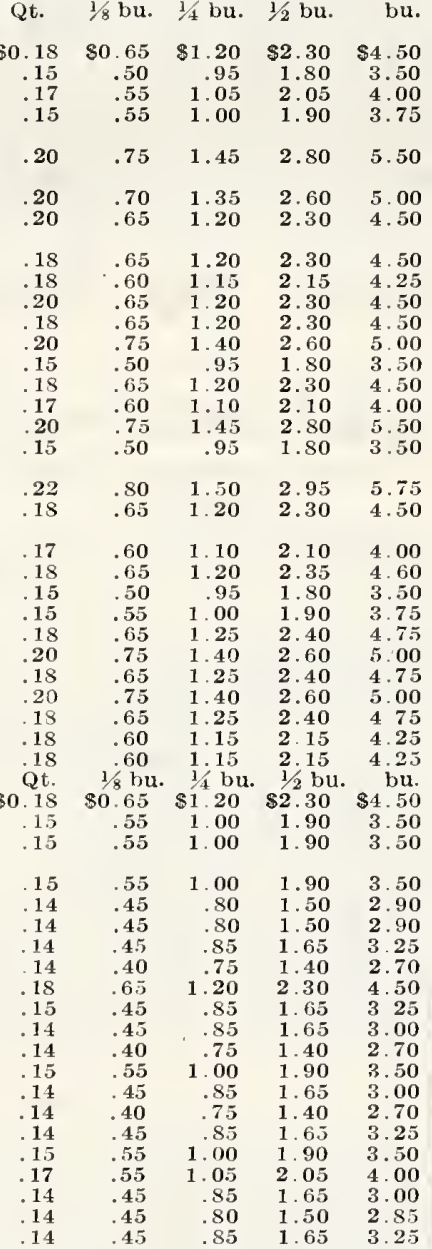

BEANS Selected

Improved Whit

Early Royal White K̇idney.

Improved Large White Marrow

Is uekbee's Improved Early Valentine.

Early Mohawk

Buckbee's Electric Tree

Dwarf Cranbcrry, or Wren's Egg

Boston White Baking

Black Valentin

Giant Stringless Green Pod.

Puefugee, or $\mathbf{1 . 0 0 0}$ to 1 .

New Extra Early Refuget

New Stringless Green Pod

Ibuckbey's Rust-Proof Golden Wax.

New Prolific German, or 1mp. Black Wax.

Challenge Extra Early Blaek Wax.

New Davis White Wax.

Wardwell's 1 mproved Kidney Wax

New Hodson Wax.

New Fageolet Wax

1mproved Golden Wax.

New Yosemite Mammoth wax

New Perfection Wax

Jones' Stringless White Wax..

Henderson's Bush Lim

Burpee's Bush Lima.

Buckbee's Improved Bush Iima

Dreer's Bush Lima.

New Jackson Wonder Bush Lima.

Kentucky Wonder, or Old Homestead

White Dutch Case Knife.

Buckbee's King of the Garden Lima.

Early Large White Lima.

Seibert's Early Lima.

Lazy Wife.

Early Golden Cluster Wax Pole

Ibuekbee's Golden Harvost Cluster Wax

Pole.

Burger's Green Pod Stringless

St. Lotis Perfection White Pole.

Mammoth Podded Horticultural.

White Creaseback.

Buckbee's Eyerbearing Stringless Pole

$\begin{array}{rrr}\text { Qt } & 1 / 8 \text { bu. } & \text { 1/4 bu } \\ \$ 0.20 & \$ 0.70 & \$ 1.35 \\ .24 & .90 & 1.75 \\ .25 & .95 & 1.90 \\ .25 & .90 & 1.75 \\ .27 & 1.05 & 2.00 \\ 27 & 1.05 & 2.00 \\ 27 & 1.05 & 2.00 \\ 25 & .90 & 1.75 \\ .30 & 1.15 & 2.25 \\ .23 & .90 & 1.75 \\ .27 & 1.05 & 2.00 \\ .40 & 1.55 & 3.00 \\ .27 & 1.05 & 2.00 \\ .27 & 1.05 & 2.00 \\ .35 & 1.30 & 2.50 \\ .40 & 1.55 & 3.00 \\ .38 & 1.50 & 2.90 \\ .40 & 1.55 & 3.00 \\ .40 & 1.55 & 3.00 \\ .40 & 1.55 & 3.00 \\ .45 & 1.75 & 3.50 \\ .45 & 1.75 & 3.50 \\ .38 & 1.50 & 2.75 \\ .45 & 1.75 & 3.50 \\ .38 & 1.50 & 2.90 \\ .40 & 1.55 & 3.00 \\ .45 & 1.75 & 3.50 \\ .45 & 1.75 & 3.50 \\ .45 & 1.75 & 3.50 \\ .22 & .80 & 1.55 \\ .32 & 1.20 & 2.30 \\ .35 & 1.25 & 2.40 \\ .32 & 1.20 & 2.30 \\ .38 & 1.50 & 2.75 \\ .20 & .75 & 1.40 \\ .25 & .90 & 1.75 \\ .22 & .85 & 1.60 \\ .22 & .85 & 1.60 \\ .20 & .75 & 1.45 \\ .22 & .80 & 1.50 \\ .32 & 1.20 & 2.30 \\ .38 & 1.50 & 2.75 \\ .32 & 1.20 & 2.30 \\ & & \\ .35 & 1.30 & 2.50 \\ .28 & 1.10 & 2.15 \\ .28 & 1.10 & 2.15 \\ .28 & 1.00 & 1.90 \\ .23 & .90 & 1.70 \\ .38 & 150 & 2.75 \\ & & \end{array}$

Reliable Beans Were Very Short Crop the Past Season. Write for special Prices in Large Quantities.
1.10 $\$ 0.25$

$\begin{array}{ll}.10 & .25 \\ .25 & .75\end{array}$

.12

.12

12

.12

15

.25

.25

18

.18

.12

.18

.20

.25

.25

.20

.40

.40

\section{GEET-Mangeis-}

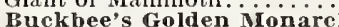

Champion Red Globe.... .

Champion Yellow Globe:

Eiffel Tow

SUUAR BEET

New Imperial Sugar.

Giant Feeding Sugar.

Extra Early ExpresBAGE

rly Express.

Extra Early Winningstadt... . .

Henderson's Early Spring.

Buckbee's Great Dane..

Dutch Winter or Hollander...

Buckbee's New Race Horse.

Charleston or Large Wakefield

Buckbee's Early Greenback

Buckbee's Extra Early Large

$$
\text { New Queen }
$$

Buckbee's New Xmas King.

Buekbee's Rockford Market

Allhead Earl

Buckbee's New Century.

Henderson's Early Summer.

Gregory's A!l Season.

Surehead.

Enkbuizen Gilory.
CABBAGE-Cont'd.

$\$ 80.30 \quad \$ 1.00$ $\$ 0.20$ Large Late Drumbead......... .30
.28
.20
Flat Dutch...

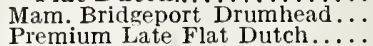
Premium Late Flat Dutch ......
Red Dutch, or Pickling....... Red Dutch, or Pickling Mammoth Red Rock.........

20 Improved American

.30 Danish Ballhead........... New Round Head Danish...

1.25 Buckbee's Early Marvel... .

\begin{tabular}{l|l}
1.25 & $\begin{array}{l}\text { Buckbee's Early Marvel..... } \\
1.25 \\
1.50\end{array}$ Louisvile Early Drumbead.... \\
New Red Polish...............
\end{tabular}

2.50

Cirizö

$.50 \quad 1.75$

$.50 \quad 1.75$

$.40 \quad 1.40$

$.45 \quad 1.60$

$\begin{array}{rr}.35 & 1.25 \\ .45 & 1.50\end{array}$

$\begin{array}{ll}.45 & 1.50 \\ .50 & .1 .75\end{array}$

1.90

$\begin{array}{ll}60 & 1.90 \\ 35 & 1.25\end{array}$

$\begin{array}{ll}.35 & 1.25 \\ .60 & 1.90\end{array}$

2.50 Improved Long Orange......

1.75 New Chantenay, or Model.

1.60 Ox Heart, or Guerande.

1.90 Isuckbee's Earliest Garden.

1.90 Half Long Danvers....

2.50 Early French Forcing i irarket

2.50 Buckbee's Pride of Market

1.90 Buckbee's Champion stock..

2.25 Buckbee's Majestic.

1.40 Buckbee's Victoria.

1.75 Buckbee's Short White...

1.75 Large White Vosges ......

1.40 Mammoth White Belgian..

.18
.2
.2
.3
.2
.2
.25
.2
.18
.1
.1
.1
.15




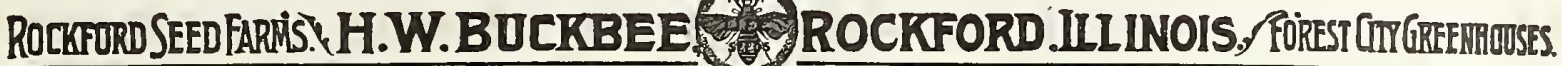

\section{CAULIFLOWER}

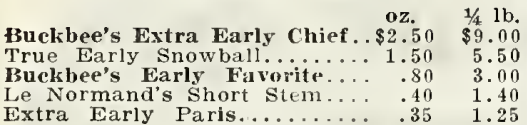

\section{CELERY}

Buckbee's All Heart..........

Buckbee's Golden Heart.

Buckbee's Goldel Yellow Self

Blanching (French Pedigreed

Iuckbee's Kaiamazoo

White Plume (finest strain)

New Columbia

Celeriac, Large Smooth Prague

Celeriac, New Delicatess.

\section{CUCUMBER}

Early Cluster .......... $\$ 0.15^{1 / 4} \$ 0.35$

Buckbce's Rockford Pickle
Buckbee's Monarch Wlite

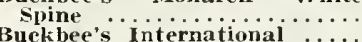

Buckbee's International

New Everbearing

Improved Long Green

Early Russian

Early Prolific Short Green...

Westerfield's Chicago Pickle.

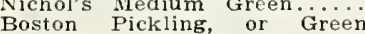
Prolific .............. Early

Buckee's New Extra Early

Klondike $\ldots \ldots$.....

Davis Perfect

Snow's Early Pickle.

Arlington White Spine.

Early white Spine......

\section{EGG PLANT}

Buckbee's New Early Large Purple $\ldots \ldots \ldots \ldots \ldots \ldots \ldots \$ 0.30$ Buckbee's New white......... .30 Improved New York Purple.. .20

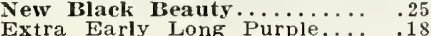

\section{LETTUCE}

Buckbee's Superb

Early Boston Market.

New Iceberg .... Black Seeded Simpson.

Imp. Black Seeded Simpson.

Buckbee's Earliest Forcing.

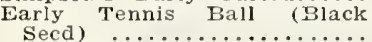
Secd ) $\ddot{\text { Hanson }} \ldots \ldots \ldots \ldots \ldots$ Dwarf White Heart, or Celery Denver Market

Taris White

Tomhannock $\quad$................

Buckbee's Ice Drumhead.

Early Prizehea

Tilton's White star............

Big Boston ................... (Private Mammoth Black-Seeded Butte Wonderful

Philadelphia Butter Buckbee's New Gold Coil.

All Season

Immensity

Iay King

Buckbee's Conbination, Mixed

\section{MUSK MIELON}

Paul Rose Buckbee's Famous Rocky Ford

Buckbee's Western Giant

Emerald Gem (Select)....

Ruckbee's New Strawberry

True Jennie lind.

Iontreal Market

Golden Netted Gem (Select)

Isuckbee's Ideal

New Early Hackensack.

Large Hackensack …....

Osage or Miller's Cream.

Buckbee's New IIoney Boy.

Hoodoo

Burrell's Gem

Admiral Tog

Buckbee's Ne

1.00

.60

1.10

.90

.50

.65

.60

.90
.50
.90

.90

.60

.60
BUCKBEE'S NEW GOLD FLESHED ROCKY FORD MUSK MELON

The most productive and sweetest of all Rocky Ford Melons. Of good size, oval shape, heavily netted over entire surface; rust resistant. Deep, solid, salmon-colored flesh, of sweet seed cavity.

Pkt., 5c; oz., 15c; 2 oz., 25c; $1 / 41 \mathrm{~b}$. $40 \mathrm{c} ; 1 / 2$ lb., $75 \mathrm{c}$; 1b., $\$ 1.25$, postpaid.

\section{WATER MELON}

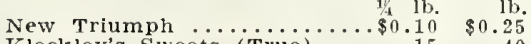

Kleckley's Sweets (True) .... 15

Hew Sugar Stick.......... $\quad .20$

Buckbee's Monte Cristo (Se- ${ }^{2}$

Fordhook Early ...............

Phinney's Extra Early... P...

less $\ldots \ldots \ldots \ldots \ldots \ldots \ldots \ldots$.

Georgia Rattlesnake, or Gy psy

Florida Favorite

Gray Monarch, or Long Icing.

Buckbee's Perfected Kolb's

Buckbee's New sweet Heart

Maule's Wonderful Sugar.

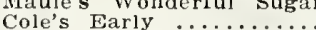

Dole's Early J ‘........

Buckbee's Everbearing Allways

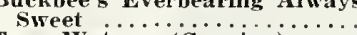

Tom Watson (Genuine):

I ceberg or Blue Gem.

Halbert Hon

Alabama Sweets

New National

Round Dark

Ruby Gold .....

Colorado Preserving

Citron Green Seed
Citron, Red Seeded.

ONION-OUR OWN GROWTII

Round or Yellow Danvers.... \$0.35

$B$ uck b e e's Pedigreed Red Wethersfield

Buckbee's Great Cardinal...

Selected Yellow Strasburg or

Buckbee's New ivampum.

Southport Yellow Globe...

New Genuine Prizetake

Buckbee's Red Giant.........

Buckbee's New Golden Globe.

Australian Brown

White Silverskin, or Portugal

Thite Silverskin, or Portugal

Southport Red Globe (Select)

Southport Selected White Globe
Buckbee's Yellow Globe Dan-

vers

Extra Eariy White Queen

Buckbee's White Piekling

\section{ONION SETS}

See Special Prices on Order Sheet.

\section{PARSNII}

$\begin{array}{llr}\text { New Maltese } \ldots \ldots \ldots \ldots \ldots \ldots \ldots \$ 0.15 & 1 \mathrm{~b} & \$ 0.40 \\ \text { Fuckbee's New Sugar } \ldots \ldots \ldots & .25 & .75\end{array}$ Imp. Hollow Crown or White :10 $: 30$

\section{PEPPER}

Buckbee's Great West....... $\$ 0.35$

Chinese Giant

Sweet Mountain

Improved Ruby íing.

Large Bell or Bull Nose.

Red Chili

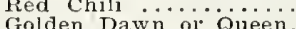

Gong

n............ 15

\section{RADISH}

Scarlet Turnip, White Tip 1/t lb. lb.

(Select) $\ldots \ldots \ldots \ldots \ldots \ldots \ldots \ldots \ldots_{0.12} \$ 0.30$

New Rosy Gem....

Buckbee's Rapid Foreing.

New Leafless ...................

RADISH-Cont'd.

Earliest White Turnip....... \$0.1 $1 \mathrm{~b}, \$ 0.35$

Buckbee's Rockford Beauty.

Earliest Scarlet Olive-Shaped

Buckbees' Improved Chartier.

Buckbees' Improved Chartier:

Early Long Brightest Scarlet.

New Icicle

Golden Rose, Winter:

Gray Summer Turnip.

White Strasburg.

California Mammoth White.

Round Black Spanish, Winter.

Buckbee's Mammoth Celestial,

Winter
Buekbee's New Early

Crimson Giant Giobe

Half Long Deep Scarlet

Earliest Radishes Mixed...

Summer Radishes Mixed.

\section{SALSITI}

Long White

Buclibec's Ali Amerie

Mammoth Sandwich Island.

\section{SPINICII}

Buckbee's New Long Scasons

Victoria

Bloomsdale Savoy-Leaved

Round Summer Broad-Leaved

Improved Thick-Leaved

Prickly, or Winter.

Monstrous Viroflay

\section{SQUASH}

Chicago, Warted Hubbard.

Buckbee's Giant Crookneck

New Delicata

Improved Boston Marrow.

Blue Hubbard (Marblehéad).

New Fordhook.

Buckbee's Mam. White Bush.

Buckbee's Improved IIubbard.

New Golden Hubbard........

Mamm

Faxon's New Brazilian.

Golden West Hard Shel.

TOMATOES

Livingston's Perfection.

New Stone (Special Stock)

Buckbee's New Beefsteak

Buckbee's Earlicst Market.

I3uckbee's New Spot Cash

Favorite

Early Acme (Select)

Maule's Success

IBuckbee's Dwarf Champion.

Ponderosa or No. 400 ...

Buckbee's New Tree, or Station

Matchless

Inuclibee's Prosperit.

New Earliana.........

Chalk's Early Jev

Inckbee's New irasterpiece.

Buckbee's Early June Pink

Dwarf Stone.

John Baer

TURNIPS

Buckbee's Purple Top Strap

Leaf (Special Stock

New White Egg.

Buckbee's Extra Early Car-

dinal

Imp. Early White Flat Dutch

Eariy Six Weeks, or Snow"ball.

Buckbee's Extra Early Cameo

White Globe

Extra Ea.

Sow Horn Seํ.......

\section{RUTA BAGAS}

Improved Purple 


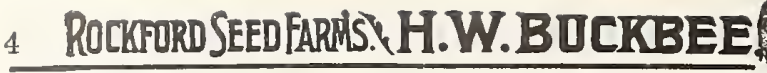 \\ ROCKFORD.ILLINOIS, FOOREST UTGKRERROOSES.}
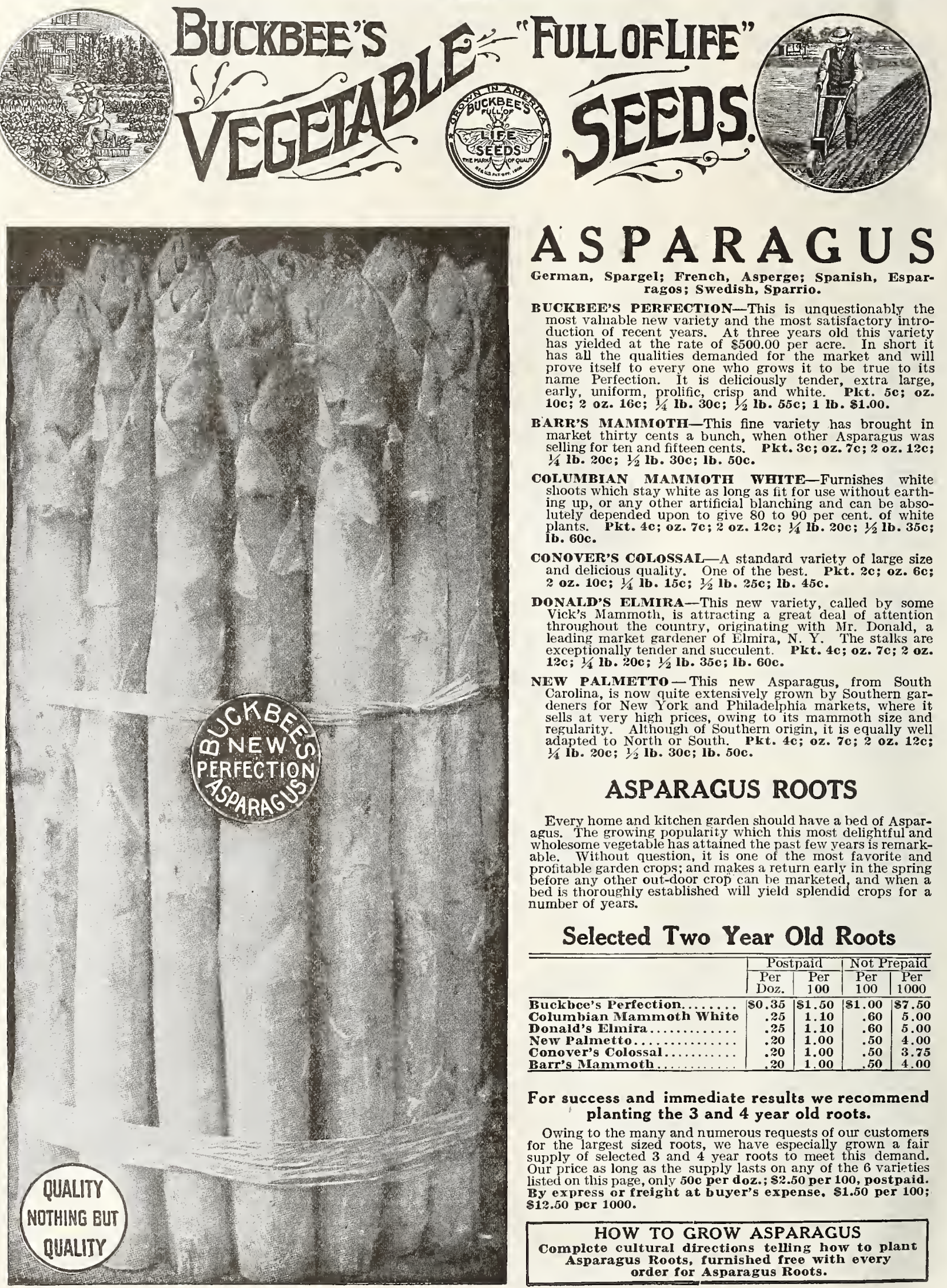

\section{AS PAR A G US}

German, Spargel; French, Asperge; Spanish, Esparragos; Swedish, Sparrio.

BUCKBEE'S PERFECTION-This is unquestionably the most valuable new variety and the most satisfactory introduction of recent years. At three years old this variety has yielded at the rate of $\$ 500.00$ per acre In short it has all the qualities demanded for the market and will prove itself to every one who grows it to be true to its name Perfection. It is deliciously tender, extra large, early, uniform, prolific, crisp and white. Plkt. 5c; oz. 10c; 2 oz. 16c; $1 / 4$ 1b. 30c; $1 / 2$ 1b. 55c; 1 lb. $\$ 1.00$.

BARR'S MAMMOTH-This fine variety has brought in market thirty cents a bunch, when other Asparagus was selling for ten and fifteen cents. Pkt. 3c;oz. 7c; 2 oz. 12c; $1 / 4$ lb. 20c; $1 / 2$ lb. $30 \mathrm{c} ; 1 \mathrm{~b} .50 \mathrm{c}$.

COLUMBIAN MAMMOTH WHITE-Furnishes white shoots which stay white as long as fit for use without earthing up, or any other artificial blanching and can be absolutely depended upon to give 80 to 90 per cent. of white plants. Pkt. 4c; oz. 7c; 2 oz. $12 \mathrm{c} ; 1 / 4 \mathrm{lb}$. 20c; $1 / 2 \mathrm{lb} .35 \mathrm{c}$;
lb. 60c.

CONOVER'S COLOSSAL-A standard variety of large size and delicious quality. One of the best. Pkt. 2c; oz. 6c; $2 \mathrm{oz} .10 \mathrm{c} ; 1 / 4$ lb. 15c; $1 / 2$ lb. 25c; 1b. $45 \mathrm{c}$.

DONALD'S ELMIRA-This new variety, called by some Vick's Mammoth, is attracting a great deal of attention throughout the country, originating with Mr. Donald, a leading market gardener of Elmira, N.Y. The stalks are exceptionally tender and succulent. Pkt. 4c; oz. 7c; 2 oz. 12c; $1 / 4$ lb. 20c; $1 / 2$ lb. 35c; 1b. 60c.

NEW PALMETTO - This new Asparagus, from South Carolina, is now quite extensively grown by Southern gardeners for New York and Philadelphia marlsets, where it sells at very high prices, owing to its mammoth size and regularity. Although of Southern origin, it is equally well adapted to North or South. Pkt. 4c; oz. 7c; 2 oz. 12c: $1 / 4$ lb. 20c; $1 / 2$ 1b. 30c; 1b. 50c.

\section{ASPARAGUS ROOTS}

Every home and kitchen garden should have a bed of Asparagus. The growing popularity which this most delightful and wholesome vegetable has at tained the past few years is remarkable. Without question, it is one of the most favorite and profitable garden crops; and makes a return early in the spring before any other out-door crop can be marketed, and when a bed is thoroughly established will yield splendid crops for a number of years.

\section{Selected Two Year Old Roots}

\begin{tabular}{|c|c|c|c|c|}
\hline & \multicolumn{2}{|c|}{ Postpaid } & \multicolumn{2}{|c|}{ Not Prepaid } \\
\hline & $\begin{array}{l}\text { Per } \\
\text { Doz. }\end{array}$ & $\begin{array}{l}\text { Per } \\
100\end{array}$ & $\begin{array}{l}\text { Per } \\
100\end{array}$ & $\begin{array}{c}\text { Per } \\
1000\end{array}$ \\
\hline Buckbce's Perfection. & $\$ 0.35$ & $\$ 1.50$ & $\$ 81.00$ & $\$ 7.50$ \\
\hline Columbian Mam & .25 & 1.10 & .60 & 5.00 \\
\hline Donald's Elmira . . . . . . . . . . & .25 & 1.10 & .60 & 5.00 \\
\hline 7 Palmetto & .20 & 1.00 & .50 & 4.00 \\
\hline Conover's Colossal & .20 & 1.00 & .50 & 3.75 \\
\hline Barr's Mammoth. & .20 & 1.00 & .50 & 4.00 \\
\hline
\end{tabular}

\section{For success and immediate results we recommend} planting the 3 and 4 year old roots.

Owing to the many and numerous requests of our customers for the largest sized roots, we have especially grown a fair supply of selected 3 and 4 year roots to meet this demand. Our price as long as the supply lasts on any of the 6 varieties listed on this page, only $50 c$ per doz.; \$2.50 per 100, postpaid. By express or freight at buyer's expense. \$1.50 per 100; $\$ 12.50$ per 1000 .

\section{HOW TO GROW ASPARAGUS} Complcte cultural directions telling how to plan Asparagus Roots, furnished free with every order for Asparagus Roots. 


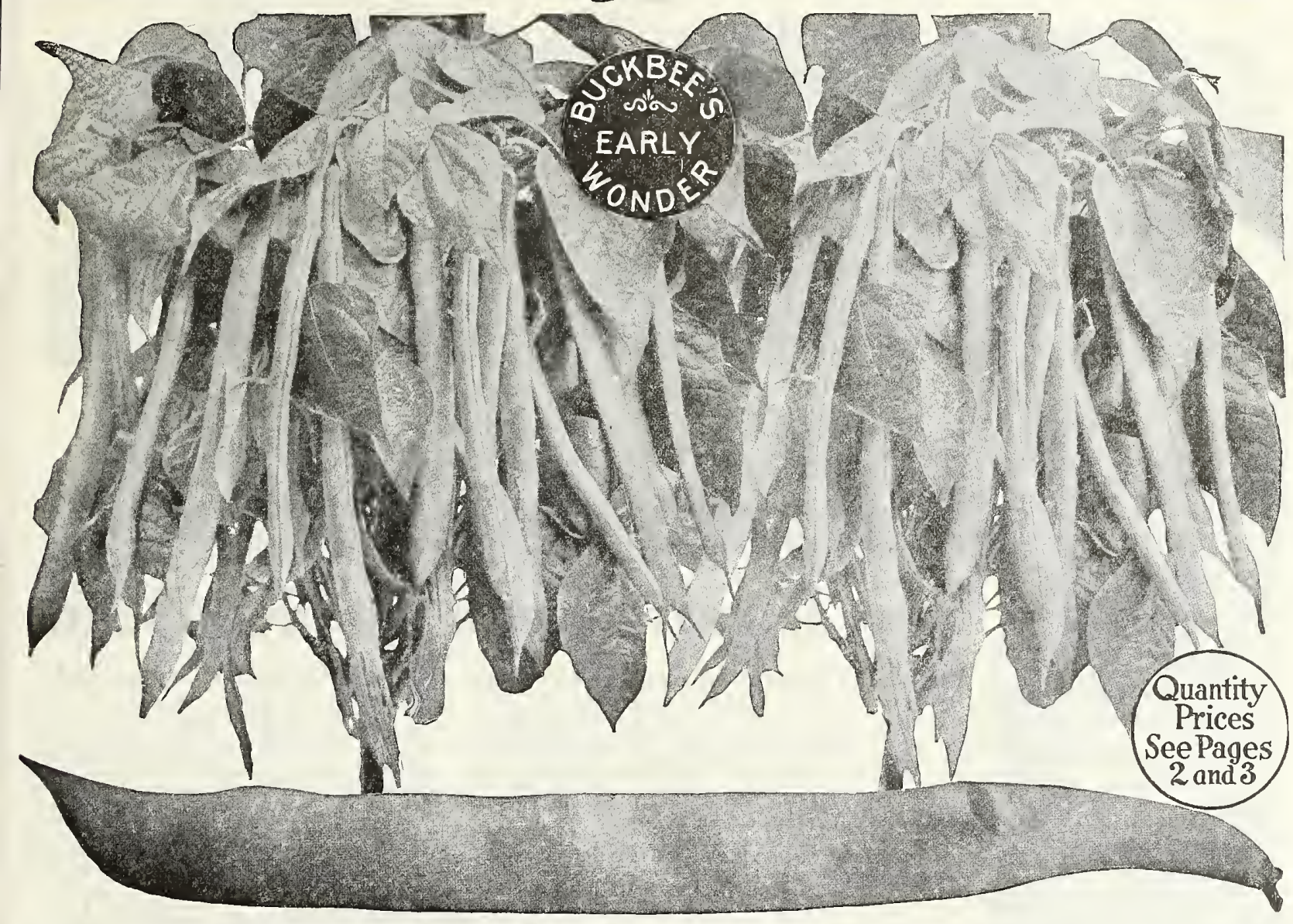

\section{Best Dwarf Green Podded Beans}

German, Bohne; French, haricot; Spanish, FRIJORENANo; Swedish, BONAR.

\section{Buckbee's Early Wonder \\ This is an Ideal snap Bean.}

Pods are $4 \frac{1}{2}$ inches long, soft green, perfectly straight and round. Flavor is most delicious;
it has the peculiarity of preserving it has the peculiarity of preserving
its delicate color, almost intact
when prepared for the table. Rewhen prepared for the table. Remarkably early, ready for use four
days in advance of any variety of merit.
Its bearing qualities are unexcelled and Its bearing qualities are unexcelled an even under adverse condition. Postpaid, pkt.
pt. 28c: qt. $50 \mathrm{c}$.

New Extra Early Refugee

Earliest of the green podded kinds, furnishing a fleshy pod of fine quality. It is usually from two to three weeks earler than ordinary smaller, are fully as hardy and vigorsmaller, are fully as hardy and vigorPods of the same size and shape, except slightly flatter. Postpaid, pkt

\section{Early Mohawk}

Much hardier than others. Can be planted earlier, furnishing Beans fit for use before any other kind. Vines large and stout, with large leaves which will stand a slight frost. Blossoms large, purple; pods point. Beans long kidney-shaped, point. Beans long kidney-shaped, brown. Postpaid, pkt. 6c: $1 / 2$ pt. 12c; pt. 22c; qt. 40c.

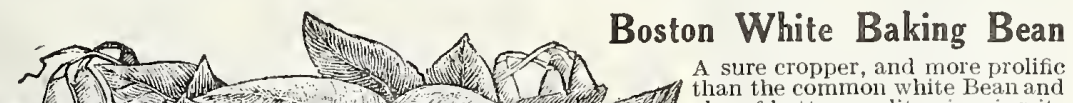

Boston White Baking Bean

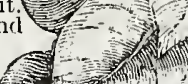
7 (

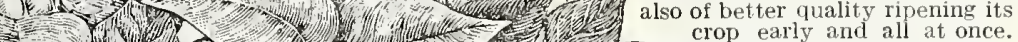
$30 \quad$ crop early and all at once:
Pods straight, short, small;

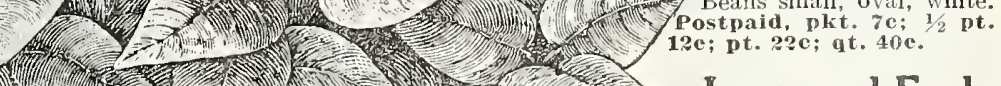
P. $\geqslant$, 3 2 洒 (2)

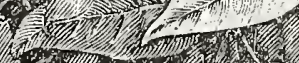
branching, productive, with
large leaves and lilac blos-
soms; pods long, straight,
narrow, handsome; Beans
long, kidney-shaped, color

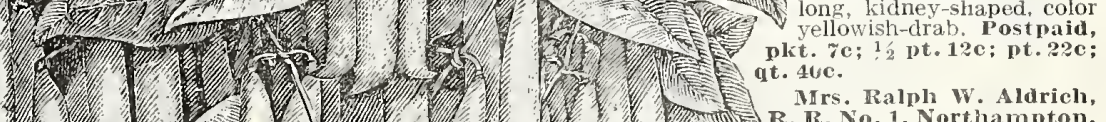
MIrs. Ralph W. Aldrich,
$\mathbf{R}$. IR. No. 1, Northampton,
Mass., writes:-The Yose-
mite Beans sent are delicious MIrs. Ralph W. Aldrich,
$\mathbb{R}$. IR. No. 1, Northampton,
mite Beans sent are delicious

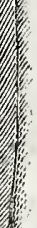

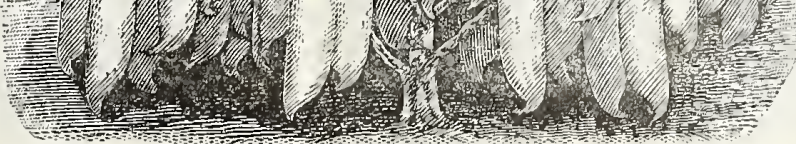
7 Boston White Baking Bean Ind., writes:quite a large list of your 'Full two years, and not a single For the Best WHITE FIELD BEAN See Page 86
Buckbee's Electric Tree 


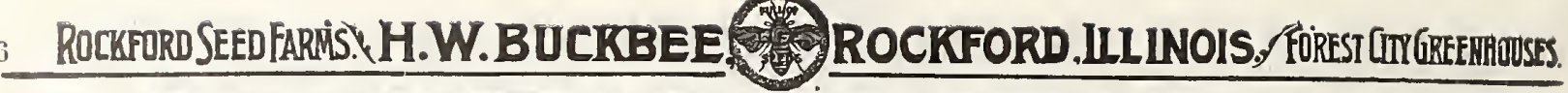

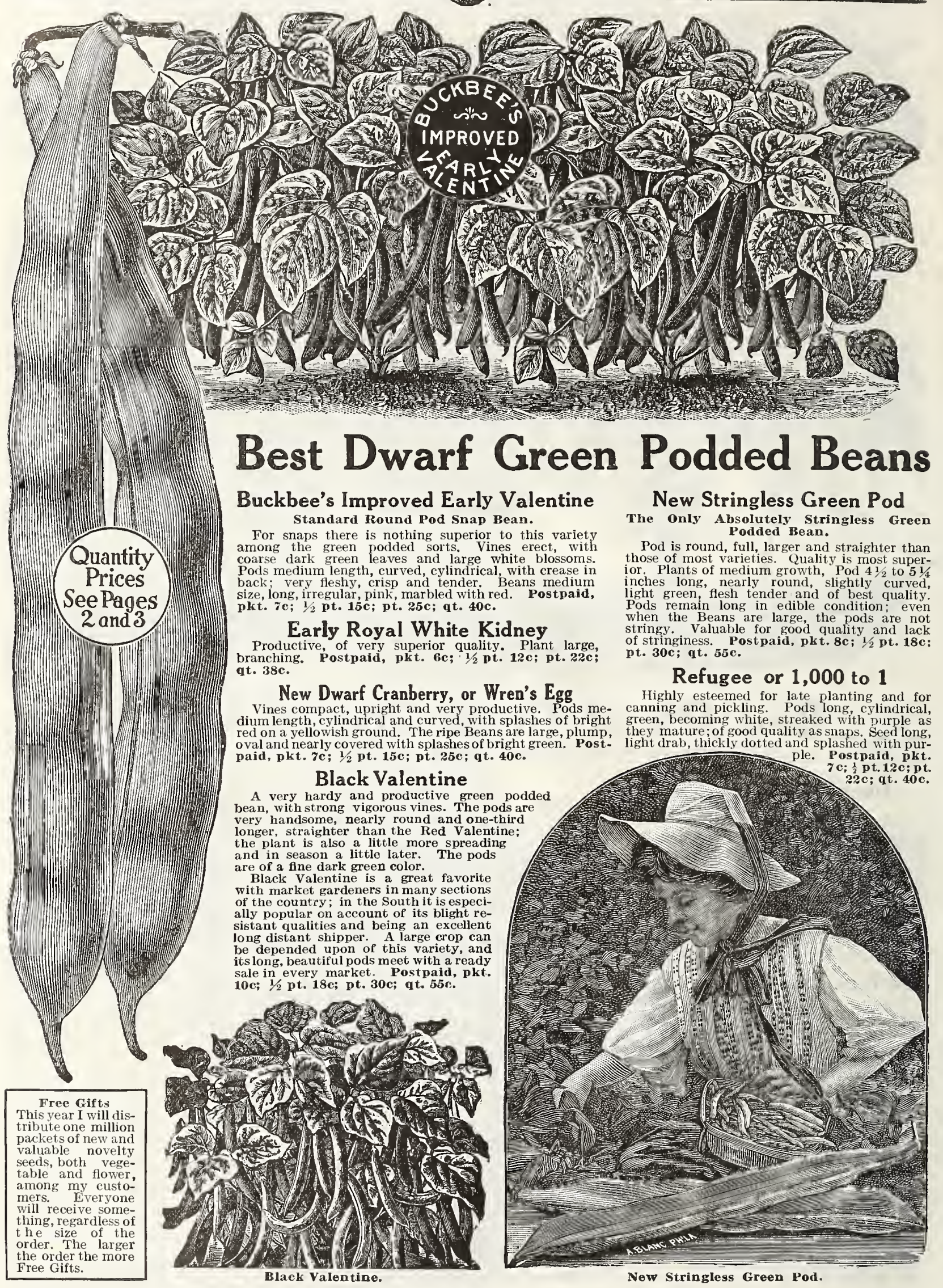




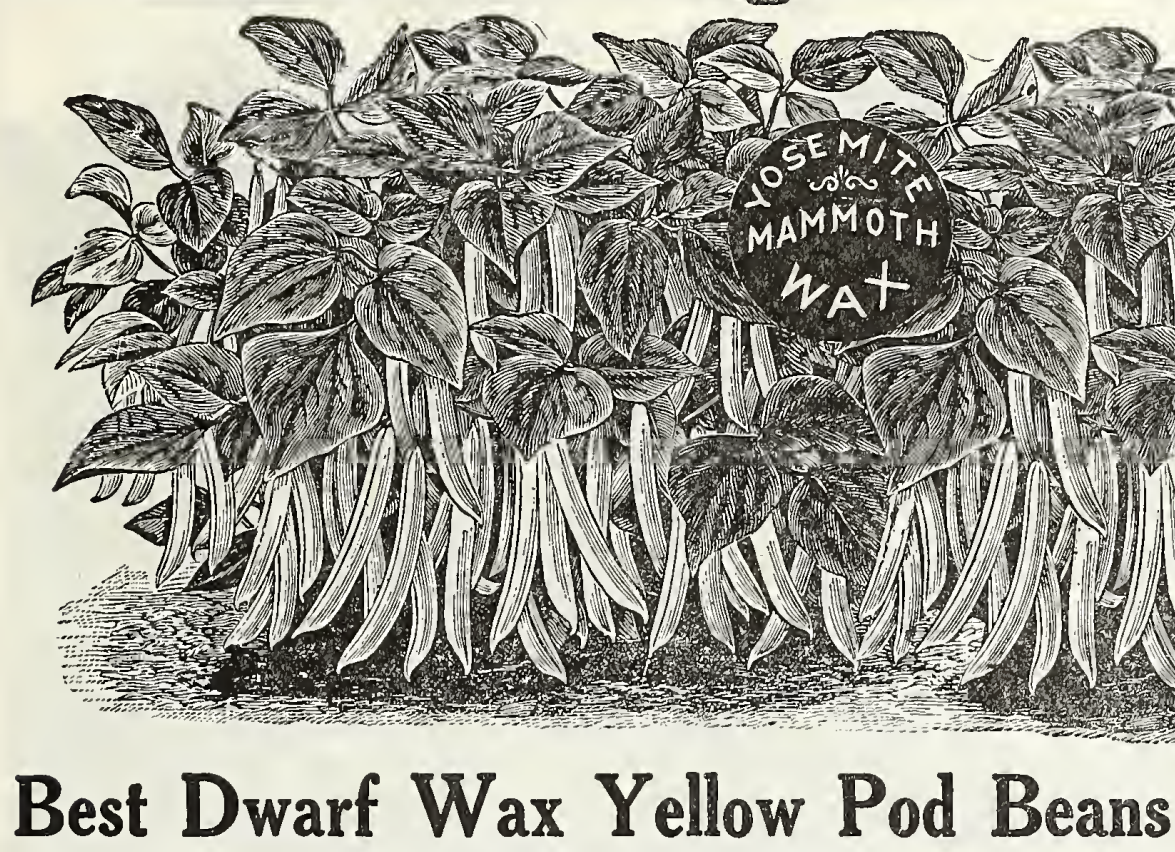

The Yosemite Mammoth Wax

\section{High Quality Monster Podded Wax Bean.}

The pods frequently attain a length of ten to fourteen inches, with the thickness of a man's finger. and are nearly all solid pulp, the seeds being very small when fit for use. A rich golden color, and are absolutely stringless, cooking tender and delicious. A popular wax Bean for family or market purposes. It is enormously productive, as many as fifty of its
one bush. Postpaid, pkt. 8c; 1/2 pt. 18c; pt. 30c; qt. 55c.

\section{New Perfection Wax}

Rich golden yellow, six inches long; broad; hang in great clusters. Extremely tender and brittle, Combines great productiveness with high quality. Postpaid, pkt. 8c; $1 / 2$ pt. 18c; pt. 30c; qt. $55 \mathrm{c}$.

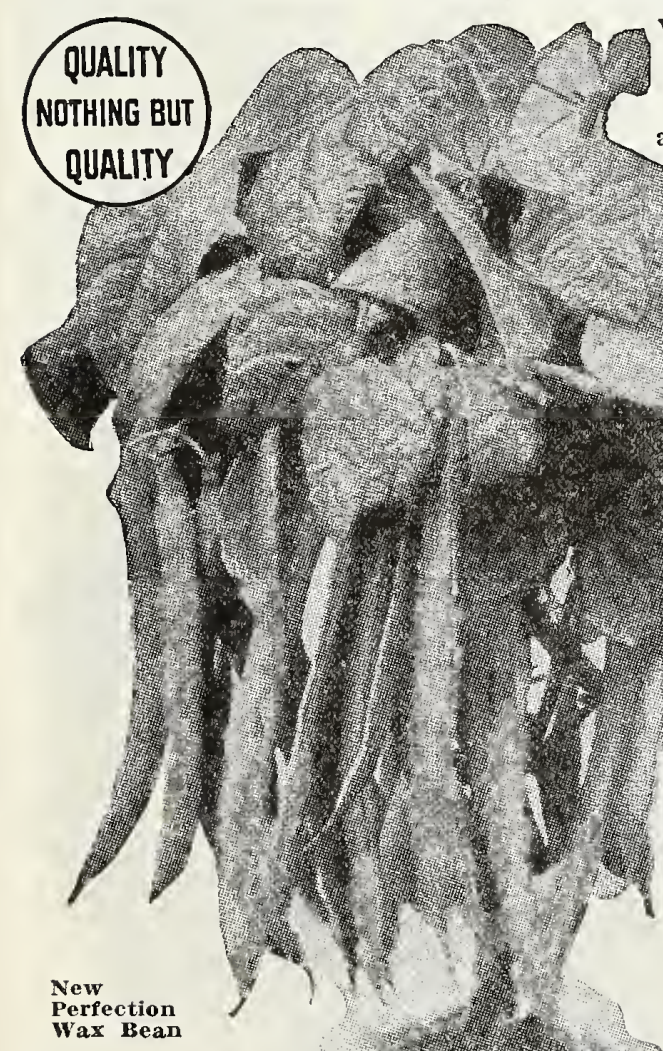

Wardwell's New Kidney Wax Most Profitable Market Gardener's This Bean is entirely distinct from that of all other Wax varieties; perfect kidney-shape. earliest and most hardy. Pods long flat, waxy yellow, brittle and (1) great profit in the South for Postpaid,pkt.8c; $1 / 2$ pt. 18c; pt. 30c; qt. 55c.

Currie's Rust-Proof Black Wax
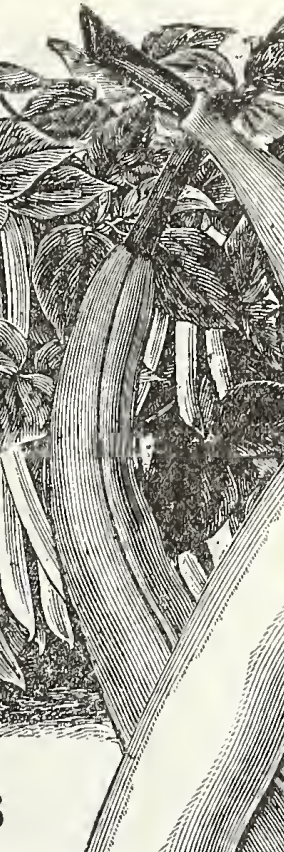


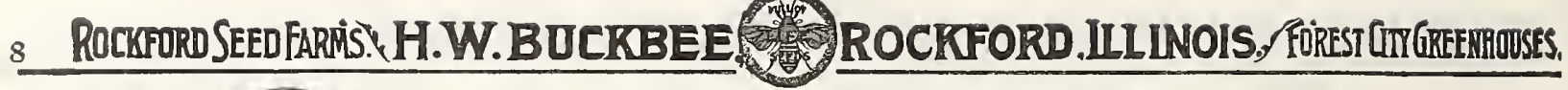

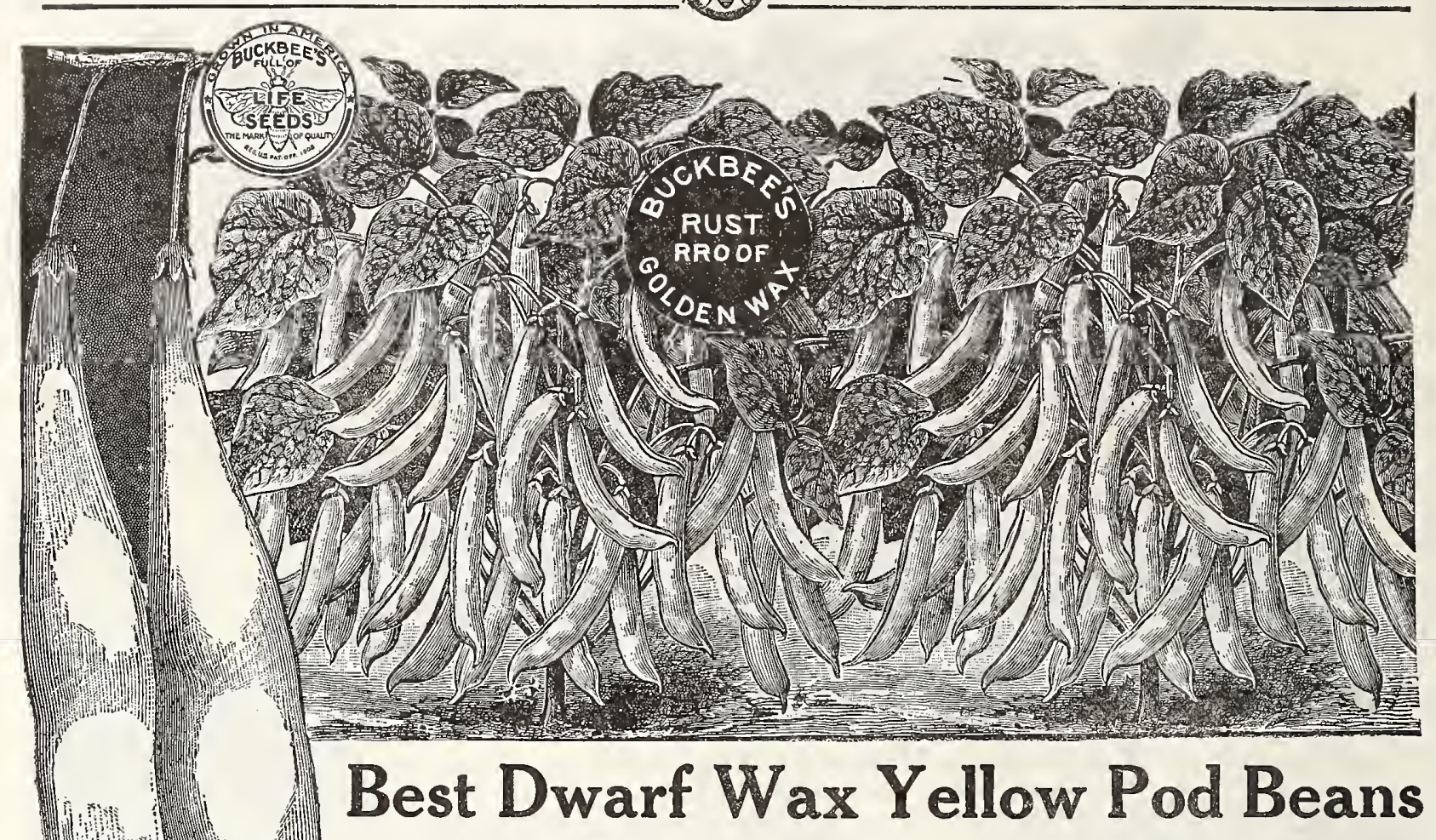

Buckbee's Rust-Proof Golden Wax

\section{The Standard Wax Variety for General Use.}

Our own original stock, unequaled in size, color and

\begin{abstract}
possesses all the good points of the old favorite, Golden
\end{abstract}
Wax, but is larger in pod and much more prolific;

color and of perfect shape. Of grand quality, showing

of tender and melting flavor at all stages of its growth. we this one of the best for canners. It market gardeners private families is which does not discolor in canning, Postno better variety can be planted. Postpaid, pkt. paid, pkt. 8c; 1/2 pt. 18c; pt. 30c; qt. 55́c.

\section{New Early Prolific German or Improved Black Wax}

Best Early Black Wax Bean for the Market Gardener.

You will be thoroughly satisfied with this greatly

improved strain of Black Wax, which is more vigorous

and by far more productive with a much longer

and more fleshy pod, which are of medium length,
borne up well among the foliage; curved, cylindrical,
of a clear waxy-white color, with long slight-
ly curved points. Vines of medium size,

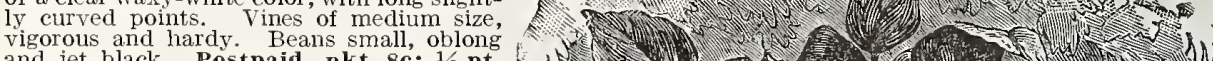

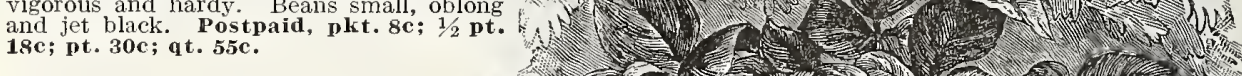
Jones' Stringless Wax

The Best White Wax Bean. STRINGLESS, BUTTERY, EARLY, PROLIFIC.

Fine white-seeded variety, round, stringless pods of unsurpassed quality; rust-proof, matures very well as the garden. The ripe Beans are salable as No. 1 medium nary purposes. This feature makes the sort of especial value to market gardeners since if

THE BEST BOOK FOR TME AMATEUR Columbia P. Wood, Editor and $P^{2} u$ Jlisher Journai-Public Health, Evansvîte, Ind. "Your little book 'How to Grow Seeds
and Flowers' received. It is the simplest and Flowers' received. It is the simplest seen. Thanks"
(See order sbcet How to Get It Free.) there is no sale for them as snaps, the leate wa nal. the crop a remunpaid, pkt. $8 \mathrm{c}$; $1 / 2$ qt. $55 \mathrm{c}$.

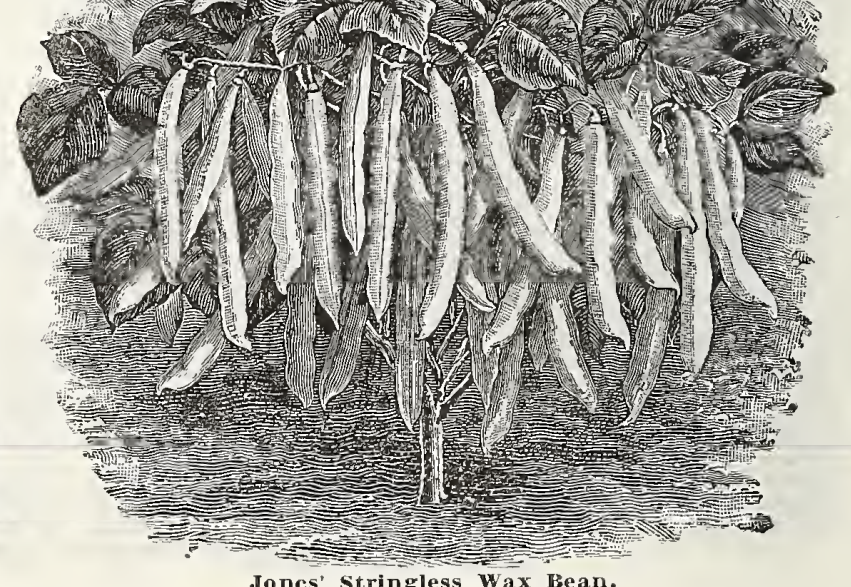

William C. Hallet, R. R. 1, East Stroudsburg,

fine success with the "Full of Life" onion nches across and 13 inches around.

Big Money Maker for Gardeners and Truckers. The vine is rustless and very vigorous, bearing its aritle bridneyped, clear white and excellent for baking. One of as I had fine success with the "Full of Life" onion 
BUCKBEE'S BEST POLE OR CLIMBING BEANS

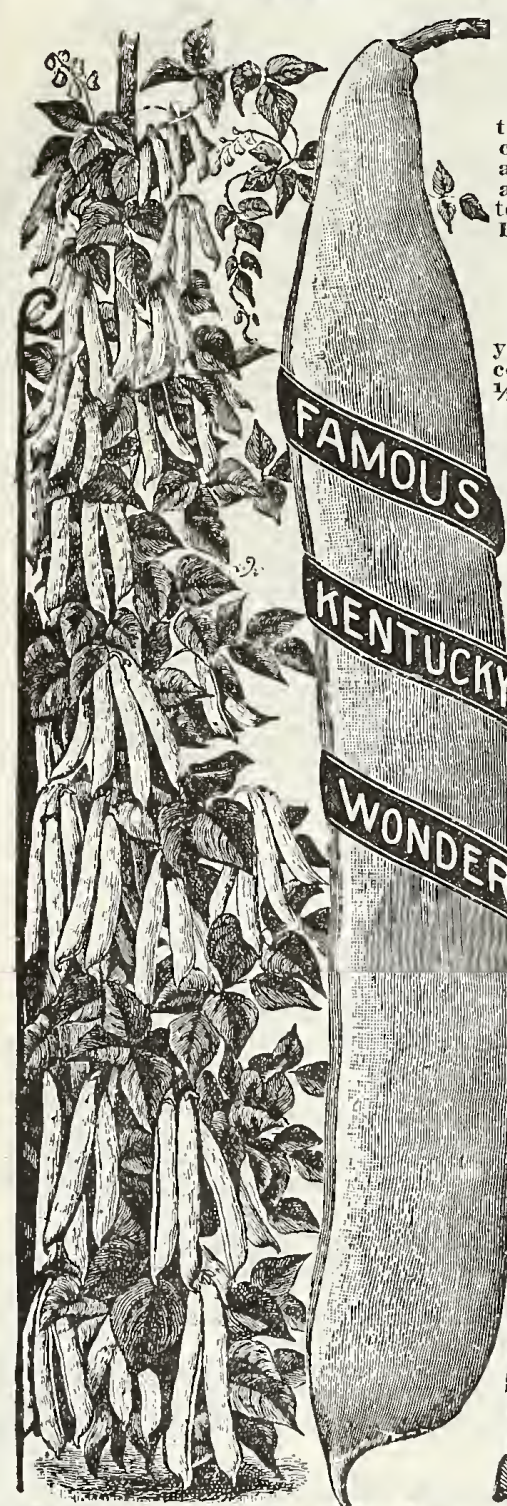

Famous Kentucky Wonder or Old Homestead

The old Reliable Standar

Very early and enormously nro.

ing in clusters from top to bottom

Burger's Green Pod Stringless
ze; 1 1/2 pt. 12c; pt. 22c; qt. 40c.

This is earlier than old Homestead and covers a longer season of pro-

lens, a verage six to eight inches in rich darls green, and so meaty as to
be really "saddle backed." The pods
almust entirely stringless. Postpaid, pkt. 8c; $1 / 2$ pt. 15c; pt. 25c; qt. $40 \mathrm{c}$.

New Golden Andalusia One of the best "Carly Wax Pole tifut yellow color and absolutely 15e; pt. 25c; qt. 45c.

\section{Buckbee's Golden Harvest Cluster Wax}

The New World Beating Wax Pole Bean.

The Everlasting Pole Bean. A magnificent variety

hat bears continualis the entire season, bearing early

average about 8 inches in length, exceedingly tender

tenderness long after they have attained a la
Postpaia, pkt. 8c; 1/2 pt. 15c; pt. 25c; qt. 45c.

\section{Early Golden Cluster Wax}

Pods 6 to 8 inches long; color bright golden condition for use a long time. Postpaid, pkt. 8e $1 / 2$ pt. $15 \mathrm{c} ;$ pt. $25 \mathrm{c}$; qt. $45 \mathrm{c}$.

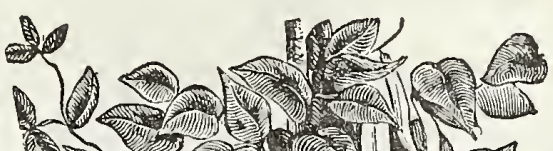
(1)

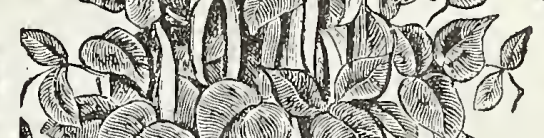
(3) 4.

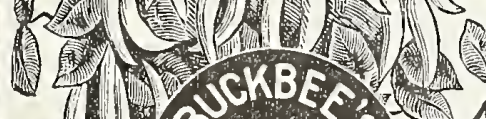

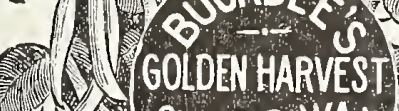

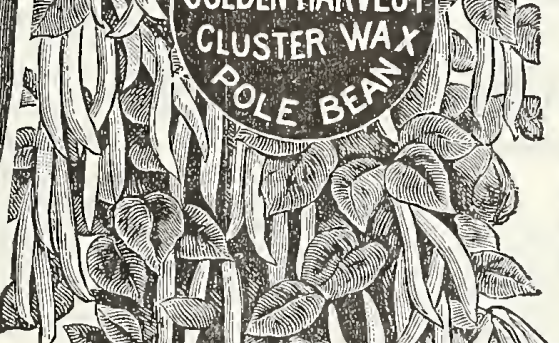

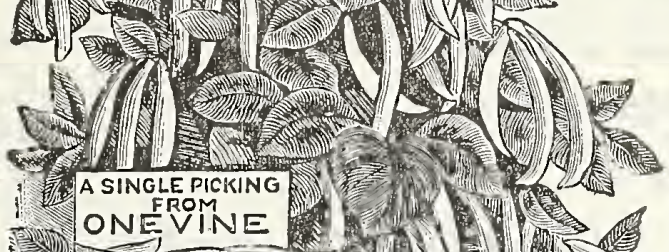

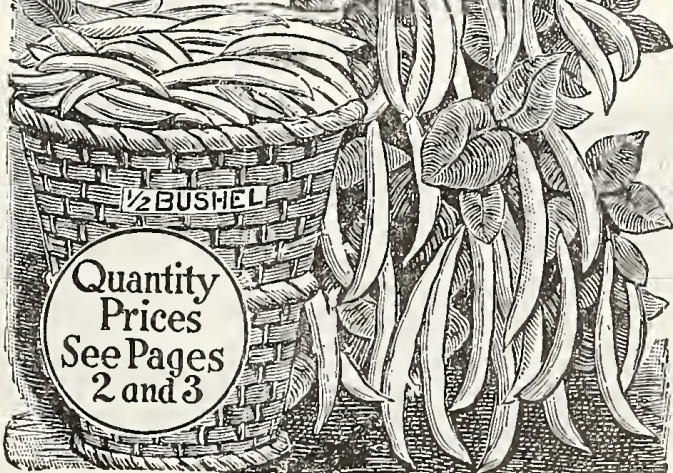

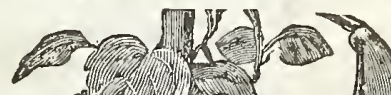

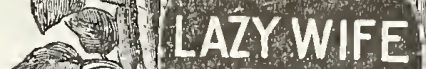
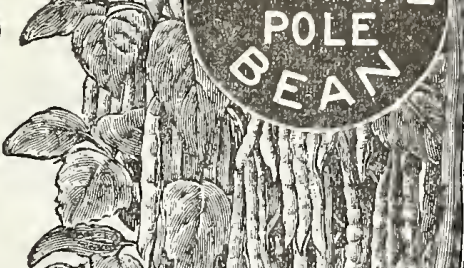

(5)

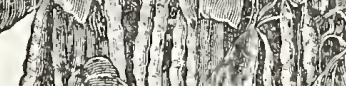

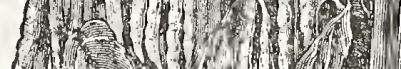
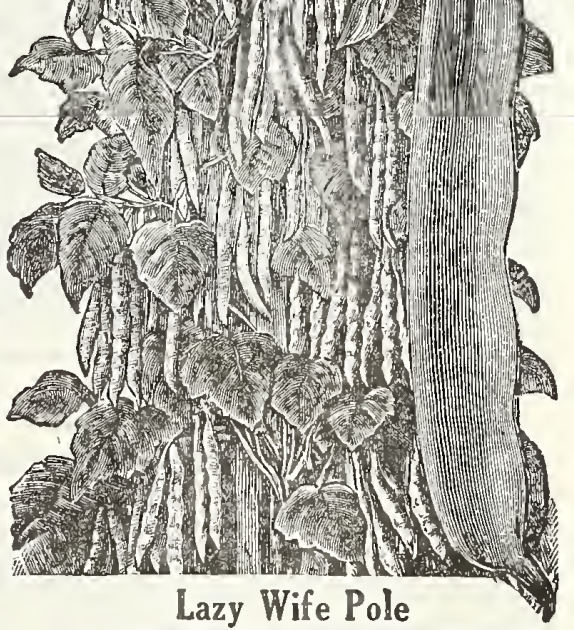

3 (3)

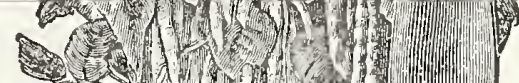

(4)

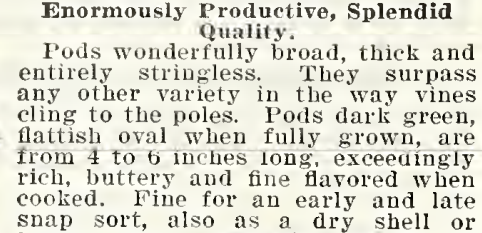

White Creaseback

Taluable for and its habit of ripening all of its pods in clusters of from four to paid, pkt. ze; 1/2 pt. 12e; pt. 22e; qt.

Red Speckled Cut Short or Corn Hill 


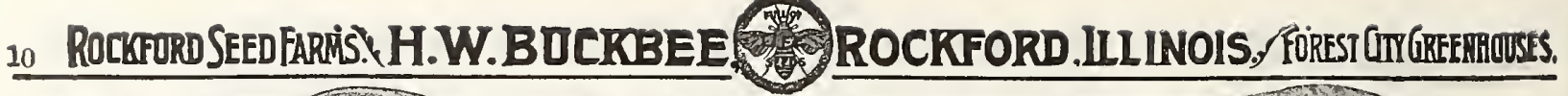

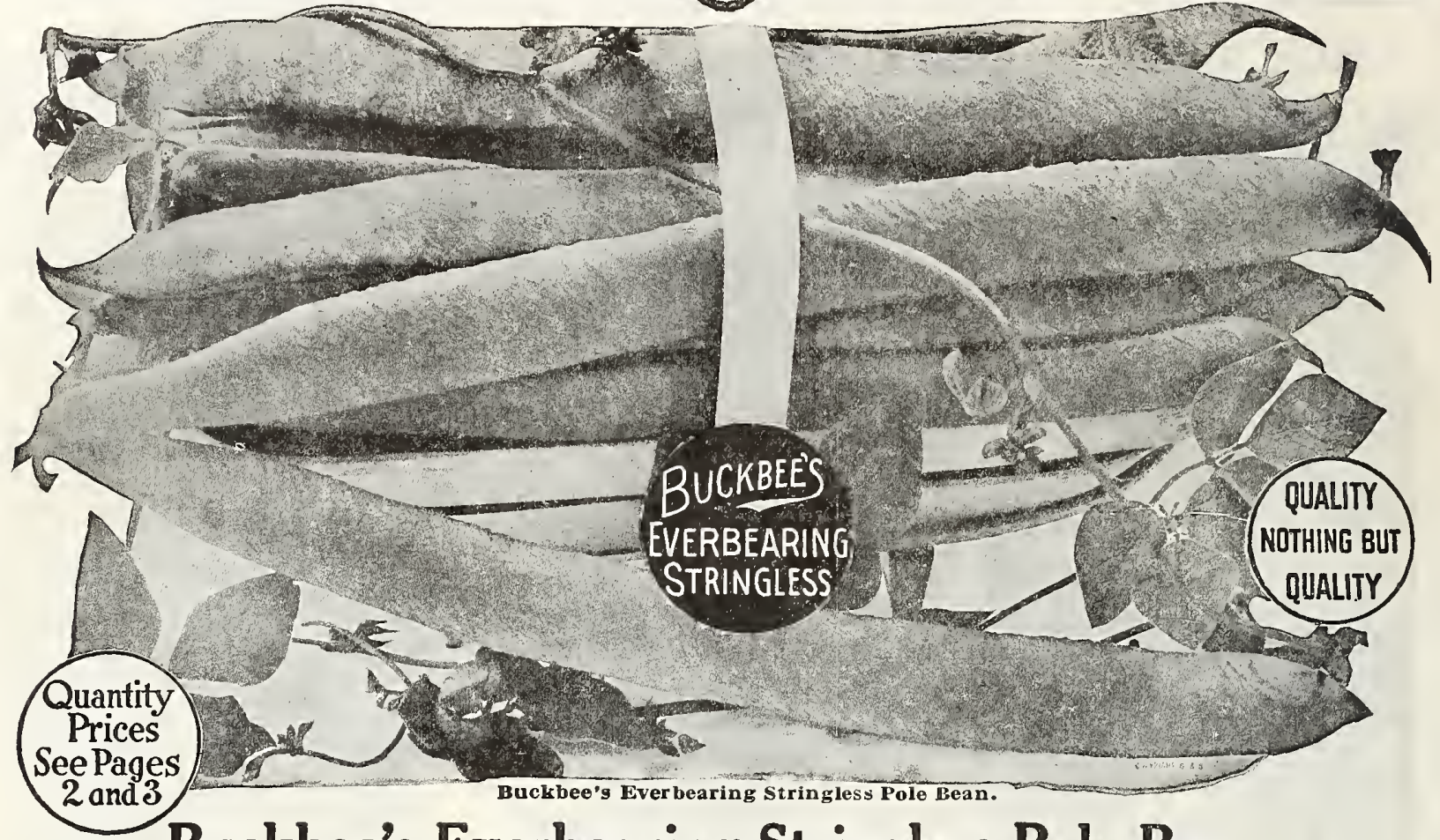

\section{Buckbee's Everbearing Stringless Pole Bean \\ The New White Seeded Marvel}

\section{Wonderfully Prolific - Continuous Bearer - Absolutely Stringless - Green}

Podded - Buttery - Rustless - World-Beating Pole Bean

This greatest of all Pole Beans, originated on Rockford Seed Farms, and has been bred up to the highest degree of perfection after years of careful work and selection. (It combines the best qualities of its parents, namely: The well known Famous Kentucky Wonder and the equally well known Lazy Wife.) Truly the indispensable, heavy yielding, Pole Bean for the home garden, unequalled for the market garden and truckers, the leader for long distance shipping. Robust hardy climbing habit, exceptionally early. The enormous, rich, dark green pods, which often measure from seven to nine inches long, produced in immense clusters, entirely stringless, containing from 5 to 7 Beans, particularly handsome, solidly meaty, admirable form, and free from coarseness-when cooked, exceedingly tender, the flavor is deliciously mild and sweet. The dry Beans are of a beautiful ivory whitelless. We own the entire stock of Buckbee's Everbearing and having harvested a good crop the past season have placed our prices within reach of all for our own growth, choicest, pedigreed, “Full of Life" Seed. Order Early. Prices, postpaid, large packet, 10c; $1 / 2$ pt. 17c; pt. 28c; qt. $47 \mathrm{c}$.

\section{BEST POLE OR CLIMBING LIMA BEANS}

Buckbee's New King of the Garden Lima

The Cream of All Pole Limas.

Practical value has been the object aimed at in the development of this grand variety, which is the outcome of skilled solection. It furnishes the largest green Beans, and is the most easily shelled of any of the Limas. The green shelled Beans are of immense size but so tender and succulent that they shrink in drying to about the size of the Large White Lima. It is the best Lima Bean ever offered for market gardeners' use. Postpaid, pkt. $8 \mathrm{c}$; $1 / 2$ pt. 15c; pt. $25 \mathrm{c}$; qt. $40 \mathrm{c}$.

\section{Mammoth Podded Horticultural}

The mammoth pods are striped and splashed with exceedingly brilliant crimson. The Beans, when in condition for use, are of immense size, of the finest quality. Postpaid, pkt. $8 \mathrm{c} ; 1 / 2$ pt. 15c; pt. 25c; q t. $40 \mathrm{c}$

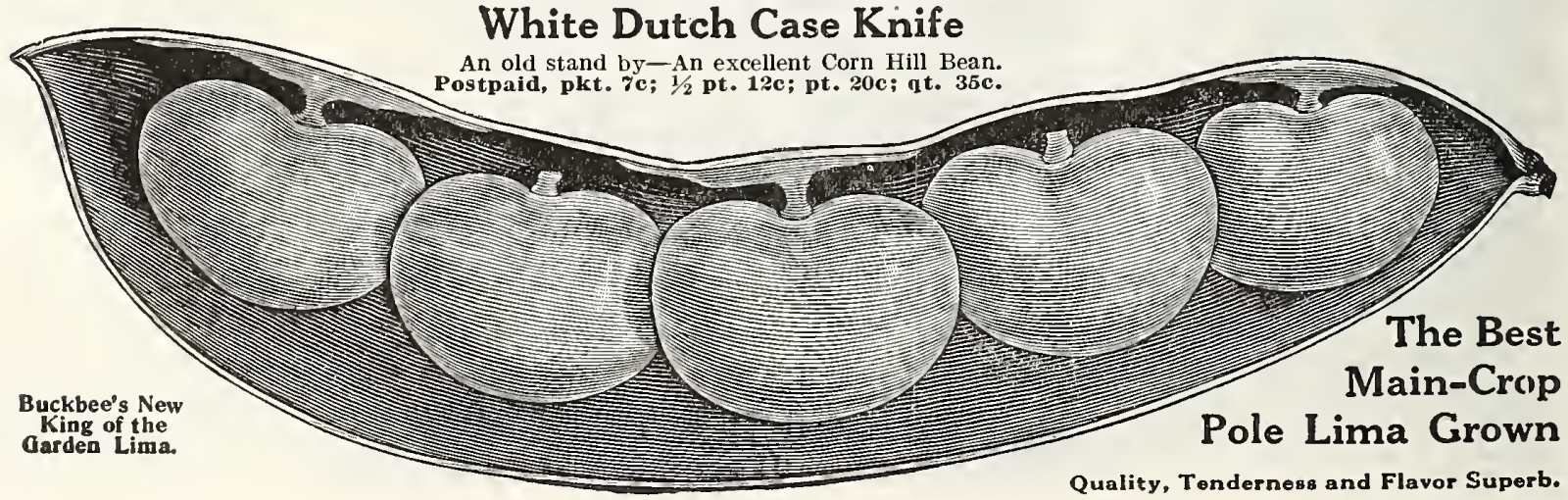

\section{Seibert's Early Lima}

Earliest of All Pole Limas.

The vine is exceptionally hardy, vigorous, and not only produces pods earlier, but continues bearing longer than any other sort. In earliness, ease of shelling, size, beauty and quality of green Beans, this variety is far in advance of all others. Postpaid, pkt. 7c; 1/2 pt. 12c; pt. 22c; qt. 38c.

\section{Early Large White Lima}

Regular strain, pods and Beans of large size. Postpaid, pkt. 6c; $1 / 2$ pt. 12c; pt. 20c; qt. $35 \mathrm{c}$

\section{Scarlet Runner}

A good Bean for snaps for green shelled; but its profusion of bright scarlet flowers makes it an ornamental climber. Postpaid, pkt. 7c: $1 / 2$ pt. 15c; pt. $25 \mathrm{c} ;$ qt. $40 \mathrm{c}$. 


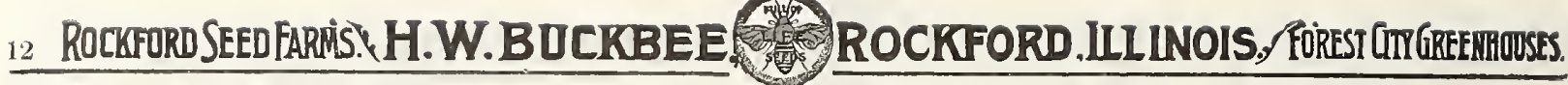
TABLE "FuCKBEE'S BEETS

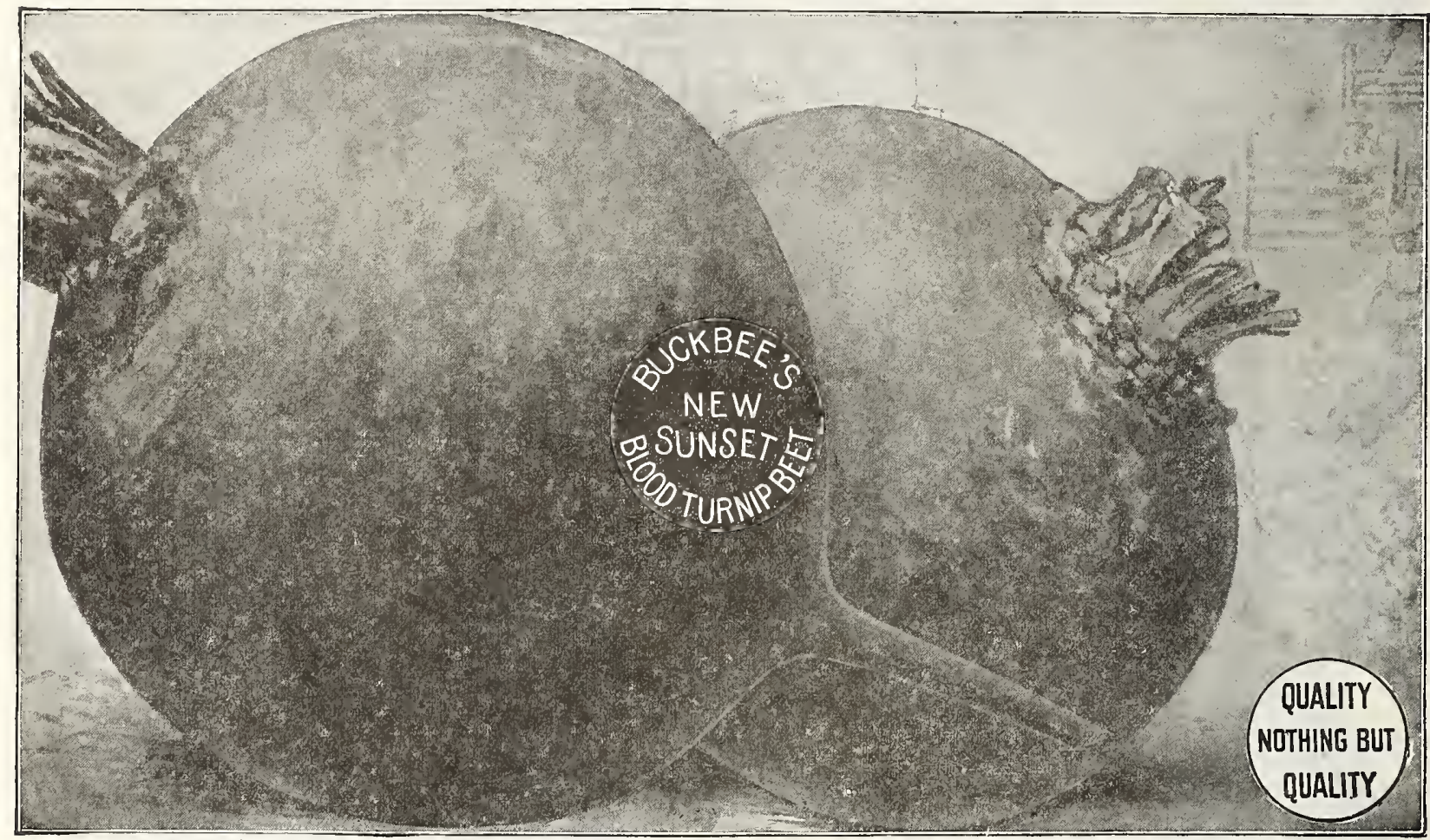

\section{Buckbee's Sunset}

Without Exception the Greatest Beet on Earth.

This grand novelty awarded Prize Medal. The director of the Maine Experimental College at Orno, writes: "I consider Buckbee's Sunset the most promising new variety." Extended experience has shown this variety of our own introduction to be one of the best sorts, not only for market gardeners, but for the home garden. This variety was introduced as an improvemen in turnip-shaped Beets for table use, and we have, by careful selection, improved cach succeeding crop, until we feel certain that it is by far the best red turnip Beet in cultivation. Tops small, upright growing so that the rows may be close together. The stock which we off $\in \mathrm{r}$ will produce a crop more uniform in shape, color and quality than any other. We control the entire

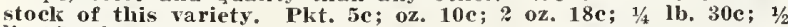
Ib. $55 \mathrm{e} ; 1 \mathrm{lb} . \$ 1,00$

\section{Detroit Dark Red Turnip}

A most excellent turnip rooted sort It grows to a large size, is of most handsome appearance, and is vcry productive in all soils and location and in all seasons. The tops are small, upright growing, so that the rows may be planted close together. Leaf stems and veins are dark red, blade green, roots globular, perfectiy smooth dark blood red. red, zoned with a darker shade, very crisp, tender and sweet, remaining so a long time. Ikt. 1c: oz, 8c; 20 $15 \mathrm{c} ; 1 / 4$ lb. $28 \mathrm{c} ; 1 / 2$ lb. $50 \mathrm{c} ; 1 \mathrm{~b}$. $90 \mathrm{c}$.

Dewing's Improved Blood Turnip

Flesh deep blood-red, very tender and sweet: grows uniformly to a good size, Plit. 3c; oz, ze; 0 oz. 1ze; $1 /$ size, Plit. 3c; $0 \mathrm{oz} ; \mathrm{c} ; 2$;

\section{Early Blood Turnip}

Good Standard Early Beet. A round, smooth variety, very eariy, vigorous grower; with small top and $2 \mathrm{oz} .12 \mathrm{c} ; 1 / 4 \mathrm{lb} .92 \mathrm{c} ; 1 / 2 \mathrm{lb}, 40 \mathrm{c} ; \mathrm{lb}, 75 \mathrm{c}$

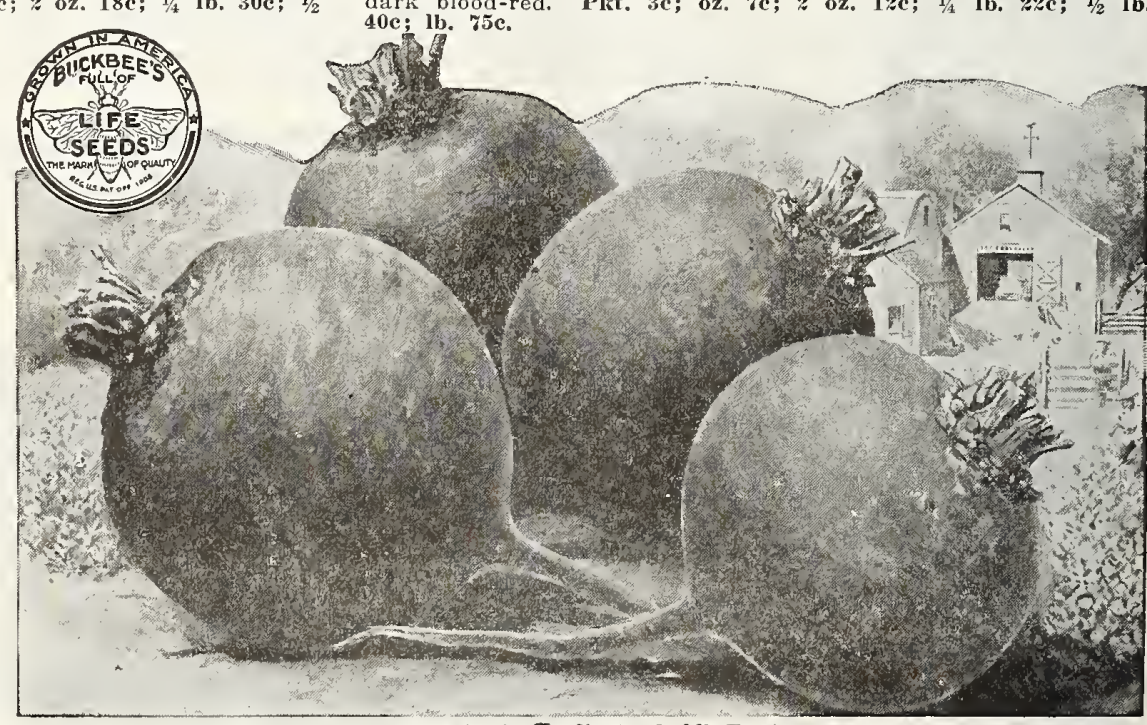

Buckbee's Earliest of All Beet.

\section{Buckbee's Earliest of All}

The Best listra Garly Red Turnip Beet.

The best red turnip beet, not only for market gardeners, but for home use, and for canning, making a strilsingly handsome product, much superior to that obtained from any other variety. Its small top, early maturing and the splendid shape and color of root make it popular with every one who plants it. Top small, upright growing, so that the rows may be close together; leaf stem and yeins dark red, blade green; root globular or ovoid and very smooth; color of skin dark blood red; flesh deep vermillion red, zoned with a darker shade; very crisp, tender and sweet and remaining so for a long time Plkt, 5c; oz. 10c; 1/4 1b. 30c; $1 / 2$ lb. $55 \mathrm{c} ; 1 \mathrm{lb} . \$ 1.00$

Edmand's Early Blood Turnip

Roots round and smooth, good marketable size; skin and flesh Plet. 3c; oz. re; 2 oz. 12c; $1 / 1$ lb. 22c; $1 / 21$ lb. $40 \mathrm{c} ; 1 \mathrm{~b} .75 \mathrm{c}$. 


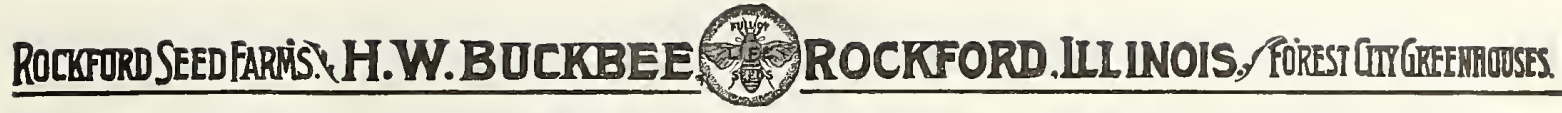

\section{BUCKBEE'S “FULL OF LIFE" GARDEN BEETS ${ }_{\text {UORE }}^{\text {TABLE }}$}

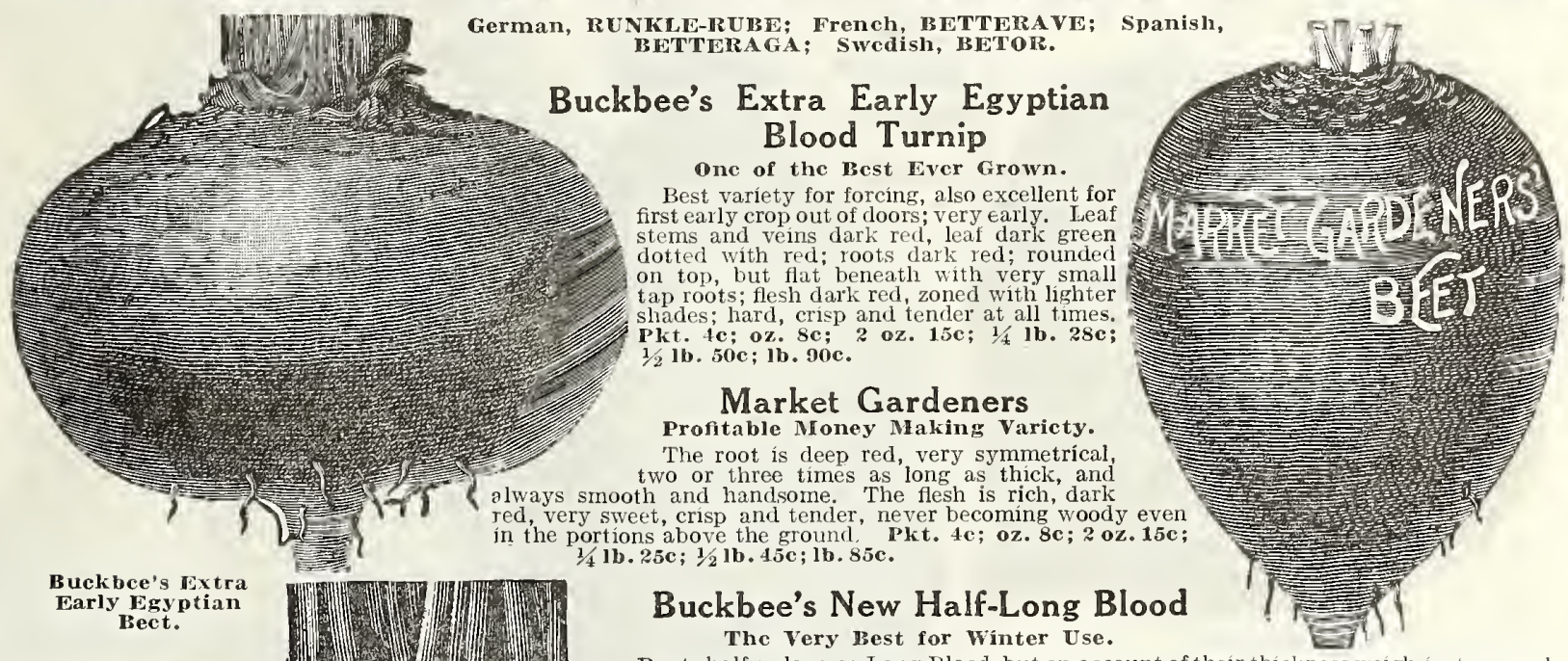

Roots half as long as Long Blood, but on account of their thickness weigh just as much. Always smooth; rich dark red flesh; sweet, crisp, tender and never woody, even

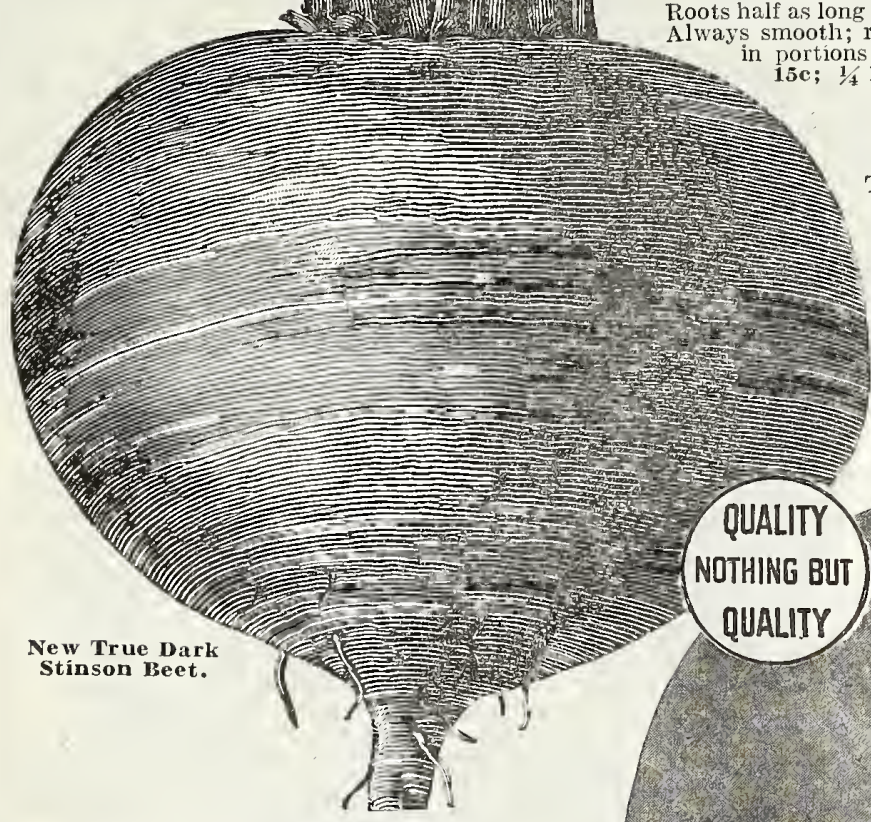

New True Dark Stinson

Dark Red Color; Long Kceper.

Excellent for the open garden. This is particularly valuable for forcing, because it produces less foliage than any other variety, and can be grown close together. The roots are smooth and regular in form; the skin is dark blood-red. Flesh fine grained and cooks dark blood-red. Remains in fine condítion for a long tíme. Pkt. 4c; oz. $8 \mathrm{c}$; 2 oz. 15c; $1 / 41 \mathrm{lb} .28 \mathrm{c} ; 1 / 2 \mathrm{lb} .50 \mathrm{c} ; 1 \mathrm{~h} .90 \mathrm{c}$.

\section{The Bismarck}

The Best Late Blood Turnip Beet.

Combines more good qualities than any other variety (Buckbee's Sunset excepted). Rich, red flesh, exceedingly tender, remarkably early. In shape it is almost round. But it is when prepared for the table that its fine qualities become most apparent. The flesh, of delicate texture, is rich, sugary and entirely free from fibre. We control the en tire supply of seed of this variety. Pkt. 5c;oz. 10c; 2 oz. 55e: $1 \mathrm{~b}, \mathrm{sic}$

Columbia

Deep Blood Red, Splendid Quality.

The roots are of a neat turnip shape, with smooth skin and deep blood-red flesh, of rich, tender quality. It is ready to use very early, growing as quickly as does the Egyptian, while it does

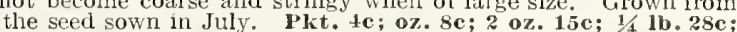
$1 / 21 \mathrm{~b} .50 \mathrm{c} ; 1 \mathrm{~b} .90 \mathrm{c}$.

A MOST ROOK HOW TO GROW FLOWERS AND VALUABLE BOOK SEEDS. It tells the whole story in a practical way. Price only 50c, or FREE with an order for $\$ 1.50$ or upwards, if requested on the order. 


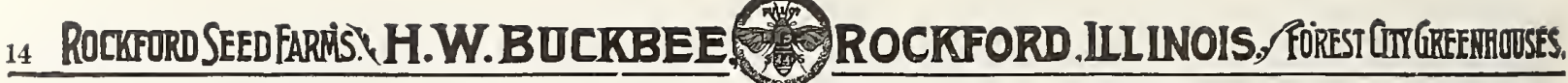 BUCKBEE'S “FULL OF LIFE” GARDEN BEETS ${ }_{\text {USE }}^{\text {FABE }}$}

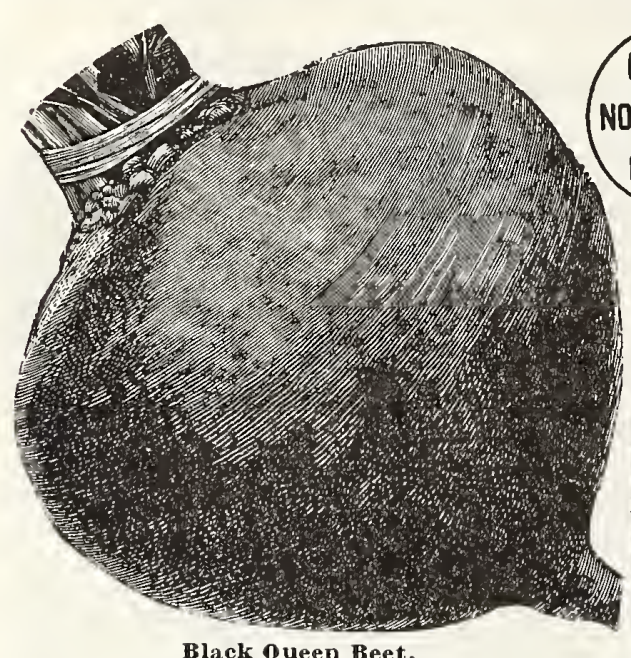

Black Queen Beet.

BLACK QUEEN

Darkest of All Blood Red Beets.

Roots pear-shaped of medium size, fine form nearly buried in soil. Flesh deep red color, almost black. leaves large, nicely crimpled. Pkt. 4c; oz. $8 \mathrm{c} ; 2$ oz. 15c: $1 / 4$ lb. 28c: $1 / 2$ lb. 50c; 1 b. 90c.

\section{BUCKBEE'S IMPROVED LONG DARK SMOOTH BLOOD}

The Standard Long Blood Beet; Excellent for Greens. Neck small, roots large, tapering towards both ends; dark red flesh; tender and sweet, and remaining so even when kept toc: $1 \mathrm{~b} .7 \mathrm{c}$.

\section{CROSBY'S EGYPTIAN}

One of the Earliest Beets in the Market. Deep red, almost black in color and of finer quality than the an, being sweeter and more tender and smoother. The most desirable sort for small Beets for early market, as it is in presentable market shape quicker than any other sort. It is a very rapid grower and can be sown outside as late as Jul

\section{EARLY YELLOW TURNIP}

\section{Similar to the A Very Popular Variety.} yellow. It is of a very sweet, fine flavor and is deservedly popular. The roots are round and smooth and are of good marketable size. The shape is the kind most desired. As a matter of fact, the Early Yellow has much to recommend it and should please you. Pkt, 4c; $\mathbf{0 z}, 8 \mathbf{c}$

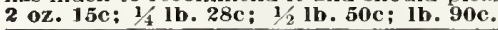

H. R. Cornwell, Loca, okla., writes:-I received your book on "How to Grow Plants and Flowers" and think it is a valuable book and every farmer should have one.

I will say your "Full of Life" seeds are excellent-proved good -and there were none of my neighbors but what wanted seed of the Jerusalem corn. The past year was dry and nothing did well but your seeds did fine. I can recommend them anywhere.

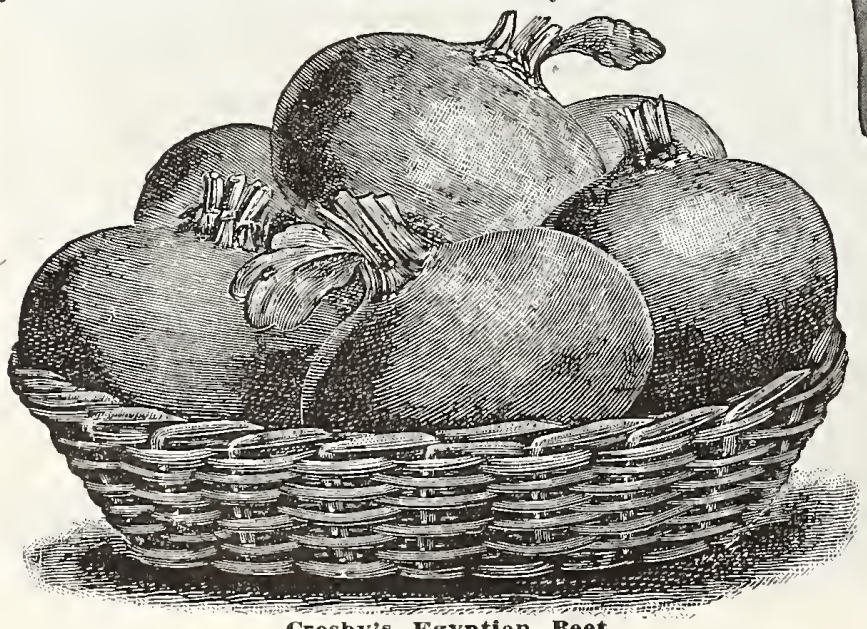

Crosby's Egyptian Beet

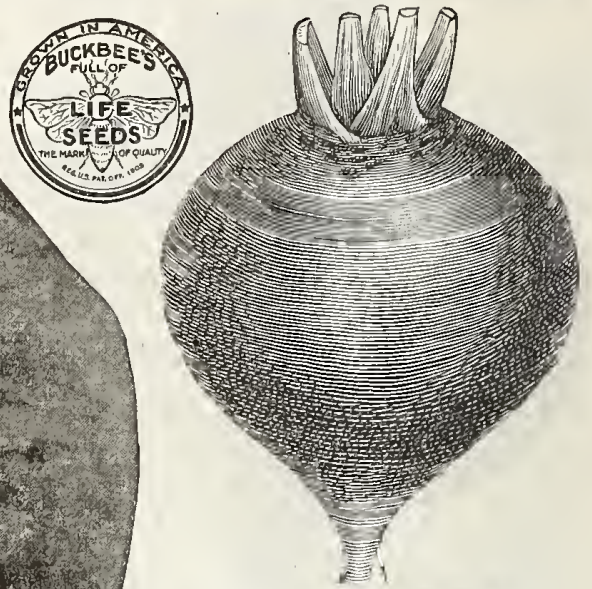

Early Yellow Turnip Beet.

\section{LATE BLOOD TURNIP} standard Late Beet.

Popular everywhere. Symmetrical in shape; flesh deep blood-red color, tender and sweet. Pke. 3c; oz. re; z oz. 12c: $1 / 41 b .22 c ; 1 / 2$ lb. $40 c ; 1 b .75 c$

NEW EARLY ECLIPSE The Popular Beet for Early Use.

Tops small, dark purplish green. Roots nearly globular, with a small tap root and collar. A splendid variety. Flesh dark red, Pkt. 4c; oz. 8c; 2 oz. 15c; $1 / 41$ lb. 25c; $1 / 21 b$. $45 \mathrm{c} ; 1 \mathrm{~h} .85 \mathrm{c}$.

A. F. STANLEY, Morriston, Ala., writes: I am pleased to send you this clipping from my duced I got from you.

\section{EXTRAORDINARY BEET}

A large Mangel Wurzel Beet brought in by Mr. A. F. Stanley for exhibition Saturday, measured 20 inches in circumference and 28 inches in length. Its weight is 11 lbs. Mr. Stanley has considerable land planted in these beets and estimates that they will vield fort $y$ tons to the acre. He uses them for stock feed.
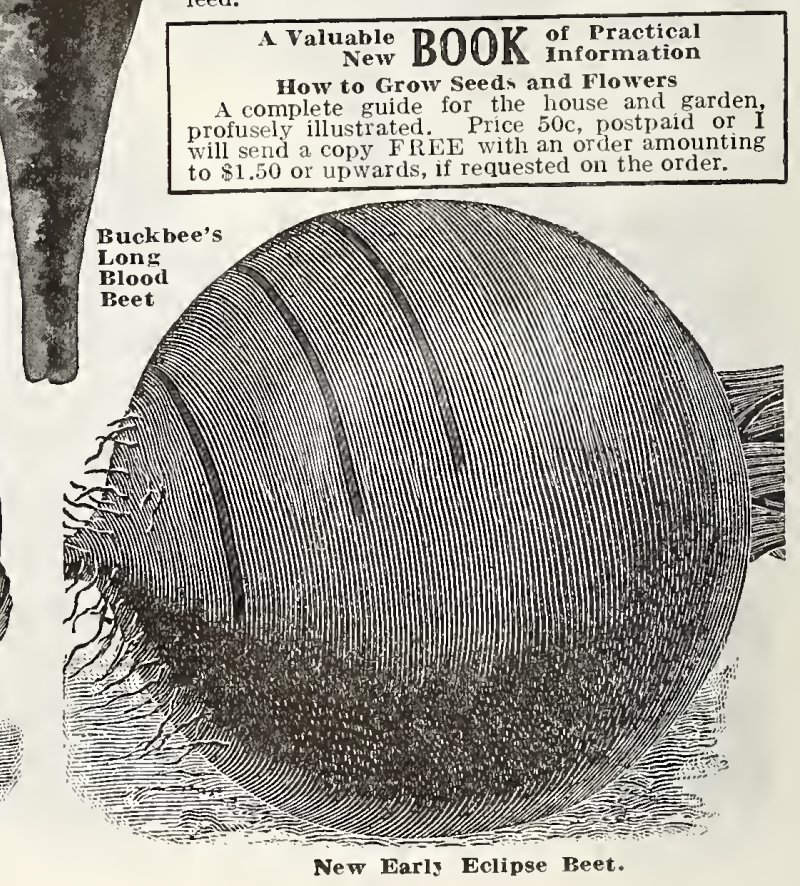


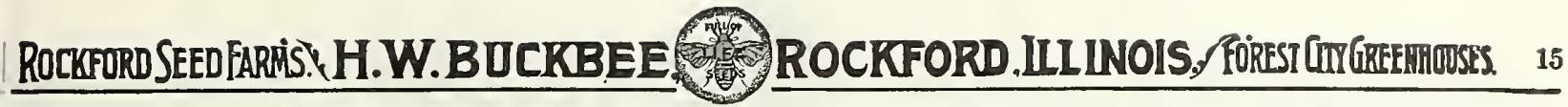

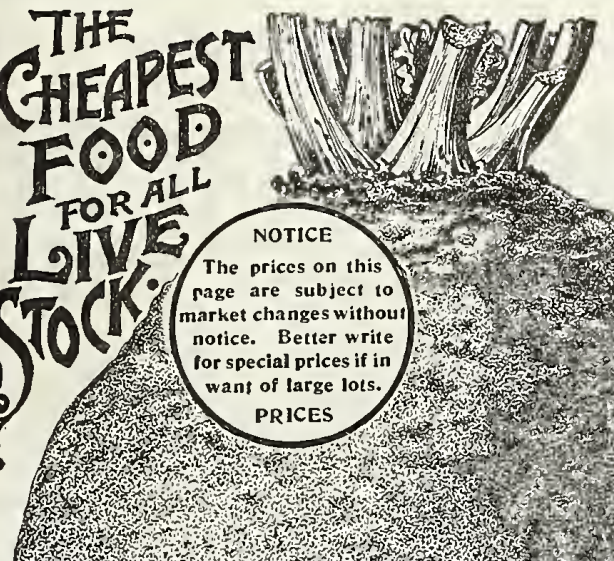

MANGEL

WURTZELS

Any land that will grow a good crop of Corn, will produce a good crop of Mangels or Sugar Beets, and is a surer crop than any other root. Plant 5 pounds of Seed per acre.

\title{
BUCKBEE'S MASTODON
}

The Heaviest Cropping and Largest of All Mangels

It is truly a Mammoth, a single root often weighing 60 pounds each and often 75 lbs, and over: in yield it is enormously productive- 1,500 to 1,800 bushels per acre is nothing uncommon on good soil. It grows well above ground and on account of its shape is easily harvested. In length it is about the same as Buckbee's
Mammoth Long Red, but is more remarkable for its handsome shape and broad shoulders, the diameter being greater, and in weight much heavier; flesh deep red, fine texture, roots solid, tops small. In fact it combines all the fine points possible to condense in a Mangel of the highest nutritive value, and is without question the best and most profitable Mangel for dairy farmers. This is our pedigree stock-especially selected, and can be relied upon as the best money can buy and our moderate prices place it within paid.

BUCKBEE'S MAMMOTH LONG RED

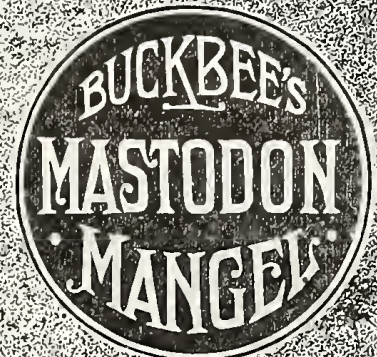

A Wonderful Yielder.

A standard and favorite Mangel, producing a very large root uniformly straight and well formed, weighing from 30 to 40 pounds each, of a beautiful dark red color, wonderfully productive, average 1,000 to 1,500 bushels per acre. Keeping qualities not excelled. Our stock is a great improvement over the old

\section{GOLDEN TANKARD}

The Great Mllk Producer.

This distinct variety is a most important addition to our list of roots for stock feeding, as it contains less water and more sugar than most Mangels. Sheep and all other stock thrive wonderfully on it. $\mathbf{0 z}$ : $1 / 4$ lb. 18c: $1 / 2$ lb. 30c: lb. 60c, postpaid.

NEW GOLDEN MONARCH A Splendid Kecper.

This entirely new and distinct Mangel grows to the largest size and is of a beautiful russet yellow color. The flesh is white. firm and sweet,
greatly relished by cattle and other stock. Easily lifted, growing more than half above ground, producing enormous crops, and is an excellent keeper. oz. 6c: $1 / 1$ 1b. 18c: 1/2 1b. 30c: $1 \mathrm{~b}$. 50c, postpald.
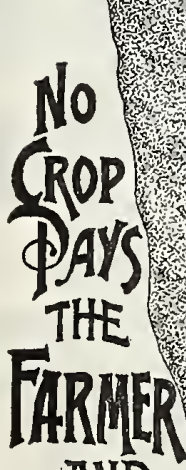

AND

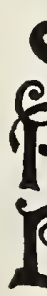

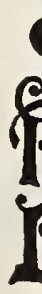

\section{CHAMPION RED GLOBE}

Similar to above except in color, which is a light red or pink. Oz. 5c: $1 / 4$ lb. 18c: $1 / 2$ lb. 25c: Ib. $45 \mathrm{c}$, post paid.

\section{GIANT OR MAMMOTH JUMBO}

A large long red variety of excellent quality. Oz. 5c: $1 / 4$ lb. 16c: $1 / 2$ lb. 25c: lb. 40c, postpaid.

\section{EIFFEL TOWER}

\author{
Produces \\ onderfully long red roots. Oz. 5c: 1/4 lb. 12c: 1/2 $1 \mathrm{lb}, 20 \mathrm{c}: 1 \mathrm{~b} .35 \mathrm{c}$,
}

\section{MIXED MANGEL SEED}

Choicest sorts mixed. Oz. 5c: $1 / 4$ lb. 15c: $1 / 21 b$. 25c: 1b. 40c, postpaid.

NOTE:-Write for special prices on larger quantities. Mangels give one-third greater increase of milk in feeding cows than does the same weight of potatocs. Send to Secretary of Agriculture, Washington, D. C., for Special Bulletin on Mangel and Beets.

Mrs. M. I3. Wilson, Taylorville, N. C., writes:--“I want to say I have raised the largest Beet from your 'Full of Life' seed I ever saw grown, one that weighted $701 / 21 \mathrm{bs}$. I certainly appreciate 


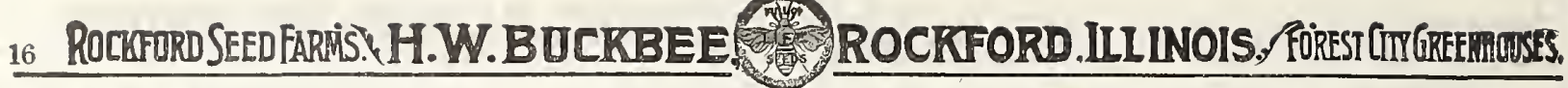

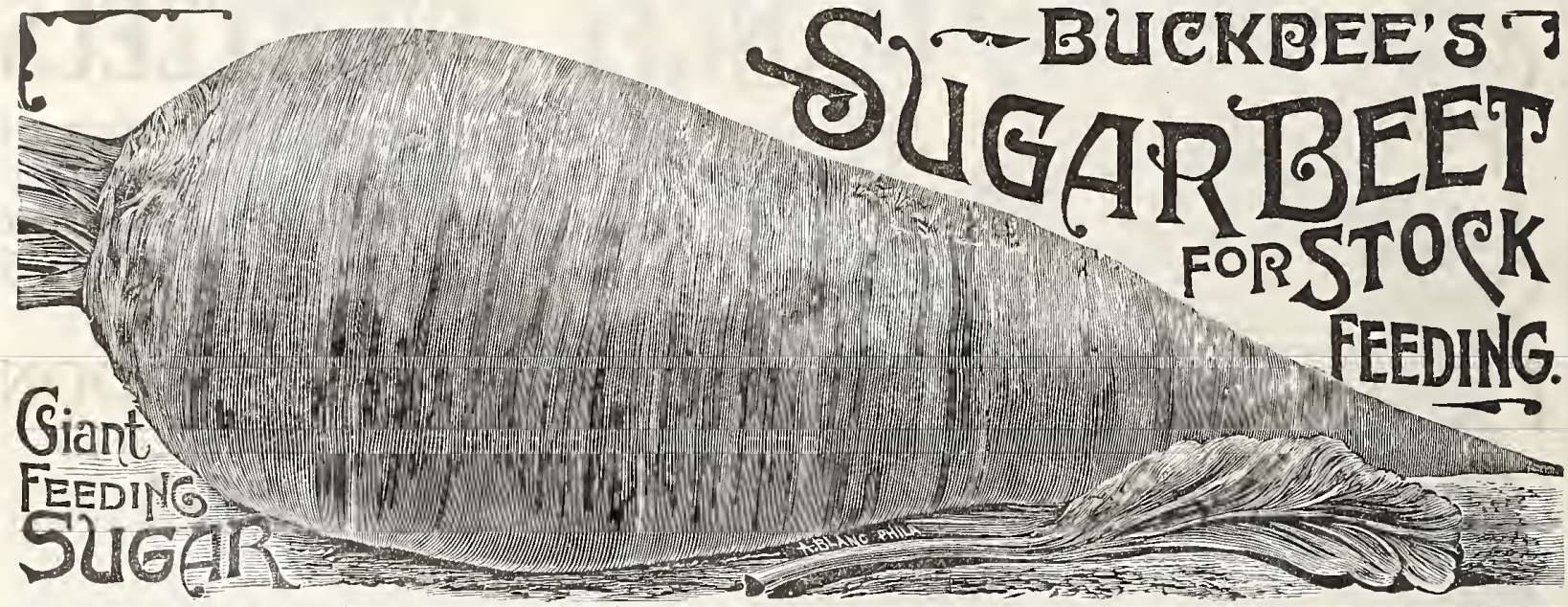

The great value of Sugar Beets for stock Feeding cannot be over estimated, analysis having demonstrated the fact that 400 pounds of Sugar Beets are equivalent to

Giant Feeding Sugar This magnificent Sugar Beet, while giving nearly as large a yield of easily grown and harvested roots as Geing really being really more valuable, pound for pound, than those of the very best strains of Sugar Beet, and the yield under egually favorable conditions being more than double. The roots grow partly out of the ground and because of this and their shape the crop can be harveste

Buckbee's New Imperial Sugar Thas Beet is the result of years of methodical and persevering selection, and rich in organic thousands of analyses showing that the percentage of sugar which can be obtained from this variety is about sixteen. Its average yield may be stated as from 12 to 16 tons an acre. Flesh finely grained and very sweet. We sell thousands of pounds each year to the large Stock Growers and Beet Sugar Factories through the country, always with the most satisfactory results. Oz. 5c; 1/1 lb. 15c; 1/2 lb. 25c; 1b. 40c,

German Sugar Beet (Klein Wanzleben.) This variety at the present time has probably a wider cultivation than any other

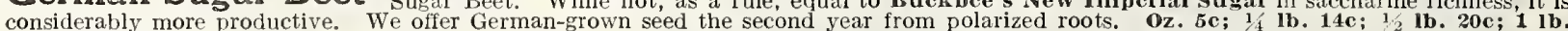
$35 \mathrm{c}$, postpaid.

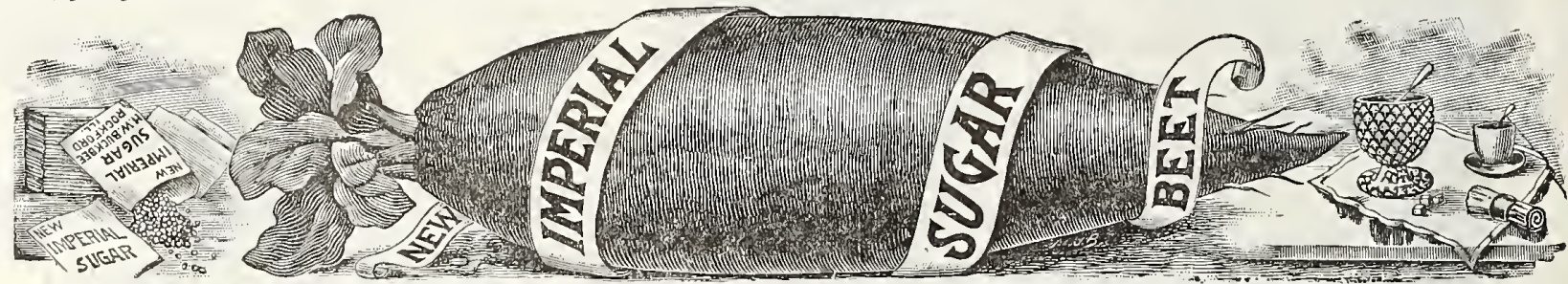

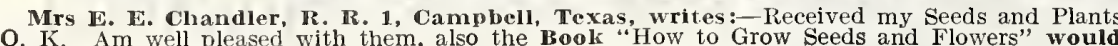
not take a dollar for it.

BROCCOLI

German, SPARGEL-KOHL; French, CHOU-BROCCOLI; SpanIsh, BRoCULI One ounce of seed for 3,5 mo plants

The culture is the same in all essentials as for Cauliflower Broccoli is grown most successit withstands greater extremes of temperature than Cauliflower. EARLY PURPLE CAPIE-This is the best vallety for our climate. It produces large heads NEW WHITE CAPE-A very desirable variety. It has medium sized heads, close and com-
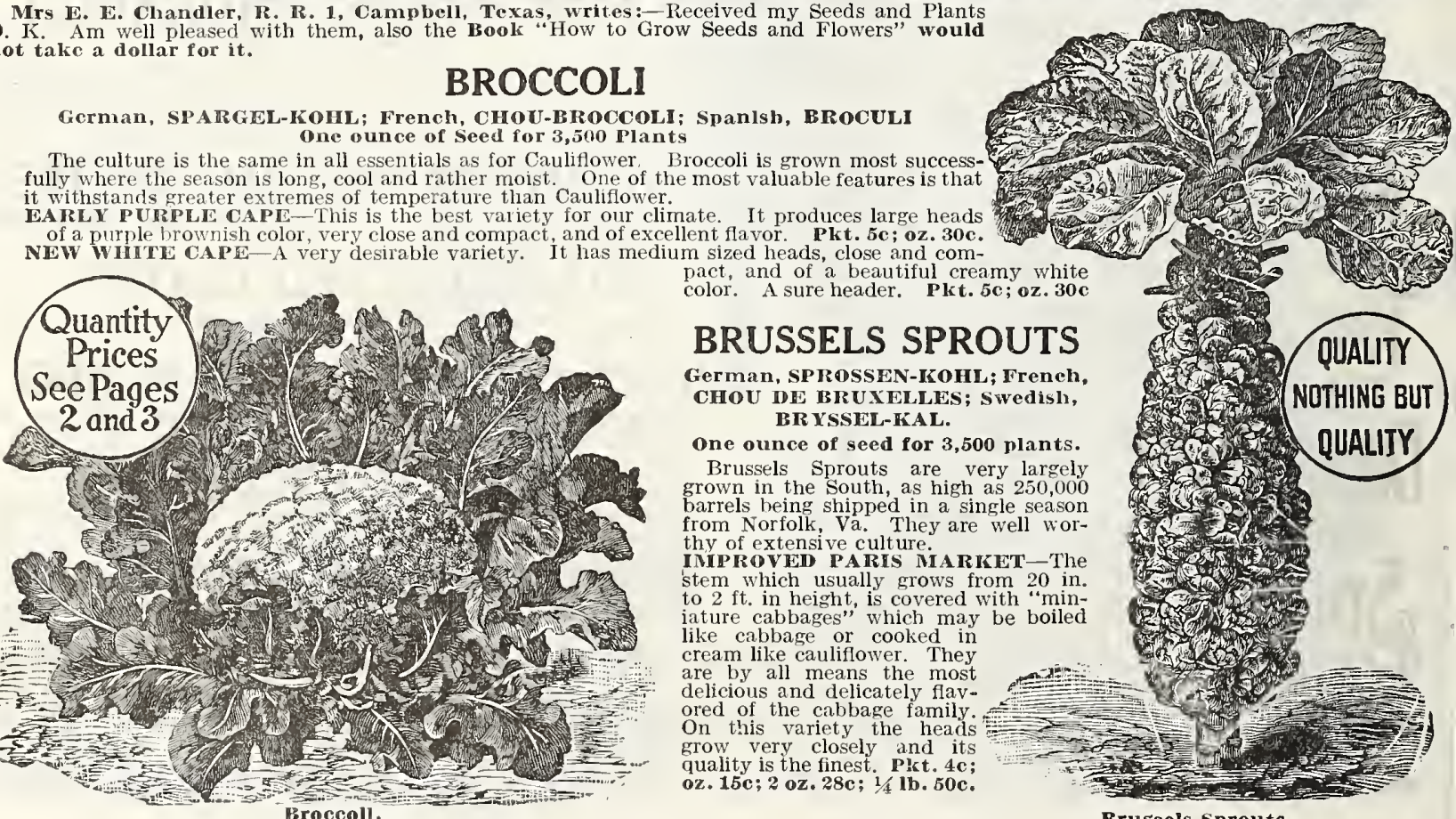

pact, and of a beautiful creamy white BRUSSELS SPROUTS German, SPROSSEN-IKOHL; Freneh, CHOU DE BRU XELLES; Swedisl, BR YSSEL-KA L.

one ounce of seed for 3,500 plants.

Brussels Sprouts are very largely grown in the South, as high as 250,000 from Norfolk, Va. They are well worof extensive culture.

IMPROVEI PARIS MARIEET-The stem which usually rrows from 20 in to $2 \mathrm{ft}$. in height, is covered with "min-
iature cabbages" which may be boiled iature cabbages"' which may cream like cauliflower. They are by all means the most delicious and delicately flavored of the cabbage family. grow very closely and its oz. 15c; 2 oz. 28c; $1 / 11 \mathrm{lb}$. 50c.

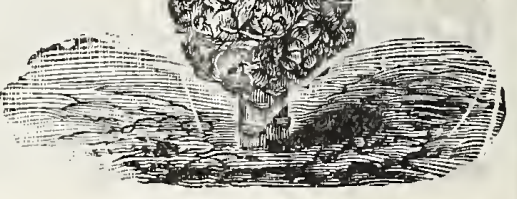

Brussels Sprouts, 


\section{BUCKBEE'S RELIABLE CABBAGE SEED}

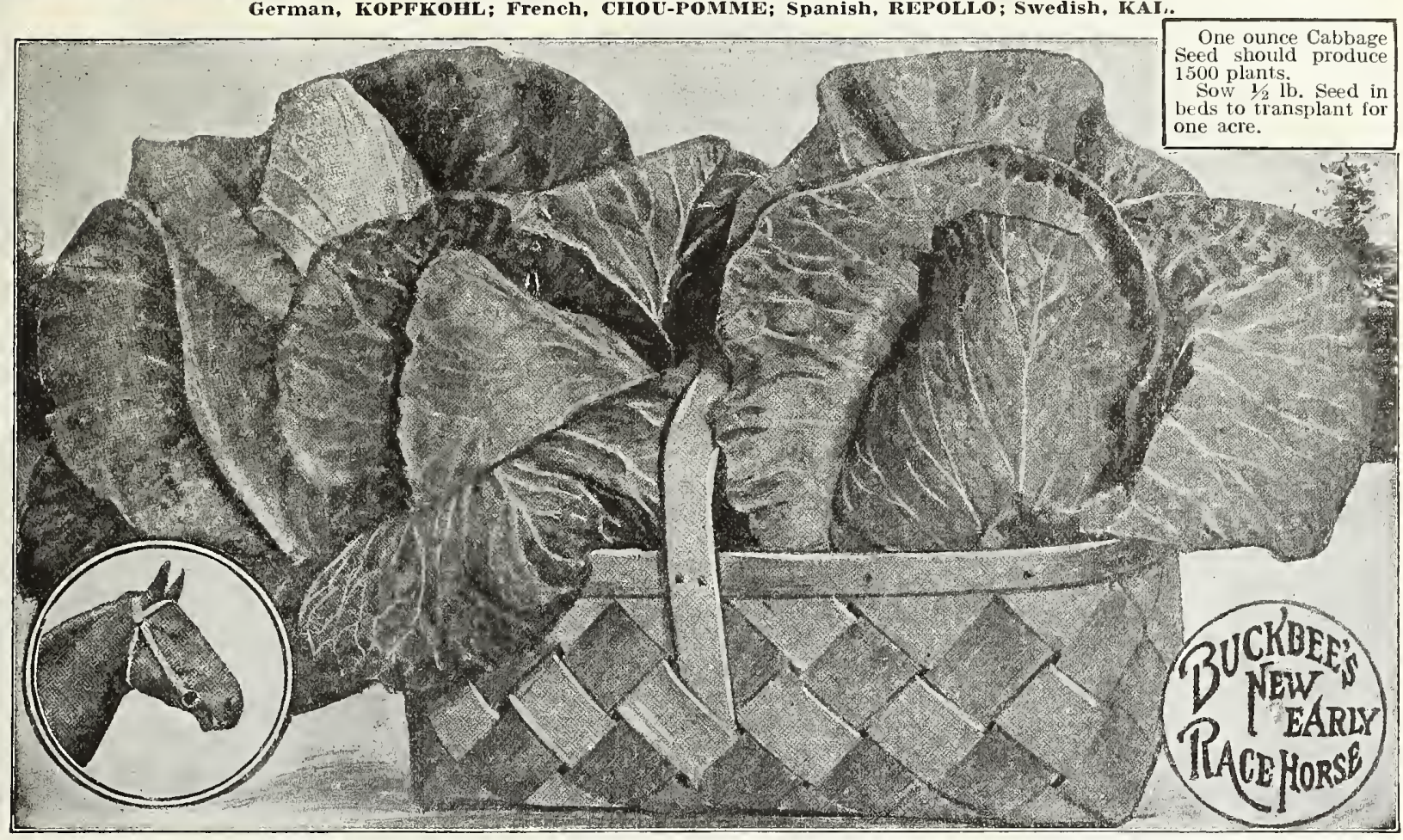

Buckbee's New Race Horse

THE EARLIEST CABBAGE IN CULTIVATION.

Ready to use in sixty days from time of planting. Heads are of good size, weigh from eight to thirteen pounds, have but few outside leaves, and therefore may be planted very close together and
yield large crops. Always of fine flavor and very solid. We control yield large crops. Always of fine flavor and very solid. We control
the entire stock of this earliest of all varieties. Pkt. 10c; oz. 30c; $20 z .50 c ; 1 / 41 b .90 c ; 1 / 21 b . \$ 1.60 ; 1 b . \$ 3.00$.

\section{Buckbee's Faultless}

\section{A Splendid Keeper and Shipper.}

One of the best second early and Fall rarieties ever introduced, is absolutely "faultless." Has been in popular and growing demand ever since its introduction. Sure to head; large and firm; has but
few outside leaves; of vigorous constitution; rapid grower; excellent keeper. Pkt. 4c; oz. 18c; 2 oz. 35c; $1 / 4$ lb. 60c; $\frac{1}{2}$ lb. \$1.10; lb. \$2.00.

\section{Extra Early Express} Good size pointed or oval heads frequently weighing 10 pounds.
Extra early, compact, solid and of fine flavor. Pkt. 3 c; oz. 12c; oz. 23c; $1 / 41 \mathrm{lb}$. 40c; $1 / 2 \mathrm{lb}$. 75c; $1 \mathrm{~b}$. $\$ 1.40$.

\section{Copenhagen Market}

A New Variety Very Popular with Market Gardeners. The heads average about ten pounds each in weight. are hard and
solid with small core. The quality is extra fine and sweet. It matures as early as the Wakefields and will yield more to the acre in weight. . It is a short stemmed variety, the heads nearly resting on the ground. The leaves are light green, rather small, saucer-shaped the field. PKt. 5c; oz. 25c; 2 oz. 40c; $1 / 4$ lb. 70c; 1/2 lb. \$1.30; Ib. \$2.50.

\section{Extra Early Winningstadt}

\section{One of the Best for General Use.}

A very fine header and will grow a hard head under circumstances where most sorts would fail. Plants very compact, with short thick leaves. Heads regular, conical and very hard. Pkt. 4e; oz, 12e: oz. 23c; $1 / 1$ Ib. 45c: $1 / 2$ lb. 80c: 1 b. $\$ 1.50$.

o. Campbell, Holtz, Ill., writes: "Buckbee's Race Horse is the nicest early Cabbage that I raise."

Mrs. Aliee Bankus, Sorrel, Mo., writes:-I used your "Full of Life" Seeds last year, and your Cabbage took the premiun at the County Fair.

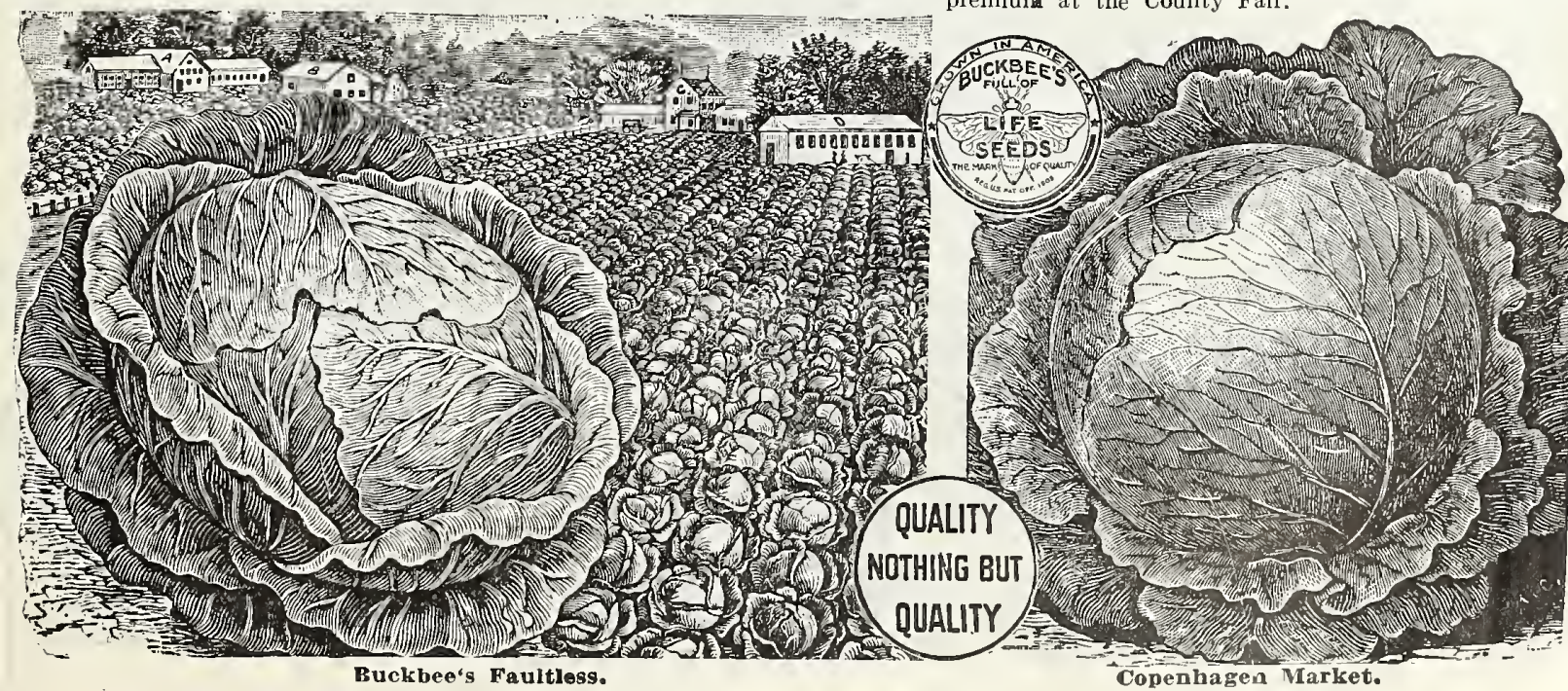




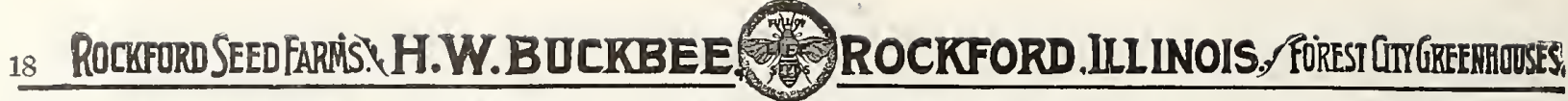
BUCKBEE'S "FULL OF LIFE" CABBAGE SEED

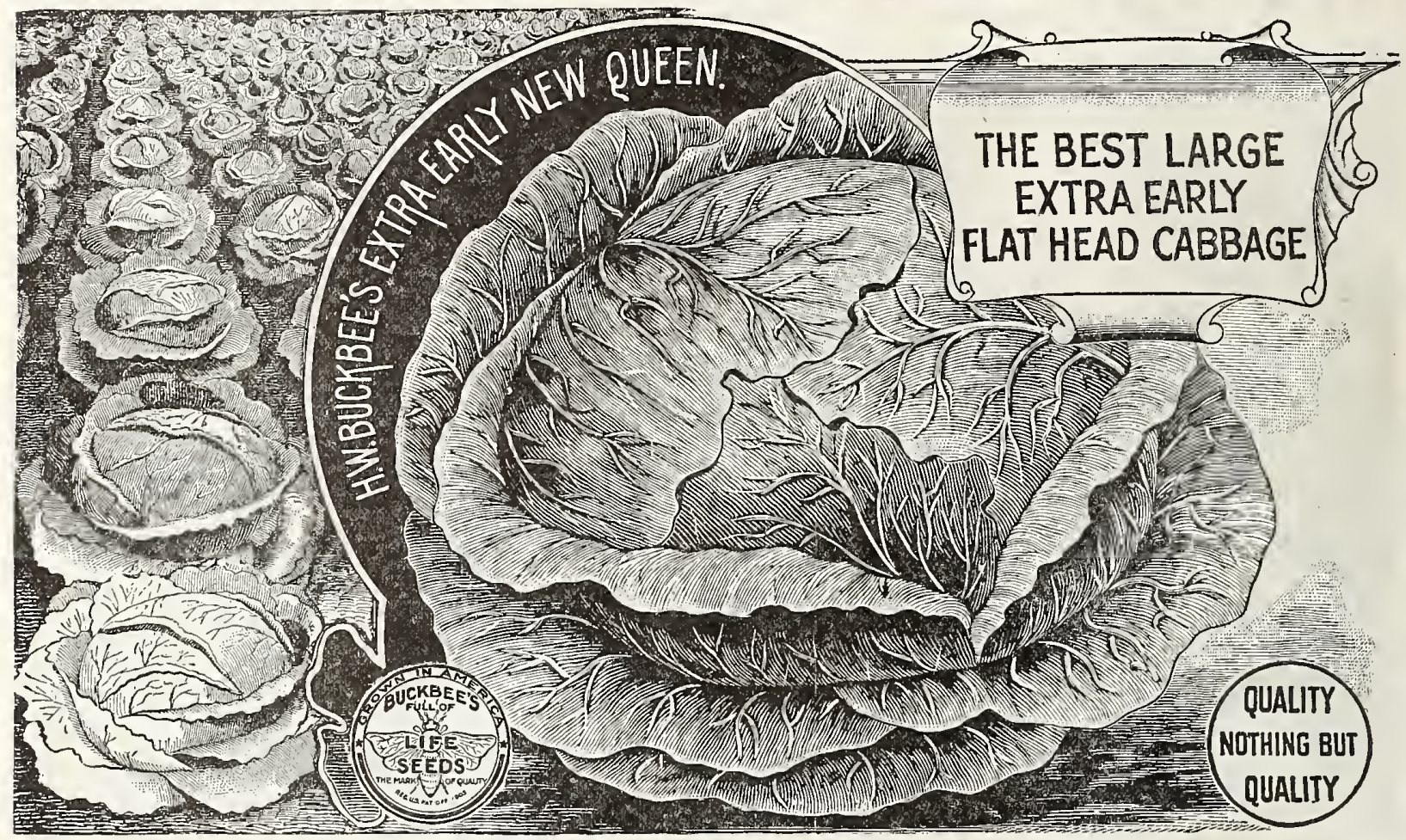

BUCKBEE'S EXTRA EARLY LARGE NEW QUEEN

The Best Large Extra Early Cabbage on Earth Early Large New Quceu has satisfied and made nore money

nearly half grout the country during the

25 lbs.), most solid headed large extra early thoroughbred

ity and always the leader in erery market. Gaines, Cole \&

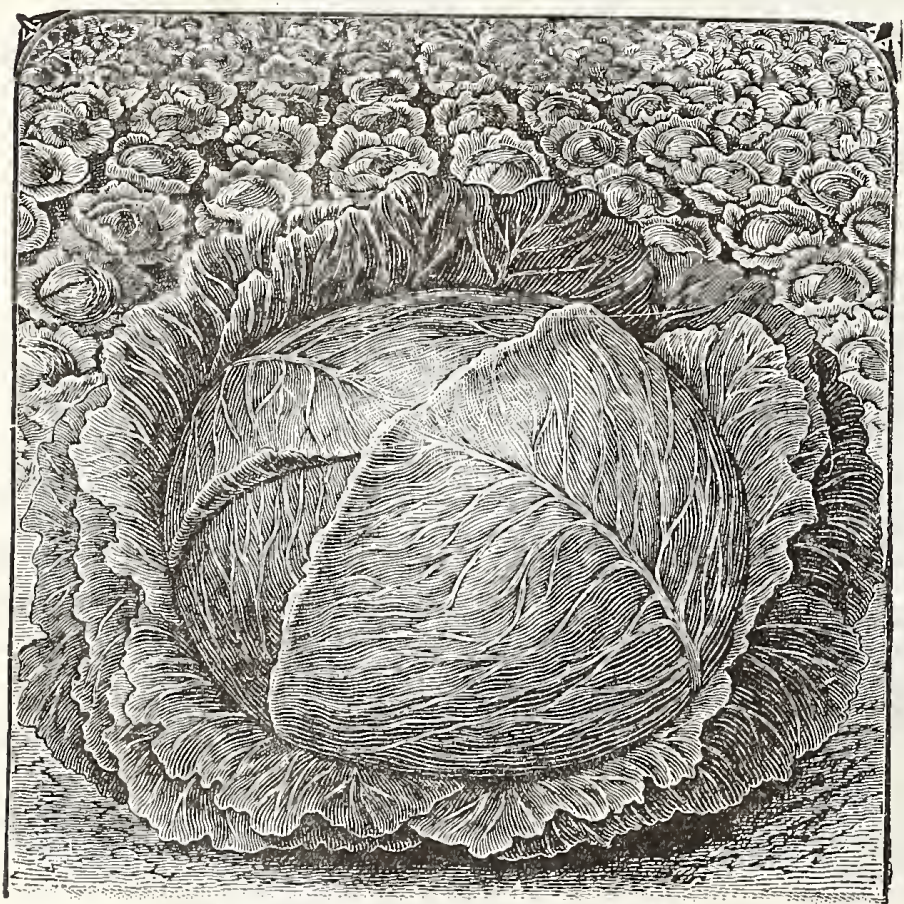

Buckbee's Rockford Market Cabbage
If rou want the best early Cabbare plant Buckbee's Extra Farly Lare New Queen and zou will not be disappointed We coutrol the entire seed supply and offer the choicest "Full of Life" Seed of our own growing at the following reaconable prices. Send to Buckbee for the true "Queen." Order Buckbee's Rockford Market

The Best Second Early Ever Introduced It has the peculiarity of heading firmly at an early stage in its growth, so that the finest Cabbage can be obtained long hefore it has attained its naturai size. Its uniformity in shape, and large vield per acre render it particularly ralunble to truckers, and its compact form and good quality render it the finest second early Cahbage. Plit, 5e; oz. 20c; 2 oz. $35 \mathrm{c}$; $\frac{1}{2} 1 \mathrm{~b} .65 \mathrm{c}$; $\frac{1}{2} \mathrm{lb}$. $\$ 1.25 ; 1 \mathrm{~b} . \$ 2.00$.

John S. Follett, 1037 Josephine St., Marinette, Wis., writes: "After three years' experience with your seeds it may be interesting to know the results. To begin with, let me say that your Christmas King and New Queen both for are undoubtcdly the best kinds ou the market oue will head. In fact, they are two of the best varieties I ever tried. The same cau be said about your Cucumbers and Tomatoes." ohio, wites: "It is a pleasure to tell you that all the sceds we ordered from you last season proved a success. The cabbage was particularly fine and celery the finest you ever saw. Success to you."

\section{MONEY IN CABBAGE}

Did If You Plant the Right Seed of setting an acre of Cabbace cultirating and marleting is no more than the cost of rowing an acre of corn? Ordinarily Cabbage yields 20 tons per acre and rarely sells below $\$ 20.00$ per ton and oftentimes $\$ 40.00$, this means quick, profitable returns to the progressive man. Can you do better than set out an acre or for some of our Pedigreed "Full of Life" Seed that always pleases. 


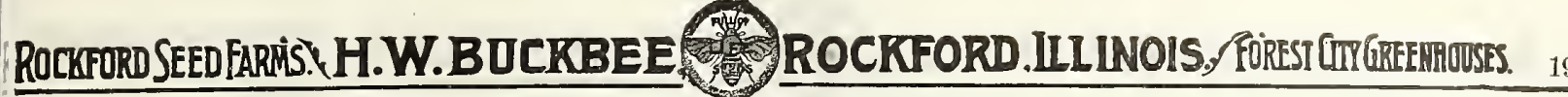 BUCKBEE'S "FULL OF LIFE" CABBAGE SEED}

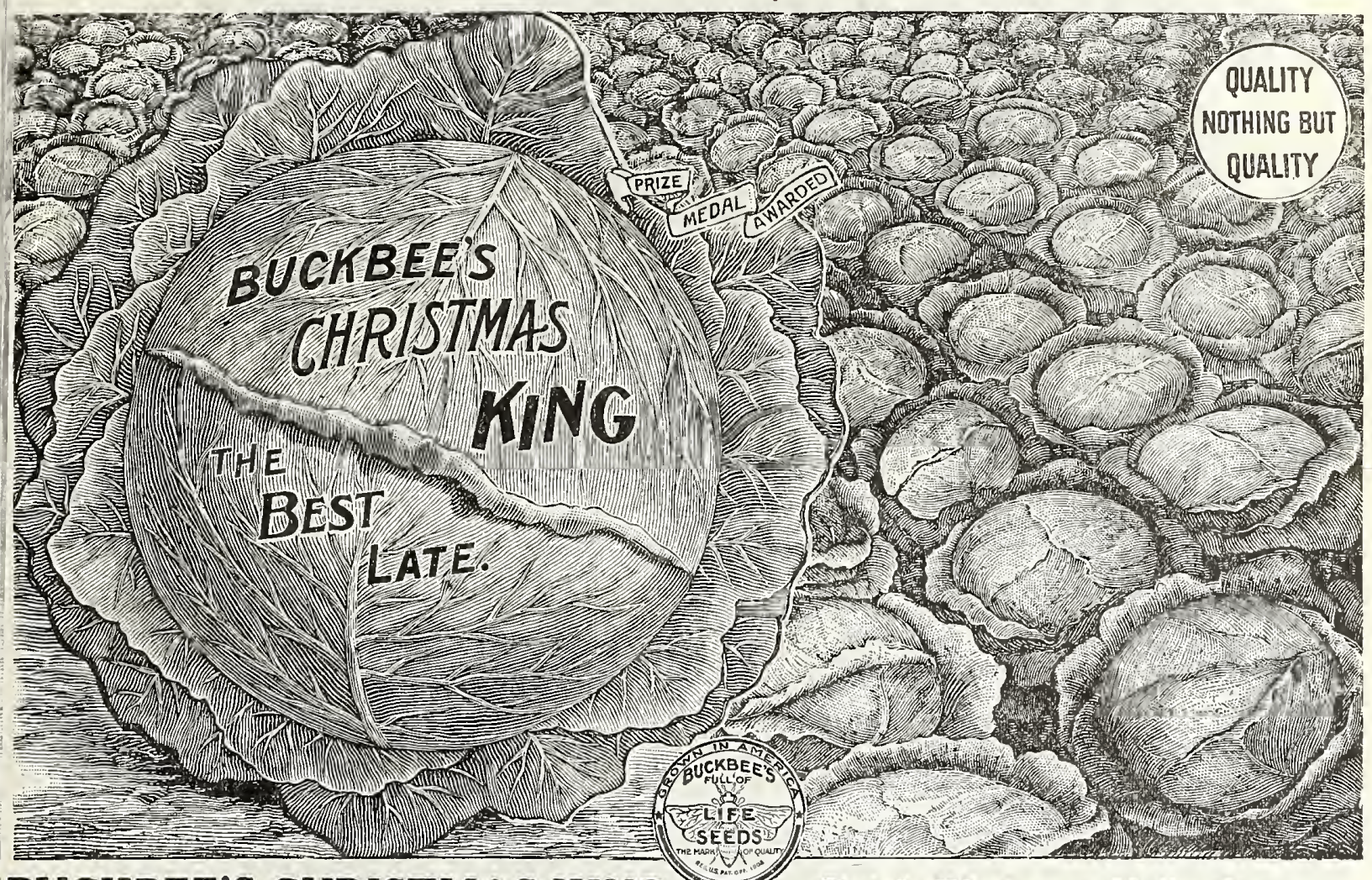

\section{BUCKBEE'S CHRISTMAS KING \\ THE BEST LARGEST LATE.}

The grandest late Cabbage ever introduced. This truly wonderfu late variety of our own introduction has had the greatest run of any late Cabbage on the market, and not one of our customers has been disappointed in the results. 999 out of every 1,000 plants will produce marketable heads, which are of mammoth size (often reaching the flavor, neight of 60 IDs. ) sound, solid, and of the most delcious, and is the best Winter keeper. Best for kraut. We control the complete stock of this variety and offer the choicest "Full of Life" Seed of our own growing at the following reasonable prices. Send to
Buckbee for the true "Christmas King". Pkt. 10c; oz. 30c; 2 oz. Buckbee for the true "Christmas King"
50c; $1 / 41$ lb.90c; $1 / 2$ lb. $\$ 1.60 ; 1 b . \$ 3.00$.

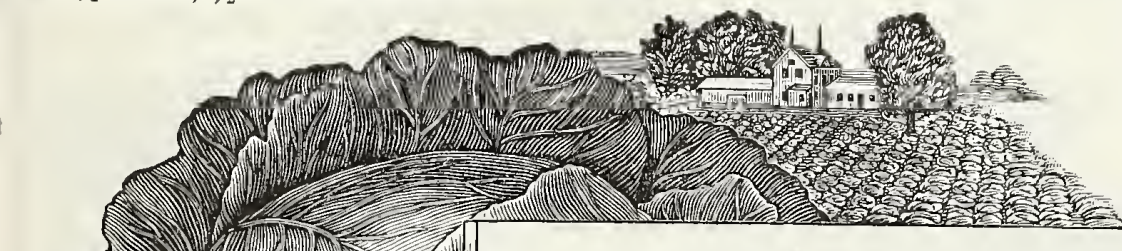

\section{Buckbee's New Century}

The Best Main Crop Cabbage

The very best for general use, being very hardy and sure to head when most sorts fail. It does well at all seasons and is a very surc cropper. Heads regular.

very hard, and keeps well both Summer

and Winter. Pkt. 5e; oz, 250

2 oz. $40 \mathrm{c} ; 1 / 41 \mathrm{~b}$. 70e; $1 / 2 \mathrm{lb}$

$\$ 1.30$; $1 \mathrm{~b} . \$ 2.50$.
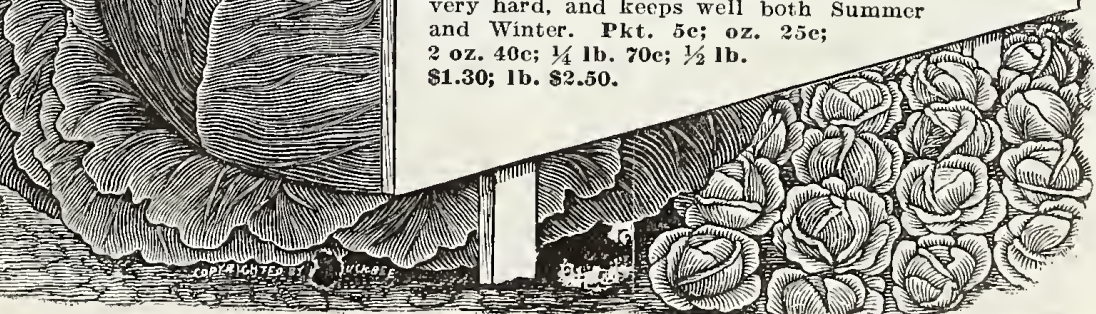

Buckbee's New Century
Large Late Drumhead Closely allied to our Mammoth Bridgepor t Drumhead though not as good a shipper,
Pkt. 3e; oz. 12e; ? oz. 200; 14 lb. 3̌se; $1 / 21 \mathrm{lb} .65 \mathrm{c} ; 1 \mathrm{~b} . \$ 1.25$.

J.L. Nesbitt, Colfax, Wash., writes:all I won eight First and two Second
Prizes at the Fair on Vegetables raised from your seeds, and that in compeRoad Company took the exhibit to the

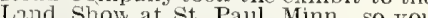
DEAD SHOT

The Magic Bug Destroyer The World's Greatest Remedy To destroy striped Bugs and Caboage Worms and Pests on al Worms, Rose Bugs and all Lice Worms, Fleas, Beetles, Bugs and Sift a small quantity of "DEAD SIIOT" Powder uron instantaneous! Tle Bugs disappear as if by magic beast. Postraid, lb. 20e; By 5lbs. 50c; $10 \mathrm{lbs}$. $75 \mathrm{c} ; 25 \mathrm{lbs}$ ; 50 ibs. $\$ 2.50$

FOR CABBAGE PLANTS See Page 84 


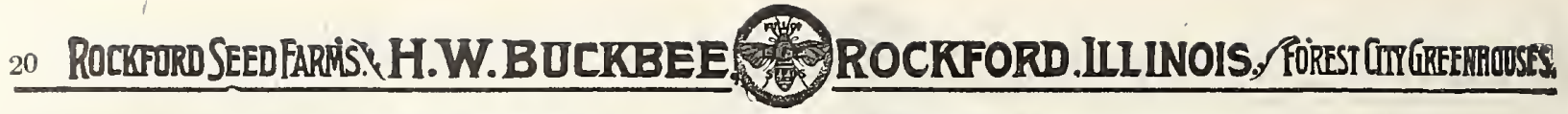
Buckbee's Great Dane Cabbage

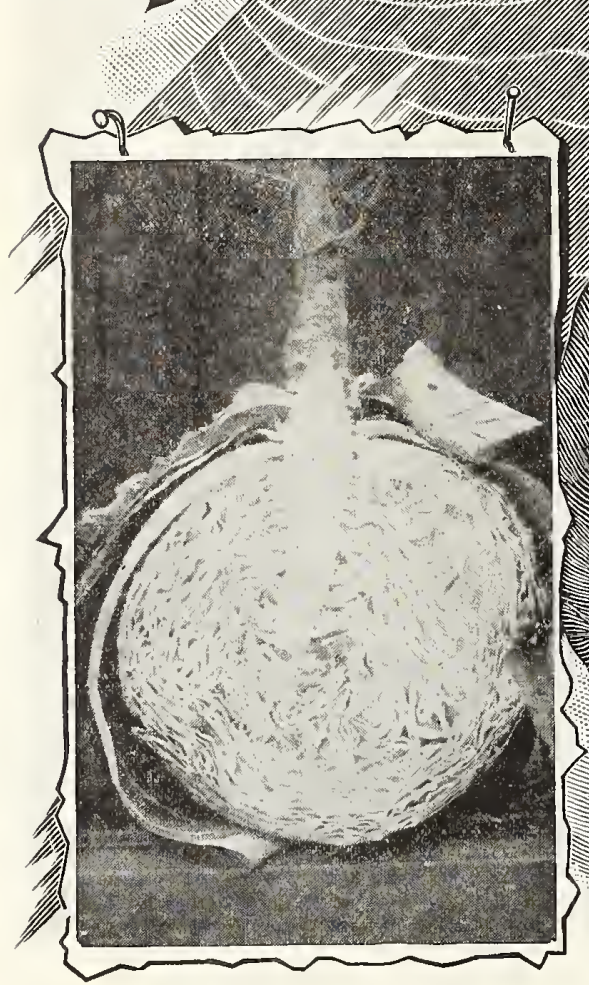

\section{BUCKBEE'S GREAT DANE-The Hardest Headed Late Cabbage}

THE GARDENER'S FAVORITE BEST SHIPPER, AND LONGEST KEEPING CABBAGE.

TOR years large quantítíes of Danish Cabbage have been imported to our leading American markets, the heads being of such solidity that 1 the demand has been far in excess of the supply, always at a price far above the ruling market rate. To get to the source of this supply we dispatched our European traveler direct to Denmark, and after careful inspection of the Cabbage growing localities came to Amack, qualities of this great Winter Cabbage: "For more than twenty years I have worked in perfecting this variety. Heads are almost as round as a ball, of good size, perfectly solid, very fne grained of the best quality. Because of its "great solidity" ' of head, and its unequalled keeping and shipping qualities, it has supplanted nearly all other varieties for winter use It is ahead of any variety grown on this side for shipping and all general uses, and I cannot too highly recommend it to gardeners in your land (America.)" We control the entire seed supply and offer the choicest "Full of Life" seed of our own growing at the following reasonable prices. Send to Buckbee for the true "Great Dane". Pkt. 10c; oz. 30c; 2 oz. 55c; $1 / 1$ 1b. 90 1/2 1b. \$1.60; 1b. \$3.00.

Martin Diefenbach, Jackson, Mo., writes:- "I thought I would let you know how our Seeds turned out last year bought of you, We had some of the earliest and best Cabbages around here; and we sold some before people thought of Cabbages. The late Cabbage also turned out good-had some that weighed 15 to 17 pounds."

John Matts, Box 34, Ypsilanti, Mich., writes:- "The garden seeds bought of you last spring were all good, the Cabbage were the

"Full of Life' seeds to every one."

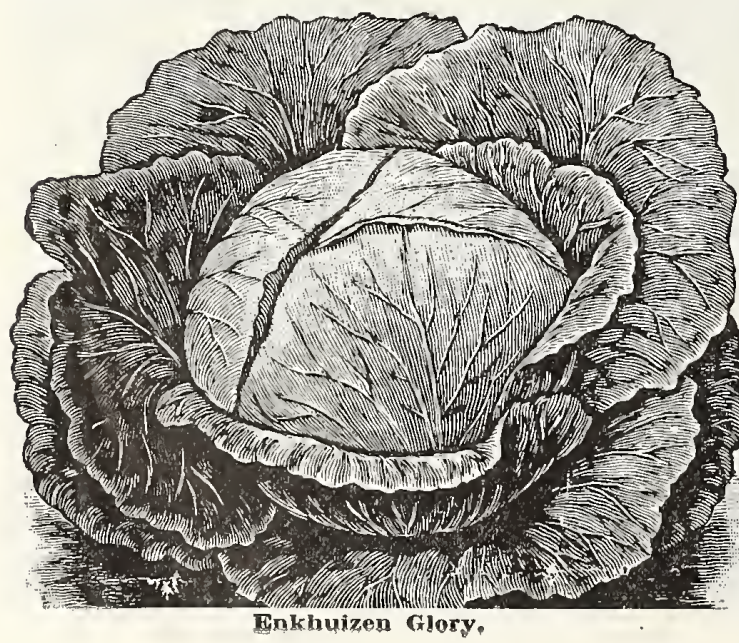

Buclsbee's Early Greenback This variety has had thorough and exhaustive trials in all the great cabbage growing sections of the Union and under varied conditions, both by ourselves and expcrt marpure and highbred that practically every plant will pro a fine, hard head. pkt. 5c; oz. 20c; 2 oz.

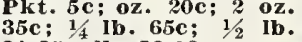
$\$ 1.25 ; 1 \mathrm{~b} . \$ 2.00$.

Enkhuizen Glory A comparatively new second early variety, very lent quality. Plant of vigorous growth, with large, leaves which are noticeably curved. He a d globular or very nearly round, very solid a variety. Pkt. 5c; oz. 25c

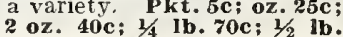
81,$30 ; 1 \mathrm{~b}, 82,60$. dhey were lovely. I shall recommend your Ed. De Berry; R. R. 4, Savannah, Tenn.; writes:-My orders last spring were received promptly and all $\mathrm{O}$. $\mathrm{K}$. I had the finest garden in the country, and the finest Cabbages I ever saw raised in this country, You may expect
several orders from this neighborhood.

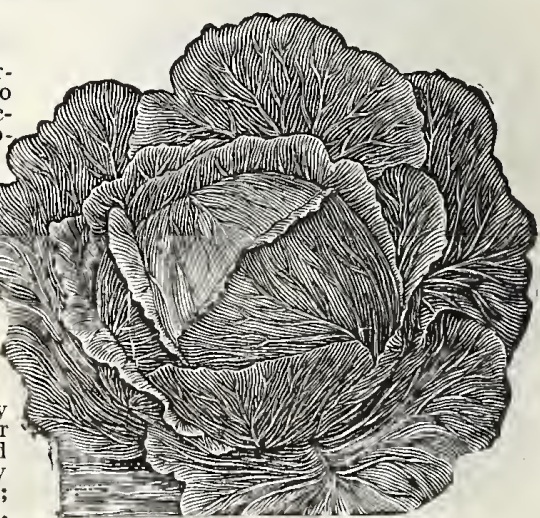

Buckbee's Early Greenback. 


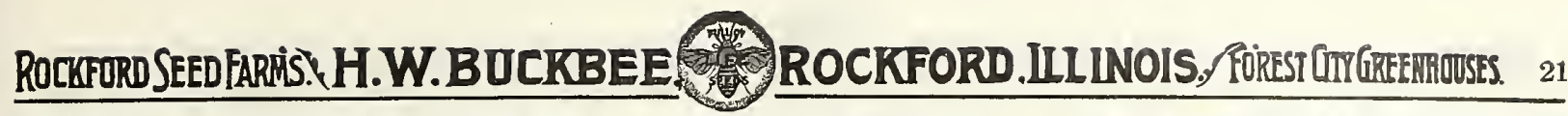
BUCKBEE'S “FULL OF LIFE" CABBAGE SEED

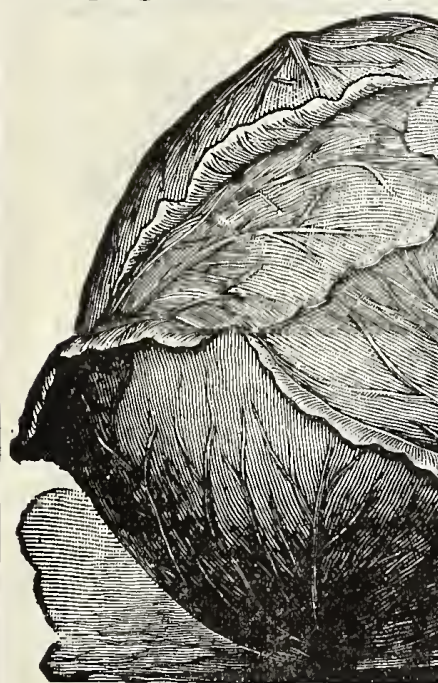

Danish Ball Head.

Danish Ball Head Extra Selected Danish Grown seod.

The heads, which are of medium slze, average a weight of about eight pounds; are very solid and deep, and of a flne white color. Their quality is superior, the heads being just as the Spring as when they are put away in the Fall. Pkt. 5c; oz. 20c; 2 oz. 82.25.

\section{New Round Head Danish}

A Short Stemmod Type.

Two weeks earlier than Ball Head, heads round, unusually solid, average larger, with less outer foliage, of more robust growth and is better able to resist blight. The heads a re beauti-
fully white when trimmed. Is especially recommended for high and light soils. Are splendid keepers.

Pkt. 10c; oz. 25c; 2 oz. 40c; $1 / 4$ lb. $75 \mathrm{c} ; 1 / 2$ 1b. $\$ 1.40 ; 1 \mathrm{~b}$. $\$ 2.75$.

\section{It Pays to Get the Best}

One of the chief departments of our seed business consists of growing Buckbee's "Full of Life" Cabbage Seed. For years we have been acknowledged one of the largest and most particular Cabbage Seed Growers in the World. Our shere that "Buckbee's Full of Life" seed is the most reliable and produces more good, marketable heads per acre than any offered.

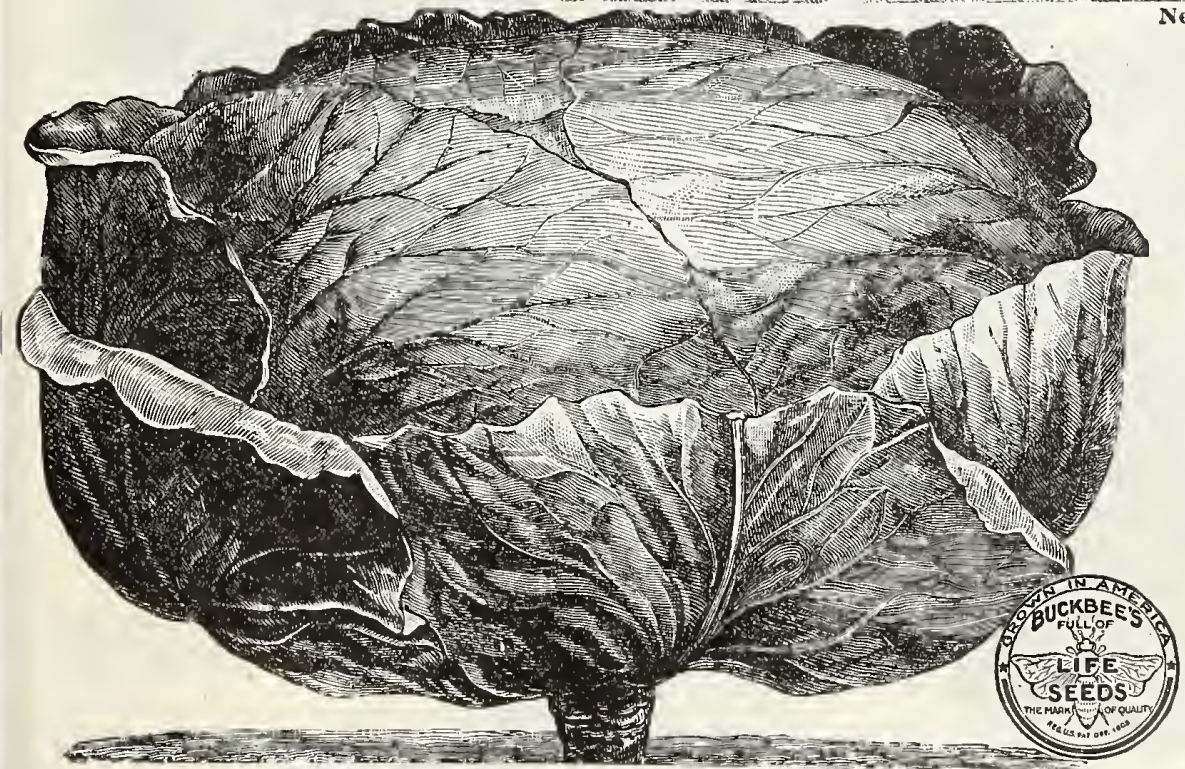

Buckbee's Mammoth Late Bridgeport Drumbead
Buckbee's Mammoth Late Bridgeport Drumhead Standard Shipping Sort.

It makes a large, round, firm head, uniform in shape and color, which seldom bursts or rots. With good cultivation heads attain a weight of twenty to thirty pounds, and are of the finest quality. Sureness in heading and regularity in growth has made this one of the most popular standard sorts for winter keeping. The quality is also . It is as natural for this Cabbage to form heads as leaves. It is one of the most profltable varieties to grow, and will give un18c: 2 oz. 35c; $1 / \frac{1}{4}$ lb. 60c; $1 / 2$ lb. $\$ 1.10 ; 1 b . \$ 2.00$.

R. H. Delaney, Theo, Ark., writes I have grown your seeds for severa years, and think they are the best ever used. I the they are tho best of praise for Buckbee's "F 


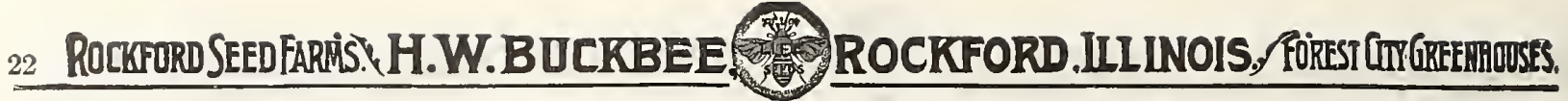
BUCKBEE'S "Full of Life" CABBAGE SEED

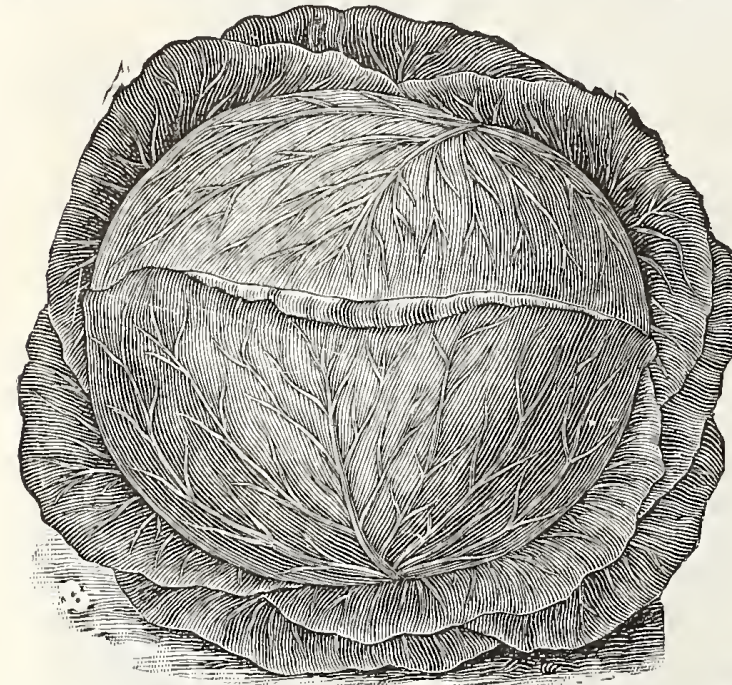

All Head Early Cabbage.

Henderson's Early Summer Standard Mid-sunimer Variety.

This variety is deservedly popular with the market pact heads of excellent quality. The heads average more than double the size of the Jersey Wakefield, while it

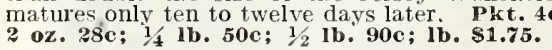

\section{Henderson's Early Spring}

The whole plant is finely bred. It possesses wonderful uniformity in shape, being round, slightly flattened. Flavor delicious, and every plant makes a good marketlb. 90e; Ib. $\$ 1.75$.

\section{SURE HEAD}

\section{A Famous Main Crop Cabbage.}

Of the "Flat Dutch" type. Heads uniform, hard, firm and fine in texture, weighing from 10 to $15 \mathrm{lbs}$. Sweet flavored; has scarcely any loose leaves; keeps well.
Pkt. 4c; oz. 15c; 2 oz. 28c; $1 / 1$ lb. 50c; $1 / 2$ lb. 90c; 1 . 81.75.

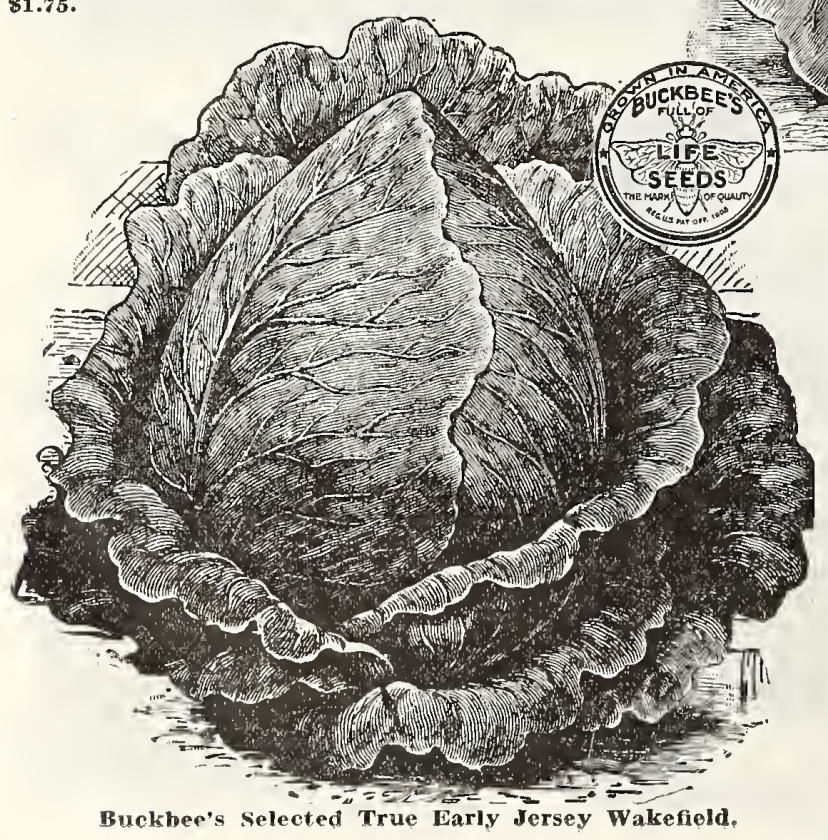

\section{Buckbee's Early Marvel}

The heads are extremely hard and solid, round, flattened on top, and ready to market nearly as early as Farly Summer, while consideram larger in size. It is as good for Autumn or Winter as for early Summer. All Head Early

often Coming in Before Early summer.

It is at least one-third larger than this popular variety, and therefore much more profitable to the market gardener, who has in this variety a Cabbage larger and ai the same time earlier-is also valuable for late Winter Cabbage. Pkt. 5c; oz. 22c; 2 oz. 40c; $1 / 4$ lb. 70c; $1 / 2$ lb. \$1.30; 1 b. \$2.50. Buckbee's Selected True Early Jersey Wakefield

It forms fine, solid heads of good size, conical in shape, with very few outside leaves, and of the best quality. We offer this as the earliest strain of this standard variety. Grown only from selected heads. Our strain is remarkably pure; always gives satisfaction. Pkt. $5 \mathrm{c} ; \mathbf{o z} .18 \mathrm{c} ; 2 \mathrm{oz}$. $35 \mathrm{c} ; 1 / 4 \mathrm{lb} .60 \mathrm{c} ; 1 / 2 \mathrm{lb}$. $\$ 1.10 ; 1 \mathrm{~b}$. \$2.00.

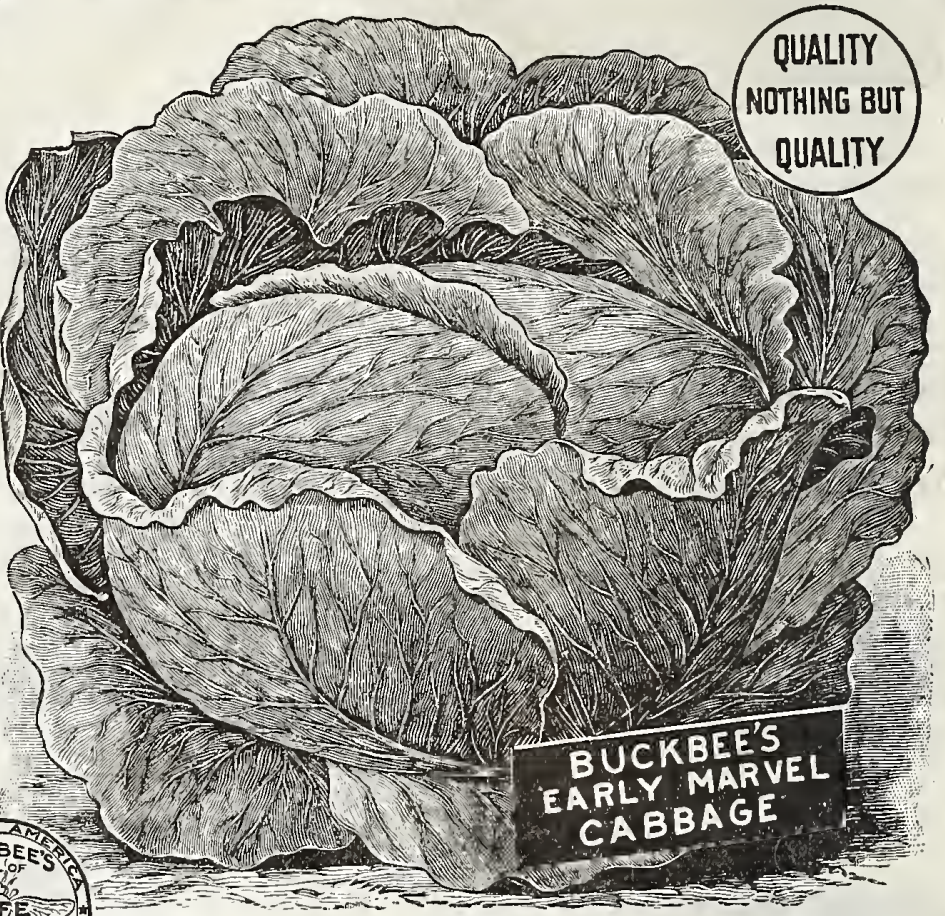

\section{Charleston Large Wakefield}

A splendid strain of Wakefield, in which the plant is larger and a little later, the head larger and not so pointed. Charleston Wakefield is a good keeper and may be planted as a second crop, to mature in the autumn, if desired. It is a first rate shipper, and in great favor with everybody who knows
$1 / 4 \mathbf{1 b} .50 \mathrm{c} ; 1 / 2 \mathrm{lb} .90 \mathrm{l} ; \mathbf{l b}$ \$1.75.

\section{Louisville Early Drumhead}

A strong and type. Plants short stemmed and compact, with broad, well rounded leaves, very full at base Head, semi-flat, thick and of good quality. Pkt. 4r; oz. 15c; 2 oz. 28c; $1 / 4$ Ib. 50c; $1 / 2$ 1b. 90c; $1 \mathrm{~b} . \$ 1.75$.

\section{Gregory's All Seasons}

The heads are hard and solid, round, flattened on top, of very best quality, and are ready for market nearly as early as Early Summer, $\$ 1.00 ; 16 . \$ 1.90$.

A. H. Benning. Jerome, Idaho, writes:-I am well pleased with results from your "Full of Life" Seeds. The Cabbage and Radish were particularly fine. 


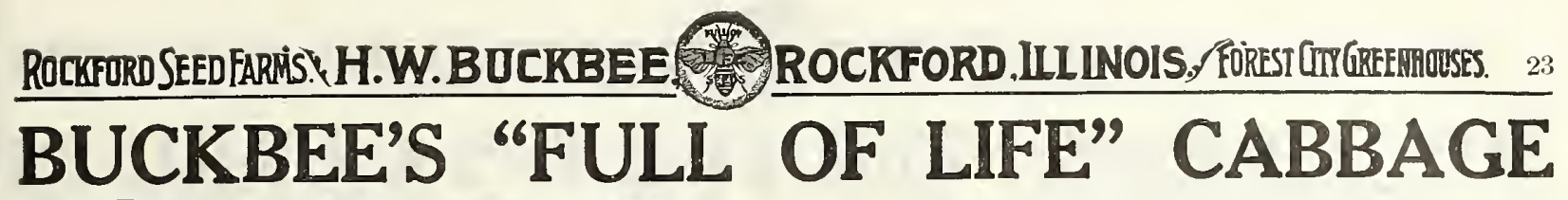
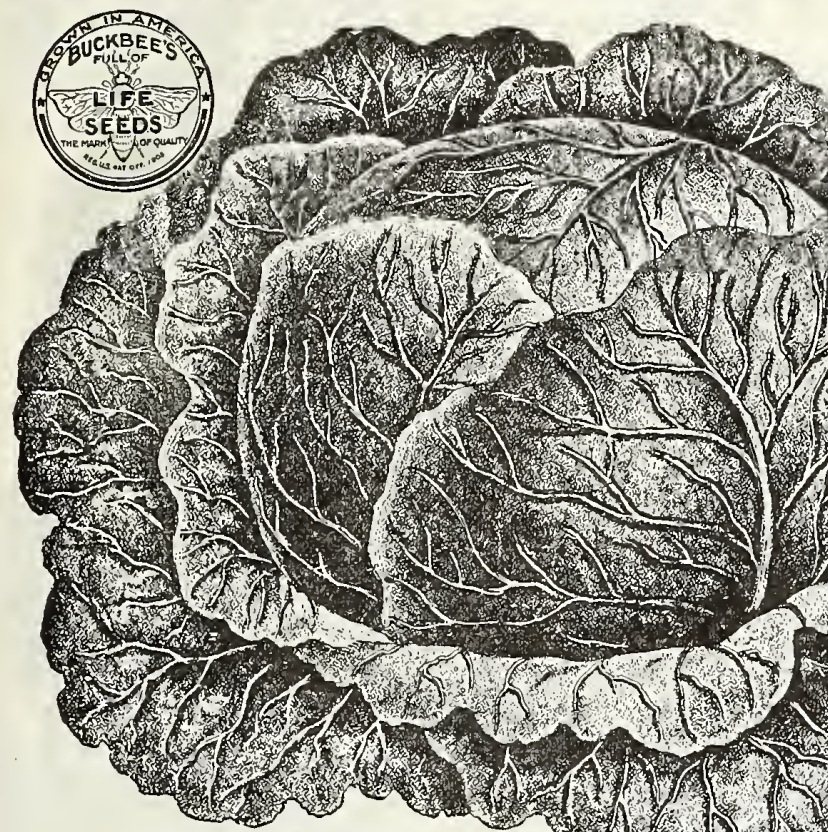

Buckbec's Mammoth

Late Fiat Dutch Cabbage.

\section{Buckbee's Mammoth Late Flat Dutch}

Everywhere A Favorite Market Variety

THE GREAT CABBAGE FOR FALL AND WINTER USE. This is the Always Sure to Head. family use it ranks high. No variety of Late Flat Dutch can approach it for fine quality and uniform reliability to produce solid, frm heads. Even during the most unfavorable weather the heads are very large, hravy, solid, flat on top, and of a bluish-green color with but few outopen, crisp, tender and white. It is the variety planted by more gardeners than any other late sort, and one of the best to grow for home market and the family garden, and sure to make a crop where other sor ts fail and sure to please everybody on all soils North, South, East or West. strain of "Full of Life" seed. Pkt. 5c;0z. 18c; 2 oz. 35c; $1 / 4$ lb. 60c; Strain of "\$1.10; lb. \$2.00.

Buckbee's Sugar Loaf Savoy Cabbage

\section{Noted for Fine and Delicate Flavor.}

This improved variety is the very best of the Savoys for home use
or the market. Most attractive, matures early, hardest headed. Plants vigorous, densely crumpled and very sure heading. Blanches beautivigorous, densely crumpled and very sure heading. Blanches beauti-
fully. Pkt. 5e; oz. 20c; 2 oz. 35e; 1/4 lb. 65e; 1/2 Ib. \$1.25; lb. \$2.00.
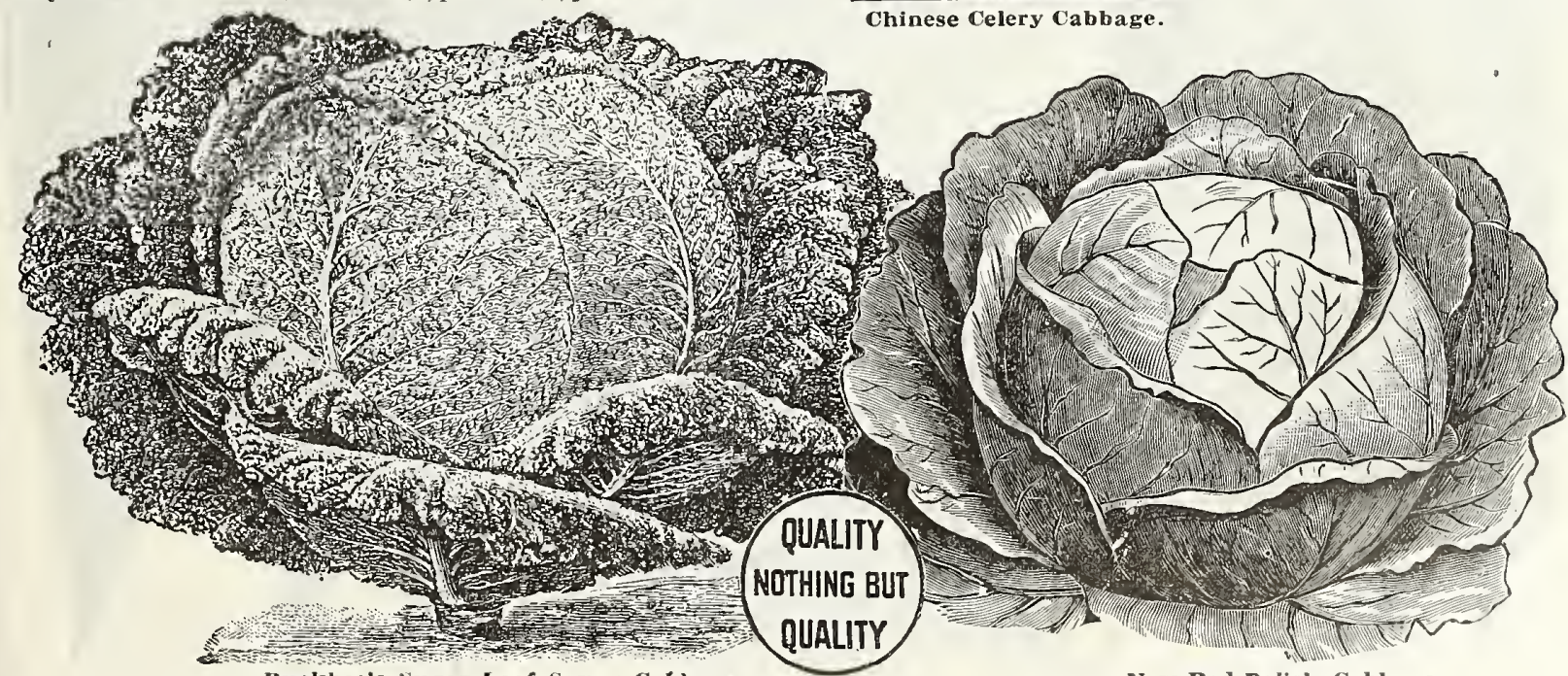

\section{Red Dutch or Pickling}

Raised extensively for picling pur-
poses. Always the first of the Red Cabbages in mariket. Average weight,
8 pounds. Plit. 3c; oz. 12c: 2 oz. 23c: $1 / 4$ lb. 45e; 1/2 lb. 80c; Ib. 81.50 . Improved American Savoy very Valuable Variety.

Adapted for private use. Grown in it is one of the most delicious of al $23 \mathrm{c} ; 1 / 4 \mathrm{lb} .40 \mathrm{c} ; 1 / 2 \mathrm{lb}$. 75e; $1 \mathbf{b}$. $\mathbf{1 1 . 4 0 .}$

New Red Polish Cabbage

The Best Red Cabbage
For Pickling or Table Use.

This new Red Cabbage is a vigorous dark red color and are extremely firm and ornamental appearance. New Red Polish is the will prove satisfactory in all respect

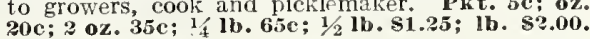

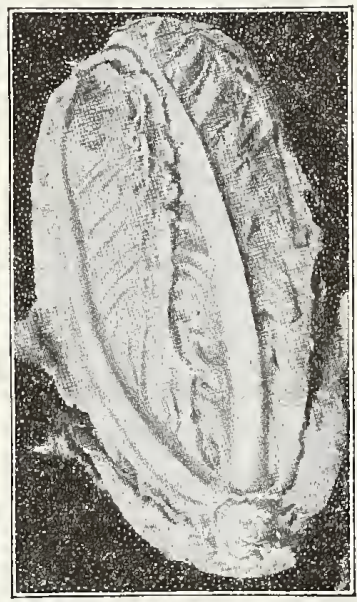

New Chinese Celery Cabbage

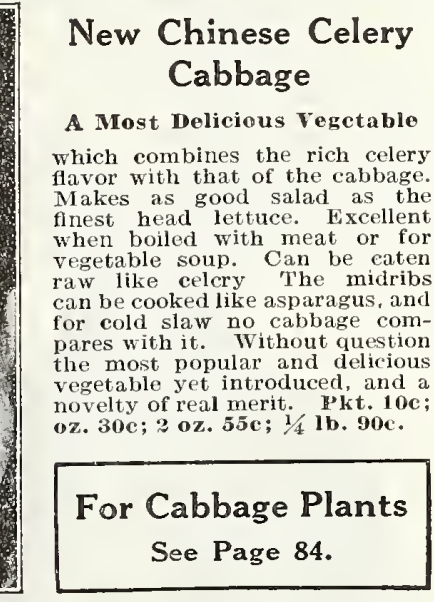

Chinese Celery Cabbage. heavy. The outside leaves are somewhat crumpled most profitable red sort with which we are ac- 


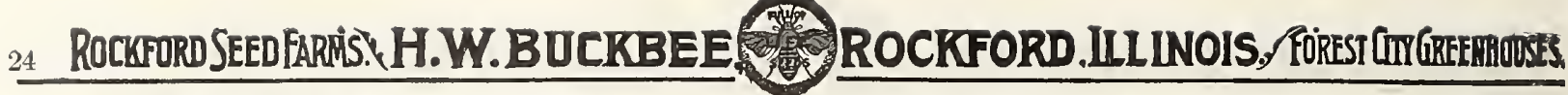

\section{BUCKBEE'S “Full of Life” CARROTS}

German, MOEHREN ; French, CAROTTE; Spanish,

One ounee Will sow a Row 100 Feet Long. Four to
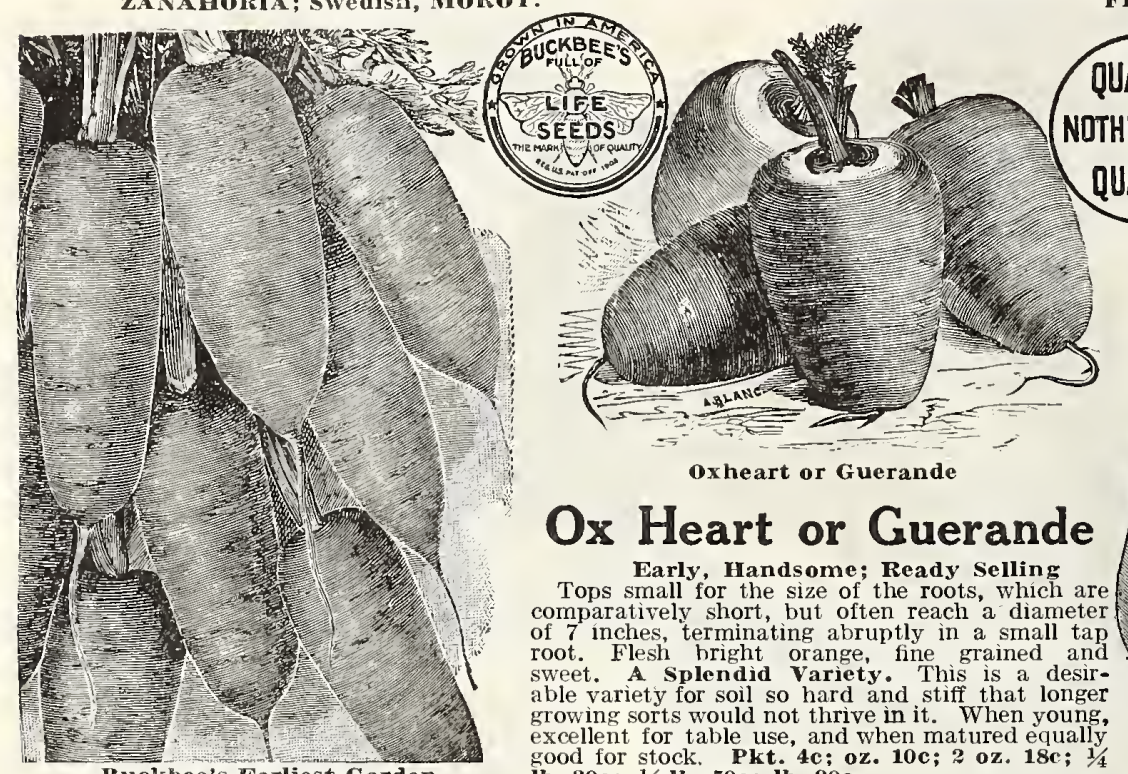

Five Pounds will sow an Acre.

Buckbee's Earliest Garden

oxheart or Guerande

\section{Ox Heart or Guerande}

Early, Mandsome; Ready Selling

Tops small for the size of the roots, which are comparatively short, but often reach a diameter of 7 inches, terminating abruptly in a small tap
root. Flesh bright orange, fine grained and sweet. A Splendid variety. This is a desirable variety for soil so hard and stiff that longer growing sorts would not thrive in it. When young, excellent for table use, and when matured equally
good for stock. Pkt.4c; oz. 10c; 2 oz. 18c; $1 / 4$ lb. $30 \mathrm{c} ; 1 / 2 \mathrm{lb} .50 \mathrm{c} ; 1 \mathrm{~b} .90 \mathrm{c}$.

\section{Buckbee's Earliest Garden}

The Earliest variety in Cultivation and Best for the Table Tops small, finely divided. The reddish orange colored roots tured they arnd with a groove about the crown and when fully mabefore they are full grown, when they are tender and delicious. Pkt. $5 \mathrm{c} ; 0 \mathrm{z} .12 \mathrm{c} ; 2 \mathrm{oz}$. 20c; $1 / 1 \mathrm{lb}$. 35c; $1 / 2 \mathrm{lb}$. 60c; 1b. $\$ 1.00$.

Buckbee's Pride of the Market

\section{Early, Long, Rich Golden Yellow, Splendid Ouality, Fine $50 \mathrm{c}$; 1b. 90c.} A large handsome main crop variety. Roots grow ten to twelve inches in length, very broad at the neck, tapering evenly to the small tap root. Grows smoothly and

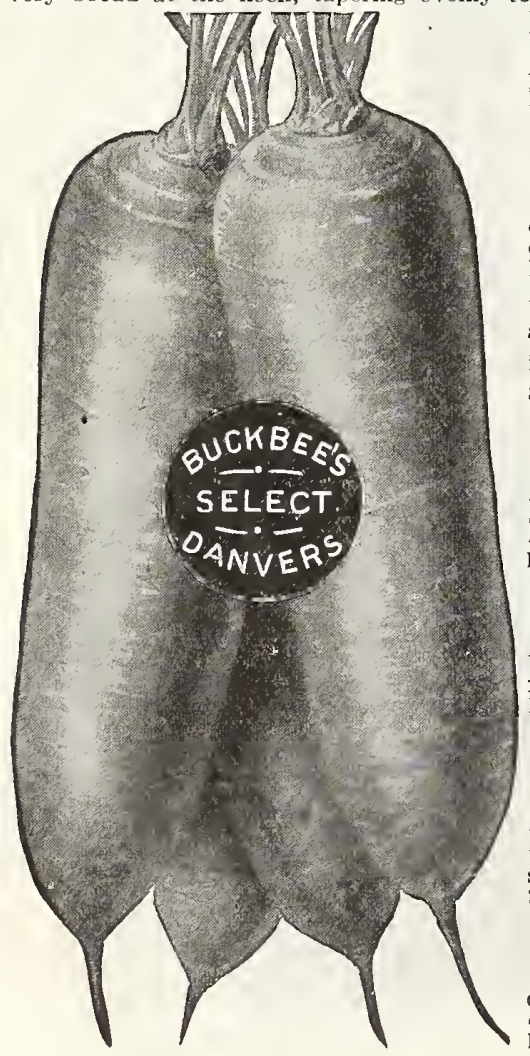
uniformly, flesh tender, sweet, and entirely free from woody coarseness. Unsurpassed for table use, and most valuable for market purposes. Pkt. 5c; oz. 12c; 2 .

\section{Buckbee's Select Danvers}

The Best Carrot for Every Purpose Yield enormous. Quality superb. The best Carrot for general crop; it is of a rich orange color, a very heavy yielder and splendid keeper, It is a first-class Carrot for all kinds of soils, valuable for both table use and stock. The Leading Carrot. We have an extra fine strain of this favorite giving the greatest satisfaction to our customers. Pkt. 5c; oz. 10c; 2 oz. 18c; 1/4 lb. 30c: 1 (

\section{Early French Forcing}

standard Extra Farly Forcing Carrot Nearly round roots of yellowish brown Nearly round roots of yellowish brown eter, and are best for use when young. Pkt. $4 \mathrm{c} ; 0 \mathrm{z} .10 \mathrm{c} ; 2$ oz. $18 \mathrm{c} ; 1 / 4 \mathrm{lb} .30 \mathrm{c}$; $1 / 2 \mathrm{lb} .50 \mathrm{c}$; lb. $95 \mathrm{c}$.

\section{Early Scarlet Horn Tender and Delicious}

A favorite for early crop. Color deep beautiful orange; has a short, stump-shaped root, large at top, therefore easily pulled. ib. 50c; $1 \mathrm{~b} .90 \mathrm{c}$.

\section{Improved Long Orange}

The most Best Keeper The most popular of the older sorts for farm use on mellow soil. Roots proporsmoother. Pkt. 3e; oz. 8c; 2 oz. 15c; $1 / 4$ lb. $25 \mathrm{c}$; $1 / 2 \mathrm{lb}$. 40c; $1 \mathrm{~b}$. $75 \mathrm{c}$.

\section{Half Long Danvers} Extensively Grown

Roots are smooth and handsome, deep orange and of medium length. Pkt. 4c: oz. 8c; 2 oz. $15 \mathrm{c} ; 1 / 4 \mathrm{lb}$. 25c; $1 / 2 \mathrm{lb}$. $45 \mathrm{c}$; 1b. $80 \mathrm{c}$.

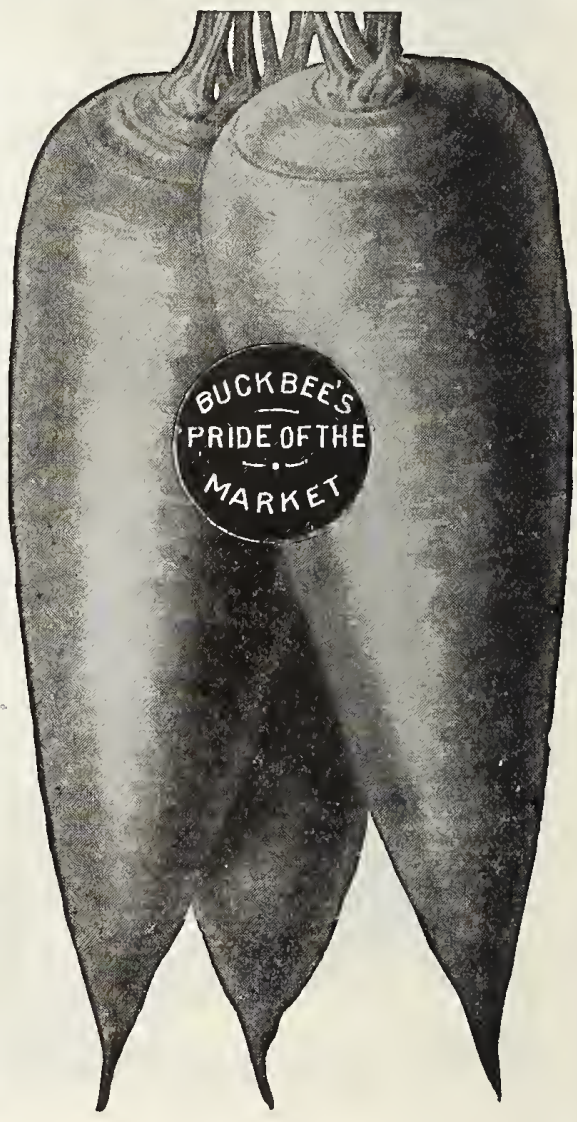




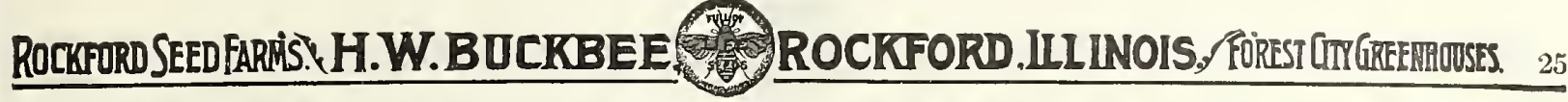
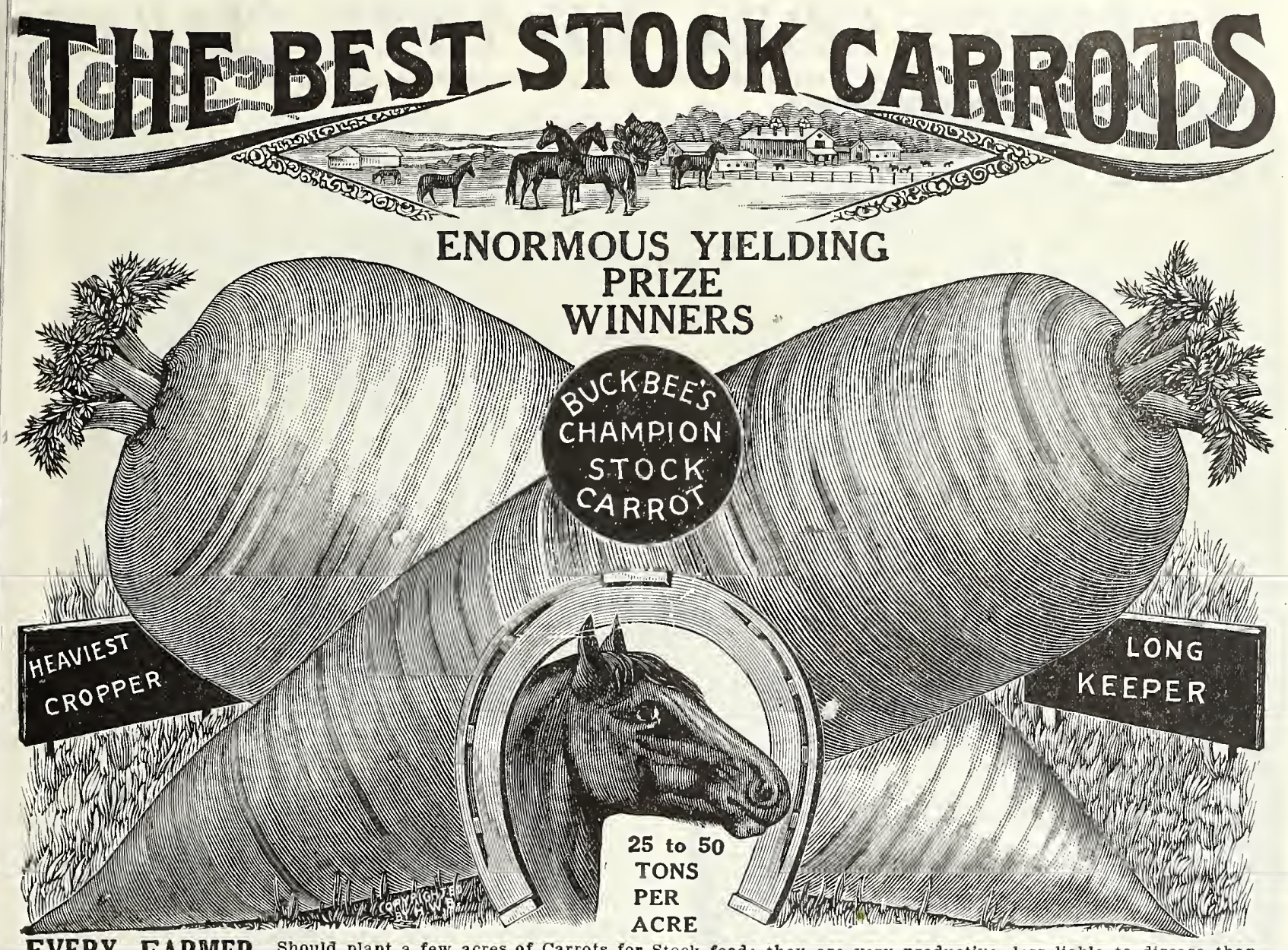

EVERY FARMER Should plant a few acres of Carrots for, Stock food; they are very productive, less liable to disease than

Buckbee's Champion

The World Beating Stock Carrot.

Buckbee's Champion is not, properly speaking, a table Carrot,

although the flesh is remarkably firm and sweet, But it is, most

emphatically, a Stock Carrot for the farmer and stoek raiser, and once used, nothing will take its place. It is the heaviest cropping sort. The flesh is white, crisp, solid and very sweet in flavor. The roots are short and very heavy at the sloulder, rendering them easily harvested. An important feature, also, is that they do not easily break in 15 to 20 inches in circumference, and 25 to 50 tons to the acre is not an extravagant statepounds each. Our own Growth, Choicest pounds each, our own Growth, Choicest

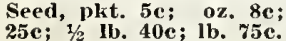

Buckbee's Improved Short White A Marvelously Good Stock Carrot. Roots half long, smooth, very heavy at the shoulder, but taper regularly to the point. Color light green above ground, white below. Flesh rich, white, solid and crisp, and of excellent flavor. A heavy $25 \mathrm{c} ; 1 / 2$ lb. $40 \mathrm{c}$; ib. $75 \mathrm{c}$.

\section{Buckbee's Majestic}

The largest and heaviest cropping and most nutritious yellow variety. The roots are remarkably fine, very symmetrical, Ing properties. Pkt. 4e; oz. 8e; 2 oz. 15e; Mammoth Yellow Belgian Identical to the White Belgian except in color, Pkt. 3e; oz. \%

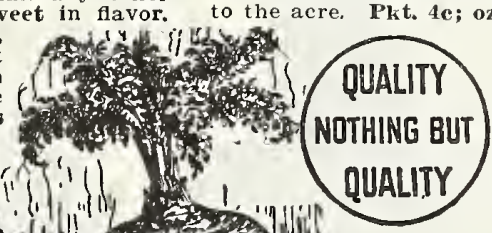

Buckbee's Victoria

Heavy Yielder, Splendid Quality.

Heavy cropping white variety. Roots short and very heavy at very casily harvested. Frequently measures 15 to 20 inches in circumference and yields 18 to 25 tons measures 15 to 20 inches in circumference and yields 18 to 25 tons
to the acre. Pkt. 4c; 0z, 8c; 20 oz. 15c; $1 / 1$ lb. 25e; $1 / 21 b .40$; 1 lb. 70c.

\section{Large White Vosges} One of the Very Best for Shallow Soil. A field Carrot especially suited for soils
that are not very deep. One of the very best for cattle feeding. Pkt. 4c; oz,

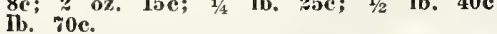
Mammoth White Belgian

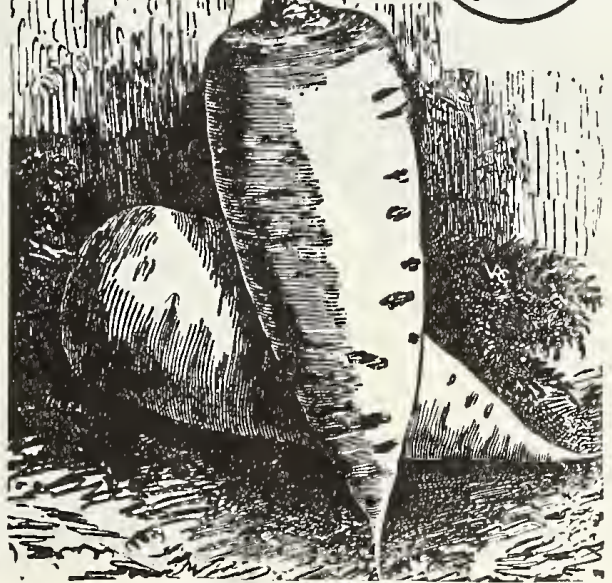
A splendid variety for fattening stock. The roots are mammoth in size and very productive, often yielding ten tons and oz. 12e; $1 / 1 / 1 \mathrm{lb}$. $20 \mathrm{c} ; 1 / 2$ lb. $35 \mathrm{c} ; 1 \mathrm{~b}$. $65 \mathrm{c}$.

\section{MONEY IN CARROTS} IF YOU PLANT TUE RIGHT SEED. There is no better food in Winter rots cut small, then sprinkled with salt and fed with meal. The yield is not unusual We would particularly recommend that those interested in growing roots for stock feeding write ington secretary of Agriculture, WashBulletin No. 11, which will give you stock feeding. Buckbee's "Full for Life" Carrot Seed is grown with great ORDER FARLY. 


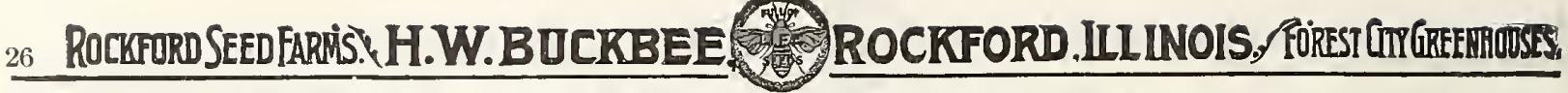
BUCKBEE'S "FULL OF LIFE" CELERY German, Seleri; French, Celeri; Spanish, Apis; Swedish, Selleri.

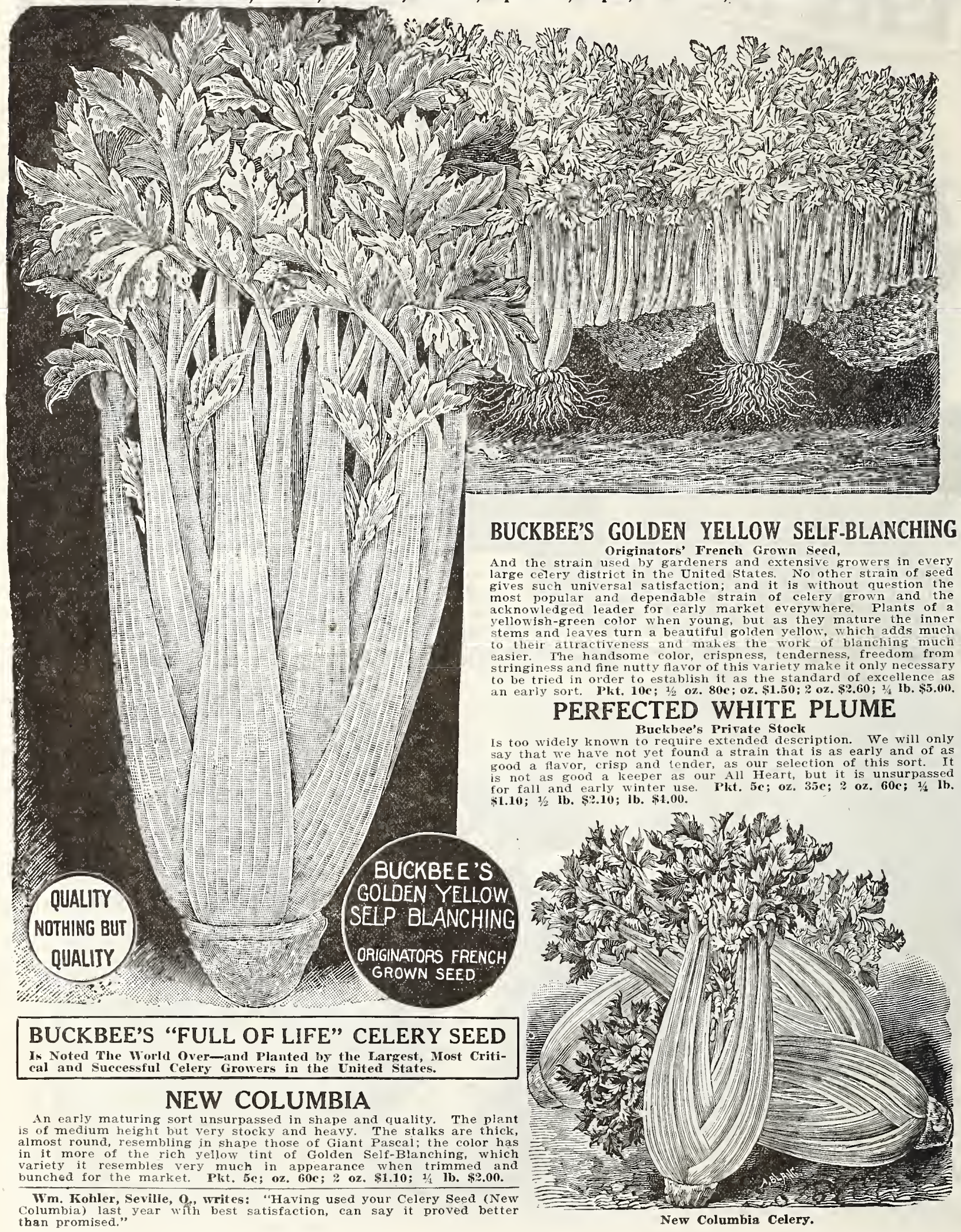




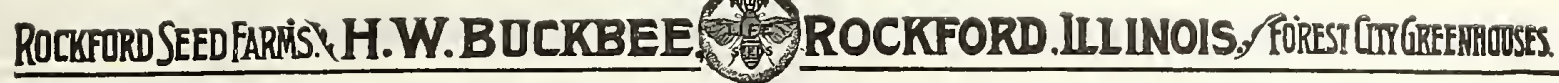 \\ BUCKBEE'S "Full of Life" CELERY}

GERMAN, SELERI; FRENCH, CELERI; SPANISH, APIS; SWEDISH, SELLERI

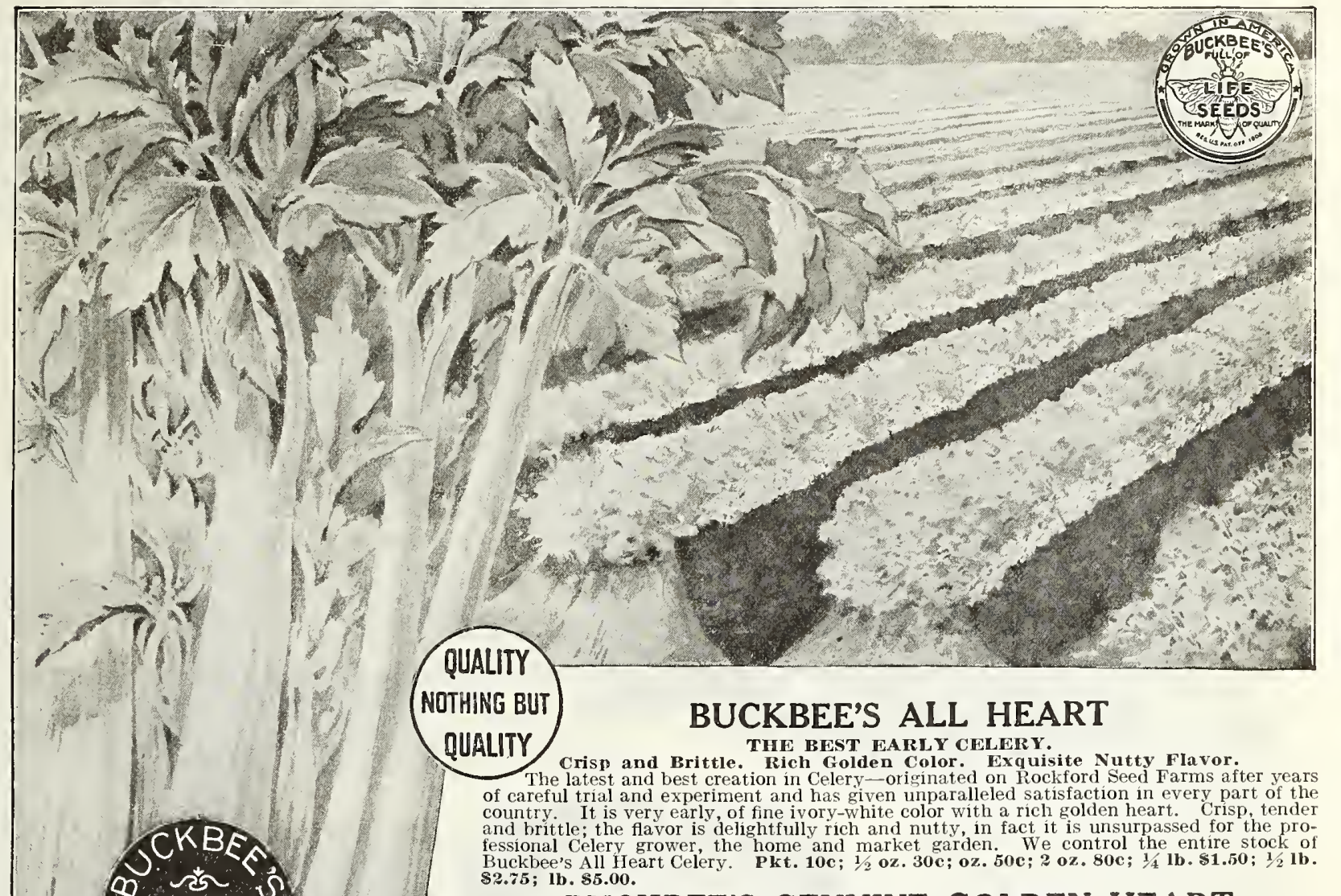

BUCKBEE'S GENUINE GOLDEN HEART

ALL HEART THE BEST LATE CELERY

Original Private stock-This variety makes a very strong and vigorous plant, with large, very white, crisp, brittle, tender and fine flavored stalks. It is late, and requires the $35 \mathrm{c} ; 1 / 4 \mathrm{lb} .60 \mathrm{c} ; 1 / 2 \mathrm{lb}, \$ 1.10 ; 1 \mathrm{lb} . \$ 2.00$.

\section{BUCKBEE'S PERFECTED KALAMAZOO}

It is an acknowledged fact that more good Celery is grown in the famous "Kalamazoo Celery Fields" than anwhere in the that inore goor Cers is Fields" than anywhere in the country. For years our heaviest sales of celust celebrated variin that section, and we have devoted much time to the improvement of Celery-of creamy-white color, ideal size and perfect shape. It is alike profitable either for market or family use
There is no waste in preparing it for the table. Pkt. 4c; oz. 30c; 2 oz. 55c; 1/4 1b. \$1.0o.

\section{GIANT PASCAL RE-SELECTED STOCK SEED}

A selection from the Golden Self-blanching, and adds to the general good qualities of its

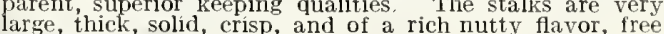

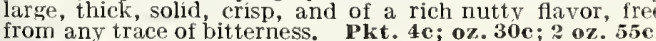
from any trace

\section{CELERY SEED FOR FLAVORING}

Oz. 5c; 2 oz. 8c; $1 / 4$ lb. 12c; $1 / 2$ 1b. 20c; $1 \mathrm{~b} .35 \mathrm{c}$

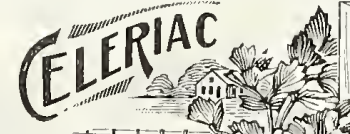

CELERY PLANTS ready early in June-See Page 84

CELERIAC, or Turnip-Rooted Celery

German, Knollen Sellerie; French, Celeri Rave

Celeriac is grown for the bulbous roots, which are

LARGE ROOTED GIANT PRAGUE

Improved form of turnip-rooted Celery, producing large and smooth roots, almosi round; few side roots. Iarge, deep green foliage. Pkt. 4c;oz. 18c; $20 z .35 \mathrm{c} ; 1 / 41 \mathrm{~b} .65 \mathrm{c}$.

NEW DELICATESS Root turnip-shaped and tender, sweeter taste,

Chas. Sietzema, Goshen, Ind, writes:-"This serves to testify that we have used Buckbee's "Full of Life" Celery Seed for the past three years, and it has given most sa

Marinus Vander Maas, Goshen, Ind., writes: "I wish to thank you for the fine variety of Buckbee's "Full of Life" Golden Self Blanching Celery Seed purchased from you for the past four years."

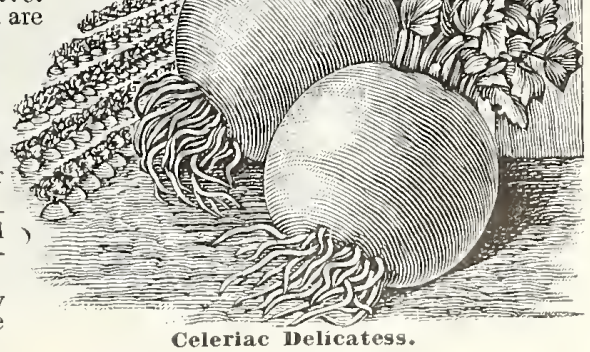




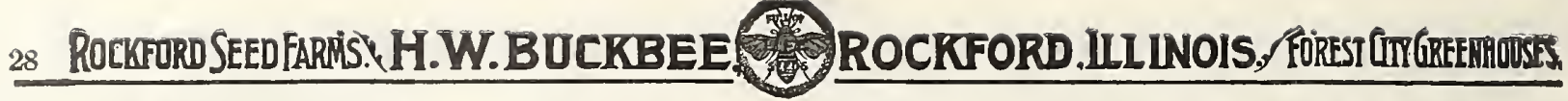

BUCKBEE'S "FULL OF LIFE" CAULIFLOWER German, BLUMEN-KOHL; French, ChoU-FLEUR; Spanish, Coliflor; Swedish, BLomkAL.

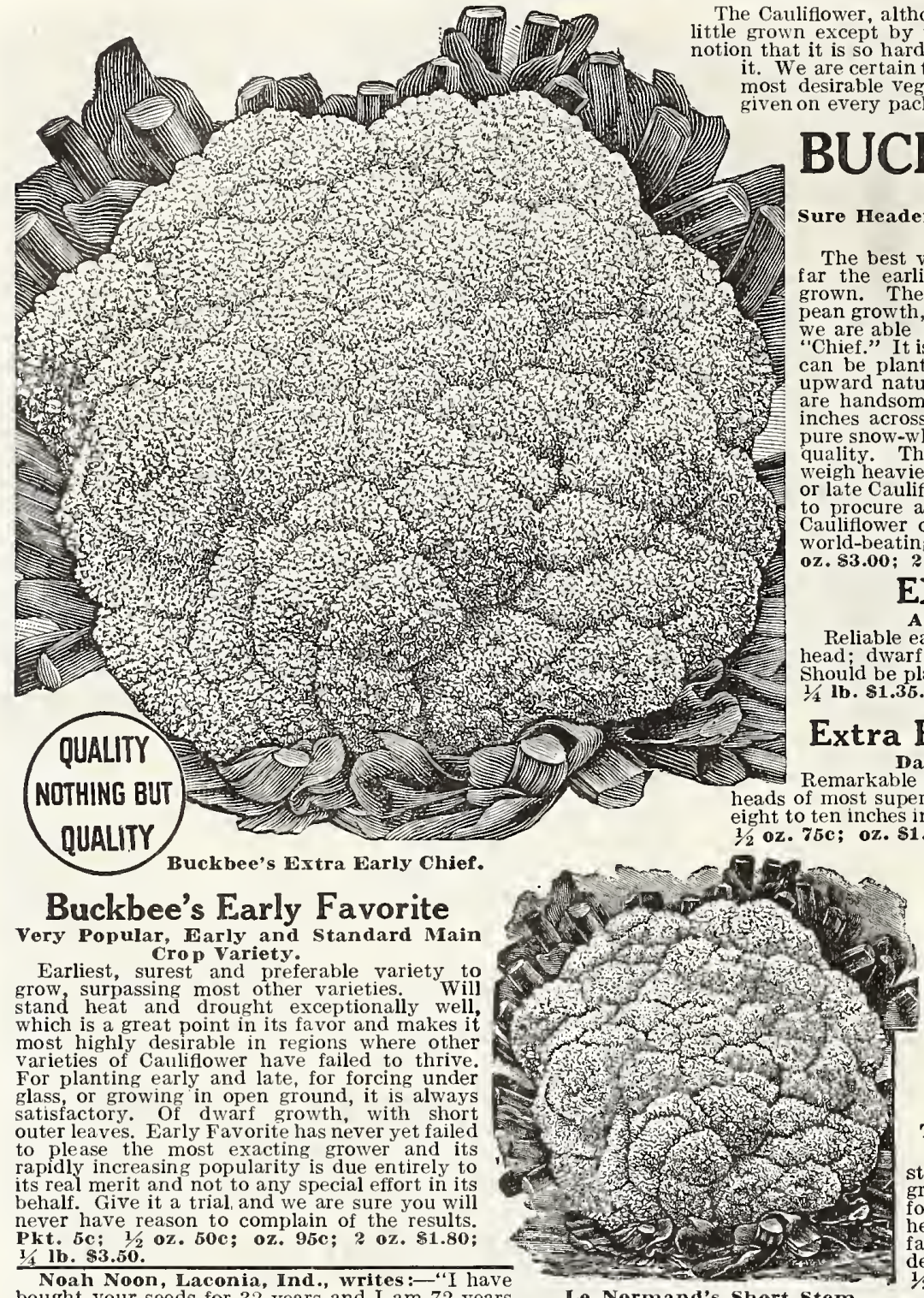

Noah Noon, Laconia, Ind., writes:- "I have
bought your seeds for 32 years and I am 72 years

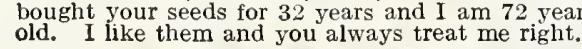

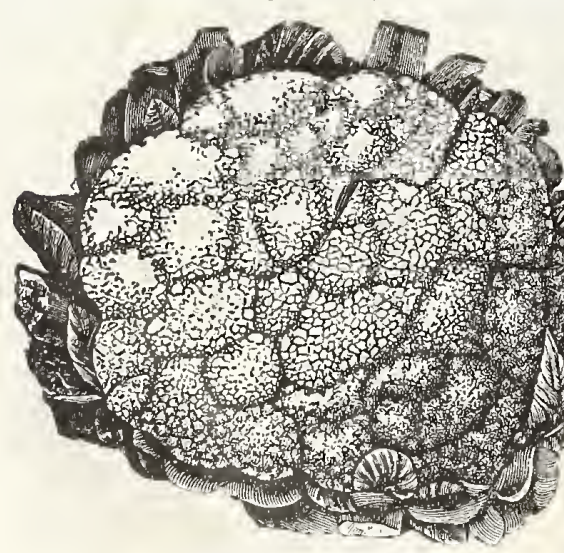

Buckbee's Farly Favorite.

Geo. N. Bowker, odebolt.
Le Normand's Short stem.

\section{Le Normand's Short Stem}

sure Heading Standard Late Variety.

The very best large late variety grown; sure to please. Curd is well protected by leaves, and header of good quality and fine in every way. header, of good quality and fine in every way.
Pkt. 5c; oz. 45c; 2 oz. 80c; 1/4 lb. \$1.50.

\section{True Early Snowball Pedigree}

The Famous "Dry Weather" Caulifower. Certainly a fine variety, great favorite and standard throughout the country; very early, close orcing under glass during Winter and spring. The fill depended upon for excellent results. Pkt. 10c; $1 / 2$ oz.\$1.25; oz.\$2.00; 2 oz. \$3.80; 1/4 lb. \$7.50:

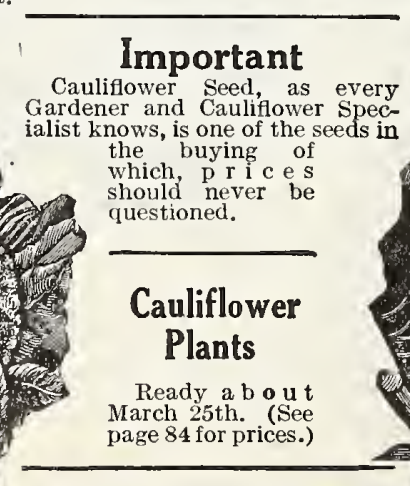
Iowa, writes:- "I am a market gardener and have bought quite found them very satisfactory.?

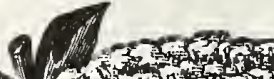

P.t.

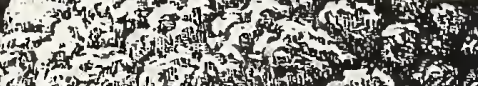

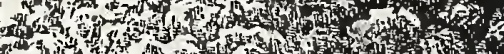

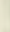

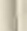

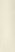




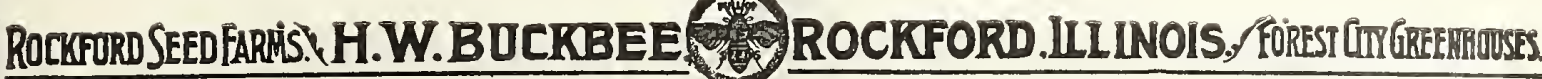 \\ BUCKBEE'S 4 WORLD-BEATING SWEET CORNS \\ GERMAN, Welchkorn; FRENCII, Mais; SPANISH, Maiz; SIVEDISH, Majas-Sot.}

\section{POPULAR VARIETIES THAT HAVE NO EQUAL}

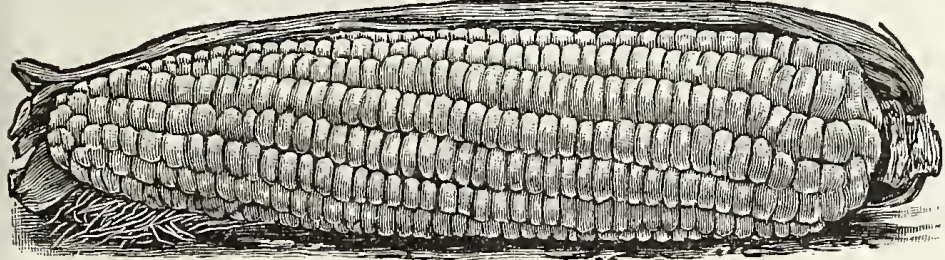

Buckbee's First of All

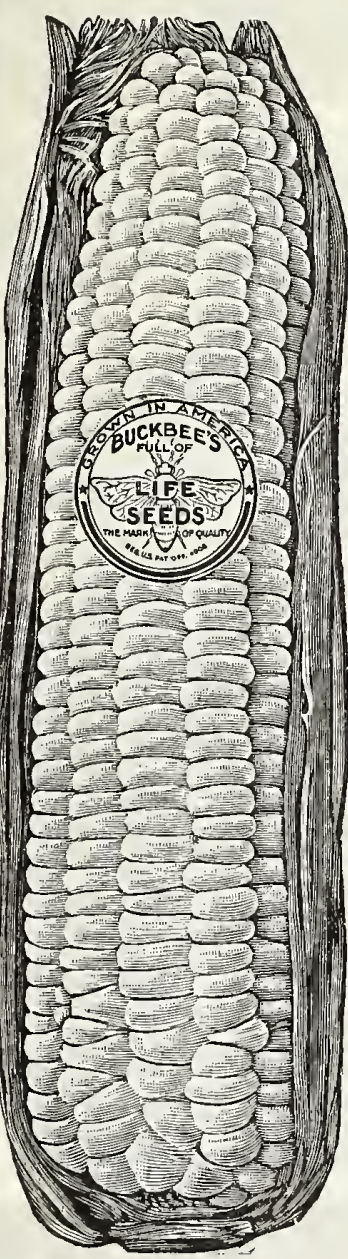

Buckbee's New Early Sunrise

The beanty and qnality of this remarkable variety give it prominenee over all others for family, market, canning, shipping and, in fact, all purposes. Ears large (the fat kind), that fairly melts in the month. Something in sweet Corn that makes everybody talk Early Sunrise as the very best introducselected with the sole abject of standard of excellence as the earliest, largest and best on reeBuckbee's First of All Sweet Corn

Extra Early Large Size, Heavy Cropper, Sweet and Tender. Comparative tests made by Sweet corn experts throughout the conntry as well as at Rockford Seed Farms have proven it to be from three days to a week carlier than Cory, making boon to market gardeners who desire to have the first Sweet Corn in market, and thereby receives the top-noteh prices. tip. Many of the ears contain from ten to twelve rows, while the Cory generally has only eight rows. In habit of growth it vigorous. The qnality is most superior, very excellent and surpassingly sweet. Postpiid, pkt. 8e; 1/2 pt. 12e; pt. 20e; qt. 30c.

\section{Buckbee's Best of All}

Early, Prolific, Sweet, Tender, Large, Frandsome. "Best of All" is of exceptionally stocky stowth and an abum-

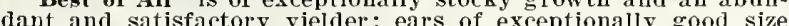
and of a perfect color, kernels very hroad and by far the sweetest, richest, whitest and most tender of any eariy variets. Not only is it valuable for family nses, but for early market and most prominent Sweet Corn specialists, writes: "Gave Buekbee's 'Best of All' a fair trial, and will say that it surpasses ommend it for all general pnrposes." We have placed the price Postpaid, pkt. 8c; 1/2 pt. 12c; pt. 20c; qt. 30c.

\section{Buckbee's Private Stock Evergreen}

For table use the quality of Buckbee's Private Stock Evergreen Sweet Corn cannot be excelled It is very and remains a long time in condition suitable for cooking. being sold. Its large ors, with long. slender crains, make it by far the most salable canned corn, and it ont-yields all other of orer 200 bushels of ears per acre. You cannot possibly be (isappointed by planting Buckbee's Private Stock Fvergreen. Our price to one and all as loug as stock seed lasts: Postpaid, pkt. $8 \mathrm{e} ; 1 / 2$ pt. $12 \mathrm{e}$; pt. $20 \mathrm{e}$; qt. $30 \mathrm{c}$.

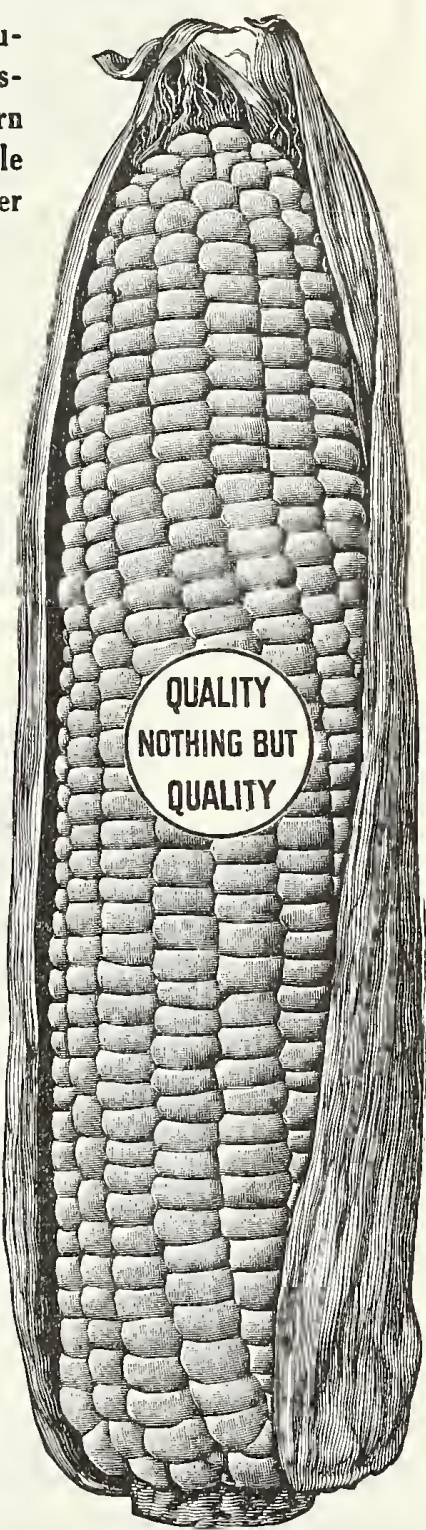

Buckbee's Early Sunrise

Buckbee's Best of All

(1)

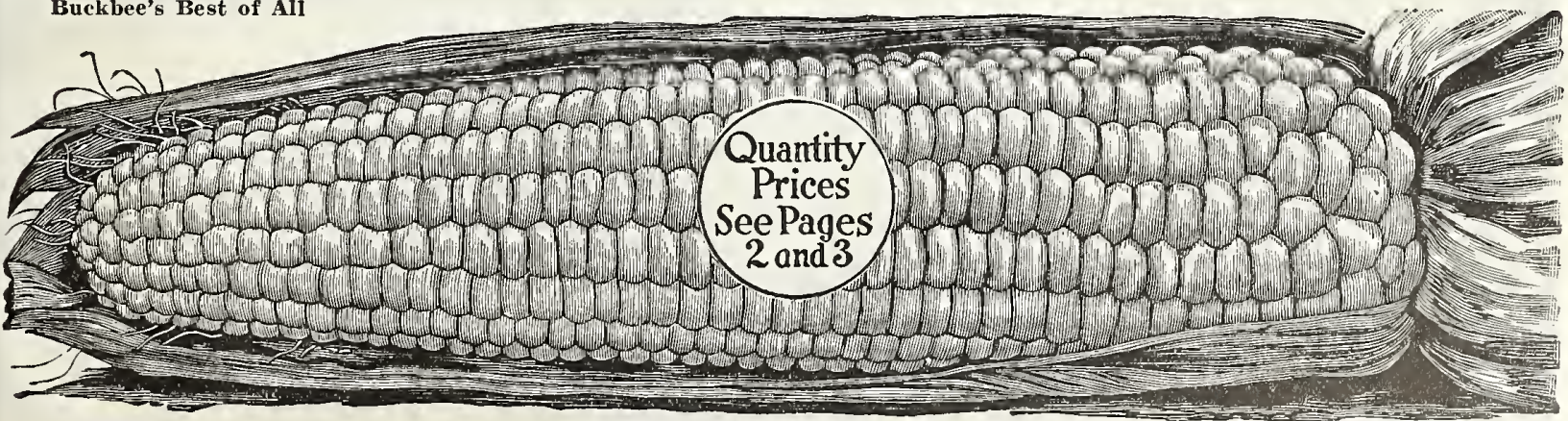

Buckbee's Private Stock Evergreen 


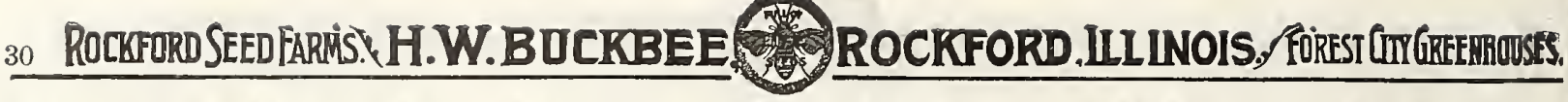

BUCKBEE'S PEDIGREED SWEET CORN

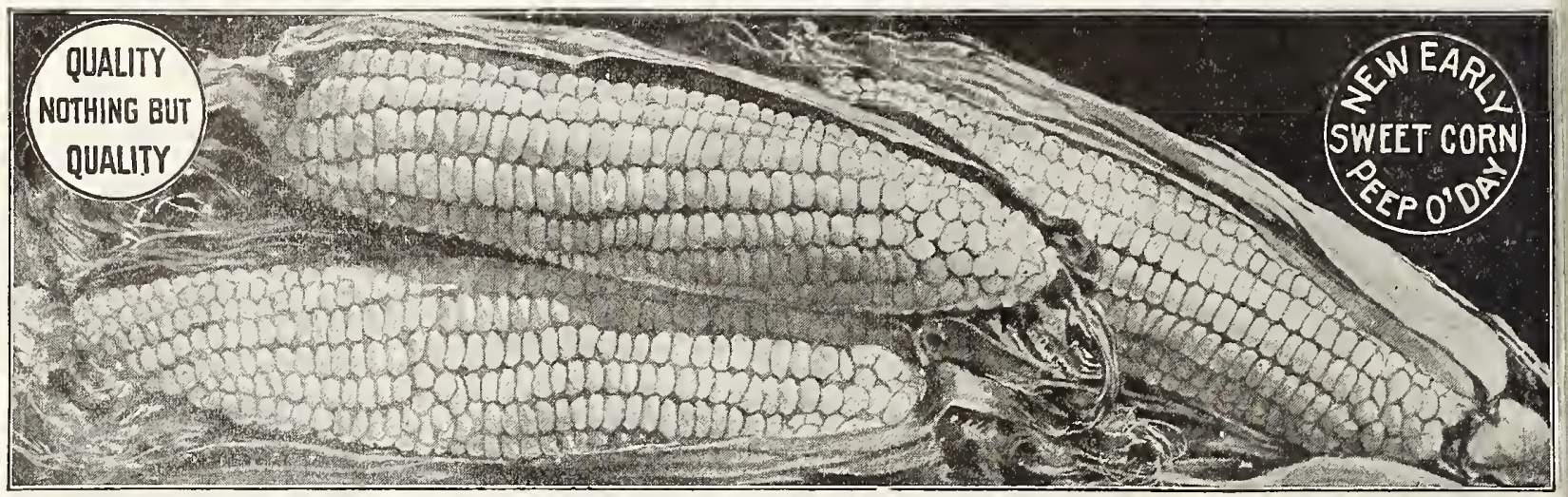

FIRST EARLY VARIETIES

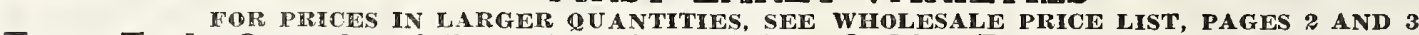

Extra Early Cory One of the most popular varieties Golden Bantam yellow grain, very tender and of excel Well filled to the very ti. Mammoth Early White Cob Cory selected for for the medium size found most suitable for the table The

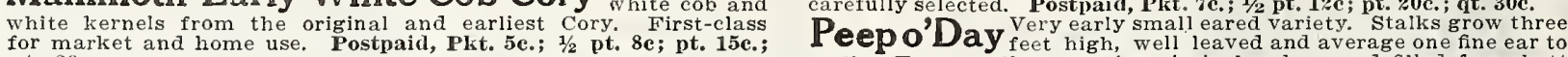
at. 28c.
stalk. Ears small, measuring six inches long and filled from butt
to tip with ten rows of small grains

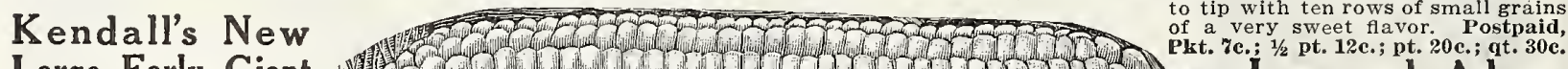

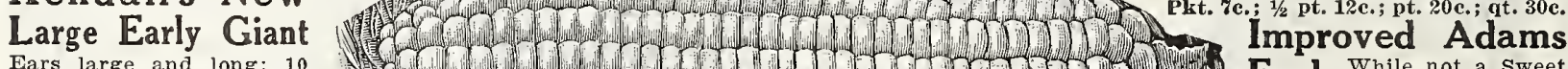
to 12 rowed. Kernels Very desirable for both poses. Postpaiil, Plikt. "ce;
1/2 pt. 12c.; pt. 20c.; qit. $30 \mathrm{e}$.

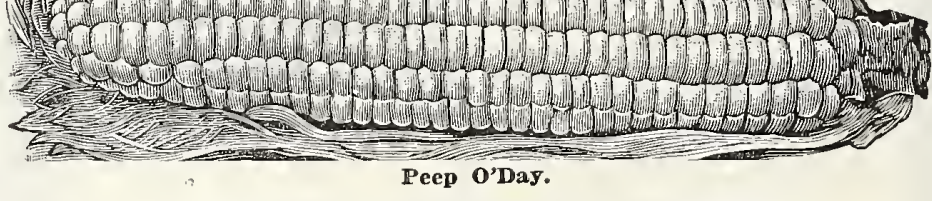

\section{MEDIUM EARLY VARIETIES}

New Honey Sweet An exceptionally fine variety for white color, and has the deepest grains, and smallest cob of any known variety. Fine quality. Postpaid, Plit. 7c; $1 / 2$ pt. 12e;
pt. 20e; qt. 30e. Moore's Early Concord

Perry's Hybrid Pkt. 5e; $1 / 2$ pt. 8c; pt. 15e; qt. 28c

Early Minnesota $\begin{aligned} & \text { This popular variety is one of the } \\ & \text { best early sorts for the market and }\end{aligned}$ the private garden. By careful selection we have developed

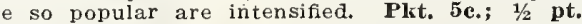

Everbearing $\begin{aligned} & \text { The ears are of good size and covered with } \\ & \text { kernels clear to the end of }\end{aligned}$ husks and stalk are of a red color; each stalk will produce one or two well-developed ears; now if these are picked when mature, the to two and even four more ears will set and develop on four dozen hills will supply a good sized family for weeks. Postpaid, Pkt. 7e; $1 / 2$ pt. 12e; pt. 20e; qt. $30 \mathrm{c}$.

Black Mexican Although the ripe grain is black, or for table, cooks remarkably white and is very tender. Desirable in the South. Postpaid, Pkt, 5e; 1/ pt. 8c; pt. 15e; at. 28c.

Early Crosby of the best flavor. Ears of medium size, 12 or 作 grown in Maine for canning, and it is the use of this variety, rather than any peculiarity of the soil that has given Maine Sweet Corn
its reputation for quality. Pkt. 5c.; 1/2 pt. 8c.; pt. 15c.; qt. 28c. eighth, quarter, half and one bushel or more will be shipped by freight or express at purchaser's expense.

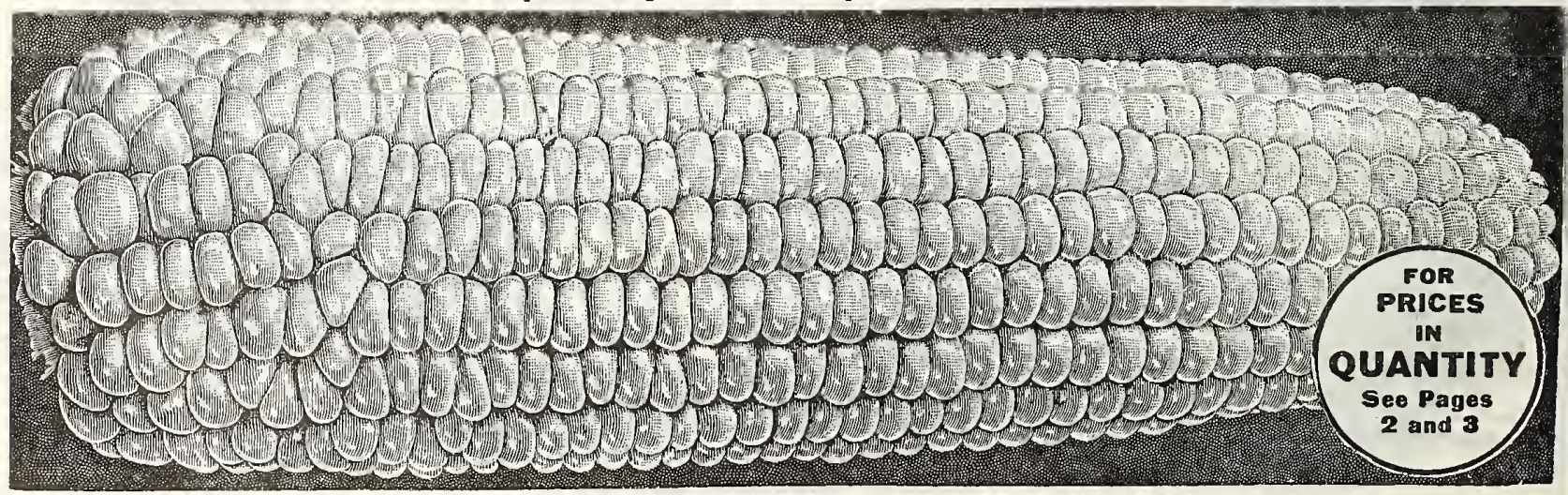




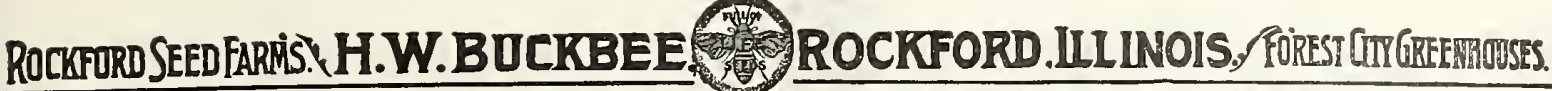

BUCKBEE'S PEDIGREED SWEET CORN IATE OR MAIN

\section{Country Gentleman}

This variety is often called the "shoe peg" corn, owing to the arrangement of the crowded kernels, which are long and very sweet. Our secd of this variety has been carefully selected and is true to name. It is far ahead in flavor of any of the late varieties. It remains tender and fit for use longer than most sorts, as the ear is enclosed in a thick pt. 20c; q t. 30c.

\section{Buckbee's Hickox}

Popular wherever known. One to two weeks earlier than Evergreen. Large, attractive ear; has a white cob and grain and remaius in paid. I kt. 7c; $1 / 2$ pt. 12c; pt. 20c; qt. 30c.

\section{Stowell's Evergreen}

The best known and most largely planted of all the late varieties.

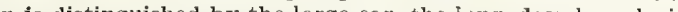
rich, sugary flavor and its long keeping qualities. Our seed has been selected for its swcetness, productiveness and large size. No better can be obtained. It is Northern grown. Our strain is particularly fine and our price is very reasonable. Postpaid. Pkt. 5c; 1/2 pt. 10c; pt. 15e; qt. $28 \mathrm{c}$.

\section{Mammoth Late or Sugar}

Produces the largest ears of any variety, a single ear often weighing two or three pounds. Of excellent quality. Postpaid. Pkt.5c: $1 / 2$ pt. $10 \mathrm{c} ;$ pt. $15 \mathrm{c} ;$ qt. $28 \mathrm{c}$

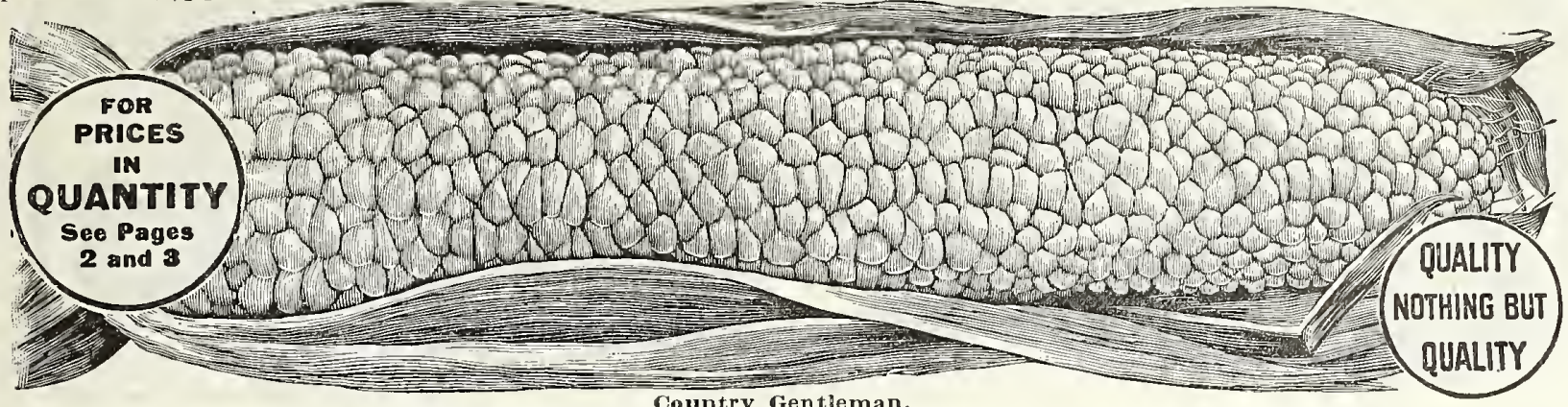

Country Gentieman.

BUCKBEE'S 'FULL

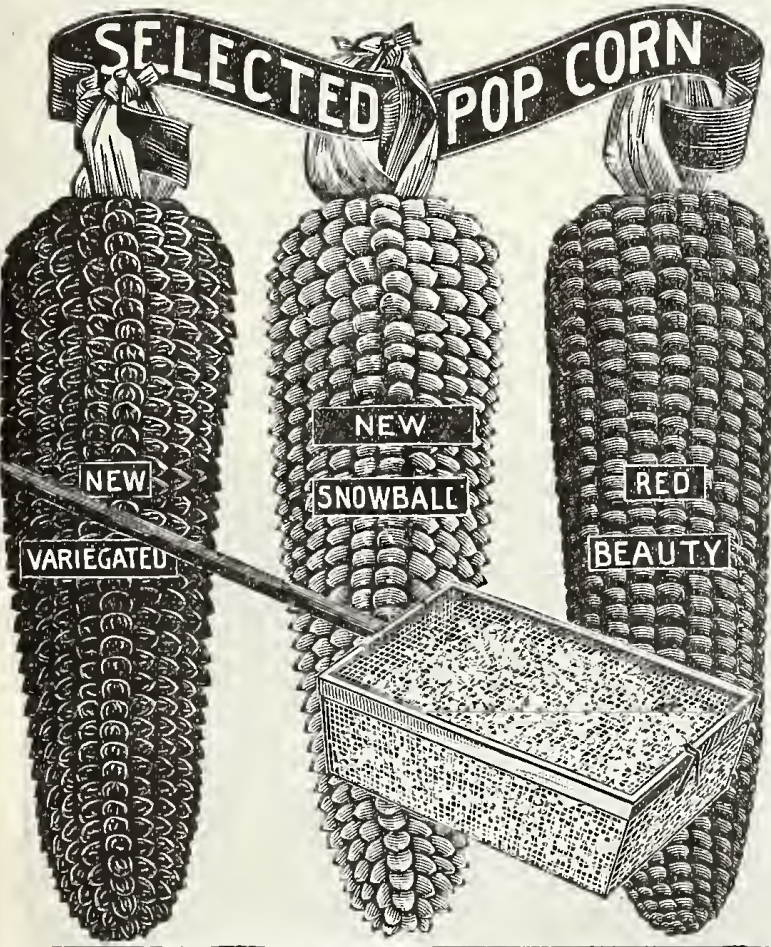

Special Offer FOR ONLY 30c we will send prepaid ONE GRAND VARIETIES OF POP CORN listed on this page.

Buckbee's New Black Beauty Pop Corn The Most Delicious of All.

An extra early variety which pops very large and is the most tender and crisp of all. Although the kernels are black, this color does not seem to show at all when popped, being then a pearly white. This new variety has been bred in Wisconsin and is extremely early, ripenin popcorn brings a very much higher price either shelled or on the ear than any other corn and usually a ready market is easily found for any quantity, while in event of an inactive market, it can always be fed, any quantity, while in event of an inactive market, it can always be fed, at. 50c; Postpaid. By express or freight, not prepaid, qt. $35 \mathrm{c}$ $1 / 8$ bu. $\$ 1.25 ; 1 / 4$ bu. $\$ 2.25$.

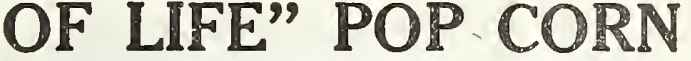

Pop Corn should be found in every garden especially if there are children to enjoy it during the long Winter evening wich bring youn people torether for social amusement. It is a fact not generally known that Pop Corn pops best when more than wrll popped it becomes twenty times its natural size; thus a quart and a half will make nearly a bushel of popped corn. In the illustration will be seen a convenient "popper," which may be bought for a trifle from a Corn as a money making crop? You will be surprised at the result. Thop is always a good market at a fair price, and if you plant our selected stock seed you will be able to sell your crop to planters in your vicinity GOLDEN TOM THUMB-The newest and best. Dwarf growing: heavy cropping; sure popper. Beautiful golden color, making pare with this strain. Send to Buckbee for true stock. Postpaid. pkt. 10c; $1 / 2$ pt. 20c; pt. 30c; qt. 50c. I3y express or freight, not prepaid, at. 30c; $1 / 8$ bu. $\$ 1.00 ; 1 / 4$ bu. $\$ 1.75$.

variety in existence belonging to the rice family. The best yielder, and far in advance of any the best popper. Postpaid. Pkt. 5e; $1 / 2$ pt. $15 \mathrm{c}$; pt. 25c; qt. $40 \mathrm{c}$ By exprcss or freight, not prepaid, qt. 25c; $1 / 3$ bu. $75 \mathrm{c} ; 1 / 4 \mathrm{bu}$. $\$ 1.25$

NEW RED BEAUTY-Fine variety. The stalks grow six feet high, and average three to four ears each from five to six inches long and cov-
ered with large rice-shaped kernels of a deep red color. Post Pkt. 5c; 1/2 pt. 15c; pt. 25c; qt. 40c. By express or freight, not prepaid, quart $25 \mathrm{c} ; 1 / 8$ bu. $75 \mathrm{c} ; 1 / 4$ bu. $\$ 1.25$.

QUEEN'S GOLDEN-One of the very best and most proliflc varieties grown. Its quality and handsome appearance when popped are very noticeable. It pops perfectly white, and a single kernel will expand the large ears arc produced in abundance. Postpaid. Plit. 5c; 1 pt. 15c; pt. 25c; qt. 40c. By cxpress or freight, not prepaid, quart $25 \mathrm{c} ; 1 / 8$ bu. $75 \mathrm{c} ; 1 / 1$ bu. $\$ 1.25$.

MAPLEDALE PROLIFIC-The stalks grow six feet high, and the ears are all large in size, with grains nearly clear white in color. An average ear measured six inches and a half long and contained 585 perfect kernels. Pops pure paper white, of fine quality. Be sure to include this remarkable variety in your order for Pop Corn. Postpaid. Pkt. 5e; $1 / 2$ ot. $15 \mathrm{c}$; pt. $25 \mathrm{c} ;$ it. 40c. By express or freight, not prepaid, quart 25e; $1 / 8$ bu. 75c; $1 / 4$ bu. $\$ 1.25$.

NEW STRIPED OR VARIEGATED-A fancy variety, very showy and of the best quality Rather large ears, filled out with clear transparent white kernels, bcautifully striped with bright crimson. A good express or freight, not prepaid, quart $25 \mathrm{c} ; 1 / 8$ bu. $75 \mathrm{sc} ; 1 / 4 \mathrm{bu}$. $\$ 1.25$.

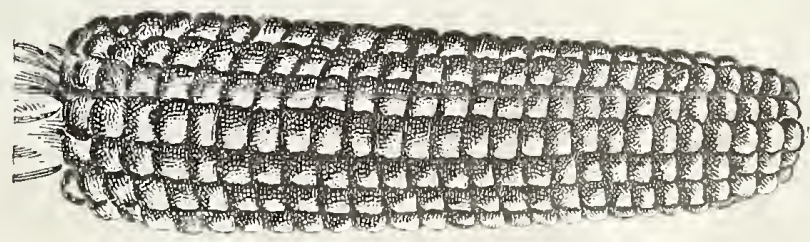

Buckbee's New Black Beauty Pop Corn. 


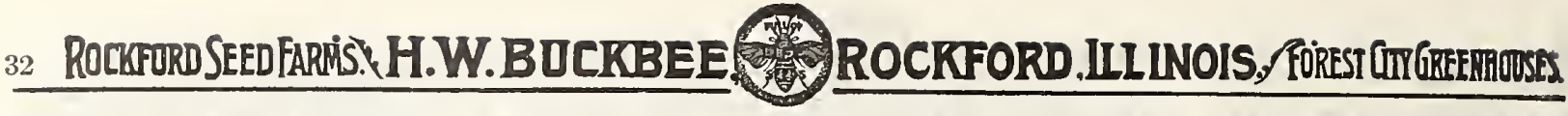
BUCKBEE'S "Full of Life" CUCUMBERS

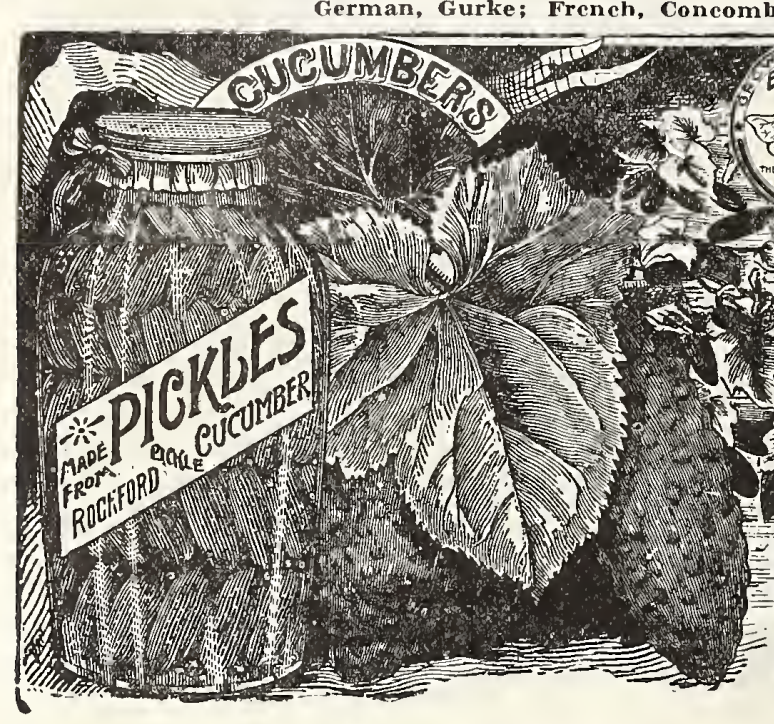

Buckbee's New Rockford Pickle

Without Question the Preferable Variety

For Pickling, Market, Table and Family Use.

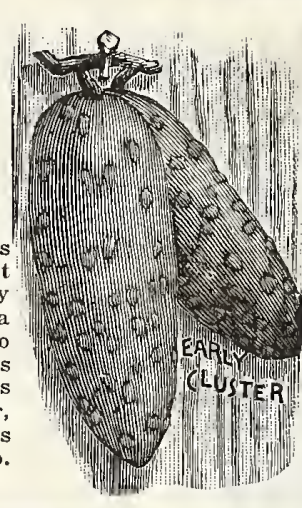

Buckbee's Monarch White Spine

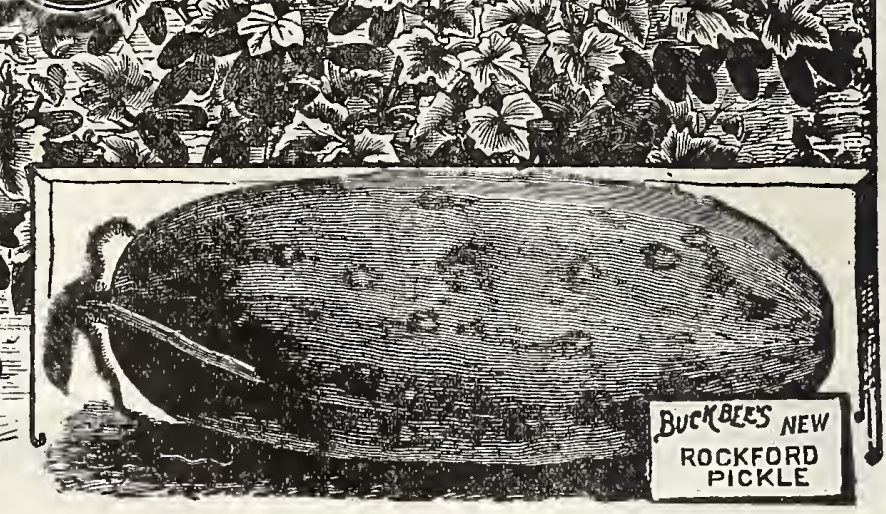

The Most Profitable Cucumber for Truckers'

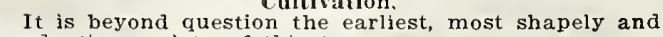

productive variety of this type.

variety has not been found wanting in any single point.
We are confident that it will always hold the highest

early and prolific, extremely productive, quite hardy

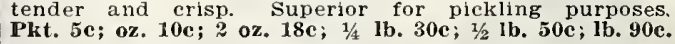

Early Green Cluster

Fruit is of the form desirable for pickling. Extraor-

hree Cucumbers. Nothing more desirable for ines will continue bearing. Plat 60c: $1 \mathrm{~b}, \$ 1.00$

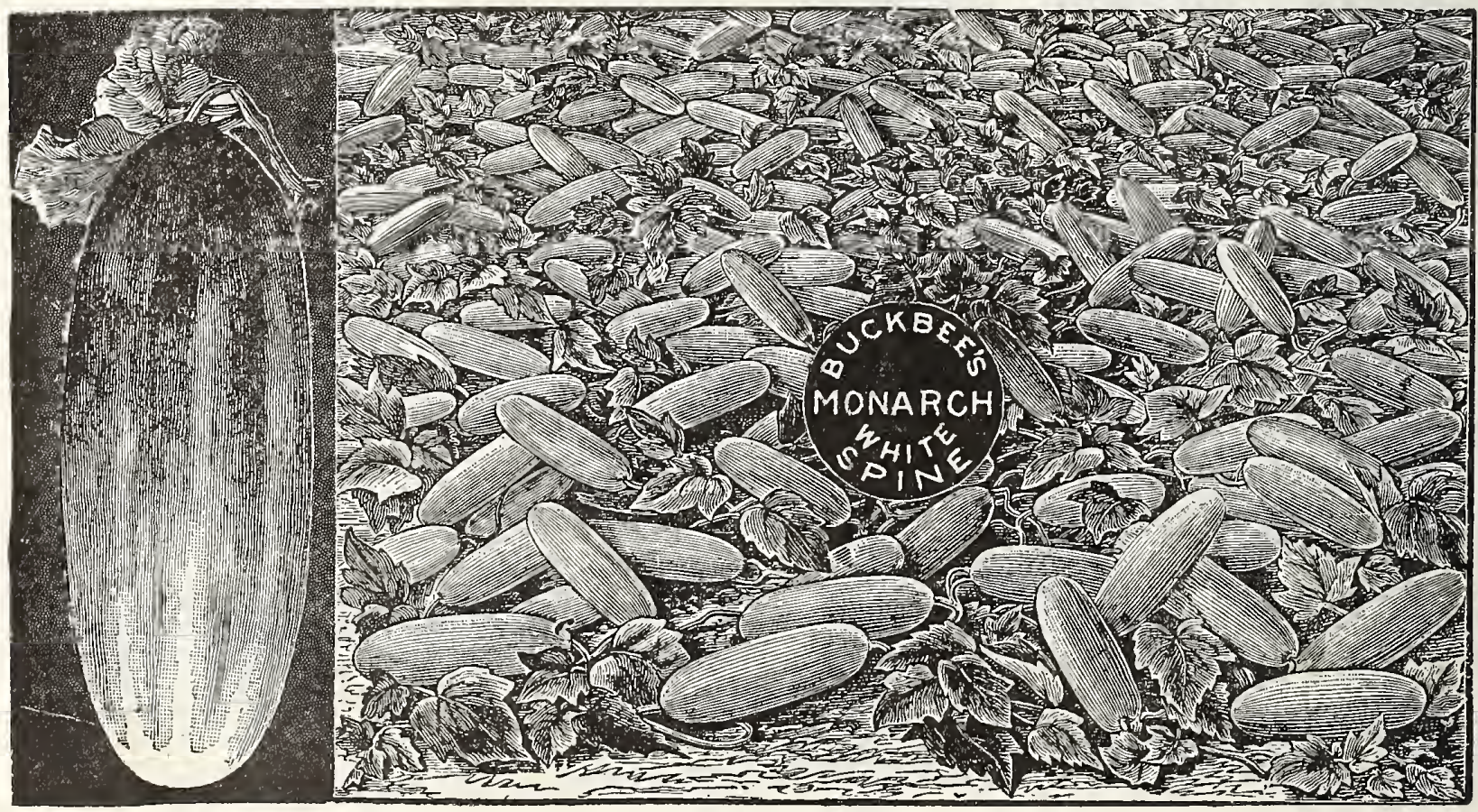




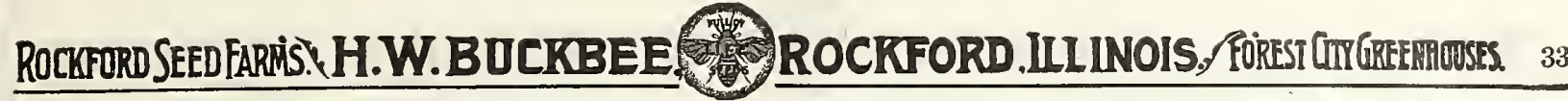 BUCKBEE'S "Full of Life" CUCUMBERS}
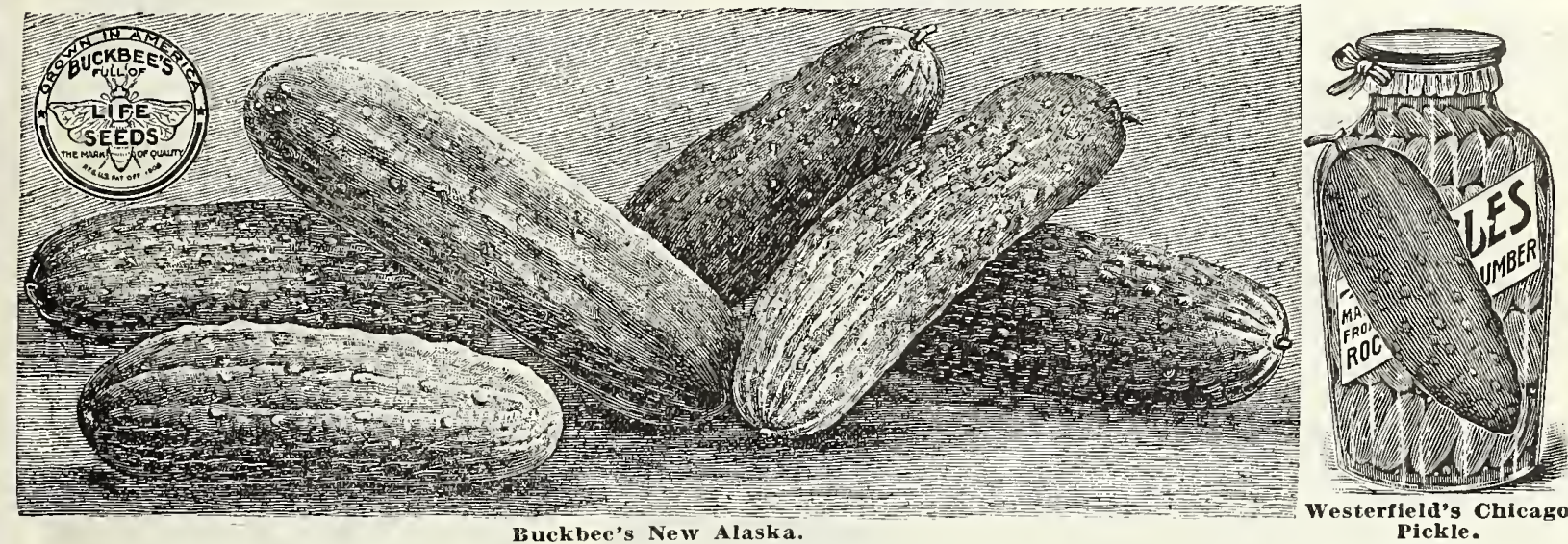

\section{BUCKBEE'S NEW ALASKA}

This is a Grand Good Cucumber.

Beautiful in shape and color and of the finest quality. An entirely new and distinct sort developed by ourselves through very careful selection, aiming to secure the best possible table Cucumber. The vine ing very early. The fruit is of splendid size, with very white, crisp and tender flesh. An excellent sort for culture under glass. Pkt
lb. $25 \mathbf{2 5} ; \mathbf{2} \mathbf{1 b} \mathbf{4 0 c ; 1 b . 7 5 c .}$

\section{KLONDIKE}

The World Reating Cucumber.

An extra fine new strain of White Spine, with very to ship North. Good for table, market or pickling. Comes into bearing early and continues through the has become their main crop and the demand for it is growing rapidly. The fruit is firm and hard and keeps in prime condition a long time after picking. Pkt. 5c; oz. 10c; 2 oz. 18c; $1 / 4$ lb. 30c; $1 / 2$ lb. 50c; 1b. 90c.

\section{WESTERFIELD'S CHICAGO PICKLE}

Hardy and improved strain of pickling Cucumber planted by the most extensive pickle growers in the west. Produces nice even growth, extra early,

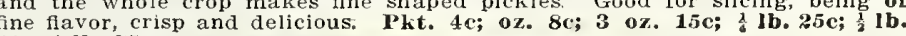
40c; $1 \mathrm{lb} .75 \mathrm{c}$

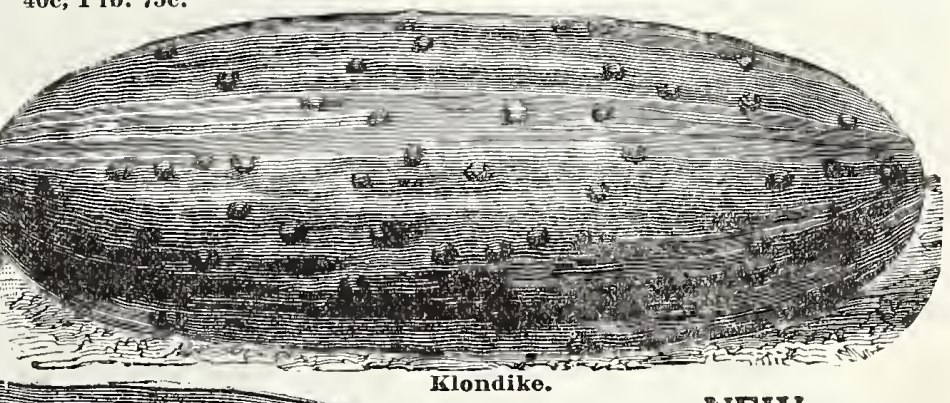

NEW

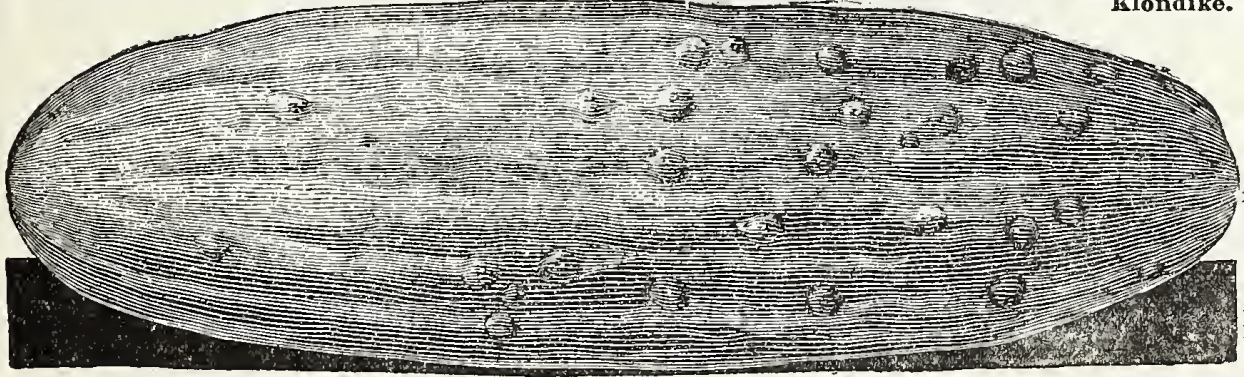

New Cumberland.

\section{CUMBERLAND}

\section{BUCKBEE'S NEW EXTRA EALRY LONG GREEP:}

\section{The Ideal Variety to Plant for General Crop.}

Produced by selection from Long Green. Vines vigorous and productive, forming fruit fit for the table nearly as early as the shorter sorts. Fruit grows about 12 inches long, firm and crisp. The young fruit makes the best pickles, and when ripe are preferable to any for sweet pickles. We offer a carefully selected strain, uniformly long and of good form, with the 1 . ib. $\$ 1: 00$.

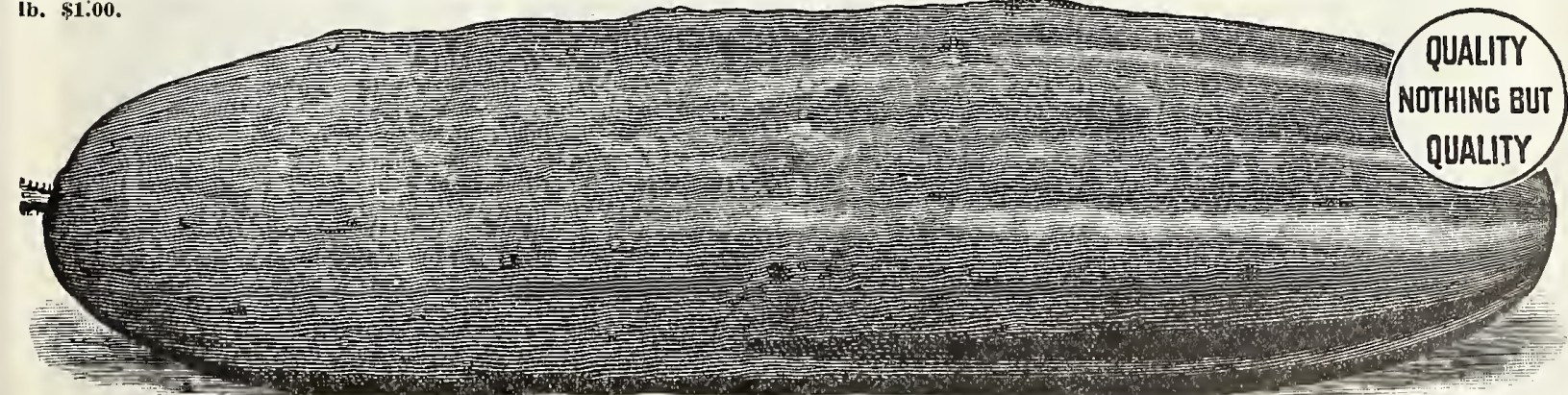




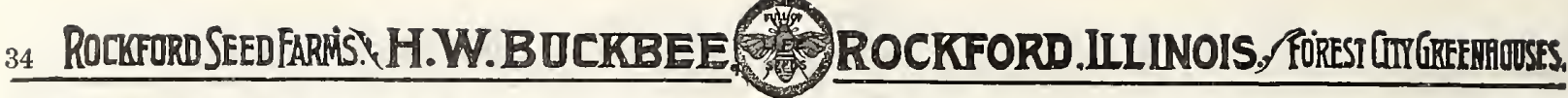

BUCKBEE'S "Full of Life" CUCUMBERS

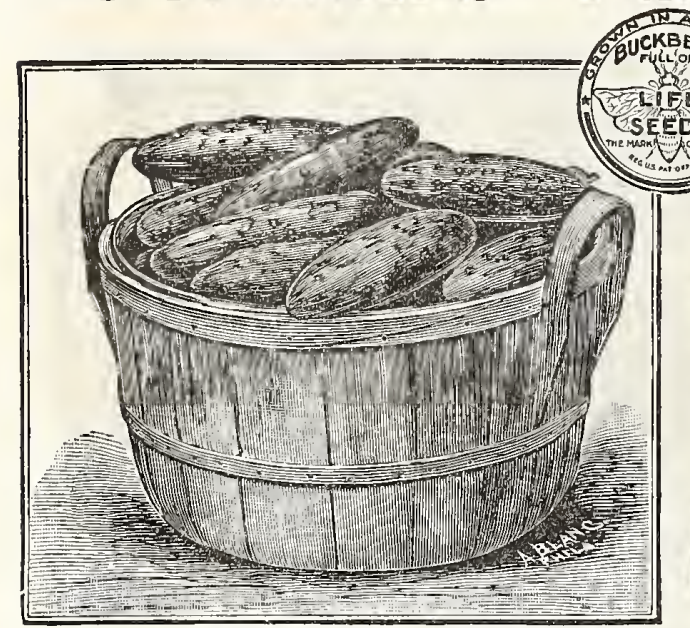

Davis Perfect Cucumber.

\section{Davis Perfect}

\section{PRIVATE STOCIS.}

By using this variety gardeners can produce out-ofdoors Cucumbers that will sell in the market for hotbouse forcing varieties. The shape is ideal. It is almost seedless one-third of its length from the stem, and the few seeds that are contained in its blossom that they are hardly noticeable. Plit. 5c; oz. 10c; $20 z$. 18c; $1 / 4$ lb. 30c; $1 / 2$ lb. 50c; 1b. $90 \mathrm{c}$.

\section{New Parisian Prolific Pickling}

Decidedly the best of all in quality for pickling. The fruit is of an unusually dark green color, so deep that no coloring matter is necessary in preparing them 5c; oz. $10 \mathrm{c}$; 2 oz. $18 \mathrm{c} ; 1 / \mathrm{s} 1 \mathrm{lb} .30 \mathrm{c} ; 1 / 2 \mathrm{lb}$. $55 \mathrm{c} ; 1 \mathrm{~b} . \$ 1.00$.

\section{New Everbearing}

The merit of this variety is in the fact that the vines produce fruit continuously until killed by frosts. stage of growth, but invariably of perfect form, even when quite small. The fruit is of fine green color and very desirable for pickling. Pkt. 4c; oz, 8c; 2 oz. 15c; $1 / 4$ lb. $28 \mathrm{c} ; 1 / 2$ lb. 50c; $1 \mathrm{~b}$. $90 \mathrm{c}$.

Early Prolific Short Green, or Early Frame

A most excellent sort for pickling as well as for table use. Vigorous, productive plants. Fruit straight, handsome, crisp and tender. Keeps green a long while. Our stock is A1. Pkt.

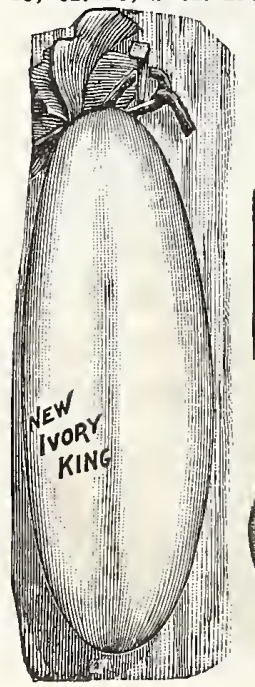

New Ivory King Fruit large, clear white, tender and excellent in flavor. Splendid for home garden, and the best white skinned variety Pkt: lb. $\$ 1.25$.

We can supply the following varieties of Cucumbers which are too
extended description, at following prices:

Arington Improved White Spine, Early White Spine, Boston Pickling or Green Prolific, Early Russian, Snow's Early Pickle, Peerless White Spine, Improved Long Green, Nichols Medium Grcen.

Plkt. $3 \mathrm{c}$; oz. $8 \mathrm{c} ; 2$ oz. 15c; $1 / 4$ lb. $25 \mathrm{c} ; 1 / 2$ lb. $40 \mathrm{c} ; 1 \mathrm{lb} .75 \mathrm{c}$.
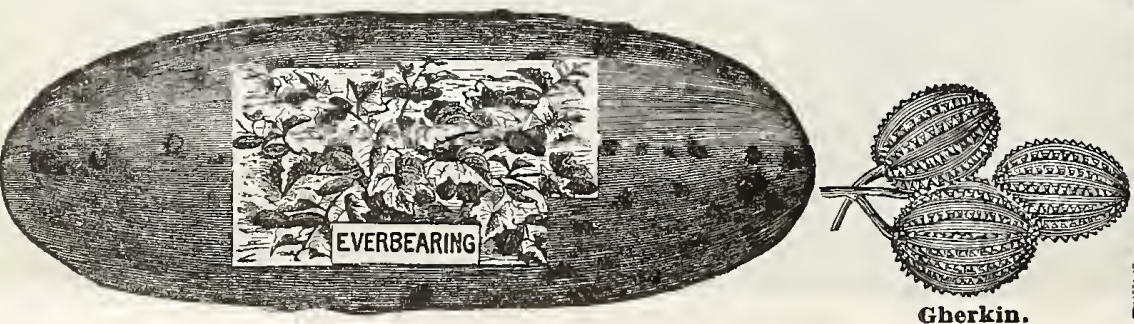

Gherkin.

\section{Snake, or Serpent} West India Gherkins

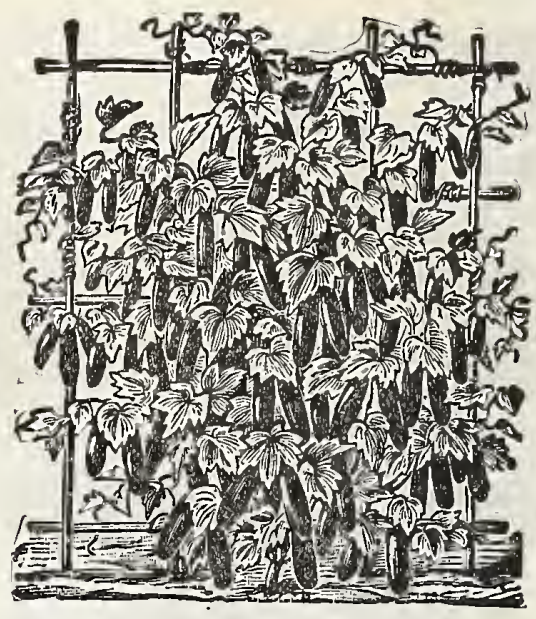

Japanese Climbing Cucumber.

The vines are of vigorous growth, with dark green foliage, and throw out strong tendrils which enable Comes into bearing quickly, and continues abundantly through the season, while the climbing habit enables the fruit to grow perfectly straight-from and delicate young makes attractive pickles. Pkt. 5e; oz. 10c

\section{Buckbee's International}

This grand, good early variety of our own in it. Has no thick ends, or rich, luxuriant growth an abundant yielder, has beautiful fruit and always ways tender and crisp. You should not fail to try it. Pkt. 5c; oz. 10e; 2 oz. 18c; $1 / 2$ lb. 30c; $1 / 2 \mathrm{lb}$.

\section{New Emerald}

A dark green Cucumber, retaining its color until quite ripe. Fruits set early. For slicing, the flesh Fxcellent pickles when young, and fine for sweet pickles when ripe. Pkt. 4c; oz. 8c; 2 oz. 15c;

This Cucumber is curious as well as useful. We have seen it six feet in length, coiled like a serpent. It is an interesting thing

Used exclusively for pickling. Small oval-shaped, prickly

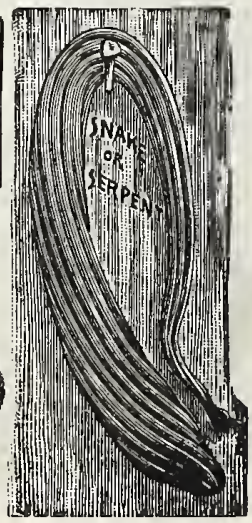




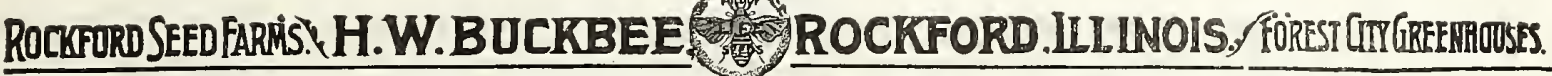

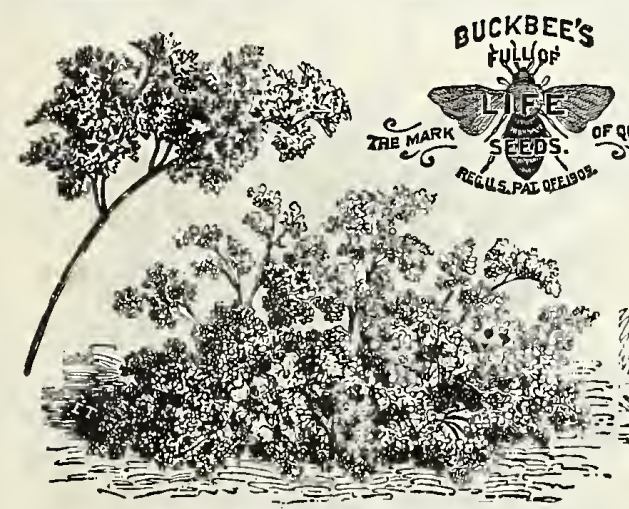

Chervil, Curled.

CHERVIL
German, GARTENIKERBEL; French, CER FEUIL Hardy annual, worthy of more general use for favoring and garnishing.

beautiful than parsley.

CURLED-Greatly superior to the old, plain variety; earlier, more handsome, having fully as 2 oz. $18 \mathrm{c} ; 1 / 4$ lb. $35 \mathrm{c}$.

\section{CHIVES}

\section{Also Called Schnittlauch.}

Chives are perfectly hardy perennial plants of the onion type. They are grown for their in the Spring, for giving a mild onion favor to various dishes. The tops appear early in the Spring, and can be shorn off close to the ground as needed. They can be grown also in pots in a sunny window during the Winter. Easily raised from seed. Pkt. 10c; oz. 50c. $\$ 1.50$ per doz., postpaid.

\section{THE WONDERFUL COFFEE BERRY}

\section{THE GREAT HEALTI DRINK.}

\section{Once Tried Always Used.}

All pronounce it better than the genuine. It is certainly the best berry to mix with other

duce a drink claimed by many to be ily raised and most enormously productive. a pound. Full directions on every' package. Our seed is genuine. La

\section{CHUFUS OR EARTH ALMOND}

In sweetness and flavor very much resem-

bles a cocoanut or almond, and sreatly liked by all children. Vary in size from a large pea to a hazelnut. The nuts grow under and very near the surface of the ground and very easily reached; relished by pigs in rows $21 / 2$ feet apart. If the seed is dry,

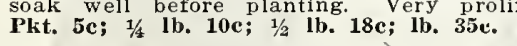

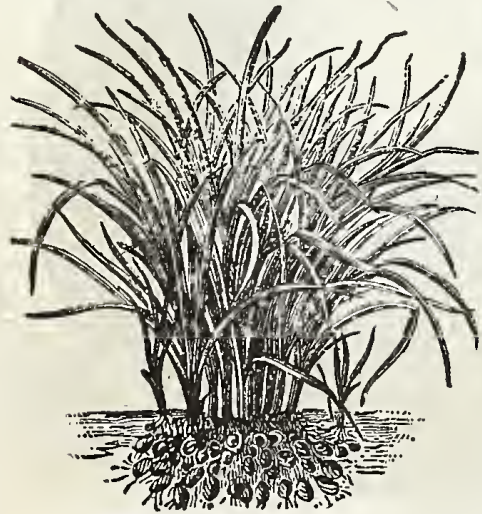

Chufus, or Earth Almond.

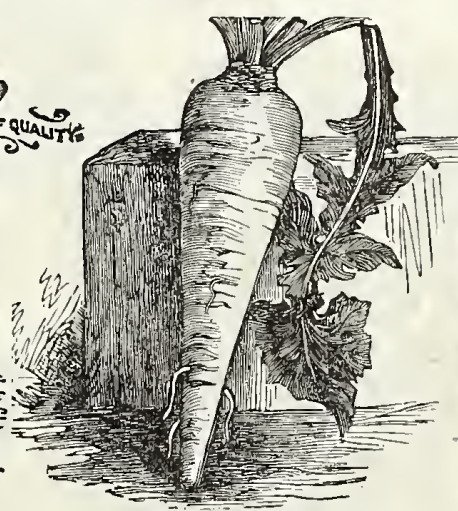

Chicory, Large Rooted.
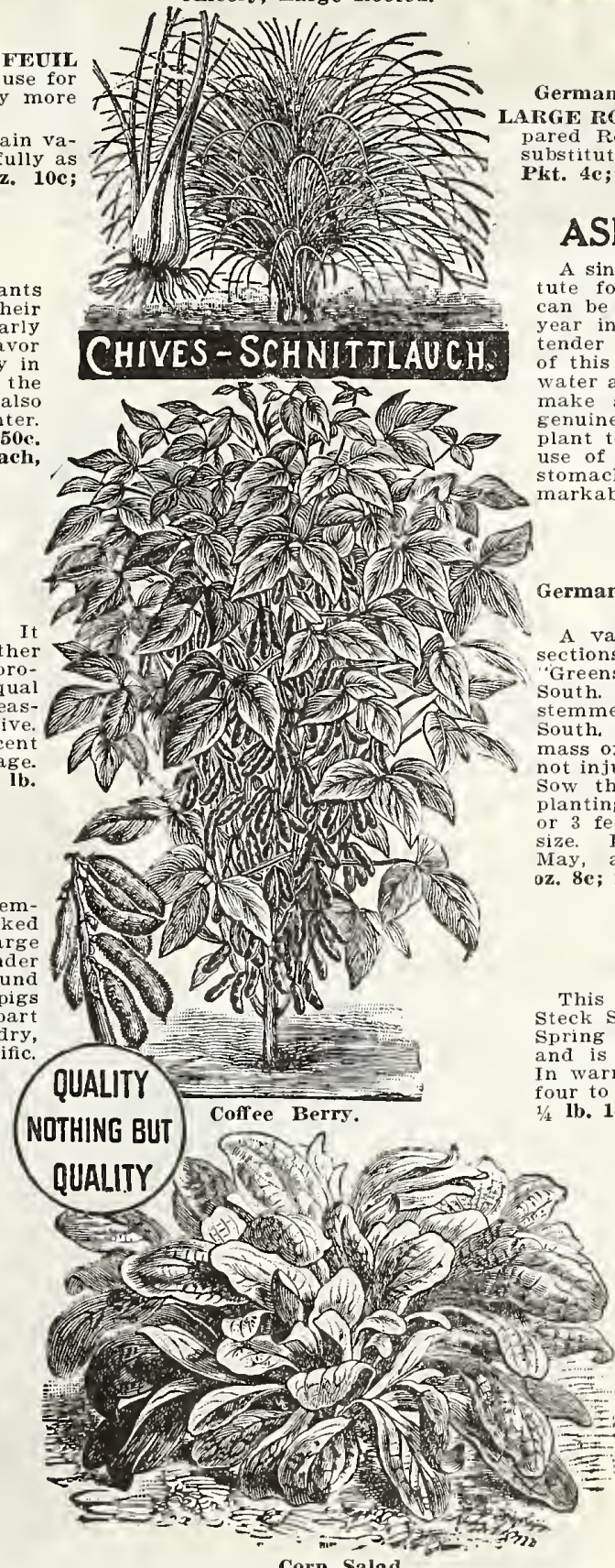

Corn Salad.

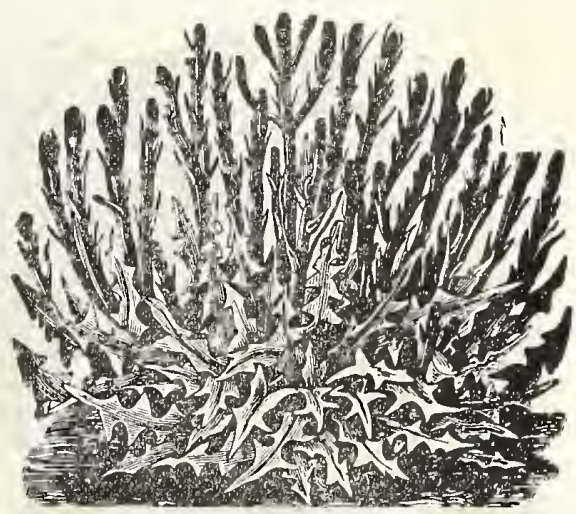

\section{CHICORY}

German, CHICORIE; Stredish, CICORIA. ARGE ROOTED, OR COFFEE-Dried and prepared Roots are used quite extensively as a
substitute for and an adulterant of coffee. Pkt. 4c; oz. 8c; 2 oz. 15e; $1 / 1$ lb. $25 \mathrm{c}$.

\section{ASPARAGUS CHICORY}

A singular, good, healthy and tasty substi which springs from the root make a most excellent substitute for the grow; the benefit derived from the stomach disease or weak digestion, is re-
markable. Pkt. 10c; 3 pkts. 25c; oz. 35c COLLARDS

German, BLAETTER-KOHL; French, CHOd Georgia, Southern or Creole.

A variety of cabbage known in different ctions as "Cole" "Colewort," or simple of leav on Freezing does feet apart in the row when the proper May, and August to October. Pkt. 4e; oz. 8c; $20 z$. 15e; $1 / 1 / 1$ lb. 25c.

\section{CORN SALAD}

(Fetticus or Lamb's Lettuce.)

This delightful salad, known as MacheSteck Salot, is used during the Winter and months as a substitute Wor lettuce, warm weather the plants will mature in lb. $18 \mathrm{c}$.

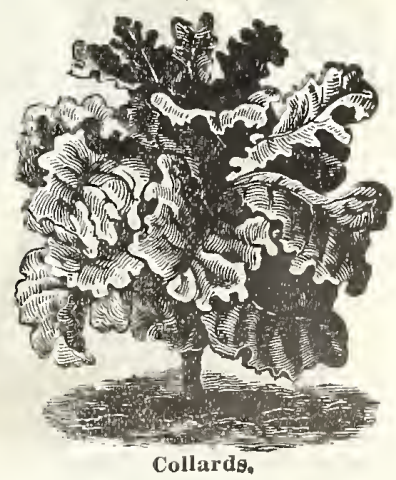




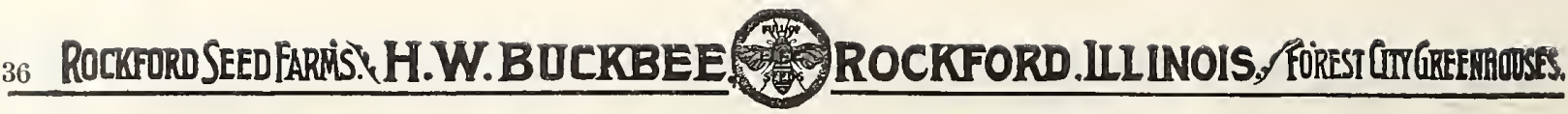

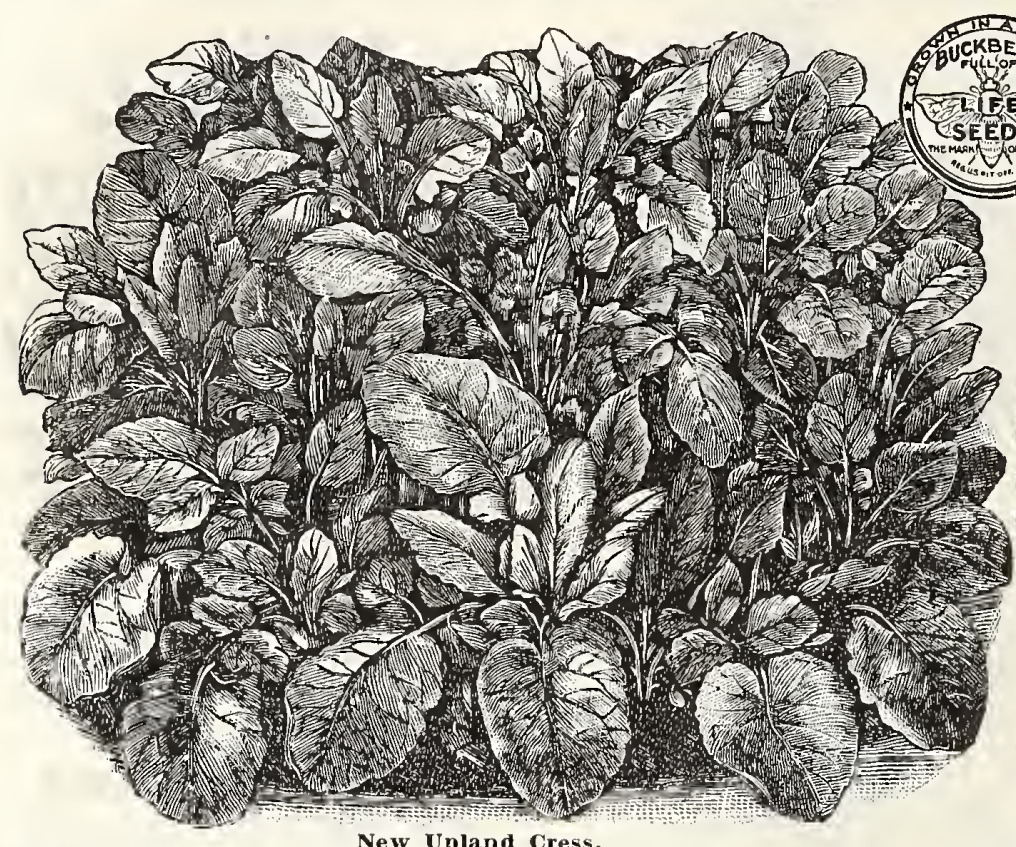

CRESS GERMAN, Kresse; FRENCH, Cresson; NEW UPLAND CRESS-Has the highly prized flavor of Water Cress. It is so hardy as to be green nearly the whole year, and is ready for use before any other Spinach. It is a perennial plant, and can be grown for several years without CURLED, OR PEPPER GRASS-This small salad is much used with lettuce to the flavor of which its warm, pungent taste makes a most agreeable addition. TRUE WATER CRESS-This is quite distinct from the last, and only thrives when its roots and stems are submerged in water. It is one of the most delicious
of small salads, and should be planted wherever a suitable place can be found. of small salads, and
Pkt. 5c; oz. 25c.

\section{BUCKBEE'S "Full of Life" EGG PLANT} EIERPFLANZE, German; AUBERGINE, French; BERENGENA, Spanish. BUCKBEE'S NEW EARLY LARGE PURPLE

Better variety than New York Purple, early, large size and high quality of fruit, and its extreme productiveness makes it the most profitable to grow. Plants large, spreading; nearly white. Plants ripen

\section{BUCKBEE'S NEW WHITE}

This variety is without a doubt the preferable one by far of all to grow either for market, family or shipping purposes. Produces much larger fruit and is mo

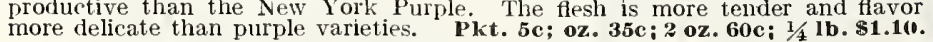

\section{IMPROVED NEW YORK PURPLE}

Large, round or oval, of excellent quality, highly esteemed in marke
4c; oz. 25c; 2 oz. 40c; $1 / 4$. 75 c.
NEW BLACK BEAUTY

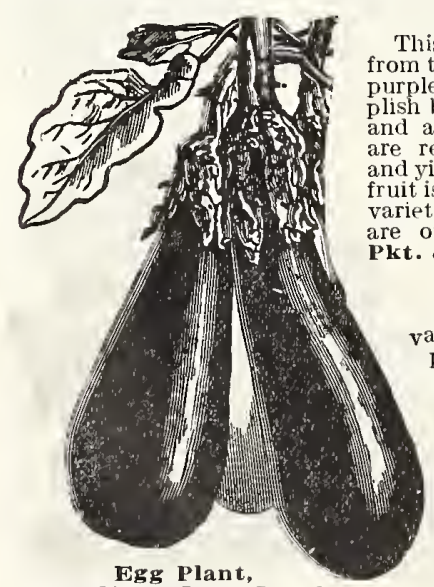

Extra Early Long Purple.
This recently introduced Egg Plant is tustrous, purlavorite where known. The plants dield an abundance of large fruits. The this of the very finest possible quality Extra Early Long Purple One of the earliest and most productive arieties. Fruit long, dark, rich purple and of fine quality. Pkt.4c; oz.

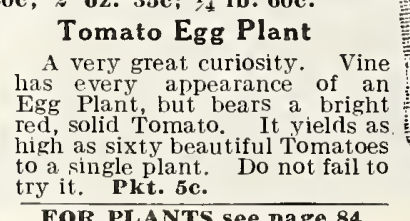

FOR PLANTS see page 84

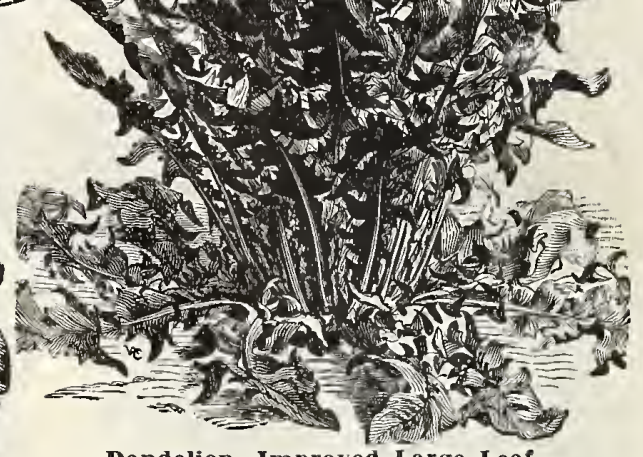

Dandelion, Improved Large Leaf.

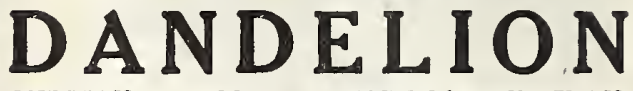
ISH, Amargon, SWEDISH, Smor-

One ounce of seed will sow 150 feet of drill. There is a growing demand for cultivated DandeGreens. If blanched like celery make a fine and delicious salad. The roots when dried and roasted are

The roots may also be taken up and planted in boxes in the same manner as parsley and will furnish a supply of fresh "greens" during the Winter montlss.

IMPROVED LARGE LEAF-An improved variety

of Dandelion, very early. Leaves fully double the careful cultivation have developed a very fine strain of seed. Sow in May or June and cultivate during the Summer, and the following Spring the leaves will fit to cut. Pkt. Ec; oz. 40c. 


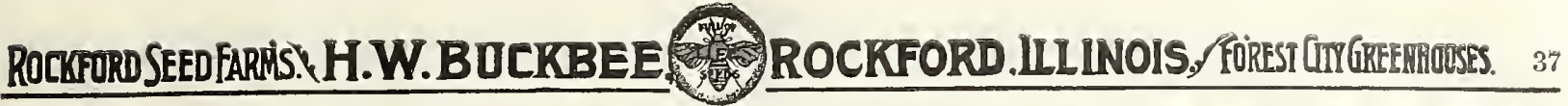

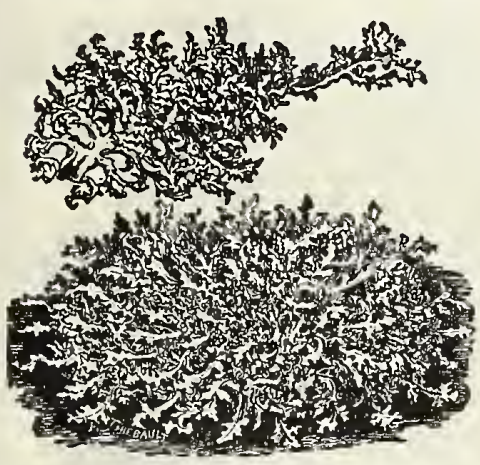

Endive-Winter Lettuce.

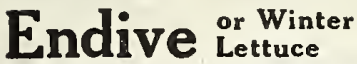

This is one of the most refreshing of all autumn and winter salads. Endive may be grown at any season of the year,
ally used late in the fall.

FINE GREEN CURLED-Is the hardiest variety : very fine, dark green leaves, which blanch to a beautiful white, tender and crisp. Pkt. 3c; oz. 8c; 2 oz. 15c; $1 / 4$ lb. 28c; $1 / 2$ lb. б0c; $1 \mathrm{~b} .90 \mathrm{c}$.

NEW MOSS CURLED-Very fine variety growing considerably denser and having the leaves much finer cut than the Green Curled variety: in fact, the whole plant is more compact. Pkt. 3c; oz.

BATAVIAN-This is the vegetable that is known to many as Escarolle. Large heads of broad thick leaves, which can be blanched Pkt. 4c; oz. 10c; 2 oz. 18c; $1 / 4$ lb. 35c; $1 / 2$ lb. $60 \mathrm{c} ; 1 \mathrm{~b} . \$ 1.10$.

\section{Garlic}

GERMAN, Knoblauch; FRENCH, Afl

The Garlic is the most pungent in taste and has the strongest odor of all the onion family. It is largely used in the south of Europe, where it is esteemed for flavoring soups, stews, etc "cloves," which are planted in the Spring. We frequently receive orders for Garlic seed, but can supply the bulbs only. Fine Bulbs $1 / 4$ lb. 15c; $1 / 2$ lb. 28c; Ib; 50c

\section{Honey Plants}

SPECIAT all the best honey 5c; oz. 15c; $1 / 4$ lb. 30c; $1 \mathrm{~b} . \$ 1.00$.

\section{Horse Radish}

Horse Radish rarely produces seed but is grown from pieces of the roots. Ordinary Horse Radish is a very profitable crop, but with this magnificent new sort from Bohemia the possibilities are wonderful. Tire roots are so much larger and heavier that the so much quicker that the crop can be sold in October. The flesh is pure white. Three and four tons per acre can be grown easily. The dest variety. Fine sets, postpaid, doz., 81.25 per 100 . By express $85 \mathrm{c} ; 500$ for $\$ 4.00,1,000$ for $\$ 7.50$. COMMON HORSE RADISH.

The old-fashioned standard vaiety. Sets or Roots, postpaid. $15 \mathrm{c}$ per doz., 75c per 100 . By express or freight, not prepaid, for $\$ 4.00$.

\section{Buckbee's XX Soap \\ For Plant Insects} See Page 158
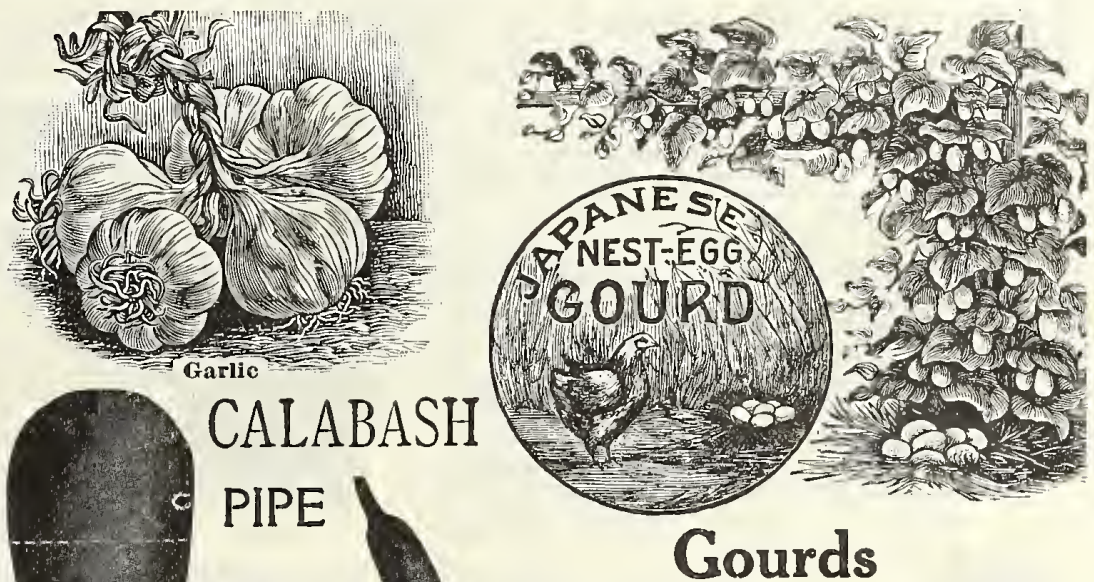

Rare, Useful and ornamental Varieties BUCKBEE'S NEW CALABASH PIPE GOURDLight and attractive pipes can be made from the fruits of this Gourd by any one at a nominal cost. They are the lightest pipes made for their size, are graceful in shape, color like mecrschaum, and are gourds are very expensive, American dealers usualty charging $\$ 8.00$ to $\$ 12.00$ apiece for them. The plant thrives and grows luxuriantly in all parts of the United States, from New England to the Gulf, and from the Atlantic to the Pacific, producing in great abundance the fruits or gourds from which the pipes are made. The Vine is also very ornamental and useful for covering fences, unsightly places, etc Price, 10c per pkt.; 3 pkts. 25e.

NEW JAPA NESE DISH CLOTH, OR LUFFA-Ornamental enough for a house vine and fruit is ver useful. Fruit enormous, two feet in length, and borne in great profusion. The lining of mature fruit, when washed and bleached, is porous, tough, elastic, sponge-like, making the nicest, cleanest substitute for dish cloths and bath sponges imaginable besides being useful for various articles of fancy work. Pkt. 4e; oz. 20c.

SUGAR TROUGH-Enormous, hard-shelled fruit, holding from 3 to 10 crallons each, and as they never rust or rot, and are very light and strong, are just right to use as receptacles for lard, salt, seed corn, soap, etc., or to use as nesting boxes, etc. They last for years. Pkt. 4c; oz. 12c; $1 / 1$ ib. 35c.

TRUE NEST EGG-Resembling in color, shape and

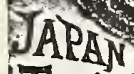
size the eggs of hens. Do not crack, last for years and make the best of nest eggs, Rapid grower and covering screens. etc. Plit. 4c; oz. 15c.

TOWEL GOUR DoR LOWA

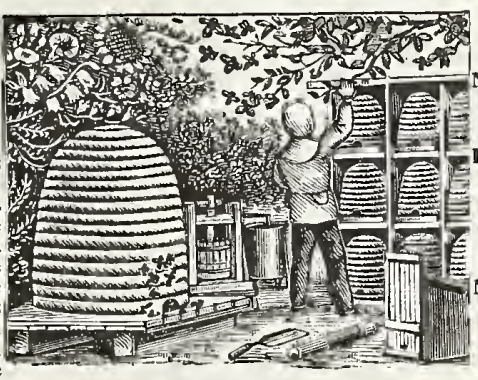

fruit, curious and at the same time exceedingly usefruit, curious and at the same time exceedingly useful to use in storing various articles, as the fruit is hard shelled and las

NEW SERPENT-A beautiful climbing variety of easy culture, heavy foliage and serving as the best
shade. None better for climbing purposes. Pkt. 5e. IPPER-Another useful gourd that, as its fruit is light and strong and does not rust, rot or heat easily is just right to use in dipping hot liquids, soap, etc. besides being useful for birds' nests, fancy hanging
baskets, etc. They hold from a pint to a quart and a half each. Pkt. 4c; oz. 15c.

NEW SPOON-Small fruits with slender neck four to five inches long, brilliantly marked in green and off ing the shell, a spoon may be made. They will be found quite useful also in darning stockings and

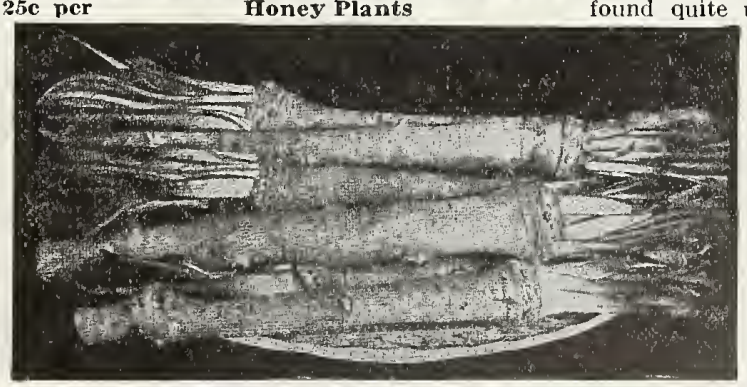

Horse Radish, New Bohemian glove-fingers, while the dry fruits with the seeds left in make fine
rattles for the baby. Pkt. 5c; oz. $25 \mathbb{c}$.

FINEST MIXED-Combining in the largest mixture the most curious, interesting and useful of the oz. $15 \mathrm{c}$. 


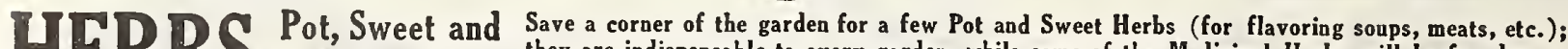

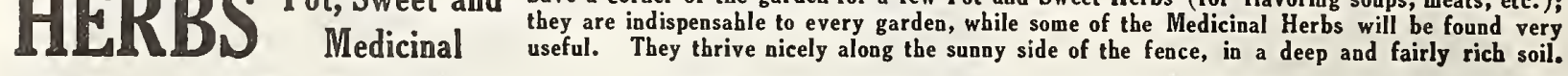
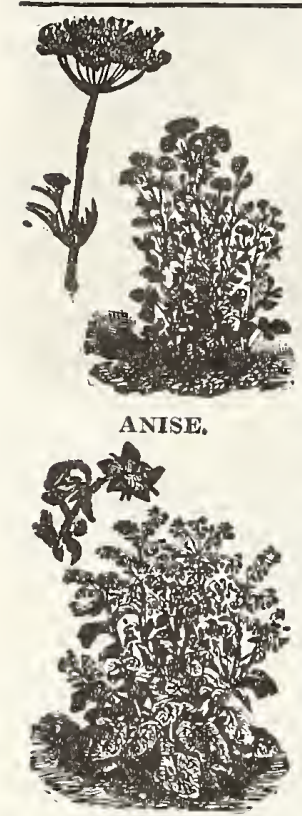

BORAGE.

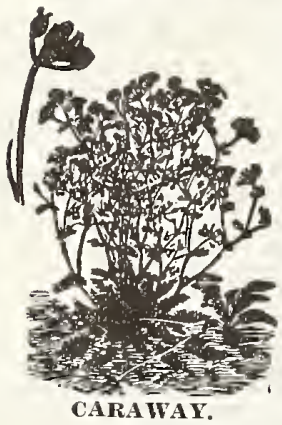
ANISE
Used for cordial. gar-
nishing and flavoring. $4 \mathrm{c} ;$ oz. 10c.

\section{BALM}

The leaves are used for making a pleasant beverage ea. Pkt. 4c; oz. 20c

\section{BASIL, SWEET}

The leaves are used in flavoring soups, stews and highly-seasoned dishes. Pkt. BORAGE

Leaves used for flavoring. and flowers furnish bee pasture; most easily grown in any waste place. Pkt. 4c:
oz. 10c. CATNIP, or CATMINT Grown for bee pasture. Leaves and young shoots are used for seasoning. Pkt. 5c; oz. 30c.

\section{CARAWA}

Seeds are used for flavoring bread, pastry, meats, etc. The oil relieves gas on the Pkt. 4c; oz. 8c.

\section{CHAMOMILE}

Makes valuable poultices. Desirable also for diseases of the stomach. Pkt. 5e.

\section{CORIANDER}

The seeds are used in the manufacture of liquors, in confectionary and culinary
preparations. Pkt. 4c; oz. 8 .

Fruit is warming, stimulating and quiets nervousness. The tea is good for colic and prevents hiccough. Used cumbers. Pkt. 4c; oz. 8c $1 / 1$ lb. $18 c ; 1 / 2$ 1b. 30c; 1b.

\section{FENNEL, SWEET}

The leaves are ornamental. When boiled are used in fish sauces, also make a splendid tea for colic. Pkt. 4c; oz. 8c

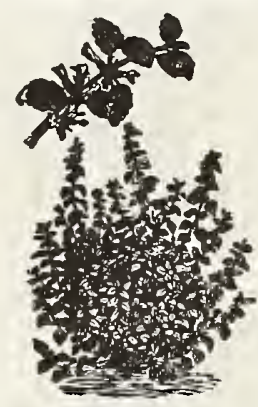

BALM.
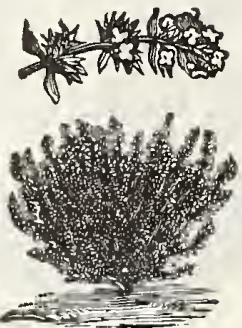

THYME.

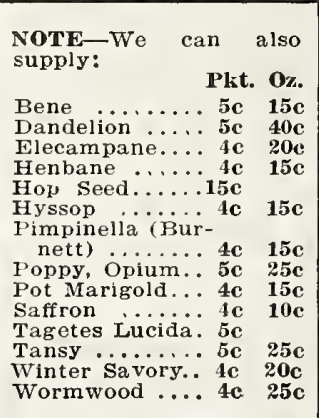

\section{HOARHOUND}

Used for seasoning, also for the manufacturing of the popular cough remedy. The tea is a remedy for colds and lung affections. Pkt. 4c; oz. $15 \mathrm{c}$.

\section{LAVENDER}

An aromatic medicinal for seasoning the flowers for perfume. Pkt. 4c; oz. 10c.

MARJORAM, SWEET

The leaves and the ends of the shoots are highly es$4 \mathrm{c} ; \mathrm{oz}$. 15c.

PENN TROXAL

The tea is valuable for colic. The fresh herb is obnoxious to mosquitos. Pkt. 10c; 3 pkts. 25c.

\section{ROSEMARY}

An aromatic herb. Leaves used for seasoning. The tea produces sweats. Oil is valuable in neuralgia, rheumatism and lumbago. Pkt. 5c; oz. 25c.

\section{RUE}

For medicinal purposes; good for fowls for the roup. Pkt. 4c; oz. 15c.

\section{SAGE}

The most extensively used of all herbs for seasoning and dressing. Pkt. 4c; 0z. 15c;

\section{SUMMER SAVOR Y}

Bohnenkraut. The leaves and flowers are used for flavoring soups and dres

\section{THYME}

The leaves and young shoots are used for seasoning: a tea is also made of the aches. Pkt. $5 \mathrm{c} ; 0 \mathrm{zz}$. 25c.

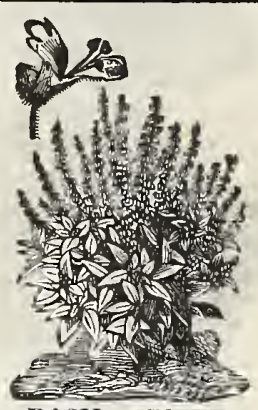

BASIL, SIVEET.

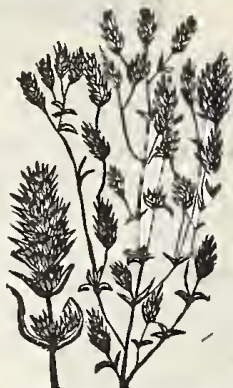

SUMMER SAYORY.

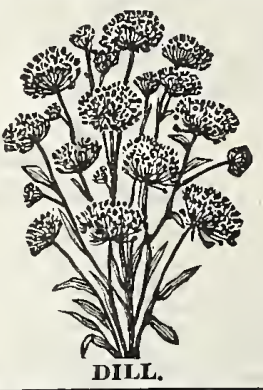

\section{THE BEST HERB PLANTS}

LAVENDER-OLD-FASHIONED SWEET-The leaves are sometimes used for seasoning, hut the plant is chiefly grown for its fragrant flowers, Strong plants: 10c each, 3 for $25 \mathrm{c}$; $75 \mathrm{c}$ per dozen, postpaid.

PEPPER IIN T - From the leaves of this plant is distilled the well known peppermint of commerce. The green leaves and stems have the same effect as the essential oil, and to most persons the flavor is very pleasant. Strong plants, each $10 \mathrm{c} ; 3$ for $25 \mathrm{c}$; doz. $75 \mathrm{c}$, postpaid.

VIIVT-The plant which produces the mint of the markets and largely used for culinary purposes. It is also used in concocting the refreshing Mint Julep, so popular in some sections. Strong plants, each 10c: 3 for 25c; doz., 75c; postpaid.

THE TRUE TARRAGON - The leaves and young shoots of which are much prized by many as an ingredient in soups, salads, stews,
pickles, etc. Leaves may be used in a fresh state, or cut in the Autumn and dried. Strong plants, each 15c, 3 for $40 \mathrm{c}$; doz. $\$ 1.25$, postpaíd.

\section{CHIVES (ALSO CALLED}

Chives are perfectly hardy perennial plants of the onion type. They are grow
produced very early in produced very early in the Spring, for giving a
mild onion flavor to
various dishes. The tops appear early in the spring, and can be ground as needed. also in pots in a grown 7 window during the 4 Winter. Easily raised from seed.

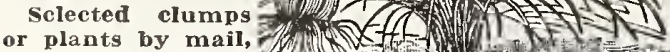
20c each, 81.50 per doz., postpaid. Chives-schnittauch.

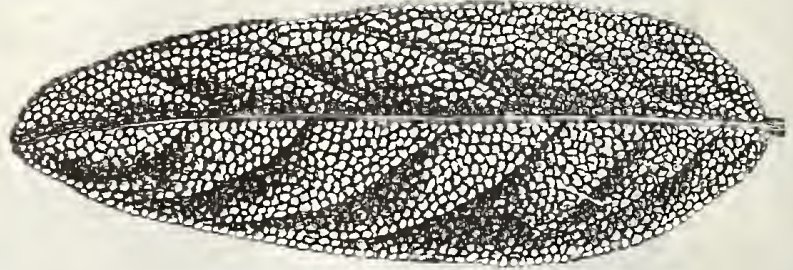

\section{Holt's Mammoth Sage}

Holt's Mammoth is a great improvement upon the ordinary Garden Sage; its leaves being four to five inches long, clean and perfect. Thev are held well up from the soil, are rich in flavor and of great 3 for $25 \mathrm{c}$ : zoc per doz., postpaid.

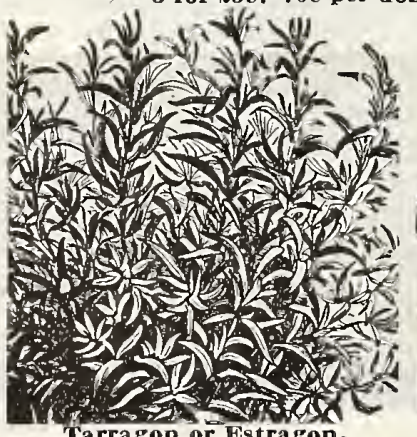

Tarragon or Estragon.

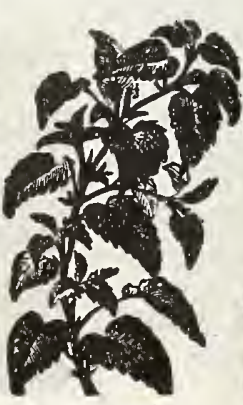

Peppermint.

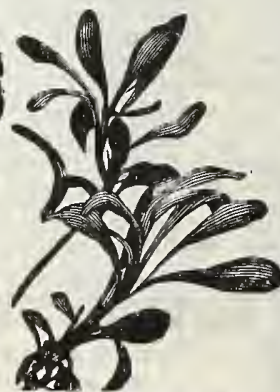

Lavender-Sweet. 


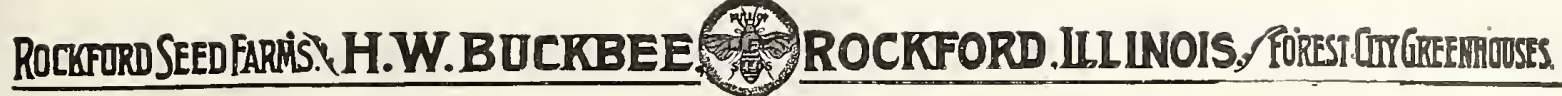

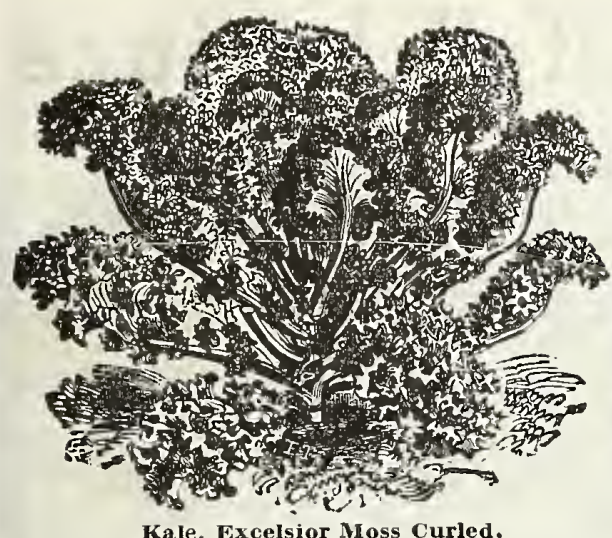

Kale, Excelsior Moss Curled.

Kale or Borecole

German, BLAETTER - KOHL; French, CHOUVERT; Spanish, BRETON.

$1 \mathrm{oz}$. of seed for 3,500 plants

DWARF EXCELSIOR GREEN MOSS CURLED I KAE- (Gcrman Greens or sprouts.)-This is hardier than Cabbage, and makes excellent greens for Winter and spring use. The leaves are as curly as Parsley, tender, and of very fine flavor. It is improved by frost. Sow the seeds in May or June, transplant in July and Northern markets, Pkt. 4c; oz. 10c; 2 oz. 18c; $1 / 4 \mathrm{lb} .30 \mathrm{c} ; 1 / 2 \mathrm{lb} .50 \mathrm{c} ; 1 \mathrm{~b} .95 \mathrm{c}$.

TALL GREEN CURLED SCOTCH-This variety is very hardy and is improved by a moderate frost. About thirty inches tall, wited and crinkled. Stands the Winters in the Middle States without protection. Pkt. 4c; oz. 8c; 2 oz, 15c; $1 / 4 \mathrm{lb}$. $25 \mathrm{c} ; 1 / 2 \mathrm{lb}, 40 \mathrm{c} ; 1 \mathrm{~b} .75 \mathrm{c}$.

SIB ERIAN - One of the best known and most largely used varieties of Kale. It is sometimes called Sprouts or German Greens. The green leaves are very large, and comparatively plain in the center but coarsely cut and distinctly frilled on the edges. The plant is 2 oz. 12c; $1 / 1$ Ib. 20c; $1 / 2$ lb. 35c; lb. 60c. SEA KALE-A valuable new vegetable, grows

\section{Kohl Rabi}

German, KoHL RABI; Freneh, CHOURABE Spanish, CALDE NUBO.

A vegetable intermediate between the Cabbare and Turnip, combining the flavor of both. Edible part is a turnip-shaped bulb, formed by hould be cut when quite small, as it is then very tender and delicate.

KING OF THE EARLIEST-WHITE-Early and choice Handsome white bulbs Pkt $4 c$; oz. 20c; 2 oz. 35c; $1 / 4$ lb. 60c.

IMPROVED EARLY IMPERIAL-PURPLE -Color bright purple, with leaf stems tinged with purple.

\section{DEAD SHOT $\underset{\text { THE MAGIC }}{\text { THESTROY }}$} The World's Greatest Remedy.
To destroy Striped Bugs and Cabbage Worms and Pests on all varieties of Plants - Currant Worms, Worms, Fleas, Beetles, Bugs and Caterpillars.

"DEAD SHOT" Pow of upon the leaves of Plants and the effect is instantaneous. The Bugs disis perfectly safe for man or beast. Postpaid, ib roe. By express or freight, not prepaid, 5 lbs. $50 \mathrm{e}$;
$10 \mathrm{lbs} .75 \mathrm{c}: 25$ lbs. $\$ 1.50$; $50 \mathrm{Ibs} . \$ 2.50$. Rose Bugs and all Lice,

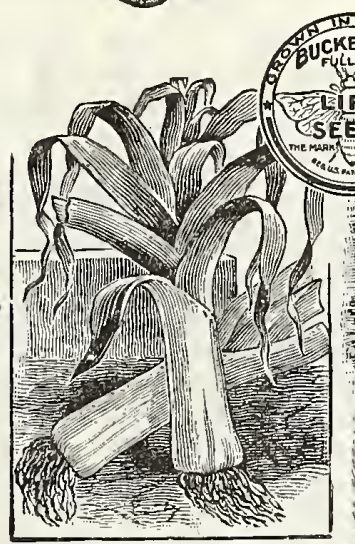

Leek, New Flag.

QUALITY Kale, Improvec siberian.

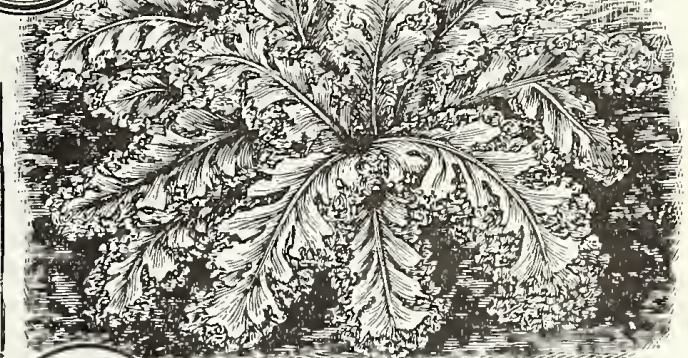
Leek

QUALITY Beed angs to the Onion family seed and care for the young plants as for to develop. When the young plant is abo the size of a goose quill, transplant to a preone-lialf feet apart and four or five inches in

NEW FLAG-We offer a very superior stock of this popular variety, so largely grown for Fall and early Winter use. It is of quick strong growth, white and of fine, mild flavor. Pkt.4c; oz. 15c; 2 oz. 25c $1 / 4 \mathrm{lb} .40 \mathrm{c}$

RY BRST WINTER-This is the best variet

on Flag, making immense, stocky stems 6 to 8 inches long Pkt. 5c: oz. 15c: ? oz. 25c;1/4 1b. 45c.

The Mango Melon or Vegetable Peach producing long stems of uniform shape and size, averaging A splendid novelty of late introduction, in color, most wonderful yielder. (See engraving from nature of a single plant in illustration.) Vines of Mango Melon

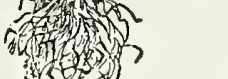
กิs
Kohi Rabi, King of Earliest.

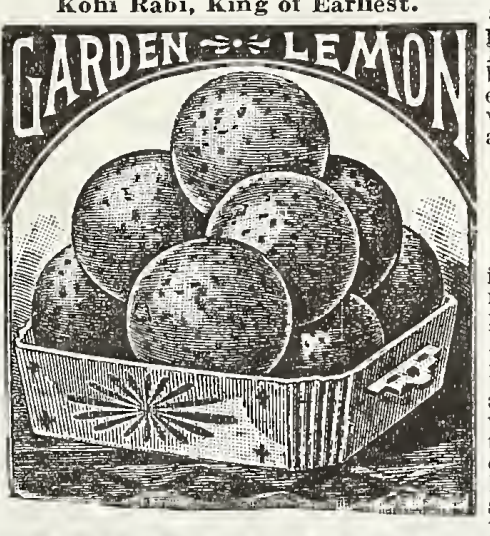
cultivation. Fruit about the size of an Orange orange shaped, and a bright orange-yellow color, For sweet pickles. pies or preserving they are splendid In the West and Northwest, where fruit is scarce, they are rapidly enormously productive, and can be used in every way as the Peach, except that they are not quite
as sweet. Pkt. 10c; oz. 25c.

\section{New Garden Lemon}

Unexcelled for Canning Purposes.

Certainly one of the greatest novelties of recent introduction. Resembles the vine Peach in manfruit is striped with very dark green spots, nearly black, and when ripe is not russeted like the Vine trifle smaller than Vine Peach. Has a finer flesh and most desirable acid flavor, thus dispensing with sliced lemon, which is so important in put ting up the Vine Peach. Unexcelled for general Melons, in hills three feet apart each way. It is such an enormous yielder that it will prove a very profitable crop to grow for market purposes, and

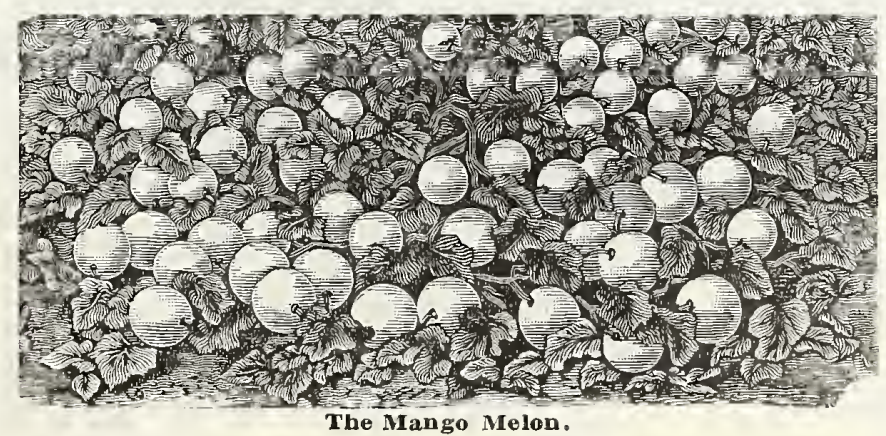

tion for all family uses. True
stock seed. Pkt.10c; oz. 25c.

\section{SPECIAL}

For only is cents we will For only 15 cents we will of the two Wondrous Novelties, New Garden Lemon and Mango MeIon.

Mrs. Mattie Brooks, Star Lime Works, Ky ., writes:-You report my success with my with Buckbee's "Full of Life" best I have ever tried. 


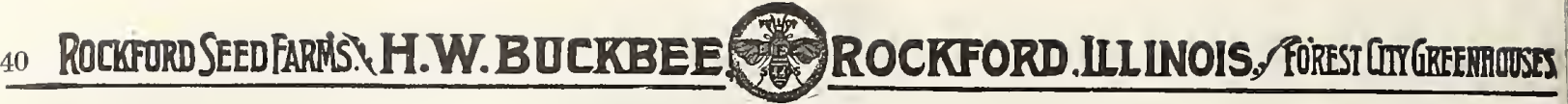
Buckbee's "Full of Life" Lettuce

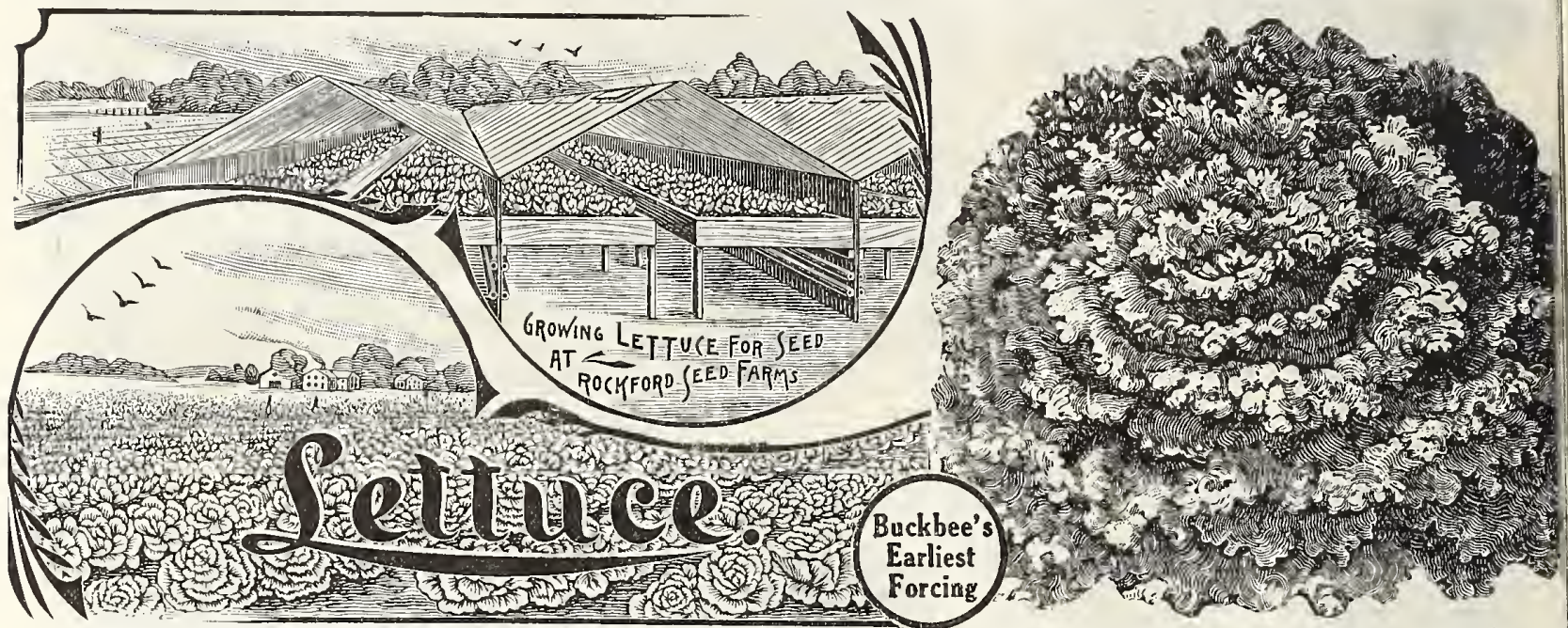

German, LATTICH-SALAT; French, LAITUE; Spanish, LECHUGA;

THE MOST USED OF ALL SALADS IN DEMAND EVERY MONTH OF THE YEAR

Buckbee's Earliest Forcing

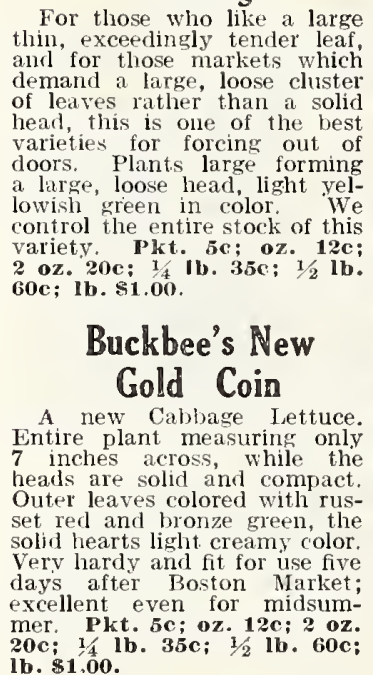

\section{Buckbee's Superb}

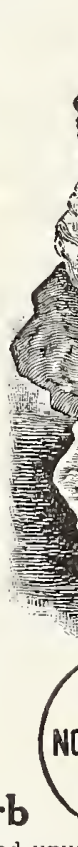

Finest of all early varieties and unusudency to run to seed. Wonderfully crisp. exceptionally tender, and above all, delici-
ous in flavor. As a forcing variety it has no superior. Excels as a family or market $5 \mathrm{c} ; 1 / 2 \mathrm{lb} .60 \mathrm{c} ; 1 \mathrm{~b} . \$ 1.00$.

Simpson's Early Curled light flavor, Pkt. 4c; oz. 8c; 2
lb. 25c; $1 / 2$ lb. 40c; lb. 75c.

Mammoth Black-Seeded Butter A strain of large, smooth-leaved head Lettuce, forming large, solid, Cabbage-
like heads of thick, brittle leaves, inner ones becoming very white, tender and
fine flavored. Pkt. 4c;oz. 8c:2 oz. 15c: $1 / 2 \mathrm{lb} .25 \mathrm{c} ; 1 / 2 \mathrm{lb} .40 \mathrm{c} ; 1 \mathrm{~b} .75 \mathrm{c}$.

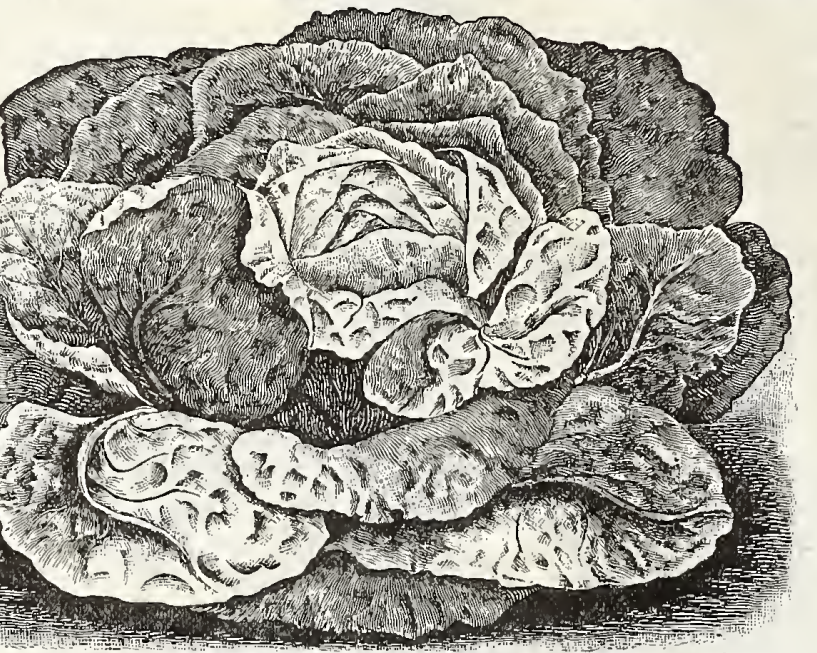

Tomhannock

The Handsome Reddish Bronzc Lcttuce.
This Lettuce doesn't headmakes a loose bunch of leaves of very fine quality. Edge bronze; within, the leaves are almost white. very crisp and 2 oz. 20c; $1 / 4$ lb. 35c; $1 / 2$ lb. $60 \mathrm{c} ; 1 \mathrm{~b} . \$ 1.00$.

\section{Improved Hanson} A Great IIeat-Resisting Large, firm heads, deliciously sweet, crisp and tender. Heads green outside, white Best for out-door 2 oz. 15c; $1 / 4$ lb. $25 \mathrm{c}$; $1 / 2 \mathrm{lb}$. $40 \mathrm{c} ; 1 \mathrm{~b} .75 \mathrm{c}$.

Grand Rapids Forcing Buckbee's Privatc Stock. quality and beautiful in pearance, a strong grower, free
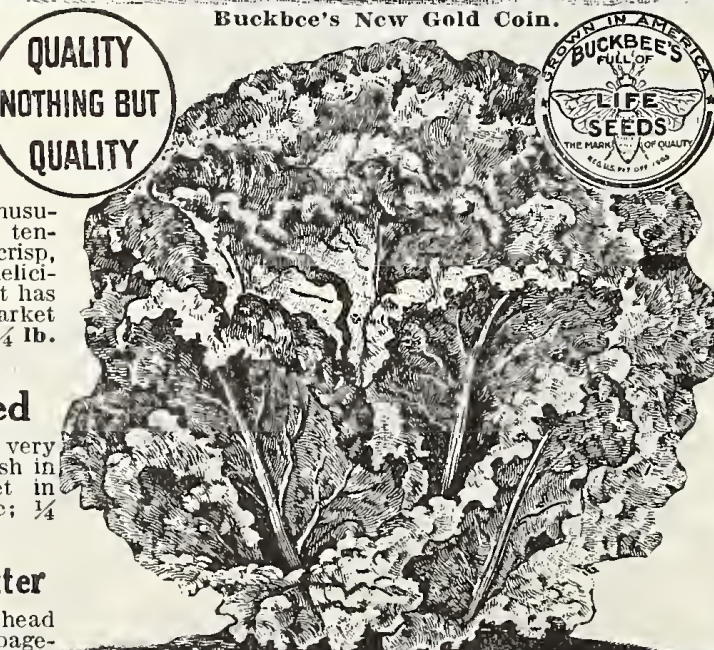

without wilting, when exposed for sale, is al than any other forcing Lettuce, Spring sowing in the open ground. Pkt. Early Black Seeded Tennis Ball One of the best Head Lettuces for early planting out-doors, and when well grown forming very solid heads, the inner leaves
being blanched to a rich creamy white and being blanched to a rich creamy white and Tilton's White Star

of the Black-Seeded Simpson type, but grows larger and more rapidly, has broader, thicker, darker-colored leaf, ess frilled at the edge; forms a larger, more distinct and solid central cluster of
leaves. Pkt. 3c; oz. 8c; $20 z .15 c ; 1 / 41 b$.

\section{Improved Black Seeded} Simpson

Buckbce's Private stock. Acknowledged the best early forcing - variety. Leaves are a delicate green, 4c; oz. 10c 2 oz. 180; 1/4 lb. 30c; $1 / 2 \mathbf{l b}$. Tomhannock Lettuce. Б0c; ib. $95 \mathrm{c}$ 


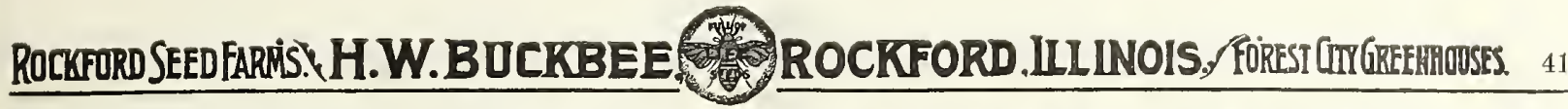

\section{BUCKBEE'S “FULL OF LIFE” LETTUCE}

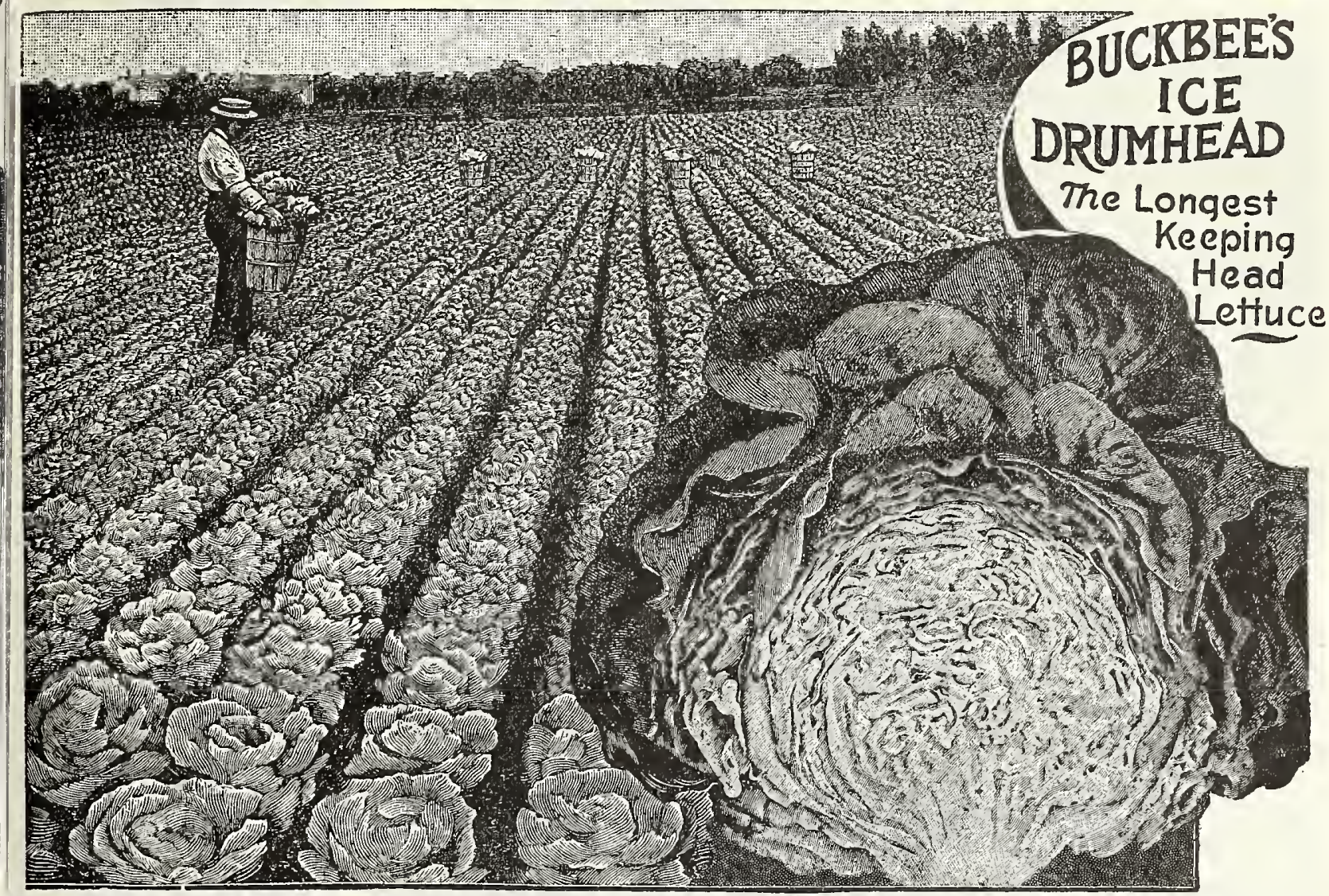

A Sure Header, Slow to Run to Seed, Unaffected by Hot Weather Crisp, Tender and Delicious. Absolutely Free from Bitterness.

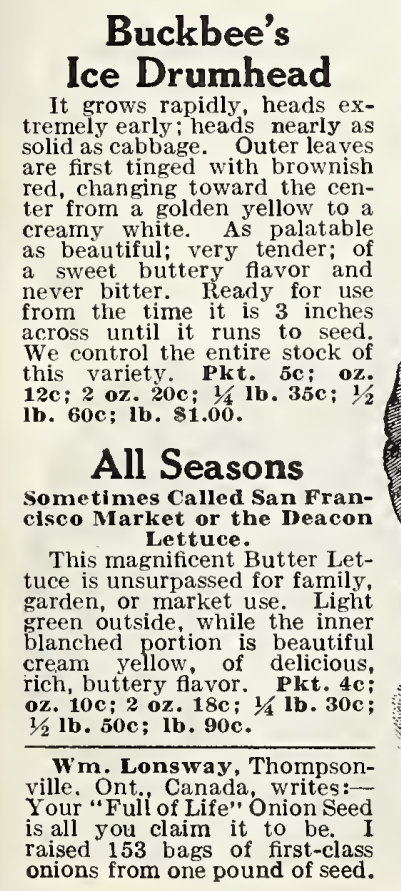

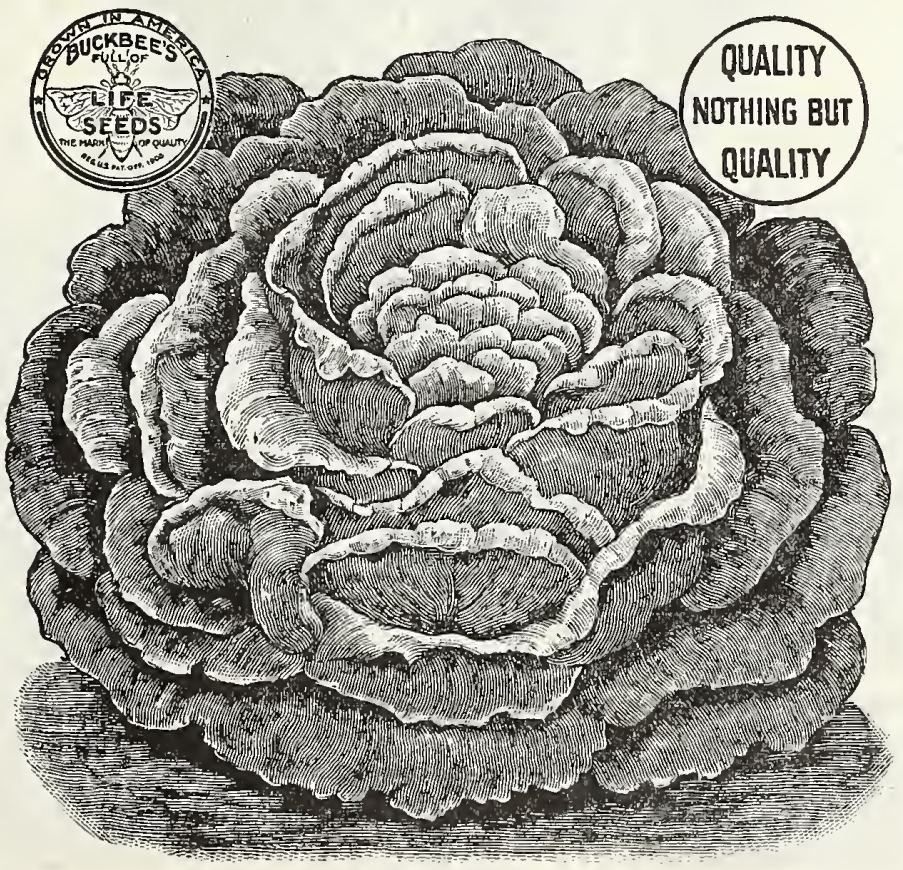

A.11 Seasons.

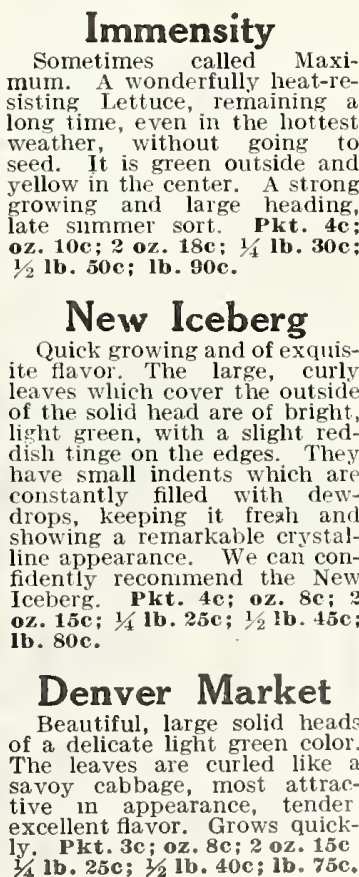




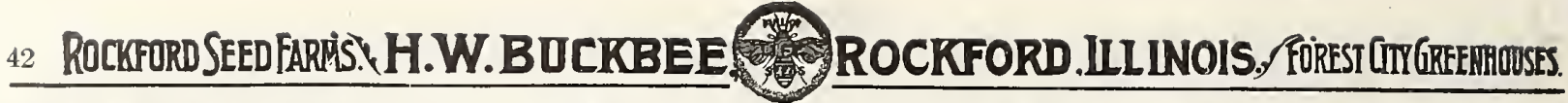
BUCKBEE'S "FULL OF LIFE"

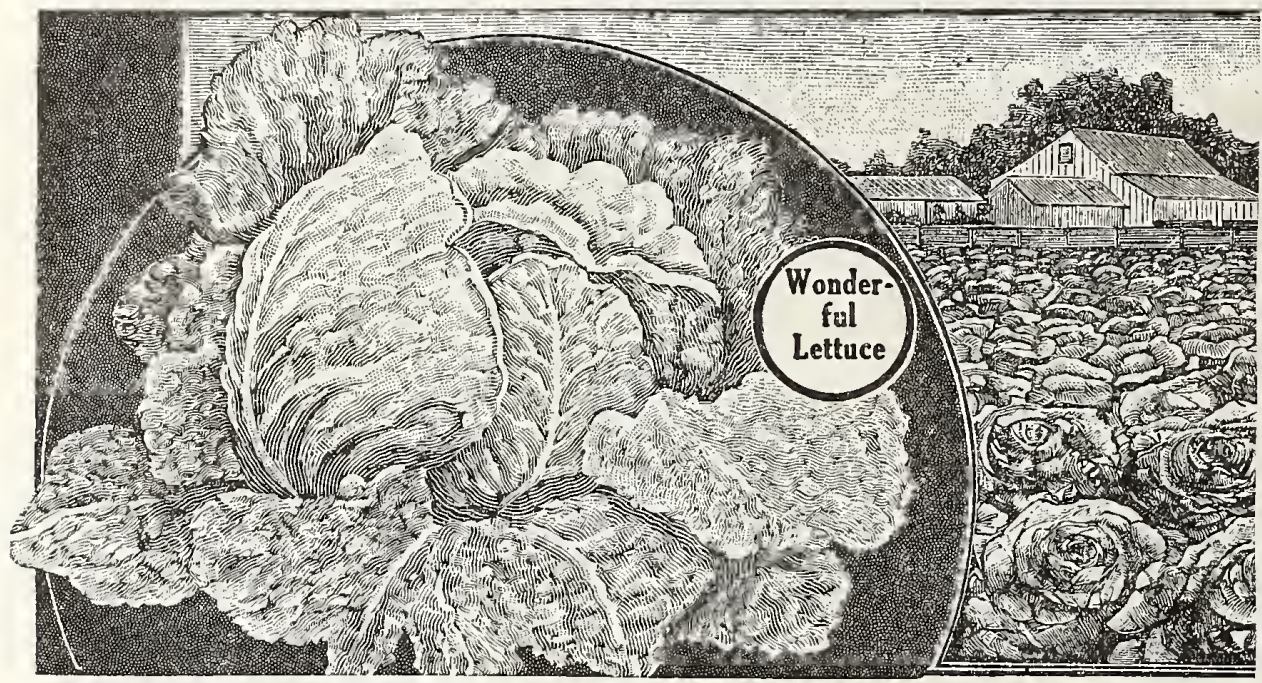
LETTUCE

Wonderful

The Big Moncy Maker

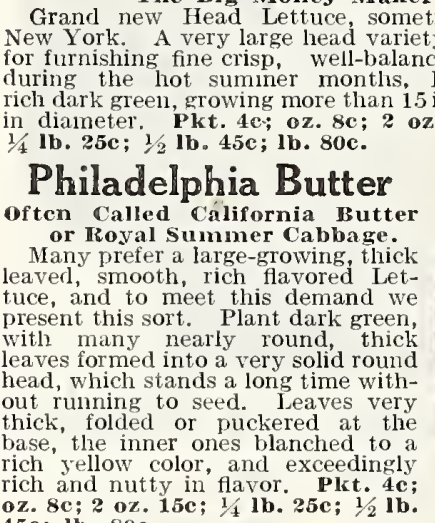

oz. $8 \mathrm{c} ; 2 \mathrm{oz}$.
$45 \mathrm{c} ; 1 \mathrm{~b} .80 \mathrm{c}$.

\section{May King}

\section{An Ideal lettuce}

ground it is unequaled. Fx in the open

and very quick growing. Plants grow from

closely folded that the plant is practically all

hcad. Of rich, buttery substance, outer leav
light green, slightly tinged with brown; inner

are bright yellow, of a spccially fine, rich, buttery

that they will carry well to market. Pkt.5c; oz. 12c;

2 oz. 20c; $1 / 41 \mathrm{lb}$. 35c; $1 / 2 \mathrm{lb} .60 \mathrm{c} ; 1 \mathrm{~b} . \$ 1.00$

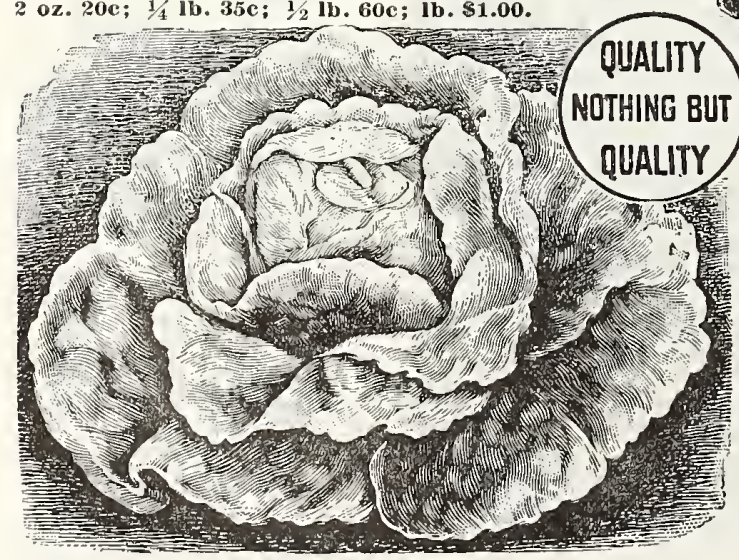

May King Lettuce.
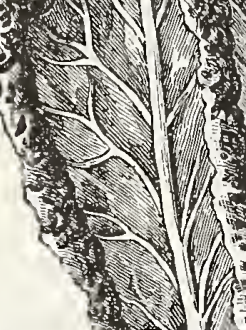

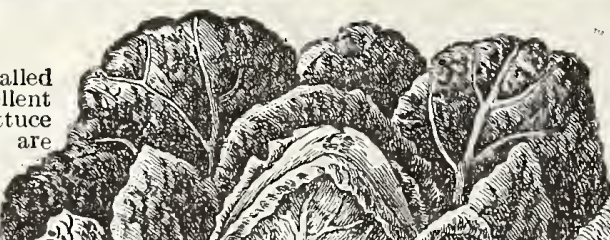

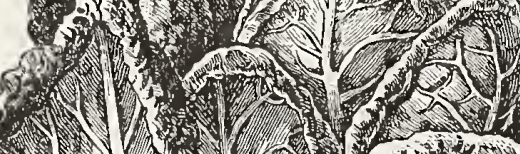

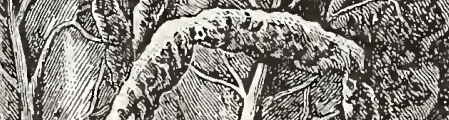

Dwart

Dwarf White Heart or Celery

Noted for Its Most Excellent Flavor. Earliest in cultivation. The plants grow inches across. Of stiff growth, every plant making a well-developed head crisp and tender. Pkt. 5c; oz, 12c: 2 oz. 20c; $1 / 4$ lb. 35c; $1 / 2$ lb. 60c;
lb. $\$ 1.00$.

\section{Paris White Cos}

Grows to very large size, producing long pointed compact bunches. of fine flavor Pkt. 4c: $8 \mathrm{c}$ 2 oz. $15 \mathrm{c} ; 1 / 4 \mathrm{lb}$. 25c; $1 \frac{1}{2} \mathrm{lb} .45 \mathrm{c}$

\section{Early Prize Head}

This old standard sort still stand at the head of the large, thin leaved clustering sorts, exceedingly tender crisp and sweet. Pkt. 4c; oz. 8c; Ib. $75 \mathrm{c}$.

Boston Market or White Secded Tennis Ball. A fine sort, fine heads, hardy, valuable to

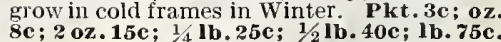

\section{Salamander}

A large, compact light green head of excellent quality. Leaves broad, thick, somecrumpled. One of the best heading Let-
Pkt. 4c; oz. 8c; 2 oz. 15c; 1/41b. 25c; $1 / 2 \mathrm{lb}$. 40c; ib. 75c.

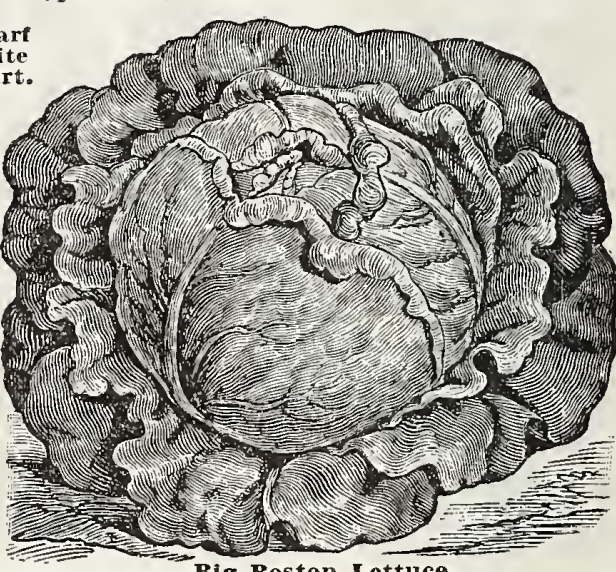

distinctively a heading
sort. Pkt.4c; oz. 8c

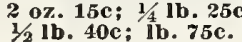

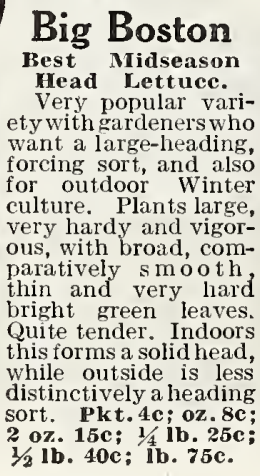

Big Boston Lettuce. 


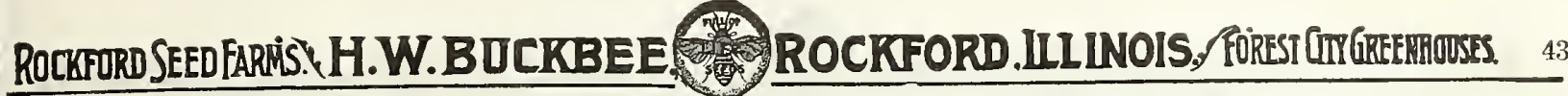

\section{BUCKBEE'S \\ "FULL OF LIFE"}

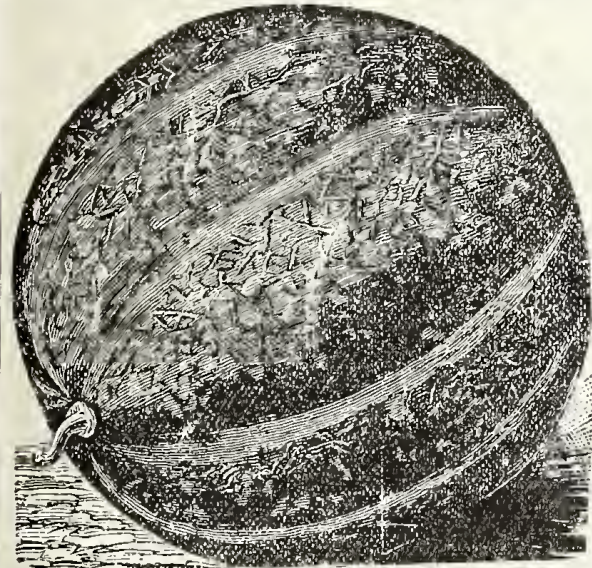

Osage Musk Melon.

OSAGE MUSK MELON

OR IMPROVED MILLERS

CREAM.

The Boss Ilome and Market

Melon. Original Stock.

This Melon has made its way

into public favor from the mar

is highly prized by those who

highly flavored Melon. It is me-

dium sized, oval, slightly ribbed,

dark

mor

and there

being but a slight cavity in the

center of even the largest fruit

ket. Large pkt. 4c; oz. 10c;
oz. 18c; $1 / 4$ lb. 30c; $1 / 2$ lb. 50c:

oz. $18 \mathrm{c}$;

\section{HOODOO}

SURE CROPPER-SPLENDID SHIPPER.

A neal or ange fleshed variety

of the very finest quality.

sisting and very productive. The

heavily netted, flesh very thick,
of rich orange color, handsome

appearance and of the sweetes
flavor. Average weight of Melon
$11 /$ pounds. Large plt. $4 \mathbf{4} ;$ oz.

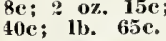

Buckbee's Famous

ROCKY FORD

PRIVATE STOCK.

Ideal Shipper-Healthy,

ceedingly Prolific.
Commands Highest

ket Prices Wherev

The Melon tlat Made Rocky Ford Famous.

This Pedigreed Melon we

have perfected from the

ducing fruit a trifle more

elongated in shape, has 10

a closely interwoven green

netting; blossom end is button, preventing crack-

ing. It is the most popu-

lar of all Melons for ship-

ping in baskets. Flesh i

melting-very thick meat-

Send to Buckbee for originators' genuine selected stock seed. Large

packet $4 \mathrm{e} ; \mathrm{oz} .10 \mathrm{c} ; 2 \mathrm{oz} .1$
$25 \mathrm{c} ; 1 / 2 \mathrm{lb}, 40 \mathrm{c} ; \mathrm{lb}$. $75 \mathrm{c}$.

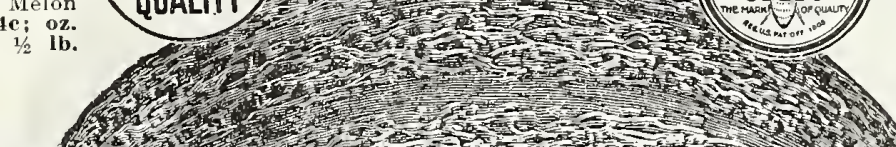

German MELONE; French, MELON;

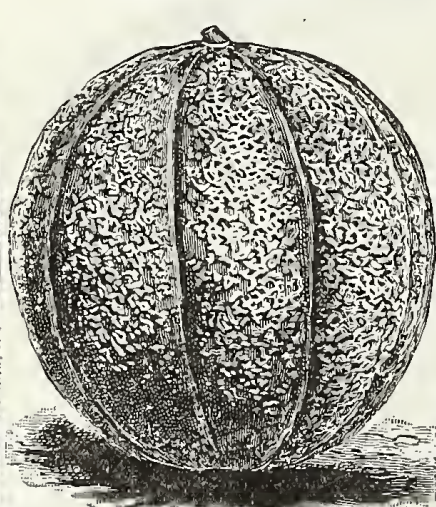

Buckbee's Prolific Nutmeg Musk Melon.
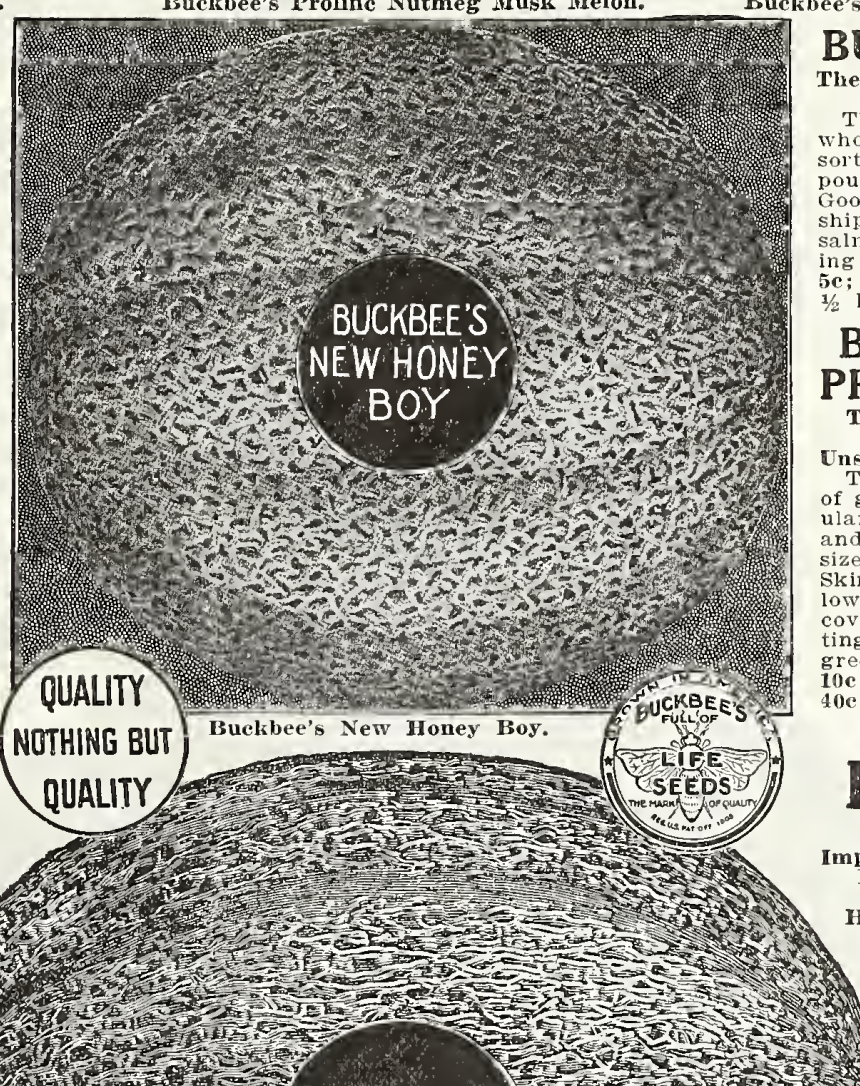

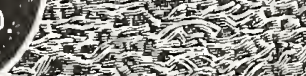

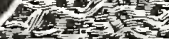

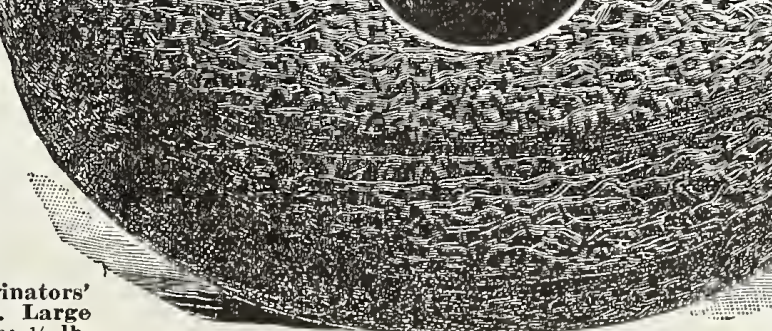

Fuckbee's Genuine Famous Rocky Ford,

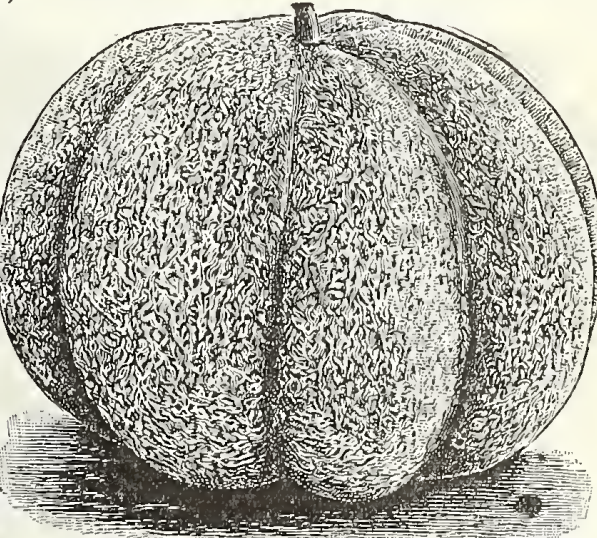

Buckbee's Ideal Musk Melon.

BUCKBEE'S IDEAL

The Most Delicious of All Musk

Melons.

ho has tried this magnificent

g and delicious flayor. Pkt

$1 / 2$ lb. 60e; lb. \$1.00.

BUCKBEE'S NEW PROLIFIC NUTMEG

THE GREATEST NUTMEG

MELON.
Unsurpassed in Luscious Flavor.

This is an extra early Melon

and market Fruit of medium

skin dark green, becoming yel-

covered with broad, shallow net-

green color, Large plit. te; oz.

\section{Buckbee's New Honey Boy}

"RUST RESISTANT.", Famous Netted Rock and

Here Is a Melon That Will

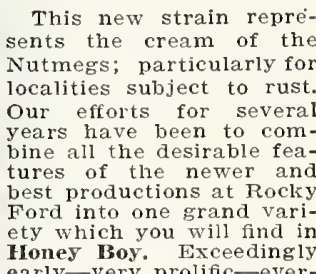

fome Grown, "Full o

year. Order Larly, Large Pkt

5e; oz, 12c; 2 oz. 20c; $1 / 4$ lb. $35 \mathrm{c} ;$
$1 / 2$ lb. 60e; lb. $\$ 1,00$,

ideal shipper-Flesh is

light green-very thick

It's the big moner retter.

Oui. 


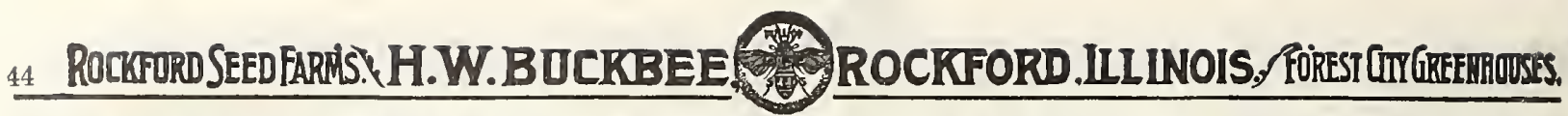
BUCKBEE'S "FULL OF LIFE" MUSK MELONS

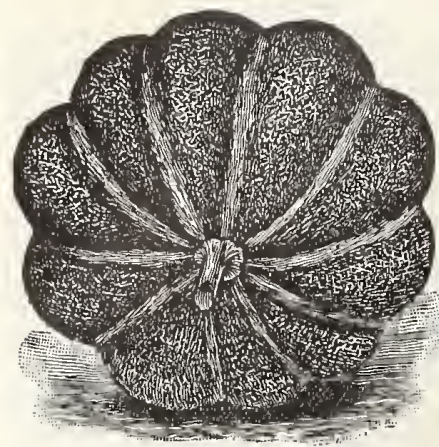

Emerald Gem Musk Melon.

Emerald Gem

Splendid Size, Color and Flavor. The standard of excellence among
the salmon fleshed varieties. Fruits small to medium size, globular or

very slightly flattened at the ends,
only slightly netted and ribbed. Skin deep green while young, becoming tures. Flesh deep salmon yellow,
thick, ripening close to the rind, Un
sur'passed in flavor. Leads them
in many in many large markets. Cloicest lb. 30c; $1 / 2$ lb, 50c; 1 b. $85 \mathrm{c}$.

Buckbee's Western Giant Noted Not Only for Its Great Size

But for Its Most Magnificent
Flavor and General Good

Largest of all yusk

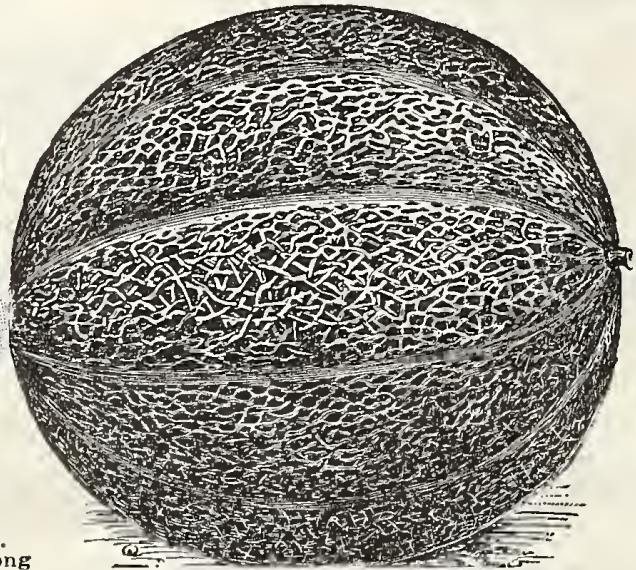

Buckbee's Prizetaker Musk Melon.
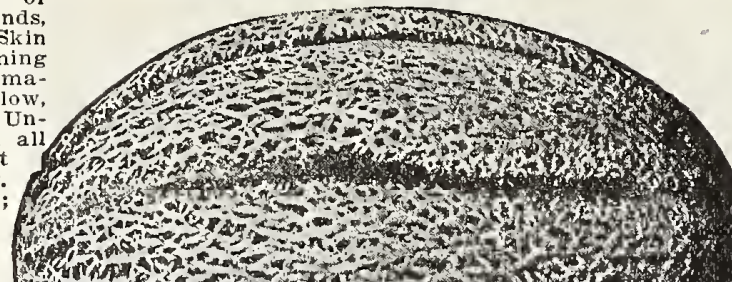
Thas Win

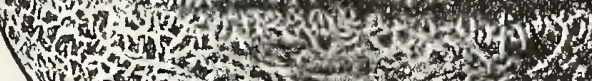
(1)

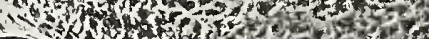
As an exhibition and large market variety it is grand. It will aston-
ish everyone by its merits, being
exceptionally desirable for family and market purposes, For ship-
ping it has no superior. Where
size is an object, and there is not a particle of danger of sacrificing plete satisfaction. Pkt. 10c; oz. $75 \mathrm{c} ; \mathrm{2b}$. $\$ 2.25$.

Montreal Market The Famous Forcing Musk Melon.

A very large "green
nutmeg" type, almost thick, luscious flesh; adapted to cooler cli2 oz. $15 \mathrm{c}: 1 / 4$ lb. 25
$1 / 2$ lb. $40 \mathrm{e} ; 1 \mathrm{~b}$. $65 \mathrm{c}$.

Admiral Togo The rdeal Table and Basket MeIon.

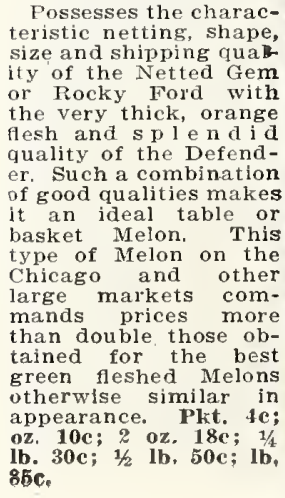
kt. 10c; ; $1 \frac{0 z}{2}$.

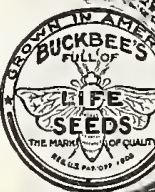

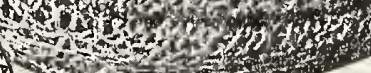

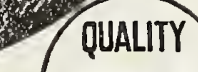
NOTHING BUT
QUALITY 1.7.

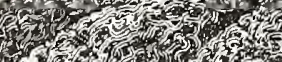

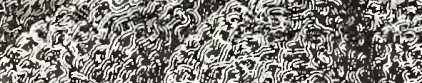
(6)

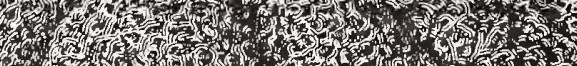

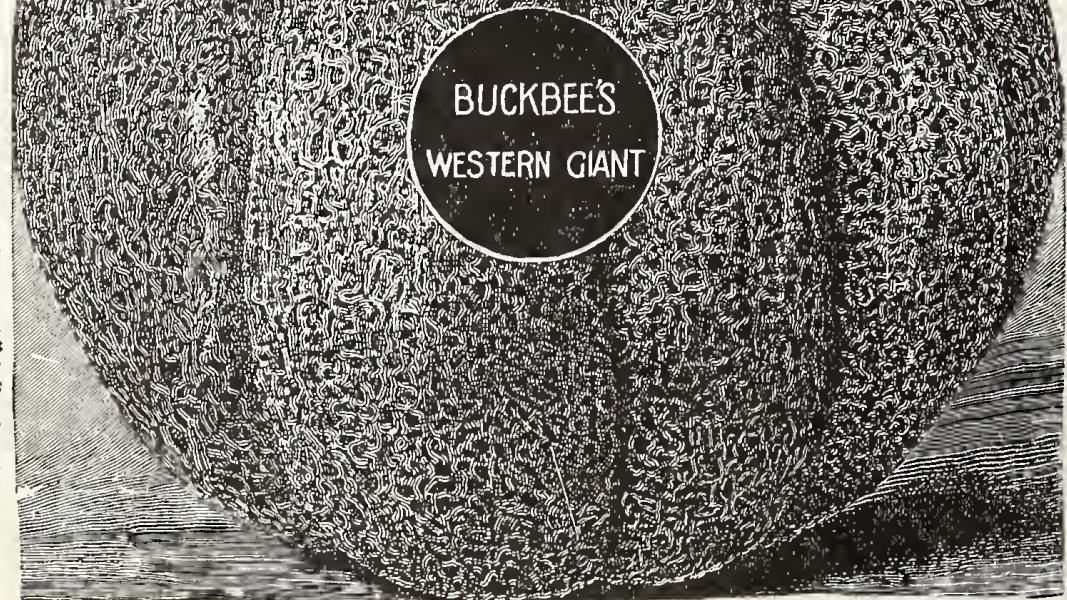
$85 \mathrm{c}$

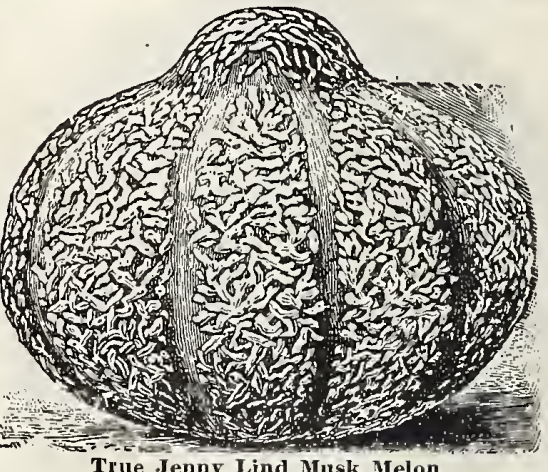

True Jenny Lind

Full of Life Strain. This is the earliest of the green Size smail, from 3 to 5 inches in diPkt. 3c; oz. $7 \mathrm{c}, 2$ oz. 12c; $1 / 1 / 1 \mathrm{lb}$ 20c:

Buckbee's Prizetaker

The World Beating Musk Melon.

This new Melon is at least ten
Jays earlier than Osage, Has a more

vigorous vine, and because of its

The fruit is a bout six inches in di-

ameter, round or slightly elongated, slightly ribbed. Color, a peculiar shade. The flesh is firm fine grained, of a rich salmon-reddish the best grown osage or Emerald Gem, The flesh extends to the ity quite to the outer shell. The flesh is thick; very thick, considera small seed cavity. It is delicious and melting. Pkt. 5e; oz. 12e; $\mathbf{2} \mathbf{o z}$. New Early Hackensack This is a splendid Melon. The fruit is medium sized, nearly round, ribbed and with a very coarse netting. The flesh is green, a little coarse, but very juicy, vored. Pkt. 4c; oz. 7c; 1/2 lb. $35 \mathrm{c} ; 1 \mathrm{t}$, $60 \mathrm{c}$.

Burrell's Cem

Combines the Flavor and Shipping Quali-

Ford, But Is Sal-

mon Fleshed.

An orange fleshed Rocky Ford, for a marfleshed Musk Melons are in demand; they prices. It has a tough thin rind, well arched ribs; covered with a closely laced and inShape quite elongated: flesh of a reddish orgrained and spicy. The Melons average about $21 / 2$ lbs, with an average size of 6 thick, and will crate more evenly than any Pkt. 4c: oz. 8c: 2 oz. $15 \mathrm{c}$; $1 / 4 \mathrm{lb}$. $25 \mathrm{c}$; $1 / \mathrm{lb}$. uc; 1b. 750 . 


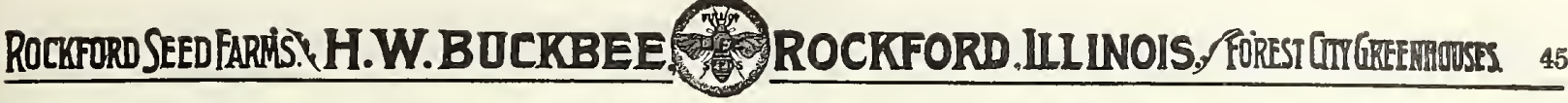

\section{BUCKBEE'S “FULL OF LIFE" MUSK}

Buckbee's New Strawberry Musk Melon

Flavor Like Tliat of a Strawberry.

This grand Melon was originated by planting the most luscious variety of two rows of a New Hybrid Musk Melon. It grows to be a desirable market size; 8 pounds weigh from 6 to appearance compares favorably with the green nutmeg of old, turning to a yellowish hue, as it were, over night, when fully ripened. an attractive orange-red color, particularly soft and melting, and with that exberry flavor leaves nothing more to be desired in a Musl of our own growing. Pkt. 10c; oz. 15e; 2 oz. 25e; $1 / 1$ lb. 10c; oz. $15 \mathrm{e} ; 2$ oz. $25 \mathrm{c} ; 1 / 41$
$40 \mathrm{c} ; 1 / 2$ lb. $75 \mathrm{c} ; \mathrm{lb} . \$ 1.25$.

Buckbee's New Triumph The best Musk Melon yet produced. It grows from ten to fifteen pounds in on the ends, stands hand-

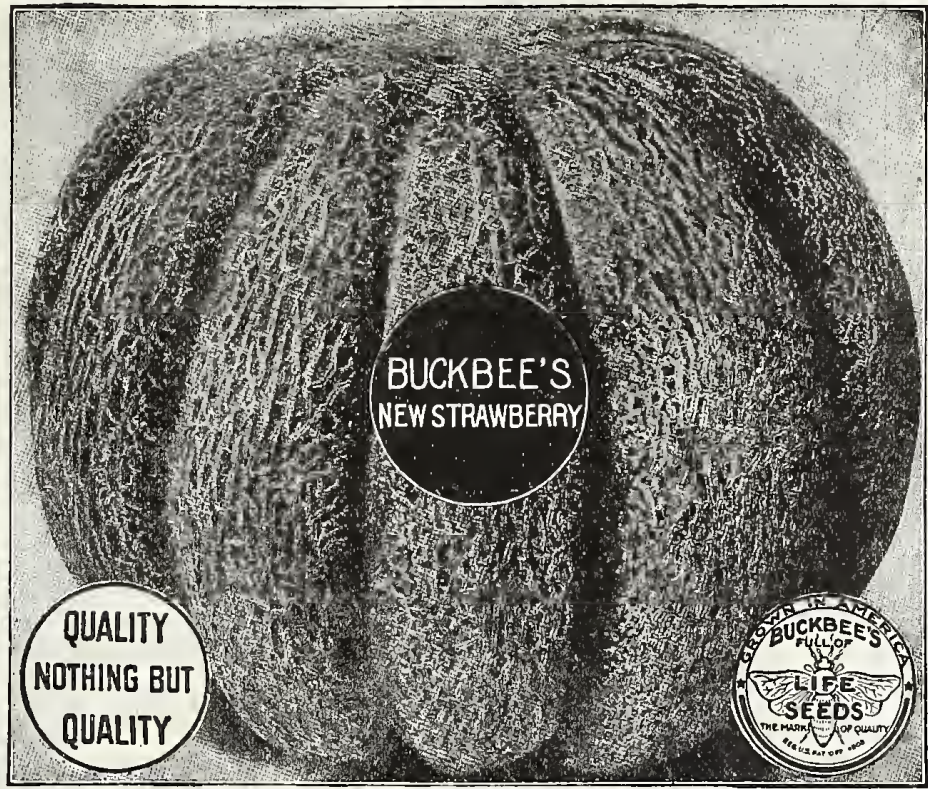

Buckbee's New Strawberry Musk Melon.
MELONS

\section{True Tip Top}

Selected Stock. The Can't Be Beat Melon. We can heartily recom mend Pedigreed Melon to every lover of this luscious fruit and to every gardener Splendid for the market. shape, distinctly ribed salmon colored, flesh firm and edible almost to the rind. Sweet, juicy, melting and delicious. A strong grower, heavy yielder and to Buckbee for "Full Life" stock seed Pkt. az, 10c; 2 oz, 18c; $1 / 4$ lb. $30 \mathrm{c} ; 1 / 21 \mathrm{~b} .50 \mathrm{c} ; 1 \mathrm{lb} .90 \mathrm{c}$

Large Hackensack The Noted "Turk's Cap" Fruit very large, the dimeter much more than the length, ribs large and of covered width, densely flesh green thick netting: very sweet and fine lavored. Pkt. 4c: oz. 7c: $20 z .12 \mathrm{c} ; 1 / 41 \mathrm{~b} .20 \mathrm{c} ; 1 / 2$ Ib ling for many days in marA great yielder. Pkt. 5c; oz. 12c; $20 z$ $20 \mathrm{c} ; 1 / 4 \mathrm{lb}$. 35c; $1 / 2 \mathrm{lb}$. 60c; $1 \mathrm{~b}$. $\$ 1.00$.

Banana Melon A Surprising Fine (Yellow Flesh.) This most curious, and most exquisitely flavored Melon inche and is eter. The flesh is quite deep. In appearance and odor it greatly resembles a early pkt $1 / 4$ lb. 30c; $1 / 2$ lb. 50c; lb. 90c.

\section{New Winter Pineapple} The Long Keeping Melon. A new Melon that can be kept until Christmas. The color of the flesh is a dicious lemon yellow. The quality They very rarely ripen on the vines so the Melons must be picked cool place, where, however, there is no danger of freezing. Pkt. 5e

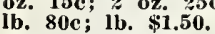

\section{Golden Netted Gem} A Pedigreed Strain.

The fruit is medium in size, oval in shape, dark green in color and just nicely netted. The flesh is thick, deep rich bright green color and fine flavor. lb. $30 \mathrm{c} ; 1 \mathrm{~b}$. $50 \mathrm{c}$.

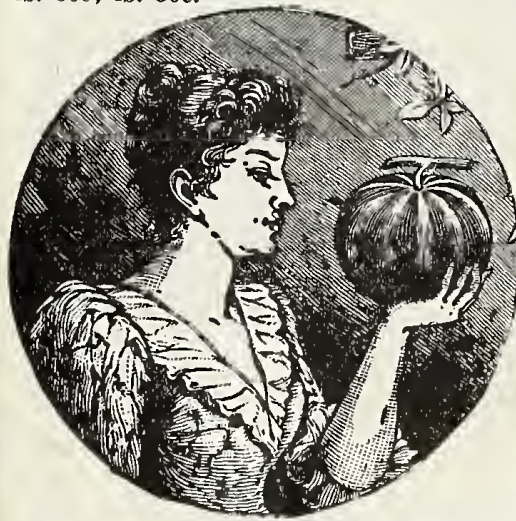

Queen Ann's Melon or Pomegranate.

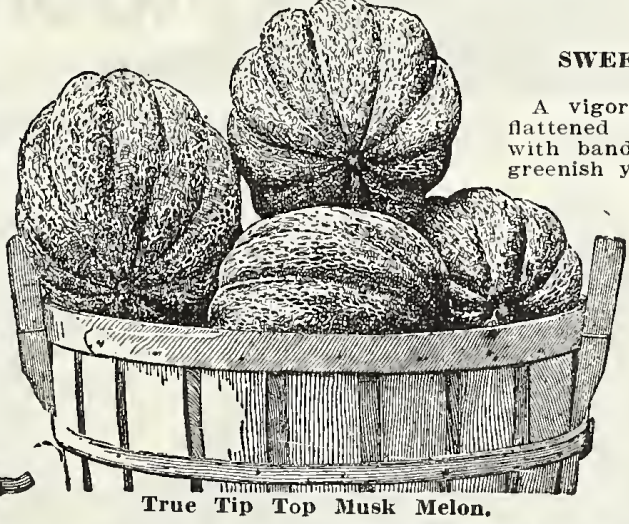

Queen Ann's

ENTED POCKET MELON OR POMEGRANÁTE.

climbing variety; fruit very small, the ends, without ribs, but marked ornent and its agreeable pungent perfume; trained on trellises or arbors it is very ornamental. It is easy to grow
and nothing is more fragrant. Pkt. 5c.

\section{Paul Rose or Petoskey}

The Favorite Basket Melon.

Fruit oval, about 5 inches in diameter. Firm flesh, a rich orange red like the osage, but even sweeter and higher $1 / 4$ Ib. $25 \mathrm{c} ; 1 / 2$ lb. 40e; lb. 70c.

\section{Cannon Ball}

The Great American Musk Melon. In some localities called cosmopolitan. Shape round, medium is light green melting The fles ciously flavored, remarkably solid with exBanana Melon.

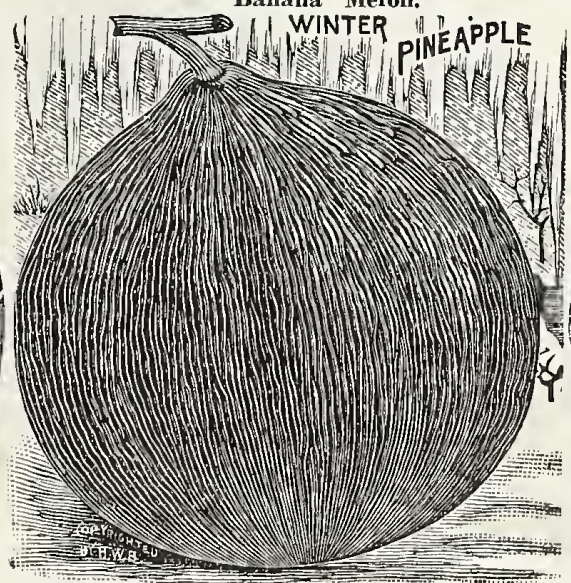

Winter Pineapple Melom. tremely small seed cavity. Pkt. 4c; oz. 8c;

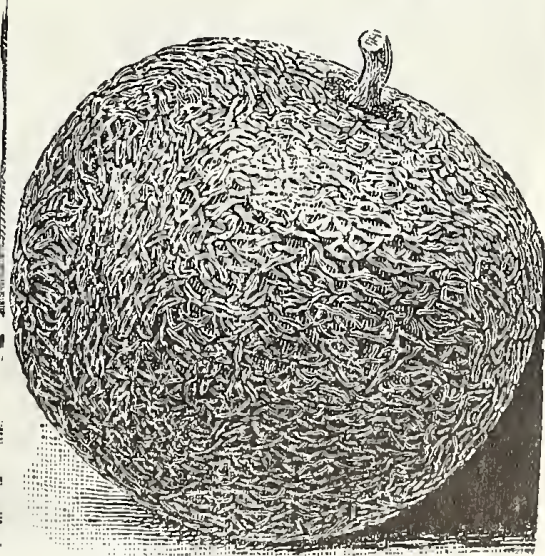

Cannon Ball Muslo neloa. size, six to eight inches in diam- 


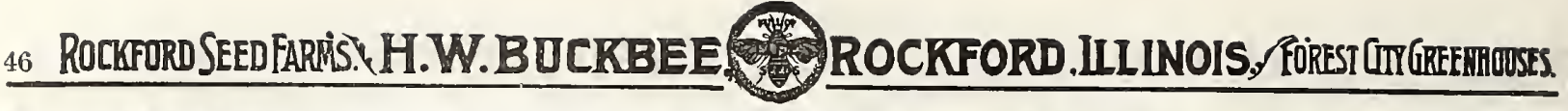

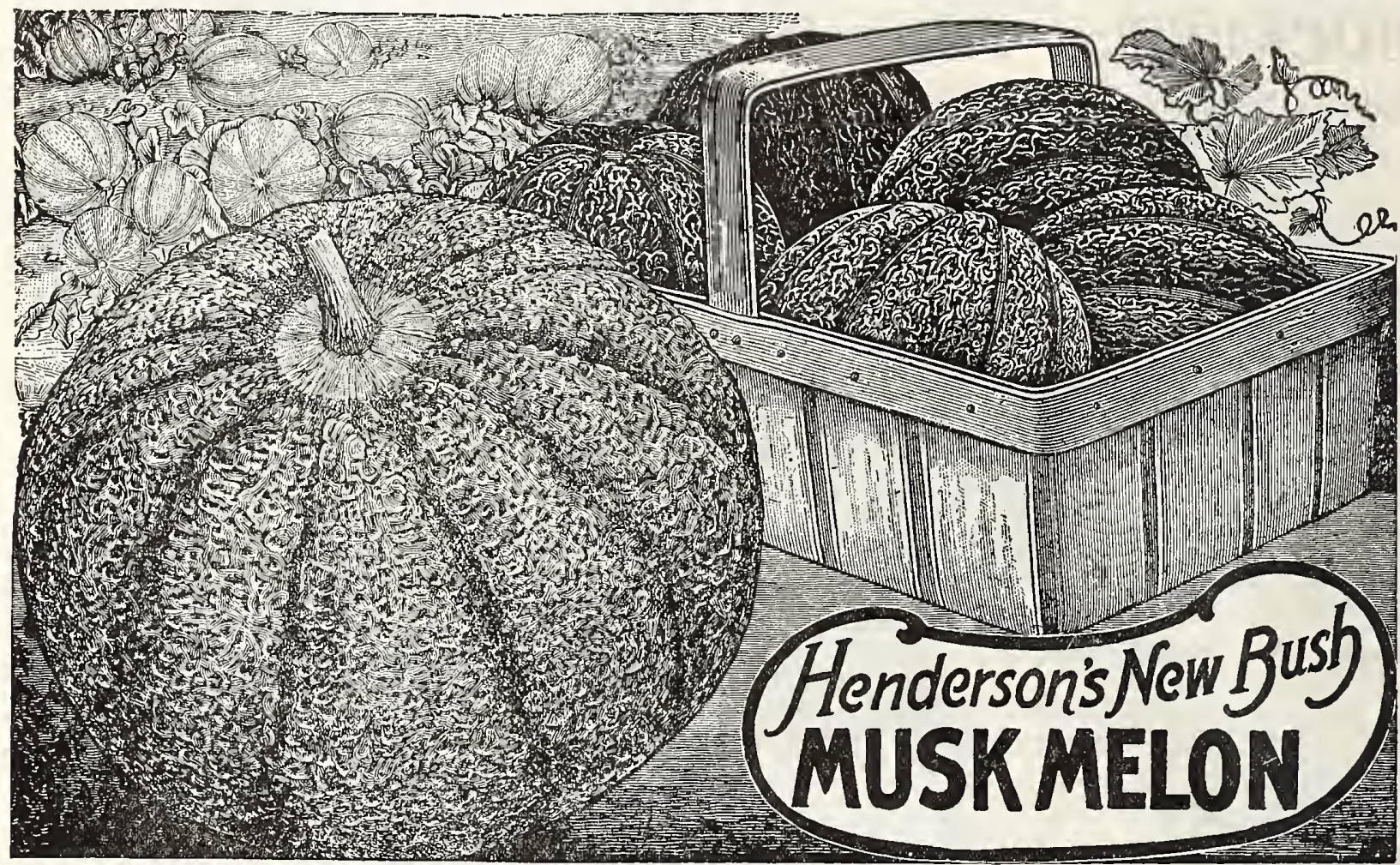

A VINELESS MUSK MELON THAT CAN BE GROWN IN EVERY GARDEN

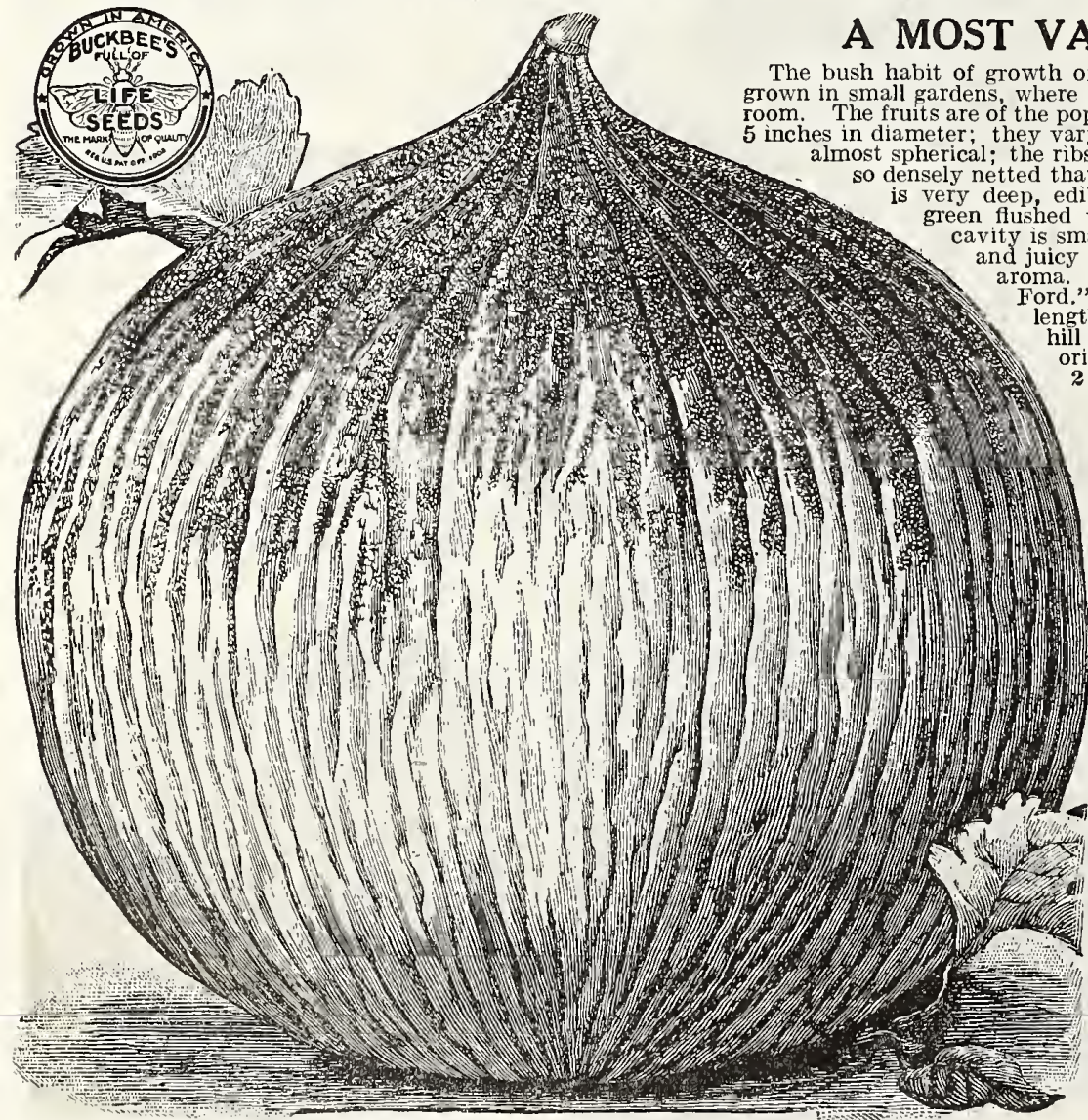

New Golden Casaba Melon.

\section{New Golden Casaba Musk Melon}

A great acquisition, and destined to become a standard vegetable just as much so as potatoes or onions. The seed should of frost is over on moist sandy loam. Do not pick until the light streaks become quite plck are cavity is small and the flesh thick, of fine texture, juicy and palatable to within delicious-almost impossible to describe to do it full justice. There is a decided flavor of pineapple as well as the best known mild and yellow. Pkt. 10c; oz. 25c.

Mrs. Mary K. Morgan, Rodeo, $\mathbf{N}$. Mex. writes:-I wish to say the 1200 pounds of Seeds ordered from vou last spring, which included Sugar Cane, Milo has proven perfectly satisfactory.

J. C. Akens, Marksville, La., writes -The "Full of Life" Seeds I purchased from you this Spring have proven far more 


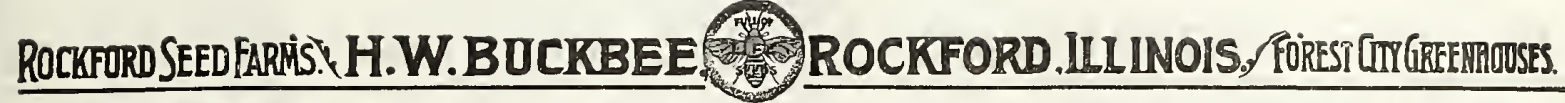

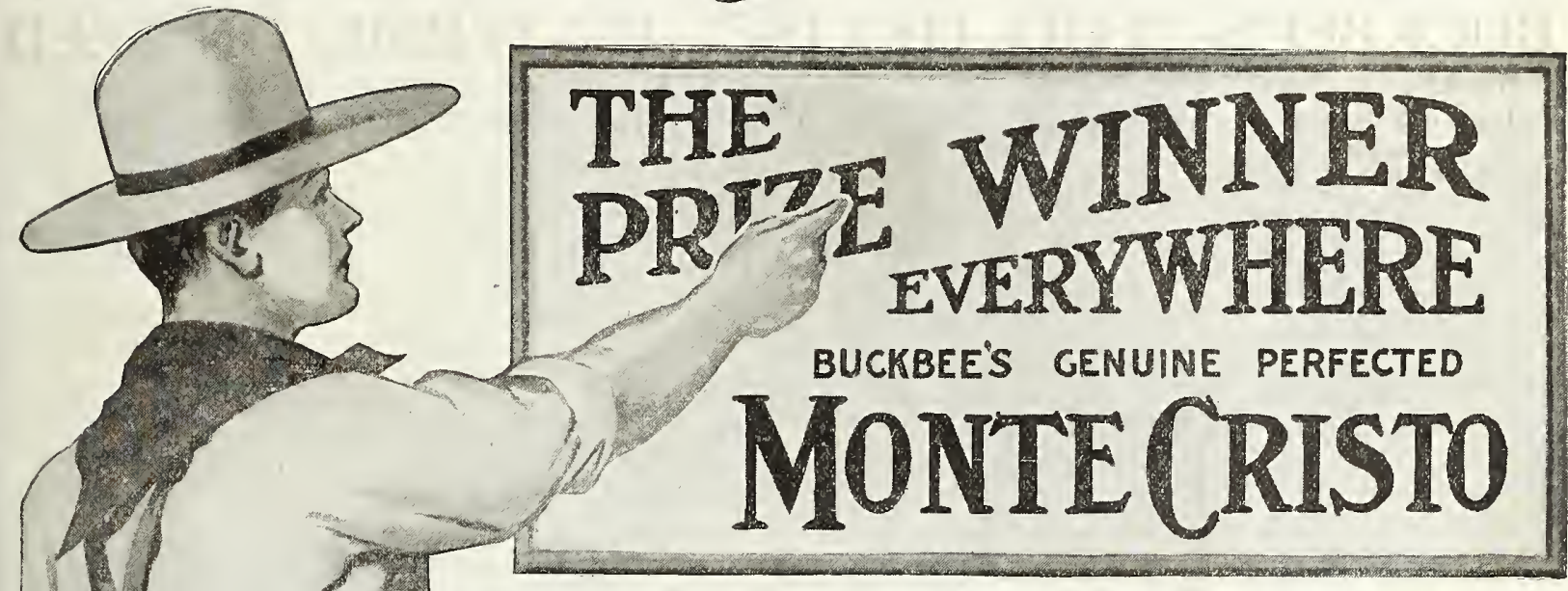

Trade Mark Registered 1914-By H. W. Buckbee, Et. Al.

\section{The World's One Unbeatable Water Melon} THE SWEETEST FLAVORED MELON KNOWN

The Best Variety for the Table-For Shipping and Long Keeping

T $\mathrm{N}$ hundreds of markets every season it finds ready sale at good prices when all other sorts go

Legging for buyers. This grandest of all varieties has becn extensively grown the past few seasons in almost every melon growing locality of the World, and in not one single instance that all are delighted with it prove that in the hands of our customers Buckbee's Monte Cristo has given the same surpassing resuits as our careful trials on Rockiord Seed Farms. The greatest yielder. The sweetest, juciest, crispest and most solid Melon ever produced, never having a hollow or pithy center when ripe. The easiest to sell on the market, for when once tried, people will have no other Many of our customers have written us that they have cleared s100 or more per acre by glowing Buckbee's Monte Cristo Melons. Under average cultivation you can do as well or better. Will you not try it this year? It is a grand, good shipper, has a firm, solid rind, not too thick, yet will stand the most severe handling. The outside skin is of a rich, dark green color, shaded with faint stripes of a somewhat lighter color. Certainly the finest appearing Melon ever grown for market, shipping or table purposes. While our supply of seed is farly large, we always have advance orders from our customers, who have planted Monte Cristo in past scasons, and we would advise all who are to plant this "King of all Melon" in 1916 to place their orders as early as possible. please romember that we control the entire product of this variety, so send to Buckbee for choicest stock seed of Puckbec's Monte Cristo Melon. The price is within the reach of all. price of choicest stock sced of monte Cristo Melon. The price is within the reach of all. Price of choicest stock sced of our own gro
35c: $1 / 2$ lb. $60 \mathrm{c}: \mathrm{lb} . \$ 1.00: 5$ lbs. $\$ 4.50$ prepaid.

J. W. Hudson, the Watermelon King, of Kahoka, Mo.; "I can truly say the World can't beat Buckbee's Monte Cristo Water Melon. Its size, beauty and quality make it the best seller."

Mr. N. Miller, Amity, Oregon; "Buckbee's Monte Cristo has proven the best Melon ever planted in this section.

W. M. Thomas, Lost Creck, Ala., writes: "The King of all Melons' is the verdict given Buckbee's Monte Clisto in this great Melon growing section.

We can furnish unsolicited Testimonials from almost every the union on grand Melon.
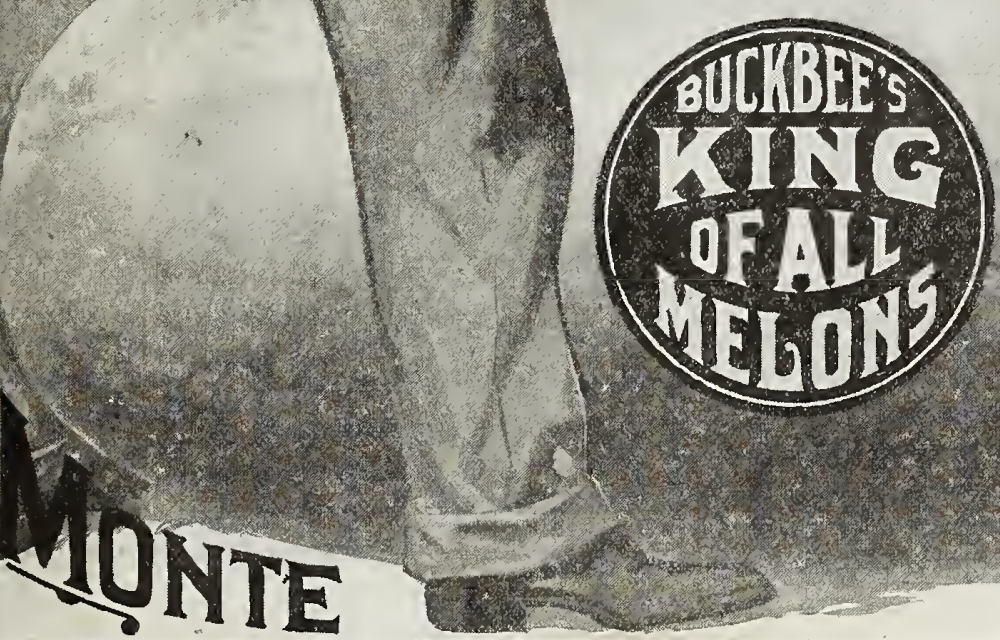

J. F, Eubank, R. R. 5 Lexington, Miss., writes:- I learn from a friend that you carry a very fine line of "Full of Life" seeds especially - Water Melon. I saw some fine specimens grown from your seeds known as "Buckbee's MONTE CRISTO", I also had the pleasure of eating one; and must tell you that it was simply fine. I am a great lover of melons and have been growing them all my life and I want you to plaee me on your mailing list for a catalogue next season. 


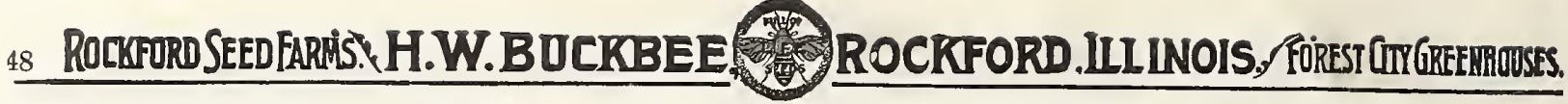 BUCKBEE'S “FULL OF LIFE" WATERMELON SEED}

Buckbee's Everbearing Always Sweet

The Melon of Real Quality. This is absolutely one of the sweetest Watermelons known, and is sure to be first in the market. It is of most delicious flavor, very juicy and sweet and is splendid for ramily use, as a few vines Everybody should try this new early Watermelon It is Melon to plant if you are in a climate where the seasons are short, for it will ripen where other varieties splendid Melon for every purpose Just the size for family use. The flesh is deep red in color and exceedingly brittle. By all means try this excellent Melon. Pkt. óc; oz. lb. 40e; ib. $75 \mathrm{c}$

\section{Buckbee's Ice}

Cream or Peerless Best of All for Home Garden. Superior in every respect. which is always fine grained, which is always fine grained, flavor Very proliflc, early, magnificent of the best for nearby mar kets and home purposes. Plkt. $4 \mathrm{c} ; \mathrm{oz} .8 \mathrm{e} ; 2 \mathrm{oz}, 12 \mathrm{c} ; 1 / 4$
$20 \mathrm{c} ; 1 / 21 \mathrm{~b}$. 35e; lb. 60c.

New Chilian Splendid High Grade Melon.

A new Melon of splendid quality which is already very popular on the doubtless take high rank elsewhere as soon as its desirable characteristics have become more gener round or slightly oblong. skin rich deep green. skin rich deep green, a still darker shade; flesh of decidedly bright verfine grained, firm and sweet Plkt. 4c; oz. 8c; 2 oz. $12 \mathrm{e} ; 1 / 4$
$35 \mathrm{c} ; \mathrm{lb} .60 \mathrm{c}$.

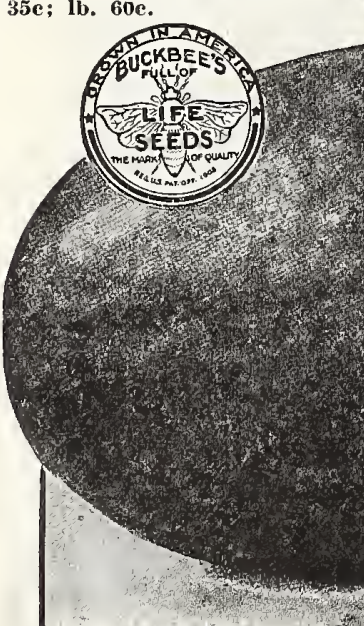

New National

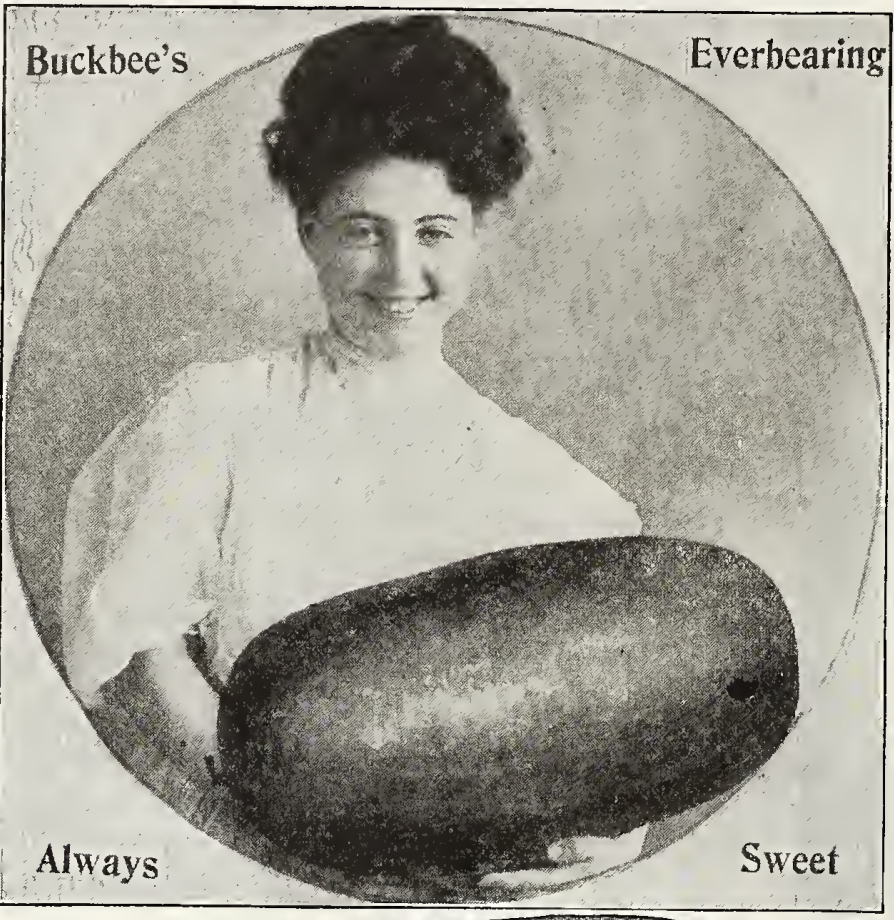

of National Renown. Extra early, very product. ive, extra large and of splendid flavor. The seed will often produce gray and green Melons on one vine, but the numer of the former pre2 oz, 12c; 1/1 lb. 18c; $1 / 2$ lb; 0e; lb. 50e.

Halbert Honey The Most Delicious Flavored Melon.

This new Melon is as handsome in color as the Kleckley Sweets, but more regular in form, and much more productive. Generally free from any appearance of neck They ength: 6 to 8 inches in in ameter. Color of rind a clear, glossy deep green. The flesh a beautiful crimson, exhalf an inch of the rind Plet. $4 \mathrm{c} ;$ oz. 8e; 2 oz. 12e; $1 / 4 \mathrm{lb}$. Maule's Wonderful Sugar Hardiest of All.

Excellent new variety of large size, Meions of 40 to 60 pounds being the average occurrence. Flesh red and de7c; 2 ox, 12c; $1 / 4$ lb. 18c; 1 1b. $30 \mathrm{c}$; 1b. 50c.

\section{Dixie Improved}

Famous Shipoing Melon. Skin dark green, beautifuly striped, fesh bright der and juicy Great favorite, strong and firm in growth. Pkt. 3e; oz. 6e; oz. 10e; $1 / 4$ lb. 15c; $1 / 2$ lb. $25 \mathrm{c} ; 1 \mathrm{~b} .40 \mathrm{c}$

Gray Monarch or Mammoth White Icing

Valuable Standard Melon. Very large, mottled gray skin; long; flesh bright erimson; flavor delicious. Pkt. 4e; oz, 7c; z oz. 12c; $1 / 4$ lb. 18c; $1 / 2$ Ib $30 \mathrm{c} ; \mathrm{lb}$. $50 \mathrm{c}$.

Buckbee's True Ice Cream Watermelon.

THE TOM WATSON - GRAND NEW WATERMELON BEST OUAUTY TIVE SHAPE

The "Tom Wats" is an The "Tom Watson" is an extra long Melon of attractive appearance, uniform in shape and quality; the luscious crimson fiesh is "as sweet as honey," melting and of superb flavor: The average Melon will weigh 35 to 40 lbs. and measures about 28 inches long and about 12 inches in diameter. The skin is dark green, with thick netting all over, quite distinct from other varieties. It originated in Georgla, a state noted for producing flne Watermelons, and this new variety is a good example of what a first-class Watermelon should be. Its appearance and quality strongly recommend tt both for home use and for market. Sure to take a leading place selection and we honestly beleve to be a graat improvement over our original planting stock secured direct from the introducer. Pkt. 5c: oz, 8c; 2 oz. 15c; $1 / 1$ lb. 25e; $1 / 2$ lb. 40c: 1b. 75e. 


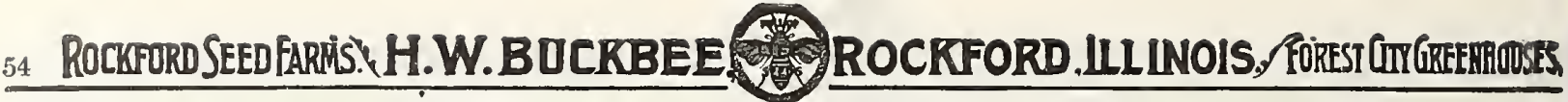
BUCKBEE'S PEDIGREED ONION SEED

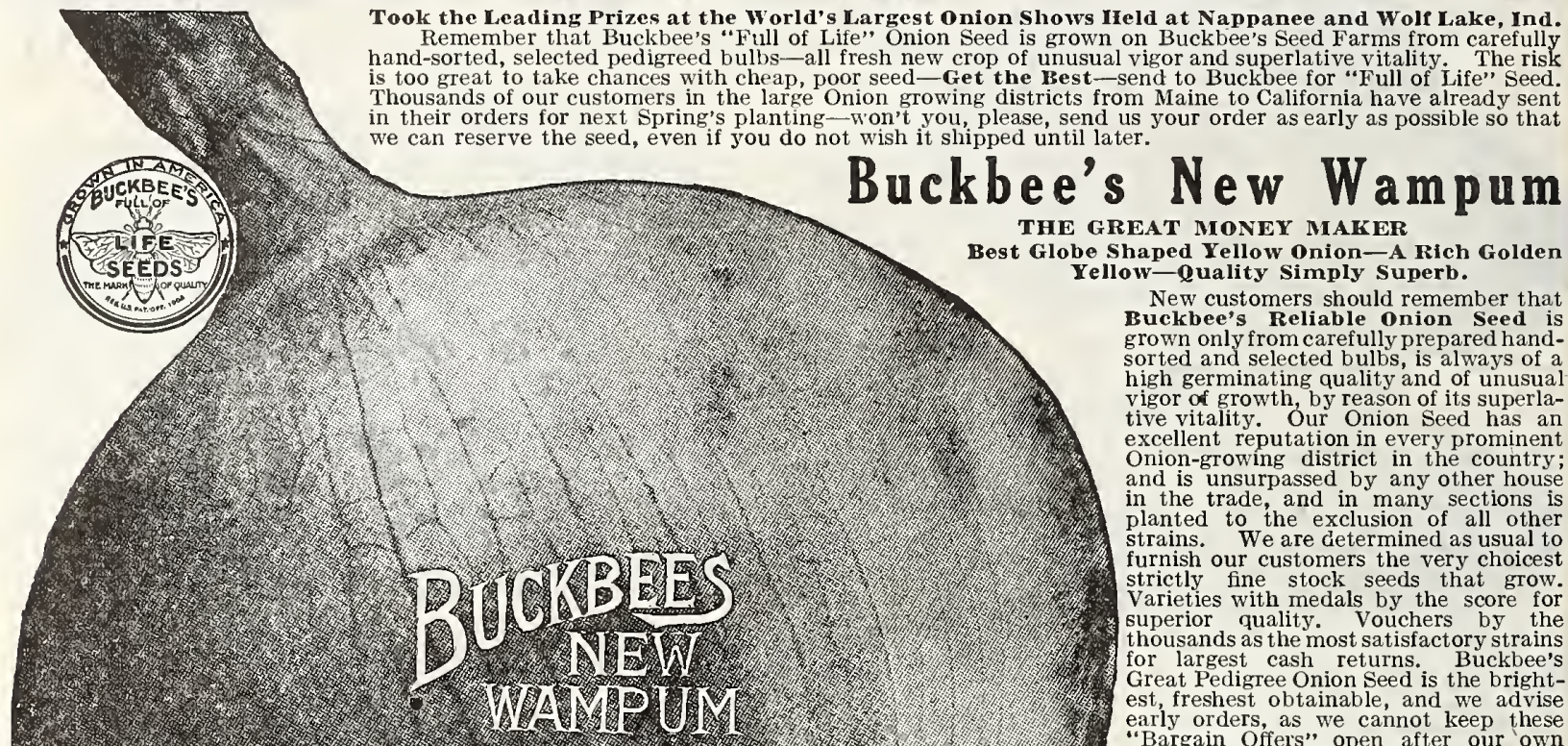

Ons Ifeld at Nappanee and Wolf Lake, Ind. hand-sorted, selected pediogeed bulbs-all fresh new crop of unusual vigor and superlative vitality. The risk

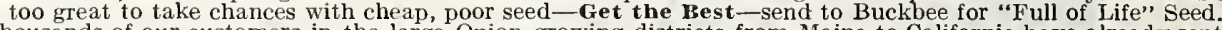
in their orders for next Spring's planting- won't you, please, send us your order as early as possible so that

THE GREAT MONEY MAKER Gellow Onion-A Rich Golden New customers should remember that Buckbee's Reliable onion Seed is grown only from carefully prepared handorted and selected bulbs, is always of a vigor of growth, by reason of its superlative vitality. Our Onion seed has an excellent reputation in every prominent Onion-growing district in the country; and is unsurpassed by any other house in the trade, and in many sections is strains. We are determined as usual to furnish our customers the very choicest strictly fine stock seeds that grow. Varieties with medals by the score for thousands as the most satisfactory strains for largest cash returns. Buckbee's Great Pedigree Onion Seed is the brightest freshest obtainable, and we advise early orders, as we cannot keep these "Barly orders, as we cannot keep these growth of seed is exhausted. Buckbec's New Wampum - The Great Money Maker-This grand new variety, which was sent out for trial in 1898, has proven as its name indicates, the beautiful golden yellow very attractive and striking. It is the most perfect globe shaped Onion in existence today.

ONION SEED

Growing is One of my Chief Specialties on Rockford Seed Farms and am offo ering My Customers Bigger and Better Bargains
than Ever Before in "FULL OF LI

Order Early.

Buckbee's

New Golden Globe Danvers Long Keeper. Best Shipper. Unrivaled Market Onion. Always in the Lead. Challenges Competition. The most perfect type of the globe-shaped Onion ever offered. It ripens early, has a very small neck, the entire crop drying down at one time. It is an immense cropper, and will yield more marketable onions to the crop than any strain we are acquainted with. Trial tests have shown this great variety to yield over 2,000 bushels have shown wile per acre, while under ordinary cultivation in past seasons bushels per acre. Remember that we control the entire supply of this variety. Our own growth choicest Northern-grown, high-grade pedigrce stock seed. pkt. $5 \mathrm{c} ; \mathrm{oz} .20 \mathrm{c} ; 2 \mathrm{oz} .35 \mathrm{c} ; 1 / 4 \mathrm{lb} .60 \mathrm{c} ; 1 / 2 \mathrm{lb} . \$ 1.10 ; 1 \mathrm{~b} . \$ 2.00$. Selected Yellow Strasburg, or Dutch Very Popular Long Kecping Yellow onion.

Bulbs are quite flat and of good size; skin yellow, of darker color than the Danvers; flesh white, of mild flavor; keeps well. This is the variety that is used the most extensively for growing yellow Onion sets. A great lelder and splewn heeper. Pkt.4c;0z.15c;20z.28c;1/1b.50c; $1 / 21 b .90 c ; 1 b . \$ 1.70$.

\section{MONEY IN ONIONS} IF YOU PLANT THE RIGHT SEED And that is what you secure if you send direct to
headquarters for THE BEST ONION SEED IN THE H. W. BUCKBEE,

Rockford Seed Farms,

Rockford, III.

Established 1871 The bulbs are frm and solid and excellen

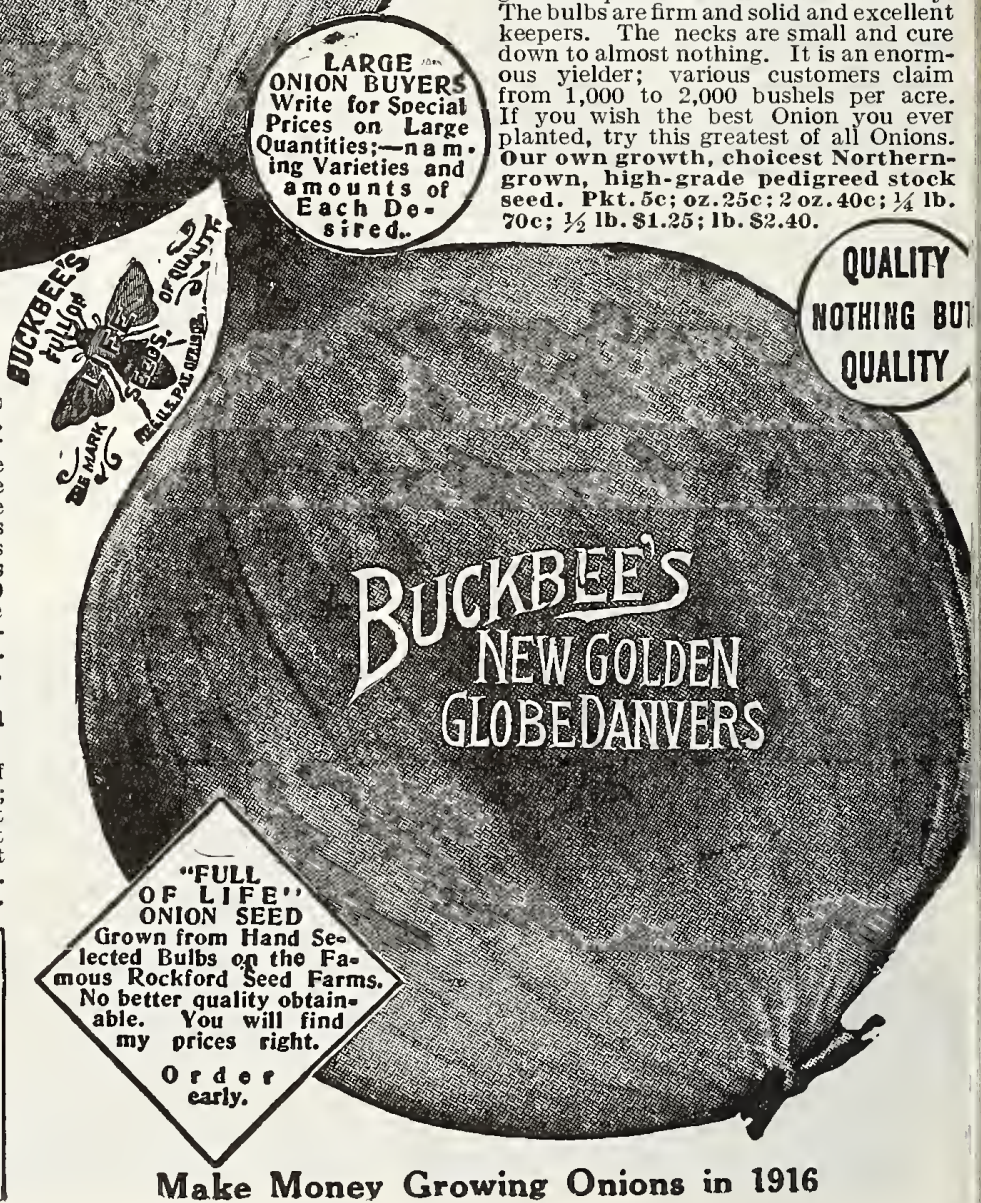


Buckbee's Large Red - Twerce The Gratest of All Early Red Onions

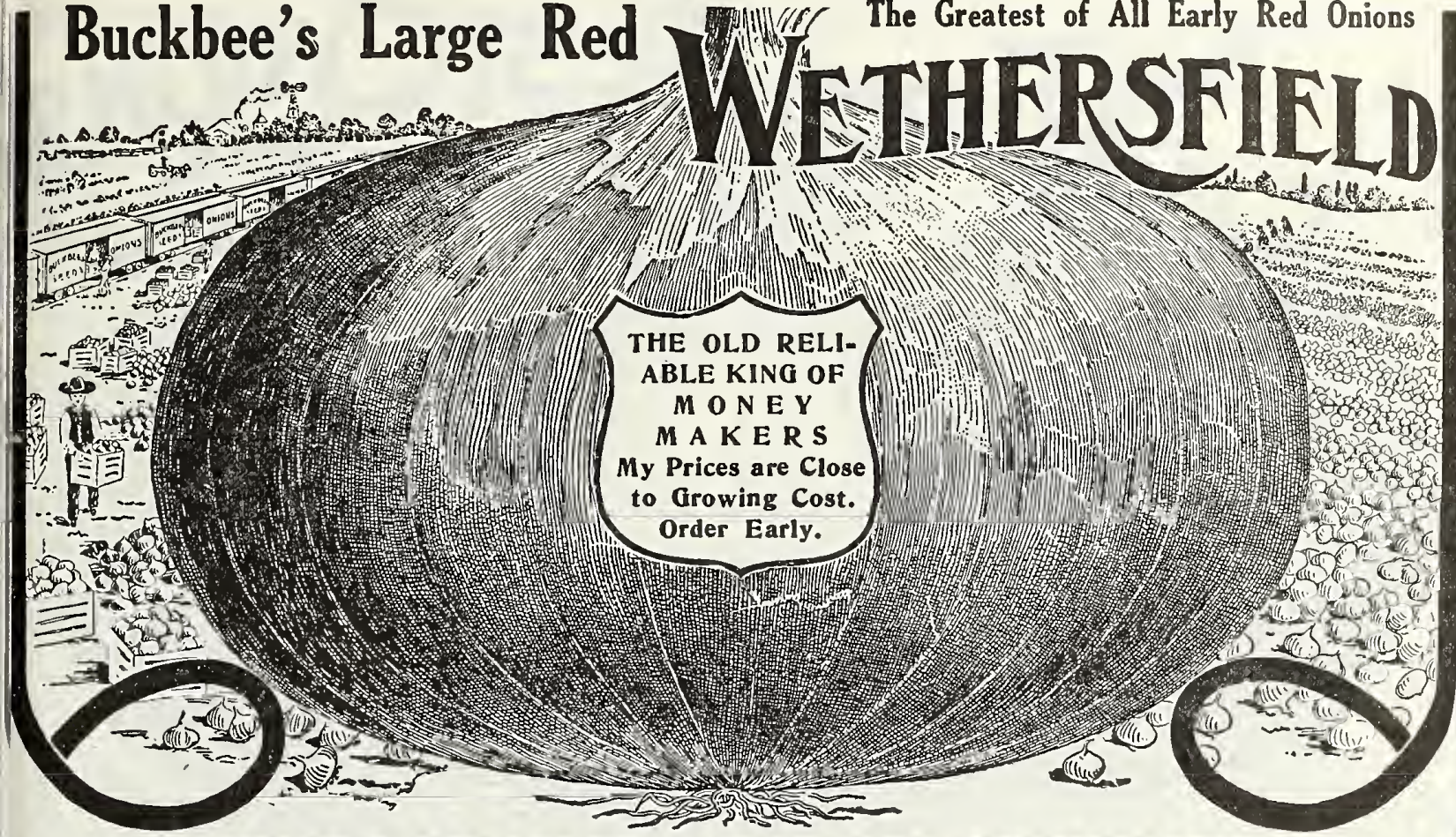

\section{BUCKBEE'S PEDIGREE LARGE RED WETHERSFIELD}

OUR LEADING SPECIALTT.

One of the chlef departments of our seed growing business consists of growing Buckbee's Pedigrce Red Wcthersfield onlon for seed purposes only. Our stock has reached such a hlgh polnt of mcrit that it is a houschold word cverywliere that “Buckbec's Pcdigree Red Wethersfield onion Sccd ls the most reliable and produces more good marketable Onlons per acre than any other offered." And, from the many thousands of unsolicited testimonials which we have reccived from all over the country, we have every reason to believe that the tlme whlch we personally spend in our onion Fields is truly appreciated by our many thousands of customers who stand by us and say: "Buckbee's Seeds Are Full of Life."

There are many strains of this justly celebrated Onion offered but we venture to say none that can surpass Buckbee's Prize Mredal stock of this famous variety. The various strains, good, bad and indifferent that are generally offered the unwary planter come to maturity all the way from August up until as late as October. This unreliability of cropping is very disastrous to most localities. THE GREATEST OF ALL RED ONIONS.

The seed which we are offering is of the earliest form, grown from hand-sorted bulbs that will produce very large Onions of immense size; $11 / 2$ to $21 / 2$-pound Onions from seed the first year are of frequent occurrence. Buckbce's Red Wethersfield grows with unusual regularity, scallions being unknown. It is a magnificent keeper. An enormous cropper. 700 to 1,000 bushels have frequently been raised upon a single acre. The shape is accurately skin is a deep rich, purplish re beautiful white, finely grained and of good flavor. Our customers throughout the country endorse it as the best Red Onion ever grown. NEVER HAS BEEN KNOWN TO FAIY.

We trust no Onion grower who receives our catalogue will fail to try at least a small quantity of Buckbee's Red Wethersfield Onion, for all ought to know how much superior it is to other strains offered. This seed
will produce highly-colored, long-keeping Onions sure to command the highest price in the market. Will yield double the amount of any seed you can secure. Our own growth, choicest Northern-grown, high grade pedigree "Full of Life" stock seed.

Pkt. 4c; oz. 12c; 2 oz. 22c; $1 / 4$ lb. $40 \mathrm{c} ; 1 / 2 \mathrm{lb}$. 75c; $1 \mathrm{~b} . \$ 1.40$.

\section{Extra Early Red}

The Earllest Red onion in the World.

A favorite early variety of fine shape. Always a good yielder and magnificent keeper; its beautiful shape and rich purplish crimson color making it extremely attractive and desirable. Selected Stock. Seed. Pkt. 4c; oz. 15c; 2 oz. 28c; $1 / 41 \mathrm{~b} .50 \mathrm{c} ; 1 / 2 \mathrm{lb}$. 90c; $1 \mathrm{~b} . \$ 1.78$.

\section{| Buckbee's Selected Yellow Globe Danvers}

Standard of Excellence for Home and Market Use.

The finest standard Yellow Globe Danvers Onion ever offered. Fine, symmetrical shape, large size, average specimens weighing from The bulbs are very choice, finely grained, exceptionally mild, and very early. It is a grand, magnificent keeper. Frequently produces 800 bushels or more to the acre from seed the first year. Our own growth, choicest Northern-grown, highgrade pedigree stock seed. Pkt. 4c; oz. 15c; 2 oz. $28 \mathrm{c}$ : $1 / 4 \mathrm{lb}$. 50c; $1 / 2 \mathrm{lb}$.90c; $1 \mathrm{~b}$. $\$ 1.75$.

\section{Australian Brown}

Long Keeping. Flne Quality.

This sort is distinct from all other Onions; is uniform in size and shape, wonderfully hard and solid, and will keep almost indefinitely. Ripens extremely early, and never makes scallions. It is of medium size, round, with skin of a

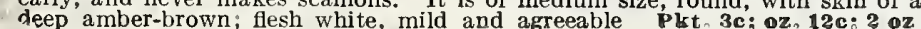
inc: $3 / 4 \mathrm{lb}$. 350 : $1 / 1 \mathrm{~b}-650^{\circ} 1 \mathrm{~b} 81.25$

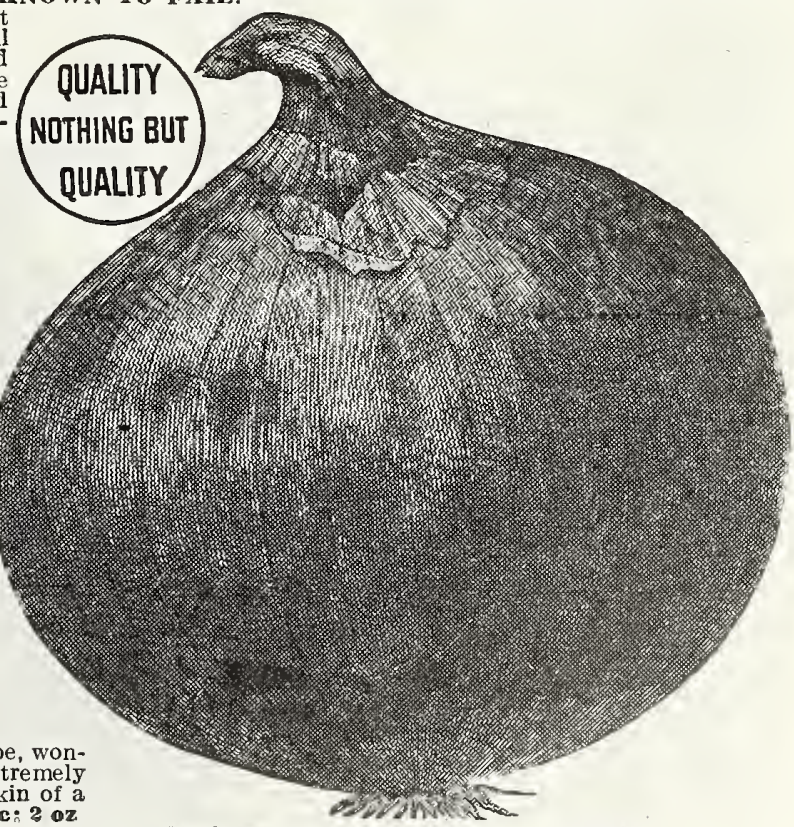

Buokbera Selocted Yellow Globe Danvers 


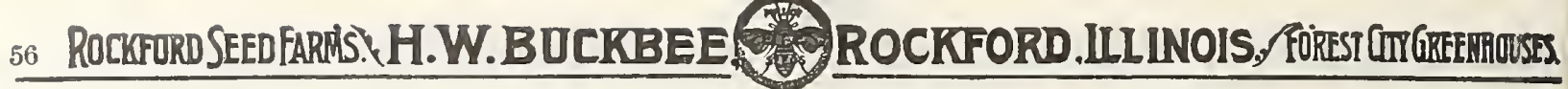

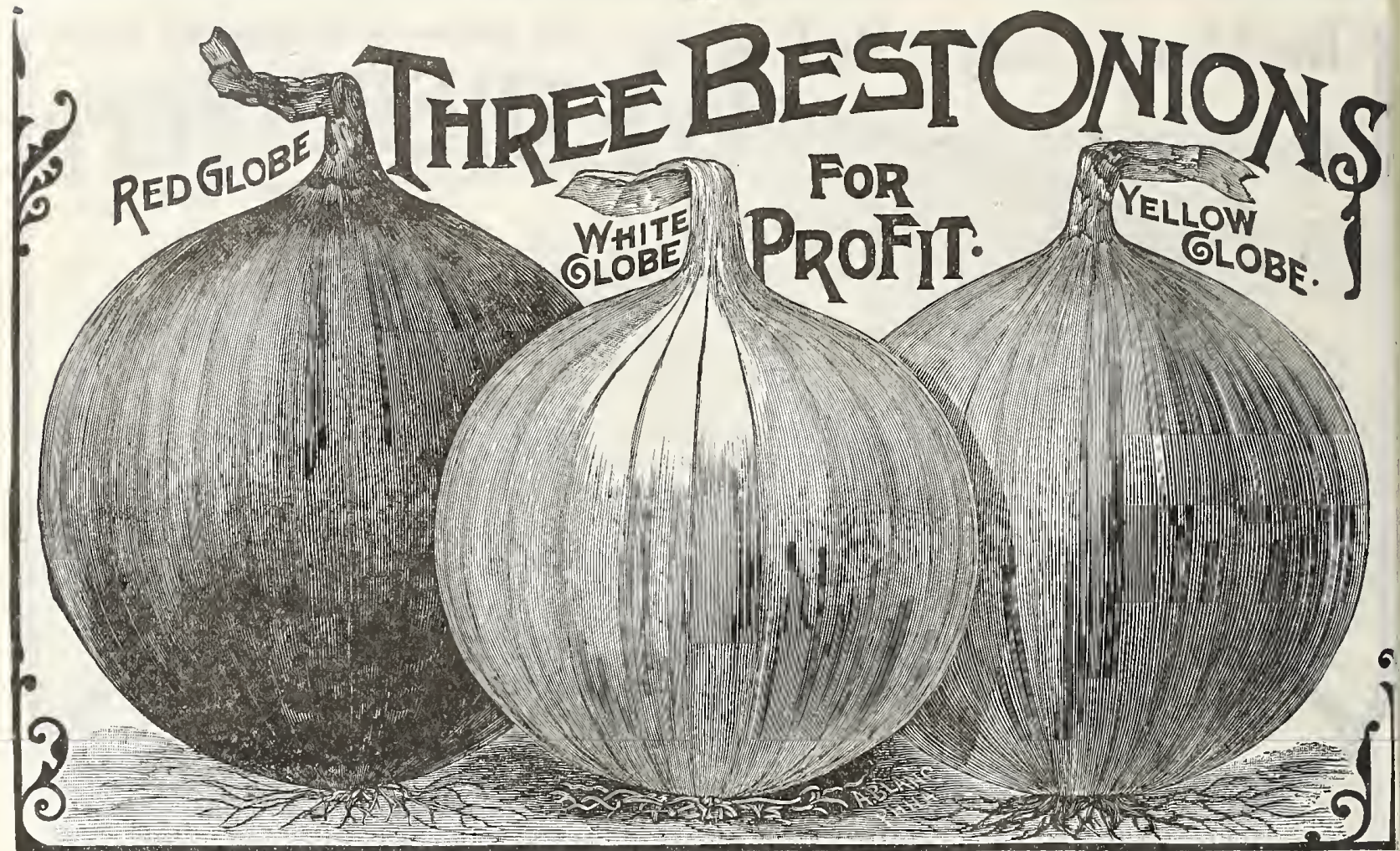

\section{MONEY MAKING} GLOBE SHAPED ONIONS

Are the Future onions.

They are the most attractive in appearance and most economical in use. They command the highest price in market. They are more profitable than the flat varieties to grow, as they occupy no more vested in September keep perfectly sound and merchantable until the following June.

\section{SOUTHPORT RED GLOBE}

The celeckbce's Re-Selected Pedigrec Seed. many years proved one of the most profitable for the market and shipping trade, commanding uniformly good prices in car-load lots. It is of large size and splendid appearance, and frequently yields from unusual merit. Flesh is firm, finely grained, very rich, yet unusually mild for a red Onion, and is sure to please the most fastidious. The crop is ready to harvest in No one that we keps well until the late Spring months. with the results obtained by planting this great Onion. Our own growth choicest Northern-grown, high-grade pedigree stock $30 \mathrm{e} ; 1 / 4$ ib. $55 \mathrm{c} ; 1 / 2$ lb. $\$ 1.00$ Ib. $\$ 1.90$. SOUTHPORT YELLOW SOUTHPORT

Buckbee's Re-Selected Pedigree Seed. Entirely distinct from Onions of the Danvers type, having noof its own. Fxcels in size, excels in yield, excels in keeping qualities, excels in mildness of flavor. Matures in early Fall. It is sure to satisfy the one Who buys a packet or the one of seed for car-load shipments. A truly grand Onion, whose large beautiful appearance sacked crated or barreled for the market. Our own growth ehoicest Northern-grown high-grado pedigreo stock seed, pkt. 5c: $0 \mathrm{z}, 18 \mathrm{c} ; 2 \mathrm{oz}, 30 \mathrm{c} ; 1 / 4 \mathrm{Ib} .55 \mathrm{c}: 1 / 2$ lb. $\$ 1.00$; Ib. $\$ 1.85$.

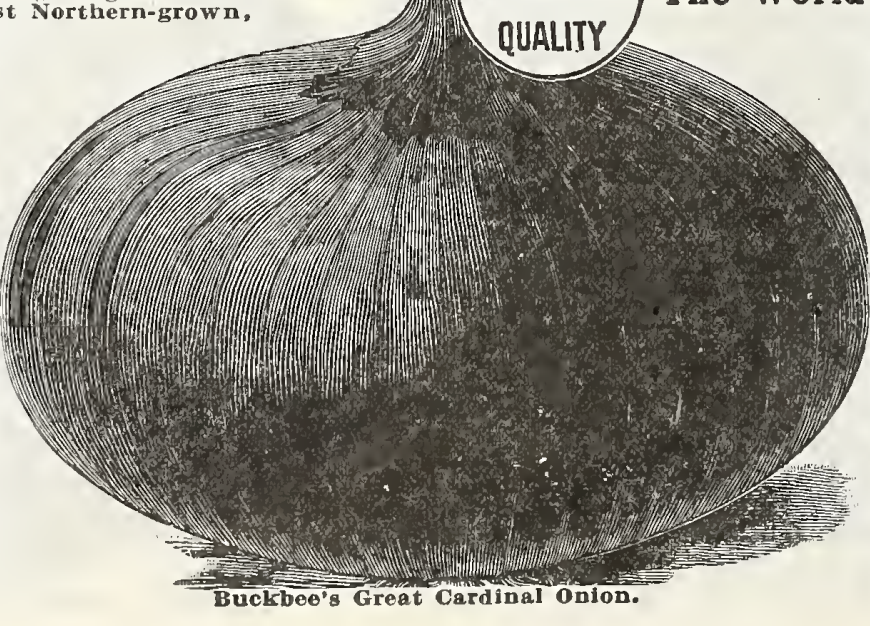

DTT R Q QUICK GROWING SURE CR OPPERS LONG KEEPERS SOUTHPORT WHITE GLOBE

Buckbee's Re-Selected Pedigreo Seed.

Handsomest of all Onions. It is of true globe form, pure white, hard, small necked, ripening regularly and evenly; a splendid keeper. The fiesh is firm and fine grained, and mild to taste. Average yields of 500 to 700 bushels per acre are of frequent occurrence. No market gardener or Onion grower can afford to plant inferior stock, with had so reasonable, the results of planting a few ounces often paying many times the first cost of the best seed.

our own growth choicest Northern-grown, high-grade pedigree stock seed, pkt. $5 \mathrm{c} ; \mathrm{oz} .30 \mathrm{c} ; 2$ oz. $50 \mathrm{e} ; 1 / 4 \mathrm{lb} .90 \mathrm{c} ; 1 / 2 \mathrm{lb}$ $1.60 \mathrm{Ib} . \$ 3.00$

BUCKBEE'S GREAT CARDINAL ONION

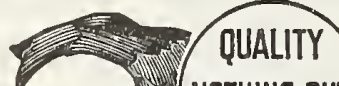

NOTHING BUT The World Beating Red Onion

An Enormous Yielder. Best Flavored. A Splendid Keeper. Handsome Color. Wonderful Shipper. Matures Early.

d on Rockford Seed Farms and has already made a reputation that is world wide. It is the money-making Onion. It has size and density, coupled with a splendid flavor, is one of troduced, and has the size and shape to recommend it in the highest degree for the market. We would not praise it so highly if we did not believe it to be alone Ne real money-makers. No one but CARDINAL, SEED. Our supply is limited. Order early. Pkt. $5 \mathrm{c} ; \mathrm{oz} .25 \mathrm{c} ; 20 \mathrm{z} .40 \mathrm{0c} ; 1 / 4$
lb. $70 \mathrm{c} ; 1 / 2 \mathrm{lb} .31 .25 ; 1 \mathrm{~b} .82 .40$. 


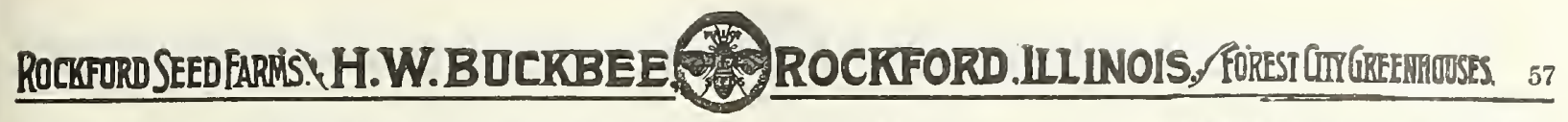
BUCKBEE'S PEDIGREED "Full of Life" ONION SEED

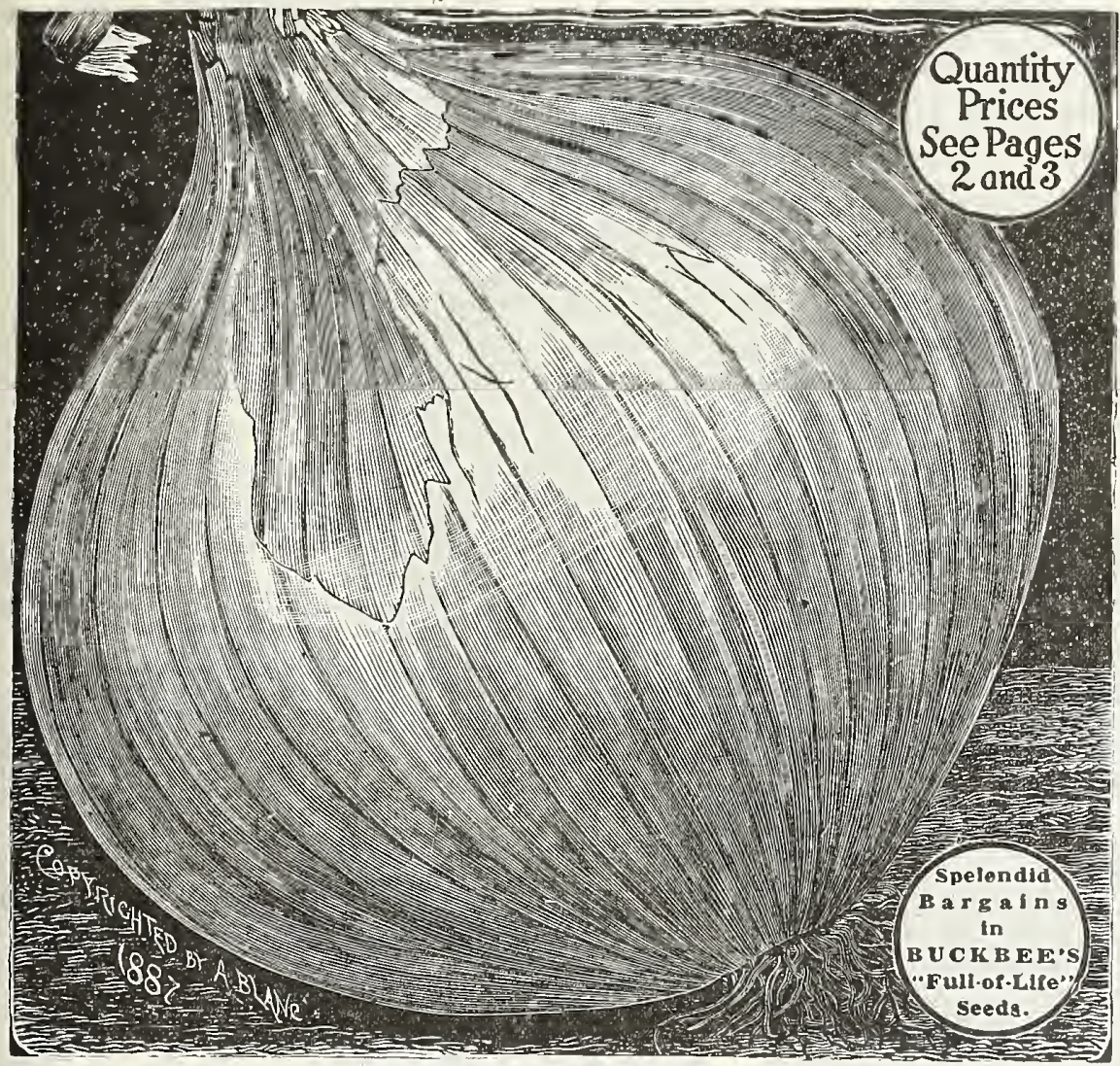

Now Genuine Prizetaker Onion.

\section{New Genuine Prizetaker}

\section{HANDSOMEST, LARGEST AND KING OF ALL YELLOW ONIONS}

Unercelled Either for Home Use or for Market

The Prizetaker Onion has proved itself to be the greatest acquisition in years and is by far the handsomest, most productive, most popula

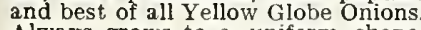
Always grows to a uniform shape, small neck, and ripens up without stiffness of the neck. In market it never fails to attract attention on bring a far better price than any other onion. It is even more attracSpanish onions sold on the city fruit stands-in fact, takes the place o that variely.

\section{A Big Money Maker}

It succeeds everywhere-East, West, North and South -and
whether grown for home use or for marketing it gives universal satisfaction, yielding Onions often 14 inches around and at the rate of Its immense 1,500 bushels per acre it to all, particularly when it is known that its keeping qualities are pale yellow, and the interior clear sparkling white. Easily grown, medium early in maturing, mild flavor. Pkt. 5e; Oz. 12c: 2 oz. 23e: 1/ 1b.

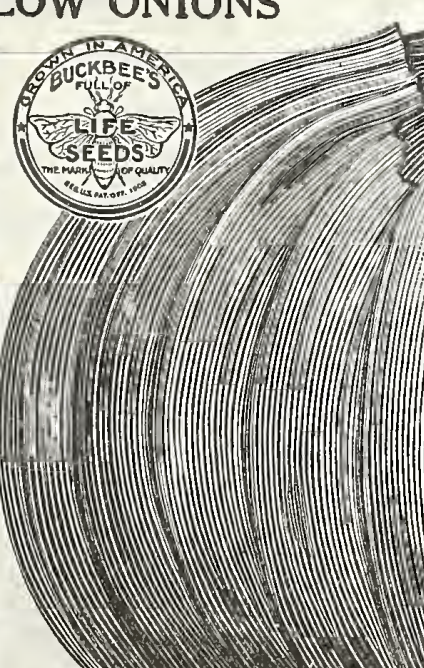

QUALITY NOTHING BUT

QUALITY

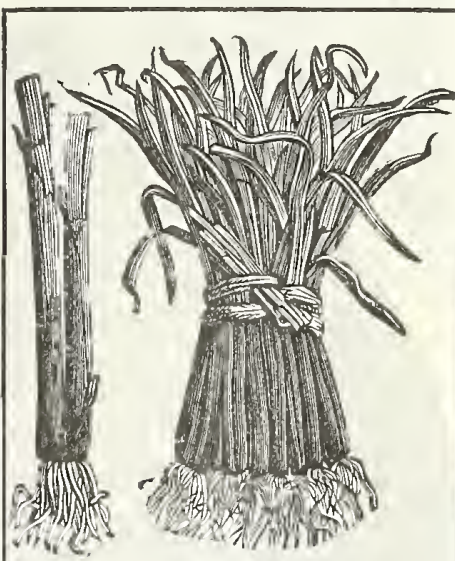

Early White Welsh.

\section{Early White Welsh}

For Green Onions.

This kind does not form a bulb, but is one of the best kinds for "green Onions," The plants are gerend for ears, Pkt, 5ce oz, 15c; ₹ oz. 28c; $1 / 4$ 1b. 50c; $1 / 2$ lb. 90c; 1b. $\$ 1.75$.

\section{BUCKBEE'S}

Round or Yellow

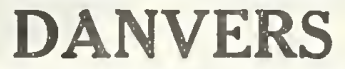

Magnificent Sort in Every Way. Very handsome in appearance, round in shape, though thick through, of fine market and family purposes skin thin, of a rich straw color; flesh is pearly white, fine grained, firm, mild and of excellent quality. Ripens early, keeps growth, Chócest Northern- rown. high-grade pedigree stock

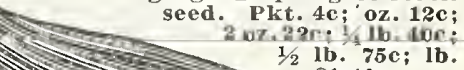
$\$ 1.40$.

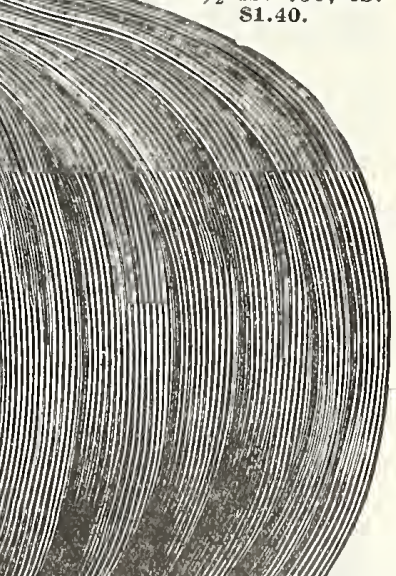




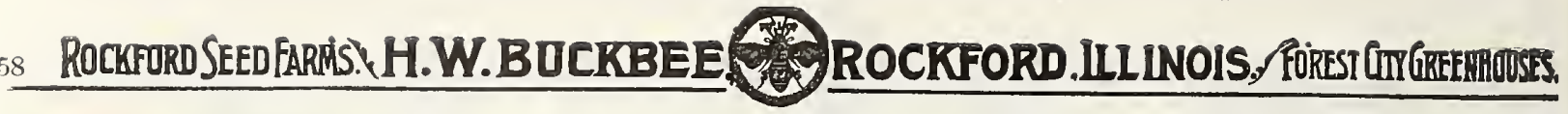
BUCKBEE'S BUCKBEE'S RED GIANT REDGIANT ONION
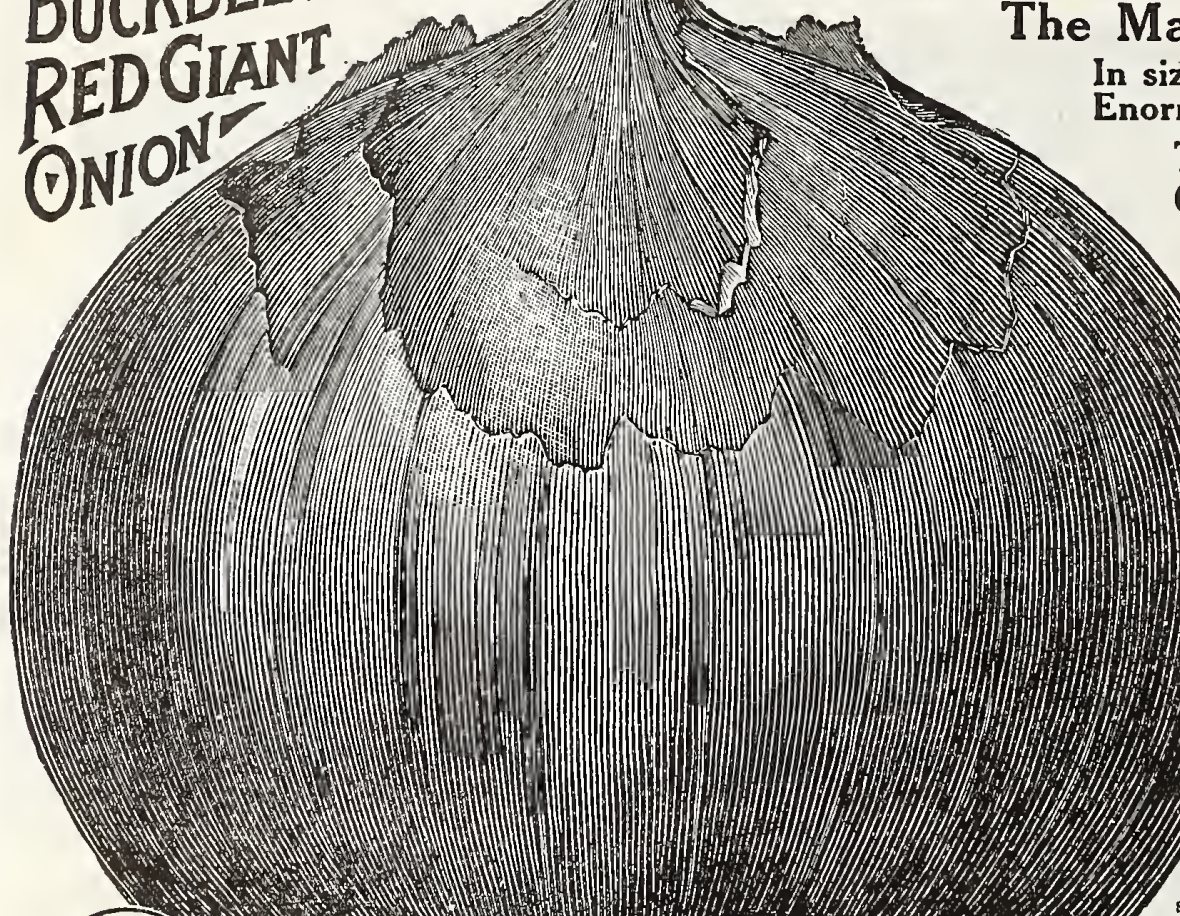

QUALITY
NOTHING BUT
QUALITY

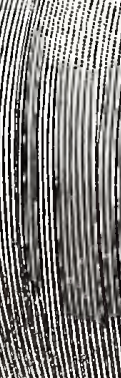

BUCKBEE'S MAMMOTH SILVER KING

ITS MILDNESS OF FLAVOR Ẫ TENDERNESS ARE UNEQUALED EVEN IBY THE BERMUDA VARIETIES.

The largest white Onion-grows to a remarkable size, average diameter is from five to seven and one-half inches. Single bulbs often attain weights of from two and one-half to four pounds each. The skin is of a beautiful silvery white, the flesh is of a snowy white, and is of a particularly mild and pleasant flavor. So sweet and tender is
the flesh that it can be eaten like an apple. the flesh that it can be e.
Pkt.5c;0z.150; $20 z$.

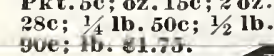
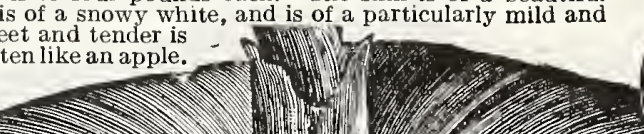

BE The Mammoth Red Onion

In size it is not excelled by the Enormous Varieties from Spain THE GRANDEST VARIETY GROWN FOR THE AMERICAN CLIMATE

This magnificent new variety of our own introduction has met with the now one of the most popular varired Onion, often weighing trom four to five pounds. Many of our customers have grown specpounds. In shape Buckbee's Red Giant is round and symbeautiful reddish hue, while the flesh is delightfully pure white, very fine grained and of pleasing stock of this grand novelty. Pkt.10c; oz. 25c;20z.40c: 1/4 1b. 70c; $1 / 21 b . \$ 1.25 ; 1 b . \$ 2.40$.

A. Wheeler, Bay City, Mich., writes:- Thinking you
would be interested to know that I Would be nterested to know that
grew as large, if not the largest crop of onlons ever grown from the "Full you last year, I am sending you pleture of part of the field which shows one acre that went 1600 bu. to the acre. I had in ail $61 / 4$. The $61 / 4$ acres netted me over $\$ 4,000$ which speaks pretty well for Michigan land. I want
to equal this next year on a larger seale and am
anxlous to get your "F Full of Life" Northern

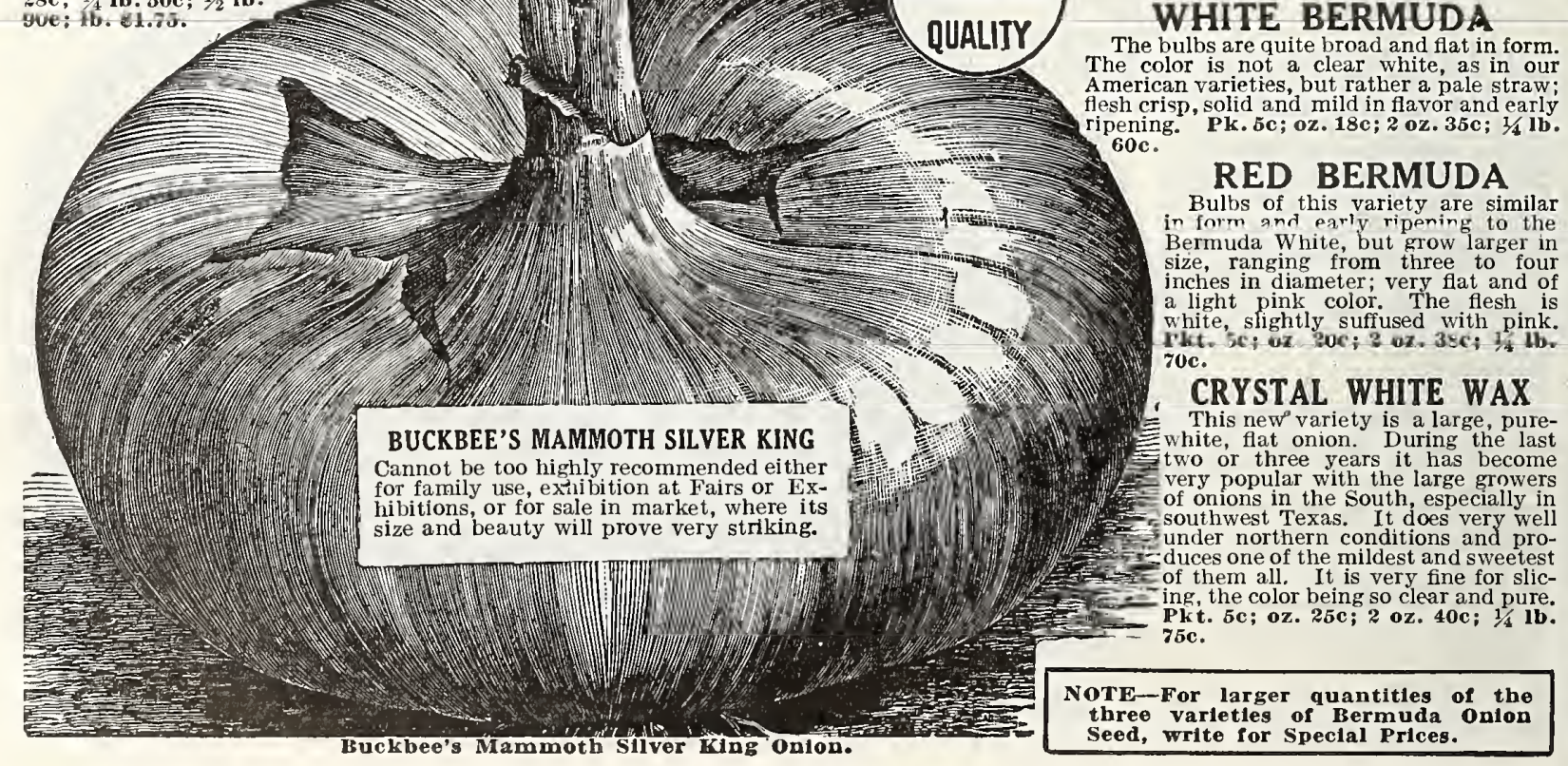

QUALITY NOTHING BUT QUALITY. (1) Grown seed.

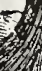
4.

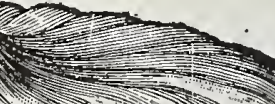
.

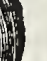

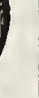




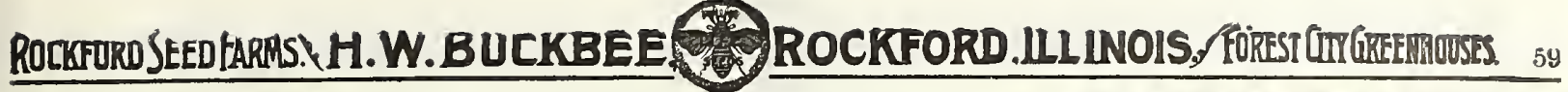

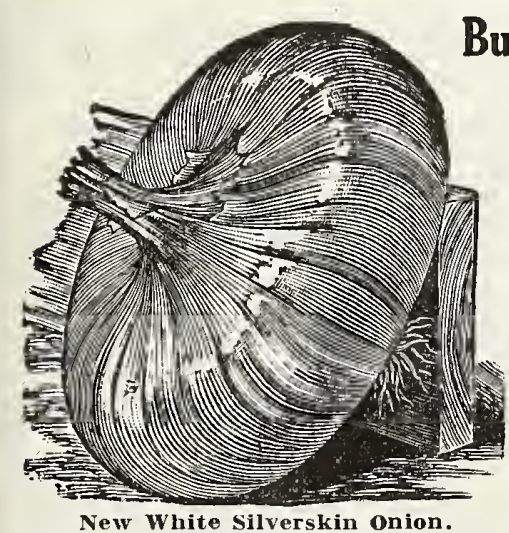

Buckbee's White Pickling Onion

This distinct variety is the very earliest Onion in cultivation, of a pure paper-white color, very mild and delicate in flavor; from one to one and one-half inches in diameter, and three-fourths of an inch in thickness. 1t: early table use as well as bunch onions for Pedigreed stock seed. Pkt. $6 c ; 0 z$.

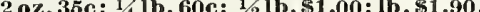

New White Silverskin or White Portugal Onion The Standard White onion for Market and Family Use. Flavor mild and pleasant, skin silver white, of handsome appearance, highly esteemed for pickling when young, also for market in early
Winter. This is the variety from which white Onion Sets are grown. It will please you immensely for any purpose Buy your seeds from first hands. Our own growth choicest Northern-grown, high-grade pedigree stock seed. Pkt. 4c; oz. 25c; 2 oz. 40c; $1 / 41$ lb. F5c; $1 / 2$ lb. \$1.40; 1b. \$2.75.

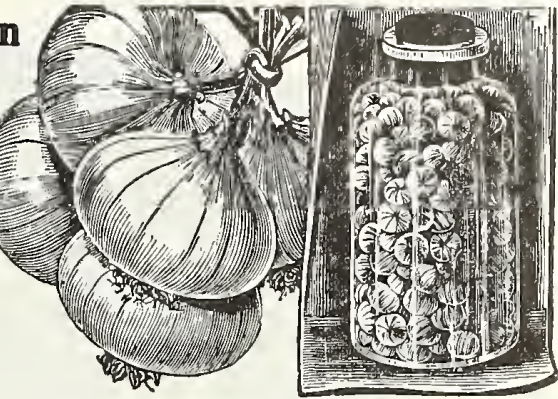

Buckbec's White Pickling Onion.

Extra Early White Queen

A silver-skinned variety of quick growth and remarkable keeping qualities. Particularly valuable for pickles Pkt. 4c; oz. 12c; $2 \mathrm{oz}$ $23 \mathrm{c} ; 1 / 41 \mathrm{~b} .45 \mathrm{c} ; 1 / 2 \mathrm{lb} .85 \mathrm{c} ; 1 \mathrm{~b} . \mathrm{S1.60}$

\section{BUCKBEE'S "FULL OF LIFE"}

\section{ONION SETS}

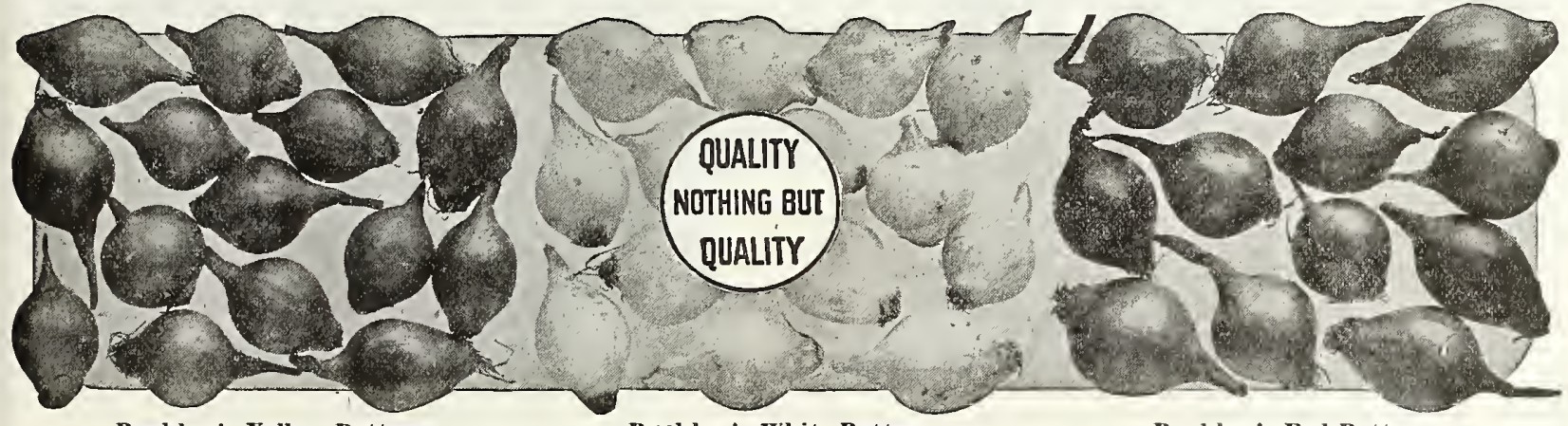

Buckbee's Yellow Bottom.

Buckbee's White Bottom.

Buckbee's Red Bottom.

Bottom Onion Sets

Bottom Onion Sets produce an Onion ready for market or the household from four to six weeks earlier than can be done by sowing household from four the six weeks earler than can be done by sowing This gives the market gardener ample time to sell his entire crop at the early high prices and permits the sowing of another crop on the land the same year. Every private garden should contain a sowing of sets.

\section{Buckbee's Improved Top Sets}

These are planted to produce both early green onions and large eating Onions. This variety increases by producing sets at the top of the stalk and does not produce seed By far the most superior variety. They are the best Onions to eat, will yield at least one-third more and ripen much earlier than other Onions. It is the best keeper that we know of, having kept perfectly solid for over a year. We season is over. Give this variety a trial. Postpaid, pt.22c; qt.40c.

\section{Potato Onion Sets}

Potato Onion Sets multiply by division of the parent Bulb and are not grown from Seed.

\section{Buckbee's New Yellow Potato Sets}

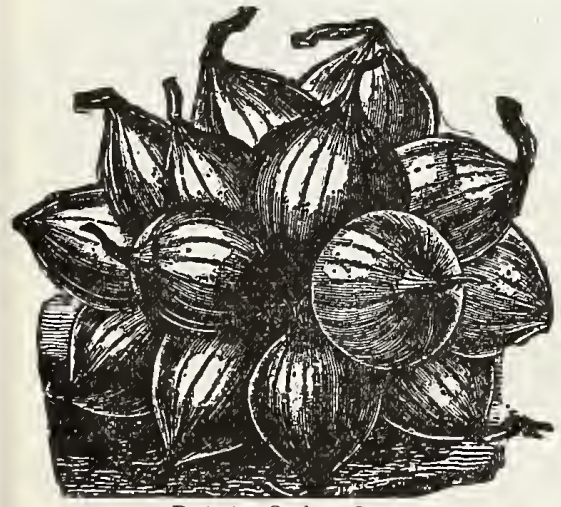

Of rich straw yelow color, of ten producing 20 bulbs in a cluster from a single bulb planted. of excellent qualbunching green: can be ripened for use as pickling Onions for this latter purpose can be more economi-
cally grown than from seed. Keep for a year. The mos t important quality is earliness ma $\mathrm{k} \mathrm{k} \mathrm{t}^{\text {t }}$ severa! weeks ahead of the Potato Ociou Set rest. Postpade

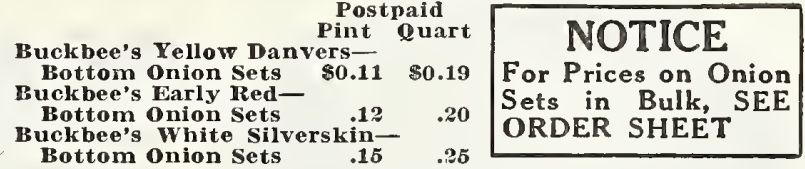

\section{Yellow Multipliers or Shallots Sets}

Multiplier Onion Sets multiply by division of the parent bulb and are not grown from seed. You will be pleased with results by planting this variety. Postpaid, pt. 20c; qt. 35c.

\section{Winter Onion Sets}

Egyptian or Perennial Tree Winter Sets-This variety never forms a large bulb. Its value lies wholly in its special adaptability to produce green Onions for Spring or Fall uses. It is perfectly hardy and when once set out will come up year after year. Can be planted either in the Spring or Fall. We can supply these September 1 st to the following March 1st. This variety increases by producing sets at the top of the stalk and Postpaid, pt. 18c; qt. 30c.

SPECIAL
NOTICE
Prices on onion
Sets in Bulk fre-
quently change
as the market
advances or de-
clines See order
Sheet for prices
by p o o or
bushel oz goore.

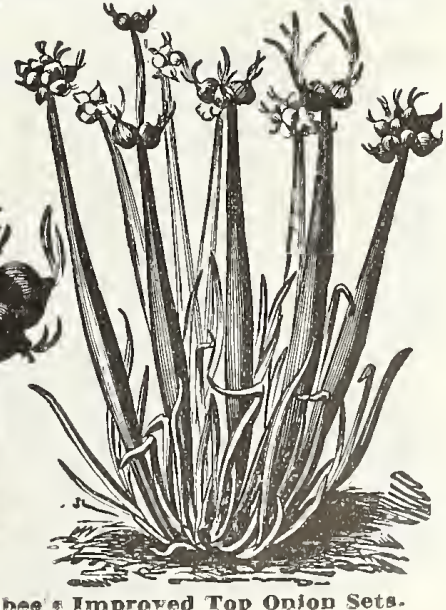




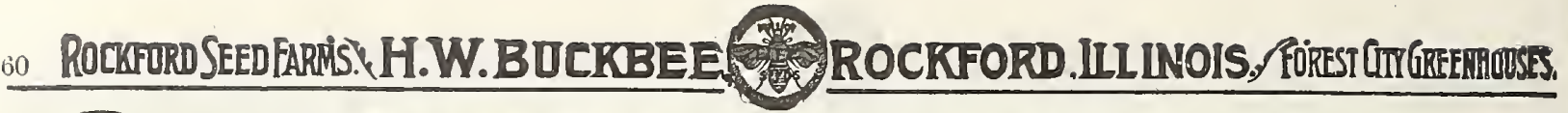

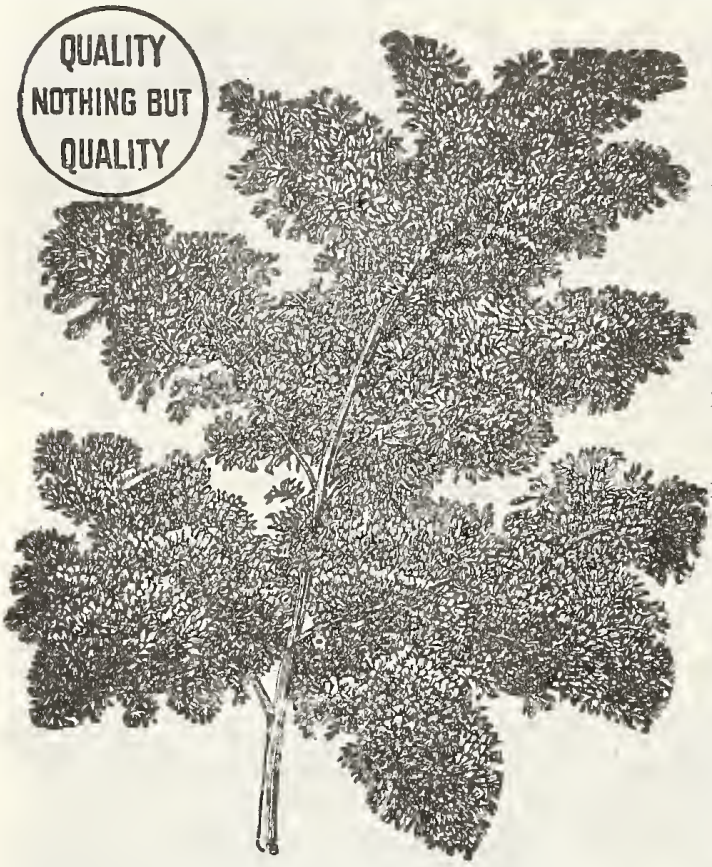

DaISLCJ $\begin{aligned} & \text { is used for seasoning soups and stews, for salads, } \\ & \text { the flower garden. }\end{aligned}$ German, PETERSILIE; French, PERSLL; Spanish, PERICIL; Swed ish, PERSALIA.

BUCKBEE'S BEAUTY - A distinct and handsome variety of quick, robust growth forming compact, ornamental plants, densely furnished with strongstemmed graceful leaves, finely cut, most beautifully curled, and of that brilliant emerald-green color so highly attractive when used for garnishing. The flavor of the leaves is also unusually rich and aromatic, rendering this variet

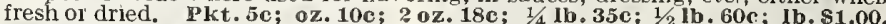
NEW MOSS CURLED - Inv aluable as a garnishing plant, and suited for mixing with dwarf, ornamental foliage plants in the garden. Pkt. 4c; oz. 10c; oz. 18c; $1 / 4 \mathrm{lb}$. 30c: $1 / 2 \mathrm{lb}$. 50c; lb. 90c.

EXTRA DWARF CURLED, OR EMERALD-The moss-like leaves are a handsome, bright green color, and are finely crimped and curled pkt. 3c: OZ. $8 \mathrm{c}$; 2 oz. 15e; $1 / 4 \mathrm{lb}$. 25c; $1 / 2 \mathrm{lb} .40 \mathrm{c} ; 1 \mathrm{~b} .75 \mathrm{c}$.

Extra Curled or Emerald Parsley

\section{A MOST
MAUABLE \\ How to Grow Seeds and Flowers \\ A complete guide for the house and garden, profusely illustrated. \\ Price 50c, postpaid, or we will send a copy FREE
order of $\$ 1.50$ or upwards, if requested on the order.}

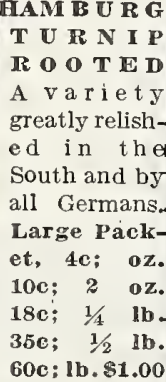

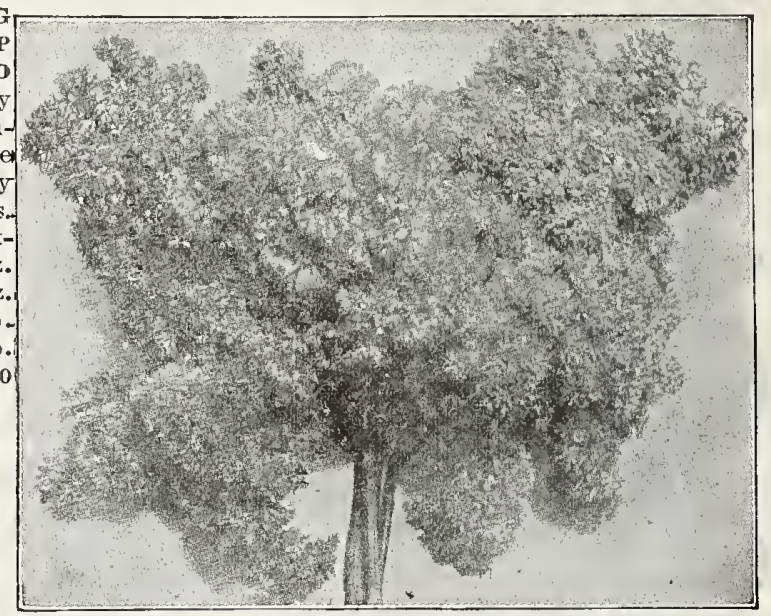

Buckbee's Beauty Parsley.

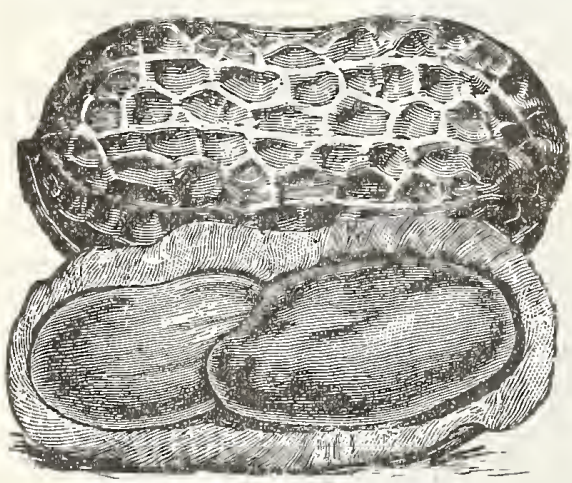

New Dixie Giant Peanut,

New Dixie Giant Peanut

Mammoth Nuts, Strong, Thick Shell. This is the JUMBO of the Peanut family and owing to the very large size and handsome appearance are very desirable in every market at fancy prices. Plants grow about 18 inches high with heavy erect stalks and large leaves and fruits near the tap root, and can be planted close togethcr, thus producing a large yield, and is more easily cultivated than the running varieties. The pods fill out well, forming few if any pops. lb. 45 c.

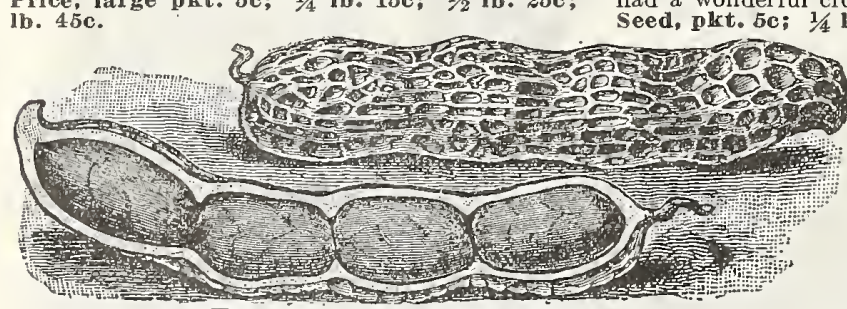

Early Long Pod Busb Peanut.

\section{PEANUTS}

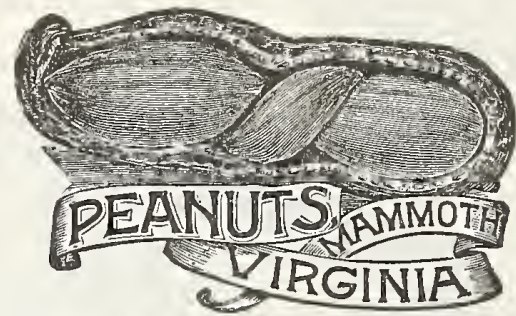

New Mammoth Virginia

Universal and Standard Favorite.

The Mammoth Virginia Peanut is the most profitable variety to grow, and is more desirable than the common spreading kind, because more easily cultivated; very erect stems and upright vines make valuable forage for stock pods; the in April and they will ripen before September. even as far North as Canada Hundreds of our ve written us that they have had a wonderful crop the past season. Choice Seed, pkt. 5c; $1 / 4$ lb. 10c; 1/2 lb. 15c; Ib. 25c.

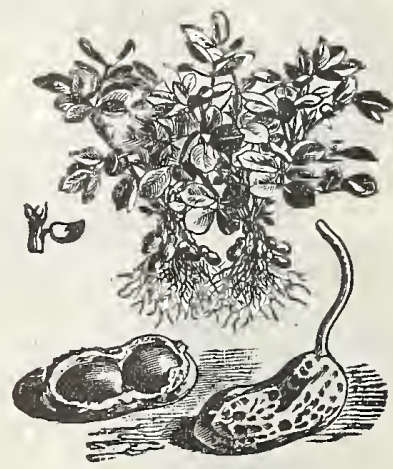

Spanish Peanut.

Spanish Peanut

A Splendid Early Variety.

The earliest variety grown: pods are small but remarkably solid and well filled with nuts of very fine quality. The yield per acre is very large. Can be cultivated with the plow. Because of their early habit and easy cultivation, it is the best variety to grow for fattening hogs. Pkt. 5c: $1 / 4$ lb. 12c; $1 / 2$ lb. 18c; lb. 30c.

\section{Early Long Pod Bush Peanut}

Originated by one of the best peanut growers in the South, and is certainly a distinct improvement in appearance over any Southern variety now in use. Will do well on most all kinds of soil, and fill out better than any other large variety. Can be pulled up with the vine same as the old Spanish peanuts. The distinct long pods grow close and are well filled, containing 3 to 4 nuts to each pod. Very productive and of a mild, sweet favor. PLt. 8c: 1/4 lb, 18c: 1/3 lb, 30c: lb. 50c, postpaid. 


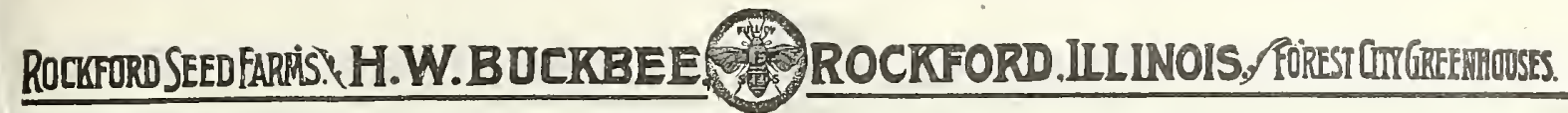

61

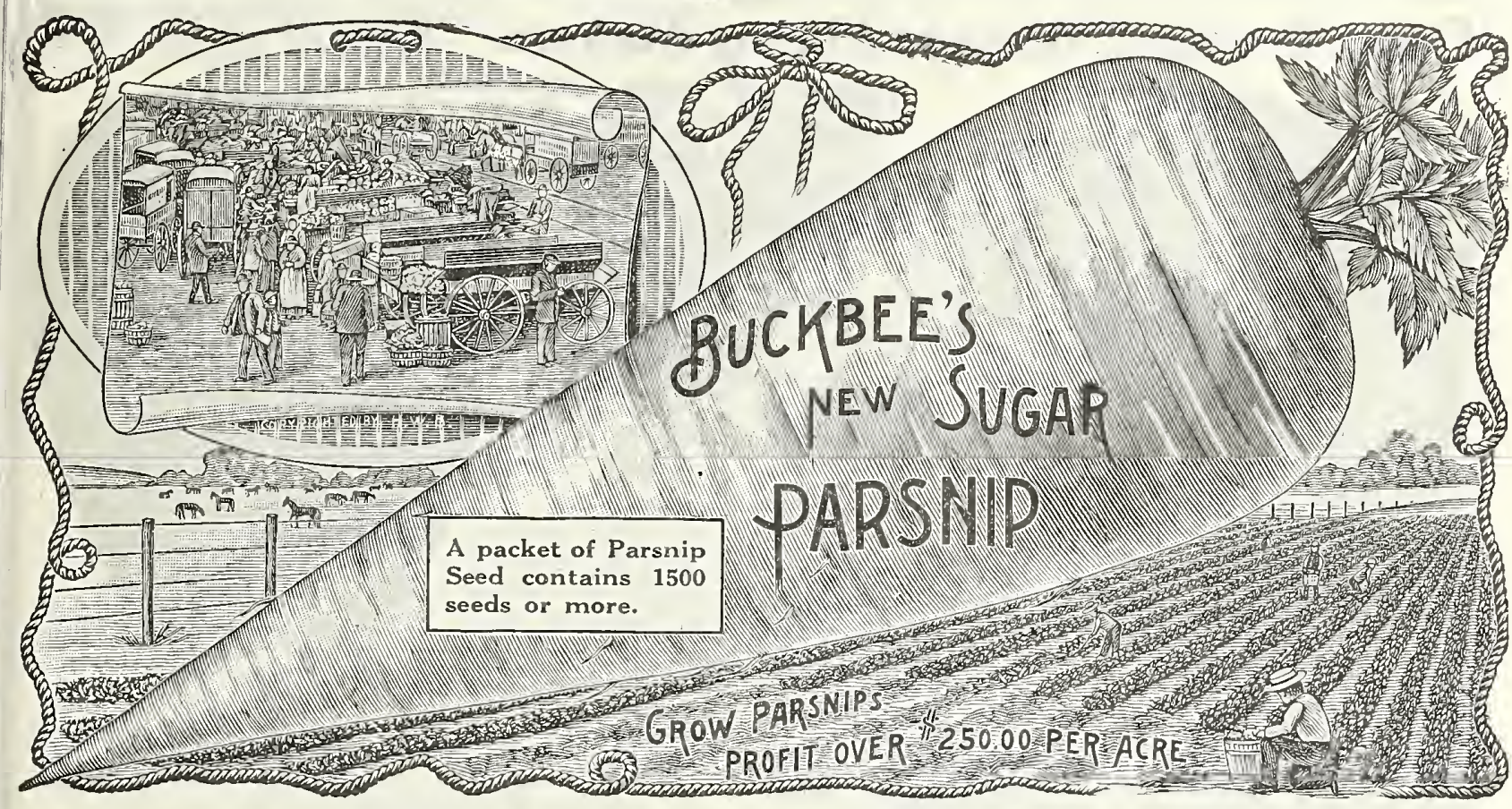

\section{PARSNIPS}

German, PASTINA KE; French, PANAIS; Spanish, PASTINACA; Swedish, PALSTERNUCKA.

PARSNIPS are one of the few winter vegetables. The roots are perfectly hardy and are improved in flavor by the action of the frost. Roots can be dug during thaws in winter or very early in spring, when a change of food is most relished. highly appreciated for the table, the great value of the parsnip for stock feeding is but little known. The roots are very rich in saccharine food, adding to the richness of the milk when freshly dug and fed to cows.

BUCKBE E'S NEW SUGAR-After repeated trials at Rockford Seed Farms, have no hesitancy in offering this splendid Parsnip as the best variety grown. Roots fine size, of good diameter, enabling them to be easily gathered are
ceedingly smooth, the flesh fine grained and of the most excellent quality magnificent cropper, yielding as high as 750 bushels per acre under good cultivation. You will not be disappointed by planting Buckbee's New Sugar Parsnip. Pkt. 5c; oz. 10c; 2 oz. 18c; $1 / 4$ lb. 35e; 1/2 lb. 60c; $1 \mathrm{~b} . \$ 1.00$

NEW MALTESE-A wonderfully fine strain. The roots do not grow as long as the Hollow Crown, but are of greater diameter and more easily gathered; ver:y
heavy cropper. Flesh fine grained and of most excellcnt quality, Pkt. 4e; oz. 8c; 2 oz. $15 \mathrm{c} ; 1 / 4 \mathrm{lb} .25 \mathrm{c} ; 1 / 2 \mathrm{lb} .40 \mathrm{c} ; \mathbf{l b}, \mathbf{7 5 c}$.

IMPROVED HOLLOW CROWN OR LONG WHITE-Roots comparatively short, ending somewhat abruptly with a small tap root; grows mostly below the
surface: has a verv smooth, clean skin. Pkt. 3c; oz. 7c; 2 oz. 12c; 1/1b. 18c; $1 / 2$ lb. 34c; lb. $60 \mathrm{c}$.

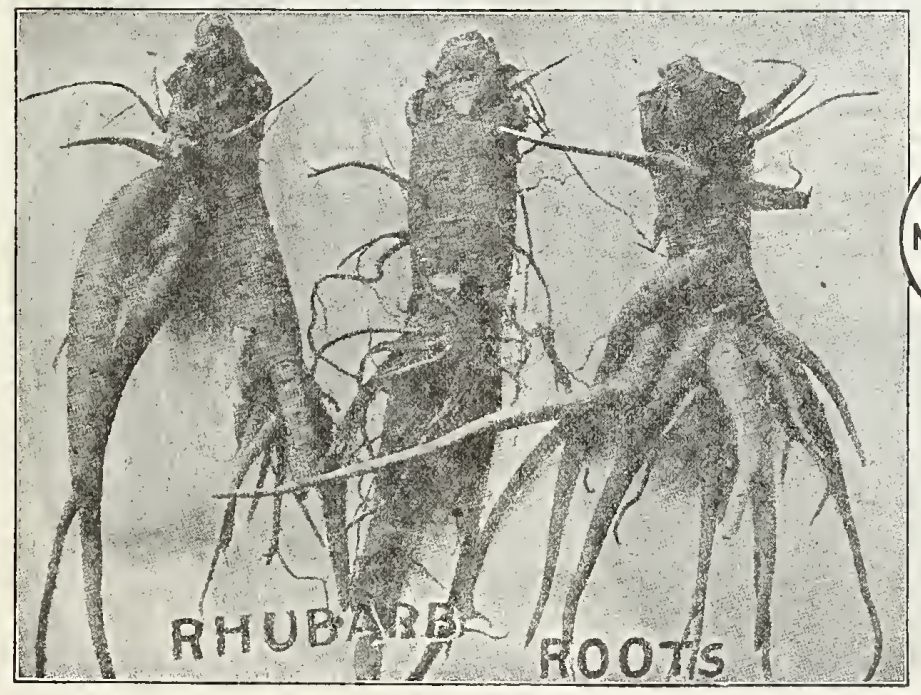

\section{PIE PLANT OR RHUBARB}

German, RHUBARBER; French, RHUBARBE;

Spanish, BASARDO; Swedish, RABARBER.

BUCKBEE'S NEW PINEAPPLE-Without doubt thi

is the earliest of all Pie Plant and a variety that can

be used not only in the early Spring but Summer as ties. Quality simply superb. Stalks of good size soft and watery. Skin so thin and tender that it is not necessary to remove it before cooking. Flavor sprightly and refreshing and has the true Pineapple
flavor. Choieest "Full of Life" Seed. Large pkt. $10 \mathrm{c} ; 0 \mathrm{z} .15 \mathrm{c} ; 2 \mathrm{oz} .25 \mathrm{c} ; 1 / 41 \mathrm{~b} .45 \mathrm{e} ; 1 / 2 \mathrm{lb} .80 \mathrm{c} ; 1 \mathrm{~b}$ \$1.50.

BUCKBEE'S WESTERN MARKET-Finest variety, very productive. Fine, large size and very early. Has a flavor similar to the Gooseberry. This is without

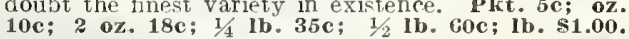

PIE PLANT OR RHUBARB ROOTS

A saving of from two to three years is made by planting

IBUCKBEE'S NEW PINEAPPLE-Price by mail, postpaid, 25e caeh; \$2.50 per doz. By Express or Freight, not prepaid, $20 \mathrm{e}$ eaeh; $\$ 2.00$ per doz.; BUCKBEF'S WES'TERN MARKET-Price by mail, postpaid, 15c eaeh; $\$ 1.50$ per doz. By Express or Freight not prepaid, 10e each; 90c per doz.; \$5.00

DATL 100 THUBRE ROOTS-10c each: $\$ 1.00 \mathrm{doz}$, postpaid.
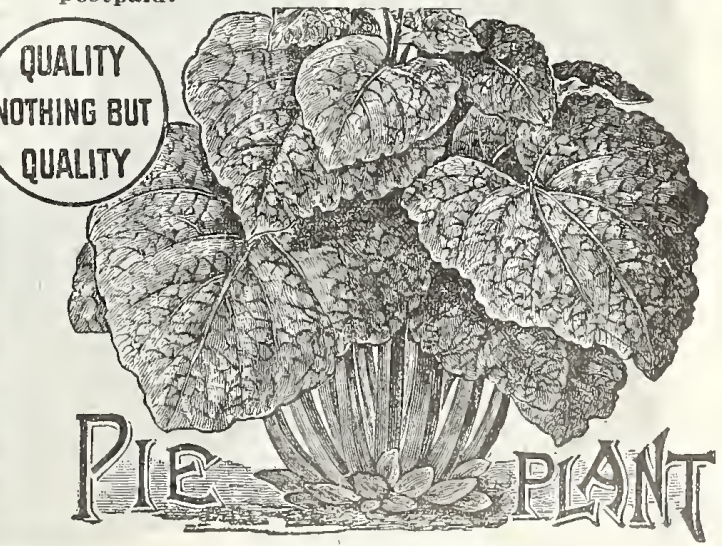

Buckbee?s New Gupeannls 


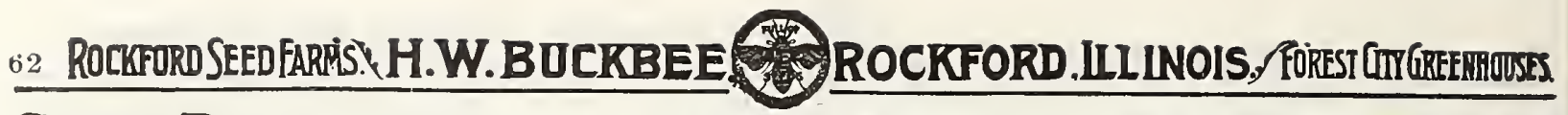
Grow Peppers, Always Money-Makers

German, PFEFFER; French, PIMENT.

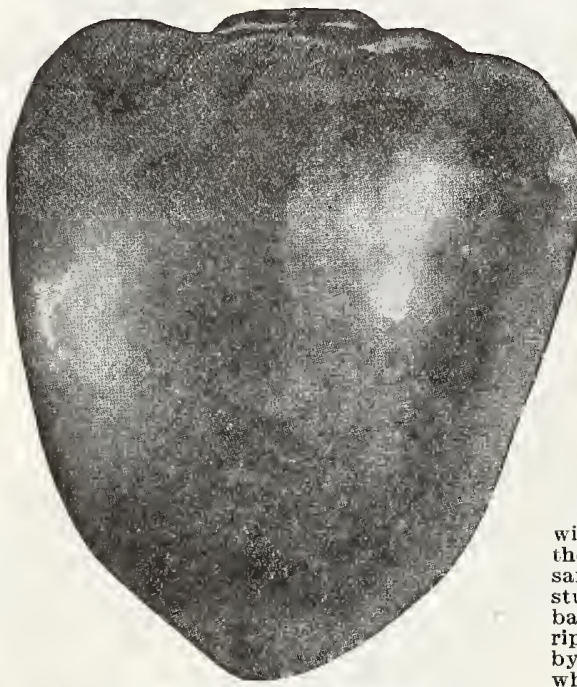

New Pimiento Pepper.

BUCKBEE'S GREAT WEST-The giant of all. The heaviest cropper. The mildest flavor, The finest appearing. The surest to grow. The one you can't do without. Beautiful red color and of mild flavor. Our stock is limited, so order ear

CHINESE GIANT-Double the size of Ruby King and equally as mild. The compact plants produce four or more extra large Peppers at the base very early in the season, which ripen while a second crop is setting on the branches. Very valuable variety for either the home or market garden. Pkt. 5c; $1 / 2$ oz. $20 \mathrm{c} ; \mathrm{oz}$. 35c; 2 oz. 60c: $1 / 1$ lb. $95 \mathrm{c}$.

CORAL GEUI BOUQUET-Plant tail, bearing a profusion of round, bríght red fruit which is very pungent when ripe. Plant very ornamental Pkt 5e: oz, 30c: 20 , 50c; 1/ lb, 90c.

SWEET MOUNTAIN-Plants very vigorous and productive. Fruit large, long, very smooth and handsome, being, when green, of a bright, deep green color, entirely free from any purple tinge. and when mature of a rich red. Flesh very thick, sweet and mild flavored. Pkt. 4c; oz. 18c; 2 oz. 30e; 1/1b. 50c.
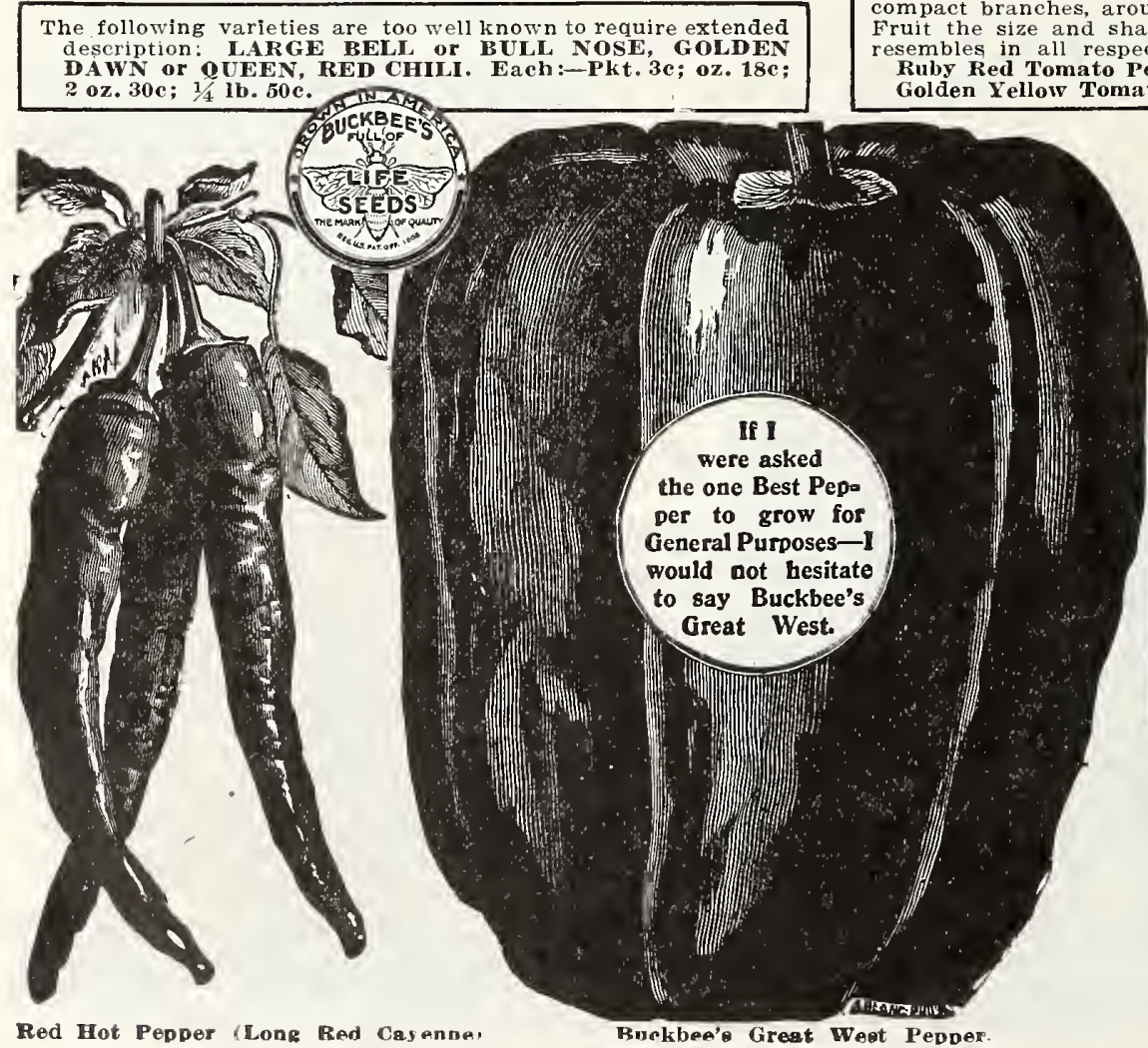

Red Hot Pepper (Long Red Cayenne,

Buckbea's Great Weat Peoper. NEAPOLITAN-Mild flave
A Packet of Pepper Seed Contains

from 300 to 500 Seeds.

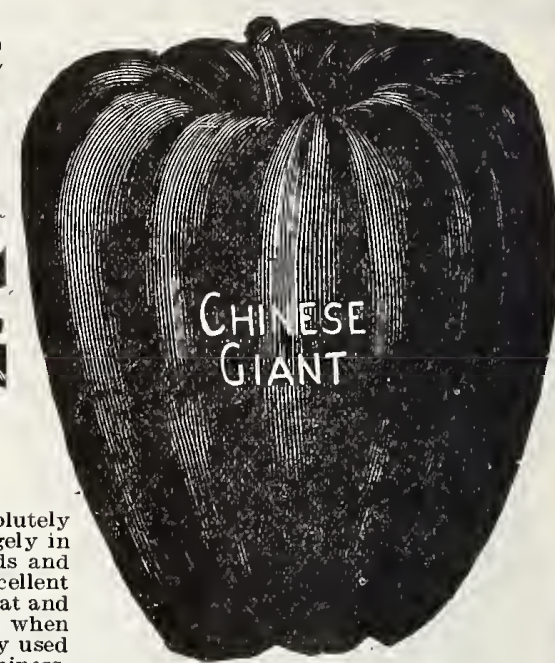

A Most Popular Pepper.

IMPROVED RUBY KING-An improved American sort, reaching the largest size, yet retaining the symmetrical shape of the mild flavored and one of the best for stuffed pickles or mangoes. Pkt. 4c; oz. 20e; 2 oz. $35 \mathrm{c} ; 1 / 4$ lb. $60 \mathrm{c}$.

THE RED IIOT PEPPER (Long Red Cayenne)-A long, sllmpointed pod, and when ripe of a bright red color Strong and pungent. Pkt. 4c; oz. 20c; 2 oz. 35e; 1/4 Ib. 60c.
EAPOLITAN-Mild flavor. Bright red color. Pkt. 5c; oz. 25e;

FINEST MIIED PEPPERS-The above and many other valuable Peppers in choice mixture. Plkt. 5c; oz. 25e; 2 oz. 40c; $1 / 4$

\section{Buckbee's New Tomato Pepper \\ This unique Pepper is new, true and distinct and entirely novel. Plants grow only one foot high, with a few short compact branches, around which the fruits are compactly set. Fruit the size and shape of a small tomato which it olosely resembles in all respects. We offer the two best varieties: Ruby Red Tomato Pepper-Pkt. 8c. \\ Golden Yellow Tomato Pepper-Pkt. 8c.}

\section{For Pepper Plants} Please See Page 84.

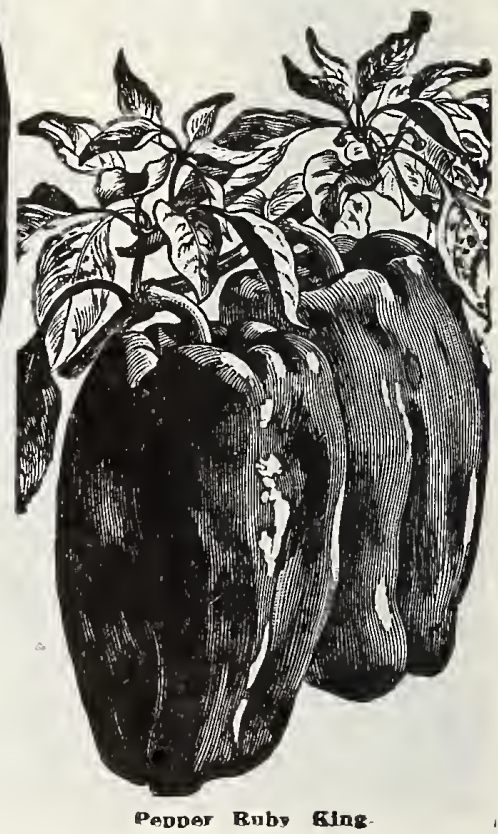




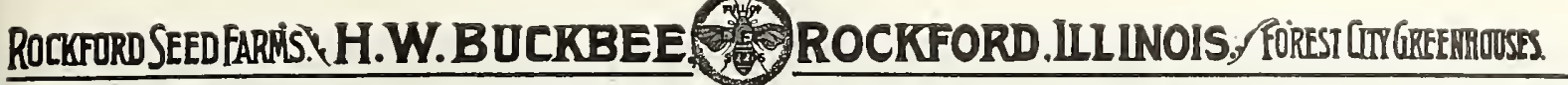 \\ 63 \\ BUCKBEE'S “FULL OF LIFE" PEAS}

German, ERBSE; French, POIS; Spanish, GUIZANTE; Swedish, ARTE.

CHOICEST EXTRA EARLY ROUND SMOOTH PEAS

\section{Buckbee's Lightning Express} EARLIEST PEA IN THE WORLD READY FOR PICKING IN 40 DAYS

They are much hardier, more productive and withstand greater changes in the weather than any other variety. They are not only the largest podded white seeded early, but they are

ENTIRELY FREE FROM RUNNERS and the Entire Crop Can Be Taken Off in Two Pickings 10,000 BUSHELS SOLD ANNUALLY

Where earliness, productiveness, largc-sized pods and sweetness of flavor are desired, this is the variety to grow; it may Peas, and stands at the head for the above flne qualities; in entire crop can be taken off in two pickings.

To the market gardener, earliness is of the greatest importance as even a few days make a great difference in price often a depreciation of from $\$ 2.00$ to $\$ 4.00$ per barrel; the inexperienced find this out when too is what is required, and BUCKBEE's You WILL MAKE YO MISTAKE. Please observe that the true stock of BUCKBEE'S LIGHTNING EXPRESS can be had through our house only. Postpaid, pkt. 8c; $1 / 2$ pt. 15e; pt. 22e; qt. $35 \mathrm{c}$.

\section{Extra Early Philadelphia}

\section{Standard Early White Seeded Splendid Quality.}

very valuable and improved strain, exceedingly productive, pods always well filled, ready for table use in 45 days. Grows well two feet for market gardeners and family use. Postpaid, pkt. 6c; $1 / 2$ pt. 10c; pt. 18c; qt. 30e.

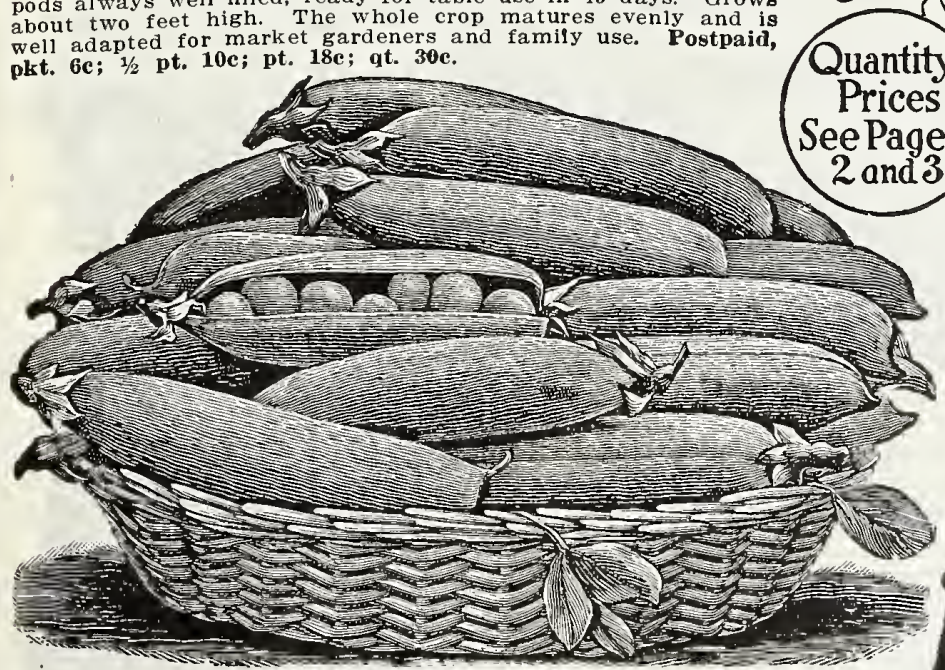

New Bountiful Pea.

Bountiful

A Grand New Mammoth Podded Extra Early Pea

The largest podded of all green seeded Extra Early Peas. In our trials the past season none of the numerous Extra Earlies compared with Bountiful in size of pod, number of Peas in a pod, or number of pods to the vine. It is also one of the sweetest and flnest flavored of the blue round Buckbee's Extra Early Tom Thumb or Strawberry

Universal Standard, Early, Dwarf, Sweet Flavored,

An extremely early variety of superior merit. Vines dwarf about 9 inches high, completely covered with an abundance of the finest well-filled It is of such upright growth that it can be planted in rows 10

\section{Buckbee's Selected First and Best}

\section{Mammoth Podded Extra Early.}

This is the earliest and most even stock of White Extra Early Peas in existence, maturing so well together that a single picking will seeure the bearing three to seven strafght pods having five to seven medium sized, smooth Peas of good quality. Postods, pkt. 6c; i/2 pt. Foc; pt. 18c; qt. 30c.

\section{Earliest of All or Alaska}

\section{Aur improved extra selected strain is verr pure and} well developed and is more largely planted by Market Gardeners and Large Pea Shippers than any other variety.

this careful selection we have developed a stock of this smooth, green seeded Pea, which in tevenness on (by any ather extra ( riety for market gardeners and canners. Postoaid, pkt. 6c; $1 / 2$ pt. 10c; pt. 18c; qt. 30c.

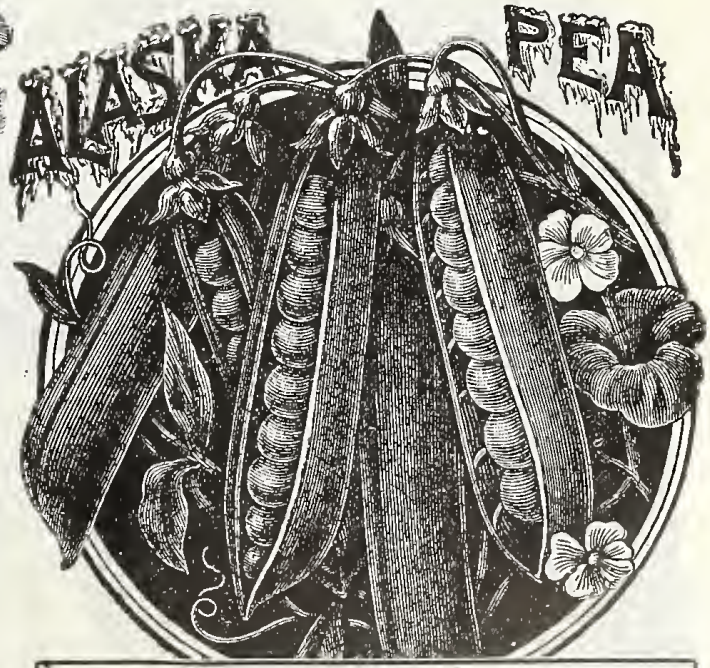

An Acre or Two in Buckbee's Pedigreed Full of Life Northern Grown Peas will bring
High Cost of Living. 


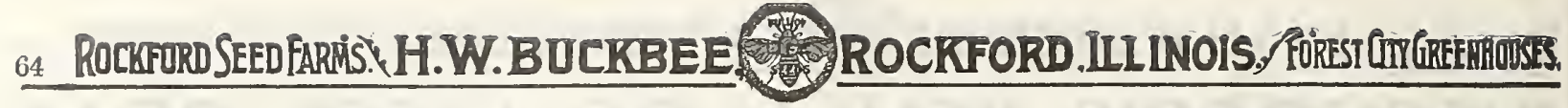
BUCKBEE'S "FULL OF LIFE" PEAS

Choicest Extra Early Sweet Wrinkled Varieties

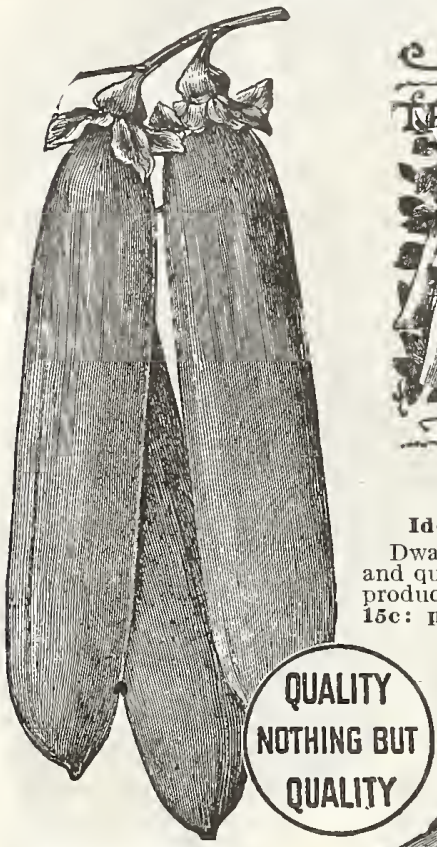

Nott's Excelsior Pca.
Nott's Excelsior Best Early Dwarf The vines are
Larger and Miore Larger and More
Vigorous than Vigorous than And Earlier and More Prolific than Premium Gem. The and quality are unsurpassed. Postpoc;pt. 25c; qt. $40 c$.

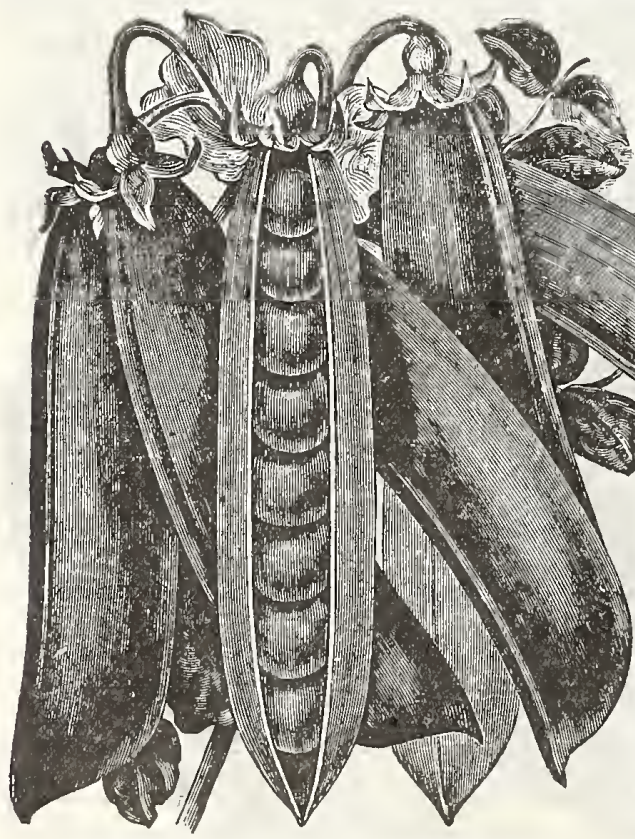

Buckbee's New Extra Early Honey Sweet c: pt. 25e; qt. 400 .

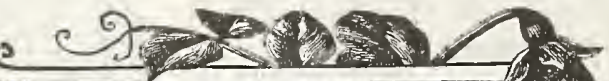

IRUEATERIAAN WONDER:

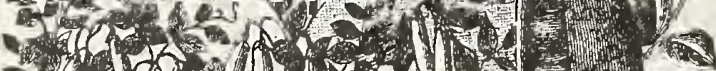

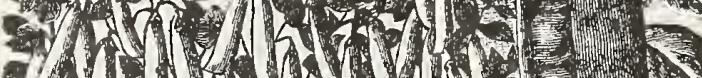

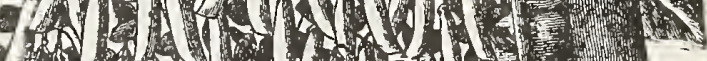

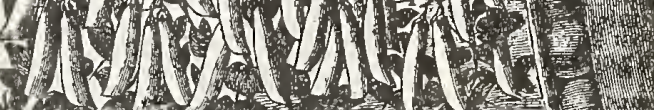

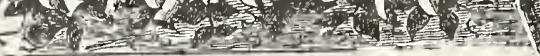

True American Wonder Ideal Early Variety and Famous 'Table Favorite.

warf-wrinkled Pea, esteemed for earliness, productiveness, flavor quality. Strong and robust, growing about ten inches high, and
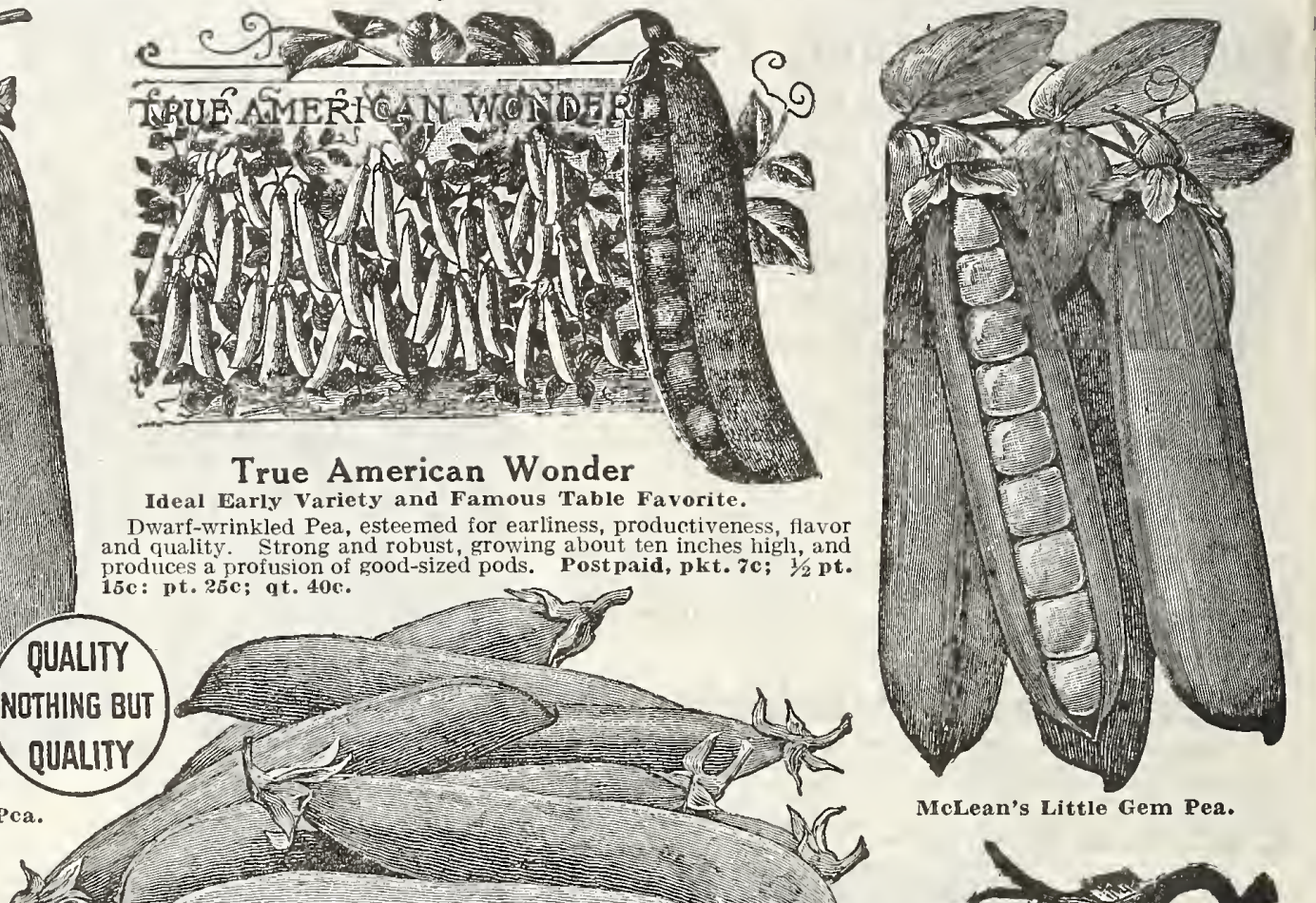

McLean's Little Gem Pea.

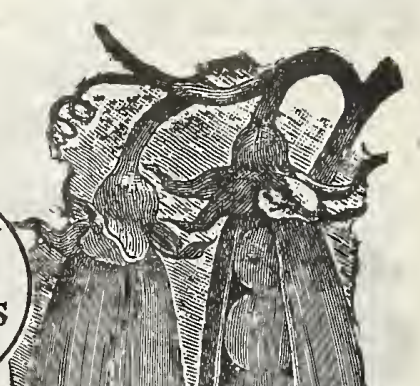

Sutton's Excelsior Pea.

McLean's Improved Little Gem Remarkably Fine Early Vines grow about eighteen inches high, and
are covered with long, well-flled pods, sweet $1 / 2$ pt. 12c; pt.20c; qt.35c.

Buckbee's New Extra Early Honey Sweet

The Earliest Wrinkled Sweet Flavored Pea in Existence. READY FOR PICKING IN FORTY DAYS

1 and a splendid drought resister. quire sticking. Prodiga long, nearly round, and are always well filled. Postpaid, pkt. 8c; $1 / 2$ pt. 15c; pt. $25 \mathrm{c}$;

New Early Gradus or Prosperity This Popular New Large Podded Wrinkled Pea of Finest Quality matures Pods only two or tliree Days later than the Grows three feet high. Produces uniformly large
pods. four to four and a half inches in length, nearly round, and well filled with very large hand some Peas of the finest flavor. The Peas remain Gradus or Prosperity tender and sweet for some time after they are large enough to use. Postpaid, pkt. Sutton's Excelsior Pods are larger and broader than the usual dwarf Peas, are Inches high Postpaid square at the ends and are light green in color. Eighteen 


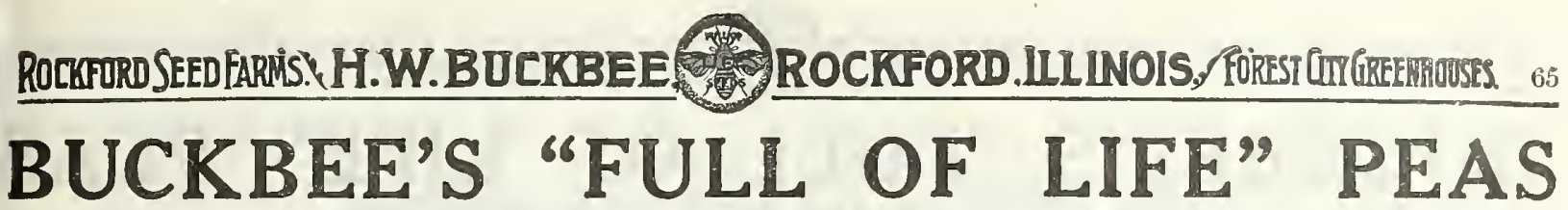
Medium Early or Main Crop Sweet Wrinkled Varieties

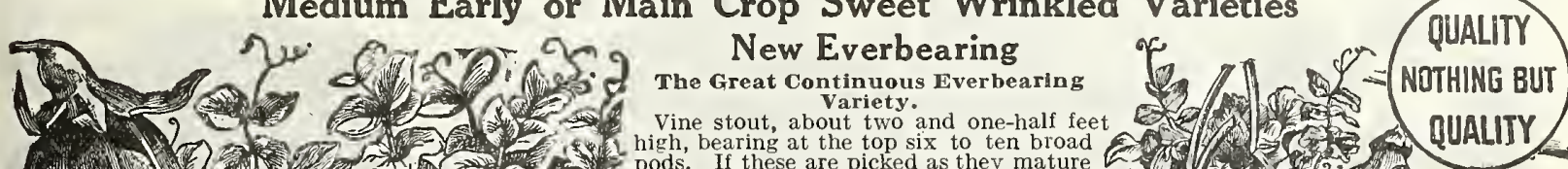

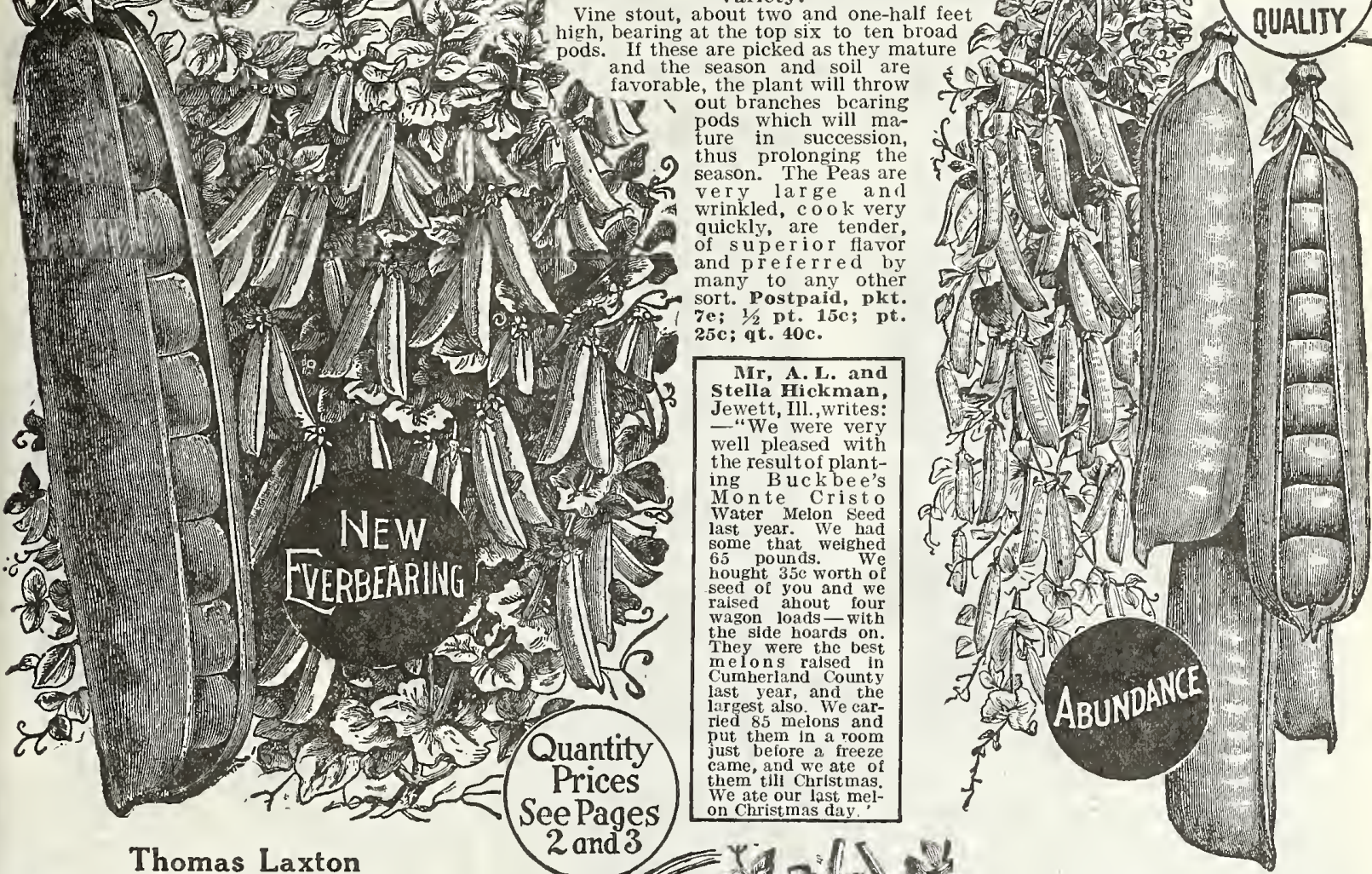

The Newest Introduction in Extra Large Podded Sweet Wrinkied Peas.

The only rival to the Famous Gradus

Peas-as a

growth is identical but the pods are a deeper richer green and square at the end. In the opinion of some experts, Thomas Laxton is even sweeter deeper green they present a more attractive apto four days after Gradus. Postpaia, pkt. 8c; $1 / 2$ pt. $15 \mathrm{c} ; \mathrm{pt}$. 25c; qt. $45 \mathrm{c}$

\section{Alderman}

The Very Best Second Early Main Crop Thisiety Variety the very best early main crop variety of the valuable Telephone type. The vines grow nearly five feet high, are dark green, vigorous and exceed-
ingly productive. Pods very large, long, dark green, similar to Duke of Albany and about the same in season. The Peas are of largest size and unsurpassed in quality. Market gardeners are demandretain their fine appearance even after shipping a long distance. The Alderman answers these requirements and firthermore is the most producservedly. Postpaid, pkt. 7c; $1 / 2$ pt.15c; pt. $25 \mathrm{c}$; qt. 40c.

\section{Abundance}

The Name Tells the Whole Story, Recognized Favorite for Home Consumption and Market Purposes.

A wonderfully productive sweet wrinkled Pea of exceptionally fine quality coming into market about one week later than the Extra Early varieties. Produces very thrifty vines about 24 inches increasing the yield many fold above the a Pods form in clusters mal and are completely filled with from 6 to 8 large delicious Peas. Send to Buckbee for the Genuine Stock Seed. Postpaid, pkt. 6c; $1 / 2$ pt. 12c; pt. 20c: qt.35c.
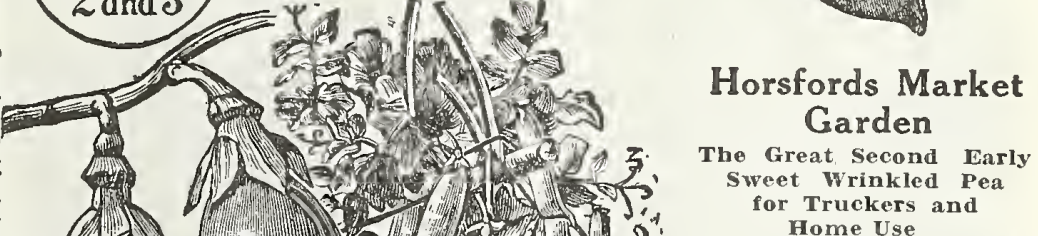

Horsfords Market Garden

Home Use

A frrst-class wrinkled Pea: inches; no sticks. It is a gardeners, as a single plant has been known to produce more than 150 pods. It is equally good for the home pods are borne in pairs, and are easily and quickly picked. yielded more shelled Peas the acre than any other pkt. $6 \mathrm{c} ; 1 / 2$ pt. 10c; pt. 18c; qt. $35 \mathrm{c}$.

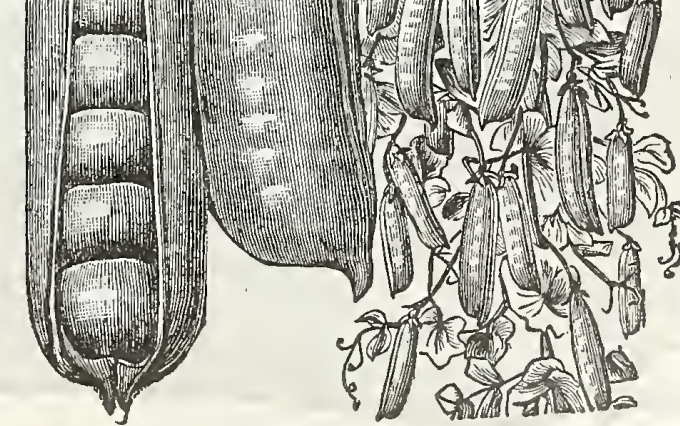

Daisy or Dwarf Telephone

Thorobred Main Crop Rich Flavored

Wrinkled Pea. 


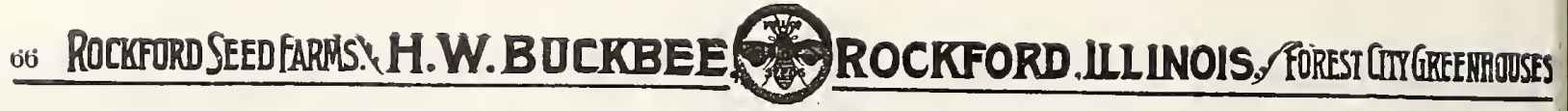
BUCKBEE'S "FULL OF LIFE" PEAS
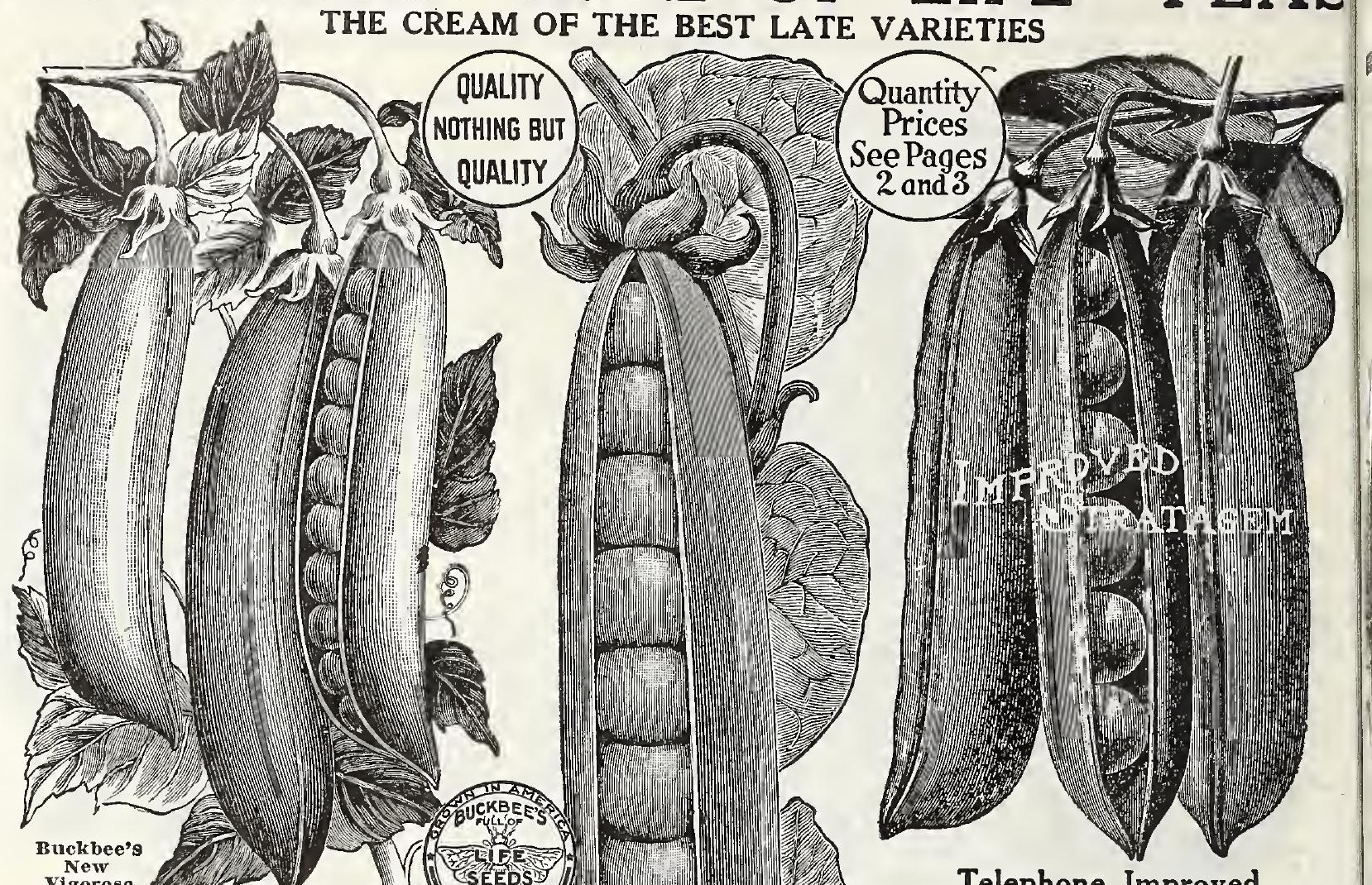

Telephone Improved

Buckbee's New Vigorosa . . The Most Valuable Late Sweet Wrinkled Pea.
The Telephone has become the leading Pea with market gardeners whose trade appreciate fine appearance and high quality. Vines vigorous, growof very large pods filled with immense Peas, which are tender, sweet and of excellent flavor. Postpaid, pkt. 6c; $1 / 2$ pt. 15c; pt. 25c; qt. 40c.
Buckbee's New Mammoth Melting Sugar Buckbee's New Mammoth Melting Sugar This new variety is far superior to all other edible Podded Peas not only in size of pods, but also in delicious quality. They are used in the same but the pod and Peas all being eaten. Peas are very large, sweet, smooth, extremely tender, so brittle that they snap, absolutely without any tall, reaching a height of five or six feet and do much better if supported. Postpaid, large packet 8c; $1 / 2$ pt. 15c; pt. 25c; qt. 40c.

\section{Large White Marrowfat}

Cultivated extensively for the Summer crop. About 5 feet high, of strong growth. Postpaid. pkt. 5c; $1 / 2$ pt. 8c; pt. 15c; qt. 28c.

Large Black Eyed Marrowfat which never become as hard as most sorts. The Peas are of fine quality. Postpaid, pkt. 5c; $1 / 2$ pt. 100: pt. 18c; qt. 35c.

Christ Johnsen, Bax 4, St.Louis Park, Minn., writes: "I shipment of 'Full of Life' Seeds and Bulbs which I thank you Arthur Young, 954 Superior St., Racine, Wis., Writes: "You will note this is 'Full of Life' mushroom spawn. The frst order of spawn
has been planted two weeks yesterday, and the last few days tew."

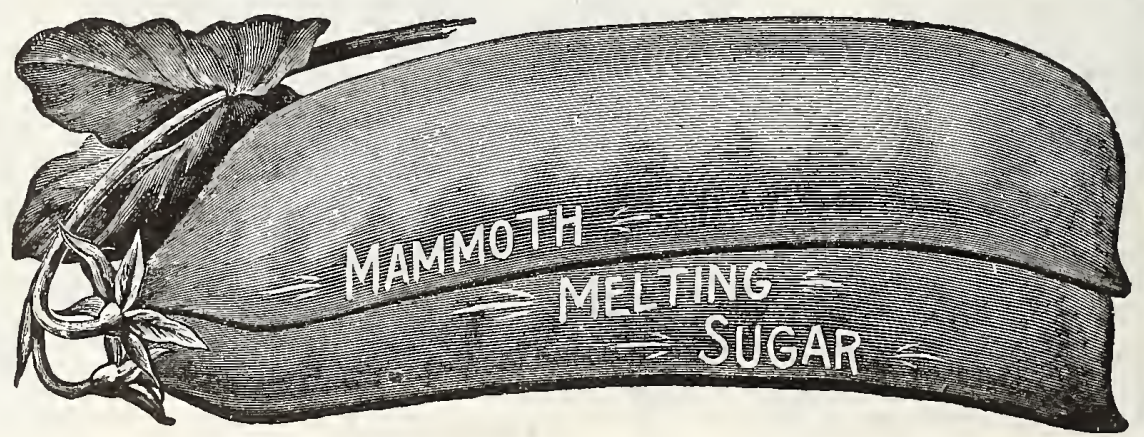

\begin{tabular}{|l|}
\hline A MOST \\
VALUABLE \\
BOOK \\
How to Grow \\
Flowers and \\
Seeds \\
It tells the \\
whole story in \\
a p r a ctic a \\
way. P r i ce \\
only 50c, or \\
FREE with an \\
order for $\$ 1.50$ \\
or upwards, if \\
requested on \\
the order.
\end{tabular}




\section{BUCKBEE'S "Full of Life" PEAS} THE CREAM OF THE BEST LATE VARIETIES

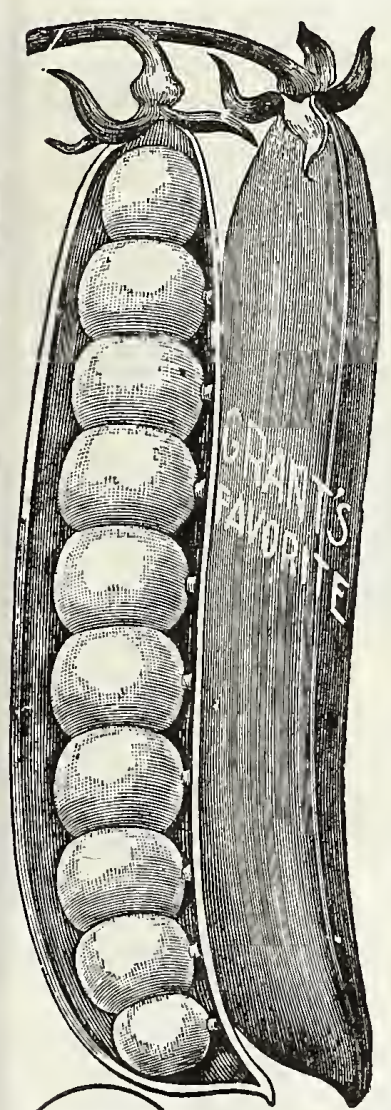

Buckbee's Mammoth Podded Sugar Marrowfat

A Very Superior Variety for General or Late Crop-The Pure Cream of Late Peas.

Here is a Pea par excellence for the home gardener-and a highly profitable shipping variety for the professional Pea Growers. For delicious ary flavor this wonderful Pea surpasses them all. Extremely prolific out yielding any known sort. Pod are 5 to 6 inches long and the photohow completely they are filled with superlative quality Peas. Vines grow about 4 feet high; should he bushed for best results, although great results are a fine crop of the choicest seed of Huckbee's Mammoth Podded Sugar Iarrowfat Peas the past season and vill put the price within the reach of all. order early. Postpaid, pkt. $7 \mathrm{c} ; 1 / 2$ pt. 12c; pt. 20c; qt. 35c.

Grant's Favorite

You Never Ate a Better Pea. This new variety of our own introducdium and late Pea ever offered, coming into use just after the early varieties into ase just after the eariant from three to four feet high The pods are of good size, and always well flled with exceptionally sweet and highly flavored Peas. It is nearly an upright grower, but will do better if staked or planted along a fence. Postpaid, pkt. 6c; $1 / 2$ pt. 15c; pt. 25c; qt. $40 \mathrm{c}$

Improved Champion of England The Standard Sweet Flavored Lato Wrinkled Pea.

Very productive and universally admitted to be one of the richest and best flavored Peas. Height four to five feet; seed light green and much shriveled. Very inferior and mixed stocks of this sort are frequently offered but when the seed is as well grown and the variety equal in quality to any in

\section{NOTHING BUT}

\section{(1)}

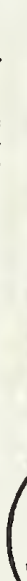

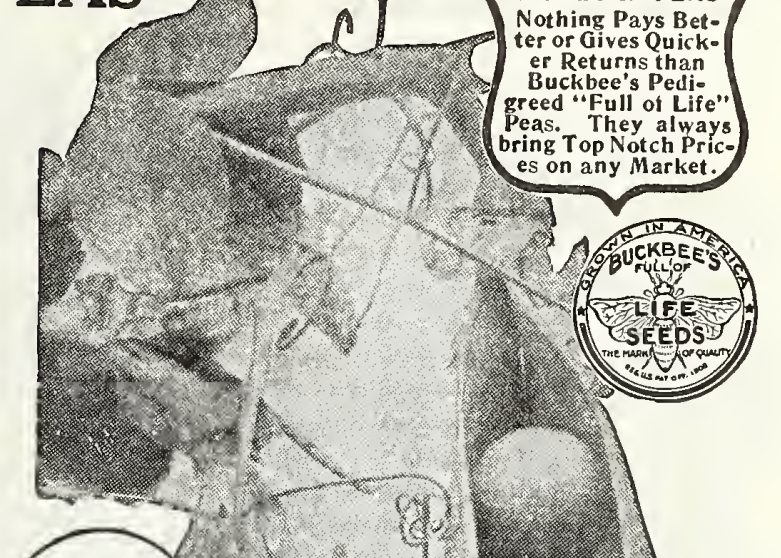

Quantity

Prices

See Pages

2 and 3

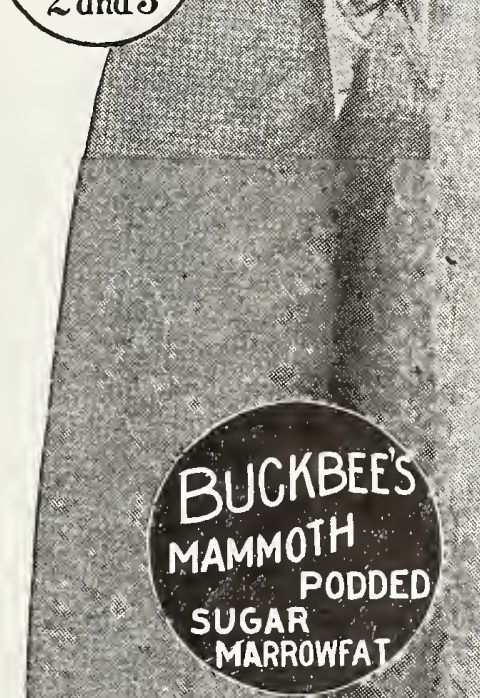




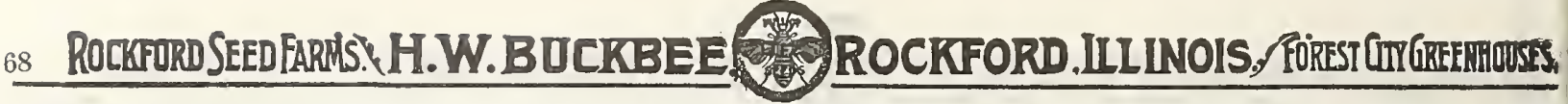

BUCKBEE'S "Full of Life" PUMPKINS

German, KUERBIS; French, CoURGE; Spanish, COLA BAZA; Swedish, PUMPA.

BUCKBEIS'S KING OF THE MAMMOTHS - Wonderfully grand and colossal variety, asmoth size and heavy weight. Think of it-a single Pumpkin weighing 469 pounds! Many of our customers saw this specimen on exhibition at the moths is always a prize winNotwithstanding its enormous and table varieties grown. splendid keeper, and exceppurpor valuable for feeding plete stock of this variety. Send to Buckbee for true stock seed. We do not save seed from 200 pounds. Plit. 10c; oz. 15c 2 oz. $25 \mathrm{c} ; 1 / 4$ lb. $40 \mathrm{c} ; 1 / 2 \quad 1 \mathrm{~b}$. BUCKBEE'S NEW SANDWICFE ISLAND-A splendid variety, coming from a remote section of the Sandwich Islands, where found furore in its markably distinct in every way, of nne size, very prolinc bearer, excellent keeper. Seed of our own growth. Pkt. 5c; oz. 15c $60 \mathrm{cz} ; \mathrm{lb}$. $\$ 1.00$.

BUCKBER'S TRUE SUGAR PIE-A particularly fine orange-colored sort, remarkably sweet, fine grained and dry. Keeps well, and cannot be 2 oz. 12c; $1 / 4$ lb. 20c; $1 / 2$ lb. 35c: Ib. $60 \mathrm{c}$.

TENNESSEE SWEET POTATO-A magnificent pear-shaped variety of fine size, a little ribbed; color with green. Has no superior for making pies and custards; When cooked it has somewhat the appearance of sweet potatoes, but of markably fine grained, dry and brittle, hardy and productive, and keeps perthe Spring $10 \mathrm{c} ; 2$ oz. 15e; $1 / 4$ lb. $25 \mathrm{c}$;

WESTERN FIELD-Sometimes called Big Tom or Connectivarieties for field purposes, varticularly desirable for stock feeding. Grows to yellow, flesh fine grained, of good flavor. Postpaid, lb. 45c. By Express or pense, 5 1bs. \$2.00: 10 lbs. \$3.50.

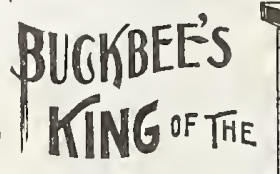

MAMMOTHS
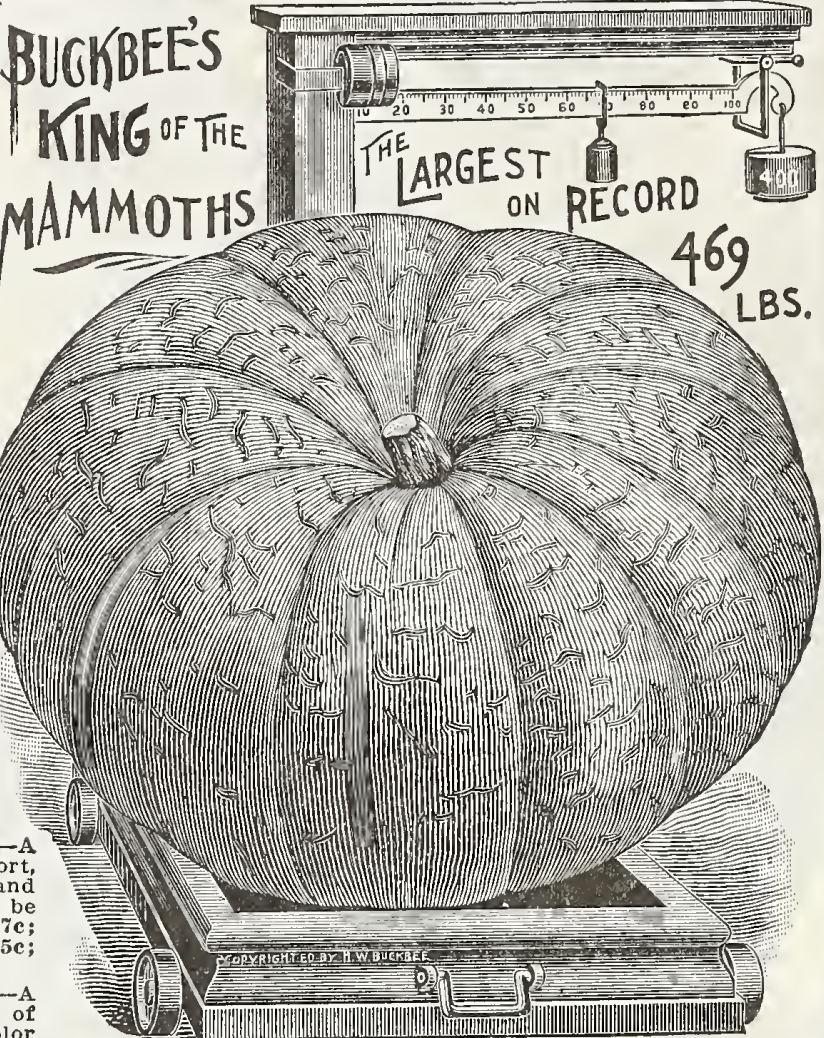

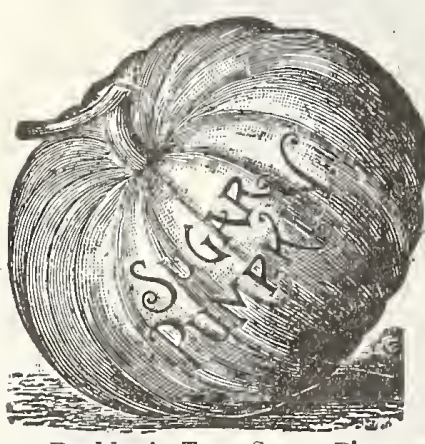

Buckbee's True Sugar Pie.
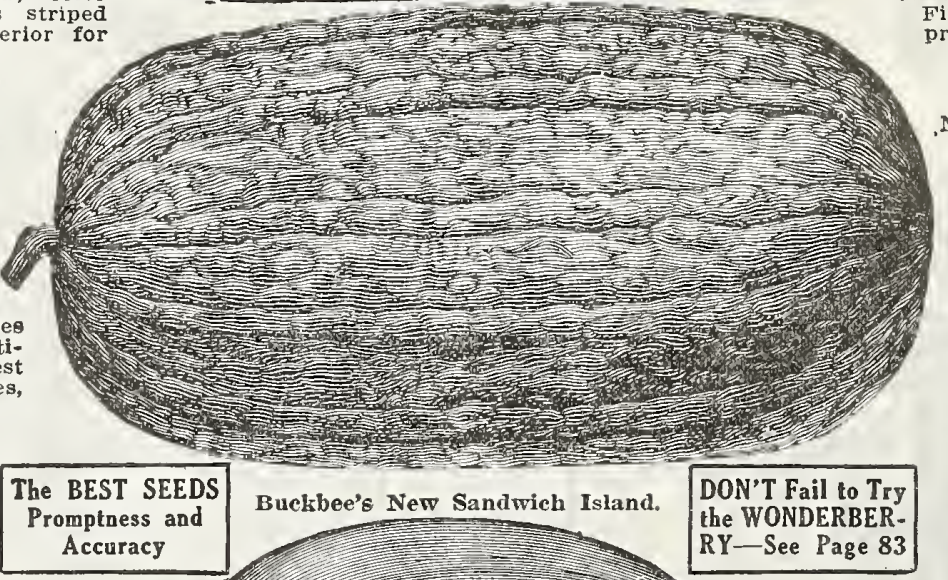

UCKREE'S PURE GOLDAcknowledged by all the best growing with corn or in fields by itself. Fxcels for feeding stock, and, best of all, makes the most delicious Pumpkin pies. Deep, rich, creamy yellow color, flesh fine grained Choice stock seed, by mail, postpaid, oz, 5e; $1 / 4$ lb. 15e; $1 / 2$ lb. 25c; lb. 40c. By ex-
press or freight at buyer's press or freight, at buyer's
expense, 5 lbs. $\$ 1.50 ; 10$ lbs. $\$ 2.75$.

CASHAW Or CROOKNECKFlesh yellow, solid and sweet. 4c; oz. 8c; 2 oz. 15c; 1/4 lb. $25 \mathrm{c} ; 1 / 2$ 1b. 40c; $1 \mathrm{~b}$. 75c.

NEIV CALHOUN-Fine variety, heavy and solid, very productive. Outside is a rich low, vit and of superior quality. Pkt. $4 c ; 0 z .8 c ; 2$ oz. 15c; $1 / 4$ lb. 25c. ARGE CHEESE-Sometimes called Kentucky Field-Flattened fruit with broad ribs; creamy buff skin; averages an excellent keeping variety, with thick flesh of exceptionally fine quality. Pkt. 3c; oz. 6c; 2 oz. 10c; 1/4 lb. 18c; QUAKER PIE-Fine grained and of rich flavor, having none of the stringy nature ties. It is early and keeps late. It is oval shaped and tapers at each end, is of out. Pkt. 4c; oz. 8c; 2 oz. $15 \mathrm{c} ; 1 / 4 \mathrm{lb} .25 \mathrm{c}$

NEW WINTER LUXURYine keeper and enormously netted an in very fincly colden russet Plt 4c; oz. $8 \mathrm{c} ; 20 \mathrm{o}$. 15c; $1 / 4 \mathrm{lb}$. 25c. NEW JAPANESE PIE-The seeds ale distinct in appearance, being curiously manner as Japanese letters. Of medium size, good keepers and weigh 15 to 20 pounds each. The ueshally a rich salmon, unwhen cooked or stewed is almost as dry and mealy sweet potato For making pies, custards, no. equal Containing but ittle water, can easily be cut and dried like dried pies or sauce for Winter use Plat 5e; oz 10c: oz. 15c; $1 / 4$ lb. 25c; $1 / 21 \mathrm{~b}$. $40 \mathrm{c} ; \mathrm{lb}$. 75с. 


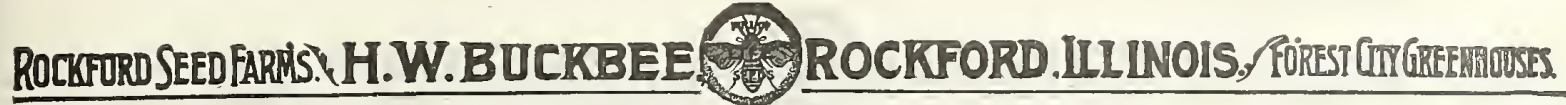 69 \\ BUCKBEE'S \\ "Full of Life" \\ RADISHES}

German, RETTIG RADIESCHEN; French; RADIS RAVE, PETITE RAVE; Spanish, RABANO; Swedish, RATTIKOR.

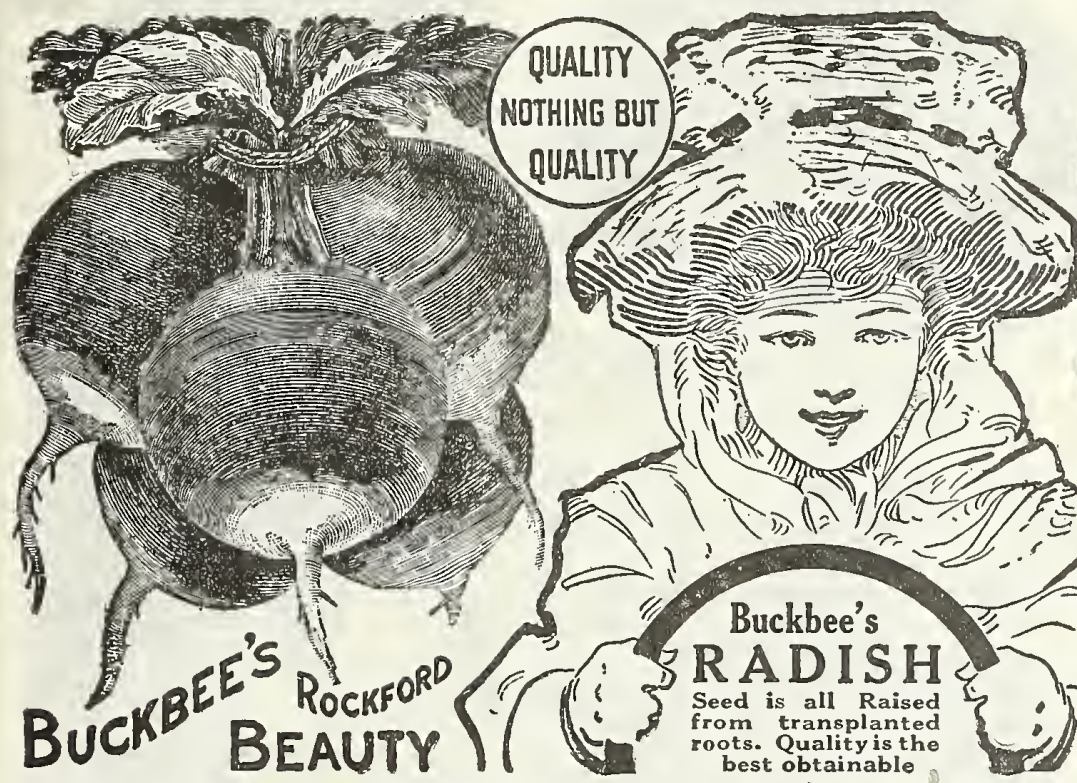

Buckbee's Rockford Beauty

\section{Handsomest and Best.}

Originated on Rockford Seed Farms. Very early, deep scarlet color with dainty white tip. Flesh crystal white, tender this variety. Pkt. 5c; oz, 10c; 2 oz, 18c $1 / 4$ lb. 30c; $1 / 2$ lb. 50c; 1b. 90c.

\section{Earliest Scarlet Turnip White Tip}

A very fine strain of this well-known kind; even in size, smooth, fine bright scarlet, with clean white tips. Exceptionposes. A good variety. Pkt. 4c; oz. fe; ? oz. 12c; $1 / 4$ lb. 20c; $1 / 2$ lb. 30c; lb. 50c.

\section{New Rosy Gem}

One of the Handsomest Turnip Radishes. One of the handsomest Turnip Radishes, and will give entire satisfaction where extreme earliness is not the primary ob-
ject. Roots slightly flattened on the under side; color very dark scarlet with a white tip; flesh white and of the best quality. lb. $35 \mathrm{c} ; 1 \mathrm{~b} .60 \mathrm{c}$.

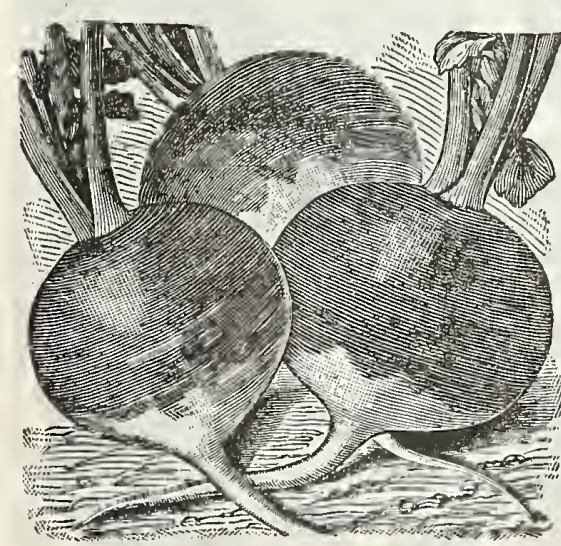

New Rosy Gem.

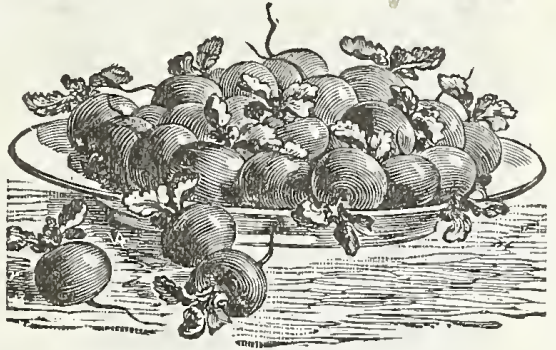

Buckboe's Rapid Forcing Radish.

Buckbee's Rapid Forcing

The Earliest of all Red Radishes. Quick growth is ane of the main Matures in about 14 days. The flesh is pure white, crísp and of very pleasant flavor, the skin is a most attractive bright admits of close sowing Remember that We control the entire stock of this variety. lb, $40 \mathrm{c}, 1 \mathrm{~b}$,

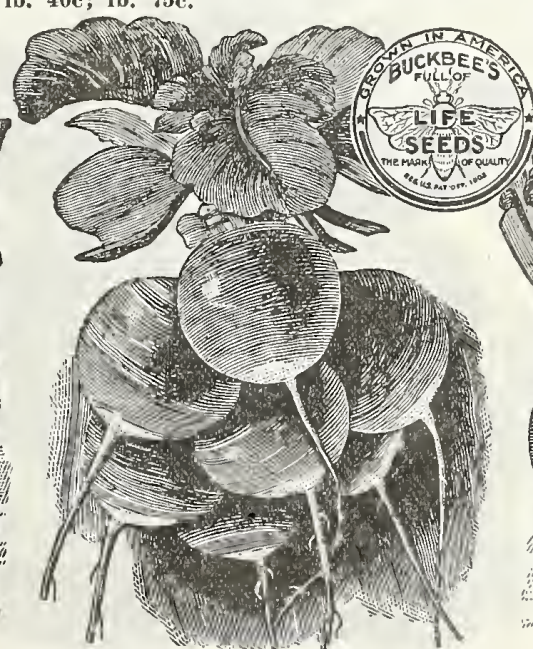

Earlest Scarlet Turnip White Tip.

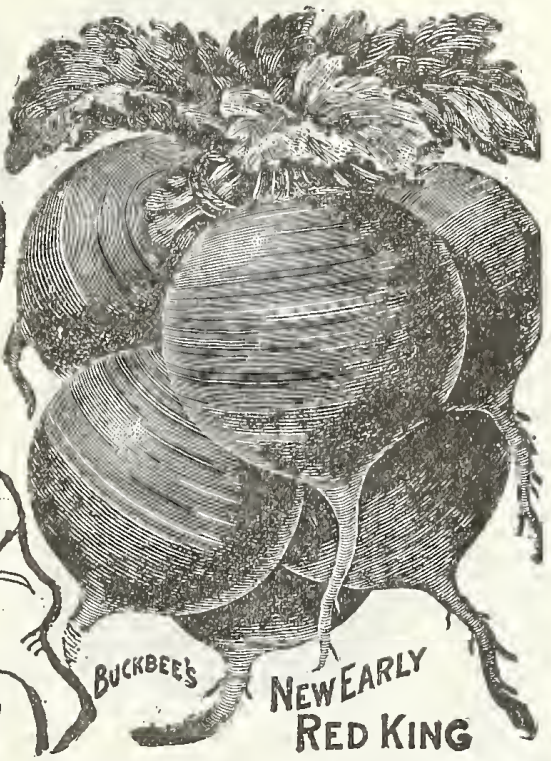

Buckbee's New Early Red King The Earliest and Best.
This new variety is our own production and is one of the earliest ever grown. It beautiful dark red skin; ivory white flesh its crispness even after quite old and never New Leafless

The extra early forcing Radishes lately sizeduced are remarkable for the small time that the latter Tlkt. 5c; oz. 10c; 2 oz. 18c; 1/4. 1b. 30c; $1 / 3$

\section{Crimson Giant Globe}

Sweet, Crisp, Juicy, Mild; Wonderful Yielder, Beautiful Color, Uniform Size. differs radically from all varieties hitherto in cultivation, in so far as its roots attain forcing varieties, without getting pithy or hollow. It is very early notwithdoors and forcing. The seed should be sown very thinly to permit full develop18c; $1 / 4$ lb. 30c; $1 / 2$ lb. 50c; lb. $80 c$;

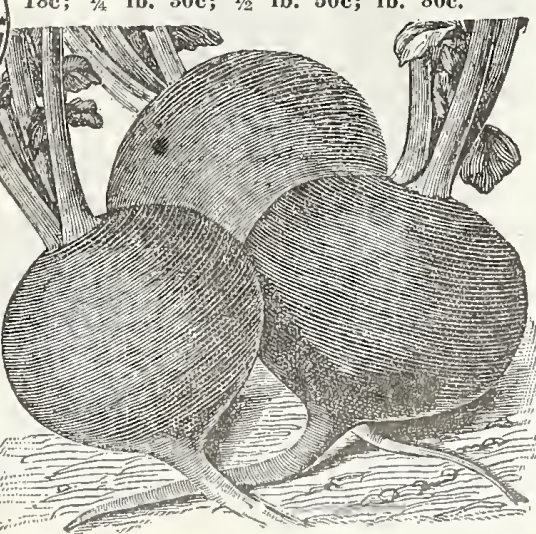

Buckbee's Crimson Giant Globe. 


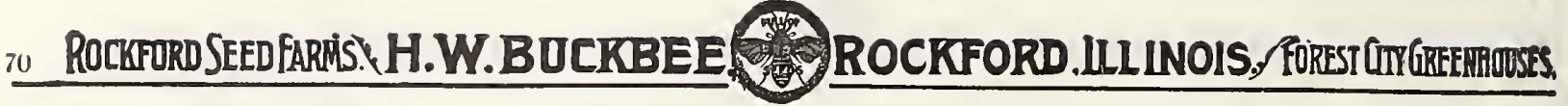

BUCKBEE'S

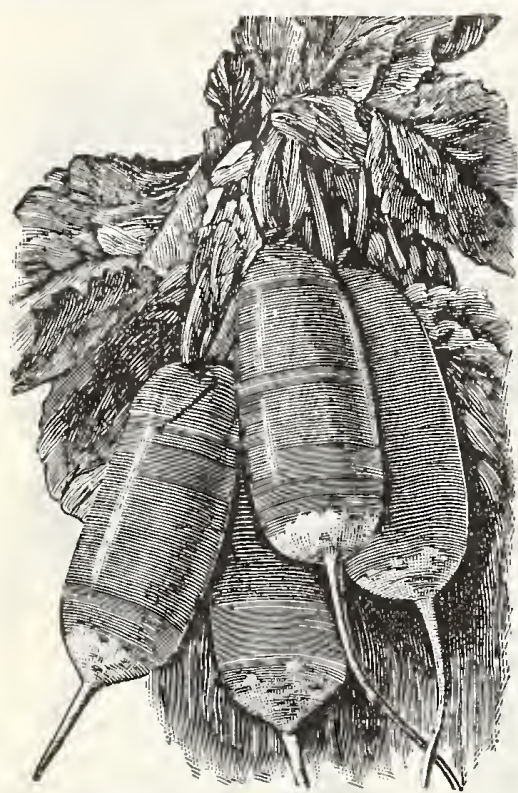

Improved French Breakfast.

Improved French Breakfast

A medium sized Radish, ollve shaped, tender, of a beautiful scarlet color, except 1c; oz. 7c; 2 oz. 12c; 1/4 3 b. 20e; $1 / 2$ lb. $35 \mathrm{c}$; 60c.

Buckbee's Improved Chartiers A standard variety. The roots come to and crisp three times as long as any other ored. Ples, wh; oz. 7e; 2 oz. 12c; 1/1 lb. 20c; $1 / 2$ lb. $30 \mathrm{c} ; 1 \mathrm{~b}$. $50 \mathrm{c}$.

\section{Vick's Scarlet Globe}

This grand radish has established a reputation as a forcing sort. Its peculiarity is that it will bear the heat requisite for forcing without becoming pithy in eharacter or suffering injury to its flavor. Its color is a rich scarlet. It has a small top and is a high bred radish. An excellent variety for sowing outdoors. Pkt. 75.

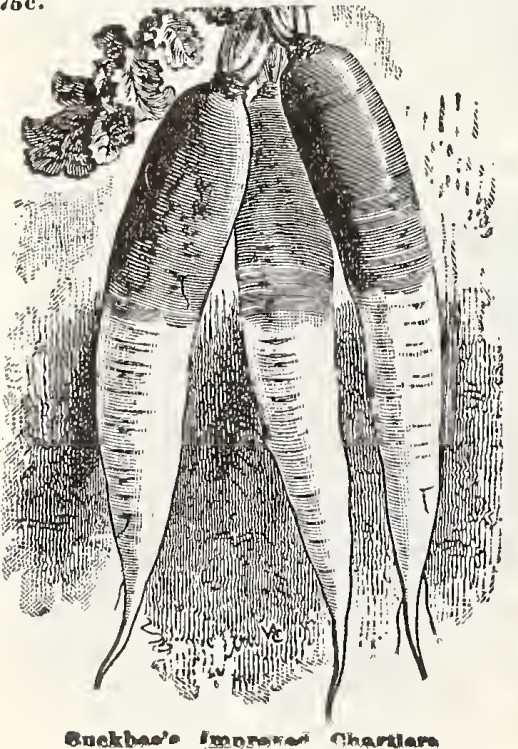

"FULL OF LIFE" RADISHES
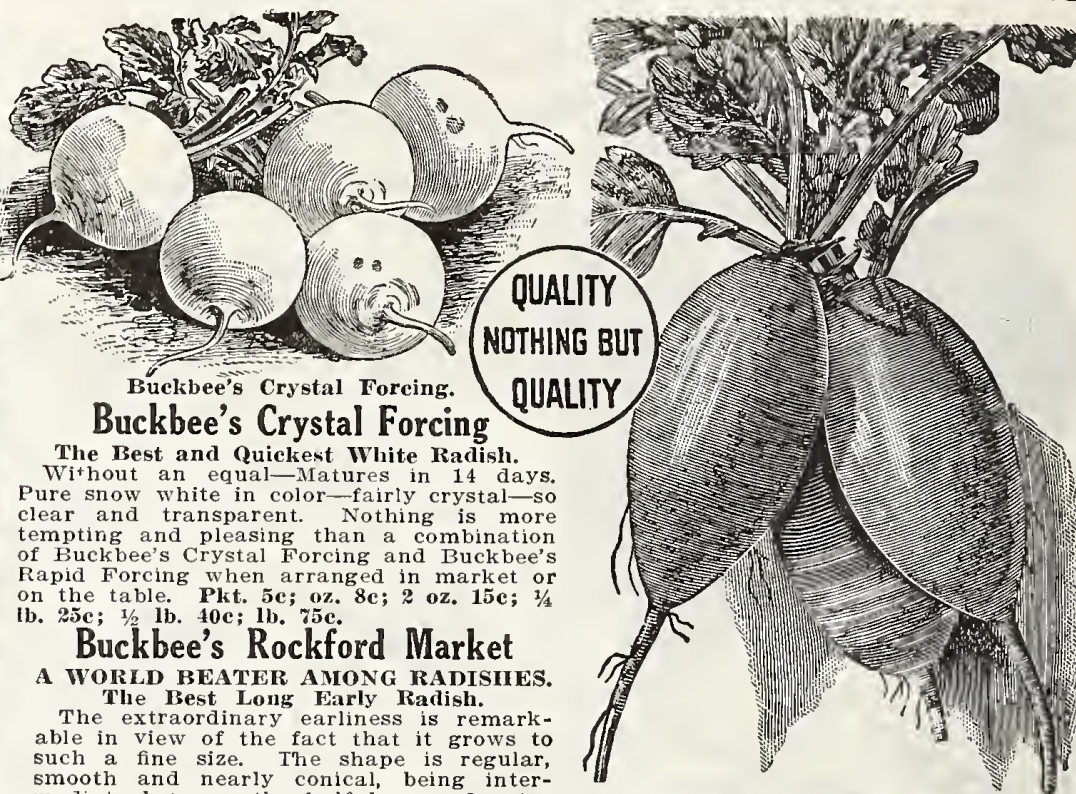

Early Scarlet Olive Shaped.

Early Scarlet Olive Shaped In the form of an olive, terminating in very slim tap root. Skin scarlet; neck cellent. Early, good for torcing and exeral crop. Pkt. 4c; oz. 7c; 2 oz. 12c; $1 / 4$ tb. $20 \mathrm{e} ; 1 / 2$ lb. 30c; 1 b. $50 \mathrm{c}$.

\section{Early White Olive Shaped} derest, of the earliest, finest, Juiciest, ten early use grown. Rich, red color; flesh Plt, 4c; oz. Te; 2 oz. 12e; $1 / 4$ lb.

Earliest White Turnip

A Favorite Standard Variety. A handsome sort, of extremely quick growth; sweet, juicy and tender. Beautiful ivory white color; flesh, pure white. New Triumph (Speckled Beauty) The flesh is very crisp and solid and of mild, pleasing flavor. Its most attractive unique color of the skin. The ground izontally and splashed with bright scarlet. Pkt. 5e; oz. 8e; 2 oz. 15e; $1 / 4$ lb. $25 \mathrm{c} ; 1 / 2$ lb. $40 \mathrm{e} ; 1 \mathrm{~b}$. 75e.

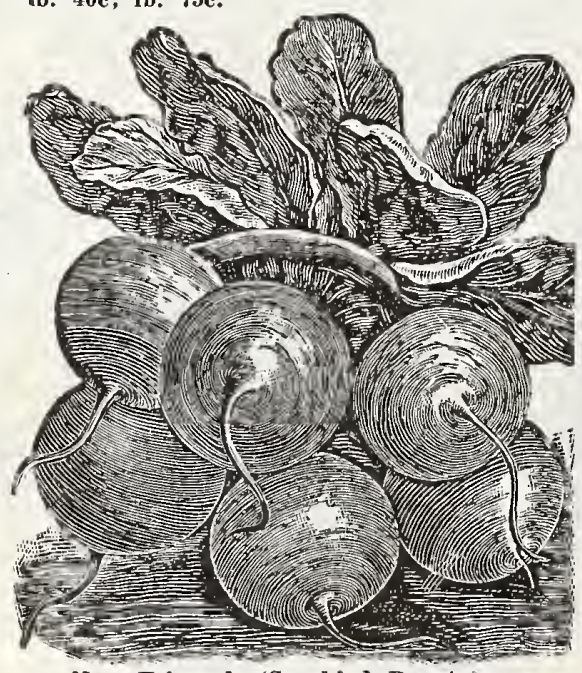

Now Trinmob (Sneckled Besuts)
Different from the Scarlet Olive Shaped In color and being a little longer. Clear oz. 7c; 2 oz, 12c; $3 / 4$ lb. 20c; $1 / 2$ lb. 30c; lb. $50 \mathrm{c}$

Paul P. Meaillard, Nat'l Soldiers Home Maine, writes: I raised Radish full size "Full of Life" seed.

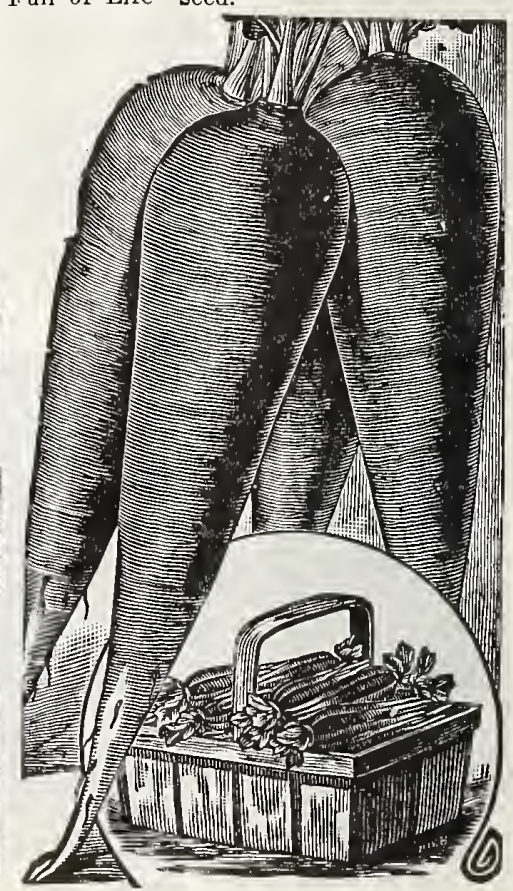

Buckbee' Rockford Market 


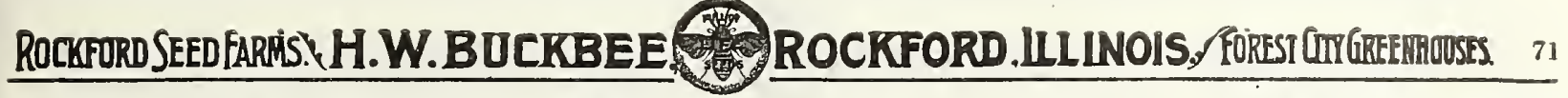

\section{BUCKBEE'S}

New Golden Dresden

A Favorlte with Market Gardeners. It has proved a universal favorite everywhere. Matures in less than 30 days. Flesh pure white, crisp, juicy and of the finest flavor. Skin of beautiful golden russet color. Market gardeners can either grow this variety in the open ground or force it, and be sure of an early, perfect and uniform crop. Unexcelled for the home garden. Pkt. 5c; oz. 8c: $20 z$ $16 \mathrm{c} ; 1 / 4 \mathrm{lb} .25 \mathrm{c} ; 1 / 2 \mathrm{lb}$. $40 \mathrm{c} ; \mathrm{lb}$. $75 \mathrm{c}$.

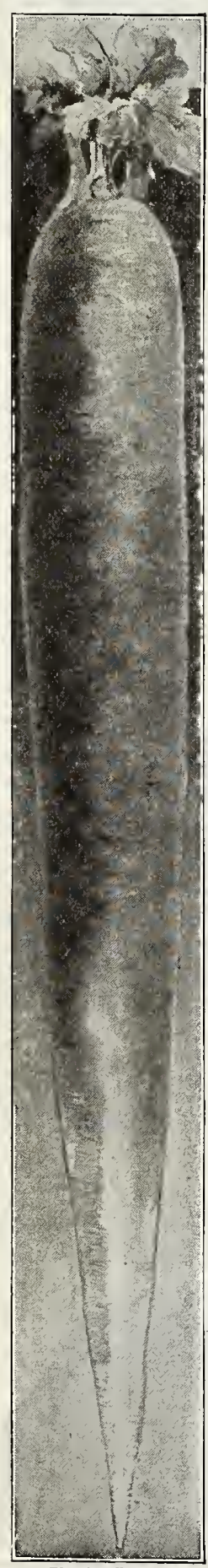

Early Long
Brlghtest Scarlet

New White Dresden When planted under first of May it is ready for the table the first of June. The tops are small and are perfectly round and smooth. The flesh is lb. 30c; 1 b. $50 \mathrm{c}$.

season.

$30 \mathrm{c}: 1 \mathrm{~b}$. $50 \mathrm{c}$. teen ounces.

\begin{tabular}{|l|}
\hline RADISHES \\
should be sown \\
for early use as \\
soon as the ground \\
can be well pre- \\
pared, and for suc- \\
cession, at intervals \\
of two or th e \\
weeks throughout \\
the season, in rich, \\
loose, warm soil, \\
as the quality de- \\
pends largely on its \\
rapid growth. Sow \\
in rows a foot apart, \\
and thin to two \\
inches in the row.
\end{tabular}
admit of the closest "Full of Life"

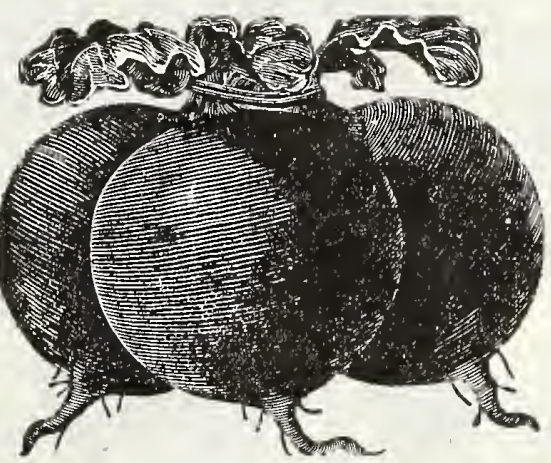

New Golden Dresden.
RADISHES

\section{New "Icicle"}

Entirely distinct, long, slender, pure whlte Earliest and finest long white, Ready for use as early as the Long Scarlet, with less ing Pkt. 4c; oz. 7c; $20 z .12 \mathrm{c} ; 1 / 41 \mathrm{~b} .20 \mathrm{c}$ $1 / 21 \mathrm{~b} .35 \mathrm{c} ; 1 \mathrm{~b} .60 \mathrm{c}$

Half Long Deep Scarlet

A brilliant deep, rich red color and half long, with a somewhat tapering point; the flesh is very white, crisp juiciness well, not becomjuiciness well, not becomPkt. 3c; oz. 7c; $20 z$. 12c; $1 / 4$ lb. 20c; $1 / 2 \mathrm{lb}$. $30 \mathrm{c} ; 1 \mathrm{~b} .50 \mathrm{c}$.

New White Lady Finger Beativiu in stape of the finest, juvor akt, 5c; oz. 8c; $2 \mathbf{o z}$. and the skin and flesh are pure snow white. 15c; $1 / 4$ lb. 25c; $1 / 2$ lb.40c; 1b. 75c.
Crisp, brittle, and of rapid growth.
Order early. Pkt. 4c; oz. 7c; $\mathbf{2}$ oz. Early Long Brightest Scarlet color over other varieties. Roots ready for use in about twenty-five days when planted outdoors. It has a small top.

Summer Radishes GOLIDEN SUMINER TUR-

NIP - It is perfectly

round in shape; neck is

finer, leaves smaller and

old Yellow Turnip Rad-

ish. Pkt. 3c; oz. 7c;

oz. 12c; $1 / 4$ lb. 20c;

GRAY SUMIER TUR-

NIP - Round, turnip-

shaped. The skin on the

upper part is mottled

Flesh mild, of greenish

white color. Pkt. 3c:

oz. $7 \mathrm{c} ; 2 \mathrm{oz}, 12 \mathrm{c} ; 1 / 4 \mathrm{lb}$.

WHI'TE $1 / 2$ liTRASBURG

This grows to the largest

size and is usable when quite

small, thus covering a long

long and about two inches

tender. Pkt. 3c; oz. 7c;

2 oz. 12c; $1 / 41$ lb. 20c; $1 / 2$ lb.

Mrs. Chauncey Sayler, Watertown, N. Y writes:- "I sent for 1 1b. of your Pure Early Rose Potatoes last Spring and raised $105 \mathrm{lbs}$. from the 1 lb. planted. They grew very large, one weighed one pound and four-

John M. Evans, R. R. 4, Tippecanoe City, O., writes:--"The Potatoes last Spring were fine-one bushel of Ohio made 17 bushels. Early Rose made 15 bushels I could sell all I have for seed.'

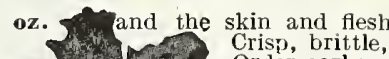
Winter Radishes CHINESE ROSE-Standard Variety - Bright rose color; flesh firm, crisp, tender, quite pungent. Pkt. 4c; oz. c; 2 oz. 12c; $1 / 4$ lb. 20c; 1 MAMNOTH CELESTIAIRoots frequently grow 14 to 18 inches in length and 6 to 8 and flesh pure paper white; mild. Pkt. sc: oz. 8c; oz. 15e; $1 / 1 \mathrm{lb}$. 25c; $1 / 2 \mathrm{ib}$ Oz. 15c; $1 / 411$

CALIFORNIA MIM MOTH WHITE - PuTE white about 1 foot long white about 1 foot long Flesh tender and crisp. Pkt. $3 \mathrm{c} ;$ oz. 7c; 2 oz. 12c; $1 / 4$ lb. 20c; $1 / 21 b .35 c ; 1 b .60 c$ ROUND BLACK SPANISH - Skin black, flesh white; highly flavored. Pkt $3 \mathrm{c} ; \mathrm{oz} .7 \mathrm{c} ; 2$ oz. 12c; $1 / 4$ lb. 20c; $1 / 2$ lb. 35e; $1 \mathrm{~b} .60 \mathrm{c}$. LONG use. Pkt. 3c: oz. $7 \mathrm{c}$; 2 oz. 12c; $1 / 4$ lb. 20c; i/2 lb. 35c $1 \mathrm{bc} 60 \mathrm{c}$

Radish Mixtures Price each of the following varieties:
Pkt. 4c; oz. 7c; $\mathbf{2} \mathbf{o z} .12 \mathrm{1} ; 1 / 4 \mathbf{l b}$ $20 \mathrm{c} ; 1 / 2 \mathrm{lb}$. $35 \mathrm{c} ; 1 \mathrm{~b}$. 60c.

EARLIEST RADISHES MIXEDFor family gardens, earliest varieties. SUMMIER RADISHES MIXED ture of all summer varieties.

WINTER RADISIIES MIXED Seed varieties, which will produce all the best Radishes for Autumn and Winter use.

Geo. E. Boyer, 2523 N. Monroe St, Peoria, Ill., writes: "My Rocky Mountain Cherries doing fine and have The Giant Himalaya Berries, all about $2 \frac{1}{2}$ feet grown about 10 feet this summer.
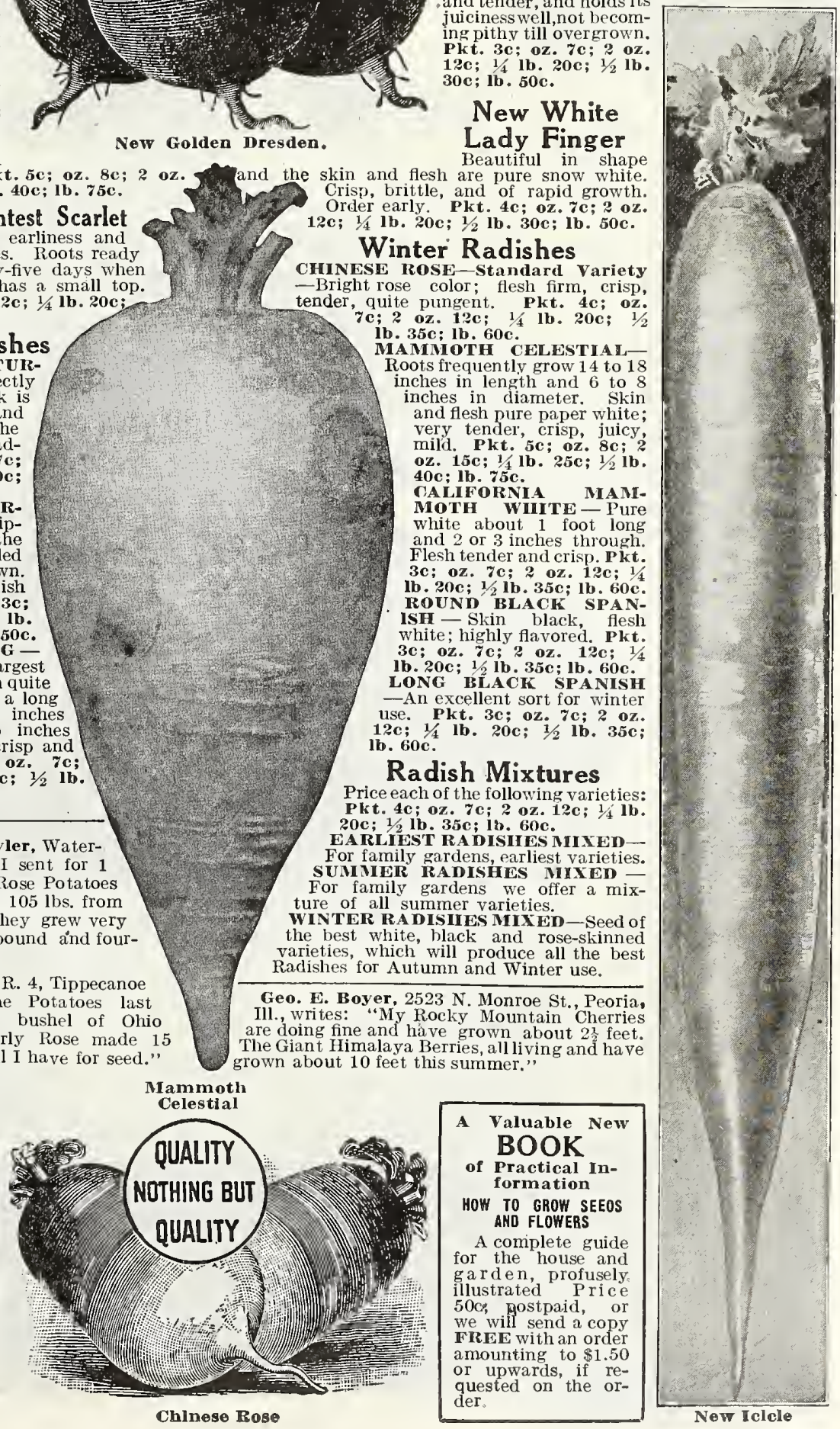


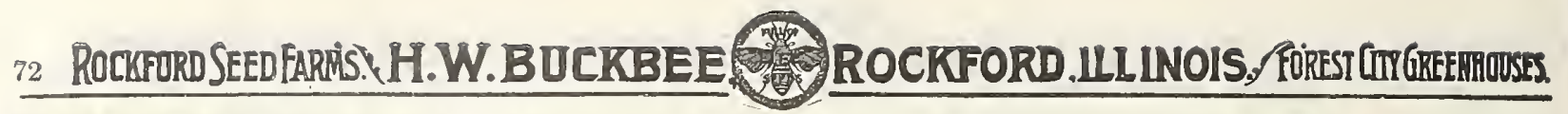

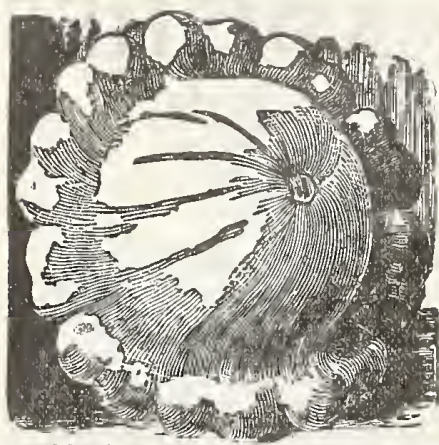

Buckbee's New Mammoth White Bush.

BEST Summer and

BEST Surly Fall
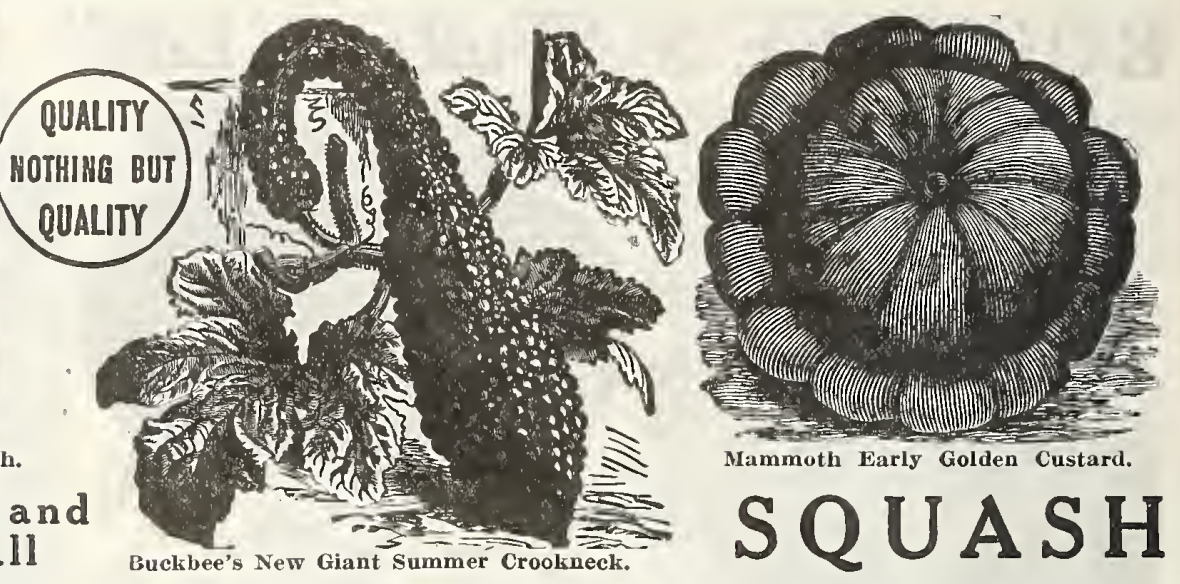

THE SQUASH is one of the most nutritious and valuable of our garden vegetables. The Summer varieties come to the table early in the season, while the Winter sorts can be had in perfection from August until the Summer sorts are again in condition. Plants Buckbee's New Mammoth White Bush

Great improvement over the Early White Bush. Great improvement over the Early White Bush.
Very uniform in shape and wonderfuly prolific, Fit to use very early, of a beautiful white color, and Grows to a large size-twelve to flfteen inches across. $4 \mathrm{c} ; 0 z$. 7c; 2 oz. 12c; $1 / 1$ lb. 20c; $1 / 2$ lb. $35 \mathrm{c} ; 1 \mathrm{lb} .60 \mathrm{c}$.

\section{Mammoth Early Golden Custard} or Early Fellow Bush, Sealloped,

Standard early summer variety, nice to use in its green state and valuable for making pies when it has attained full size. Plit. 4c; oz. $1 / 4$ lb. 20c; 1/2 lb. 35c; lb. 60c.

Summer Crookneck

Standard Early.

Splendid Quality.

Twice as large as the ordinary Crookneck, more warty combination makes it the most desiraor private garden. Pkt. 4c; oz. 8c; 2 oz. 15c; $1 / 41 \mathrm{~b} .20 \mathrm{c}$;
$1 / 2$ lb. $40 \mathrm{c} ; 1 \mathrm{~b}$. $70 \mathrm{c}$.

Faxon's New Brazilian

Long Keeper, Superior Quality.

Its $\mathrm{valuable}$ points are earliness, long-keeping and high table qualities. Dry and rich, without regard to the size; something entirely different in this respect from any other Squash. We recommend it to all for general
use in the home garden. Pkt. 4c; oz. 8c; 2 oz. 15c; 1/4 lb. 25c; $1 / 2$ lb. $40 \mathrm{c} ; 1 \mathrm{~b}$. $75 \mathrm{c}$.

\section{Delicata}

Delicious Both for Summer and Winter Uso.

\section{IMPORTANT}

While Squash Seed cannot be planted as early as some other vegetables, we advise early orders so that on hand ready for planting as soon as weather permits.
New Fordhook

Hardy, Most Dependable, Fine for Baking. The flesh of this Squash is very dry and sweet. It is one of the earliest of the Winter varieties, and if stored in a cool, dry place will keep until the following June. The outside color is bright yellow; inside color, straw yellow. The skin is so thin that it need not be removed for cooking. The meat is thick and can be used at any stage of their growth. Pkt. 4c; oz. $8 \mathrm{c} ; 2 \mathrm{oz} .15 \mathrm{c}$; $1 / 4$ lb. $25 \mathrm{c}$; $1 / 2 \mathrm{lb}$. 45c; lb. $80 \mathrm{c}$.

\section{Pikes Peak, or Sibley}

IIard Shelled, Fine Keeper, Excellent Quality.
One of the best keepers. Large oval fruit tapering One of the best keepers. Large oval fruit tapering
at the blossom end. Skin dark olive-green; cellent qua lit y. Vines of strong growth and very productive. Pkt. 4c; oz. $8 \mathrm{c} ; 2$ oz. $15 \mathrm{c} ; 1 / 4$
lb. $25 \mathrm{c} ; 1 / 2$ lb. $45 \mathrm{c}$; lb. $25 \mathrm{c}$;

New Turban The Popular Turk's Cap or Essex.
Hybrid Squash. A distinct and valuable Fall and Winter varie ty. Flesh is dry, sweet and thick, of a bright orange color, and its keeping qualities are admirable. It will please you. Pkt. $4 \mathrm{c} ;$ oz. $8 \mathrm{c}$; lb. $40 \mathrm{c} ; 1 \mathrm{~b}$. 75c.

Boston Marrow

One of the Very Best for Quality-Fine Keeper.

A desirable Fall and Winter variety, very popular everywhere. Of oval form; skin thin: when ripe bright orange mottled with light cream color; flesh rich salmon yellow, fine grained, and for sweetness and excellence unsurpassed. Pkt. 3c; oz, 6c; 2 oz. 10c; $1 / 4$ lb. 18c; $1 / 2$ lb. 30c; lb. 50c.

This beautiful Squash is orange-yellow, splashed and striped with dark green on the outside. The flesh is rich, dry and particulariy fine. For private use we can recommend it as surpassing in richness of flavor any of the large old-fashioned sorts. A desirable feature is its small size; not too large for an ordinary family; is wonderfully solid and heavy, the seed cavities being very small; it is aiso extremely early (the earliest of any Vine Squash), maturing about the same time as the Summer Squashes, and for eariy

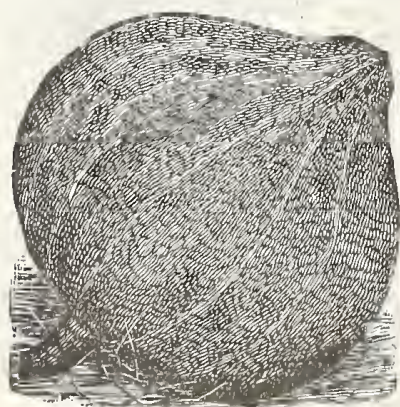

Faxon's New Brazllian. use will doubtless supplant this class on account of its superior dryness and flavor, while its
extreme solidity renders it fully as good a keeper as any of the Winter varieties. Pkt. 4c; oz. extreme solidity renders it fully as good a

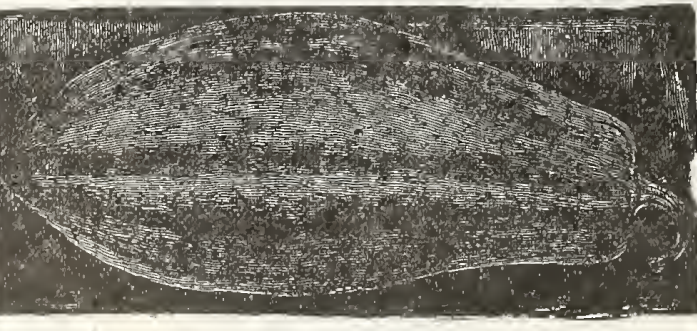

New Fordhook

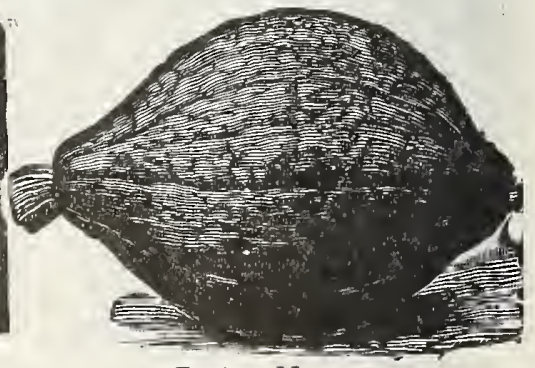

Boston Marrow 


\section{BUCKBEE'S “FULL OF LIFE" SQUASH}

THE SQUASH is one of the most nutritious and valuable the table early in the season, had in perfection from August again in condition. Few farmers appreciate the value of winter squash as a food for stock. An acre of Squash, and much less to secure, will give as much food available for feeding stock as an urge our readers to try a patch for this purpose. The plants are very tender and sensitive to cold. and planting must be delayed ture are the same as those given for Cucumbers and Melparticular as to soil. The summer varieties should be planted mer varieties should be planted the winter sorts 8 to 10 . Three plants are sufficient for a hill. of all our garden vegetables. while the winter sorts can be costing no more to curre will until settled warm weather.

New Golden Hubbard

The Onc Variety of Squast That is Never Troubled by Bugs.

Justly Popular Wherever and Whenever Grown. This is a True Hubbard Squash, Except in Color, which is bright:Golden. It ripens its crop very early. The fruits are very uniform in size, weighand in shape are like the Hubbard. Though maturing early they are wonderfully long over in good condition fl Spring use. The shéll is warty, beautiful orange. cept for a bit of olive green is a deep orange, and uniformly so to the end, never having able in other sorts. It cooks good flavored. Has no super-

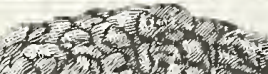
ior as a table Squash. Pkt. 5e; oz. 8c; 2 oz. 15c:
Buckbee's Improved Hubbard Squash for All purposes.

The Grand old Favorite. This is a superior selection of this bright orange yellow, fine grained very dry, sweet and rich flavored. Keeps perfectly good throughout the winter. Boils be as good baked as a fine regard to quality of the flesh the shell, but the latter peculiarities are largely determined by the soils in which the Squashes are raised. Our fruit will be a pure Hubbard Send to Buckbee for the best

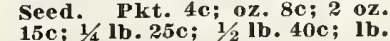
$15 \mathrm{c}$;

\section{Mammoth Whale} The Heavyweight Jumbo of the Squash

The Largest of All. Single specimens have grown to the enormous weight of 300 pounds. of rich yellow color; quality good, very nutritious, making it exceptionally market purposes. Its size makes it profitable to grow for stock feeding also. Pkt. $5 \mathrm{c} ;$ oz. 15c; 2 oz. 25c; 1 Ib. 40 .

Mr. Thos. $\overline{\text { Wagstaff, }}$ Gdr., Iake Forest, Ill., writes:-You will rememyou and was very pleased with them. I have been gardening for over 60 years and will say that I never handled such fine plants before.

R. B. Leffingwell, Des Plaines Ill.. writes:-The Lawn Grass Seed that I Law Grass Seed that I
The Famous Standard Winter famous variety, and one of the and is esteemed by many to most carefully selected with customers can plant this variety in perfect confidence that every Outer color a rich orange ber that last spring I got was the best I have eve seen in my life.

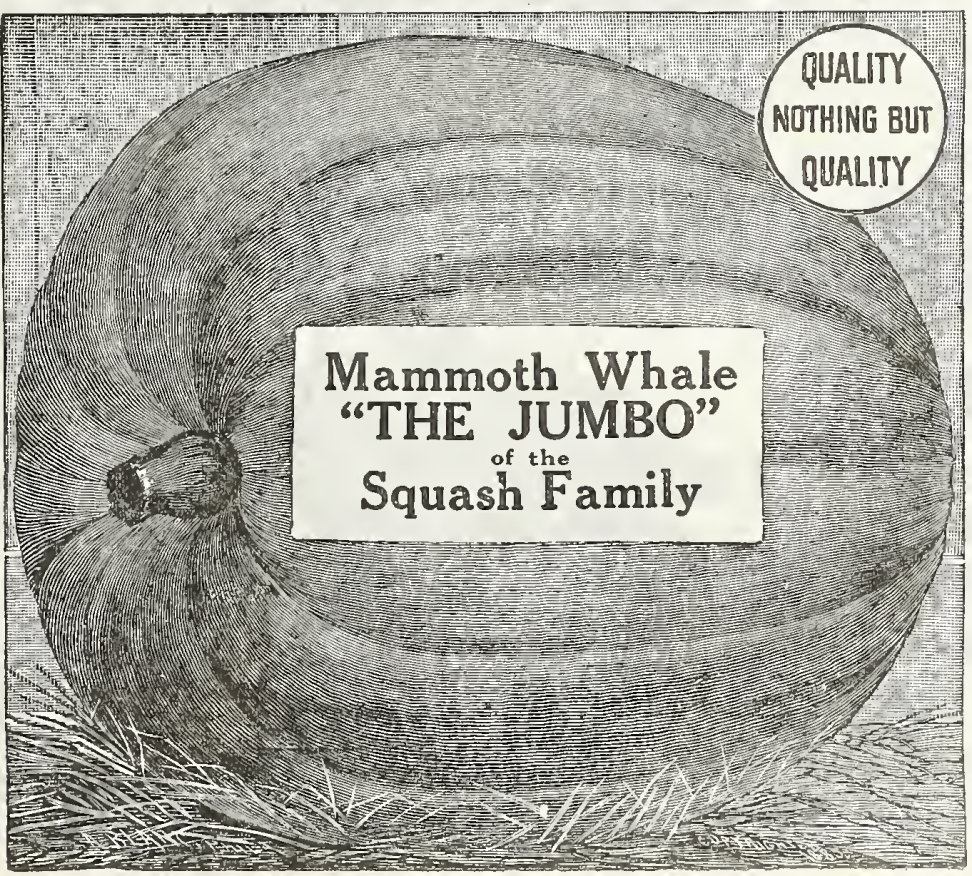

Golden West Hard Shell Greatest of All-Long Kceper. This grand Fall and Winter Squash originated by a "cross" in a
feld of Hubbards and is practically "bug resistant." Quality is delicious; beautiful golmakes the very best baked Squash and pies. Don't fail to plant this grand variety. Our price for choiccst "FULL onable. Order Early, Pkt. $5 \mathrm{c} ; 0 \mathrm{z} .10 \mathrm{c} ; 2 \mathrm{oz} .15 \mathrm{c} ; 1 / 4 \mathrm{lb}$ $25 \mathrm{c} ; 1 / 21 \mathrm{~b} .40 \mathrm{c} ; 1 \mathrm{~b}$. $75 \mathrm{c}$.

Chicago Warted Hubbard The Leader in Many Markets.

Our strain of the above will produce what we consider the Ideal Hubbard for home or for market. For thirty or forty years this It is shipped thousands of miles in car-load yielder; very profitable for lots from West to East every year. With the growing of it in a large way heaviest, dark, roughvaluable and most salable. Choicest stock seed of our own growing. Send to Buckbce for the best Seed. Pkt. 4c; oz. 8c; 1b. $40 \mathrm{c} ; 1 \mathrm{~b} .75 \mathrm{c}$.

Blue Hubbard or Marblehead

The Famous Standard Variety.

Without question this is Winter the best Fall and bright, creamy yellow, fine grained, very dry, sweet keeps splendidly throughout the Winter. Splendid Buckbce for the best Seed. Pkt. 4c; oz. 8c; Ib. $50 \mathrm{c} ; 1 \mathrm{~b} .90 \mathrm{c}$.

Rufus Haynes

Haynes, Box 


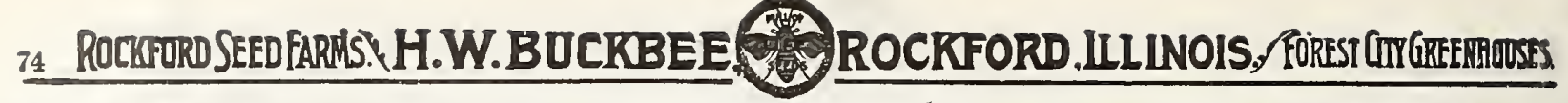

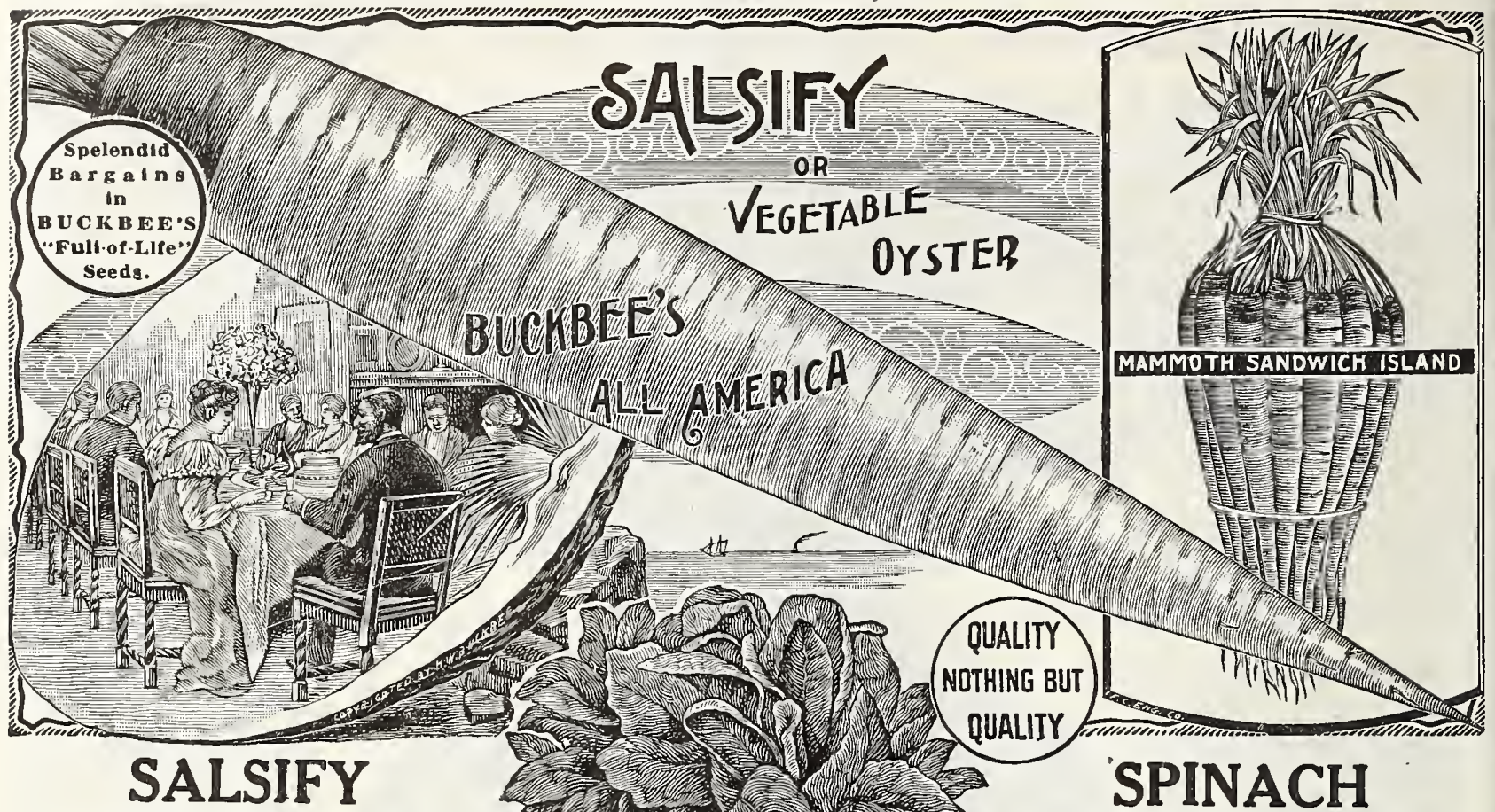

German, HAFER WURZEL; French, SALSIFIS; Spanish, SALSIFI BLAMCO. This really delicious vegetable should
be more generally grown. It surpasses for table use, both parsnips and carrots, acoyster flavor. The roots should be left in the ground to be dug up during thaws boiled like parsnips or carrots, or is halfboiled and grated, then made into balls like oysters. Very Best Salsify-A truly American variety of the highest merit. Introdiate popularity. The long, white tapering roots are of the most superior now on the market. Pkt. 10e; oz. 15c;

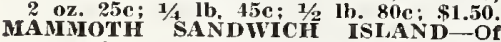
extra large size, in every way preferstronger growing, and less liable to ers. Pkt. 5c; oz. 15e; 2 oz. 25c; $1 / 4$ lb. 40c; $1 / 2$ lb. $75 c$; 1 b. $\$ 1.25$.
LONG WHITstandard variety that has stood the test of time. Pkt. 3e; oz. 10e; 2 oz. SCORZONERA OR BLACK SALSIFYConsidered by many better than White Salsify. Somewhat harder to raise, al: oz, 15c: 2 oz. 25c; 1/4 lb. 45e: $1 / 2$ lb. $80 \mathrm{c} ; 1 \mathrm{lb}, \$ 1.50$.

\section{SWISS CHARD or Summer Spinach}

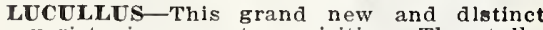
are as thick and broad as Rhubarb. The plants grow to a height of from 2 to $2 \frac{1 / 2}{2}$ long and $11 / 2$ inches broad. Pkt. 5c; oz. $10 \mathrm{c} ; 2 \mathrm{oz} .18 \mathrm{e} ; 1 / 4 \mathrm{lb} .30 \mathrm{c} ; 1 / 2 \mathrm{lb}, 50 \mathrm{c} ; 1 \mathrm{lb}, 90 \mathrm{c}$ LARGE RIBBED WHITE-AIso called Bilver Beet and Sea Kale Beet-The leaves are used for greens the same as spinach or easier to prepare than splnach, and far superior to beets. Nothing in the garden stant crop from July to winter and can be suter $1 / 4$

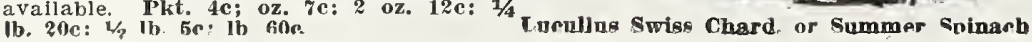
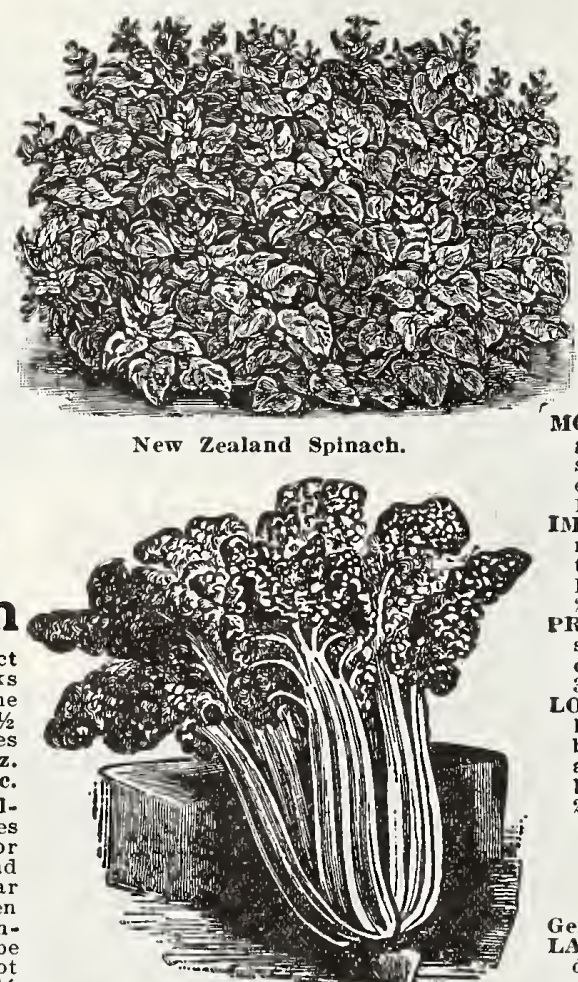

German, SPINAT. French, EPINARD BUCKBEE'S NEW LONG SEASON-An improved round-seeded strain of excel ties of the ordinary sorts and contin uing in condition for use much longer. rich $1 / 4$ lb, 20c; 1/2 lb. 30e; lb. 50c; 4 lbe. VICTó postpaid. leaf, which is somewhat savoyed in the center, For market or the private

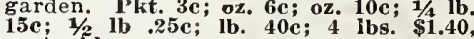
IMPROVED ROUND SUMMER BROADLEAF-Excellent for early Spring sowing. Leaves large, thick and fleshy. Pkt. 2e; oz. 4c; 2 oz. 7c; 1/4 lb. 12c; $1 / 2$ Ib. 20c; lb. 35e; 4 lbs. \$1.20, postpaid. variety available for use during th hottest months of the year. Quite different from any other Spinach, and Large pkt. 5c; oz. 10c; 2 oz. 15c; $1 / 41 \mathrm{lb}$. SAVOY LEAFED-Often called Norfolk lavoy. Leaves are numerous, succuCabbage. produces winkled like savoy plet of crop as the ordinary sorts. lb. 20e; lb 35e; 4 lbs, \$1.20, postpaid. ROU everywhere. Pkt. 2c; oz. 4c; 2 oz. $7 \mathrm{c} ; 1 / 4$ lb. IMPRo VED TIICK LEAVED-Grows rapidly, forming a cluster of large, very Plkt. 2c; oz. 4c: 2 oz. 7c; $1 / 4$ lb. 12c; $1 / 2 \mathrm{lb}$.

seed is prickly, The oz. 4c; 2 oz. 7e; $1 / 4$ lb. 12c; $1 / 2$ lb. 18c; lb. 30c; 4 lbs. \$1.20, postpaid. little later than the round leaved sorts, but furnishes a large quantity of thick and well flavored leaves. Prickly seed. 20c; lb. 35e; 4 lbs, \$1.20, postpaid.

\section{SORREL}

German, SAUERAMPFER; French, OSEILLF LARGE-LEAVHD GARDEN-The best garden variety, having large pale green leaves of fine qualit 


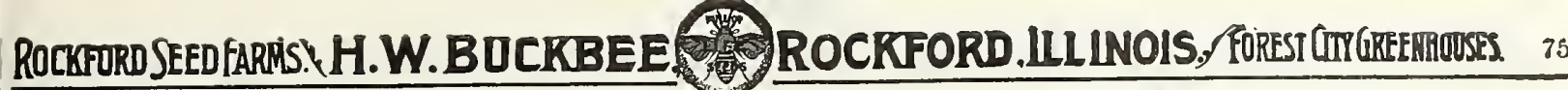

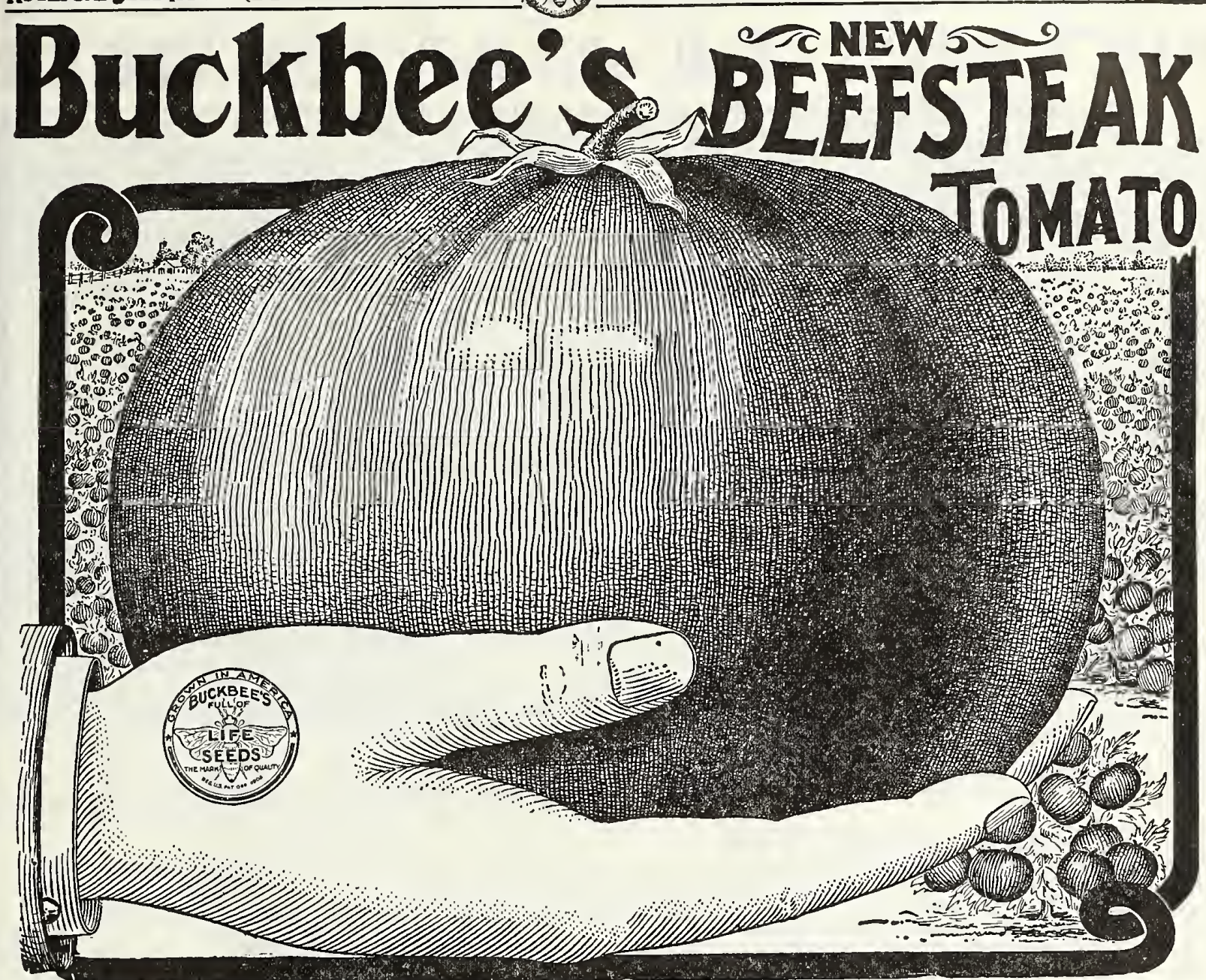

Trade Mark Registered 1914-By H. W. Buckbee, Et. Al.

\section{BUCKBEE'S BEEFSTEAK The King of All Main Crop Tomatoes}

NOTING in the way of a Tomato Creation has ever achieved in so short a time, the tremendously exceilent reputation that NoTHing in the way of a Tomato Creation has ever achieved in so short a time, the tremendously exceilent reputation that has come to BUCKIEE's BEEFSTEAK. Growers from every section of the wide world have sent in unsolicited praise, and

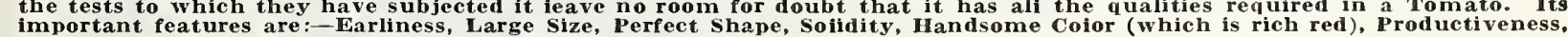

Everbearing, Fine Flavor, Best Keeper, Spiendid Shipper. canning. It is a sturdy healthy grower and is practically Everbearing, yielding enormous quantities of tomatoes always smooth and handsome until killed by frost. For a main crop there is no variety that can equal Buckbee's Beefsteak, and it is particularly desirable for large growers and shippers as it stands rough handling well, while its beautiful bright red color and handsome shape makes it very valuable as a

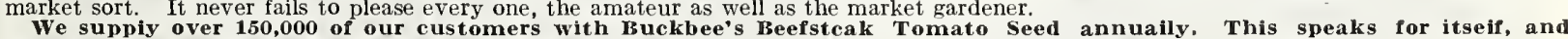
substantiates our ciaim that Buckbee's Beefsteak is the "King of Ail Tomatoes," and the most extensiveiy pianted of any variety.

\section{THE WORLD'S ONE UNBEATABLE TOMATO}

We controi the entire seed suppiy and offer the choicest "Fuli of Life" Seed of our own growing at the foilowing reason-

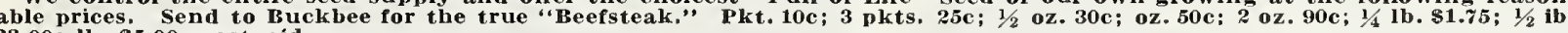
$\$ 3.00 ; 1 b . \$ 5.00$, postpaid.

WHAT SOME OF OUR CUSTOMERS SAY ABOUT BUCKBEE'S BEEFSTEAK

Mrs. D. S. Biack, Gainesviiie, Ark., writes:-Buckbee's Beefsteak Tomatoes are the finest I ever saw, some of them weighed over a pound.

Wm. S. Roberts, Avonia, Va., writes:-We planted Buckbee's Beefsteak Tomato last year and they were splendid--best ever.

Mrs. W. M. Curtis, Clay City, Ky.: "Among my Beefsteak Tomatoes was one that weighed a pound and three-quarters."

Mr. Jas. MI. Bateman, Harrisonvilie, Mo.: "I raised Beefsteak Tomatoes that were as large around as a saucer."

Miss Leathie Davis, Nectar, Aia.: "My Beefsteak Tomatoes are the finest I ever saw; they will weigh a pound or more each, and

were $141 / 2$ inches around on July 15 th.

Irs. Wm. Steele, Genoa, N. Y.: "The Beefsteak Tomatoes were the largest I ever saw,"

Louis Stolko, Hermann, Mo., writes:-Your seeds were a complete success last year. Buckbee's Beefsteak Tomato is truly the ${ }^{0}$ King

of All Tomatoes," One specimen of it weighed exactly two pounds. I raised about twenty that weighed over a pound each.
Mrs. Wilis Gooch, R. R. 2, Box 66, Hanson, Ky., writes:-Your Tomatoes certainly are fine

Tomatoes they ever saw. Some of my friends five miles away wanted some of the seed

Tho ahove are identical with thnisands of others in our correspondence filea 


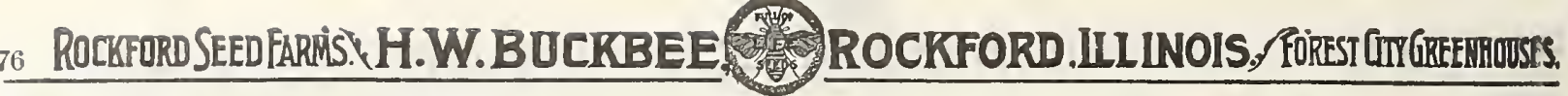

\section{BUCKBEE'S "Full of Life" TOMATOES}

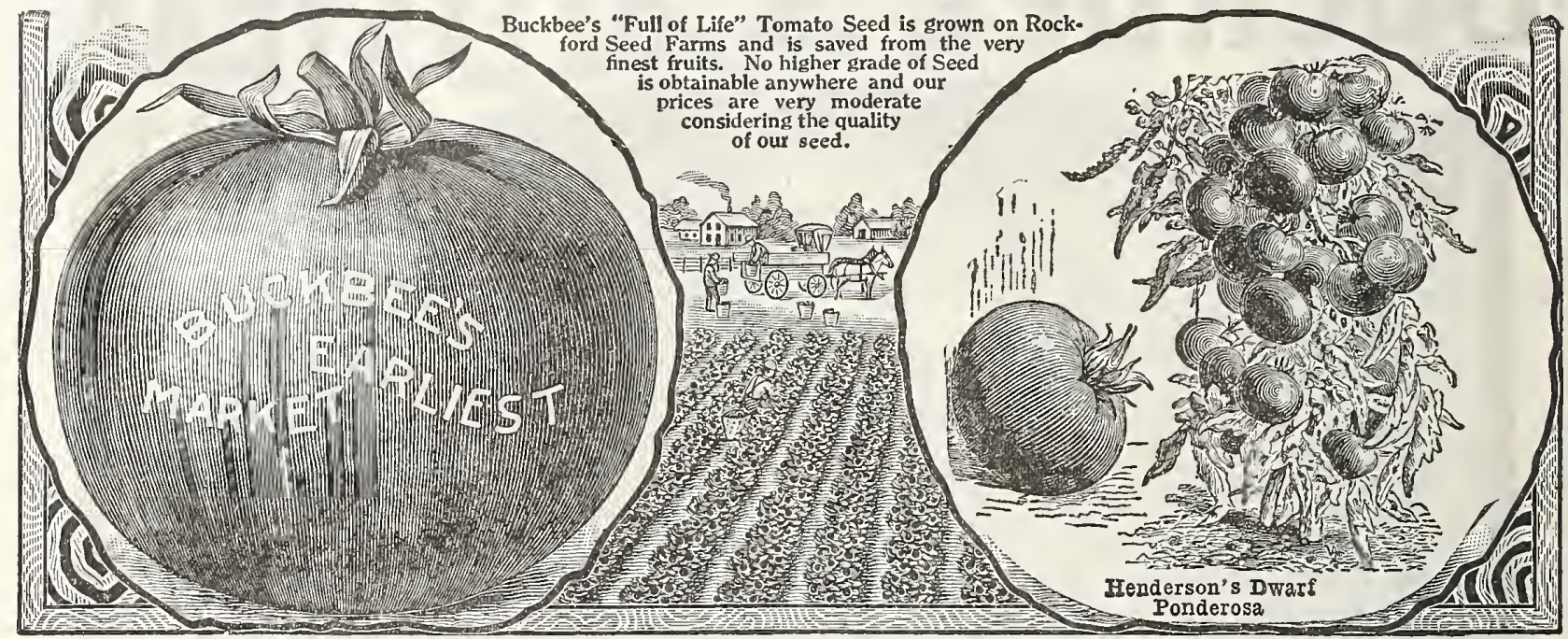

\section{BUCKBEE'S EARLIEST MARKET}

Bnckbec's Earliest Market-A variety bearing fruit which in size, shape, color, solidity and quality compares favorably with Farms and elsewhere has demonstrated that it ripens up a larger portion of its crop the earliest of any variety. Earliest Good Tomato. Gardeners and Tomato Fanciers will readily see the advantage obtained over their competitors by growing Buckbee's moothest, best flavored and highest colored extra early Tomato. Pkt. 10c; $1 / 2$ oz. 20c; oz. 35e; $20 z .60 \mathrm{oc} ; 1 / 4$ lb. $\$ 1.00 ; 1 / 2$ lb. $\$ 1.75$

\section{BUCKBEE'S COUNTY FAIR}

This magnifcent sort of our own introduction certainly is in the lead of all other Tomatoes. In form and color the fruit resembles the Acme; it is always symmetrical and attractive in appearance; the skin tougli and the flesh solid. The ripe fruits will keep in ent a solid meaty center with small seed cells and of particularly fine rich flavol. Never requiring any support, but always standing

MANSFIELD TREE OR MAMMIOTH PRIZE

This wonderful variety grows from 10 to 15 feet in height, and will begin to tipen by July yth and bear untill killea by rirost

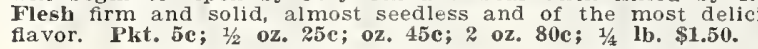

\section{BUCKBEE'S WORLD'S FAIR}

\section{of Dwarf Upright Tree-Growing Habits.}

The fruit is a beautiful golden yellow shade, the richest color by far yet attained, good size, round and solid, with few seeds, flesh sort plt.

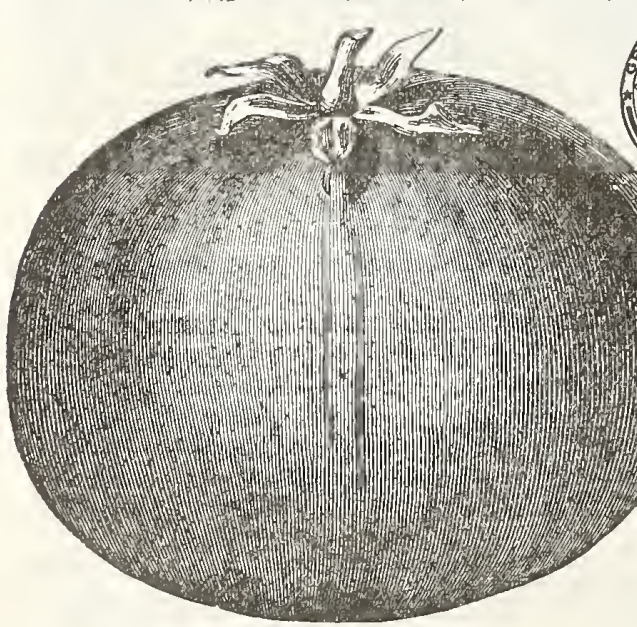

Buckbee's World's Fair Tomato.

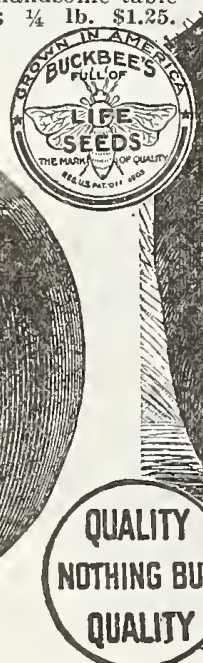

\section{HENDERSON'S DWARF PONDEROSA}

Quite Distinet from Original Ponderosa.

It is a cross between Dwarf Champion and the original Tal Ponderosa. The fruits are glossy, purplish-red, slightly oblong in shape, very deep through, with solid, meaty, bright-red flesh, no core, scarcely any watery pulp and but few seeds. Plants in clusters from July until frost. Pkt. 10e; 3 pkts. for 25 .

HENDERSON'S PONDEROSA or No. 400 Shape Perfect, Size Massive, Extra Prolific, Early and Late, Quality High.

Monster Tomatoes, often weighing two or three pounds each: rich, bright crimson; solid meat, exceptionally free from seed delicious flavor, raw or cooked; a single Tomato enough for a oz. 35e; 2 oz. $60 \mathrm{c} ; 1 / 1 \mathrm{lb}$. $\$ 1.00 ; 1 / 2$ lb. $\$ 1.75 ; 1 \mathrm{~b} . \$ 3.00$.

\section{ROYAL RED}

Fruit large, bright red, very uniform in size and shape and seldom cracks. Pkt. $4 \mathrm{c}$; oz. 16c; 2 oz. $30 \mathrm{c} ; 1 / \frac{1}{1 b}$. 50c; $1 / 2 \mathrm{lb} .90 \mathrm{9}$;

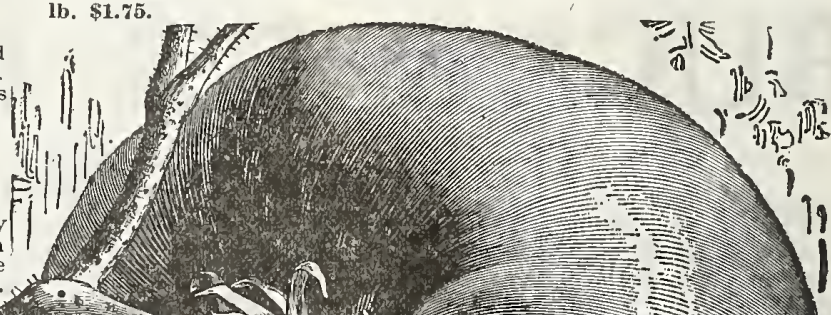




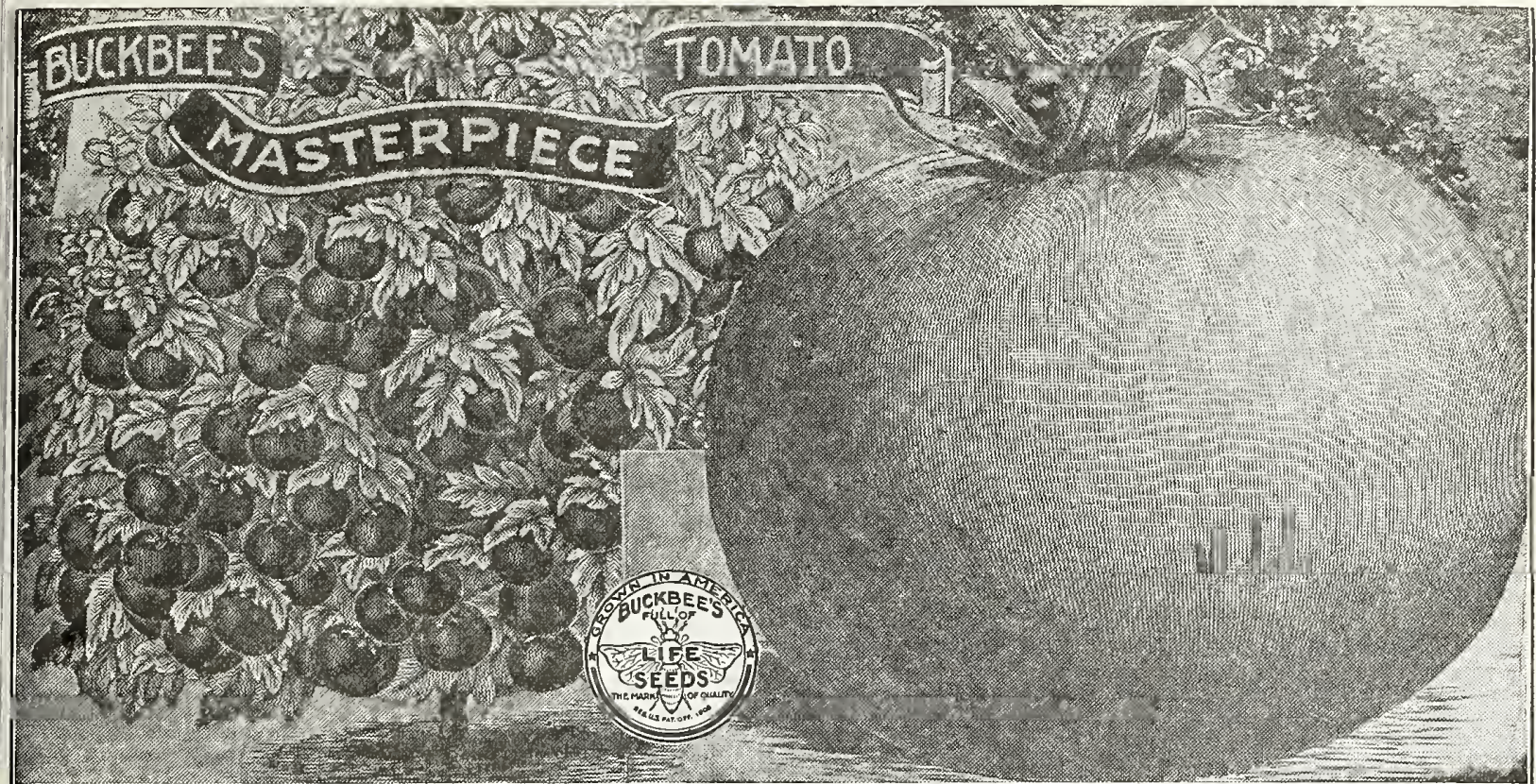

\section{(1)}

\section{BUCKBEE'S NEW

The Tomato that will surprise you for large size, handsome shape, beautiful rich crimson-purple color, thin and tough skin, solid meaty flesh, small seed cells, with few seeds, rich appetizing flavor, smooth clean fruit that does not crack, no hard or green core; and the true dwarf tree ty pe, plants well branched, strong and vigorous, phenomenally productive, bearing regular sized fruits continuously
until frost. In fact, New Masterpiece is the acme of perfection in the Tomato family, and the largest and best all around dwarf growing

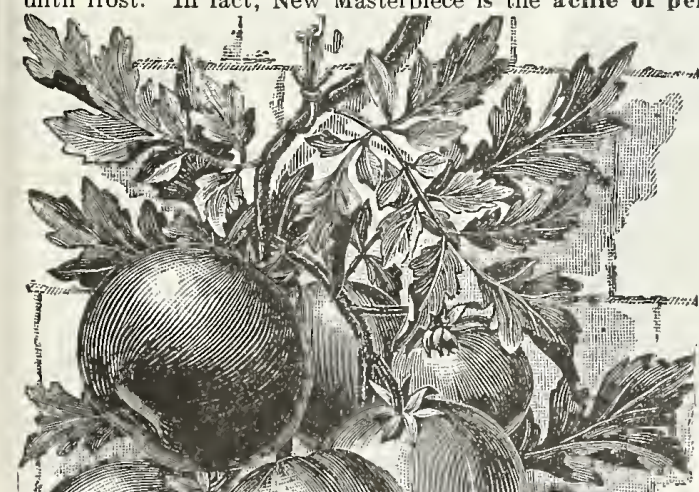

the for the home garden and market purposes and mill satisfy and surprise quently we have no hesitancy in offering "New Masterpiece" as a candidate for public favor; knowing a trial will convince the most skeptical it is the real thing in Tomatoes and stands at the head of the class as the leader. $25 \mathrm{c} ; 1 / 2$ oz. 35c; oz. 60c; 2 oz. $\$ 1.10 ; 1 / 4 \mathrm{Ib} . \$ 2.00 ; 1 / 2 \mathrm{Ib} . \$ 3.50 ; \mathrm{Ib} . \$ 6.00$.

\section{Buckbee's Golden Prize}

New golden yellow sort. Flesh thick and of extra quality. Grows in clusters. Produces enormous crops. Even if you should he prejudiced against a yellow sort, this will please you. Pkt. 6c; oz, 20c; 2 oz. 35̄c; $1 / 41$ lb. 60c; $1 / 2$ lb. $\$ 1.10 ; 1 \mathrm{~b} . \$ 2.00$.

\section{Buckbee's New Early June Pink}

An extremely early pink fruited Tomato similar to the popular scarletfruited Earliana in growth of vine, shape and size of fruit and time of maturing. Tomato. Pkt. 5c; 0z. 25c;2 oz. 40c; 1/4 1b. 75c; 1/2 Ib. \$1.40; 1b. \$2.50.

$$
\text { }
$$

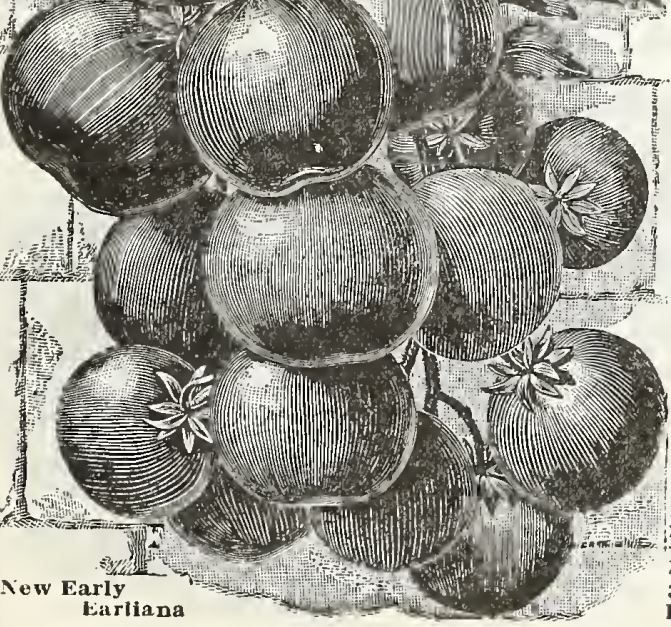

New Earliana An extremely early,
smooth, bright red Tomato of good size and flavor. Is among for the market, and not only remarkable for its very large size, bright red color. Pkt. $4 \mathrm{c} ;$ oz. 18c; 2 oz. $35 c ; 1 / 4$ lb $60 c ; 1 / 2$

\section{Early Acme} One of the earliest rieties. Medium size perfectly smooth and regular; very solid fruit, borne propurplish tint. Pkt. 4c; oz, 16c; 2 oz. lb. 90c: lb. 81.75 .

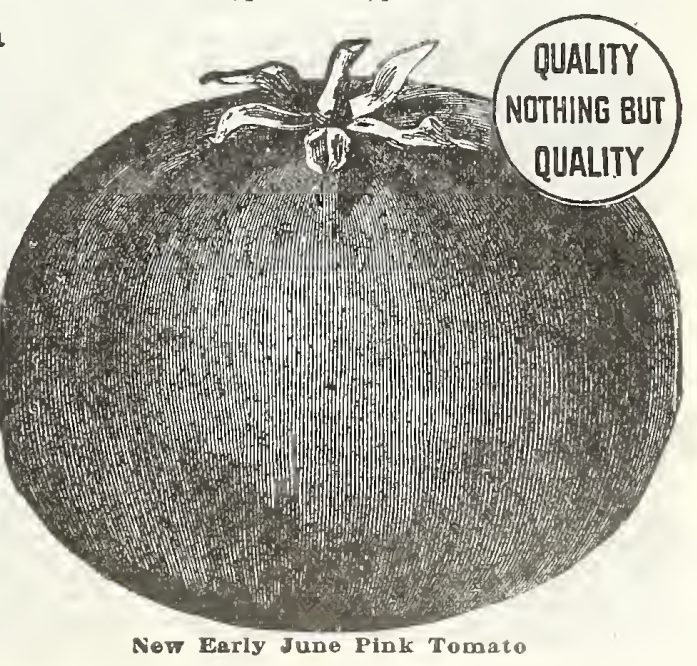




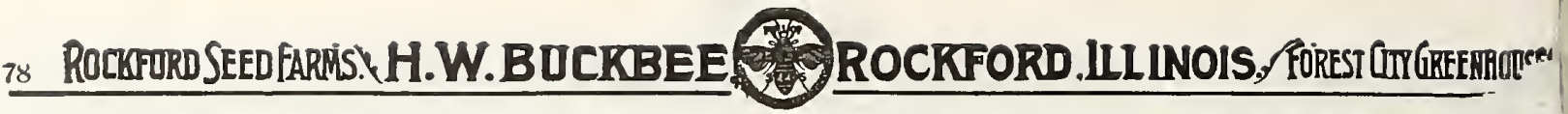
BUCKBEE'S "FULL OF LIFE" TOMATOES

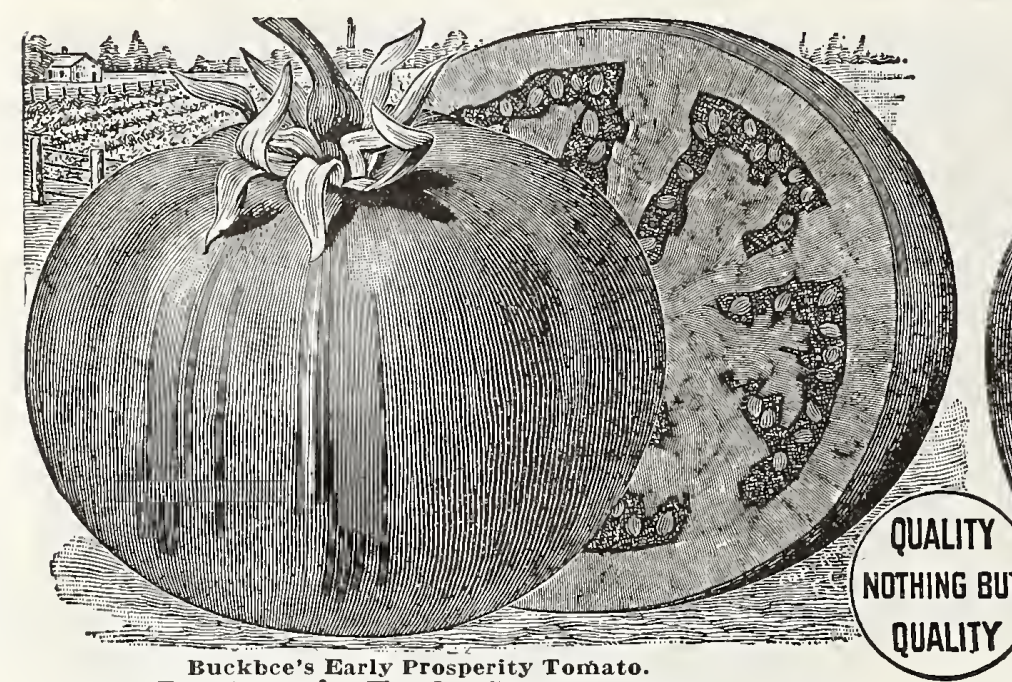

Buckbee's Early Prosperity

Prosperity is a Tomato of sterling worth; one that is bound to please. IT IS EARLY. IT IS A SPLENDID KEEPER. IT IS perfect fruit, excellent keeper and fine shipper; in fact we consider garden or for shipping purposes. Pkt. 10c; $1 / 2$ oz. 25c: oz. 40c: 2 oz. $750 ; 1 / 4$ lh. 81.25
Buckbee's New Tree or Station Tomato This Tomato owes its wide popularity to its stiff, vigorous, upright growth with fruit well above the
soil, and to the earliness with which it reaches and it is always round, smooth and symmetr A good shipper. Pkt. 10c; $1 / 2$ oz. 25c; oz. $40 \mathrm{c}$; $20 \mathrm{oz} .75 \mathrm{c} ; 1 / 1 \mathrm{lb}$. $\$ 1.25$

\section{Livingston's Globe} A new, very large, purple fruited Tomato of excellent quality. Fruits rather uneven

than most main crop sorts. The average Tomato is very deep, and almost globelb. 90c; $1 / 2$ lb. s1.50; lb. s2.50.

\section{Beauty}

We have been perfecting this to a larger, smoother fruit than the original stock, and think we have made it the smoothest and best of the large purple sorts. Fruit, large, unitorm excellent flavor. pkt. 3c; oz. 16
lb. 50c; $1 / 2$ lb. 90c; lb. $\$ 1.75$.

\section{Maule's Success}

Color bright red, smooth shape, well formed, an uncivaled home tonato, stiptser and cauning varity. Pkt.

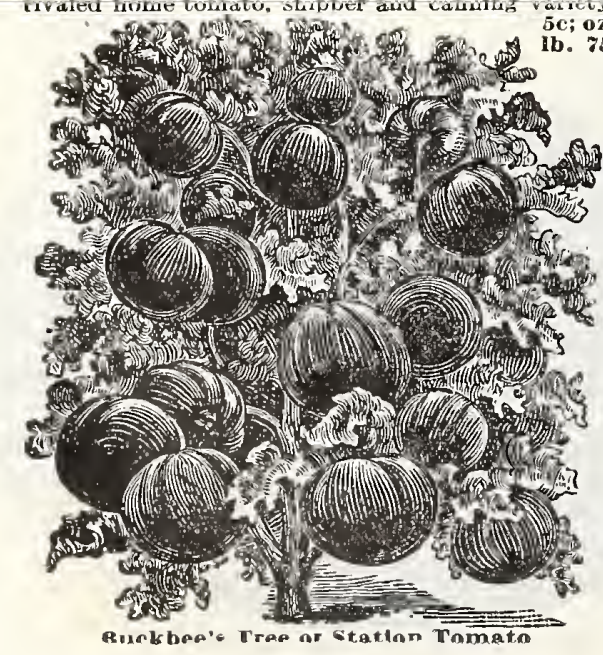

$5 \mathrm{c} ; 0 \mathrm{z} .25 \mathrm{c} ; 1 / 4$
$\mathrm{lb} .75 \mathrm{c} ; 1 \mathrm{~b} .32 .25$.
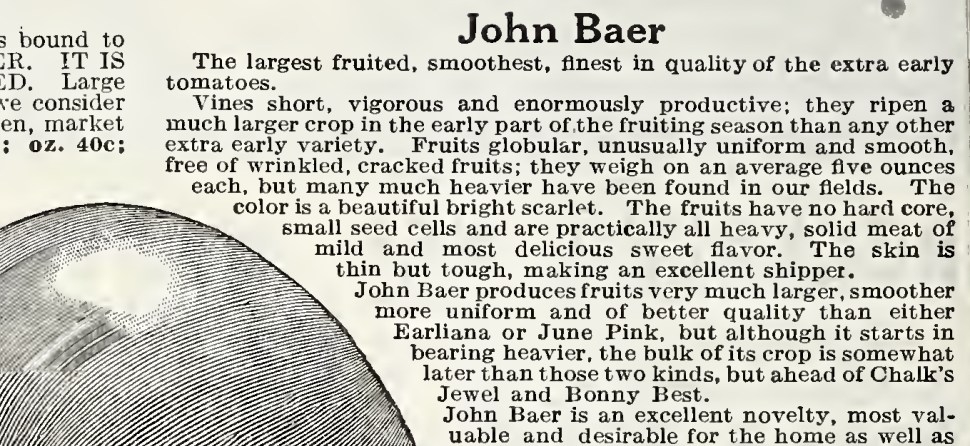

tomatoes. Vines short, vigorous and enormously productive; they ripen a extra early variety. Fruits globular, unusually uniform and smooth, free of wrinkled, cracked fruits; they weigh on an average five ounces each, but many much heavier have been found in our flelds. The color is a beautiful bright scarlet. The fruits have no hard core, small seed cells and are practically all heavy, solid meat of
mild and most delicious sweet flavor. The skin is thin but tough, making an excellent shipper.
John Baer produces fruits very much larger, smoother
more uniform and of better quality than either Earliana or June Pink, but although it starts in
bearing heavier, the bulk of its crop is somewhat later than those two kinds, but ahead of Chalk's Jewel and Bonny Best. uable and desirable for the home as well as the market gardener. Pkt. 10c; 1/2 oz. 20c; Buckbee's Spot Cash Fruit medium sized, oval, very smooth, of excellent quality and of exceedingly bright crimson scarlet color. Pkt. бc; oz. 35c; $1 / 41 \mathrm{~b}$. 75c; $1 \mathrm{~b} . \$ 2.50$.

\section{Buckbee's Snowball}

THE NEW WHITE TOMATO. A grand new variety of recent introduction, which always gives the best of satisfaction. Color is pearly white inside, skin nearly the same Almost a continual bearer coming into fruit early ickling or canning purposes, Pkt, 5c;1/2 25

\section{Honor Bright} Bright red, never rots. Pkt. $5 \mathrm{c} ; \mathrm{oz} .20 \mathrm{c} ; 1 / 4 \mathrm{lb} .65 \mathrm{c} ; 1 \mathrm{~b}$. Early Dwarf Champion The dwarf habit and upright tree-like growth permit close
planting. Hard to beat for
home use. Color purplish pink. Fruit smooth, symmetrical, $\Rightarrow$,
solid and meaty. A deservedly

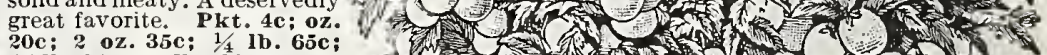
1/21b. \$1.25; lb. \$2.25.

The New Stone (Buckbee's Improved Strain) The Tomato for a Main Crop. We call this the king of the Livingston kinds, which
are the best ty pe of large, smooth, solid, "beefy" Toma4c; oz. 16c; 2 oz. 30c; $1 / 4 \mathrm{lb}$.

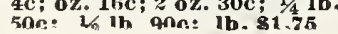

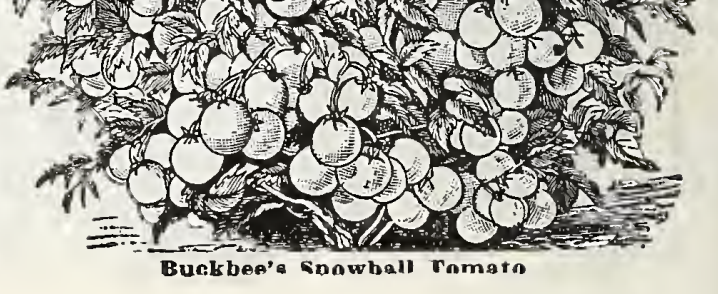




\section{Buckbee's}

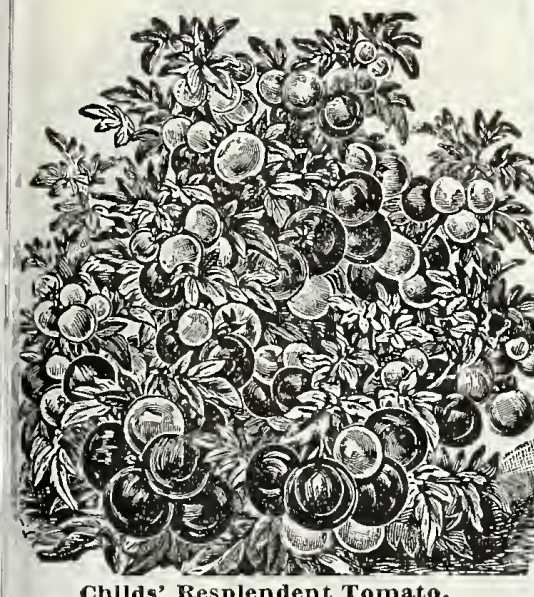

\section{Childs' Resplendent}

Fruit of all colors, green, white, lemon, pink, orange, yellow to deep ruby-red, abundance. Showy and attractive beyond description. Plant dwarf, stout, upright with novel foliage. Fruit large with more other. Pkt. 10e; 3 pkts. for $25 \mathrm{c}$.

Chalk's Early Jewel

Large extra early bright, red. Within a week to ten days as early as Earliana. being almost round or ball-shaped. Skin thin, good shipper. Pkt. 4c; oz. 18c;
2 oz.35c;1/4b.60e; 1/2lb.s1.10; lb.\$2.00.

\section{Matchless}

A large-fruited standard bright-red Tomato. Our superb strain should not be compared with seed of this variety com| keeper. Pkt. 4c; oz. 18c; 2 oz. 30c; 1/4

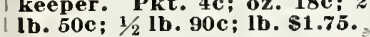

The Peach Tomato

This is the most delicious and handsomest Tomato ever introduced, having an appetizing fruity

New Rose Peach, Pkt. 5c; oz. 25c.

New Yellow Peach, Pkt. 5c; oz. 25c

\section{Red Cherry Tomato}

Looks just like cherries when growing. Fruit small, about five-eighths of an inch in diameter, perfectly round and smooth. Fine for pickles and preserves. Pkt. 4c; oz $20 c$.
YELLOW CHERR Y This variety differs from Red Cherry in color only. Pkt. 4c; oz. 20c.

\section{Golden Fig Tomato} The illustation shows its exact shape and habit of producing fruit in numerous clusters. It is wonderfully productive, yielding double that of other sorts. Makes pickles and preserves of the finest quality. Pkt.

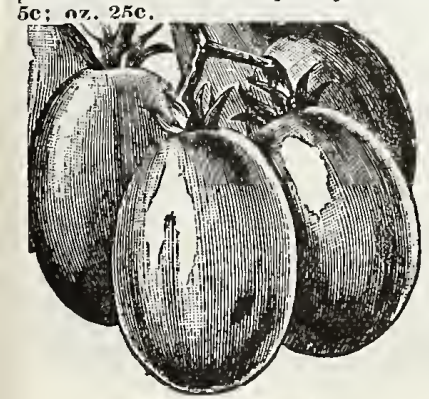

Foldan Fig Tomsto

"Full of Life" Tomatoes

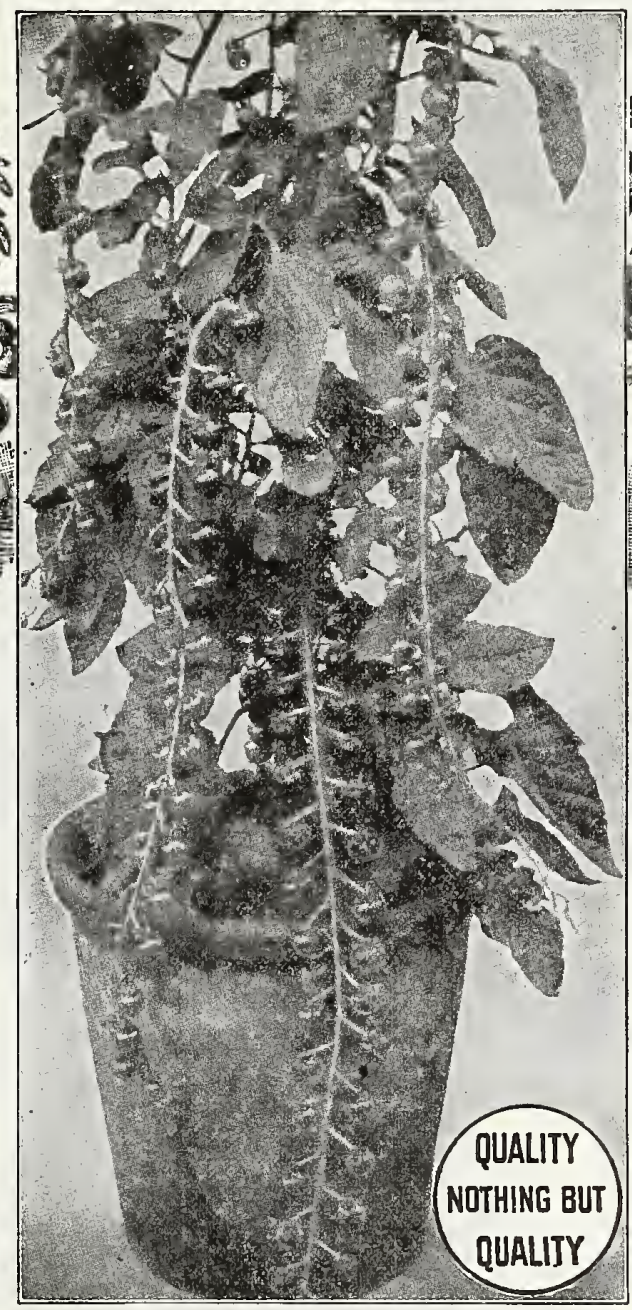

Burbank New Grape Tomato.

\section{Burbank's New Grape Tomato}

It somewhat resembles the Tomato, but its habits of grow th are more like the Grape. Of a handsome red excellent for preserving and using in various ways. Pkt. 6c; 3 pkts. 15c; $1 / 2$ oz. 35c; oz. 60c.

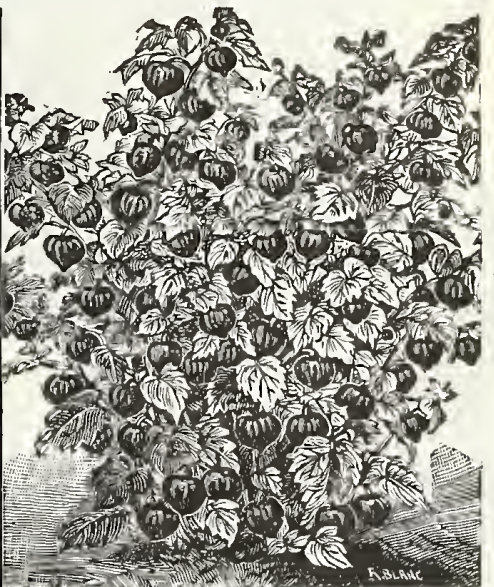

Strawberry or Husk Tomato.

Strawberry Husk or Winter Cherry Tomato

A Splendid Preserving Frult. The fruit has a pleasant strawberry-like flavor, and is much relished raw, but genexcellent. The small yellow fruits are enclosed in a husk or covering, and when ripe are half an inch in diameter. They are easy to grow and do well on almost any dry soil. Plants of low spreading growth and immensely productive. Pkt. 5c; oz. 25c.

\section{Plum Tomato}

Fruit true plum shape. Much esteemed for preserving.

Red Plum, Pkt, 4c; oz. 20c.

Yellow Plum, Pkt. 4c; oz. 20c.

\section{Pear Tomato}

This is a leading favorite for preserves. Red Pear, Pkt. 4c; oz. 20c.

Ceíow Pear, Pkt. 4c; oz. 20c.

Red Currant Tomato Extremely small, exquisite, delicate flavor. Pkt. 4c; oz. 20c.

Mixed Tomato Seed

For the benefit of many customers who would like to try all kinds, we offer this mixture of many sorts. Pkt. 5c; oz. $20 \mathrm{c} ; 2 \mathrm{oz} .35 \mathrm{c} ; 1 / \mathrm{lb}$ lb $60 \mathrm{c}$.

Mammoth Purple Ground Cherry Tomato

Enormous size fruit, $11 / 4$ to $21 / 2$ We can also supply the following new and standard varieties of Tomatoes, which are too well-known to require extended descriptions, at the following very reasonable prices:

Atlantic Prize....

Pkt, Oz. 20z, 1/1b.1/21b. 1b.

Favorite.

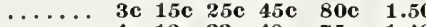

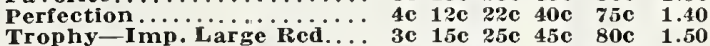

New Magnus.

Ignotum .........

Crimson Cushion.

Optimus

New Imperial

Dwarf Arlstocrat

Paragon.

Eariy Mlchigan

Buckbee's New Re gal.

Buckbee's State Fair .

Dwarf Stone

New Dwarf Glant....

Mikado or Turner's Hybrid.

3c $15 \mathrm{c} 25 \mathrm{c}$ 45e $80 \mathrm{c} \quad 1.50$ $\begin{array}{llllll}4 \mathrm{c} & 16 \mathrm{c} & 30 \mathrm{c} & 55 \mathrm{c} & 1.00 & 1.90\end{array}$ 4c $16 \mathrm{c}$ 30c $50 \mathrm{c}$ 90c 1.75 $4 c$ 16e 30c 55e 1.00 $5 \mathrm{c} 35 \mathrm{c} 60 \mathrm{c} 1.00$

3c $15 \mathrm{c} 25 \mathrm{c} 45 \mathrm{c} \quad 80 \mathrm{c} \quad 1.50$ $4 \mathrm{c} 16 \mathrm{c} 30 \mathrm{c} 50 \mathrm{c}$ 90c 1.75 $4 \mathrm{c} 25 \mathrm{c} 45 \mathrm{c} 80 \mathrm{c}$

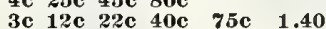

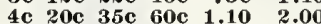

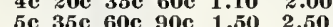

$10 \mathrm{c} 40 \mathrm{c} 75 \mathrm{c} 1.25$

5c 35c 60c $90 \mathrm{c} \quad 1.50 \quad 2.50$ $10 \mathrm{c} 40 \mathrm{c} 75 \mathrm{c} 1.25$

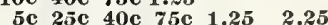
FOR TOMATO PLANTS SEE PAGE 84 inches in diameter. The flesh is green while the color of the skin is green, changing to a purple. When made
into preserves, has the appearance of green gages. Pkt. 5c; oz. 40c.

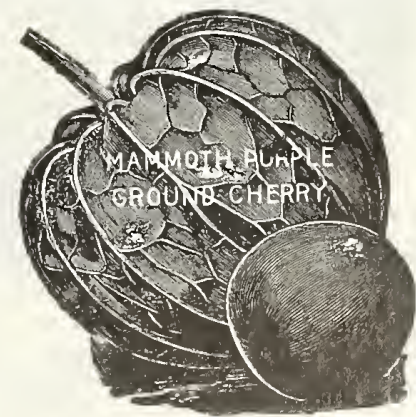




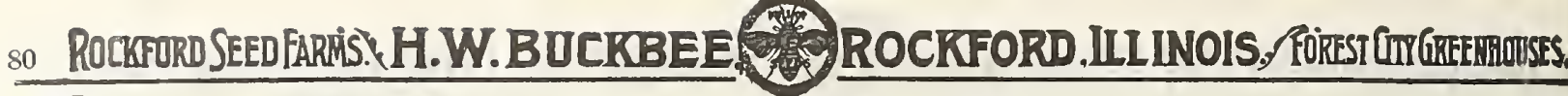

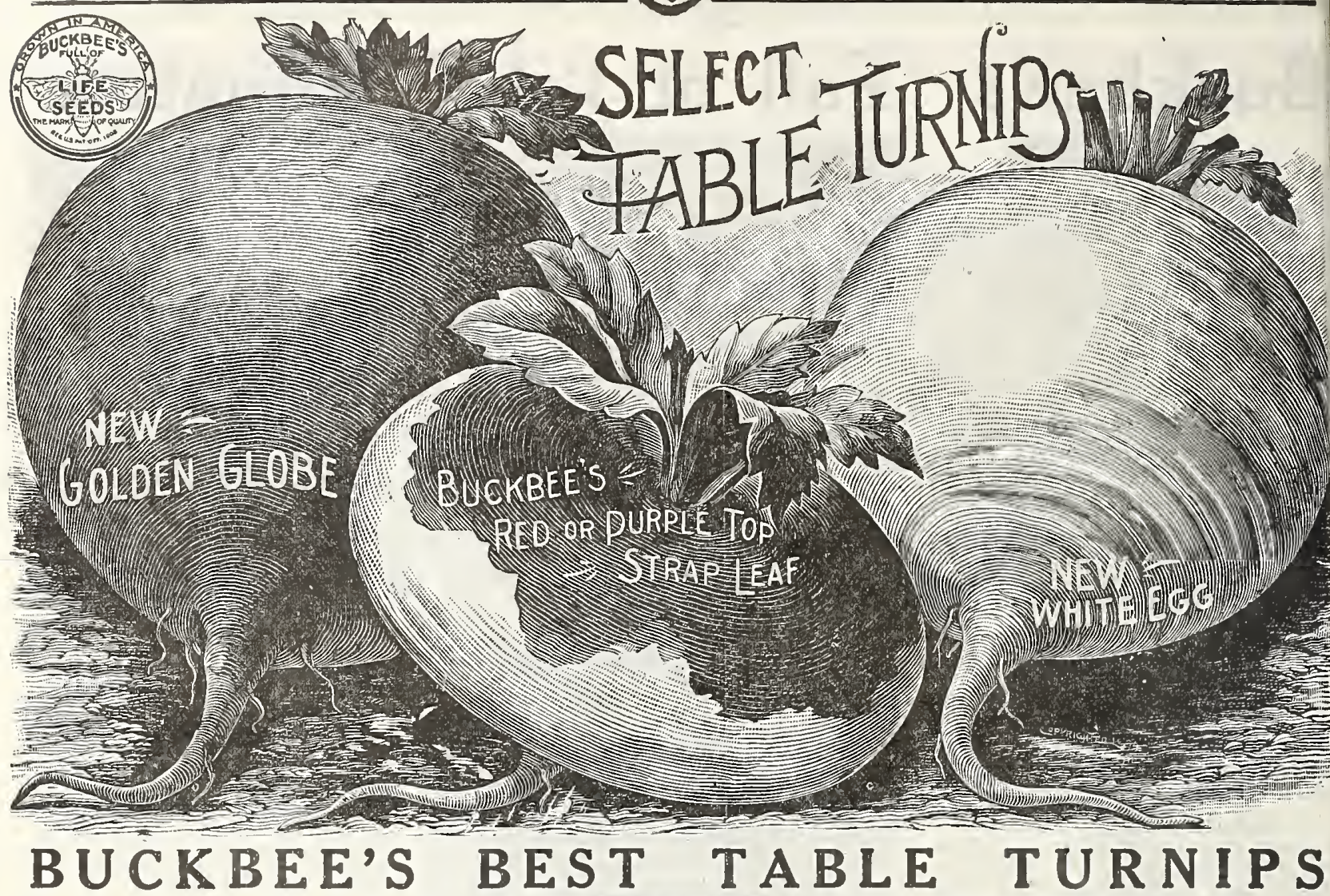

Buckbee's Red or Purple Top Strap Leaf There is probably a larger amount of seed of this rariety sown annually than any other turnip. As a
market variety, without doubt the peer of all. Has single tap root and a bright purple top. Matures 8
or 9 weeks from sorting. Plit. 4 c; oz. 6c; 2 oz. 10c; or 9 weeks from sorving. Pkt

\section{New Golden Globe}

Most delicious and sweetest of all sellow fleshed Turnips, very superior for all general purposes. Pkt. $4 \mathrm{c} ; 0 \mathrm{z} .7 \mathrm{c} ; 2$ oz. $12 \mathrm{c} ; 1 / 4$ lb. 18c; $1 / 2$ lb. 30c; 1b. 50c.

Early Snowball or Six Weeks

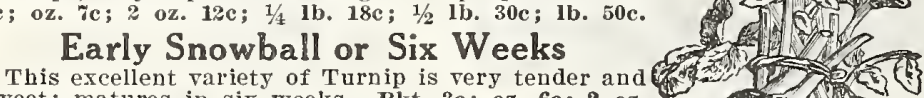
sweet; matures in six weeks. Pkt. 3 ; oz. $6 c ; 2$ oz. $10 \mathrm{c} ; 1 / 41 \mathrm{~b} .18 \mathrm{c} ; 1 / 21 \mathrm{~b} .30 \mathrm{c} ; 1 \mathrm{~b} .50 \mathrm{c}$.

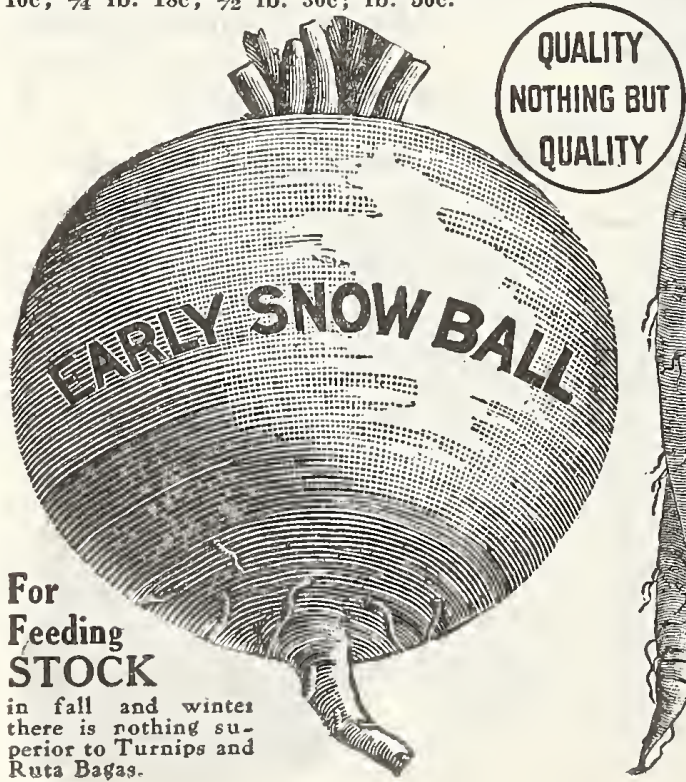

July is the time to plant Turnip Seed for Best ReEARLY and have your
hand.

in (3)
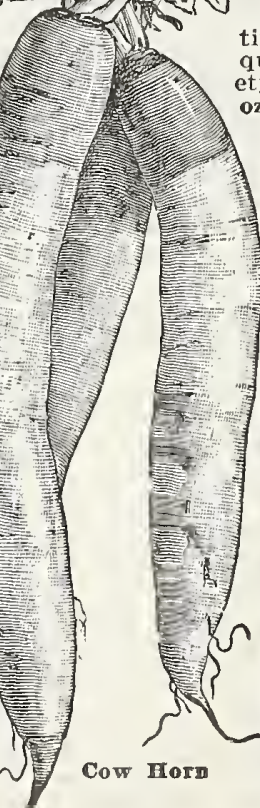

Cow Horm
NEW WHITE EGG

This is certainly one of the very choicest and finest varieties; comparatively new and producing beautiful egg-shaped roots with thin white skin. They are always firm, solid and of stwcet flavor. Pkt 4c; 0 z, $7 \mathrm{c}$ 2 oz. 12c; $1 / 4$ 1b. 18c; $1 / 2$ 1b. $30 \mathrm{c} ; 1 \mathrm{~b} .50 \mathrm{c}$.

\section{Cow Horn}

Sometimes called long White It is pure white with a little shade of green on top. Well flavored and of rapid growth. Fine for Fall and early Winter use. Verv valuable as a soil enricher; to improve worn ont land. Plkt. 4c; oz. $7 \mathrm{c}$; 2 oz. 12c; 1/4 1b. 18c; $1 / 2$ lb. 30c; 1b. 50c.

Buckbee's New Purple Top White Globe A globular variety, very eren in shape and of beautiful appearance. The flesh is white, of excellent quality and desirable for table or stock. This variety is a good keeper and a tine market sort. Pkt. 5c; oz. $8 \mathrm{c} ; 20 \mathrm{z} .12 \mathrm{c} ; 1 / 4 \mathrm{lb} .18 \mathrm{c} ; 1 / 2 \mathrm{lb} .30 \mathrm{c} ; 1 \mathrm{~b} .50 \mathrm{c}$.

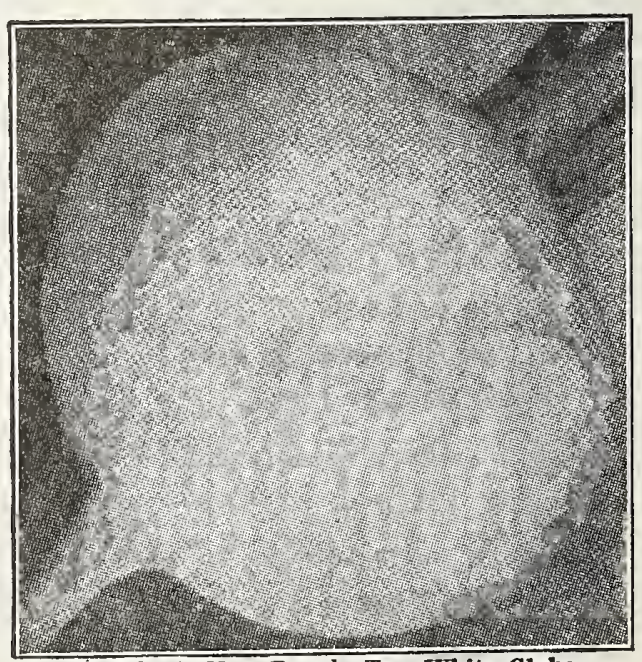

Buckbee's New Purple Top White Globe 


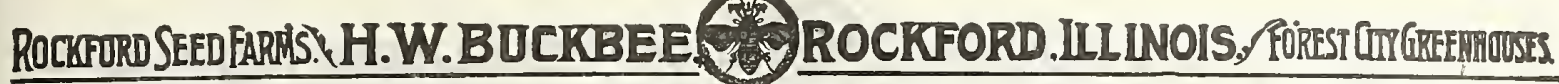

BUCKBEE'S BEST TABLE TURNIPS

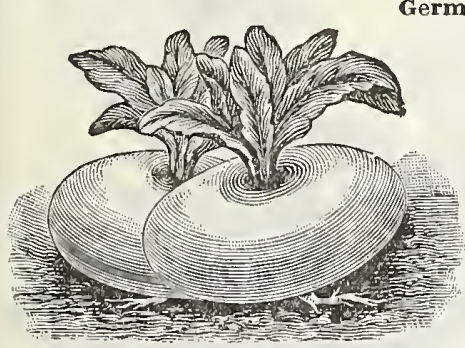

Buckbce's Extra Early Cameo

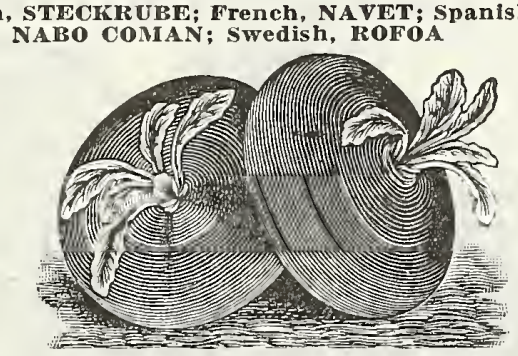

Buckbee's Extra Early Cardinal.

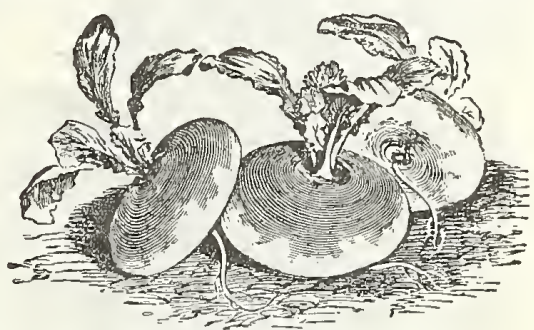

Extra Early Purple Top Milan.

\section{Buckbee's Extra Early Cameo}

A grand acquisition from the land of the Czar, identical with Buckbee's Cardinal in every way except color which is a beautiful pearl white. By all means include it in your order. Pkt. 5c; oz. 8c: pearl white. By all means include it in your

\section{Buckbee's Extra Early Cardinal}

Called by some Scarlet Kashmyr-Greatest Turnip Novelty ever offered. Very early variety, of magnificent shape, handsome appearance and wonderful keeping qualities. Outside skin brilliant cardinal red color. Tender and crisp. Pkt. $\mathbf{5 c} ; \mathbf{o z} .8 \mathbf{8} ; \mathbf{2} \mathbf{o z} .15 \mathbf{c}$; $1 / 4 \mathrm{lb} .25 \mathrm{c} ; 1 / 2 \mathrm{lb} .40 \mathrm{c} ; 1 \mathrm{~b} .75 \mathrm{c}$.

\section{New White Strap Leaf}

Identical with Buckbee's Red or Purple Top in valuable qualities, differing only in color, which is a beautiful ivory white. pkt. 3c; oz. 6c; 2 oz. 10c; $1 / 4$ ib. 15c; $1 / 2$ 1b. 25c; 1b. 40c.

\section{Yellow Aberdeen} A turnip of high merit, The flesl is yellow, tender, sugary and very solid. lb. $20 \mathrm{c} ; 1 / 2 \mathrm{lb}$. 30c; $11 \mathrm{~b} .50 \mathrm{c}$.

\section{THE BEST RUTA BAGAS}

Are you aware that Ruta Bagas, or Swedish Tur-

nips, are among the most valuable root crops?
Extra Early Purple Top Milan

The tops of this variety grow very small and are distinctly strapleaved, growing very erect and compact. The roots are small and Flesh white. Pkt. 5c: oz. 8c: 2 top of the root, clear white below lb. $80 \mathrm{c}$.

\section{Improved Early Flat White Dutch}

Excellent early garden variety and very much used. The root

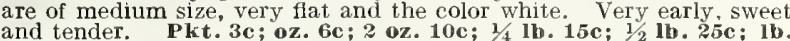
$40 \mathrm{c}$.

\section{Southern Seven Top}

Cultivated extensively and with profit in the South for the tops. which are used and are most excellent for greens. It is very hard will grow all Winter, but will not produce a good root Hardy keep well. Pkt. 3c; oz. 6c; 2 oz. 10c; $1 / 1$ 1b. 15c; $1 / 2$ lb. 25c; 1b. 45c.
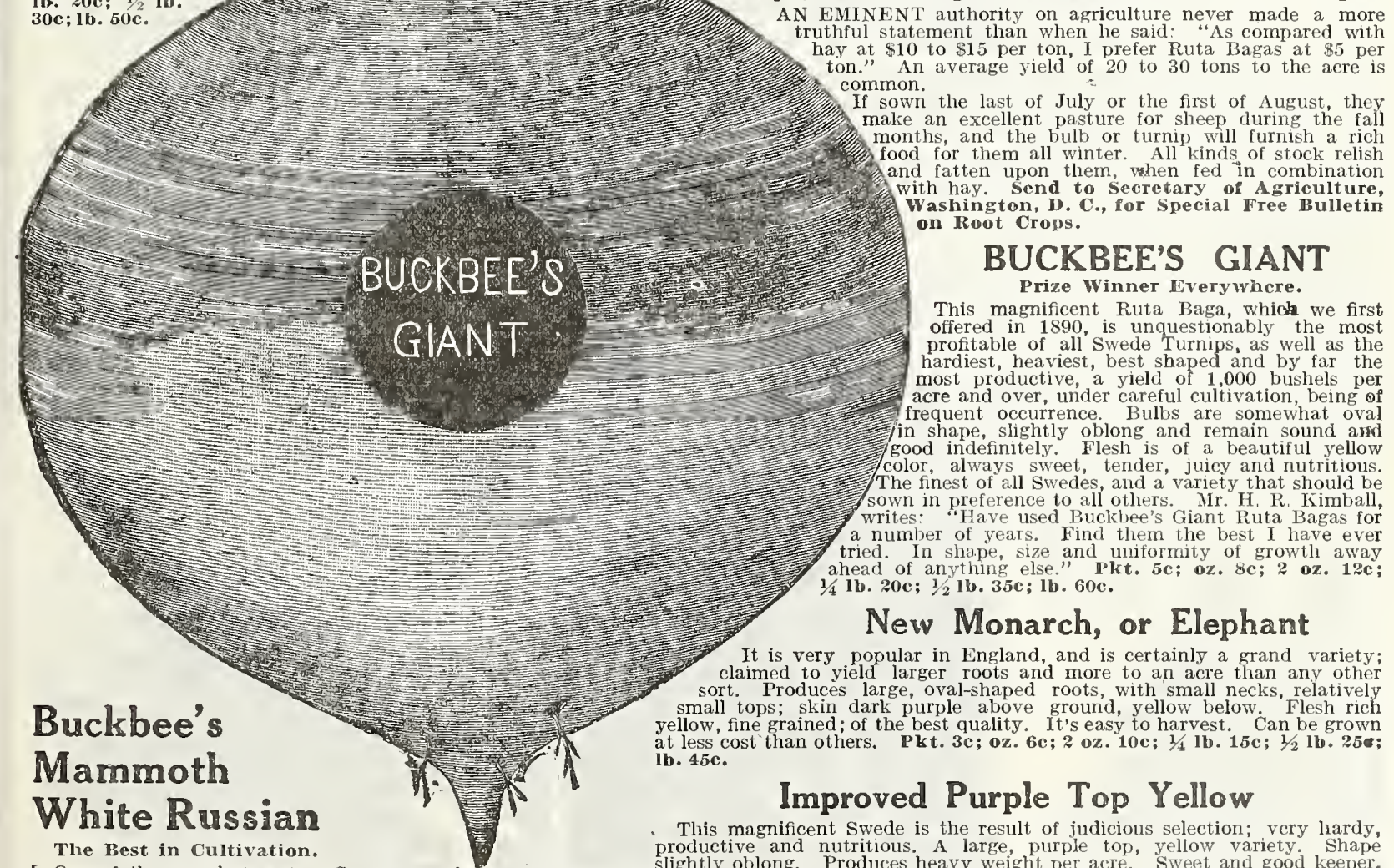

\section{BUCKBEE'S GIANT}

Prize Winner Everywhere.

This magnificent Ruta Baga, which we first offered in 1890, is unquestionably the most profitable of all Swede Turnips, as well as the hardiest, heaviest, best shaped and by far the most productive, a yleld of 1,000 bushels per frequent occurrence. Bulbs are somewhat ova in shape, slightly oblong and remain sound and
good indefinitely. Flesh is of a beautiful yellow
color, always sweet, tender, juicy and nutritious. The finest of all Swedes, and a variety that should be
sown in preference to all others. writes: "Have used Buckbee's Giant Ruta Bagas for a number of years. Find them the best I have eve ahead of anything else." Pkt. 5c: oz. 8c; 2 oz. 12c: $1 / 41 \mathrm{~b}$. 20c; $1 / 21 \mathrm{~b} .35 \mathrm{c} ; 1 \mathrm{~b}$. 60c.

New Monarch, or Elephant

It is very popular in England, and is certainly a grand variety, claimed to yield larger roots and more to an acre than any other small tops; skin dark purple above ground, yellow below. Flesh rich yellow, fine grained; of the best quality. It's easy to harvest. Can be grown lb. $45 \mathrm{c}$.

\section{Improved Purple Top Yellow}

This magnificent Swede is the result of judicious selection; very hardy, productive and nutritious. A large, purple top, yellow variety. Shape One of the grandest sorts. Grows very large with single tap root, small top, short neck. Strong constitution; certain cropper. Will stand severest weather. Produces a very heavy weight per acre, Keeps sound till late Spring. The //2 lb. 15c; $1 / 21 \mathbf{b}$. 25c; $1 \mathbf{b} .45 \mathbf{c}$.

Mrs. E. E. Chandler, R. R. 1, Campbell, Texas, writes:-I received my lants . W. plants and seeds all O. K. Am well pleased with them: also the 


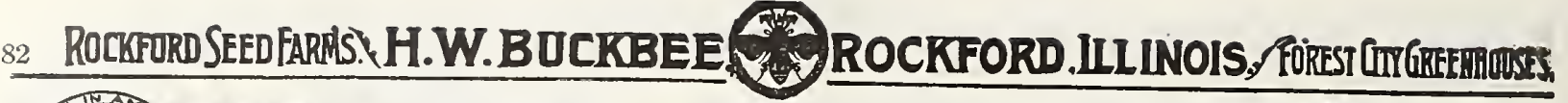

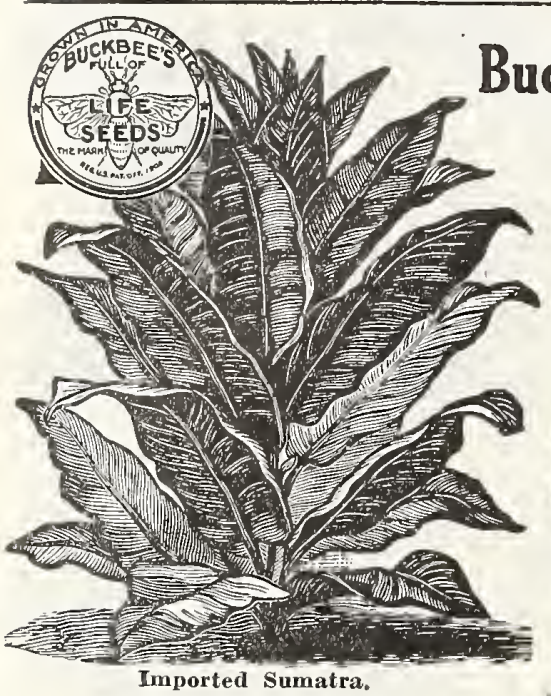

Cigar Varieties

Vuelta De Abajo-The finest, silkiest and highest flavored Havana Tobacco grown Pht. 10c; $1 / 2$ oz. 25c; oz. 40c. a high price. Pkt. 5c; 3/2 oz. 35e; oz. 60e. sometimes used as a manufacturing sort. Large, long leaf: very early, making two crops a season in some sections. Pkt. 4c; oz. 25e.

smoking Tobacco

Cozt. 4e; $1 / 2$ oz. 25e; oz. 40e. Plit, Cuban Seed Leaf-Imported Stock, acclimated and makes a fine Plkt. 4e; $1 / 2$ oz. $25 \mathrm{c}$; oz. $40 \mathrm{c}$.

\section{Select Varieties}

Bradley Broad Leaf-A popular variety for severai types-export, manufacturing and cigars. A good reliable variety and
succeeds where yellow tobacco can be grown. Pkt. 4c; oz. succeeds where yellow tobacco can be grown. Pkt. 4c; oz.
20c. Honduras-The newest bright Mahogany, one of the health Improved IIester-Adapted for wrappers, cutters, fillers or cigars. Fine long leaf of medium width, and cures bright. Pkt. 4e; Improved Long-Leaf Gooch-For cutters and wrappers. Has long. leaf of fine texture and makes fine bright tobacco. Pkt. Improved White Burley-This variety is especially valuable to manufacturers either for cut or plug tobacco. Often used for Improved White Stem Oronoko-Fine for wrappers, cutters and 1/2 oz. 25e; oz, 40e. Improved Yellow Oronoko-For yellow wrappers, cutters and

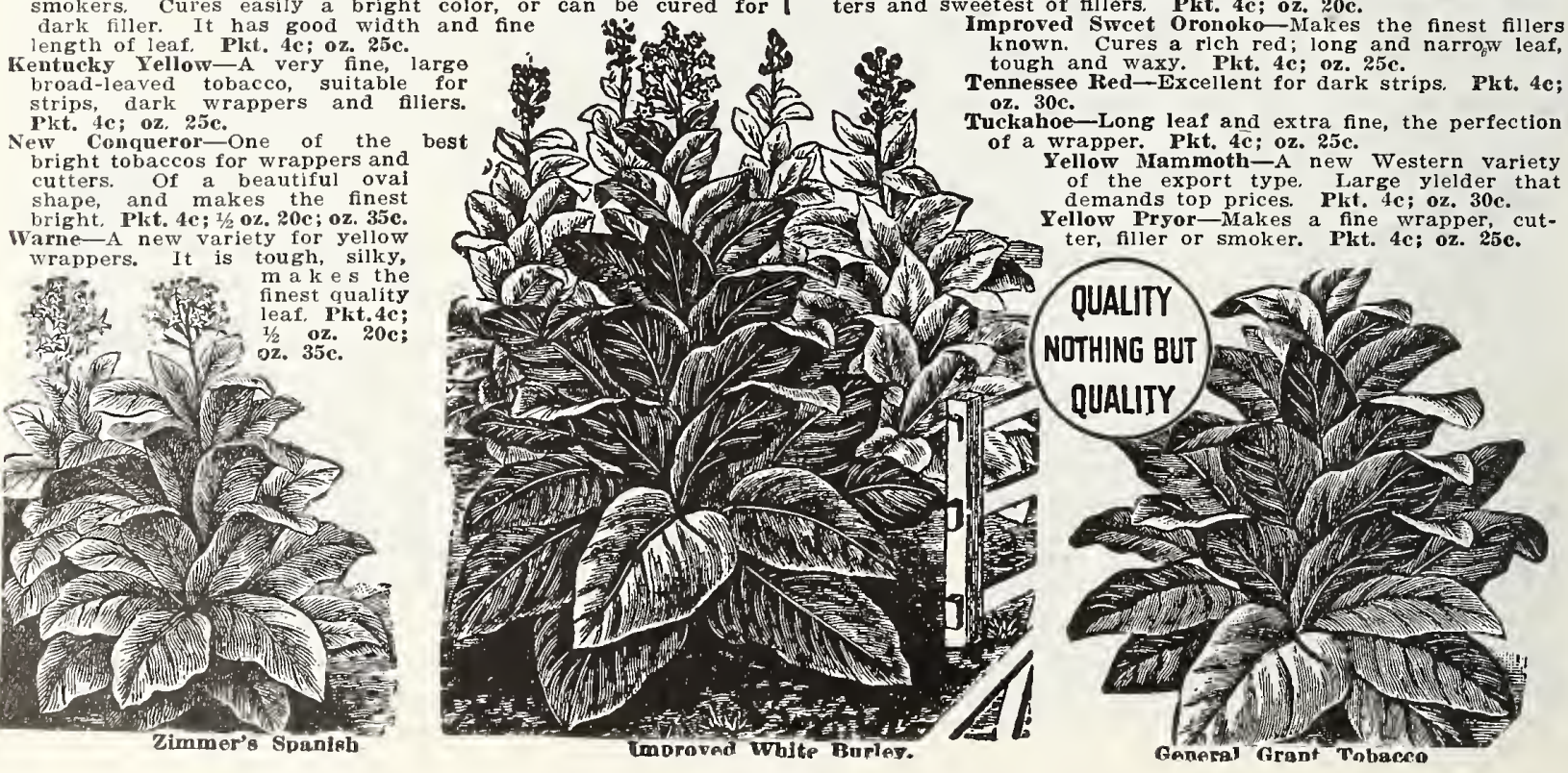
finest of high grade Cigars. Plkt. 10c; $1 / 2$ oz. 60c; oz. 95c. splendld plpe Tobacco, as it has a fine cinnamon fiavor. Pkt. $4 \mathrm{c} ; 1 / 2$ oz. 20c; oz. 35c.

General Grant-One of the finest, earliest and most popular kinds for Cigars. Matures far north as Canada; leaves large. Pkt. 5c; $3 / 2$ oz. 20c; oz. 30c.

Imported Harana-The finest Cuban stock, imported from the famous Vuelta Valley. Plit. 4e; $1 / 2$ oz. 25e; oz. 40c.

Pennsylvania Seed-Leaf-The best grown in the famous Lan-

Persian Rose Muscatelle-Finer than Muscatelle, and can be relied upon to make the finest Cigar stock. Pkt. 4c;

Zimmer's Spanish-Calied by some Comstock Spanish, One of the finest Cigar Tobaccos, producing leaves of silky texture; 20c; oz. 35e.

\section{Standard Varieties}

Beat All, or Lacks-A heavy, dark type and makes a splendid mahogany. Good texture for dark wrappers and fillers. Pkt. 4c; oz. 30c.

Blue Pryor-A large, long and broad leaf. Makes a rich, waxy tobacco for black wrappers, strips and fillers. Pkt. 4c; oz. 25c. (or making

Gold Leaf-For plug wrappers, cutters and fillers. Pkt. 4c; $1 / 2$ oz. 20c; oz, 35c.

Little Dutch-Popular variety, succeeds nicely in the Northern States, Valuable for all purposes, Plit. 4c; oz, 30c.

One Sucker-A ark manufacturing sort

leaf, and good, rich quality, Pkt. 4c.; oz. 25c. Improved Swcet Oronoko-Makes the finest fillers known. Cures a rich red; long and narrow leaf, Tennessee Red-Excellent for dark strips. Pkt. 4c; oz. 30c.-Long leaf and extra fine, the perfection of a wrapper. Pkt. 4e; oz. 25e. Western variety of the export type. Large ylelder that demands top prices Plat, 4c; oz, 30c. Yellow Pryor-makes a fine wrapper cut- 


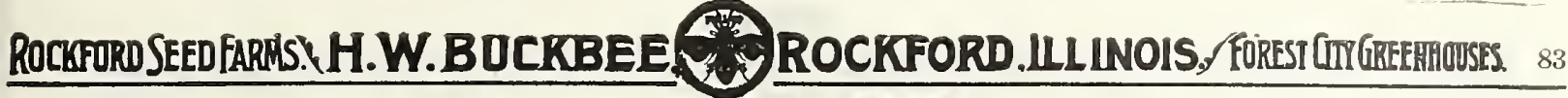

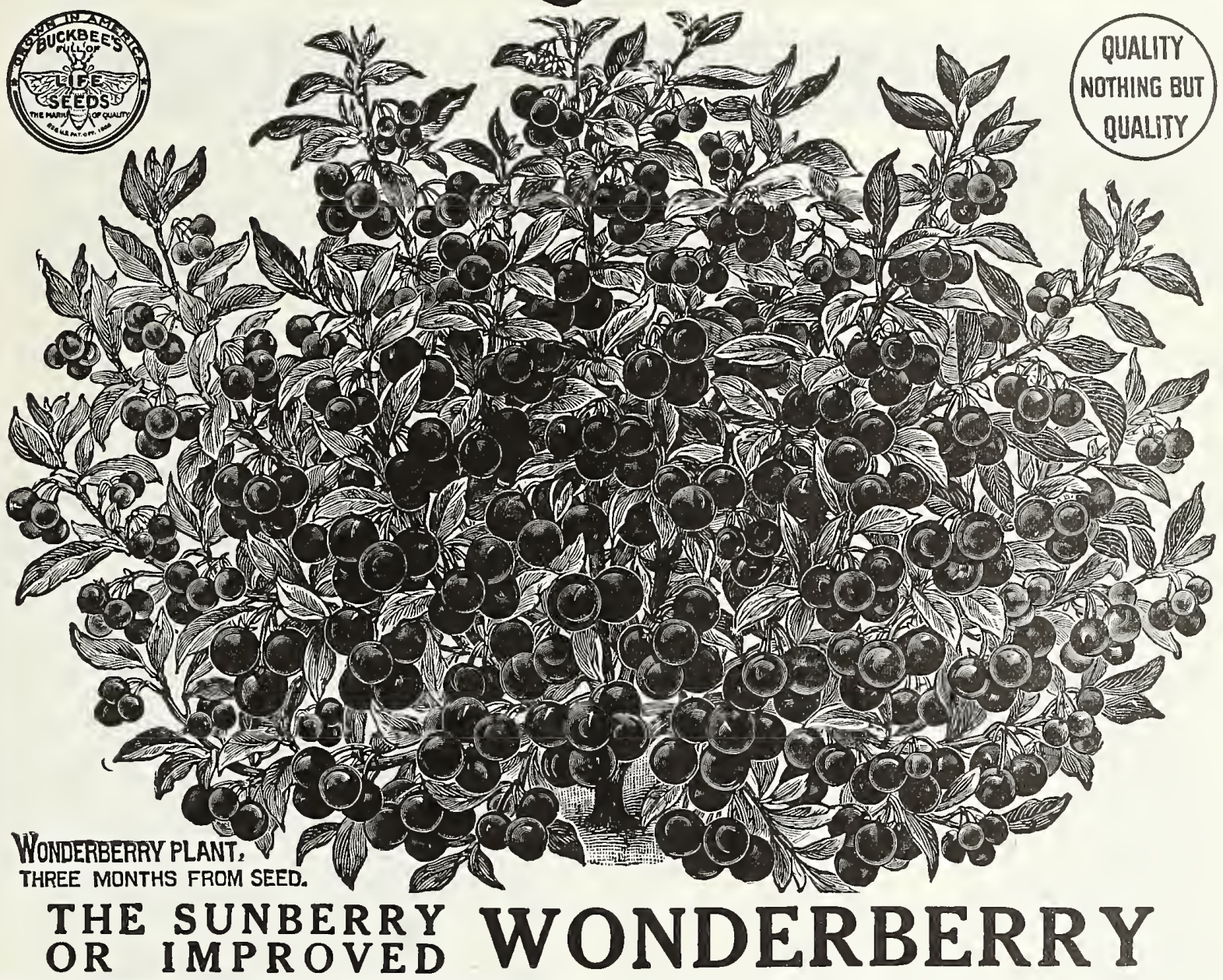

THIS IS LUTHER BURBANK'S NEWEST AND GREATEST PRODUCTION; A LUSCIOUS BERRY THAT MLY BE GROWN AND

RIPENED FROM SEED IN ANY SOIL OR CLIMATE IN THIEE MONTIS.
Fruit more like a great, rich, luscious blueberry than anything else. Blue-black in color, fine in flavor and unsurpassed for eating raw, cooked, canned or preserved in any form. It is easily the greatest garden fruit ever introduced, and equally valuable for the North, South, East or West, or, in. short, any part of the world. Easiest plant in the world to grow. Succeeding anywhere and yielding great masses of rich fruit all Summer and Fall. The greatest boon to the family garden ever known. Everybody can the fruit wanted. THE QUALITY of the Sunberry or Improved Wonderberry is sweet and delicious when fully ripe. Like the grape it should have time to ripen well after turning black in full sun. Skin, which may seem a little tough in a raw state, cooks tender. Seeds small, one-quarter the size of Tomato seed, and cook soft, and a re not noticeable. PRICE OF SEED: Pkt. 10c; 3 plts. 25c; $1 / 2$ oz.
60e: oz. \$1.00. PRICE OF PLANTS. We can supply a limited number of nicely started plants at 10e each; 3 for $25 \mathrm{c}$; 75 e per doz. postpaid.

\section{Burbank's Upright Sweet Sunberry \\ An Absolute Novelty.}

This type of the Sunberry is noted for its more upright growth and ease of picking, due to such characteristics of growth. It is a very superior berry and as it is not as much of a spreading habit a the older type it conserves the garden area. Pkt. 10c.

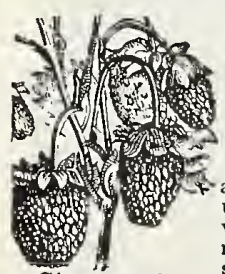

\section{Strawberries} from Seed

\section{BRAZILIAN EVERBEARING}

It will begin to bear fruit in about four month after seed is sown and continues to produce fruit until very late in the fall. Seeds sown in April will give ripe berries in July. The berries are not as large as the standard varieties, but arc of Strawberries superior quality and have the rich wild Straw-

from Seed. berry flavor. The plants are everbearing in all summer, and comes perfectly true from seed. It also makes a beautiful pot plant, will grow well in the house, and even fruit during the winter. Perfectly hardy everywhere and easy to grow. A packet of seed should produce 40 to 50 plants. Pkt. 10c 3 pkts. 25e.

\section{SMALL FRUIT SEEDS}

Blackberry-Pkt. 10c; oz. 50c. Currant-Pkt. 10c; oz. 20c.

Gooseberry-Pkt. 10c; oz. 30c.

Raspberry-Pkt. 10c; oz. 20c.
LARGE FRUIT SEEDS

Pkt. Oz. 1/4 lb. 1b.

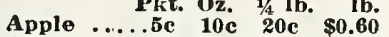

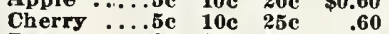

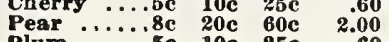

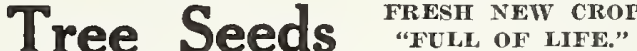

Evergreen seeds should be sown very early in Spring, in a firm, sandy seed bed. Give the young seedlings some shade the first summer. Deciduous tree seeds should be planted from April to the middle of May in drills about 2 feet apart and covered about half an inch in depth. It should also be remembered that while fome lie dormant a whole season.

\section{EVERGREEN TREE SEED}

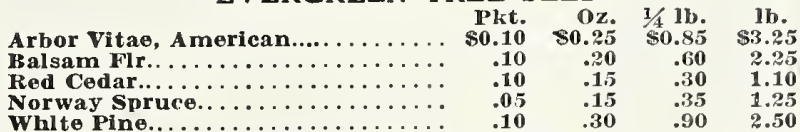

Whl te Pine.

DECIDUOUS TREE SEED

Ash, Whlte. . . . . . . . . . Pkt. Oz. $1 / 41 b . \quad 1 b$.

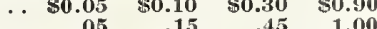

$\begin{array}{cccc}0.05 & .15 & .45 & 1.00\end{array}$

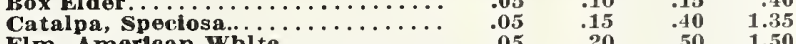

Elm, American whl te.........

Honey Locust. . . . . . . . . . . . . .

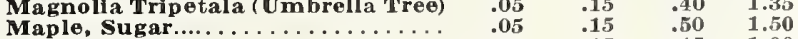

Maple. Sugar.

Osage Orange.

$.05 \quad .15$

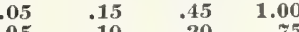

Russlan Mulberry..................

NUT BEARING TREE SEED

Black Walnut, postpaid, lb. 25c; not prepaid, 10 lbs. for $75 \mathrm{c}$

Butter Nuts, postpaid, lb. 25c; not prepaid, 10 lbs. for $95 \mathrm{c}$. 


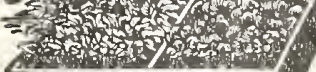

TOMATOES: CABBAGES

Hammond's Slug Shot

Guaranteed to destroy

Potato Bugs and those on

Tomatoes and Egg Plants.

Currant Worms. Cabbage

Beetles and Striped Bugs

on Melons, Turnips, Beets,

Onions. Postpaid, 1b, 15c

ny express or freight,

not prepaid, 5 lbs. $30 \mathrm{c}$

$101 \mathrm{bs} .50 \mathrm{c} ; 25 \mathrm{lbs} . \$ 1.25 ; 50$
lbs. $\$ 2.25 ; 100 \mathrm{lbs} . \$ 4.25$.

\section{EARLY CABBAGE-}

The Best Hand Transplanted Stock.

Buckbee's Extra Early New Queen

Buckbee's New Early Race Ho

Henderson's Farly Summer

EARLY CA ULIF LOWWI-

The Best Hand Transplanted Stock

Buckbee's Extra Early Chief

Henderson's Early Snowball. .

Extra Early Erfurt..

EARLY PEPPER PLA N̈TS

The Best Hand Transplanted Stock

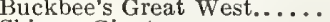

Ruby King.

Sweet Mountain...

EARLY EGG PLANTS-

The Best Hand Transplanted Stock.

Buckbee's New Large Purple.

WEET POTATO PLANTS

The Very Best Stock

Buckbee's Extra Early Yellow.

Buckbee's Extra Early White

Yellow Jersey

Yellow Nansemond.....

Red Bermuda DOZENS B M MAL POSTPAID; HUNDREDS AND THOUSAND LOTS BY EXPRESS AT BUYER'

It is important that you send your order in early so that we can reserve our best plants for you; to be shipped We

We make a specialty of raising the most Superior Grade of Vegetable Plants, especially Early Cabbage Tomato Plants for gardening, etc. Our plants are started early and grown in a low temperature, transacking and thoroughly hardened; produced from the very finest stock seed. By our perfect system of Plants by Express.

Time When Vegetable Plants are Ready for Shipment.-Early Cabbage and Caulifiower about Apri and Late Cauliflower about June 1 st; and Celery, June 25th.

Positively No Orders Fillcd for Less Than one Dozen of any Variety, DON"T ASIK IT.

This List is Subject to Change Without Notice, Owing to Damages from Bad Weather, Insects, Etc.

\begin{tabular}{|c|c|c|c|}
\hline Per & Per & & \\
\hline Doz. & 100 & Per & Per \\
\hline Post- & Post- & 100 & 1000 \\
\hline paid. & paid. & by Ex. & by Ex. \\
\hline$\$ 0.30$ & $\$ 1.35$ & S0.95 & $\$ 7.50$ \\
\hline .30 & 1.35 & .95 & 7.50 \\
\hline .30 & 1.35 & .95 & 7.50 \\
\hline .25 & 1.25 & .90 & 7.25 \\
\hline .25 & 1.25 & .90 & 7.25 \\
\hline .30 & 1.35 & .95 & 7.50 \\
\hline .30 & 1.35 & .95 & 7.00 \\
\hline .30 & 1.35 & .95 & 7.50 \\
\hline .30 & 1.35 & .95 & 7.50 \\
\hline .30 & 1.35 & .95 & 7.50 \\
\hline .30 & 1.35 & .95 & 7.50 \\
\hline .20 & .80 & .60 & 4.25 \\
\hline .15 & .70 & .55 & 3.75 \\
\hline .20 & .80 & .60 & 4.25 \\
\hline .15 & .70 & .55 & 3.75 \\
\hline .20 & 1.10 & .85 & 7.50 \\
\hline .20 & .65 & .45 & 3.25 \\
\hline .20 & .65 & .45 & 3.25 \\
\hline .15 & .60 & .40 & 2.75 \\
\hline .15 & .60 & .40 & 2.75 \\
\hline .20 & .65 & .45 & 3.25 \\
\hline .20 & .65 & .45 & 3.25 \\
\hline
\end{tabular}

\section{Buckbee's Frost Proof Cabbage Plants Will Double Your Buckbee's Frost Proof Cabbage Plants Profit, Why?}

There are a number of sea islands along the South Carolina sea oast where the soil and climatic conditions are just suited for growing tough, hardy Cabbage plants during the winter and early spring. The seed is planted in the open fleld in the months of October, November December, January and February. The plants make a slow but steady growth, until at $\mathbf{8}$ to 10 weeks of age they are very tough and hardy, the buds are purple and the outer leaves a reddish brown. When in this condition they can be shipped to territory farther north and planted in the open ground a month to six weeks sooner than the home-grown hot bed or cold frame plants could be planted. These frost-proof Cabbage plants will stand a temperature of 8 to 10 degrees ered with ice, sleet or snow after they are planted will not injure them.

The top of the plant does not grow until your regular spring weather opens up, but the roots grow from the time they are planted and just as soon as spring weather starts, the established root growth assimilates the fertilizer in the soil, the plants grow very fast, maturing headed Cabbage 10 days to three weeks sooner than you can miture them from hot bed and cold frame plants. You know what the difference in profit will be if your crop is matured and marketed before the general crop from home-grown plants is matured.
To get the advantage of these frost-proof Cabbage Plant they must be planted a month or six weoks earlier than you would plant home-grown plants.

Our Cabbe seed and are shippcd direct from our growing station in South Carolina by mail or express. We can fill orders from December 1st to April 15th. We guarantee plants to arrive in good condition.

The plants will be somewhat wilted añd have a hard, stunted appearance, which will bo disappointing to persons who have never used these plants before. Regardless of appearance, they will produce the results.

Can supply only the following varieties of frost-proof Cabbage Plants: Early Jersey Wakefleld, Charleston or Large Wakefleld, Succession and Early Flat Dutch.

Plants packed $500,1,000$ or 2,000 to the crate. Ordered in these quantities, they weigh about 25 pounds per 1,000 crated for shipment, and can be shipped to any point where they will arrive within four or five days. No plants shipped C. O. D.

Prices: By mail, postpaid, 35 cents per 100. By express, purchaser paying charges, which under special rates are very low, 500 for c1,00; in lots of 1,000 to 4,000 at $\$ 1.50$. 1,000 in lots of 5,000 to 9,000 at $\$ 1.25$ per 1,000 ; in lots of 10,000 at $\$ 1,00$ per 1,000 .

\section{Rhubarb Roots (See Page 61)}

\section{Asparagus Roots (See page 4)}

Mrs, W.J. Iutchinson, Caspiana, La., writes; Thank you very

Mrs. A. L. Wood, Thurman, Neb., writes; I received the Sweet Potato Plants by mail in the best of condition. Thank you for your romptness.

Robt. Gr. Martin, 952 S. Cooper St., Memphis, Tenn., writes; I received the order of Plants all $O$. $K$., and must say, you certainly know how to sbip plants. They look as fresh as if they had just been taken out of the bed.

Mrs. H. P. Henriekson, Box 73, Ulen, Minn., writes; I received the plants in good shape and was well pleased with them

Mrs. Grace Hyde, Springfleld. Tenn.. writes: The plante I re celved from you arrived in fine condition.

much for the splendid plants you sent me. I am sure they will all grow.

Ir. L. Sierra Horeasitas, Loma del Ray, Facubaya, Mexico. writes: The plants you sent me some days ago by Wells-Fargo Express came in satisfactory condition. I am very much pleased with them and congratulate you for your skillful manner of packing plants to long distances. Notwithstanding the plants were delayed seven days in transit they reached me fresh and green. Sure to live. 


\section{BCA}

a 3 .

2.1. 5.

\section{"Full of Life"}

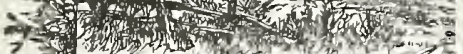

Th:

\section{Farm Seeds}

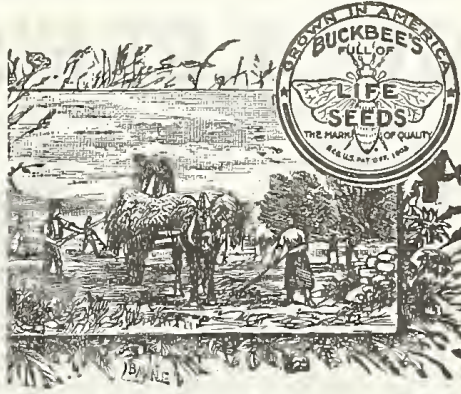

SPECIAI NOTICE For lowest market prices on Farm Seeds, Potatoes and SPECIAL NOTLE Onion Sets in Bulk, see back page of order sheet, and if the 10-day limit has expired before you are ready to order, send for new list, which will be mailed promptly on request.

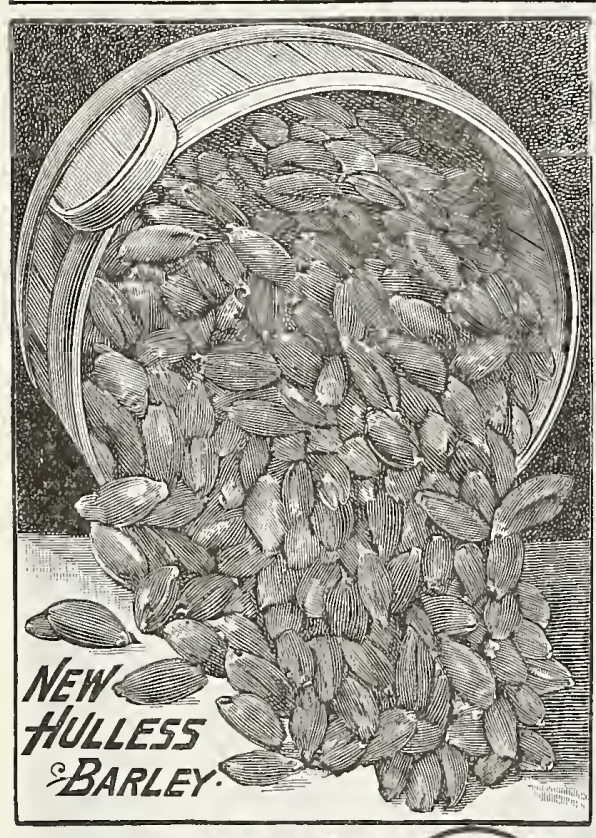

\section{BARLEY}

A SPLENDID NURSE CROP AGH IN FEEDING VALUES

\section{the} beardless and as easy to grow and handle as Oats, and is a heavy cropper, yielding from 50 to 75 bu, per acre, quality excellent. Prices, postpaid, 1b, 25 ; 3 los. 60c. grazing; or it may be cut before it heads out, as a hay crop. As Barley stools well out it really makes better grown and succeeds so well throughout the ser should be much more largely prized. Sow washing of solls by Winter rains it is highly lb. $25 \mathrm{c} ; 3$ lbs. $60 \mathrm{c}$.

NEW WIITE HULLESS BARLEY-A Barley with a grain like

Wheat. An excellent feeding sort, especlally

Weighs over sixty pounds

as the midd or paid, per ib. 25e; 3 lbs, 60c.

ODERBRUCKER, or WISCONSIN No. 55 BARLEY

about the same as Manshury in time of maturity, manner of

growth and general appearance, but has

tent of 15 per cent., or nearly double the

it a very valuable leading farmers and stockmen, who are now appreciating more and more the value of Barley as a food for all kinds
stock, horses as well as cattle. On account of its large centage of protein, it is also one of the best malting Barleys. Prices, postpaid, per 1b. 25e; 3 lbs. 60e.

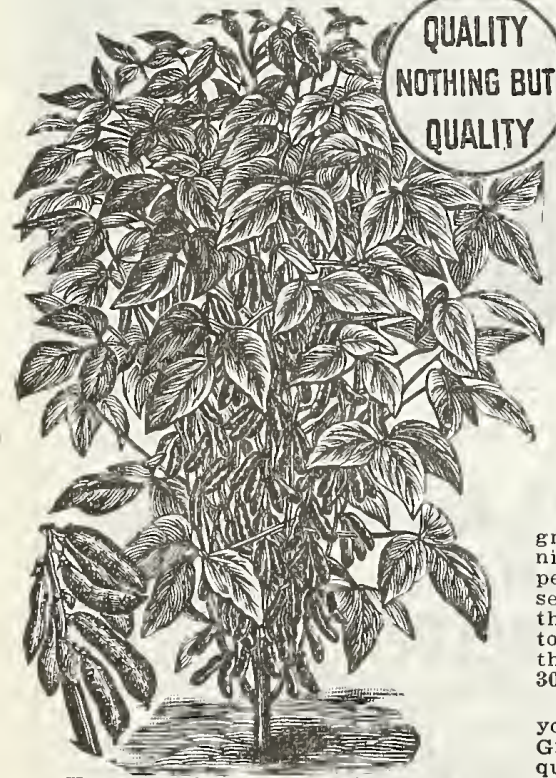

SOJA, OR SOY BEANS As a forage and feed crop, Soja Beans are proving very desir-
able. They make a large growth, stand up well, and can be cut able, They make a large growth, stand up well, and can be cu
and cured to advantage. They furnish rich feed and are, in fact, heavy soil, and are a most desirable land-improver. We haveneve for any weeds to grow where a crop of Sojas are They also resist drought and hot weather to a remarkable rate of one to one and one-half bushels per acre. The thicke nable them to EVAN' ' ARIY SOJ Crined Bean specialist of Mi- Originated by Mr. Evans, the noted soja planting in the Northeln, Eastern or Western States Choicest stock Seed (Northern grown), postpaid, lb. 30e; 3 lbs. 75c. Northern grown Seed. Postpaid, lb. 25e; 3 lbs. 60e.

NEW VELVET BEAN It is the rankest growe the ground 2 to 3 feet thick with a mass of foliage and vines 20 to 25 feet lopg, no matter how poor the soil. It leaves a mulch on 30c; 3 lbs. 75c.

L. M. Firmin, Branson, Mo, writes: The Seeds I ordered from you have all proven satisfactory. I got a fine stand of Buckbee's Great Liberty Corn and a bumper crop of ears. It has created For Bulk Prices on All Farm Seeds by Express or Freight, see Order Sheet 


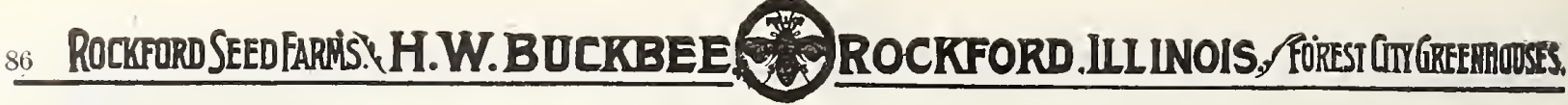

BUCKBEE'S ELECTRIC TREE BEAN

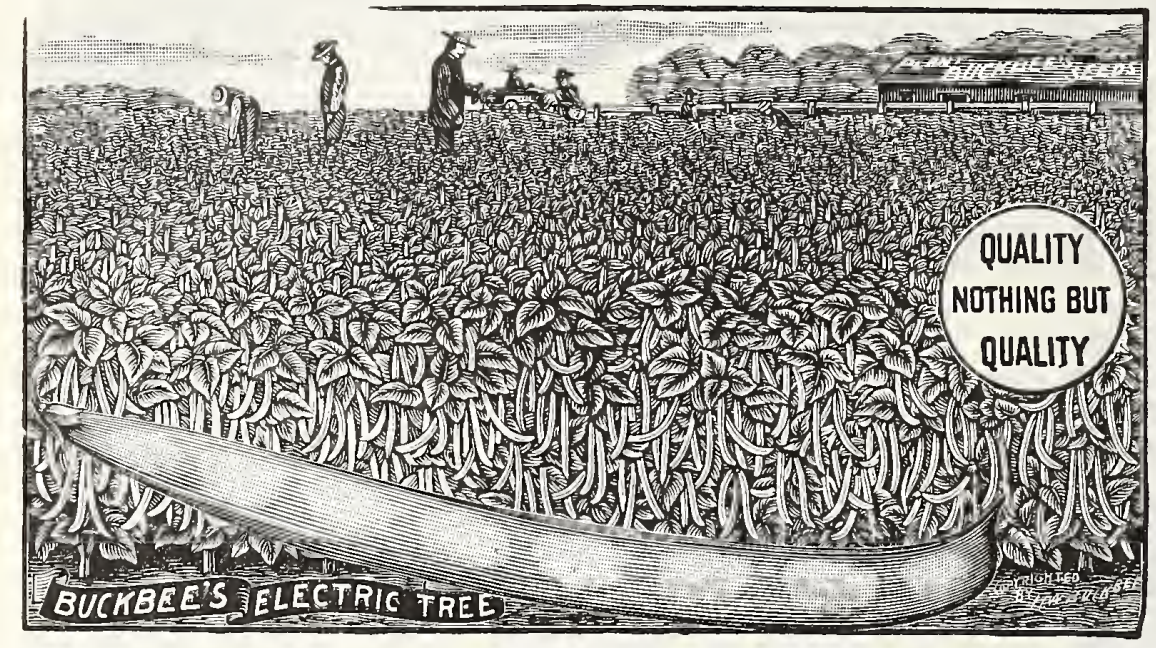

The Most Productive and Heaviest Cropping White Field Bean Known and the Best Bean for Baking
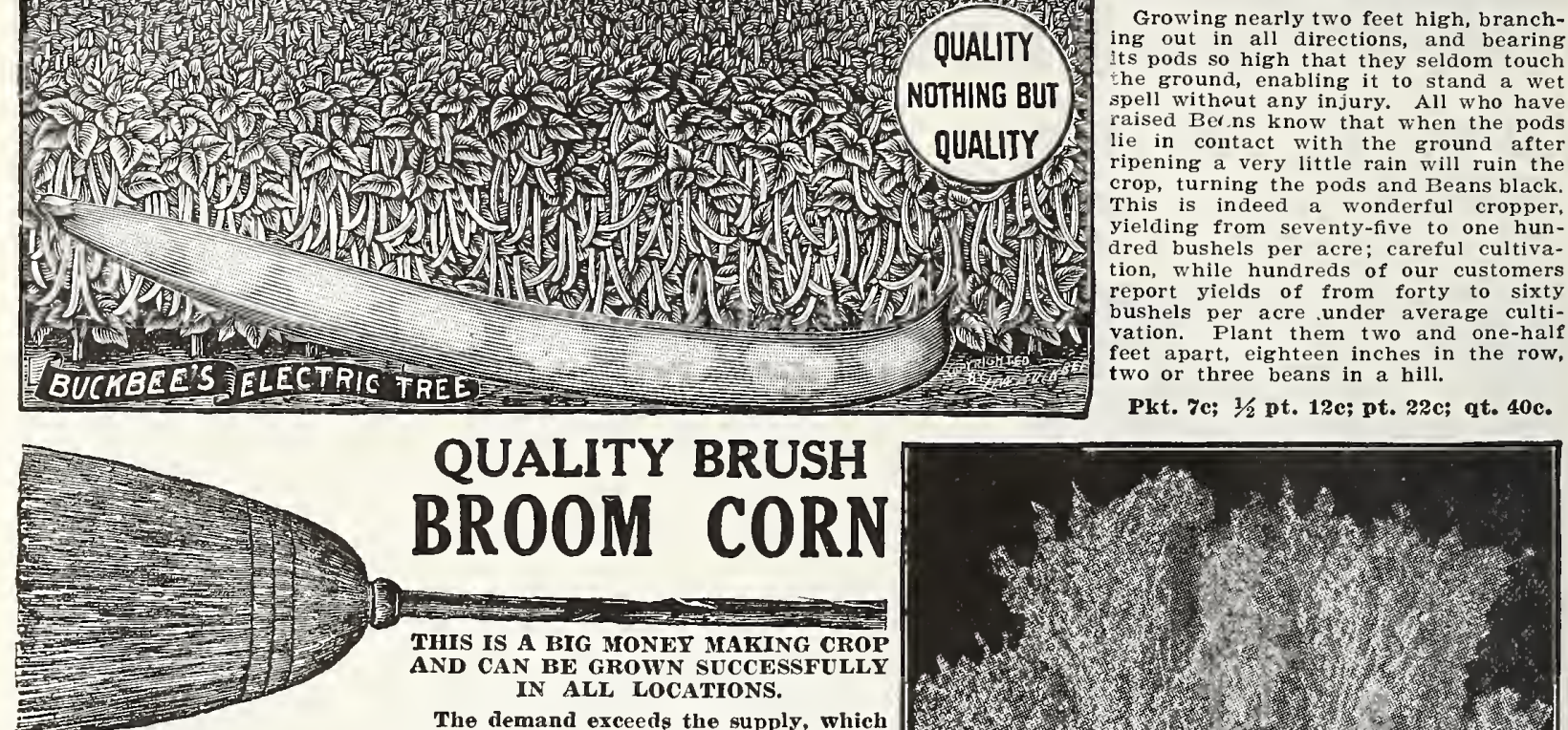

\section{QUALITY BRUSH BROOM CORN}

THIS IS A BIG YONEY MTAKING CROP AND CAN BE GROWN SUCCESSFULLY IN ALL LOCATIONS.

The demand exceeds the supply, which You will find ready market for all the good Broom corn you can grow. Buckbee's Improved Superior Evergreen THE STANDARD VARIETY.

variety in the market. The origal seed was secured in Tennessee, then bred and climated, thus making the brush of brush is raised and cultivated especially for seed. Postpaid, 1/2 1b. 15e;
1b. 25 ; 3 lbs. 65.

\section{California Golden}

Carefully selected and improved so that the brush ls straight and long. Of finest quality; light green color, turning to light yellow when allowed to Oklahoma Dwarf

Grows from three to four feet high, with straight, smooth brush, princlpally used for making whisks and brushes, though can be used very nicely Dwarf Japanese

Popular in many sections on account of its extreme earliness. Straw Broom Corn

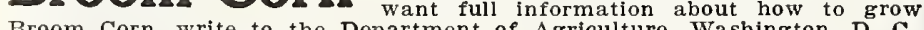
for Farmers' Bulletin on Broom Corn.

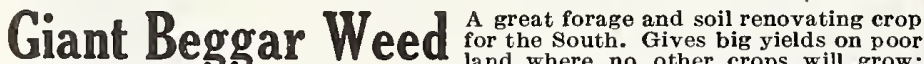 There no other crops will grow: Sow 10 to 12 pounds broadcast per acre or 3 to 4 pounds in} lb. 60c.

The New Tepary Bean $\begin{gathered}\text { This Bean grows in the mountains and canyons of the } \\ \text { Southwestern States and has been cultivated there fo }\end{gathered}$ centuries by the Indians. It is somewhat similar to the Navy Bean, but smaller. When soaked a few hours, it swells to twice its original size and more than double in weight. They are highly desirable as a food, when well cooked are light and mealy and have a rich bean-like aroma. According to experiments made, a Tepary produces four times the crop that can can be grown
of the Common Beans. with a limited water supply. With conditions favorable, Teparies yield from twelve to flteen hundred pounds per acre.

Profitable crops are grown in regions which have rainfall limited to eight or nine inches or less. Sometimes weeks elapse between showers, but the Tepary takes eare of itself during the weeks of protracted drought, returning to full vigor immediately rain comes. It has no equal for afteins, yield and quick growth. It is the earliest maturing Bean and can often be planted manure crop. When the Tepary is grown under irrikation, the crop matures in sixty-five days. The best time to plant is in spring when danger of freezing is past and again about the midere or July. The best crops are secured in dry-farming by planting at tho beginning of
the rainy season. Two or three seeds should be dropped about every twelve inehes, in rows three feet apart. Twelve pounds of seed are required to plant an acre. Price, postpaid. $1 / 41 \mathrm{~b} .15 \mathrm{c} ; 1 / 2 \mathrm{lb}$. 25c; $1 \mathrm{~b} .40 \mathrm{c}$.
THE LABOR SAVER

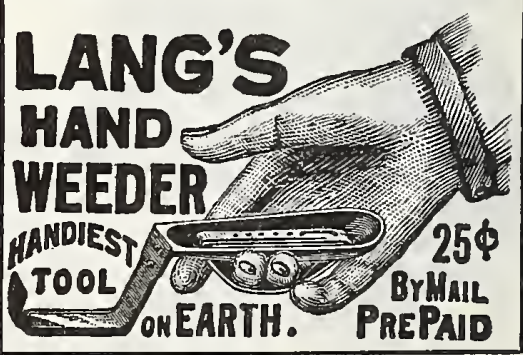




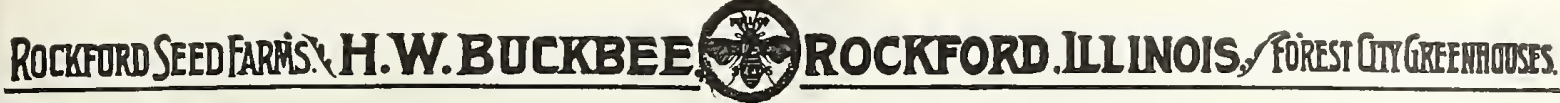
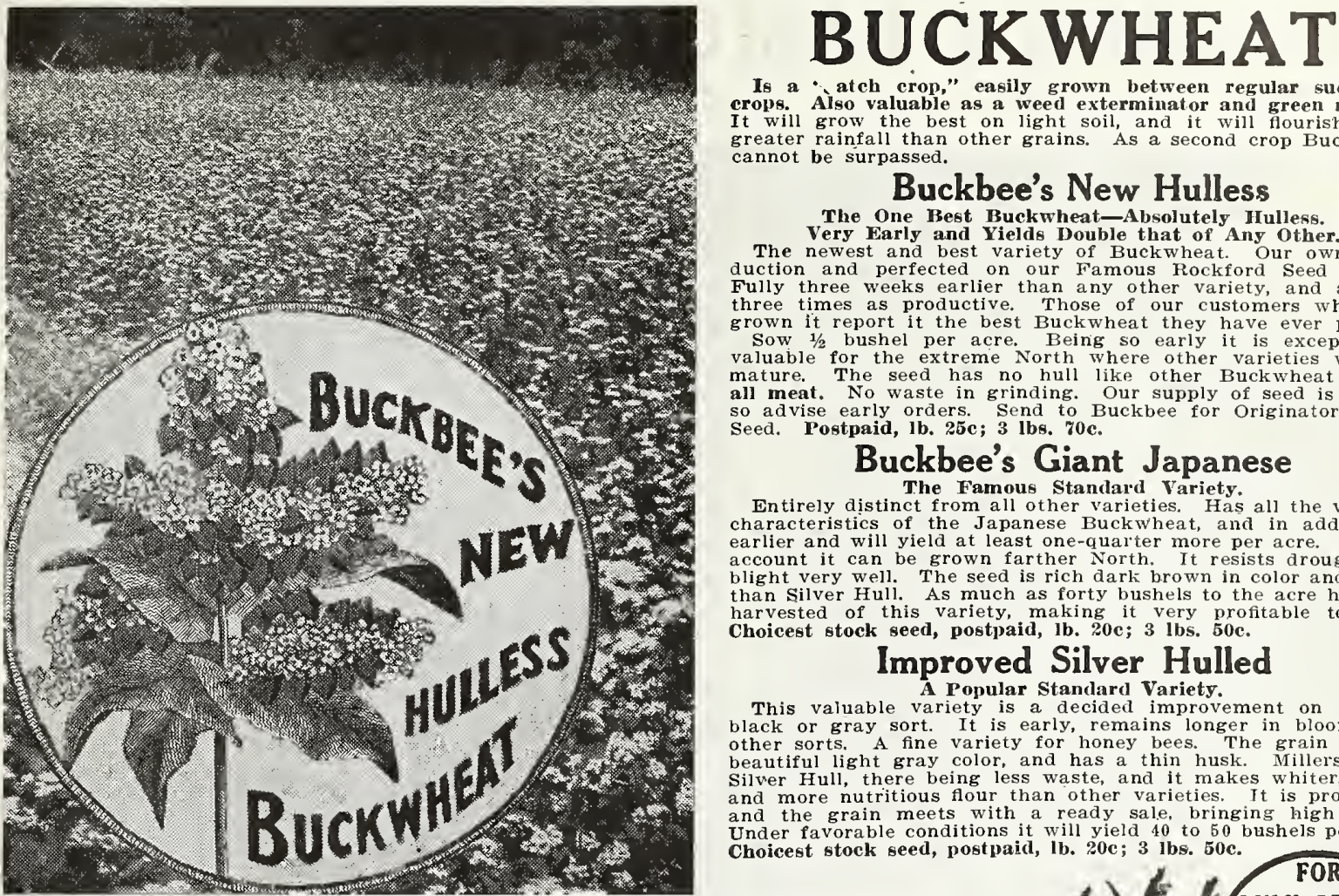

Is a "atch crop," easily grown between regular succession crops. Also valuable as a weed exterminator and green manure. It will grow the best on light soil, and it will flourish under greater rainfall than other grains. As a second crop Buckwheat
cannot be surpassed.

\section{Buckbee's New Hulless}

The One Best Buckwheat-Absolutely Hulless. Very Early and Yields Double that of Any other.

The newest and best variety of Buckwheat. Our own introduction and perfected on our Famous Rockford Seed Farms. Fully three weeks earlier than any other variety, and at least three times as productive. Those of our customers who havê grown it report it the best Buckwheat they have ever valuable for the extreme North where other it is exceptionalny mature The seed has no hull like other Buckwheat but is all meat. No waste in grinding. Our supply of seed is limited so advise early orders Send to Buckbee for Originators Stock seed. Postpaid, lb. 25c; 3 lbs, 70c.

\section{Buckbee's Giant Japanese}

\section{The Famous Standard Variety.}

Entirely distinct from all other varieties. Has all the valuable characteristics of the Japanese Buckwheat, and in addition is earlier and will yield at least one-quarter more per acre. On this accunt it can be grown farther North. It resists drought and than Silver Huli. As much as forty bushels to the acre has beèn harvested of this variety, making it very profitable to raise, Choicest stock seed, postpaid, $1 \mathrm{~b}$. $20 \mathrm{c} ; 3 \mathrm{lbs}$. 50c.

Improved Silver Hulled

$$
\text { A Popular Standard Variety. }
$$

This valuable variety is a decided improvement on the old black or gray sort. It is early, remains longer in bloom than other sorts. A fine variety for honey bees. The grain is of a Silver Hull, there being less waste, and it makes whiter, better and more nutritious flour than other varieties. It is productive and the grain meets with a ready sale, bringing high prices. Choicest stock seed, postpaid, 1b. $20 \mathrm{c} ; 3 \mathrm{lbs}$. 50

Wm. E. Johnson, Cross Village, Mich., writes: "I have grown your New Hulless Buckwheat this season and consider it No, 1 and a most profitable crop to grow. Yield is enormous. I recommend it as a profitable crop."

H. B. Elliott, Harbor Springs, Mich., writes: "I have grown your 'Hulless Buckwheat" and consider it far superior to any other kind of Buckwheat I have ever seen; have thoroughly tested its quald

\section{SUGAR CANE OR SORGHUM \\ Buckbee's Northern Grown}

\author{
(Plant $1 /$ bushel Seed to an Acre)
}

Buckbee's New Honey Syrup Cane

\section{The Favite Syrup Producer.}

As a syrup producer it has no equal, being exceedingly juicy and sweet, making from 200 to 400 gallons per acre, highly flavored. It grows 10 to 12 feet high, is very prolific, sometimes producing five to seven stalks from one seed. Matures about the middle of August to October, owing to time of planting. will keep green and stand, if desired, until killed by frost, allowing the farmer to take his own time to harvest for syrup. Also a splendid forage crop for green feeding, making excellent hay if sown in drills very thick, and may be Buckbee's Improved Early Amber

Successfully grown even valuable for fodder and pasture purposes, but it makes a high-grade cane syrup or sorghum. Price, postpaid, 1 b. 20e; 3 lbs. 50c.

Buckbee's Improved Early Orange

An exceedingly valuable variety. Very large, of strong and vigorous habit. An exceedingentuable highly flavored syrup per acre. Price, postpaid, lb. 25e; 3 lbs. 60c. Sugar Cane for Fodder

(Plant 1 1 $1 / 2$ bushels of Seed to an Acre.)

Valuable for Pasture, Soiling. Green Feed in Cut Form as Well as for Feeding in Dry State Through the Winter Months.

Sugar Cane not only possesses high value in producing syrup, but as an addition to the daily ration for stock it is almost invaluable, City owners of horses have found that Sugar Cane added to the feed of their stock gives splendid conditioning and strengthening returns-more fat more ability to stand hard work. Farmers who raise stock, even in a limited way, will find Sugar Cane, in the stalk, a wonderful help in fattening and conditioning. It is not desirable as a full ration, but as an addition it beats all the stock foods results. It can also be used to advantage as summer pasturage, and is especially satisfactory for sheep and hogs-for this purpose it should be sown way as fodder corn. When grown for sugar or molasses the "heads" can be cut and stored and fed either dry or soaked, but the grain should be crushed or coarsely ground. Mixed with equal quantities of Oats, Peas or Soja Beans common uses of Cane seed is as a feed for poultry; it is highly prized an is especially recommended for laying hens. Post paid, Ib. 20c; 3 ibs. 50c

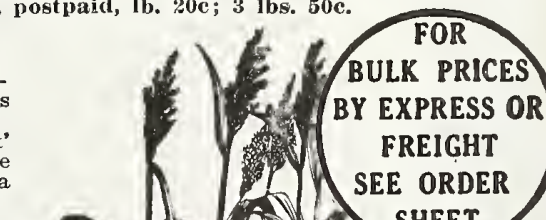

For Bulk Prices on All Farm Seeds by Express or Freight, see Order Sheet 


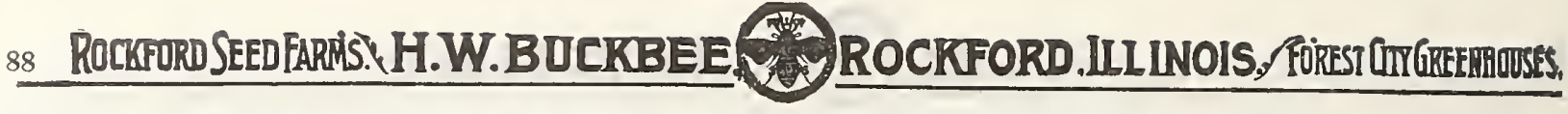
BUCKBEE'S FAMOUS SEED CORN In offering the following varieties of Field Corn we desire to say that they are the Buckbee "FuII of Life" Brand and can be relied on. CAREFULLY HARVESTED, HAND-SORTED, FIRE-DRIED, PEDIGREED STOCK SEED

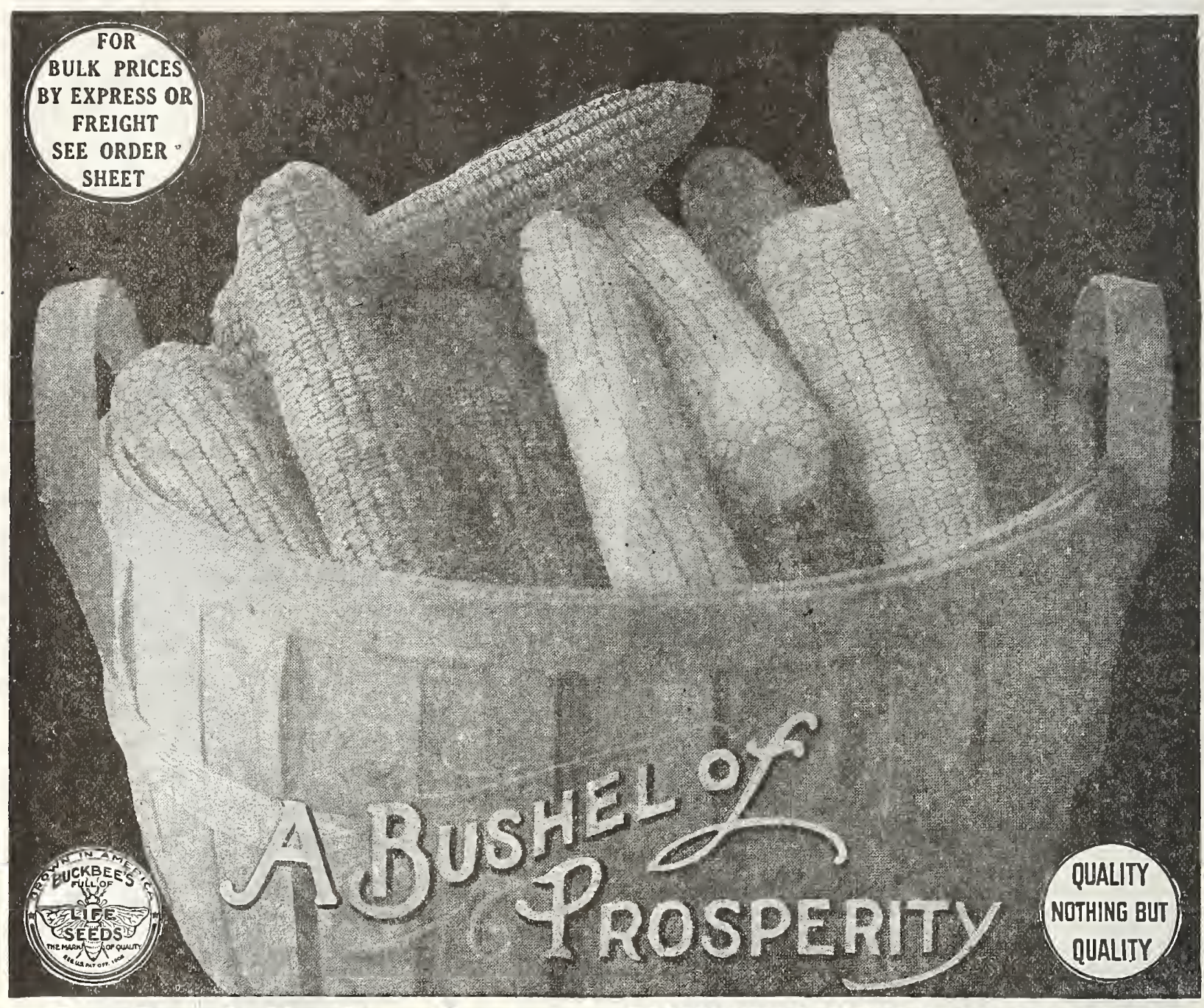

\section{Our Corn Is Northern Grown}

We regret to say that a great deal of Nebraska, Iowa and even Missouri Corn is sold each year by seedsmen as Northern Grown Seed. The term "Northern Grown" is somewhat indefinite, and
advantage is taken of this to deceive. With us "Northern Grown" means

THAT EVERY BUSHEL OF OUR SEED CORN OFFERED HEREIN IS GROWN ON AND ARED CORN OFF
HOME FARMS.

While in unusually long seasons the earliest varieties of Nebraska and Iowa grown seed will sometimes mature in the Northwestern states, it is as a rule about thirty days later than Illinois Grown Seed. We cannot believe that any intelligent
farmer in the Northwest will knowingly plant Southern seed when for a few cents an acre more he can secure true and reliable planting stock that will mature. Those who want early maturing Corn should buy nothing but the true No
Seed, and absolutely know that they are getting it.

\section{Buckbee's New Early Prosperity}

Best 90 Day Early Yellow Dent Corn.

Prolific, hardy and vigorous. Stalks grow to a height of seven or eight feet, and set the ears about three and one-half to four feet from ground-just right height for easy picking. A wonderful peculiarity of this Corn is that it never produces a barren stalk-every one has an ear, and generally two, sometlmes three. will make more than sixty pounds of shelled Corn. Prices, postpald, lb. $25 \mathrm{c} ; 3 \mathrm{lbs}$. $60 \mathrm{c}$.
BUCKBEE'S NEW EARLY ILLINOIS

The Best 90 Day White Dent Corn.

A fitting companion to Buckbee's New Early Prosperity, the one being all that a White Dent ought to be, the other a Yellow Dent of surpassing merit, yields of 115 bushels per acre being about in these two Corns than in any ten other varieties in cultivation. in these two Corns than in any ten
Prices, postpaid, $1 \mathrm{~b}$. 25c; 3 lbs. $60 \mathrm{c}$.

Buckbee's Great Western Yellow Dent

The type is very even, ears measuring ten to twelve inches in length, often weighing one and one-half pounds or more. Very uniform in size and shape, with sixteen to eighteen rows of deep, pure golden yellow kernels set on small-sized cob, which is well filled out over the tip and butt. The grains are of good size, long, flat, and closely set together, deeply dented, and solidly fill the but it often ripens in ninety-five days. Prices, postpaid, 1b. 25c; 3 lbs. 60c.

Buckbee's Great Western White Dent

A most marvelous variety of White Corn which will, in yield and quality, surprise everyone who plants it. The stalks generally bear two good ears each, and frequently three are found. It yields splendid crops even on light soil. All ears are uniform and well filled out, and will easily make sixty pounds of shelled Corn to the bushel. Prices, postpaid, lb. 25e; 3 1bs, 60c. Prosperity seed corn bought from you on March $22 \mathrm{nd}$, and on July 16 th I gathered some of it and planted again for another crop. Just think, raised my seed; and planted again from this seed and matured that crop also-that's going some!"

留 For Bulk Prices on All Farm Seeds by Express or Freight, see Order Sheet 


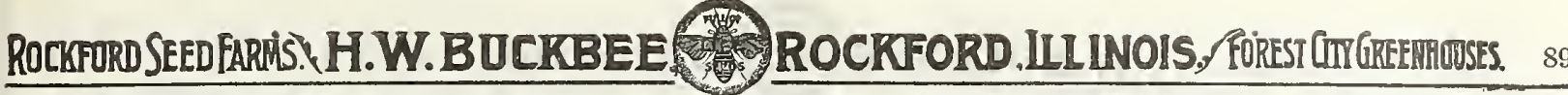 BUCKBEE'S "Full of Life" FIELD CORN}

\section{Buckbee's Early Gold Mine}

This great variety will usually produce a be planted up to the middle of June and still be depended upon to ripen by the mlddle of September. It produces a matho good-slzed Buckbee's Great Liberty Field Corn
Bub the stalk, with large kernels, cob well filled. Postpaid, ib.

This new variegated Corn combines more solid merit than any Corn in cultuation. Expert Corn Growers pronounce it a perfect Field Coru as to yield, size of the of color, size of cobs, length of grain, size of grain, size of folder, Early White Cap Yellow Dent

A very strong grower with heavy fodder and large ears. Matures in 90 days. The grain has white cap, yellow body. Heavy yielder. Postpaid, lb., 25e; 3 lb., 60c. Reid's Yellow Dent rows, with narrow space between; kernels light yellow. Matures under favorable conditions in 110 to 115 days. Postpaid, lb., 25e; 3 lb., 60c

Thoroughbred Leaming

Deep golden color; striking uniformity. The ears range from 9 to 12 inches long. Kernels broad, thlck, deep, rather rough, rounding wedge shaped. Red
cob, medium in size. Matures in about 115 days. Postpaid, lb., 25c; 3 lb., 60c.

Extra eariy, dark red kernels, (Short crop.) Postpaid, lb., 25c. 3 lb., 60c. Minnesota King

A Famous Half-Dent, Eirht Koowed Corn

A most valuable sort for the Northern States PPostpail, lb. 25c; $3 \mathrm{lb}, 60 \mathrm{c}$.

Buckbee's New Early Copper Mine

This new variety is a copper-colored Gold Mine corn; in size and shape of ears and productiveness fully equal to the best strain of that variety, but different in than 90 days and can be recommended for planting as far north as northern Iowa. Try this new corn; it is well bred, grows very uniform and is most productive, 3 lbs., 60e. Great Brazilian Flour Corn

One of the Greatest Norelties Ever Introduced

It yields at the rate of 100 bushels of green fodder per acre for cattle, of the most delicious, sweet, tender, juicy, nutritious food we have ever seen. th makes flour in quality equal to wheat. Of course, it is not so white, but oh,

Q.
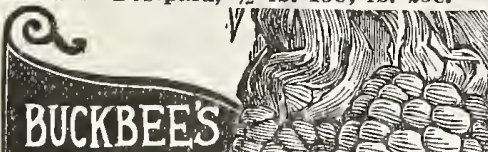

EARY

NORTHER

YELLOW

FiNT

con

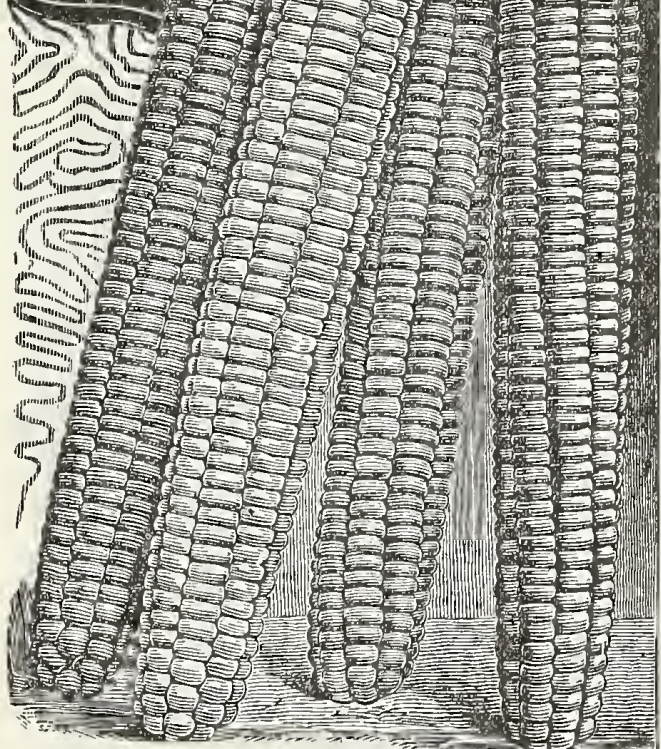

Field Corn-Extra Early Flint Buckbee's Early Norther The Greatest Yielding Wlint Corn
The Only Corn for the Extreme Nortl.

Ears ten to

Enormously productive, outyielding of rich, yelo

We have ever seen in the far North. Mature

good height. The ears average and the stalks are of

well up so as to readily admit being cut by the harvester. fodder. Will surely prove of the Northern Minnesota Wisconsing particularly the Dakotas, and big yielding Flint Corn. Postpaid, $1 / 2$ lb., 15c; 1 b.

Improved Indian Squaw Corn

Holds more records for wonderful performances under difficult conditions than any Corn ever grown. Perhaps the most Wonderful quality. of this corn is its
power to reslst drougth. The most protracted dry weather wet season equally well. It can stand as much dry of our most handsome varieties. The kernels are o ars a curiously beautiful yellow and white, giving the in length and are of Longfellow

Has Individuality That Commends.

apted to the North. It is an eighturowed sort, with ears twelve inches in diameter. Small cob, large kernel and very North Dakota White Flint An Early Maturing Variety.

This is a acteristics, including early maturity and medium size, $1 / 2$ lb. 15c; $1 \mathrm{~b}, 25 \mathrm{c}$.

\section{Extra Early King Philip}

Farliest A Ted Flint That Is Unbeatable. Ripens within elghty days from time of planting. Ears large:

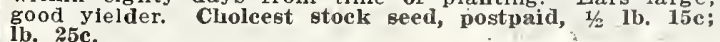

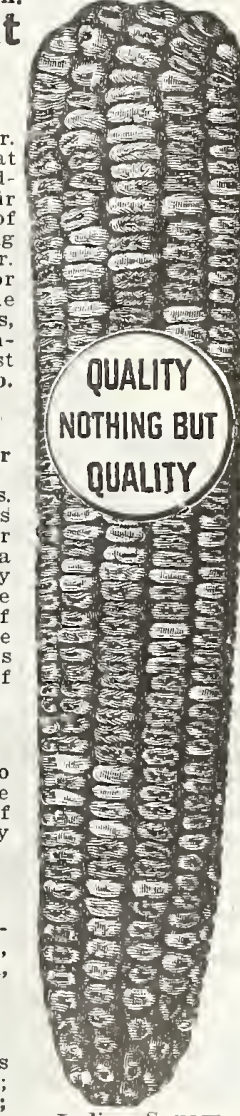

Indian Squaw.

For Bulk Prices on All Farm Seeds by Express or Freight, see Order Sheet 


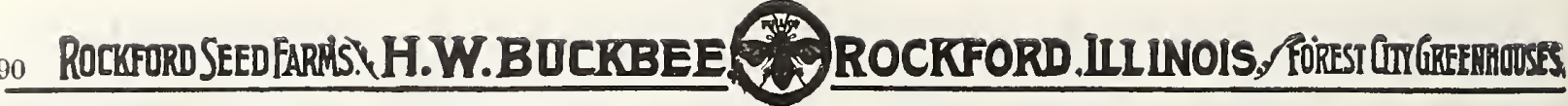

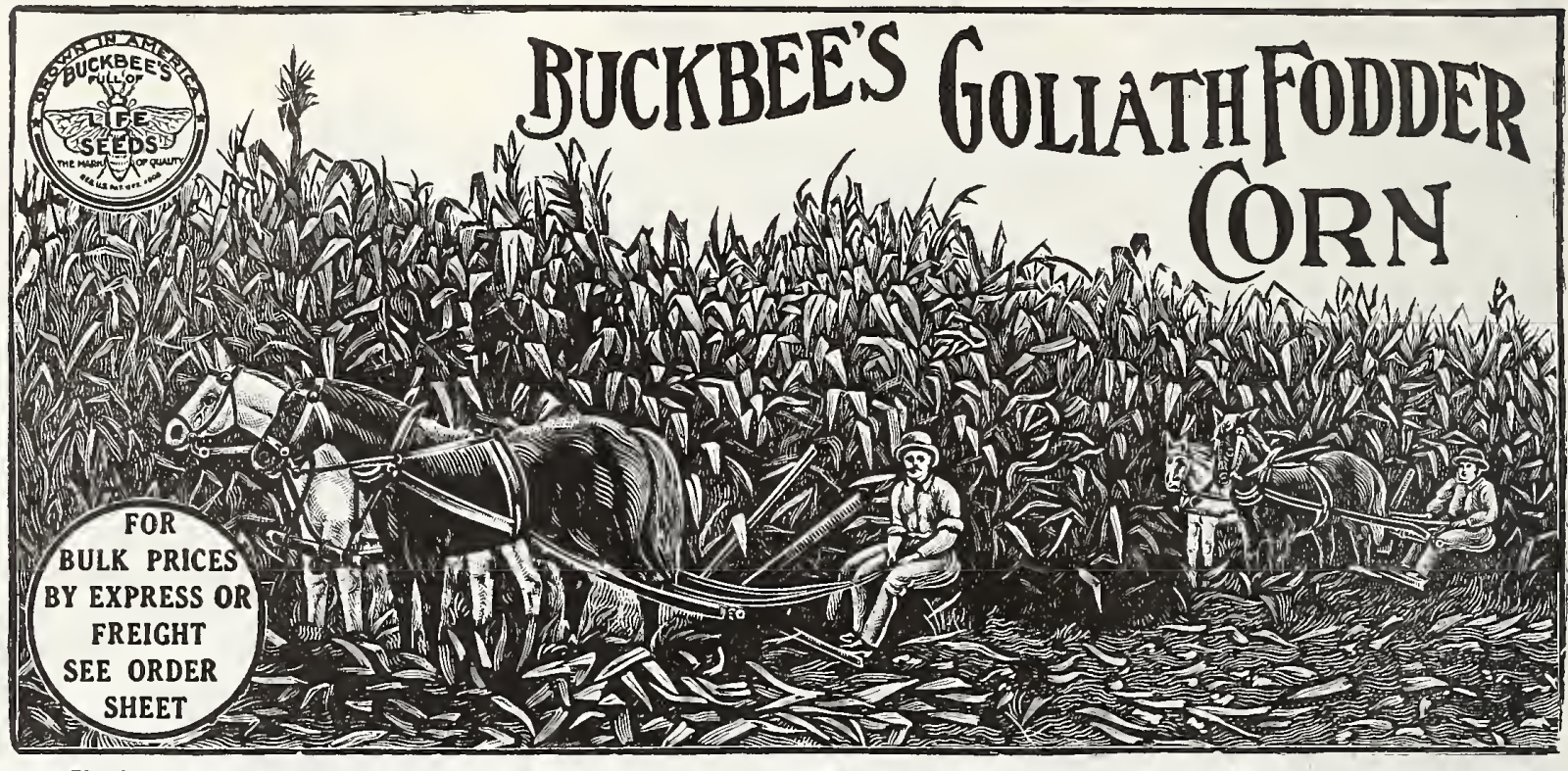

BUCKBEE'S GOLIATH FODDER CORN

THE WORLD-BEATING FODDER PRODUCER. SURPASSES ANY OTHER FODDER CORN ON EARTH.

which we have been developing for years. Thousands and thousands of our customers in every part of the country assert that it stands without a peer for feeding either in the green state or for silo purposes. It is very rich in nutriment and rich, juicy, immense yielder. Grows rapidly, is early, short jointed, tall, and produces an overwhelming abundance of leaves

\section{Red Cob Ensilage Corn}

\section{One of the Best Fodder Corns.}

Beyond doubt the best fodder corn, either to feed green right from the field, to put up for the silo, or to cure and stack away. It is a pure white coln, cropping as high as 45 tons per acre. It any other variety; has short joints and therefore an abundance of stalked as some varieties. Price, postpaid, lb. 25c; 3 lbs.60c.
White Cob Ensilage Corn

\section{A Popular Standard Variety.}

A pure white Corn with a white cob of tall growth, short joints and leafy, giving an abundance of fodder; sweet, tender and juicy, cropping as high as 45 tons per acre. It is a popular standard variety which has a wide reputation all over the country and may be successfully grown for fodder in almost any latitude. Drill $111 / 4$ bushels to the acre

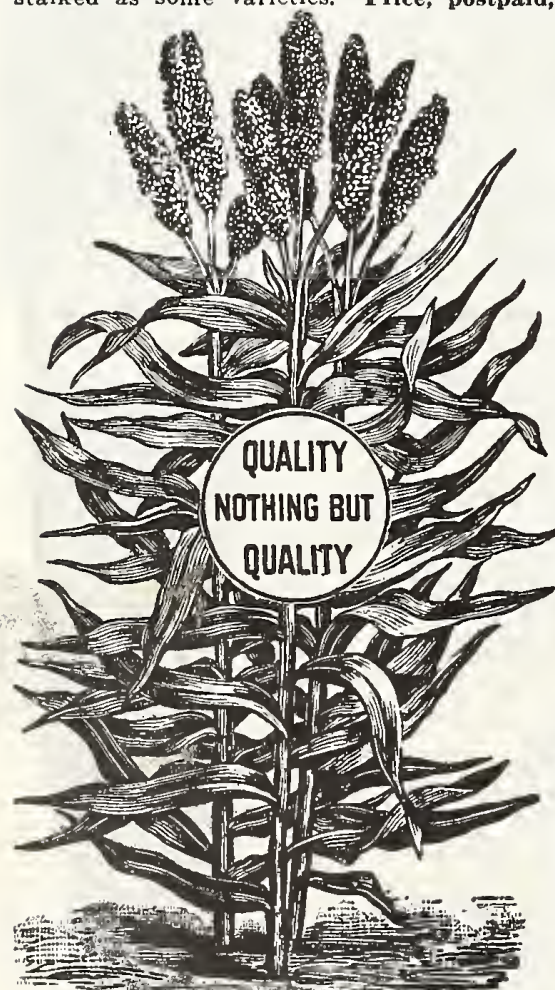

Buchbee's Superior Kalfir Trin.

\section{BUCKBEE'S SUPERIOR EARLY KAFFIR CORN}

\section{A Great Drought Resister.}

Kafir corn not only produces a foliage of excellent forage quality but its seed is, as a grain, almost if not quite equal to Indian Corn, practical farmers and scientists affrm, while it is successfully and profitably grown on land high or low, rich or poor, and whether the season is wet or dry. Easily yielding two crops of fodder in a season. tendency and produce numerous wide leaves.

The stalks do not harden as do other fodder

most excellent fodder, either green or dry.

being highly relished by all stock. It should

6 inches in the rows. Use from 10 to $15 \mathrm{lbs}$. unaffected, even as far North as Dakota. It is immensely productive and does well everyand one which makes it of unusual importance in regions of limited rainfall, is that its growth may be suspended, perhaps a month, when the rains come it continues its growth interruption. same as if there had been no Seed of strong germination. Postpaid, $1 / 2 \mathrm{lb}$.

\section{JERUSALEM CORN}

A New Forage Plant of Great Merit. Belongs to the non-saccharine Sorghums, and was brought a few years ago from the arid plains of Palestine. It is pronounced the best and surest grain crop for dry countries and sejasons-even better than Kaffir heads on side shoots, often as many as eight heads on a stalk. Very valuable for feeding stock, and proves a gold mine for chicken foed. Plant five to ten pounds per acre. Postpald, $1 / 2$ lb. 15e; lb. $25 \mathrm{c}$; 3 lbs. 60c.
D. F. Burkhalter, R. R. 1, Erick, oklaD. F. Burkhalter, $\mathbf{R}$. R. 1, Erick, oklahoma, writes: The Seed corn bought of you Northern Grown "Full of Life" Seeds do the best of all in this section.

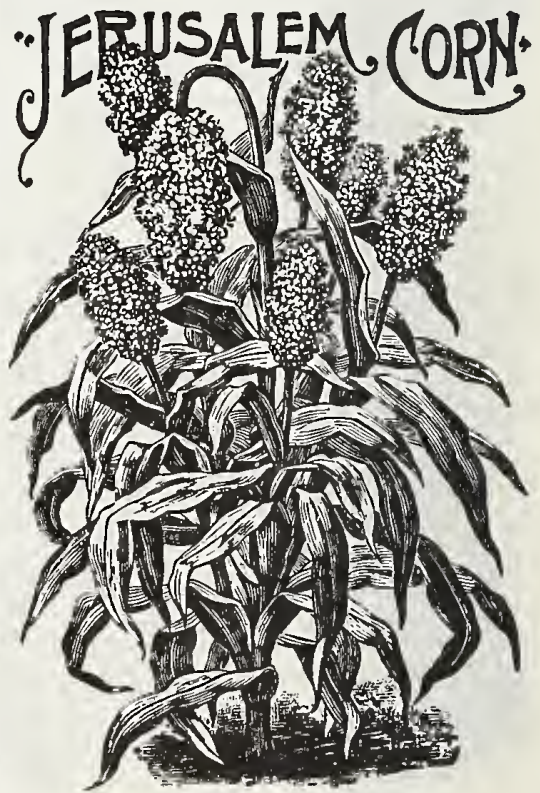
For Bulk Prices on All Farm Seeds by Express or Freight, see Order Sheet 


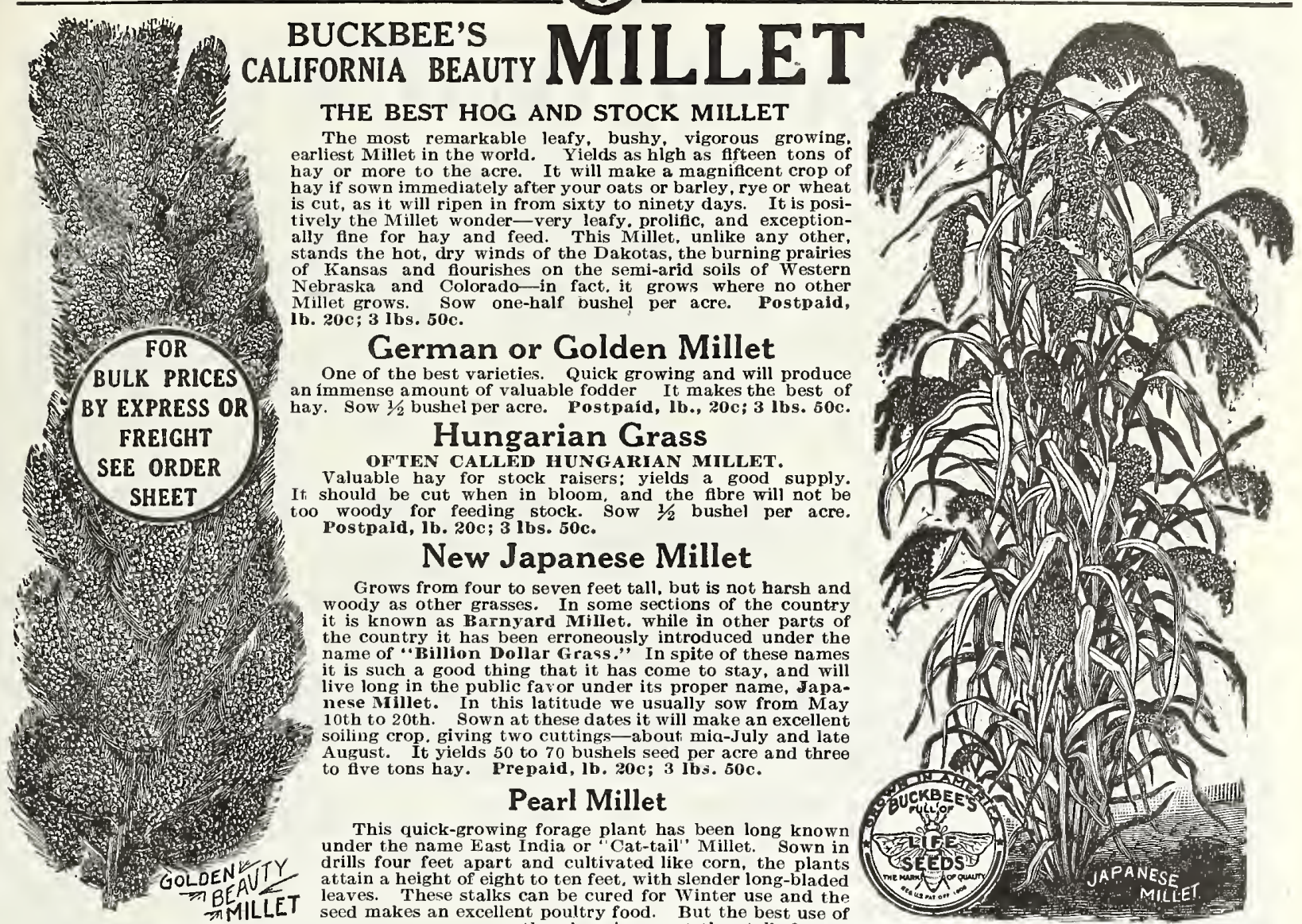

Branching Dhoura Corn

Ylelds from six to sixteen stalks from one seed. Being allied to Sugar Cane, cattle, horses and hogs will eat it ravenously. If cut down it starts again with renewed strength. It yields at the first cutting at the rate of sixty-eight tons to the acre. Plant flve pounds in rows per acre.

\section{Wonderful Milo Maize Corn}

Excellent Fodder Plant for Feeding. In a great many sections it is planted to the exclusion of all others It will produce an amazingly large crop of the riches where. The of superlative quality. It will grow anywhere. The seed is an excellent

Postpald, $1 / 2$ lb. 16c; lb. $25 \mathrm{c} ; 3 \mathrm{lbs} .60 \mathrm{c}$.
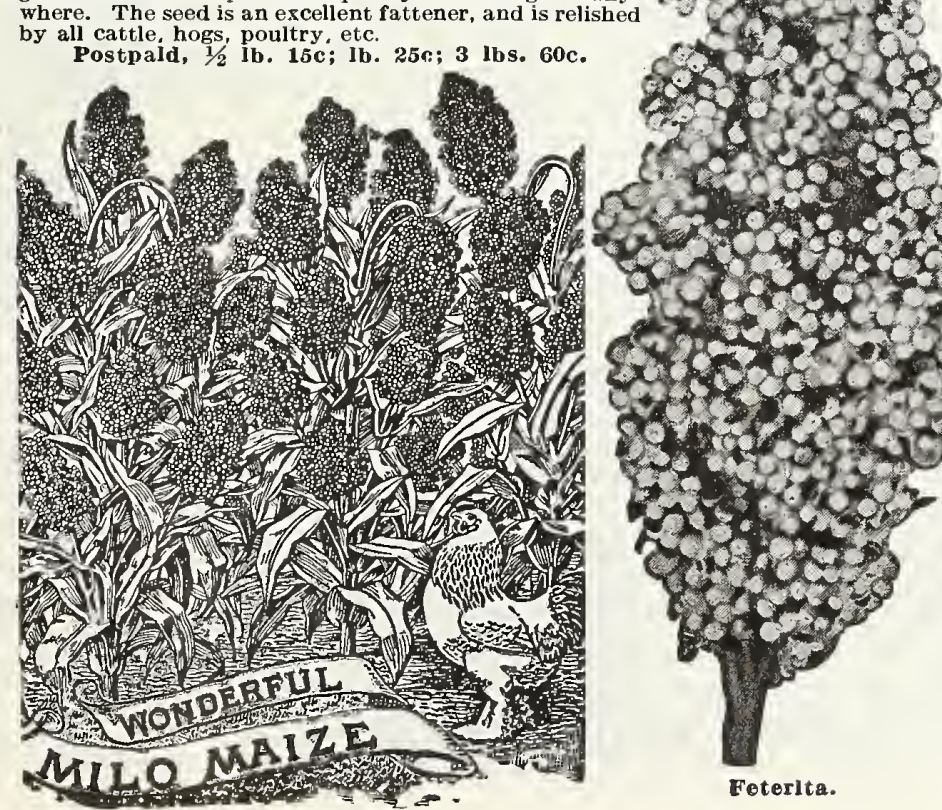

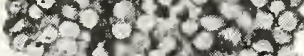
(1.) the plant is to cut the stalk for green forage when about three feet high, and allow

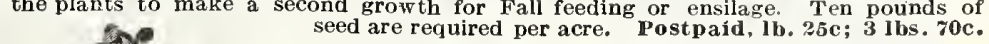
SE? FETERITA THE BEST FORAGE CROP aforean This new grain was introduced by the United States Department of Agriculture from British-Egyptian Soudan. 1t produces a stalk of medium height and size, bearing ten to twelve leaves of medium size and a large head well flled with pure white or bluish-white seeds. The grain is larger Its milo, is fully as soft and much whiter than Kaffir. is an excellent drought resister. It stands erect, branches out from the root and matures 25 days earlier than Kafilir. Postpaid, 1/2 lb. 15e; lb. 25e; 3 lbs. 70c.

\section{Egyptian Wheat or Shallu}

A valuable new grain, entirely different from wheat. Some people say it

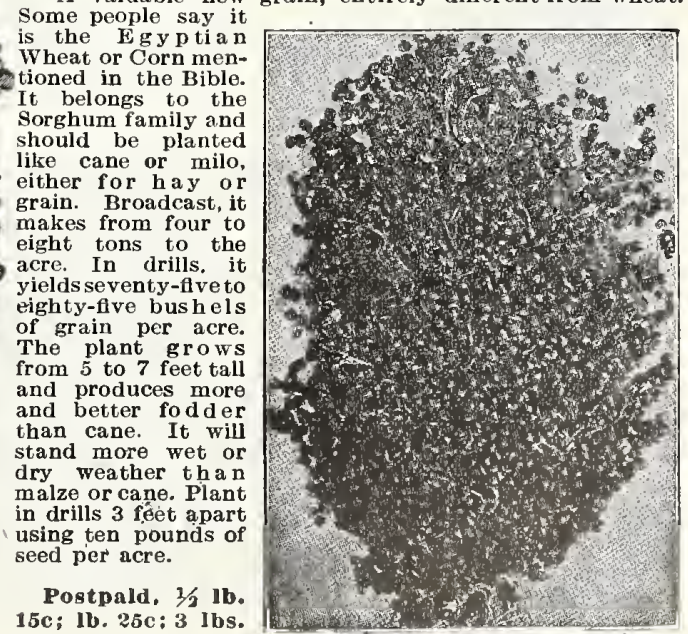

70c.

Egsptian Wheat or Shalli. 


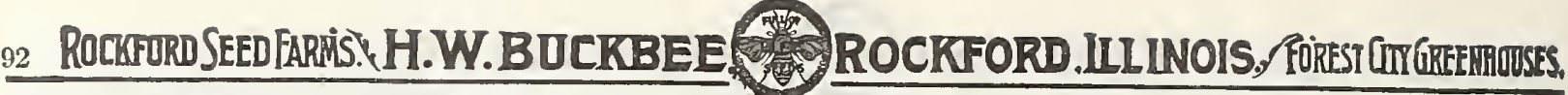

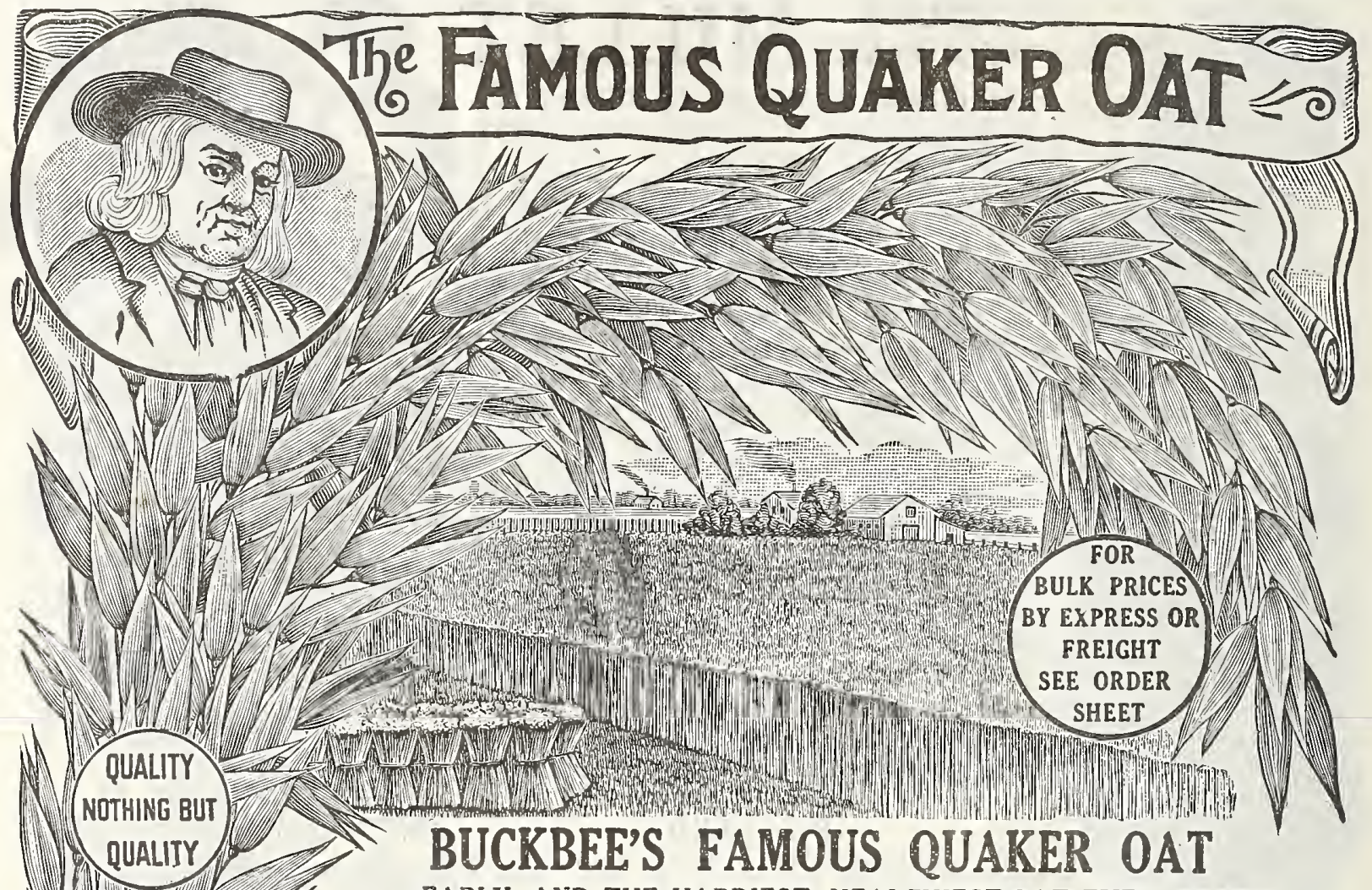

EARLY, AND THE HARDIEST, HEAL THIEST OAT EVER GROWN

QUAKER OATS ARE THE HARDIEST AND HEALTHIEST OATS IN EKISTENCE. StraW is strong, stif and free from rust. The grain is the heaviest known; bright as a new gilver dollar. Wonderful yielder, producing 100 bushels or more per acre under average conditions. For absosatisfaction, plant only "Quaker oats." Send to Buckbee for choicest stock seed. BUCKBEE'S ILLINOIS

Extremely Early. Grain Large and Weighty. Straw Very Heavy and of Good Length. Type Well Fixed. Bred for sowing on the rich soils of the Prairie States; so that there would be strong
straw to carry the heavy grain. It is an ideal sort for any soil. Postpaid, $1 / 21 \mathrm{lb}, 15 \mathrm{c} ; \mathbf{1 b}$. 25c; $\mathbf{3}$ lbs.700. EARLY BLACK PROLIFIC TARTARIAN

Heaviest Cropping Variety of Pedigreed Black. Oats.

Tests made by many progressive farmers convince them that these Black Oats are more reliable croppers than White Oats. They are very eary. The gran is short and plump, and of the best quality. long, and the grain yield is heavy. Postpaid, $1 / 21 \mathrm{lb}$. 15c; $1 \mathrm{~b} .25 \mathrm{c} ; 3 \mathrm{lbs}$. 70c.

SWEDISH SELECT, Regenerated Pedigreed Seed

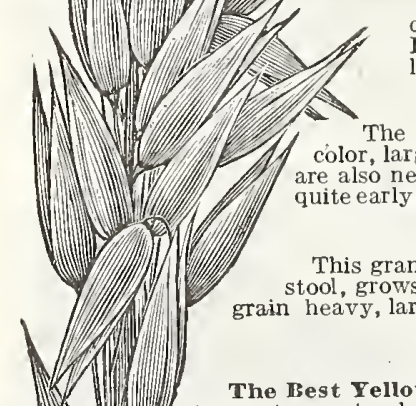
iy all meat, the hull being exceedingly thin making them especially valuable as a feeding Oat. They are to smut and rust. Postpaid, 1/2 lb. 15c; 1b. 25c; 3 lbs. 70c

\section{IMPROVED WHITE RUSSIAN}

This grand new variety can be recommended with confdence. Very prolific, extremely hardy, makes a strong GOLDEN FLEECE

The Best Yellow. This is a very fine Yellow Oat It is a heavy cropper, handsome sample, grains yellow and plump, strong straw, stands up well. The blade is much larger than the ordinary Oat, attesting to its vigor and productive capacity;
stools remarkably in strong land, seventeen shoots having been counted from one seed sown. Postpaid, lb. 20c; 3 lbs. 50c. MICHIGAN WONDER

Cit is very productive, having yielded more to the acre than any of the standard varieties. Very early and has thus far proved itself rust-proof. Stands up remarkNEW APPLER WINTER TURF OAT

This is undoubtedly one of the best all round Oats for planting in the Fall as they afford a valuable pasture the greater part of the Winter and early Spring, thus reducing the quantity of other necessary food. They may be harvested early enough in the Spring for other crops to follow. This variety spreads and stools out enormously, especially when grazed, and if stock be taken off by March will yield a large crop of grain. This is a very popular Oat in the South, especially on the light sandy soils of the coast region. Postpaid,

This splendid variety has proven immensely popular and satisfactory wherever it has been grown. When sown early and the roots thoroughly established in the soil, it is as hardy as Wheat, and will stand as much cold as that crop. Its stooling propensities are remarkable

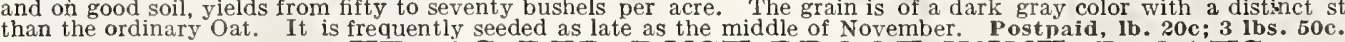

TEXAS RED RUST-PROOF WINTER OATS

standard favorite not only in Texas, from which it derives its name, but all through the Southern States, The Texas grown Oat has a very heavy berry. nearly everyone has a distinctive beard. Postpaid, $1 \mathrm{~b}, 20 \mathrm{c}: 3 \mathrm{lbs} .500$. 


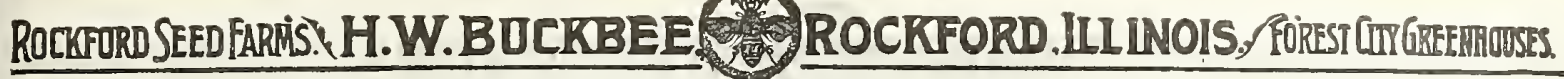

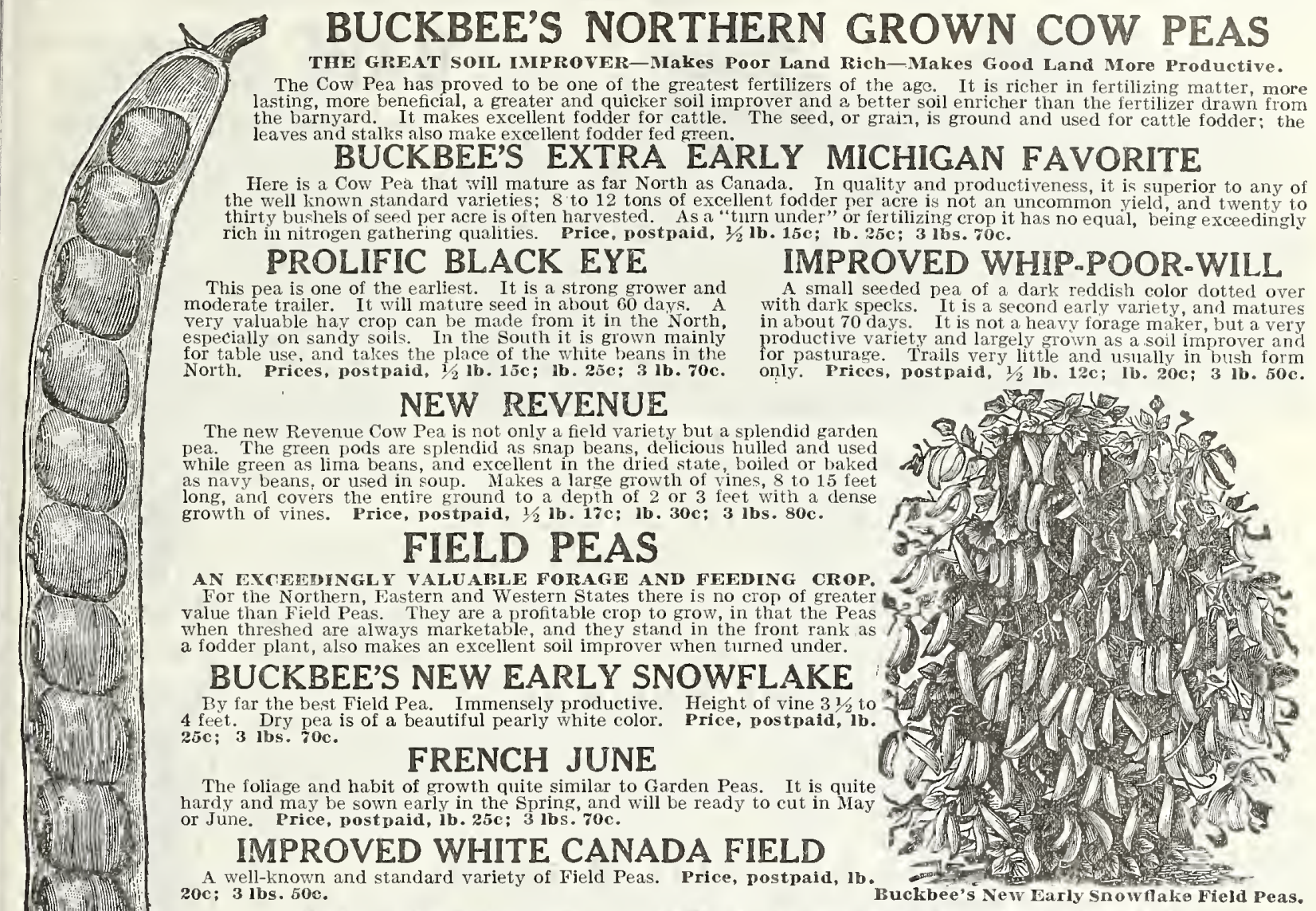

\section{BUCKBEE'S GREAT SAND VETCH}

THE WONDERFUL SAND OR HAIRY WINTER VETCH (Vicia Villosa)

Our Seed is Government Inspected and will show a test for Purity of $98 \%$ and Germination better than $90 \%$

AS A PASTURE PLANT FOR LATE FALL AND FARLY SPIING IS WITHOUT AN EOUAL, FURNISHING GREEN FORAGE IURING TWO PERIODS OT SCANTY VEGETATHON.

This Vetch is, beyond doubt, one of the most valuable fodder plants for the West and Northwestern States, owing to its adaptability to withstand severe drought, heat and cold. The vines are very similar to pea vines, but are more slender and much more thickly clad with leaves and side stems, which furnish-nice same ground. The Washington Department of A griculture estimates the value of an acre of this Vetch plowed under on the lent to putting into the ground $\$ 25$ to $\$ 45$ worth of commercial fertilizer. lent to putting into the ground $\$ 25$ to $\$ 45$ worth of commercial fertilizer. One important feature is that
a sowing made in August or September covers the ground before Winter sets in and prevents washing of
the soil during the Winter and early Spring, thus saving a great portion of soluble mineral fertilizers
contained in soil, which otherwise would wash or leech out. Can also be sown in April and will be ready to cut by the middle of July, the second growth affording
during the Summer.

FOR A HAT CROP IT IS PAR EXCELLENCF.

Make sowings in early Spring at the rate of $30 \mathrm{lbs}$. per acre broadcast, with the addition of one-half bushel Rye or Oats to furnish support for the vines. This latter method will give the best satisfaction. On good rich soll it yields enormous crops of green fodder. It is also a remarkable grower on sandy and thin land. Don't fail to try it. Our seed is the very choicest Northern Grown. Postpaid, lb.25c; 3 lbs. 70c.

\section{SPRING VETCH}

This annual variety is extensively used for planting with Oats for Summer and Fall fodder. Grown and used in the same manner as Winter Vetch, though not so hardy strong and vigorous. Post paid, $1 \mathrm{~b} .25 \mathrm{c} ; 3$ lbs. 70c.

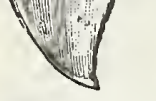

New Revenue
Cow Pea.

NOTICE

For Bulk

Prices by

Express or

Freight see

Order Sheet

\section{GIANT SPURRY}

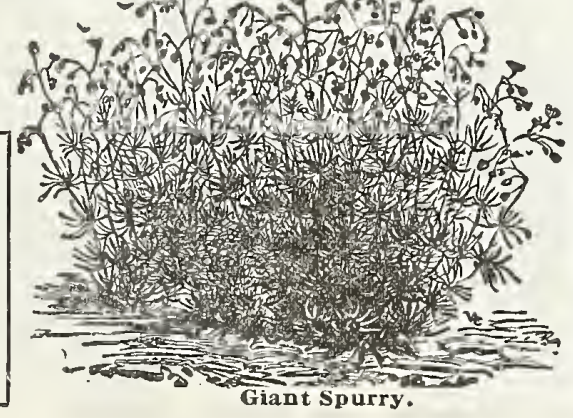

\section{CAANT SPURR} no other plant flouriches. It comes next to Clover as a fertilizer. It is of very rapid growth and is sown the latter part of March, April or May, at the rate of 10 Ibs. per acre
if wanted for hay. The seed is sown broadcast on well prepared soil and covered lightly by harrowing. It germinates quickly, and in usually cut for hay the first time, and pastured afterward for the rest of the Sumacre are sown, and when from 15 to 20 inches high, plowed under. Two crops can be plowed under in one year on account of
Postpaid, oz. 10c : $1 / 2 \mathbf{l b}$. 20c; $\mathbf{1 b} . \mathbf{3 5 c}$ : lbs. 95 c.

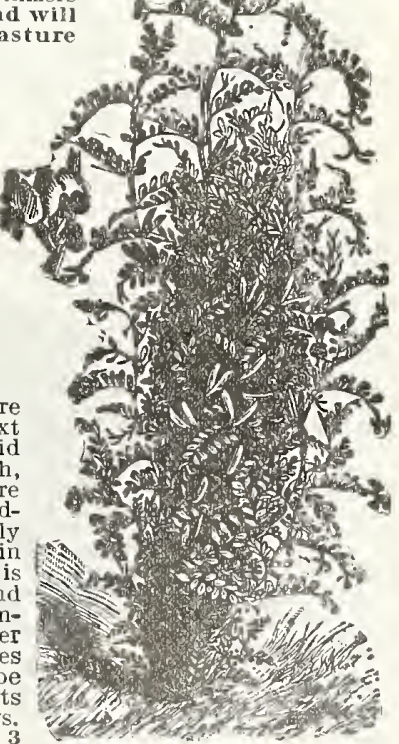

Buckbee's Sand Vetch. 


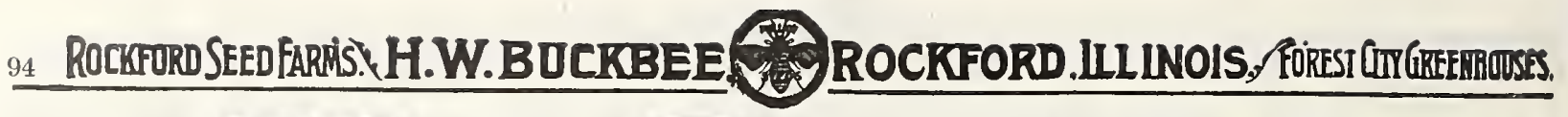

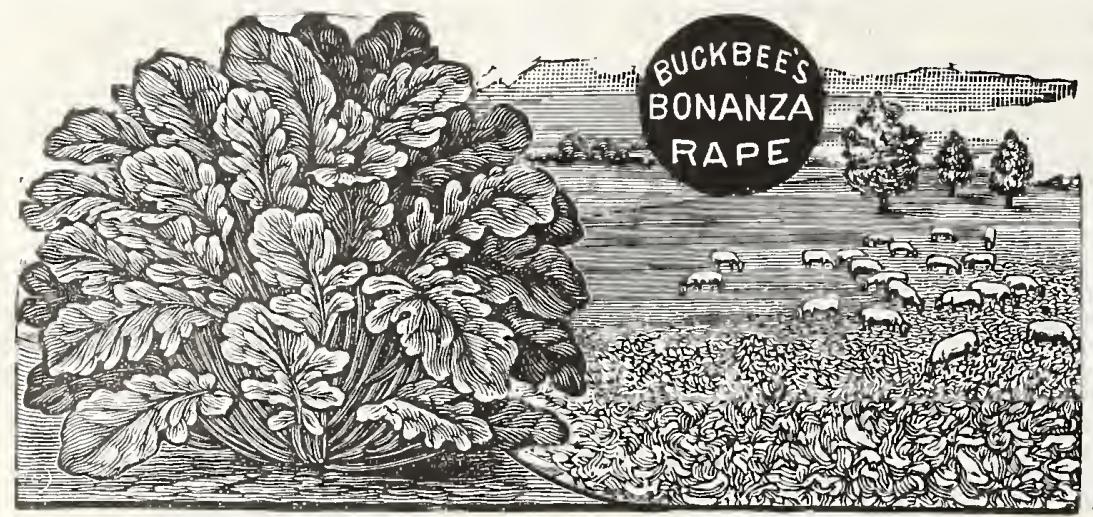

RADA The Best Fodder for Buckbee's Dwarf Bonanza

Dwarf Essex Rape

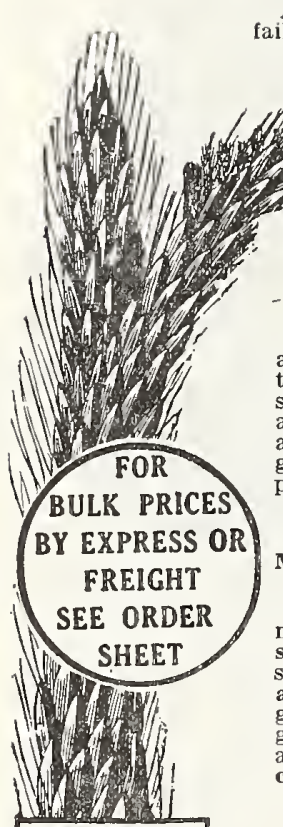

BUCKBEES

FULLOOLIFE

RYE

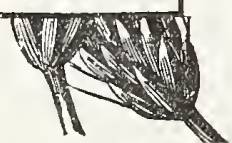

standard variety. Not quite so strong and vigorous a grower as Dwarf Bonanza, but never ails to give the best of satisfaction. Fine imported seed; price, postpaid, Ib. $25 \mathrm{c} ; 3$ ibs.60c.

\section{MAMMOTH SPRING RYE}

This is quite different from the Winter Rye and is highly valued wherever known. It is not only more productive, but the grain is of finer cellent catch crop where winter grain has been killed out, or for sowing where a Fall crop has not been planted. The straw is of special value as it stands six or eight feet high, being better than that of Winter $R$ ve and producing nearly four times as much straw

as oats. Produces 30 to 40 bushels of gran to the acre Rye, not less than two bushels to the acre should be sown. Prices, postpaid, 1 b. 20c; 3 lbs. 50c.

\section{GIANT WINTER RYE}

This crop is used all over the country for Fall, Winter and Spring pasturage, early green food and for green manuring, as well as for grain. It is very hardy and will grow on poorer land than any other grain crops. It is a good Spring soiling crop, giving the earliest bite of green stuff and makes a fair quality of hay if cut in bloom or before it is fully headed out. Used for a grain crop its straw makes the best bedding for cattle and horses and if carefully threshed sells at high prices for collar making and other manufacturing purposes. It is also an excellent per acre. Prices, postpaid, per ib. 20c; 3 lbs. 50c.

\section{SPRING SPELTS OR EMMER}

Makes a Good Crop with Aimost Any Condition of Soil and Climate. outylelds any other grain and makes better feed than Bariey or Oats.

It is neither wheat, rye nor barley, and yet it appears to be a combination of the three. It is more like wheat than any of the others mentioned. For fattening cattie, pouitry, horses, sheep, pigs, etc., it is claimed to be ahead of other grains; in fact, all kinds of animals seem to thrive on it. Yieids 80 to 100 bushels of richer food than corn, besides giving as much as 4 tons of good hay per acre. Excellent for pasture and can be fed in the
green state. Wiil grow weii and produces enormous crops on land where wheat will not grow. Those who have not grown Spelts should not let another season go by without giving it a place and an important place, too, on their farms. Sow 2 bu. per acre. Our own growth,
choicest Northern grown pedigree stock secd, postpaid, pkt. 5c: 1b. 20c; 3 ibs. 50c.

\section{WINTER SPELTS OR EMMER}

\section{Produces more Nutrlment than any other Crop.}

A new, variety first introduced from France by the Department of Agriculture several years ago; and has been tested on many of the experimental farms with good results: yielding from 40 to 77 bushels per acre. As a teed crop it is equal to or superior to, the spring or sun Spelts. It does well on all kinds of soils and lands-bottom, second bottom, table and hillwith apparently no preference. It gives uniform good success everywhere, and changes no more than other crops. It produces more nutriment than any other crop-more than corn in the corn belt, and can be grown more cheaply. In a number of the Central, Southern and not be hardy, there is a large demand for a winter Cereal to be used as stock feed It will ripen earlier than oats, yield better, and furnish a considerable quantity of Fall and Winter Winter IEmmer will fill that demand exactly and satisfactorily. The preparation of the land, seeding and subsequent management of the Winter Emmer crop are practically the same as that required for Rye and Winter Wheat. Our own Growth Choicest Northern Grown "Full of Life" Seed. Prlce, postpaid, pkt. 10c; lb. 25c; 3 lbs. 70c.

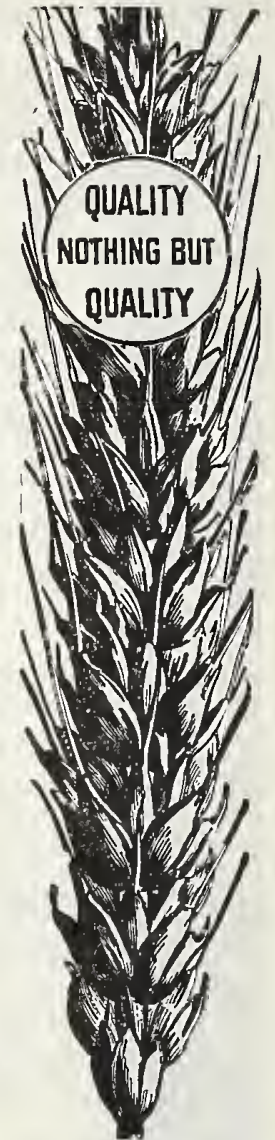

Spelts or Emmer.

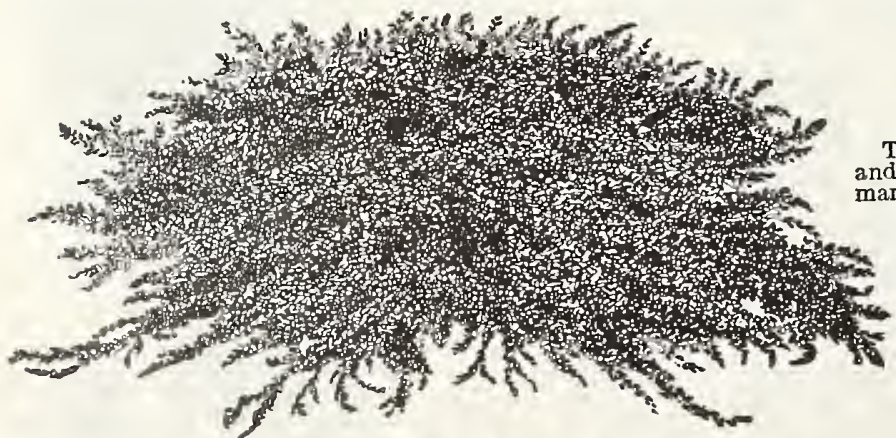

A ustrallan Salt Bush

\section{AUSTRALIAN SALT BUSH}

A. Forage Piant for Aikali Solis and Regions Subject to Perlodic Droughts.

This is a most wonderful forage plant, as it will grow freely in arid and alkali lands that will produce no other vegetation, yielding a arvelously liberal foliage which is eagerly eaten by all kinds of stock. It is of creeping habit. From twenty to thirty tons of green fodder have been harvested from one acre. It has further been proven that after three or four crops have been grown on alkali land the soil is then capable of producing anv other vegetation. In many sections of the States tluis is in itself of priceless value This plant has been very extensively tried where single plants grown on the poorest alkali ground have reached a diameter of sixteen feet in teand of seed will seed an acre. It grows

Pricon Dostpald, pkt. 5c; oz. 15c: 1// lb. 350? $161 \mathrm{~b}, 60 \mathrm{c}: 1 \mathrm{~b}, 81.00$ 


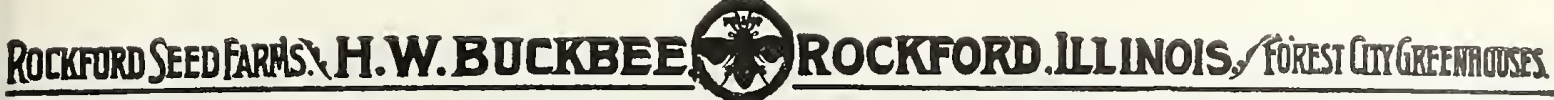

95

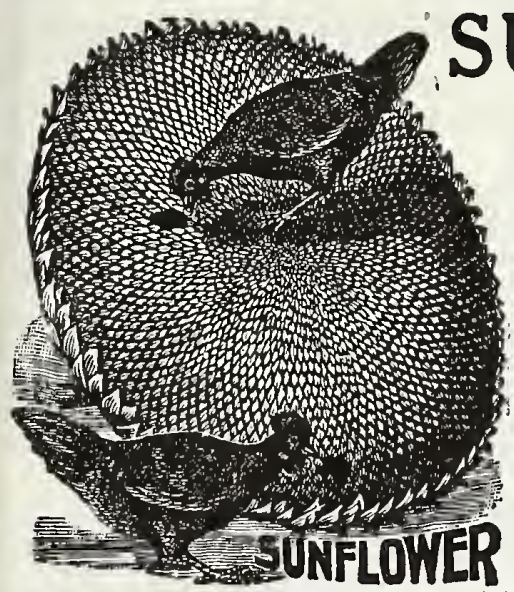

UNFLOWER

MAMMOTH RUSSIAN

up to July.

It is used as a medical her

It is fattening to either poultry or cattle.

In fact, it is the most wonderful, cheapest and best poultry food known.

Three pounds will sow one acre and the average yield is 100 bushels to the acre. Postpaid, oz. 5c; $1 / 2 \mathrm{ib}$ 16c: 1b. $75 \mathrm{c} ; 3 \mathrm{lb}, 70 \mathrm{c}$.

\section{Teosinte}

The Worid Beating Fodder Piant.

Here is a truly wonderful forage plant worthy of general cultivation It comes to us from the rich, fertile plains of the Nile; where travelers tell us, the enormous yield of 300 tons green fodder per acre is not unteommon. This is what it does in Egypt. What does it do in America Almost equally as well. Give it a ricli, warm, balmy soil, and it will yiel from 100 to 150 tons of Down in Georgia, in Florida and North Carolina its yield is all from 100 to 200 tons of green fodder per acre. It grows to a height of 18 feet in those states, while a single kernel will produce from 60 to 100 stalks of the most nourishing green fodder imaginable. Our test in the North gives it an average yield of about 50 tons of green fodder per acre. On our Rockford Seed Farms, where the soil is sandy and warm, it yielded at the of fully 60 tons per acre, sencing forth from 20 to 60 shoots from one kernel seed are required per acre. PRICE OF SEED, postpaid, oz. 10c; $1 / 1 \mathrm{~b}$. $25 \mathrm{c}$ 1b. 95c.

\section{Buckbee's "Full of Life" Flax Seed}

No. 25 or Primost Fiax

This is a pure bred flax. It is selected from a variety which came to the Minnesota Experinient Station from the U. S. Depart-

In 1896 numerous individual plants were selected from a bed of this Flax, some wlth heavy bushy tops to be used in breeding for a larger yield of seed, others with tall, slender stems for fibre. Each of these selected mother plants was grown in the nurplants selected for seed is the Minnesota No. 25, and named Primost. Our supply of this seed is limited, Send your orders lbs. 50c.

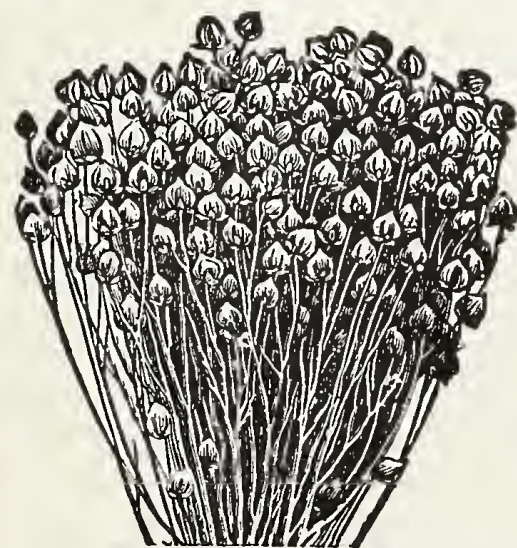

No. 25 or Primost Flax.

\section{Field Lupines \\ A Good Fodder Piant.}

One of the best plants known for reclaim ing poor soll, particularly sandy and old worn out land, by Lupins such land can be made very valuable It is so highly valued in Germany that it is called the "Gold of the Desert" or "Desert Reclaimer." It makes good fodder in either the green state or as hay. The seeds are very fattening when used with hay. Sow in the early Spring at the rate of 60 to lb. 30 c.

\section{多} 1 ancin 新的 \%र Nov

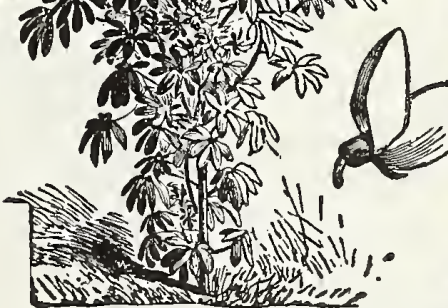

Fleld Lupines.

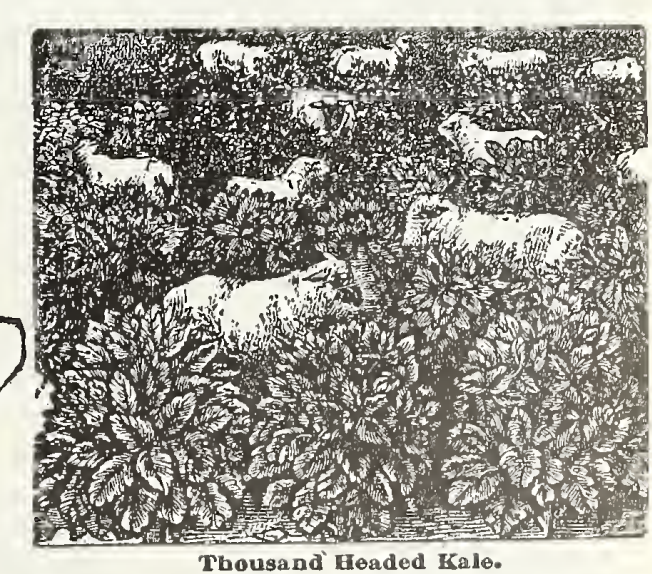

Thousand rieaded Kale. Dwarf Essex Rape and on account of the enormous amount and superior quality of feed Rape in some sections and among many shrewd farmers Thu of cabbage The plant attains a height of three to four feet. The stem is covered with leaves, which form small heads. Animals, especially sheep, eat it greedily. It grows wels may be either drilled or broadcasted. Plant in rows 26 to 30 inches apart, if drilled; thin to 16 to seed per acre Bostpaid 1/ lb, 20c; 1b. 50c. 


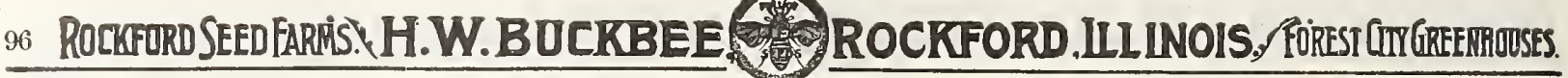

\section{BUCKBEE'S "FULL OF LIFE" W HEAT}

New Marquis Spring Wheat

The Earliest and Hardiest Spring wheat Grown.

Beardless, Grain Hard, Plump, Dark Red, Straw Long, Very Stiff, Wonderful Yielder

In introdueing "Marquis" Wheat we are offering our eustomers absolutely the earlies and hardiest Spring Wheat grown. It is from one week to ten days earlier than Red Fife. I grades No. 1 hard for milling purposes, and outyields the Red Fife. In appearanee "Marquis" Wheat is similar to Red Fife but the heads, as a rule, are heavier and the stalk is shorter, making it less liable to lodge. The kernel is flinty, a little darker than the Red Fife and more plump than that variety. Price, postpaid, 1b. 20c; 3 lbs. 55c.

Minnesota No. 169 Blue Stem Spring Wheat

This variety has no beards and is espeeially adapted to the older wheat seetions of th Northwest. The kernel is of the hard variety, similar to the Red Fife; very prody

Red Fife Spring Wheat

Noted for its earliness, vigor and freedom from smut and all diseases. Beardless. The kernels are hard and flinty, whereby it is reeognized as an A No. 1 milling Wheat, adapted to all states where Wheat ean be grown. Price, postpaid, lb. 20c; 3 lbs. 55c

\section{Macaroni or Durum Spring Wheat}

A most valuable variety for loealities subjeet to summer droughts and hot winds. It is bearded and gives the best results on new land. It does not shell or bleaeh and is also hail-p roof owing to the tightness of the hull. The straw is very strong. Price, postpaid, lb. 20c; $31 \mathrm{lbs} .55 \mathrm{c}$.

\section{New Red Wave Winter Wheat}

It is a bald brown ehaff. dark, medium long, large grain; strong, thick-walled, golden straw; medium tall and stoeky; heads very long and broad, flled with medium long, large, hard, dark kernels, rieh in gluten. Price, postpaid, 1b. 29c; 3 lbs. 55e.

\section{Red Wonder Winter Wheat}

A most valuable bearded variety and is adapted to a great many soils. It ean be depended upon for an abundant yield even in unfavorable seasons. It grows a little above medium height; straw jointed and stoeky The straw is very strong at base of head whieh accounts in a great
measure for its ability to withstand storms without lodging. Price, post paid, lb.20c; 3 lbs.55c.

\section{Fultzo-Mediterranean Winter Wheat}

This is a beautiful variety in growth, straw, head and grain. If sown thinly or damaged in winter it will stool out and produee 20 or more stalks from one grain. Chaff white. heads smooth or beardless; grains large, color red. Price, postpaid, 1 b. 20c; 3 lbs. 55c.

\section{BUCKBEE'S "FULL OF LIFE"

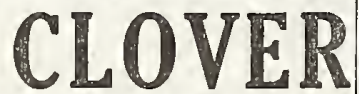

NORTHERN GROWN, RE-CLEANED GOVERNMENT INSPECTED SEED

Every bushel of Buckbee's Famous "Full of Life" Clover Seed that we send out test 98 per cent or better for purity, and 95 pcr cent or better for germination.

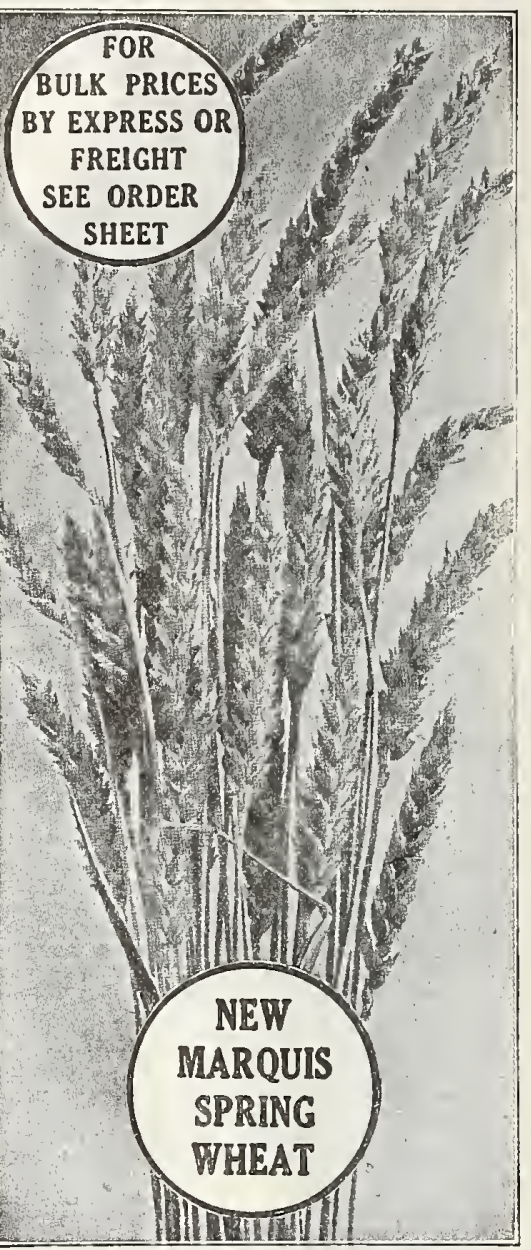

\section{ALFALFA}

THE OUEEN OF ALL THE CLOVERS.

There is no State in the Union Where it Cannot be Successfully Grown.

Alfalfa ranks higher than Timothy hay in feeding value. Experie ment Stations place the feeding value of Alfalfa hay at twenty dollars per ton as against Timothy hay at twelve dollars per ton. Cut and eured for hay it is the greatest money-maker known, averaging over forty dollars per aere elear profit.

Comparative Value-The Wisconsin Experiment Station says that one aere of Alfalfa yields as mueh protein (the milk and meat producer) as three aeres of common clover or nine of Timothy or twelve of Brome grass.

As a Meat Producer-Feeders in the West claim to be able to put fat cattl on the market 20 to 30 per cent cheaper with Alfalfa s balanee of feed than on eorn alon

The Dairyman's Stand-by-The Kansas Agrieultural Station reports a case where a dairyman maintained ten milch cows for a whole summer without any grain, on two aeres of Alfalfa, cut and fed to them fresh three times a day.

The U. S. Dept. of Agricultural says: "In addition to tbe hay erop. Alfalfa at two yeats adds $\$ 100$ to the value of every acre on whieh it grows."

Alfalfa produees from 3 to 7 tons of hay to the acre.

It has as mueh protein as Wheat bran.

360 stalks have been grown from one seed.

It does not exhaust the soil, it enriehes the soil.

It ean bo ground into meal to feed hogs and chickens.

It will grow 3 to 5 crops a year

One aere will pasture 20 hogs for 6 months.

Four to flve pounds makes tull feed for fattening aged sheep.

Thirty-five pounds make full f 81 for fattening steers.

A lamb will winter and thrive on 3 pounds a day.

Sbeep fed on Alfalfa will gain from 8 to 15 pounds in 75 days and will double with small grain ration added.

Lambs wintered on Alfalfa will produee one to two pounds more of wool than when on the range.

Alfalfa is a fine poultry feed when eut fine and this is also a good way to feed it to hogs in winter.

Many interesting faets in addition might be cited about Alfalfa. It

would hardly be possible to say too much about Alfalfa, it is a work-

ing plant whieh is changing the destiny of many farming sections.
"Its long, branching roots penetrate far down, push and crowd the earth this way and that, and thus constitute a gigantic subsoiler These beeome an immense magazine of fertility. As soon as eut. they begin to deeay and liberate the vast reservoir of fertilizing matter below the plow, to be drawn upon by other erops for years to come."

\section{Montana Alfalfa}

Montana produees a very fine grade of Alfalfa. The seed is usually xeeptionally large and of high germination. Montana grown Alfalfa is extremely hardy and some prefer it to seed from any other loeality. Our seed is obtained in those seetions where plants have endured the extreme cold of winter and thrive in high altitudes. Not only has our experienee of several seasons demonstrated the superiority of this seed under adverse climatic eonditions throughout the entire Northwest but more recent experiments of both the Minnesota and North Dakota, Wisconsin and exherimis of both the Minnesota and North Dakota, hardiness of Montana grown Alfalfa. Price, postpaid, 1b. 35c; 3 lbs. $\$ 1.00$.

\section{Turkestan Alfalfa}

Seed of this Alfalfa colleeted in Asia by Prof. N. E. Hansen of the South Dakota Experiment Station was sent out several years ago by the United States Department of A grieulture. The results have been so very satisfaetory that we have no hesitancy in reeommending it as one of the hardiest and best varieties. Our seed is the genuine Turkestan. grown in Asia. Price, postpaid, $1 b .35 \mathrm{c} ; 3$ los. $\$ 1.00$.

\section{Dry Land Alfalfa}

The extension of Alfalfa growing into the regions of limited rainfall has created a demand for Alfalfa seed espeeially adapted to those conditions. Seed whieh has been produeed from Alfalfa grown on dry land and without irrigation is of course mueh preferable for dry land culture to seed produeed under irrigation or normal rainfall.

The Alfalfa we offer as Dry Land is all its name implies. It was grown under severe eonditions of low temperature in winter, usually with little or no eovering of snow, and hot weather in the summer. Plants whieh survive this treatment and produce seed are very hardy plants. The seed inherits the tendeneies of the parent plants.

Price, postpaid, 1b. $40 \mathrm{c} ; 3$ lbs. $\$ 1.10$.

SPECIAL NOTICE,-Send to Secretary of Agriculture, Washington, D. C., for Free Bulletin on Alfalfa Culture. by Express or Freight: see Order Sheet. 


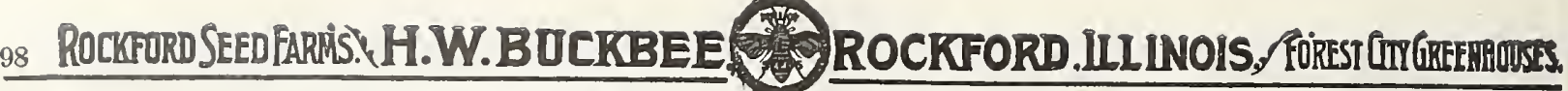 \\ "Full of Life" CLOVER}

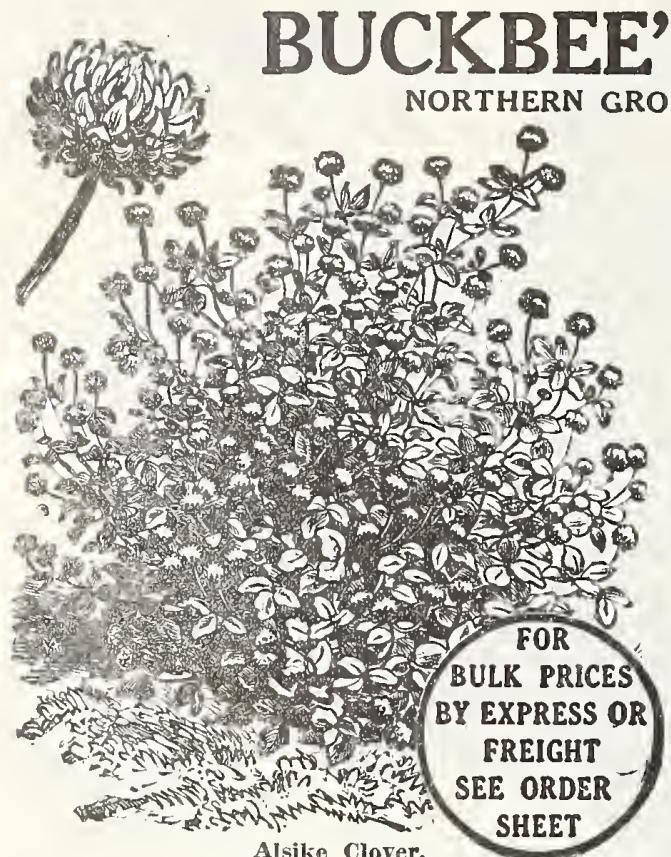

Alsike or Swedish Clover

This is one of the hardiest varieties known. It is a perennial and does not winthan any other variety of Clover, and is suitable for either hay or pasture. When und with other grasses in porm It is frequently sown with both Medium Red Clover and Timothy and the quality of hay thus produced is excellent. It is finer and more leafy than Red Clover, although it does Bees, and cattle preferit to all other Clovers. Also valuable for soiling. Clover sick land producing fine crops of Alsike. Sow broadrowed cround Fall or spring on trashy har lbs, per acre. Postpaid, 1 b. 35 c; 3 lbs. $\$ 1.00$.

Medium Red or June Clover This is the most important of all Clovers pasture. It is known as Common Red or June Clover in many sections Our Northern- rown Clover Seed has become widely known for its purity, strong vitality, hardiing qualities, so that now we receive many orders from the most distant parts of the United States. It has been tested by the parts of the country and ranks among the parts of the country and ranks among the are beginning to appreciate the difference be-

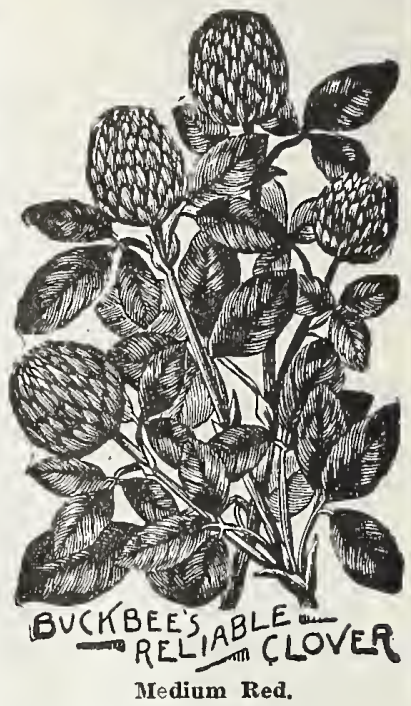

tween it and ordinary grades. It pays to have the best. Buckbee's "Full of Life" Grade the plumpest, cleanest, purest, fanciest grade; tested and of high vitality. Farmers usually sow 15

Crimson Clover (Giant Incarnate)

This fine Clover is one of the most valuable Fali crops the farmer can put in as it will make the earliest green feed of any of the Clovers. It will tons of green reed per acre or $11 / 2$ to $21 / 2$ tons or hay and is worth as a fertilizing crop $\$ 20.00$ to $\$ 25$.0arly Spring crops and in warm climates four or five cuttings are made during the season. Postpaid, lb. $30 \mathrm{c} ; 3$ lbs. 8 z̃c.

\section{White Clover (For Lawns)}

Bokhara, Sweet or Bee Clover (Melilotus Alba) This plant is grown mostly for fertilizing purposes, although It is a valuable preparation for Alfalfa because the same bacpreferably from April 1st to September 15th. Especially adapted Will grow anywhere, even if the land is as solid as a rock. Mammoth Red or Sapling Clover This is rrown largely for pastures and to restore fertility to depleted soils. Being a rank grower, it is very valuable for fertilizing purposes. Sow $15 \mathrm{lbs}$. per acre. Price, postpaid, lb. $35 \mathrm{e} ; 3$ lbs. $\$ 1.00$.

\section{Serradella Clover}
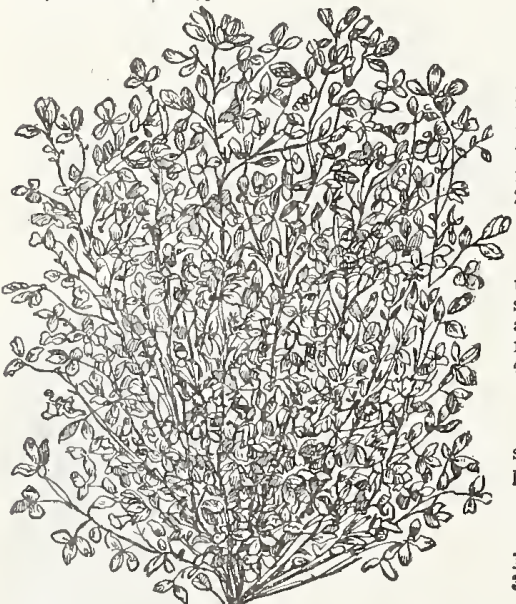

Bokhara Sweos or Beo Clover

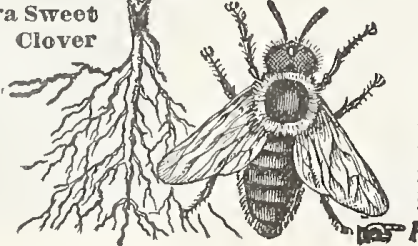

The greatest honey producing plant in the world. For light, poor or sandy soils Serradella is one of the lbs. per acre and can be sown either with Winter Wheat or by itself or in Rye in early spring, growing rapidy after the grain has been cut. Postpaid, lb.

\section{Sand Clover}

Here is an especially rich, hardy herbaceous Clover, that will grow and thrive poorest soils and in avidity by sheep, cattle and horses; useful in mixture for dry solls. Sow 20 lbs. to the acre. Postpaid, lb. 40c; 3 lbs. \$1.15.

\section{Yellow Trefoil Clover} Allied to common Red Clover. Valuable for dry,
sandy or poor soil. Sow 12 to 14 lbs. per acre. Postsandy or poor soll. Sow

Sand Lucerne Clover Especiaily adapted to sandy soils. Largely used in
Europe. Sow 12 to $14 \mathrm{lbs}$. per acre. Postpaid, lb. 40c; Burr or Japan Clover

This not a true clover, but in appearance and habit growth is much like White clover. It is especially on poor and exhausted soils that are too poor to produce profitable crops of any other forage plant. It is an annual but once sown reseeds itself from year to year and in that way wiil last indefinitely. Usually from July to October Postpaid, 1b. 35c;

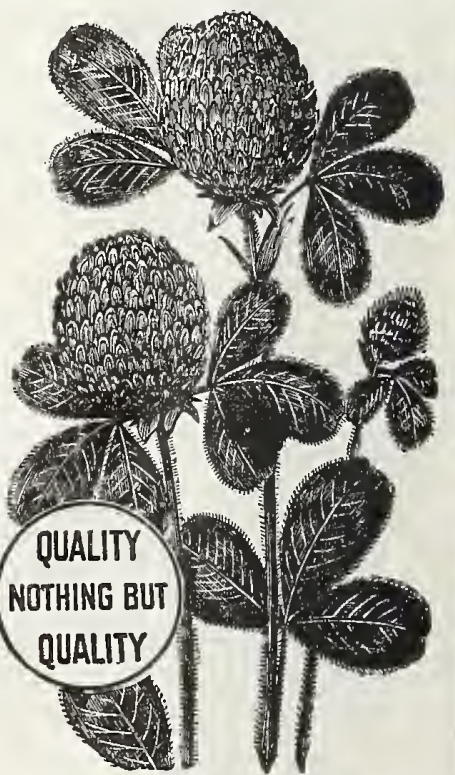

Mammoth or Sapling Clover.

For Lowest Wholesale Prices on Clover Seed in Large Quantities, see Order Sheet 


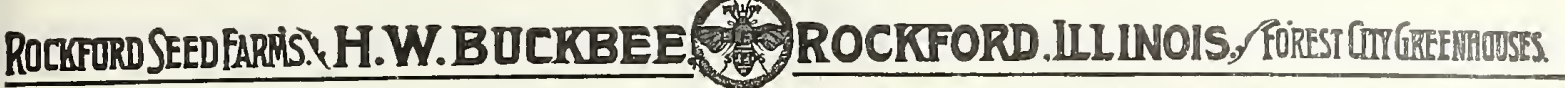 BUCKBEE'S "FULL OF LIFE" GRASS SEEDS}

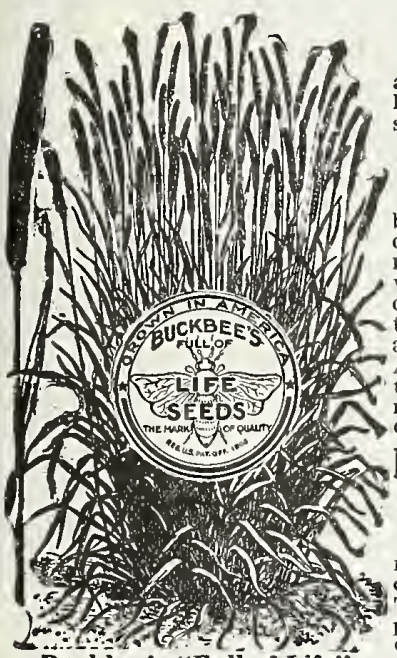

Buckbee's "Full of Life" Timothy.

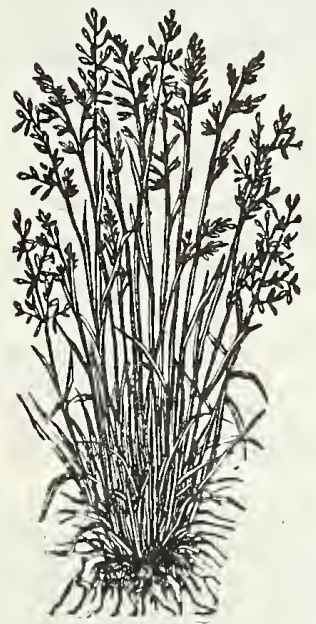

Red Top.

\section{HIGH GRADE-PEDIGREED}

The best obtainable, both as respects purity and high germination-pure and elean, plump,

\section{Timothy}

As a crop for hay, Timothy is probably unsurpassed by any other grass. It is greatly relished by all kinds of stock, especially horses. It yields more nutritive well suited for a permanent pasture as jt will hold its own for several years, before running out. Well adapted to early Spring grazing, as it starts up quickly in the spring Autumn as well. Our "Full of Life" Brand will stand the test of any Pure seed Law in the World. Wil range prices, postpaid, lb. $30 \mathrm{c} ; 3 \mathrm{lbs}$. $75 \mathrm{c}$ Bromus Inermis Acknowled ged King of the Iakes Lots of Early Spring and Latc Fall Feed. Besides Good Crop of Hay

A hrdy pereminh it it is well adapted to cold climates and exposed situations. Produces satisfactory crops on land too poor for Timothy and other grasses. pronounced a great boon to farmers because IT PAYS ON ANY GROUND.

It does well sown with clove and Timothy. Use twenty pounds to the acre, if well together.

Choicest Northcrn grown stock seed, that will stand the test of any Purc seed Law in the world, postpaid, $1 / 2$ lb. $15 \mathrm{c} ; 1 \mathrm{~b} .27 \mathrm{c} ; 3 \mathrm{lbs}$. $75 \mathrm{c}$.

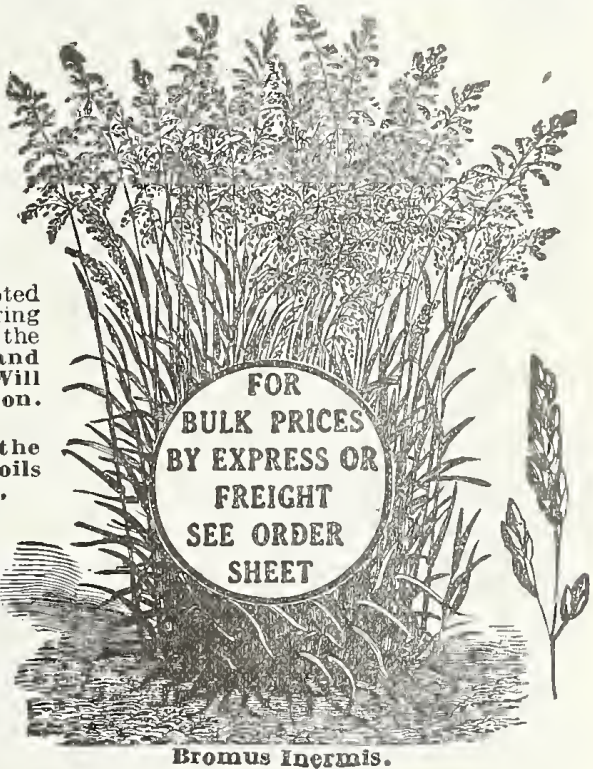

STANDARD LIST OF LEADING GRASSES

Used for Hay and Permanent

Pastures. Buckbce's "Full of Life" Brands Recommended for Purity and Germination.

\section{KENTUCKY BLUE GRASS}

\section{RED TOP.}

ORCHARD GRASS.

CISH PERENIAL RYE Griss.

TALIAN RYE GRASS. (Lolium Itaicum)

CREEPING BENT GRASS. (Agrostis Stolonifera) ...

CRESTED DOG'S Tail Grass. (Cynosurus Cristatus)

IIARD FESCUE GRASS. (Festuca Duriuscula)

MIEADOW FESCUE GRASS (Festuca Pratensis)

RED or CREEPING FESCUE. (Festuca Rubra).

SITEP'S FWSCUE. (Festuca Ovima)

TOUE STALED MEADOW GRAS.” (Poa Trivialis)

MEAD W FOXTAIL GRASS. (Alopecurus Pratensis)

TALL MEADOW OAT GRASS. (Avena Elatoir)

TII MEADO

(Festuea Elatoir) ....................

WOOD MIEADOW GRASS. (Poa Nemorais)

SWEET VERNAL. (Anthoxanthum Odoratum)

JOHNSON GRASS. (Sorghum Halapense

\begin{tabular}{|c|c|c|}
\hline \multirow{2}{*}{$\begin{array}{c}\text { Lbs. } \\
\text { per } \\
\text { bu. }\end{array}$} & \multicolumn{2}{|c|}{ PRICES POSTPAIO } \\
\hline & $\begin{array}{l}\text { Per } \\
\text { lb. }\end{array}$ & $\begin{array}{l}\text { Per } 3 \\
\text { lbs. }\end{array}$ \\
\hline 14 & $\$ 0.25$ & 50.70 \\
\hline 14 & .30 & .85 \\
\hline 14 & .27 & .8 \\
\hline 14 & .25 & .8 \\
\hline 14 & .25 & .7 \\
\hline 14 & .40 & 1.1 \\
\hline 14 & .40 & 1.1 \\
\hline 12 & .35 & 1.00 \\
\hline 14 & .27 & .8 \\
\hline 14 & .40 & 1.1 \\
\hline 12 & .35 & 1.0 \\
\hline 12 & .48 & 1.4 \\
\hline 12 & .40 & 1. 1 \\
\hline 12 & .35 & 1.0 \\
\hline 12 & .40 & 1.1 \\
\hline 12 & .48 & 1.4 \\
\hline 12 & .35 & 1.00 \\
\hline 25 & .25 & \\
\hline & .60 & $1 . \%$ \\
\hline
\end{tabular}

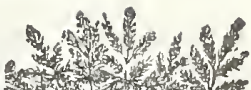

$\sqrt{3}$

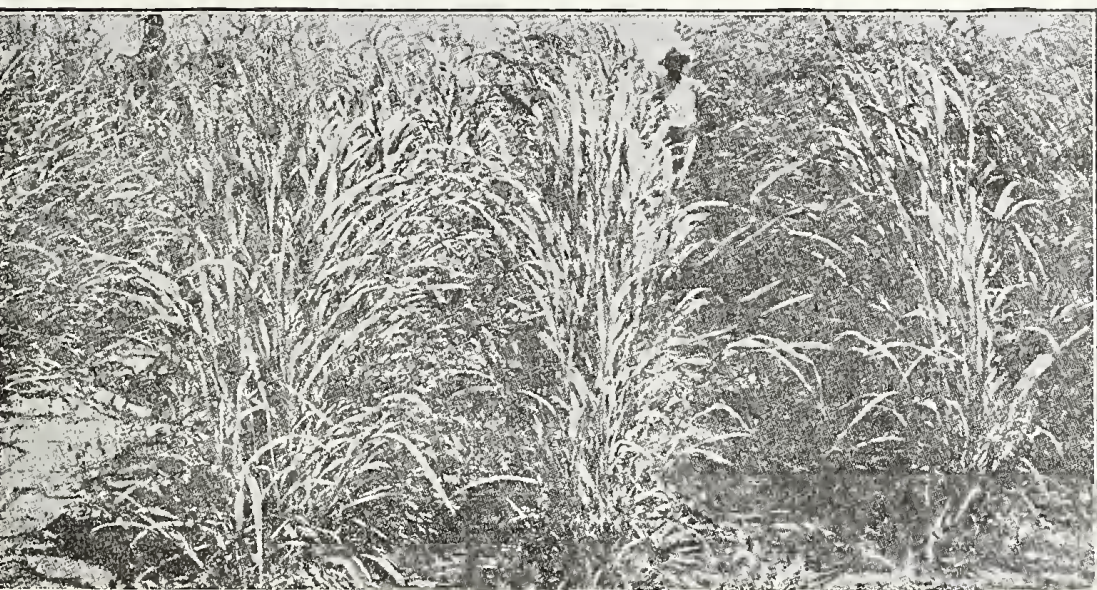




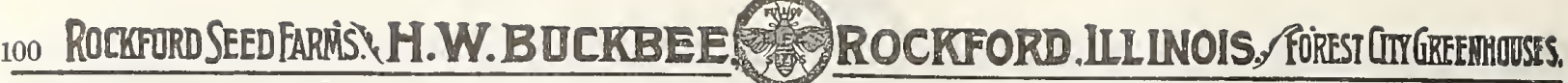

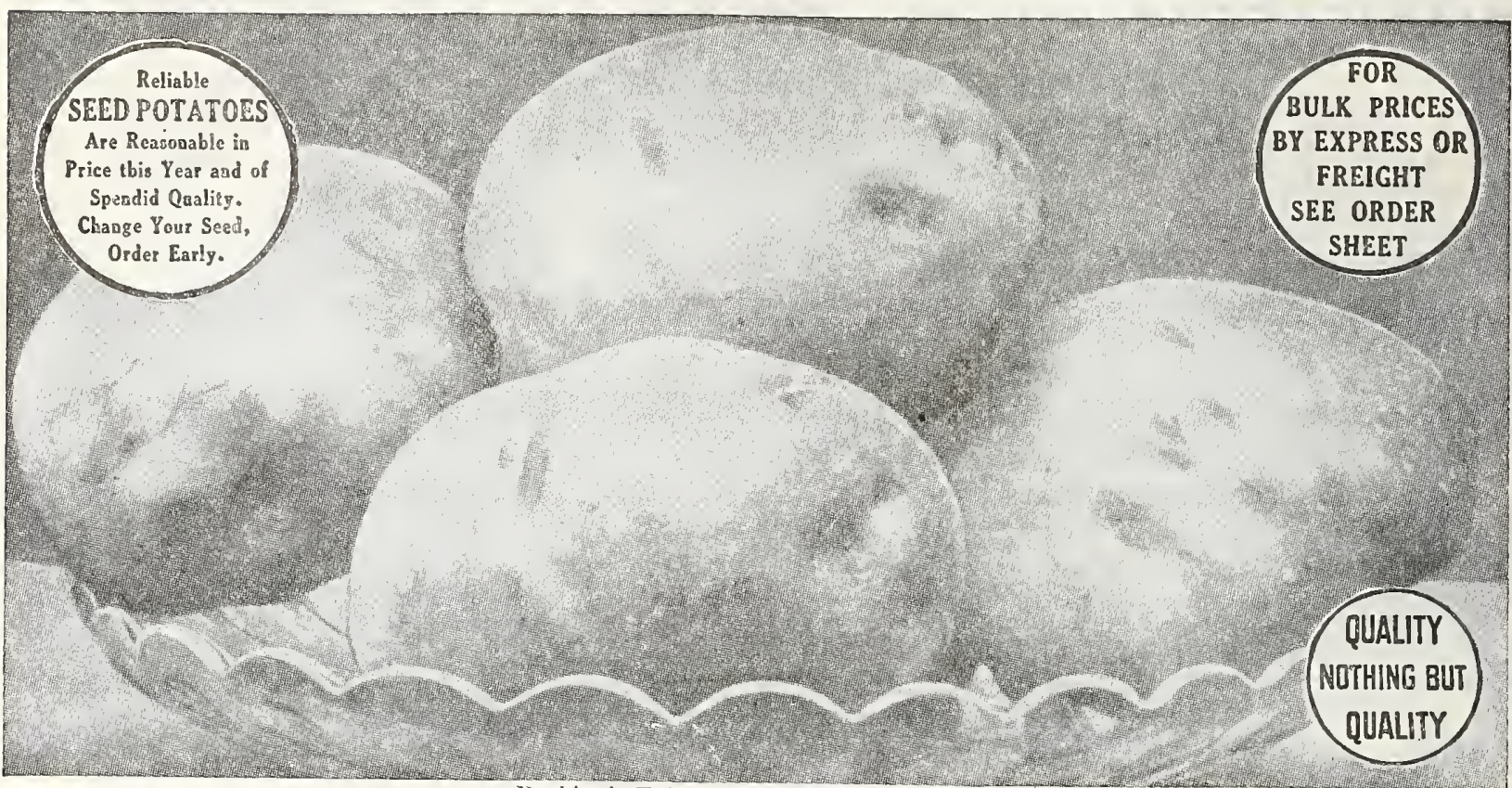

BUCKBEE'S

Pedigreed Stock Grown in the Famous Red River Valley of the North Expressly for Seed

No seed Potatoes can be compared with those produced in the North, either for vigor and freedom from disease, or for producing and long-lieeping qualities.

DATE OF SIIPMENT-Potatoes will be shipped at any date ordered at purchaser's risk, but where no special instructions are given to the contrary, we will hold same until in our judgment there will be a minimum danger from freezing. Of the many varieties that claim public favor, we have selected the best in cultivation.

Buckbee's Extra Early Rockford

TRULY A WONDERFUL POTATO.

Handsome, Blight-Proof Variety. Very Heavy Yielder, Cooking Quality the Best.

A new Extra Early Variety of great promise. Makes an extremely quick growth and considering its Extra Earliness is a wonderfully heavy yielder. Is of very handsome appearance
with pinkish tinged skin and white flesh. Prices, postpaid, $\mathbf{1}$ lb. 30e; 3 lbs. 70c

\section{Buckbee's Noroton Beauty}

The Noroton Beauty is one of the earliest Potatoes ever grown, being about two weeks earlier than the Early Rose. Large table size tubers have been grown in sixty days. It is fully as proVariety yields nearly so heavily. It is handsome in appearance, having a russety white ground, splashed with pink, and pinkish eyes, and more uniform in size and shape than any other variety. its tubers mature simultaneously, a fact which, combined with blight, or disease, or bugs. Its table quality is superb; flesh blight, or disease, or bugs. Its table quality is superb; flesh
is white, dry, and the flavor unsurpassed. Prices, postpaid, lb. 30c; 3 ibs. roc. Early Six Weeks

Fine Potato for Southern Truckers.

This is a fine new Potato of the Ohio type and seems to be in demand everywhere. It has been sold under the Six Weeks, Early Market, Extra Early Six Weeks, etc. Several seedsmen claim to have introduced it and more than one has represented it as ready for market six weeks after planting. We never it as ready for market six weeks after planting. We never had any such success with it, however. It is Extra Early all should give this variety a trial. As now improved, we consider it one of the best extra early market varieties grown. As a table Potato they are not excelled; even for late Spring they
keep sound and solid. Prices, postpaid, 1 lb. 25c; 3 Ibs. 60c. Bliss' Red Triamph

\section{A Most Popular Variety.}

There is good reason why the TRIUMPH should be popular. It is from seven to ten days earlier than the Ohio, and that oftentimes means a difference of many dollars in the crop. The Potato is of good size, squared at ends. Skin is red, flesh is
very white and firm. It is productive, and for several years very white and firm. It is productive, and for several years buyers than any other sort. Our stock is genuine. Prices, postpaid, 1 lb. 25e; 3 Ibs. 60e.
New Early White Ohio

An ohio with a White Skin.

It is a true ohio of the best type in all except color, which instear of being pink, as in the parent, is a beautiful creamy
white with pink eyes. Prices, postpaid, 1 lb., 25e; 3 lbs. roc. For Frices in Bulk by Expres

\section{Pure Early Rose}

The good old favorite, which continues in great popularity. A proilific yielder, sure cropper and popular market Potato. Every farmer and gardener knows the good Early Rose and nothing more need to be said in its favor. The seed we offer is the purest and best that can be put on the market. Choicest Pedigreed Stock Seed. Prices, postpaid, 1 Ib. 25c; 3 lbs. G0e.

\section{Irish Cobbler}

It is a most excellent extra early variety, maturing good sized tubers seven weeks from time of planting. It has also the remarkable characteristic of producing very few, if any, small Potatoes, all the tubers being of marketable size. The vines make short, upright growth, so that the hills may be only a short distance apart. The flesh is pure white, with a clean, smooth skin; and in quality they are excellent, always cooking dry and mealy. They are splendid keepers, and taking it all in all, it is a first-class sort and worth the attention of all Potato growers. Specially suited to dry climates on account of paid, 1 lb. $25 \mathrm{c} ; 3$ lbs. $60 \mathrm{c}$.

\section{Sir Walter Raleigh}

\section{A Grand Late Potato.} A white-skin, main crop Potato much resembling Rural New
Yorker No. 2, of which it is a seedling. It is decidedly better than its parents; the tubers being quite uniform in size, with but few small ones among them. It is from four to siy days later than the parent stock. The color is the same, the skin and flesh being white. In fact, it can be justly claimed for Sir Walter Raleigh that it is the whitest fleshed and finest grained potato on the whole list of main crop varieties. Prices, postpaid, lb. 25c; 3 lbs, G0c.

Rural New Yorker No. 2

(Also Known as Dusty Rural.)

The Standard White Market Potato.

One of the largest yielding varieties in existence. Large and unusually smooth, with few and shallow eyes, skin white, as is also the flesh, which is of superior quality. Medium Iate and best drought resister. There is no other Potato of more handsome appearance than the Rural New Yorker. Although it is a large yielder it grows but few and small vines. Prices, postpaid, 1 lb. $25 \mathrm{e}$; 3 lbs. $60 \mathrm{c}$.

\section{Burbank}

A Standard Late Variety.

Continues in good demand and is more largely used than any other. It is of good size, of fine form and an excellent yielder. 'The flesh is white, very mealy and of fine flavor and quality. The best potato for baking. This variety is well adapted for heavy soils. Prices, postpaid, lb. 25e; 3 lbs. 60c. 


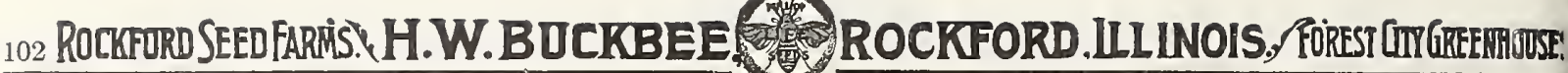

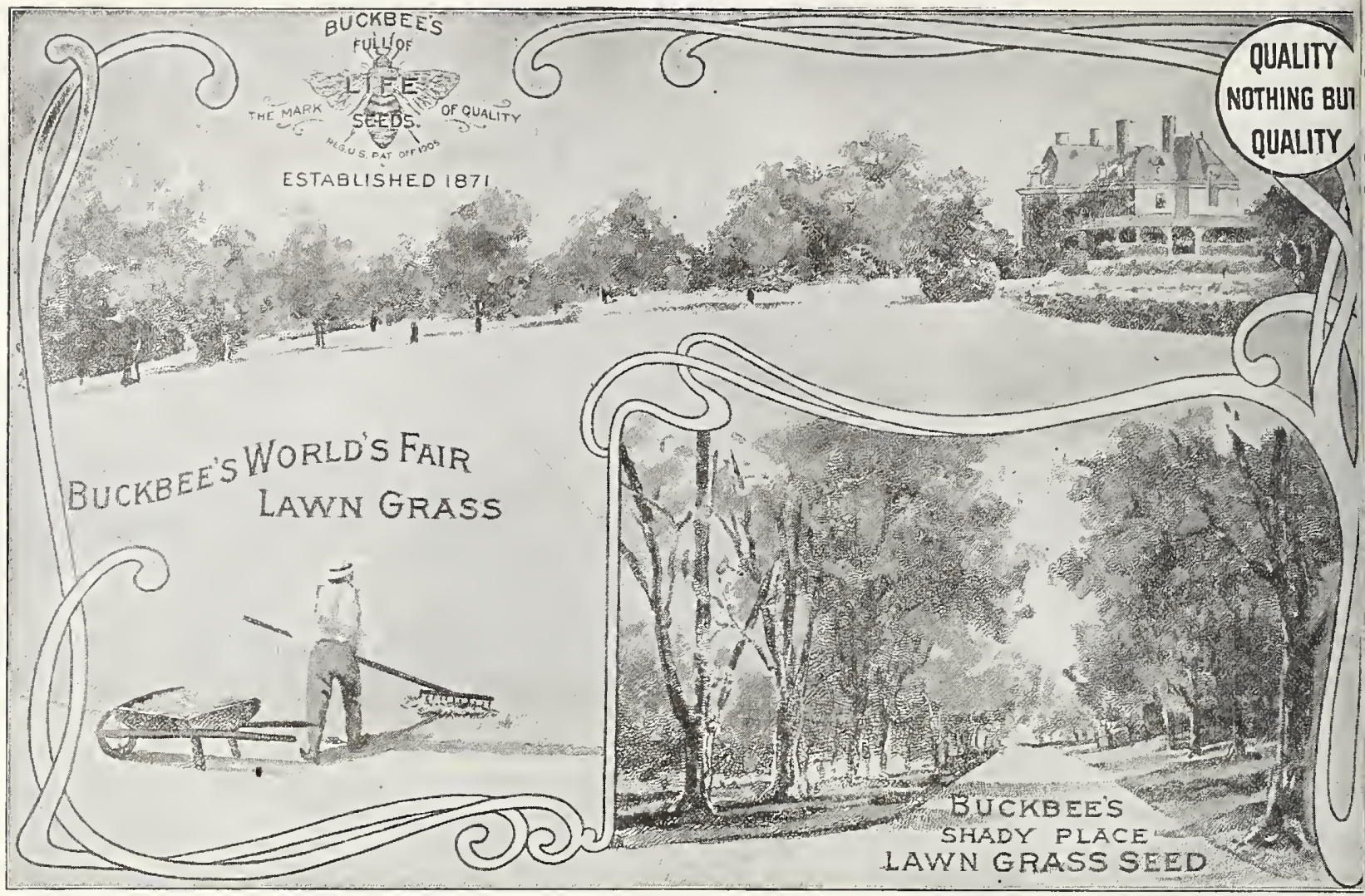

\section{Buckbee's Famous "Full of Life" Lawn Grass Seed HARDY, LUXURIANT, ALWAYS GROWS, ALWAYS THRIVES}

\section{Our Lawn Grass Seed}

Produces a per luxuriant richness, with closely interto and elastic turf and it is generally ready for mowing in six weeks from time of sowing and is composed of a thoroughly balanced combination of weaving habit, that fourish under varied c zcitions, soils and 列 that a deep green, smooth and velvety sward free from clumps is maintained from snow to snow without burning brown in the hot months of summer. The latter is not oniy much less expensive but much more satisfactory, as better grasses can thus be obtained, and the the appearance and the permanency of the Lawn.

\section{BUCKBEE'S WORLD'S FAIR LAWN GRASS}

The Very Best Lawn Seed Ever Offered,

This famous Prize-Winning Lawn Grass is made up of a most evenly balanced combination of native and foreign fineleaved, deep-rooting grasses that interweave and flourish in different soils and climates, each showing its best strength at seasons different from the others, and thus keeping the Lawn vigorous and green from winter's end to winter's next advent. warded the great Columbian Prize at the World's Fair. Lawns, which were without question on of the greatest features of the Fair. It is the Ideal Mixture, and is unrivaled for purity and luxuriance in growth and will anyone secure a beautiful Lawn Complete and explicit dlrections on "How to Make a Lawn" accompany every package of this seed. The quantity table on this page shows the amount of seed to plant in a glven area. Price, postpaid, $1 / 2$ lb, 17c; lb. 30e; 3 lbs, 87 c. Large lbs. $\$ 1.90$; 15 lbs. $\$ 2.80$; 25 lbs. $\$ 4.50$.

\section{How to Make a Lawn}

Is fully deseribed in our new pamphlet, which will be given frce with every package of Lawn Seed.

\section{Special Quotations} We shall be pleased to quofe special prices to Golf Clabs, Clover Seeds in large quantities.

\section{SHADY PLACE LAWN GRASS}

The Very Best Obtainable-Carefully Blended.

On nearly all lawns there are unsightly bare spots under th shade of trees, which have baffled all efforts to get into grass, but with this mixture there need be no further difficulty. It is a combination of fine dwarf-growing, evergreen varieties which in their wild or natural state are to be found growing in the woods or other sheltered and shaded spots. "Ground that has been densely shaded by trees is frequently "sour" and if the drainage is defective it is apt to be covered with moss and the grasses. In such cases an application of slaked lime, bushels to the acre, is an excellent corrective and sweetener, but the moss should be first removed

Sow from 50 to 60 pounds per acre for a new lawn or bowling green; 15 to 20 pounds per acre wlll be sufficient to express or freight, not prepaid, 5 bs. $\$ 1.25 ; 10$ lbs. $\$ 2.45 ; 15$ lbs. $\$ 3.60 ; 25$ lbs. $\$ 5.75$.

\section{VELVET GREEN LAWN GRASS}

A Splendid Standard Mrixture.

This special mixture does not include so great a number of expensive grasses as our "Famous Mixture," but full provision is made for a succession of growth and a careful blending in proper proportion and thoroughly mixed for quickly producing a permanent, thick and velvety sward of uniform growth and 15c; 1b. 25c; 3 lbs. 70c. By express or freight, not prepaid, 5 lbs. 85c; 10 lbs. \$1.65; 15 lbs. \$2.40; 25 lbs. $\$ 3.85$.

\section{Quantity of Lawn Grass Seed to Use}

1 lb. for 350 square ft. $25 \mathrm{lbs}$, for one-fourth acre.

50 lbs. for one-half acre.

100 lbs. for one acre.

\section{BUCKBEE'S EXTRA SPECIAL LAWN FERTILIZER}

Makes the Lawn Strong and Keeps it Healthy.

The lack of a good fertilizer is the reason there are so many poor, rusty-looklng, unsightly lawns. Use this Lawn Fertilize If you would have a beantiful and sturdy growth of grass. This fertillzer, used in connection with any of our speclal Lawn Grass Seed Mixtures, will entuble you to produce a perféct lawn. Price, postpaid, lb. 20c. By express, not prepaid, 5 lbs. $30 \mathrm{c}$ 10 lbs. 50c; 25 lbs. $\$ 1.00 ; 50$ lbs. $\$ 1.60 ; 100$ lbs. $\$ 2.95$. 


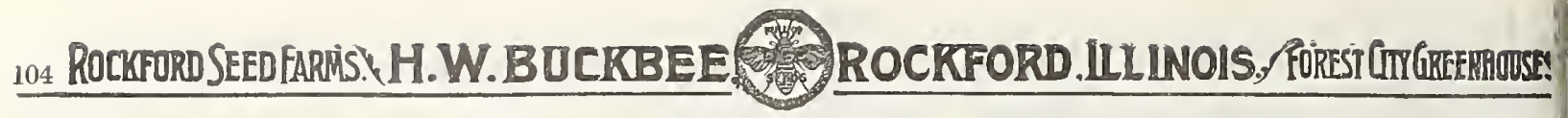

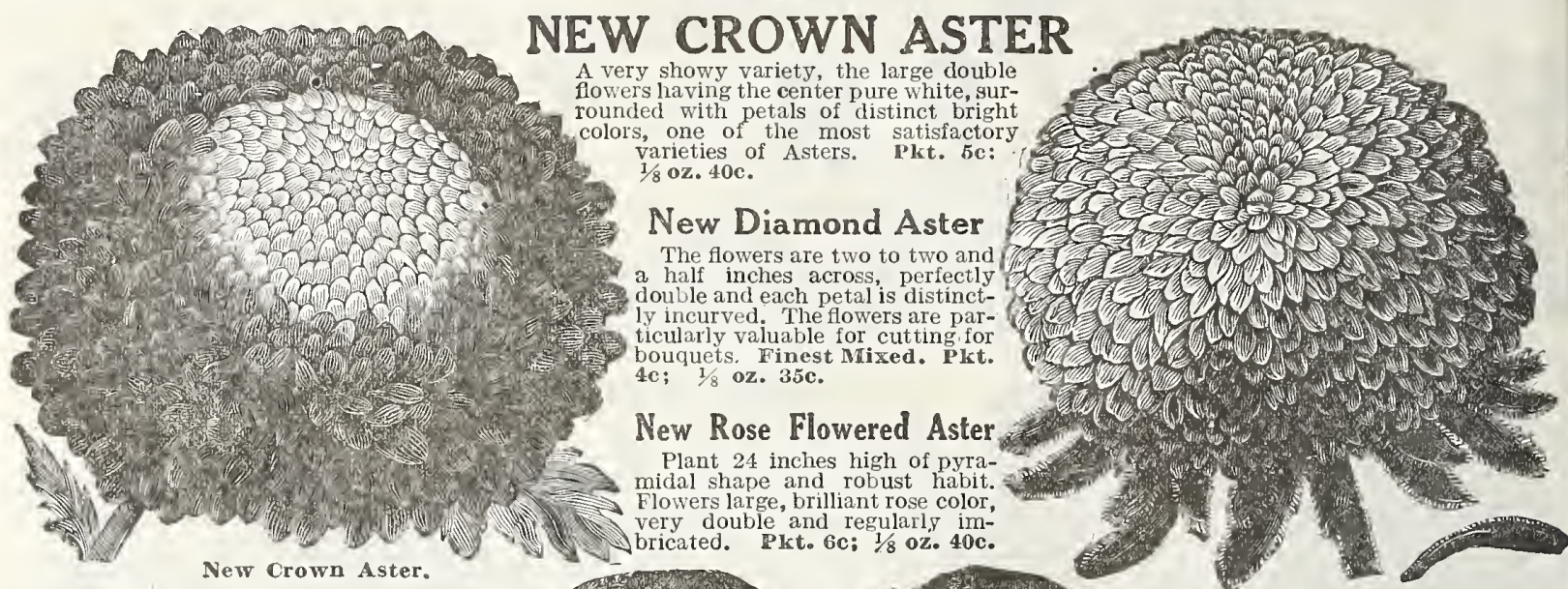

Buckee's Giant Branching Aster

The flowers are the most beautifully form-

ed of all large Asters, and quite different in

branching habit is accompanied with great

vigor of growth and profusion of bloom. The

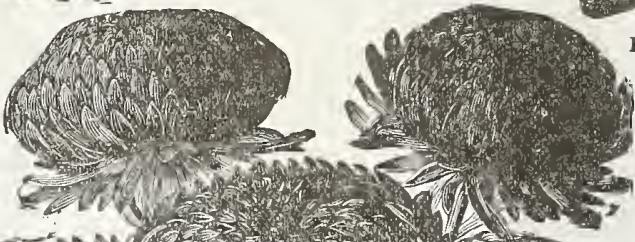

Buckbee's Improved Victoria Aster

long stiff stems, and the colors are clear and

substance, and, in consequence, the
flowers last long in perfection. These magnificent blossoms being gracefully poised on strong, well-leaved stems,
15 to 18 inches long; are unsurpassed as cut flowers for vases and
home decoration. We offer the following scparate colors:

Pure White-Pkt. 6c: $1 / 8$ oz. 25e;

oz. 90c.

$07.90 \mathrm{c}$

Rose Pink-Pkt. 6c; $1 / 8$ oz. 25c; oz. 90c.

Lavender-Pkt. 6c; $1 / 8$ oz. $25 \mathrm{c} ;$; oz. $90 \mathrm{c}$.

Crimson-Pkt. 6c; 1/8 oz. 25e; oz. Asters-Mixed. Pkt. 6e; $1 / 8 \mathrm{oz}$. New Giant Quilled Aster A Most Handsome Variety The flowers are very large, often
five inches across, are produced on long, thin wiry, stems, perfectly double, with long needle or quillshaped petals, giving the blossoms a very distinct appearance, The plants are of healthy and vigorous 15 inches, Choice Mixed. Pkt. $6 \mathrm{c} ; 1 / 8 \mathrm{OZ}$. $25 \mathrm{c}$.

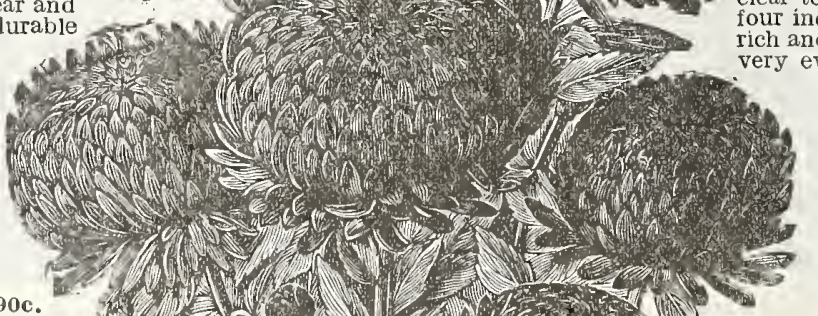
Magnificent flowers, massive and howy, with regular overlapping petals our inches and over across, and are of evenly, pyramidal in form, about eighteen inches high and carry rom twenty-five to forty flowers. The stems being long and strong makes them fine for cut flowers. Scparate Colors 6c; $1 / 8$ oz. Flesh Color-Pkt. 6c; $1 / 8$ oz. Rich Purple-Pkt. 6c; $1 / 8$ oz. $35 \mathrm{c} ;$ oz. 51.25
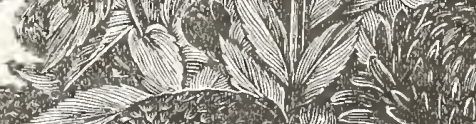

Dark Crimson-Pk

Peach IBlossom-lkt. 6c; $1 / 8$ Victoria 350 ; 0 . $\$ 1.25$.

Mixed-

Fire King Aster

The Mlost IBrilliant Aster Ever Introduced.

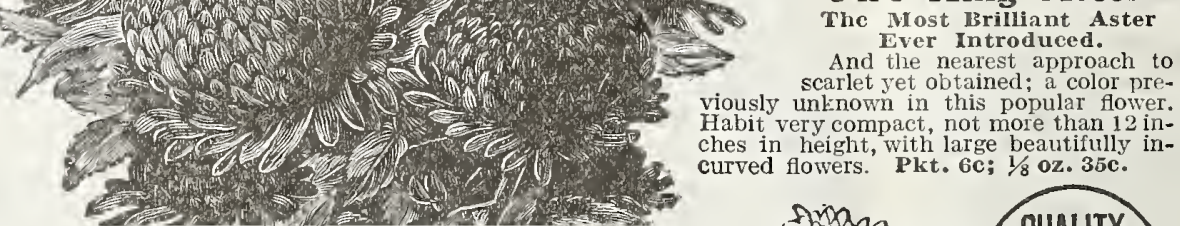

And the nearest pproach to scarlet yet obtained; a color pre-

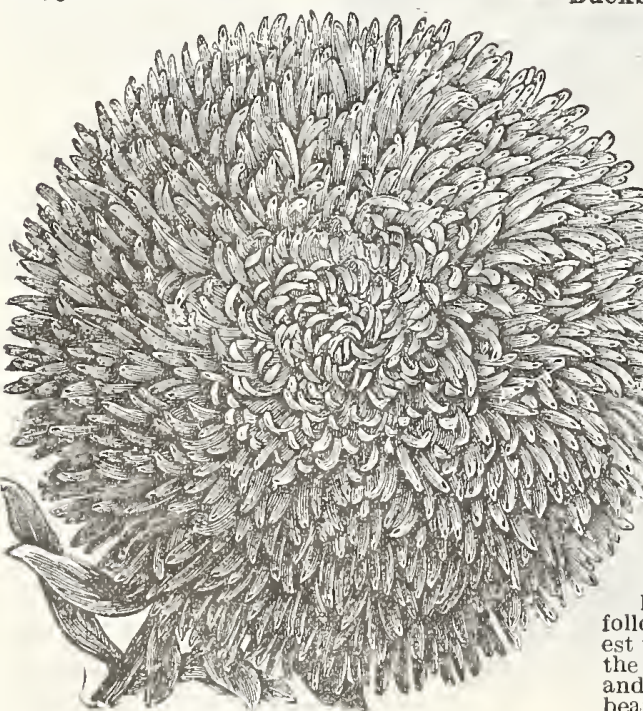

New Giant oulled Aater
Buckbee's Giant Branching Aster.

Snowball Aster

A most pro-

fuse bloomer

single plant

of en produc-

ng as many

as twenty-

\section{pure snow-}

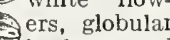

of extraor-

Pkt. 6c:
oz. 35c.

J. H. Penhall,

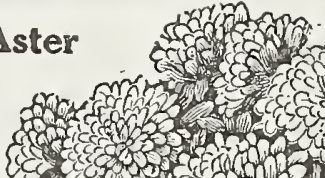

sinin

\section{QUALITY} NOTHING BUT

hall, QUALITY

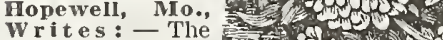

you bore four

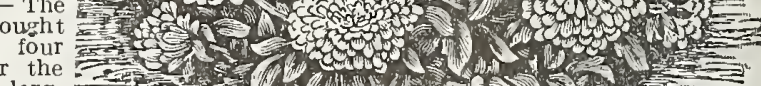
lemons this year the
following sizes: the larg.
est was 17 inches around, and 23 ounces, can that be exhlbition at this place

Buckbee's Soowball Aster. 


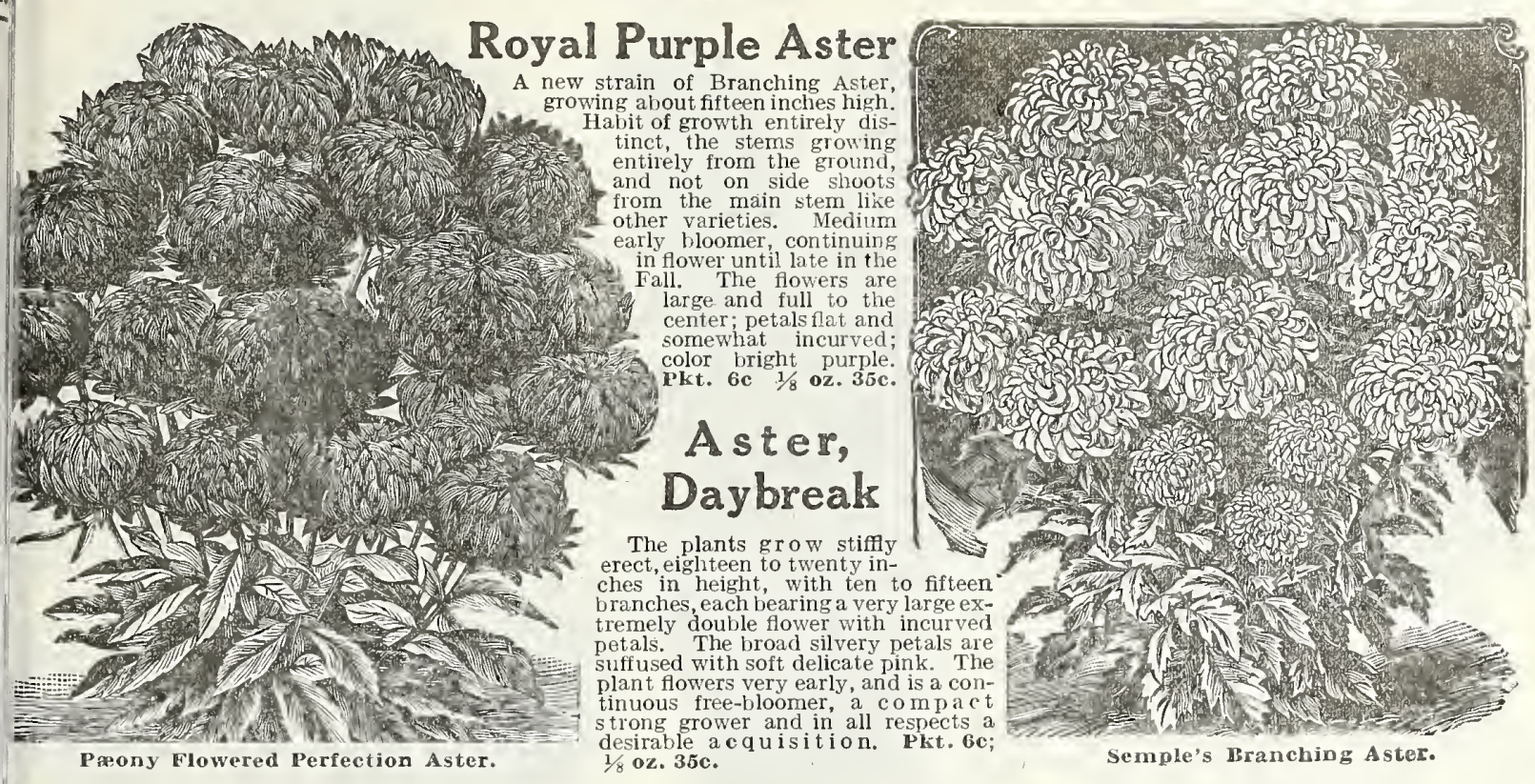

Paeony Flowered Perfection Aster

One of the most perfect and deservedly one of the most popular all Asters; very double, large and beautful flowers, with incurved tals; height 18 inches to 2 feet. It is one of the most beautiful ad extensively cultivated varieties, Separate Colors.

right Red-PKt. 4c; $1 / 8$ oz. $25 \mathrm{c} ;$ oz. \$1.20.

dear Whitc-Pkt. 4c; $1 / 8$ oz. 25c; oz. \$1.20.

each Elossom-Pkt. 4c; $1 / 8$ oz. 25c; oz. $\$ 1.20$.

iolet-Plkt. 4c: $1 / 8$ oz. 25c; oz. $\$ 1.20$.

lue-Pkt. 4c; $1 / 8$ oz. $25 \mathrm{c} ; 0 \mathrm{z} . \$ 1.20$.

erfection Mixed-Pkt. 5c; 1/8 oz. 20c; oz. $95 \mathrm{c}$.

\section{Semple's Branching Aster}

The plants form strong robust bushes about two feet high, bearing profusely on long, strong stems, handsome double Chrysanthemumprofusely on long, strong stems, handsome double Chrysanthemumof the stiffiness usual to most Asters, making them particularly desirable as cut flowers. They come into flower from two to three weeks 1 ater than most sorts. Separate Colors.

Whitc-Pkt. 4c; 1/1/ oz. 20c; oz. 75c.

Pink-Plkt. 4c; $1 / 4$ oz. 20c; oz. $75 \mathrm{c}$.

Purple-Pkt. 4c; 1/4 oz. 20c; oz. $75 \mathrm{c}$.

Lavender-Pkt. $4 \mathrm{c} ; 1 / 1$ oz. 20c; oz. $75 \mathrm{c}$.

STMPLE'S BRANCHING-Mixed. Pkt. 5c; $1 / 4$ oz. 18c; oz. 60c.

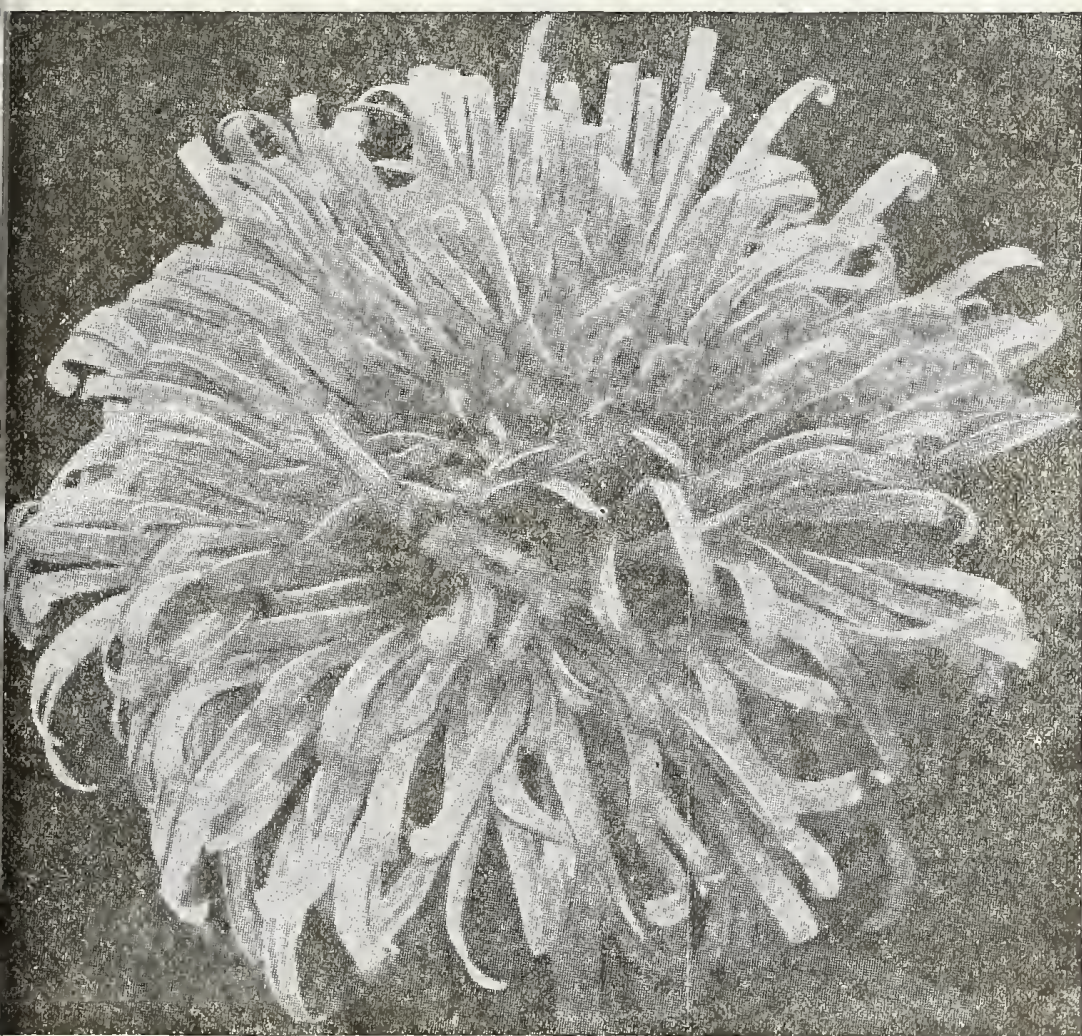

Now Giant Ostrich Feather Agter.
New Giant Ostrich Feather Aster This magnificant Aster may be briefly described as being the finest of the Comet type yet introduced; differing in the candelabra form of growth and greater ceedom of bloom, but its greatest merit is in the flowers, much longer, more loosely formed petals, equalling the best Japanese Chrysanthe mums. Blooms in August. When used for cutting, the flowers should be picked when about half expanded and allowed to $1 / 8 \mathrm{Oz} .30 \mathrm{c}$.

\section{Buckbee's Superb Mixture Giant Asters}

\section{ARSOLUTELY UNEXCELLED}

Producing heautiful flowers, rigantic in size, gorgeous in colors, perfect in form. This mixture includes the cream of all the Asters on this and the other two pages together with many other sorts of the most beautiful forms and brilliant colors. Especially selected from the and large sized, double-flowering types, pleased and astonical fower wide range colors and varieties, and we guarantee it will give satisfaction. Pkt. 10c; $1 / 8 \mathrm{oz} .40 \mathrm{c}$ oz. $\$ 1.75$.

\section{Buckbee's Fine Mixed Asters}

This is a most splendid collection of the leading types of this most beautiful flowe in choice mixture. We have made the price so low that you cannot pass it by. Pkt. 5c: $1 / 80 z .30 \mathrm{c} ; \mathrm{oz}$. 75c.

\section{Good Mixed Asters}

Many bright colors from standard varieties, free bloomers and strictly frcsh, new seed. Pkt. 3 c: $1 / 3$ oz. 20c: 0z. 600 . 


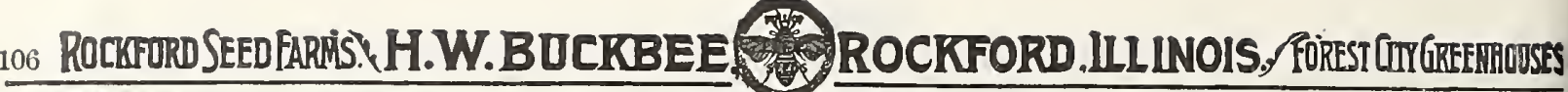

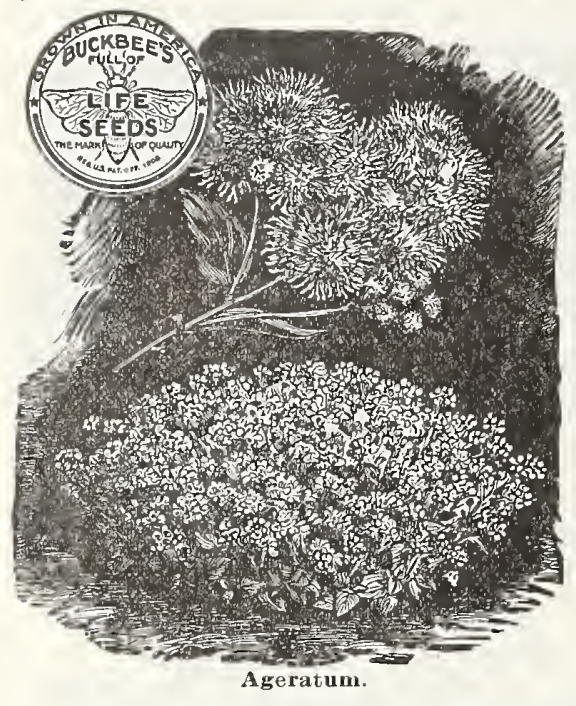

Ageratum

One of the best of Summer-flowering plants grown from seeds. The plants start readily, grow rapidy, and soon come into bloom, and flower uninterruptedy throughout the season. Iruring the hot, frymmer months there are no brighter or white. Finest Mixed. Pkt. 3e; 1/4 oz. 10c.

\section{Abutilon}

Frequently called "Flowering Maple" or "Chi nese Bell Flower." Blooms quickly ; easily grown lings Mixed. Pkt. 8c.

\section{Ambrosia}

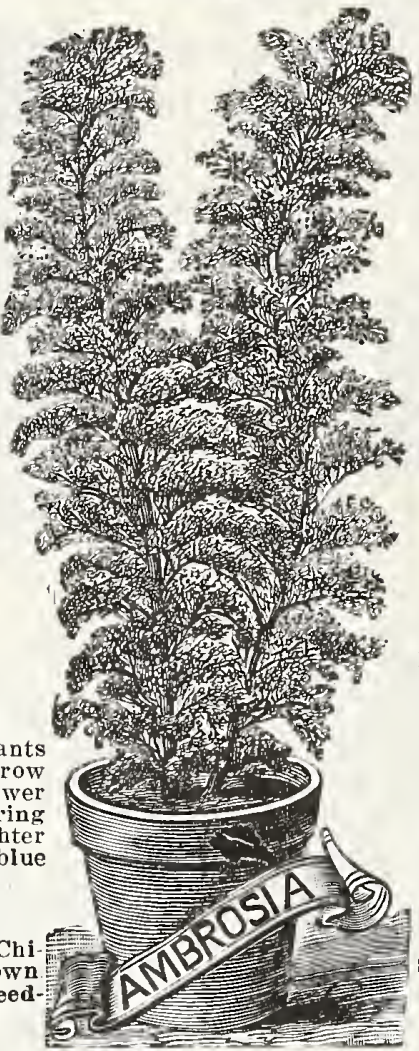

A hardy annual, exceedingly fragrant. It is as desirable as the Rose Geranium as a plant with fragrant foliage and for making into bouquets and other floral work. Pkt. 4 c.

Bachelor's Button (Double)

Also known as "Ragged Sailor," "Corn Flower" and "Blue Bottle." It has been so perfected that fully 80 per cent of the flowers are double and semidouble, and present many bright colors and distinct markings which have hitherto been unknown in this old-fashioned favorite flower, Double Fine Mixed. Pkt. $4 \mathrm{c} ; 1 / 2 \mathrm{oz} .10 \mathrm{c}$.

\section{Balsam Apple}

A beautiful climbing plant with queer shaped fruits. Which if preserved in alcohol, make a most useful liniment Foliage gracefully cut and al though tender annuals, the vines run ten feet or more during the season. Pkt. 5c; 1/4 oz. 12.

\section{Balloon Vine}

A rapid and graceful climber. Tender annual. 6 feet high. The flowers resemble small balloons. Pht. 3e; $1 / 2$ oz. $15 \mathrm{c}$.

Baby's Breath (Gypsophila)

An annual that should be in every garden for it thrives ever ywhere and furnishes the loveliest material for all kinds of bouquets. Pkt. $4 \mathrm{c}$.

$$
\text { a }
$$
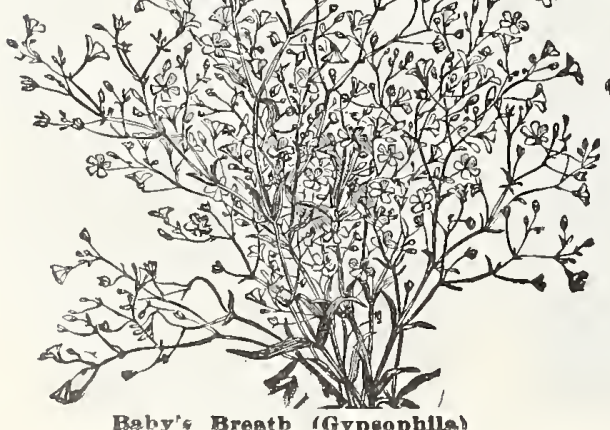

Raby' Breath IGypandilla

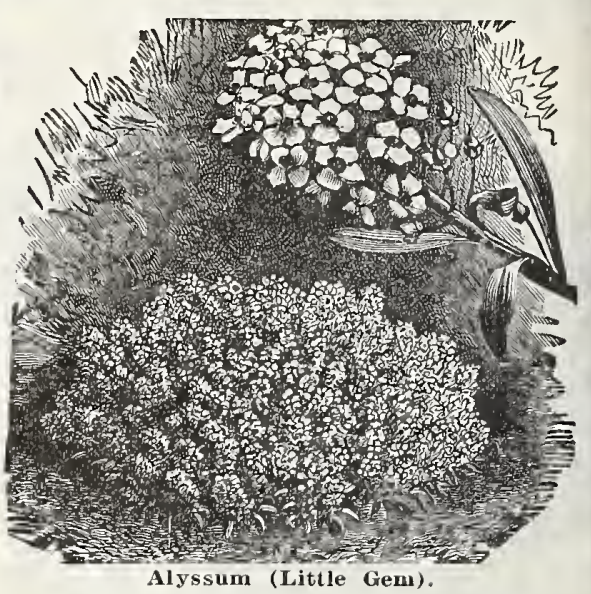

\section{Alyssum}

LITTLE GEM-This should really be called th "Snow White Carpet Plant" for the plants which are only a few inches high, grow sc dense, and are so completely covered with snow. white blossoms, it creates the impression of ? beautiful carpet spread over the ground. W know of no other white flower which is so par
ticularly well adapted to borders, ribbons, etc. as "Little Gem" Alyssum. The plants com. mence to bloom when quite small, and wil flower uninterruptedly all summer long nuti late in the fall. Added to all this is the sweel fragrance, and we cannot see how a garden could be complete without it. Pkt. 4c; 1/4 oz. 20c.
WEET-Pure white, free bloomer. Pkt. 3c; i/ oz. $10 \mathrm{c}$.

\section{Anchusa}

The Heavenly Blue Flower.

A hardy annual of more than ordinary beauty. I grows about two feet high, branching freely and bear ing a profusion of the most lovely flowers similat in all respects to the Forget-Me-Not, though thi always taken for a beautiful large-fowering For get-Me-Not and for bouquets and cut flowers $i$ is indeed supper to it. It blooms early and con tinues all Summero Pkt. $40,1 / 2$ oz. 150

Bean (Scarlet Runner)

A Favorite old-Fashioned Climber.

One of the very few Beans that is bot ornamental and useful. It grows rapidl to a height of ten to twelve feet, and $\mathbf{i}$ : covered from July until heavy frost witl clusters of beautiful scarlet flowers. Pkt. 5c; $1 / 41$ b. 15c.

\section{Bean (White Runner)}

Same as the above with exceptiol of the flowers, which are pure whit Pkt. 5e; $1 / 4$ 1b. 15c.

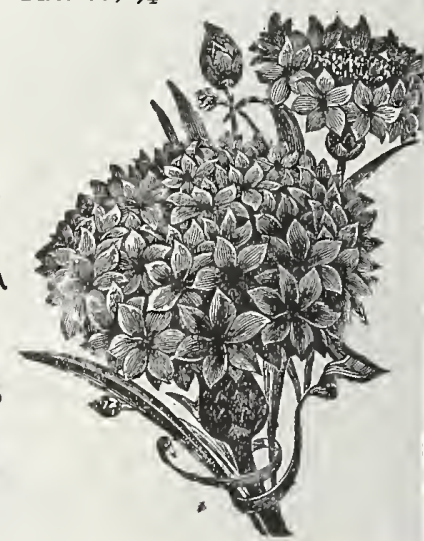

Aachelor's Button. 


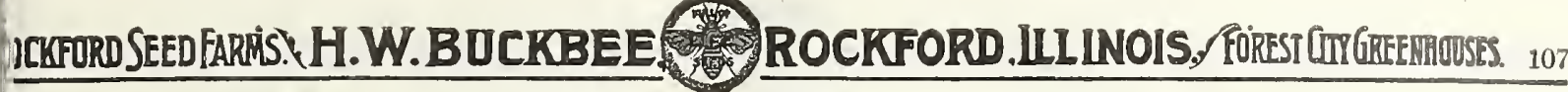

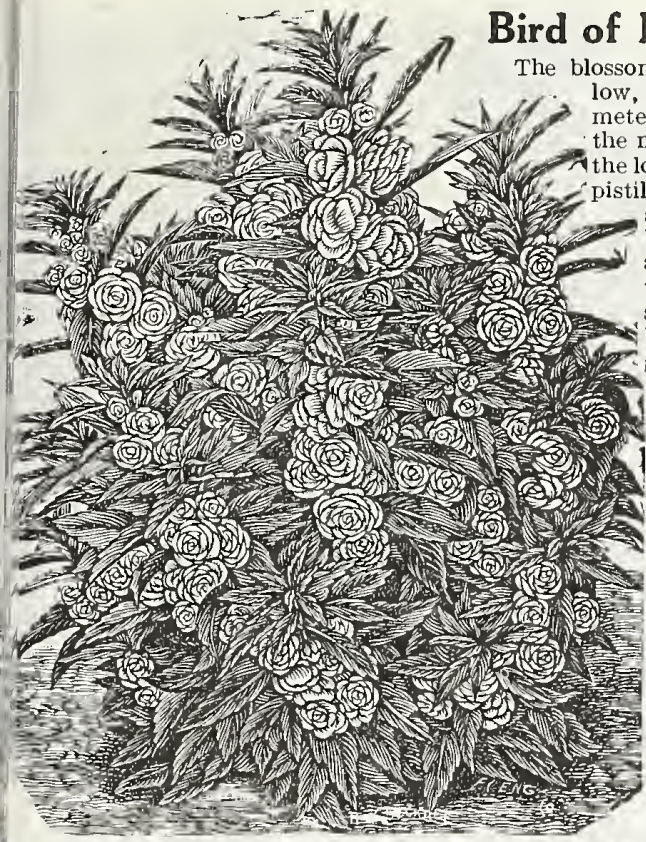

Balsam (Lady Slipper) UCKBEE'S SUPERB DOUBLE MIXXE-The most perfect in form and largest double-flowered Balsam yet developed. And unrivaled for diversity of rich and delicate colors, orten two inches across and offer a very choice selection of numerous hybrid sorts and a most careful painstaking mixture, Pkt. 6c: $1 / 4,0 z, 30 c: 0 z . \$ 1.00$

OOD MIXED-This mixture is comprised of the standard sorts and will give good results. Pkt. 3 ;

\section{Butterfly Flower} They form compact plants literally covered with beautiful, orchid-like f flowers all delicately fringed and lilac, purple and yellow blotches Fínest Mixed. Pkt. 4c.

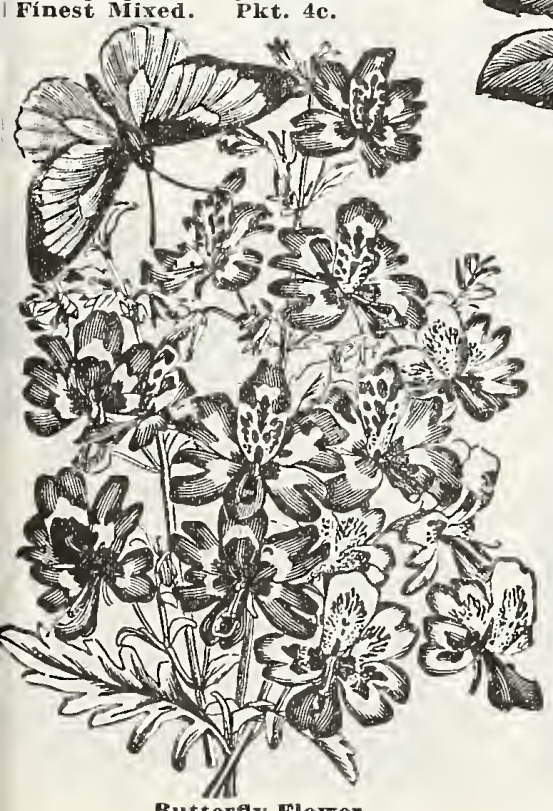

Pkt. 6c.

NOTE. - We also offer a limited num offer a limited num plants only $\mathbf{2 5 c}$ OUALITY
NOTHING BUT
QUALITY

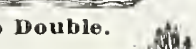

(4)

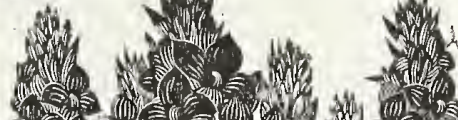
H E

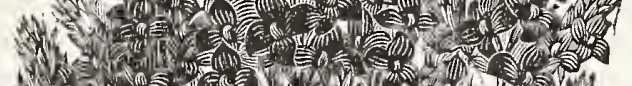
- 1 .
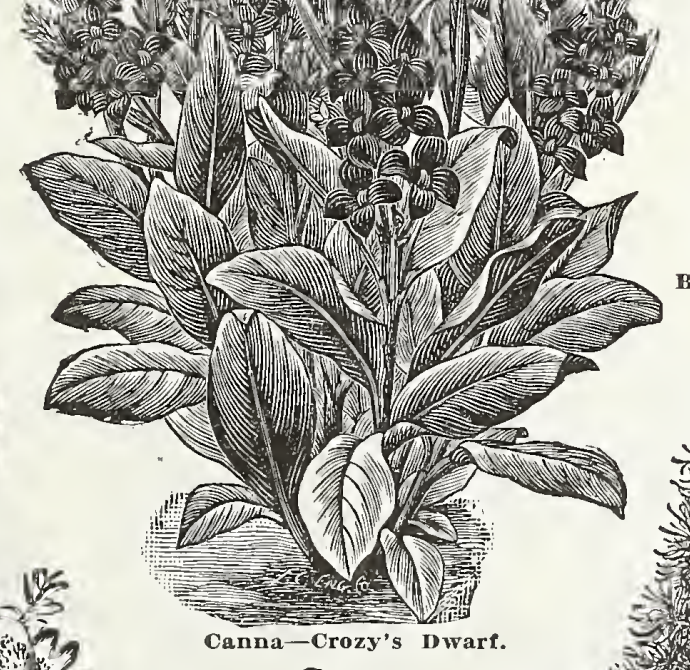

Canna

Crozy's New Dwart

But few people know that these beauiful flowers can be so easily grown from seeds, and can be so easily grown from popular of bedding plants while tive in the garden. Sow singly in smal pots as soon as convenient, and grow as rapidly as possible The roots can be clump will give six to eight good roots for planting out the following Spring,

\section{Canna}

Common Tall Mixed or Indian Shot. A splendid assortment of the oldFor Canna Plants seo Page 130 sown before
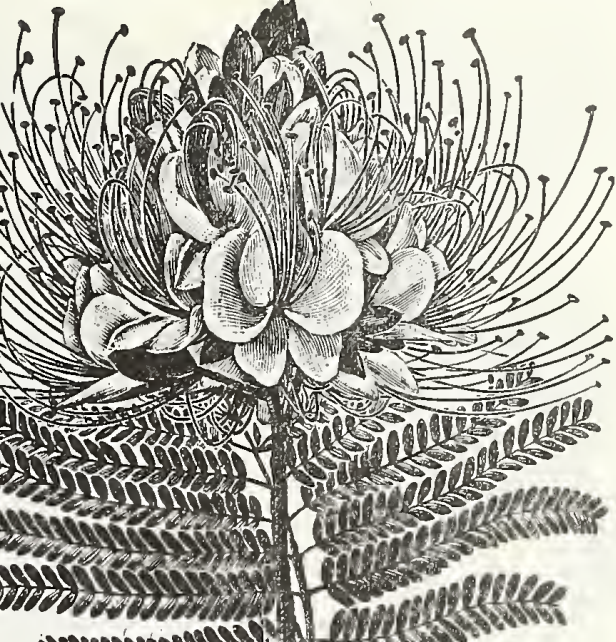

Bird of Paradise.

Burning Bush (Kochia)

\section{Or Summer Cypress.}

This beautiful annual bush is rapidly coming into prominence. It grows 2 to $21 / 2$. Feet high and resembles a close shaped or pyramidal bushes are close and compact, and of a pleasing light green color. The plant may be grown singly or in the form of a hedge or background. In early Autumn the whole bush become carmine or blood red, whence the name of It is also called Belvidere, Standing or Mock Cypress, Flowers small and numerous, but not conspicuous. The beauty of the plant is in its shape and colors, 5c; $1 / 2$ oz. $10 c$.

\section{Begonia Vernon}

One of the most satisfactory pot plants for the house, and a popular bedding plant for the garden or lawn. Fiowers a low centers, and the foliage waxy and glossy. Pkt. 6e.

Begonia Plants. See pages 135,136 and

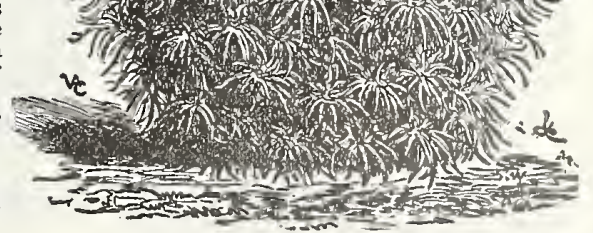

Burning Bush. (Kochia) 


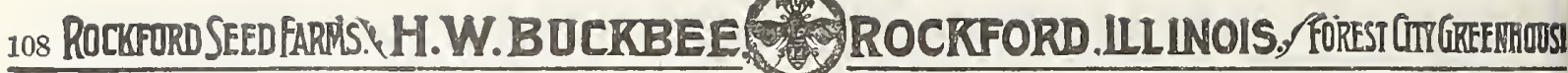

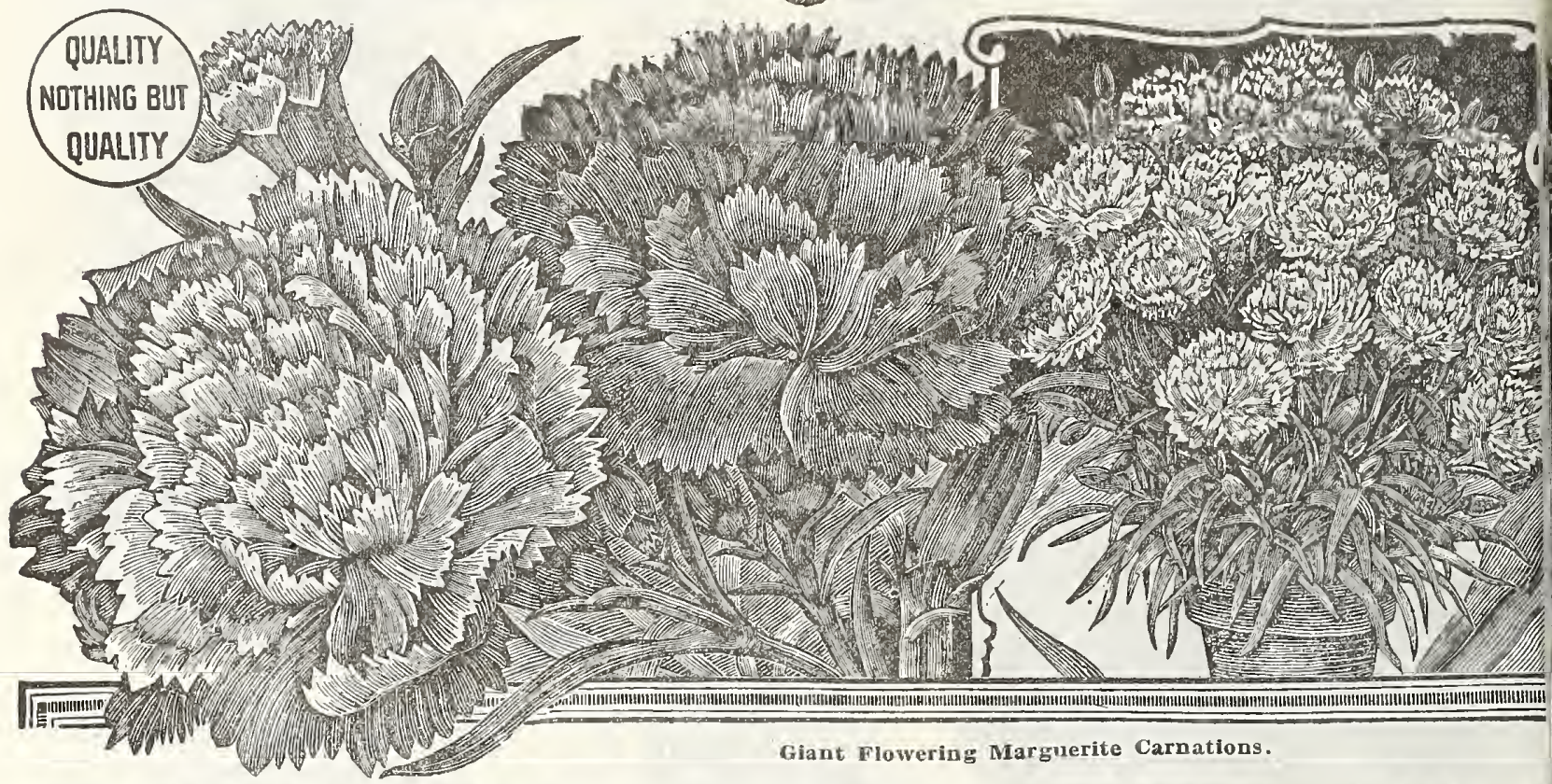

\section{CARNATIONS}

GIANT - PLOWERING MARGUERETE

Which Flower in 3 or 4 Months from Seed?

These lovely, fragrat Carnations, produce fine double flowers which often measure three inches across, The varicty of color includes white, blush, decp pink, salmon, carmine, cif ully variegated flowers. Most of them have (a) delightfully fragrant One grcat merit of these Carnation is that they commence to flower in about twelye weeks' time from seed. Seeds sown in the sprin win produce luxuriant plants that will be conby severe frosts, or seeds may be sown durin important flower seed novelty in many years. They are alike valuable for pot culture and for rarden use The plants grow easily everywhere, both in sandy soil or heavy loam, and will give perfect satisfaction.

All Choicest Colors Mixed. The finest

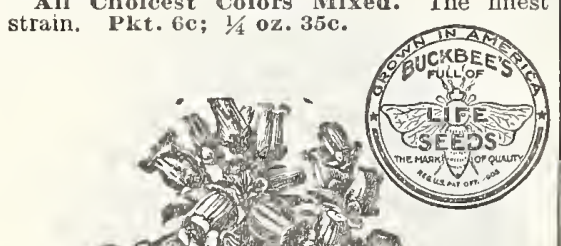
Wemer for the winter-flowering plants.

CANARYBIRD FLOWER

(Tropaeolum Canariense.)

Beautiful climber, the charming little canary-colored blossom bearing a fancied resemblance to a bird with its wings half expanded. The plant has a luxuriant, ramthe side of arbor or trellis will run about wenty feet, and will blossom from July Pkt. 4c; $1 / 2$ oz. 15c; oz. 25c.

\section{CANTERBURY BELLS (Campanula)}

Well-known popular pcrennials producin bcll-shaped flowers of many difierent colors Single Mixed, all colors:

Double Mixed all colors:

\section{CACTUS SEED}

There is a great deal of pleasure derived in growing Cactus from Seed, even if they slow growth

or a variety or shar secure new and rare varieties. The sced may be sown in flnely sifted sand in flat pans or boxes, which should be picce of glass. Seeds will come up in 3 to 4 Our mixture of seed is very flne, You will be surprised at the odd looks of Cacti just sprouting from thc earth.
Choice Mixed. Pkt. 8c.
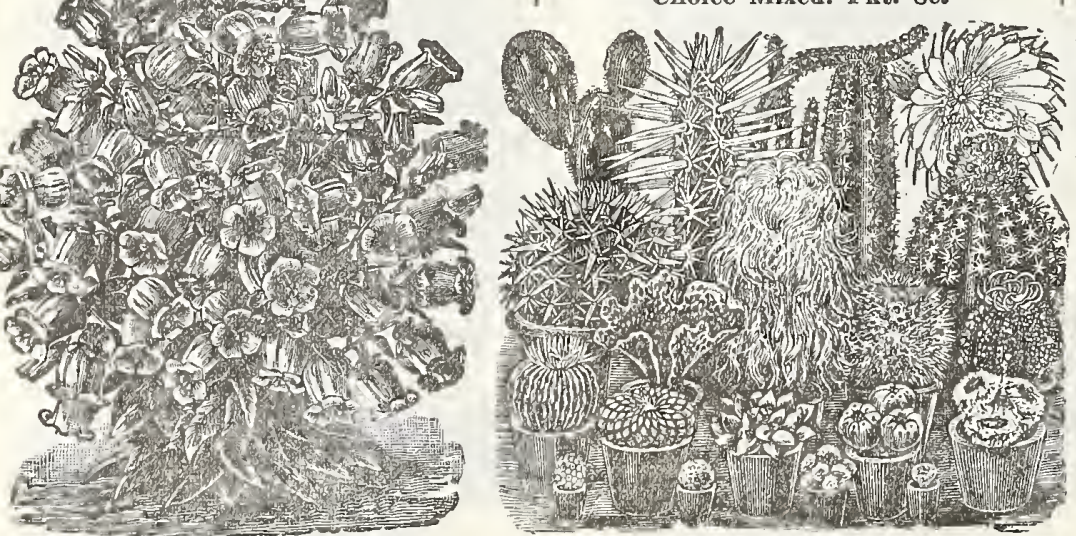

Cactus from seed.
CARNATION:

GREENHOUSE IVER-HLOOMLNG Buckbee's Extra Choice - "Full of Life Double Mixed.

This is the famous Carnation that is grov o extensively by Florists and Amateurs f Cut Flowers and Pot Plants, Our Seed is sav from our wonderful collection of Carnati Plants, grown in our celebrated forest hand fertilization of the best and most vari colored flowers. This class of Carnation propagated also by cuttings and you will fli fne young Plants of the leading varieties th will bloom nicely the coming season, listed , page 137 of this Catalog at very reasonat will produch of douk flowers and the chances are that many new al rare varietics will develop from this careful hand fertilized Seed. Would respect
early orders. Pkt. $8 \mathrm{c} ; 1 / 8 \mathrm{oz}$. 75c.

\section{CALLIOPSIS or Coreopsi}

Very handsome and showy plants of t] easiest culture require no care and thrive any garden Produce flowers in nearly eve shade of yellow, orange, crimson, red, brow situation and always be admired,

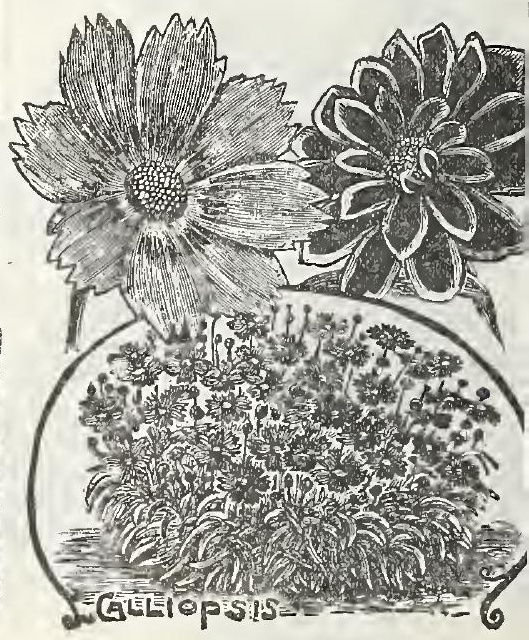

Calliopsis or Coreopsis. 


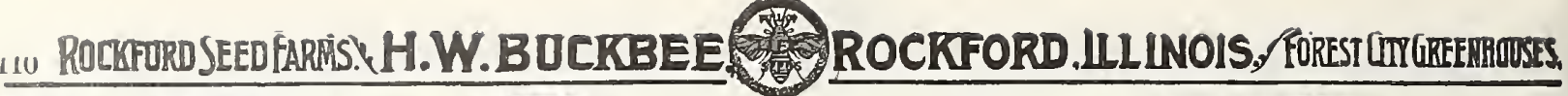

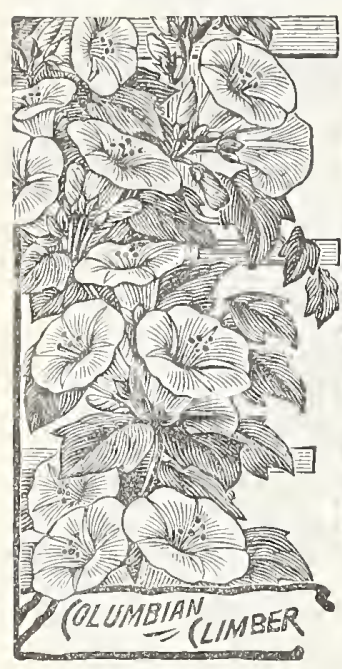

Columbian Climber

The most superb of all climbers and used almost exclusively for the World's Columbian Exposition, wher and always a mass or all. It is a nne,

Pkt. 5c; $1 / 4$ oz. 20c.

Cobrea Scandens (Cathedral Bells)

Although it docs grandly outside, it is also a splendid house climber, and will do well running over windows in the house, and will reward the grower with abundance of beautiful, large bell-shaped flowers, green at first, but rapidly changing to a beautiful deep violet blue. Plet. 5e; $1 / 4$ oz. $15 \mathrm{c}$.

Crab's-Eye Vine, or Weather Plant

This beautiful plant has during the last few years created a great scnsation throughout the world.

If the leaves stand upward the sky will be cloudless. If they stand out straight, changeable weather is indicated. When the leaves bang straight downward, water may be expected to fall in torrents., A local storm is indicated by the curling together of the leaves.

pods, which, when dry, burst open, disclosing brilliant red seeds with black eyes, used for making beads and other ornaments. be soaked in lukewarm water before planting. Pkt. 6c; $1 / 2$ oz. 15c.

\section{Burbank's Ornamental Rainbow Corn}

A highly decorative ornamental plant. The leaves are beautifully striped crimson, yellow, cream, soft rose, white, bronze, pink, green, etc. It is exceedingly effective as a border plant, more beautiful than

\section{Cockscomb (Celosia)}

DWARF OUEN - This is the plants about eight inches high heads ten to twelve inches across. They grow very uniformly. Color, a rich, ruby red, of extreme brilliancy. Pkt. 4c; $1 / 8$ oz. 25c. plumes of bloom, more like Ostrich feathers or Pampas grass than anything else. These magnificent plumes are one to two feet in

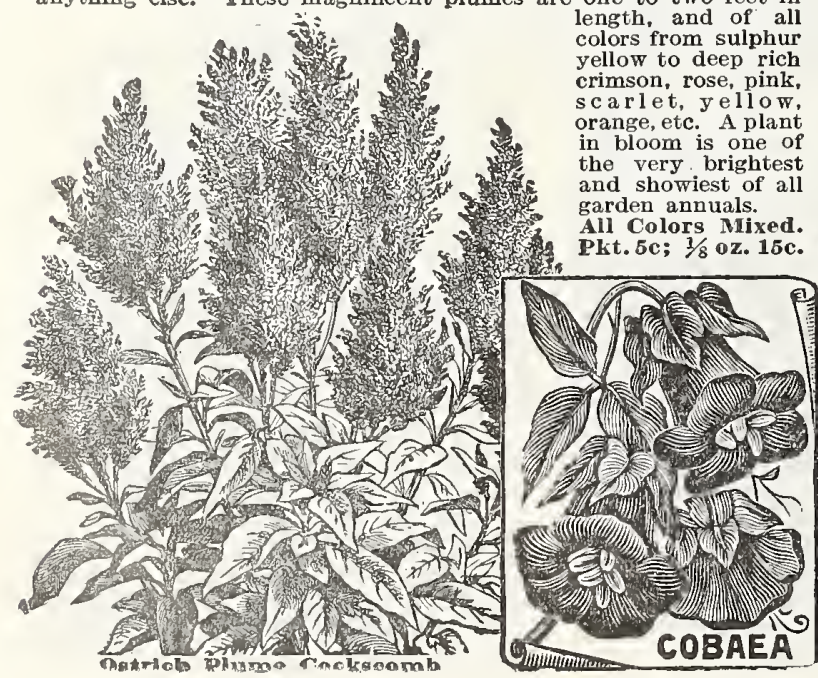

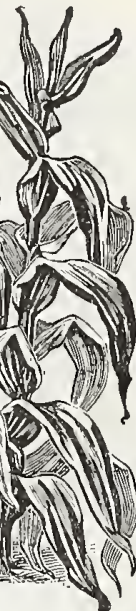

New

urora
Burbank's New Aurora Corn

Its advantages are: absolute uniformity in size. growth and colorings. Lasts a long time in first-class condition. It is proftable to raise for green corn, as well as for beauty of the foliage. Pkt. 10c.

\section{Coleus, Hybridus}

One of the best known and most universally admired ornamental foliage plants. Pkt. 6e. FINE MIXED.-Pkt. 4c.

Coleus PLANTS, See page 140.

\section{Coccinea Indica}

A remarkable, pretty climber. Ivy-like foliage, bright and luxuriant; never troubled with insects and admirably adapted for trellises, arbors, etc. The small flowers are soon followed by numerous fruits, two inches long, which turn to brilliant scarlet, spotted with white. Pkt. 4c.

\section{Clarkia Elegans}

Beautiful, hardy annuals from California with rose-colored, white and purple flowers, in delicate but very brilliant shades. The plants are about eighteen inches high and profuse bloomers.
Double Mixed. Pkt. 3c; 1/4 oz. 10c.

\section{Cypress Vine}

A most beautiful climbcr with delicate dark green feathery foliage and an abundance of bright, star-shaped rose, scarlet and white blossoms. Tender annual. All Colors Mixed. Pkt. 4c; $1 / 2$ oz. 10c. Cyclamen

Charming plants, with bcautiful foliage and rich colored, fragrant flowers, universal favorites for Winter and Spring blooming. The Giant varieties have large lcaves and stout flower stalks, throwing the flowers well above the foliage. Seed may be sown any time during the Spring or Autumn.

PERSTCUM.--Persian Splendid Mixed. Pkt. 5e.

GIGANTEUM.-Very Large Flowered Mixed. Pkt. 8c.

\section{Cosmos, Giants of California}

This strain is noted both for beauty and the gigantic size of its flowers, which measure four to flve inches across; the colors are very varied and beautiful. Choicest Mixed. Pkt. 5c; 1/4 0z. 12c.

\section{Cosmos (New Early Flowering)}

Grace, daintiness and brilliancy, are the characteristics of this pretty flower, with its yellow heart, encircled with broad, daisy-like petals, carried on long slender stems, rising from a cloud of feathery foliage. This Early Flowering strain produces flowers from July to November. Superb Mixed. Pkt. 6c; $1 / 40$ oz. 15c.

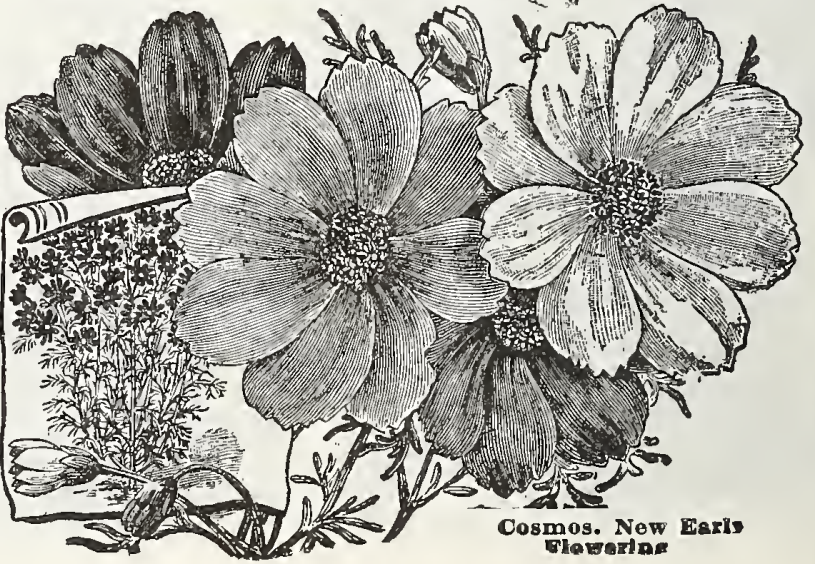




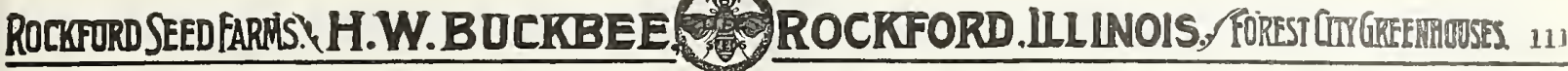

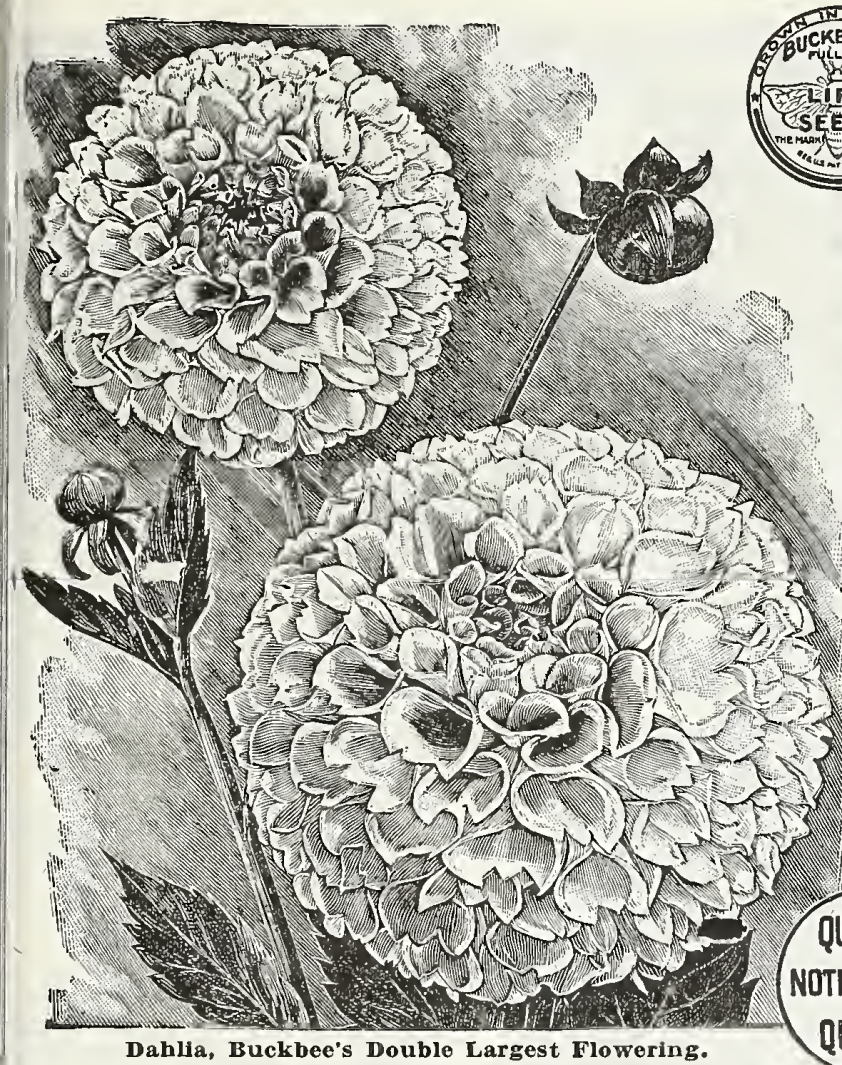

DAHLIAS

The Dahlia still holds its place as ling of all the out-door autumn flowers, and they may be grown to the greatest perfection from seed blooming beautifully the first summer. As easy to grow from seed as the most common plant. Anyone can have a magnificent display profusely until frost, when the bulbs may be taken up, stored where may be continued year after year with success. BUCKBEE'S DOUBLE LARGEST FLOWERING MIXED-A superb mixture of the finest double varieties of the largest size and
finest colorings. pkt. 8c. DoUBLe CACTUS Flowering For Dahlia Plants MIXED-The most beautiful in cultiva-
tion. They are unequaled for rich and varied colors and perfection of form. PKt. 7c. $25 \mathrm{c}$.

SINGLE NOVELTY MIXED-Brilliant flowers running through a wide range of striking colors. Pkt. $4 \mathrm{c}$ :

\section{$1 / 4$ oz. 20c.}

DIGITALIS (Fox Glove)

\section{Handsome and highly ornamental}

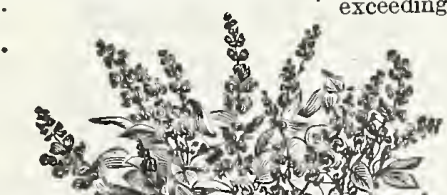
OUALITY
DUUALITY

Very hardy and beautiful. Large branches, dark green foliage 5 to 7 inches across the meuth and form three distinct flowers orowing each within the other. Very fragrant. Pkt. 50.

\section{DATURA or Trumpet Flower}

Single trumpet-shaped blossoms, Pkt, $3 \mathrm{c}$; $1 / 40 \mathrm{ar} 10 \mathrm{c}$.

\section{DOLICHOS (Hyacinth Bean)}

A showy annual climber grows luxuriantly about 10 feet high, branching out well from the bottom foliage, insect proof, and forms excellent screens as well as being exceedingly ornamental. The sweet-pea-like blossoms are borne in long, xceedingly ornamental seed pods, Finest Mixed. Pkt. $4 \mathbf{c}$; oz. 10c.

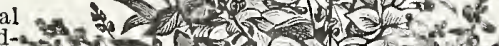

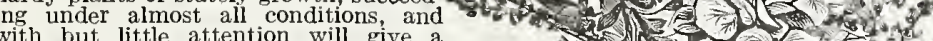
with but little attention will give a Mammoth Flowered Mixed. Pkt. $4 \mathrm{c} ; 1 / 8 \mathrm{Oz} .15 \mathrm{c}$.

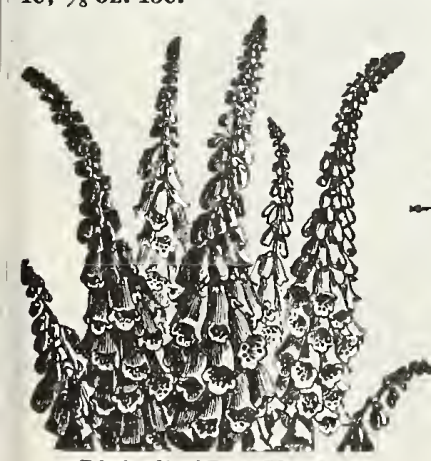

Digitalis (FnT Sinve)

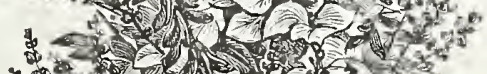
3.

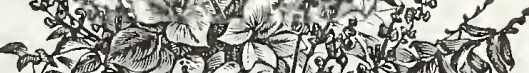

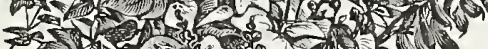

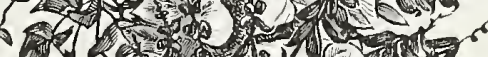
* 0 .

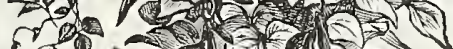
- to 1 .

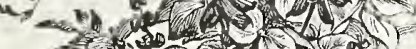

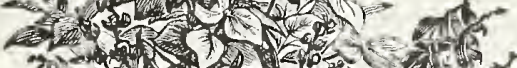
3. - 2 - 25 . Daliabos. Guaciutb Bagn

\section{DIAMOND FLOWER}

A dainty little annual with tufts of tiny foliage and beautiful little white and violet blue thowers that bloom within a month from the time seed is sown. Pkt. 4c.

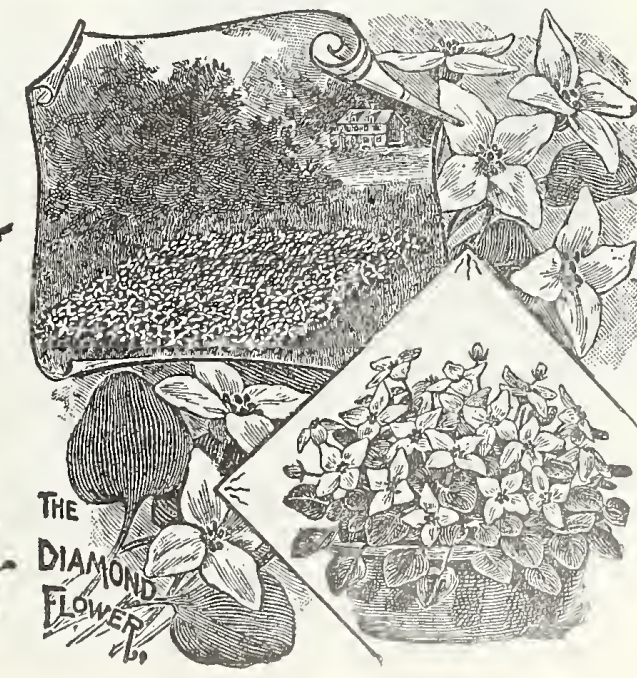




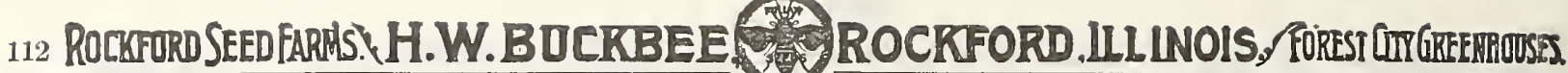

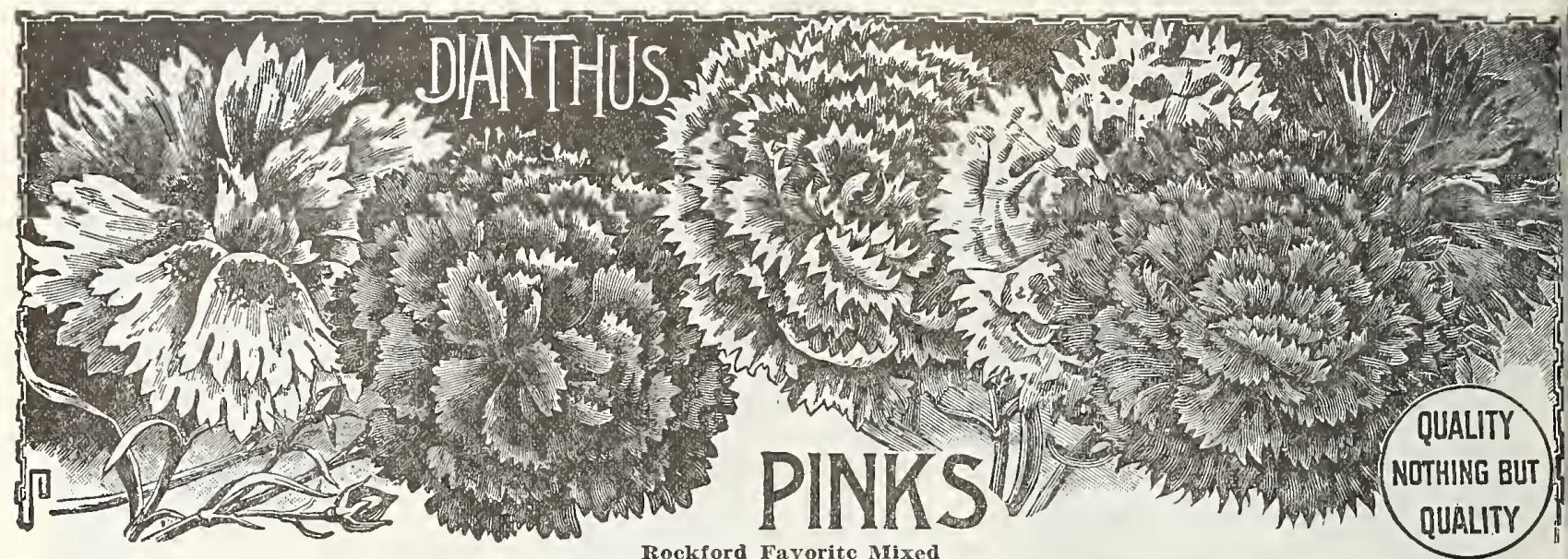

DIANTHUS PINKS are one of the mosi useful and desirable plants and for beauty and variety of colors and markings cannot be surpassed, ranging from pure white to the most delicate pink and glowing deep crimson. A bed of these in a flower garden will make a grand display at a small cost. Plants from seed grow and bloom very quickly.

\section{Dianthus Pinks}

ROCKFORD FAVORTTE MIXED -Comprises over 50 of the choicest Chinese and Japanese varieties, sorts, all the colors in spotted, striped and hand(a) varieties of late ble ble. This magnificent mixture family, and unexpected results by planting package. We cannot recommend $1 / 40 \mathrm{oz} .25 \mathrm{c}$.

FRINGED AND RUTFLED-(Laciniatus Mirabilis)-Petals are deeply cut into fine strips of their length, and are twisted in all pect: in color they vary greatly, having all shades from pure white to deep purplish-red with red and DOUBLE ROYAL PINKS-The flowers range in color from blood-red to pure fringed. The enormous blooms are especially adapted for cutting, the stems being long. Pkt. 5c; $1 / 10 z$. $20 \mathrm{c}$.

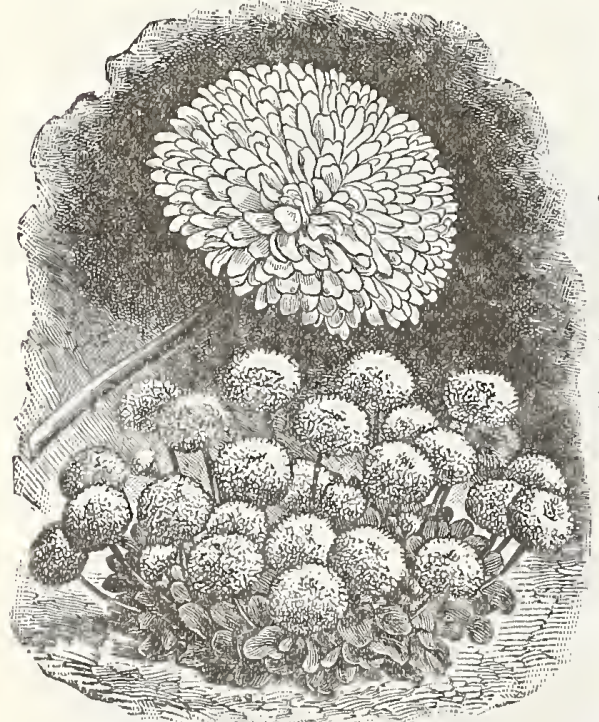

Double Daisy-Mamomoth or Giant.

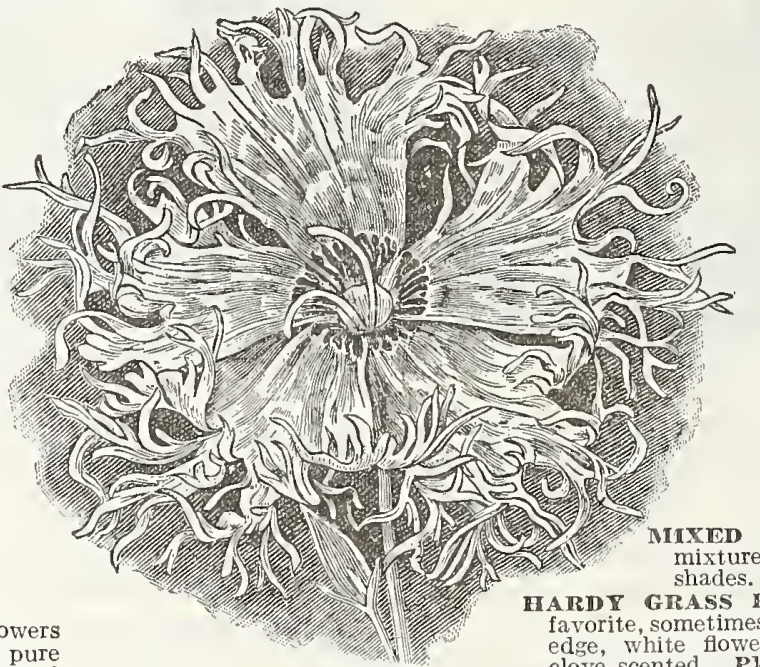

Fringed and Rupred Pinks.

\section{DAISY, Double}

\section{Daisies are easily grown from Spring sown seed}

LONGWELE W-Double, dark red rose. Pkt. 4c;

MAMIIOTI WHITE-Double purest white. Pkt.

DOUBEE QUILLED MIXED-A new strain. Pkt.

MANRTO'TH or GIANT MIXIDD-Finest offered.

oz. $45 \mathrm{c}$.

GERMAN DOUBLE-Good Mix-

ture, Pkt. 3e; $1 / 8$ oz. 25e.

\section{Blue Daisy}

(Agathea Coelestis)

A Beautiful Bedding Plant and

an Excellent Indoor Bloomer.

The flowers are the very counter-

blue with a yellow disc, of easy

the year. Pkt. $4 \mathbf{c}$.

\section{African Golden Daisy}

(Dimorphotheca Aurantiaca)

DOUBLE FIREBALL- A beautiful, very dwarf and compact growhe pink, Filowers are perfectly double and color a rich velvety blood red The plants begin to flower shortly after they are up and continue to bloom profusely Effective for garden beds or pot and as a cut flower. Pkt, $\mathbf{5}$. DOUBLE SNOWBALL - T $\mathrm{h}$ i $\mathrm{s}$ dwarf dianthus belongs with beautiful, differing only in being pure white instead of red, It has all the sterling qualities of that sort. It is equally hardy and deMOURNING CLOAK-A magnifiventh very double large flowers of a very dark mahogany, almost black, petals margined pure white. Pkt. 5c. xture includes all the best colors and INIS- (Single) - The old reliable with 4c: $1 / 4$ oz. 15c. Double and semi-double varieties.
Good range of colors, having a strong clove fragrance. Pkt. 60

Rare and extremely showy annual from South Africa, destined to become a great favorite on account of its easy culture and blossoms. $21 \%$ to 23 inches in diameter, are of a unique shade of glossy terra cotta orange, which brilliant coloring is rendered the more con8 black rone plat fo

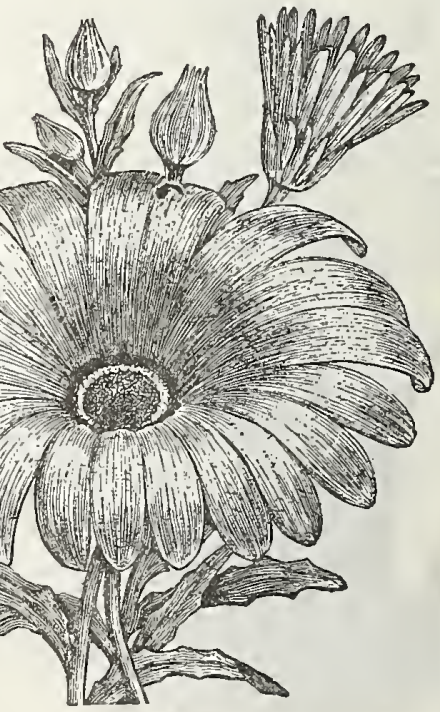

African Golden Daís. 


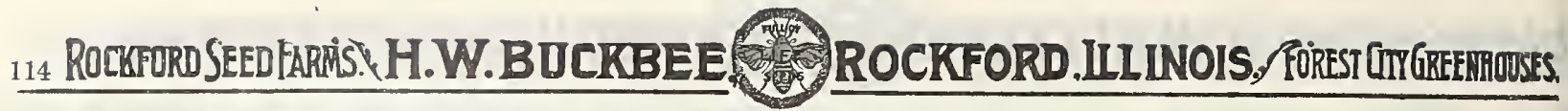

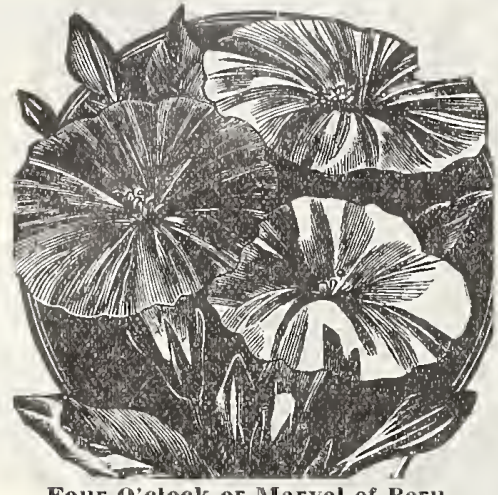

Four O'clock or Marvel of Peru. FOUR O'CLOCK

(Marvel of Peru.)

No flower makes a prettier border than the most brilled Four olock. It is one of the grown Finest Mixed. Pkt. 4c; $2 z_{10}$.

\section{NEW FRAGRANT TREE FERN}

(Artemisea)

This new ornamental foliage plant intro-

duced from China is an annual, and owing

the year of sowing. It forms grand pyramidal

bushes of 3 to 5 feet high. As a solitary

plant it looks like a nicely grown-out Christmas Tree. Also as pot plantit isvery grown in groups and borders, similar to Kochia trichophylla. the SummerCypress. The color of the finely pinLast, but not least, it may be mentioned that cut branches last very long, and may to the greatest advantage, For its great availability and its most easy culture this novelty may most teurs. Pkt. 5c.

\section{GAILLARDIA}

PERENNIAL-Grandiflora Hybrids One of the showiest Hardy Plants. ceeding in any soil in a sunny position; entire season. The flowers are of gorgeous coloring. The centre retals are orange and vermilion, and often a combination of all in one flower; excellent for cutting. Pkt. $5 \mathrm{c} ; 1 / 8 \mathrm{oz}$. 18c. Rev. Geo. Mayr, Fort Wayne, Ind,
writes:--The Cosmos Seed received from
you last year produced grand flowers and

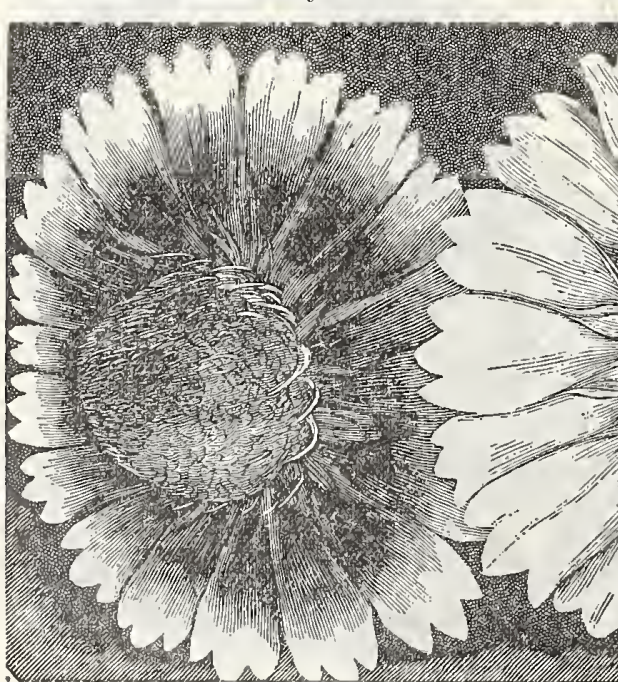

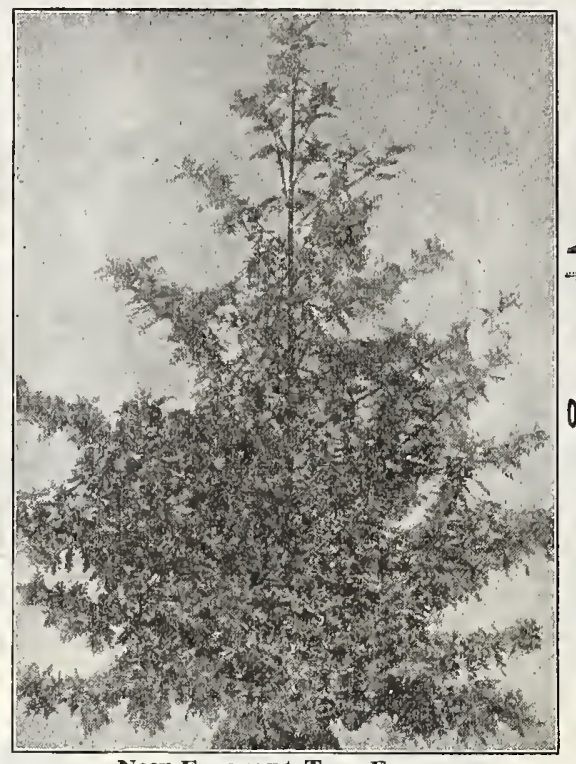

New Fragrant Trce Fern.

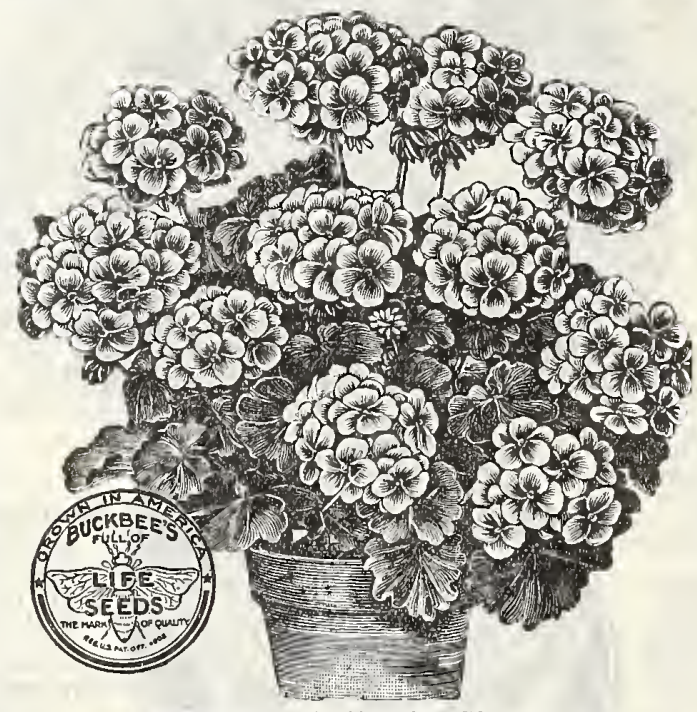

Geranium, California Giants.

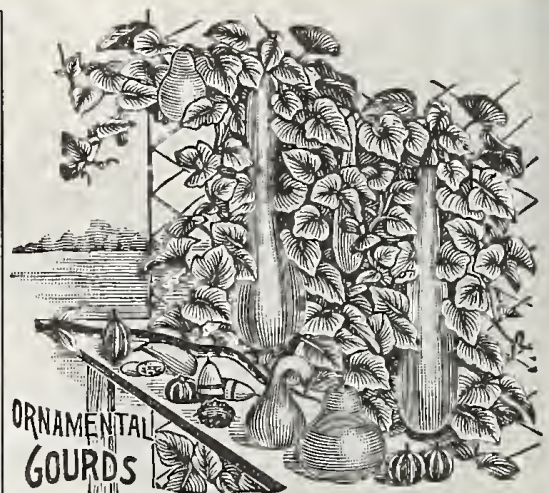

GOURDS (Ornamental)

Tender annual climbers, with curiously shaped frint in various colors peculiarly marked. Forms may be wonderfully varied by tying strings around the young fruit or y enclosing same in a carved mold while years, being very hard shelled. Mixed. pkt. $4 \mathrm{c} ; 0 \mathrm{z}, 15 \mathrm{c}$.

\section{GERANIUMS}

They rvill bloom from seed in four to five months, and will frequently reward the cuve vator with charming new varieties; in fact, propogation by seed is the only sure CALifornia GIANTS-Seed saved from finest double, semi-double and single varieties of the most gorgeous and brilliant colors; all shades of scarlet and crimson, rose, pink, salmon, cream veined, pink, blush, snowy white, and all the new auriole

ZONALE-(Mixed)-A superb strain. Pkt. 4c.

LADY WASHINGTON-These are the well-known rich-colored show Pelargoniums. Our mixture includes all the best varieties.

PKt. 15c.

APPLE SCENTED-The old-fashioned favorite apple-scented Geraniums.

GAILLARDIAS (Blanket Flower)

ANYUAL VARIETIES-Greatly adfor their forms and rich blending of colors, the gay colored flowers being abundantly produced thrive anywhere. Single and double mixed. Pkt. 3c; $1 / 8$ oz. 15c.

Buckbee's XX Insect Soap For House and Garden Plants $25 \mathrm{c}$ Postpald

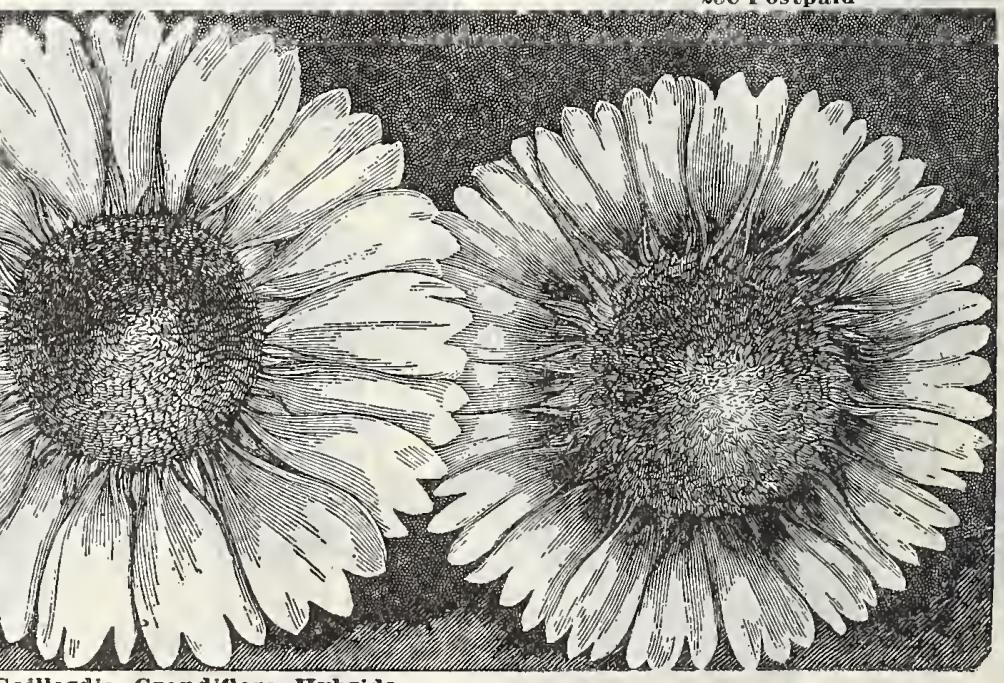




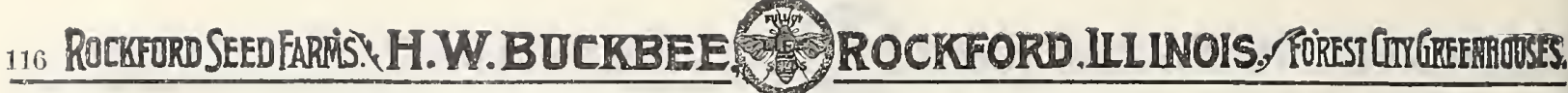

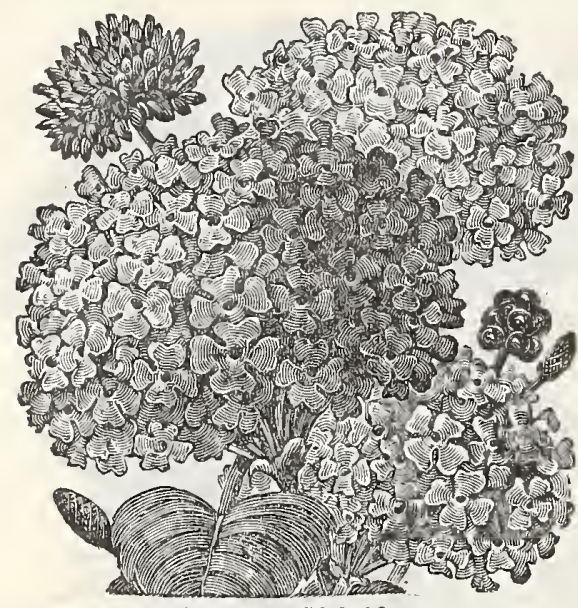

Lantana, Hybrida.

LANTANA, Hybrida

Well-known shrubby plants with clusters of veloena like howers, and producing their pink, They have an agreeable aromatic per-

fume. Finest Mixed. Pkt. $4 c ; 1 / 8$ oz. 10c.

LINARIA (Kenilworth Ivy)

A vely pretty hardy perennial trailing plant, for covering rock work and very useful for hanging baskets. The flowers are small, but pretty

\section{LARKSPUR (Delphinium)}

NEW DOURLE HYBRIDS-(PERENVIAL) Prontuce beautiful spikes or lmmense flowers in length. The colors are very beautiful, ranging from pure white through all the shades of Colors. Plt. 6c. DWARF DOUBLE-Well-known annuals of great

Mixed. Plat,

LOBELIA (Finest Mixed)

A beautiful dwarf-growing plant with delicate vases. Pkt. 4c; 1/8 oz.

MIGNONETTE (Reseda)

BUCKBEE'S FINEST ROCKFOID IIXED-The

Finest Mignonette Mixture ever blended. It includes all the well-known sorts, together with
many new Hybrids. Pkt. 5e; 1/2 oz. 15e; oz. 25e. Many new Hybrids. Pkt, 5e; 1/2 oz. 15e; oz, 25e, flowers, powerfully fragrant. Plt. 3e; 1/4 oz. 10c. fragrant blossoms. Plit. 4c; 1/ oz. 15c

NEW GIANT RED FLOWERED-Intense red, color Very swether PURE MACHÉT-Massive spikes of deliciou SWEET- Reseda Odorata Grandiflora) Large howered. The old favorite
improved. Plit. 3e; oz. 10c.

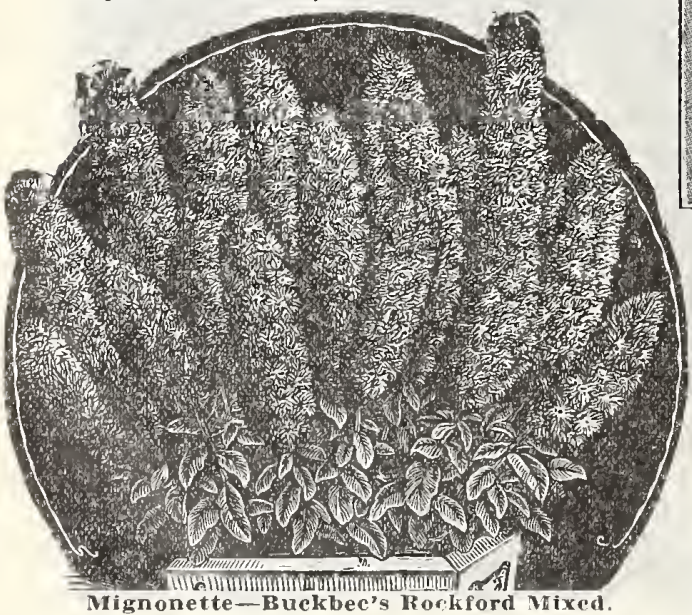

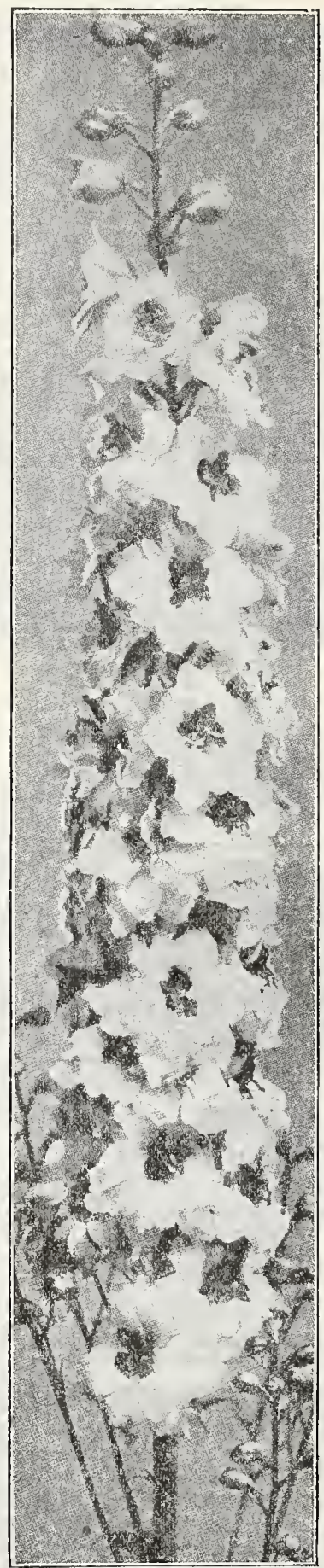

Larkspur New Double Hybrids.

MONKEY FLOWER (Mimulus Tigrinus)

Singular shaped, and brilliant colored flowers, blotched and spotted in every conceiv. MUSK PLANT

(Mimulus Moschatus)

A well-known and favorite plant both for outside borders and for pot culture. Cultivated plit. 4e.

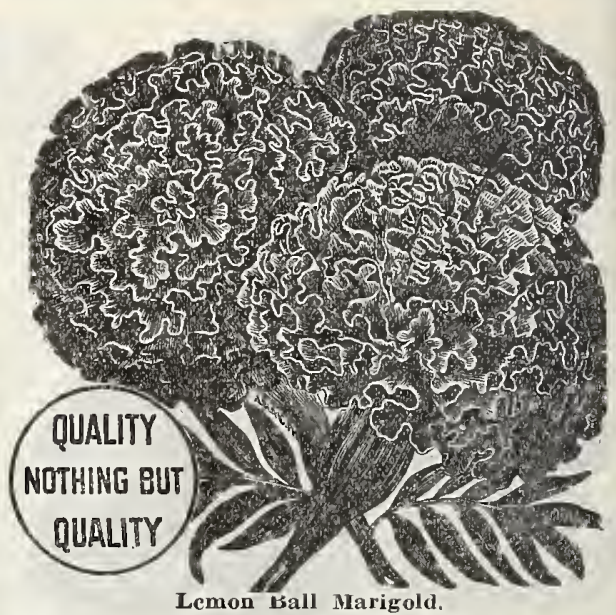

\section{MARIGOLD}

LEMON-BATL-The extra ectly rounded-of nearly "ball-like" form; the preavily rolled and are clowded so color is a clear canary-yellow: the brightness resemble large donble Fellow Dahlias-oniy produced to mich more abundantly and for a ing freely, two and a half feet high Pkt. 5e. ETDORADO-The flowers are from three to fou Therecty double. They embrace four shades of colorcep orange Ikt. 4c; 1/8 oz. 10c. in bushy variety, bearing rich, golden yellow each petal. Plit. 4e; 1/1 oz. 15e.

, lom FRENCH, DOURLE MIXED-A showy

flowers of rich and be utiful colors, Pkt. 4c;

\section{MOONFLOWER}

(New Cross-Bred or Hybrid Variety) of great value for the North, as it is in full bloom one month before the White seeded. The and be Wril grow 30 to 40 feet in a single season, MOONFLOWER, New Ivy-Leaved (Day Blooming)

A new Moonflower which opens its blossoms early in the morning (instead of evening), and creamy white; leaves ivy-shaped. Pkt. 6e.

MOONFLOWER (White Seeded) larger in flower and of sweeter odor than the Black Seeded variety which we have now disarded. Pkt. 4c; $1 / 2$ oz. 20c.

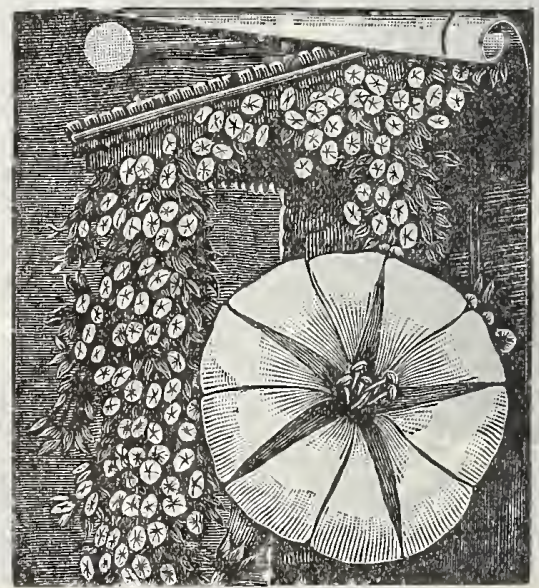

New Cross Bred Moonflower. 


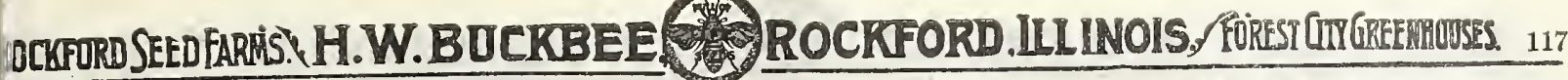

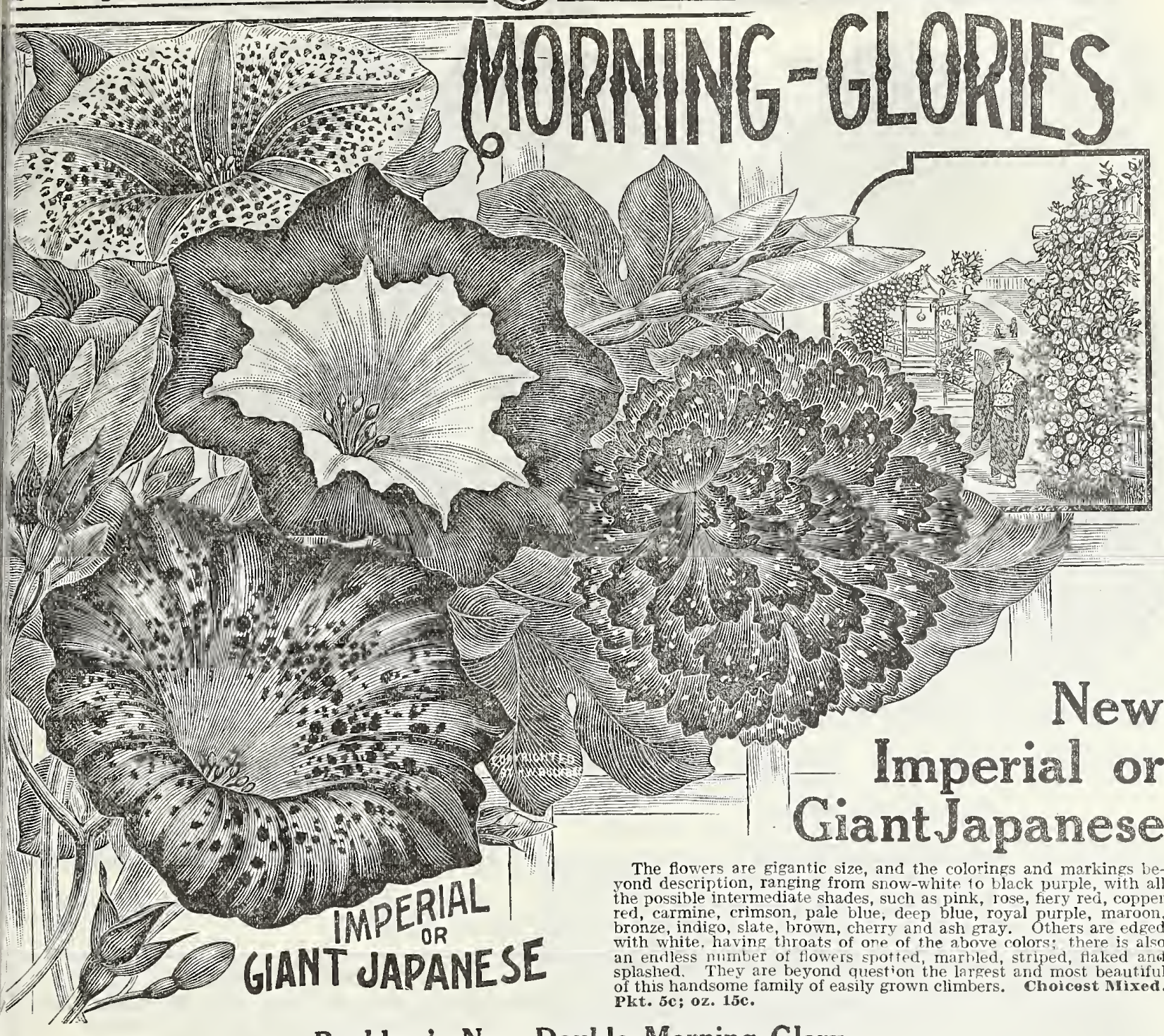

Buckbee's New Double Morning Glory

This Double Morning Glory will be greeted as a welcome addition to this class of plants. It is of rapid growth, producing its large double owers very freely. They are of beautiful form and delicate coloring, being white with a sligit shading of red or blue at the base of the larger

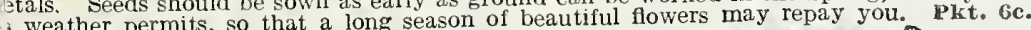

lew Fuchsia-Flowered Morning Glory

'The vines or shoots are gracefully slender, but

ery numerous and most densely cover1 with five fingered deep green leaves. ring tall poles or trellis with a dense reten of the peculiarly at tractive foliage, nd during the late summer ank fiowrs. The seed-pods quickly form on the nd of the long wire-like stems and bear a riking resemblance (giving a most harming cffect) to the flower buds pro-

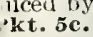

mproved Tall or Climbing Morning Glory (Convolvulus Major Grandiflora.)
dost popular climber in cultivation. Of apid growth. Our seed is selected from he best varieties only, and is a great imrovement over the old-fashioned sorts.
jelect MIixed. Pkt. 3c; oz. 8c; 2 oz. 12c.

\section{Dwarf Morning Glory}

The wonder of the age as a Winter
unuse blooming variety. Flowers richly colored. Mixed. PLt. 4c: oz. 10c.

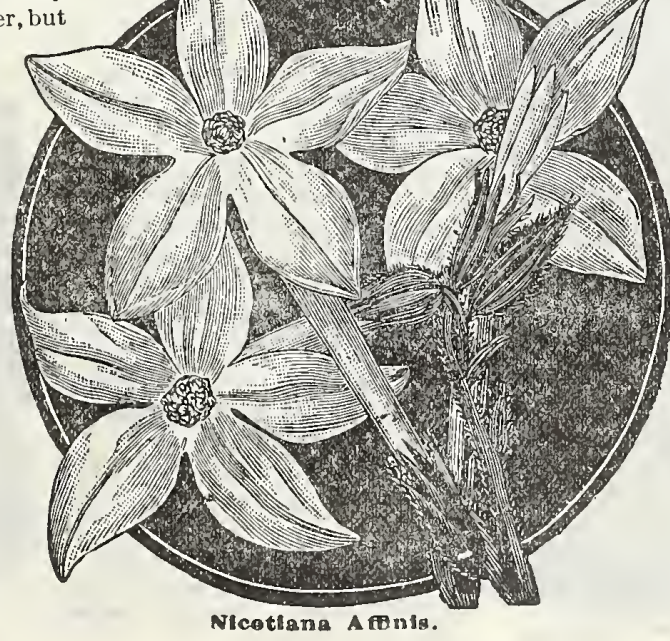

NICOTIANA AFFINIS

Sweet Scented Tobacco Plant Handsome and well-known hardy annuals that grow easily from seed, forming compact bushes, about 3 feet high, which are in continuous bloom throughout the sweet-scented, and desirahle as cut-flowers, also fine for pots. Pkt. 4c; $1 / 1 / 10 z$. $15 \mathrm{c}$.

\section{NIGELIA}

A popular old-fashioned flower; free flow ering with finely-cut foliage surrounding the curious looking flowers and seed pods. Pkt curious looking

\section{NOLANA}

Beautiful trailing plant, almost equal to Portulaca for glowing in masses, and u. surpassed for baskets, pots, vases or rock Morning Glory. Fine Mixed. Pkt. 3e;

Children's Bargain Collection FLOWER SEEDS 16 Best Varieties FOR ONLY 25c。 


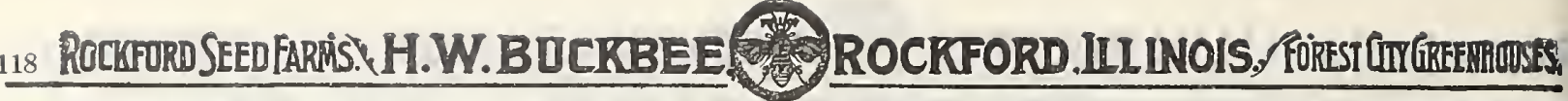

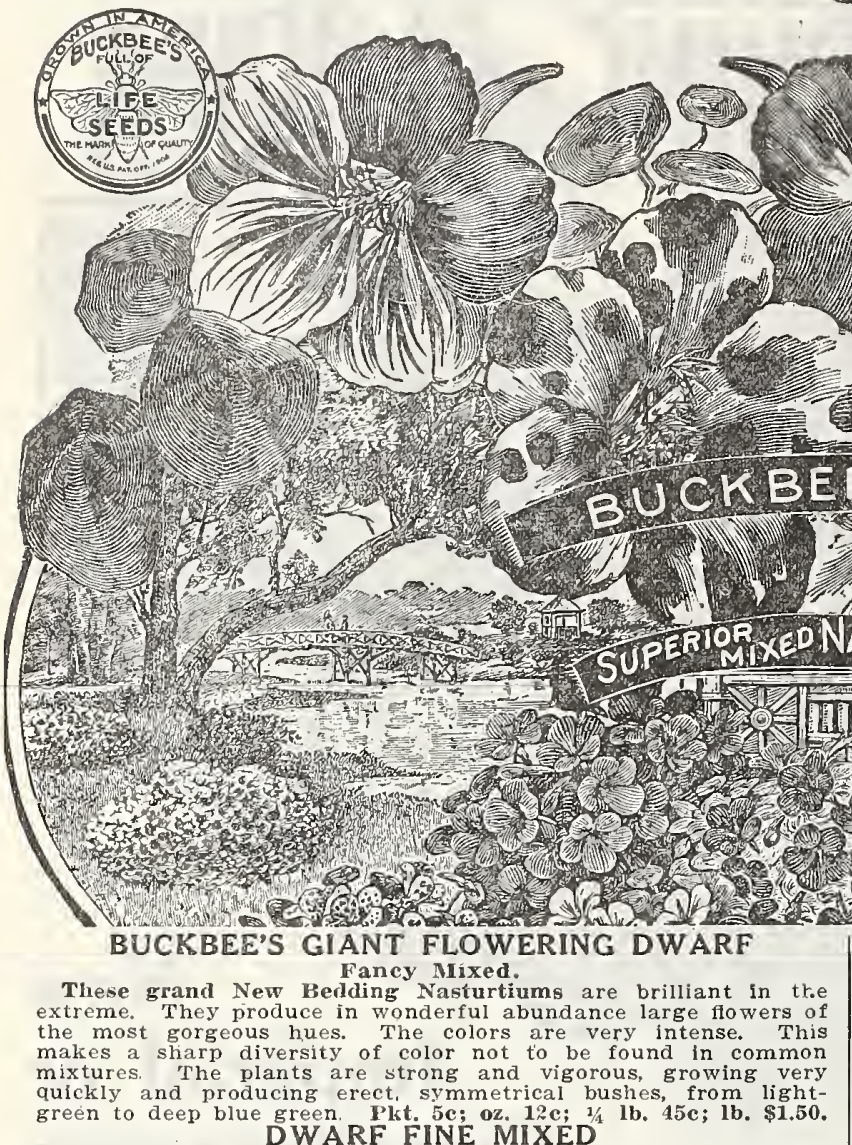

DWARF FINE MIXED

A first-class mixture from selected colors that

DWARF GOOD MIXED

This mixture includes many cholce and showy colors. Pkt. 3c.;

oz. 8c; 1// lb. 18c; 1b.65c.

class, with thick green lobed leaves resembling those abundance throughout the season, are of medium size, and pecuPkt. 5c.; oz. 15c.
NEW DWARF VARIEGATED LEAVED

The very best of the variegated leaved Nasturtiums. The leaves are marked with white, green and yellow and contrast nicely with the $15 \mathrm{c}$

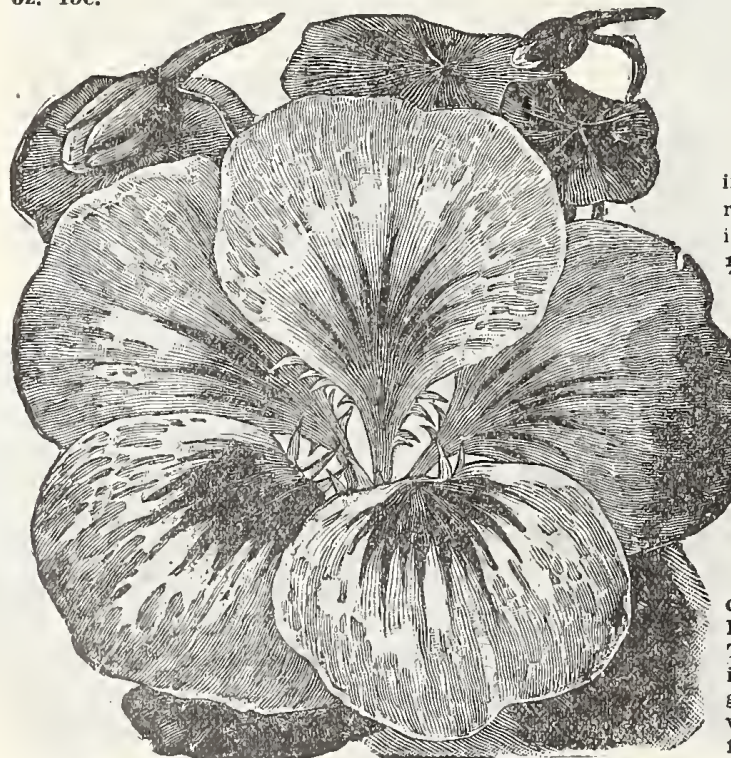

Buckbee's Giant Flowering Dwarf Nasturtium
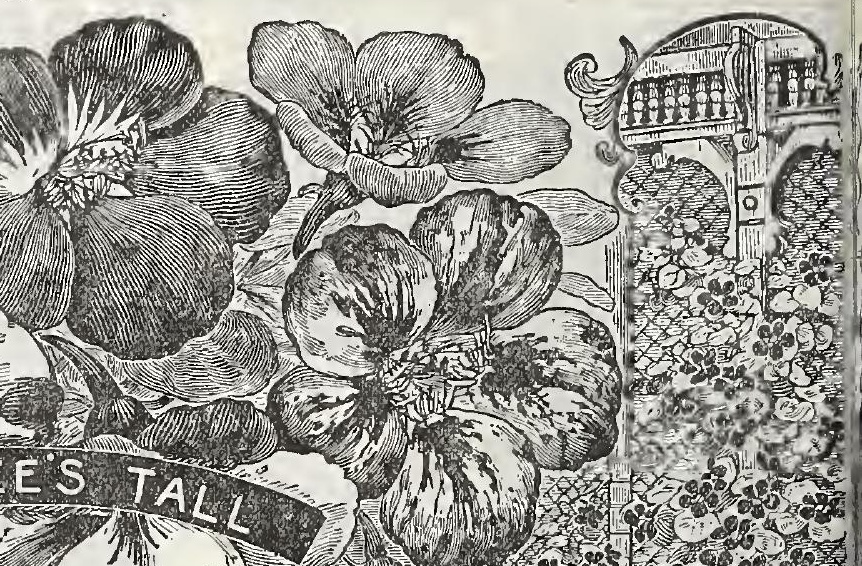

T. 1090 4 (1)

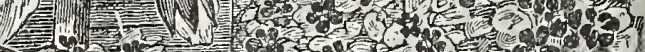
S.

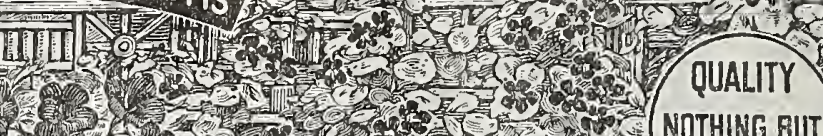
QUALITY EY

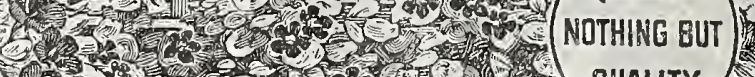

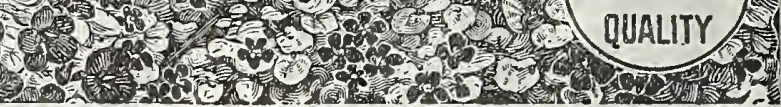
BUCKBEE'S TALL SUPERIOR MIXED Giant Flowered Best Varieties.

A wonderful diversity of rich colors and new and striking combinations are found in this unequalled mixture. A row in full bloom is truly gorgeous beyond description, containing as it does, every shade and tint of yellow, rose, scarlet, carmine, orange, lemon, bronze, violet, purple, maroon, ruby, cream and showy and exquisite ways. Pkt. 5c.; oz. 15c.; 1/t lb. 50c; 1b. \$1.50.

TALL SELECT MIXED

This mixture is a most beautiful assortment of rich and brilliant colors, and is surpassed only by Buckbee's Superior Mized. Plkt. 4c.; oz. 10c.; 1//1b. 30c.; 1b. \$1.00.

\section{TALL FINE MIXED}

A good selection from a wide range of colers. Pkt. 3c.; oz. $8 \mathrm{c.} ; 1 / 4$ lb. 20c; 1 b. 60c.

\section{ONE OUNCE}

of Nasturtium will plant a bed 20 feet in diameter and will make a better display, for chree months,

than almost any other plant.

\section{HYBRIDS OF MADAME GUNTER]}

New Climbing Nastur-

most beautiful strain flowerprofusely, and having a wide ange of bright and distinct color

(Pkt. 4c.; oz. 12c.; 2 oz. $20 \mathrm{c}$. lb. $35 c$.

NEW TALL "IVY-LEA VED" NASTURTIUMS

\section{The plants are of running} growth, with star-like pointed with white. Pkt. 5c.; oz. 15

NEW TALL VARIEGATED LEAVED NASTURTIUMS

The flowers are of many bright colors in charming contrast to the handsomely variegated foliage. iegated with yellow, white and ween that the plants would be worthy of culture almost for the folfage alone. Superb Mixed. Pkt. 5c.; oz. 15a.
Mrs. Mínnie Herbst, Cunningham, the order of "Full of well pleased with Plants received

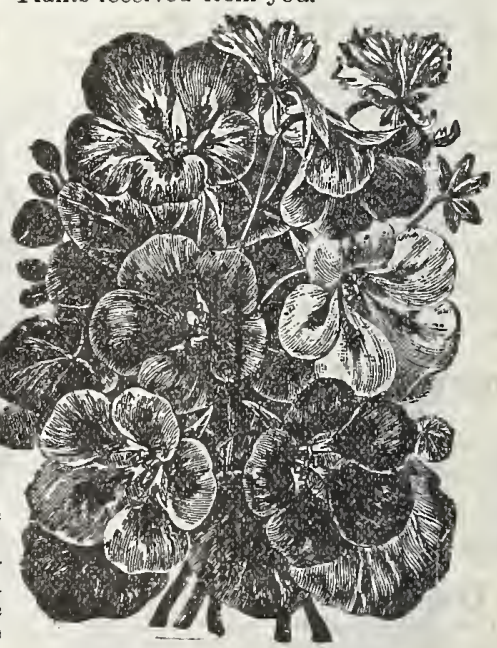

Bybrids of Madame Gunter. 


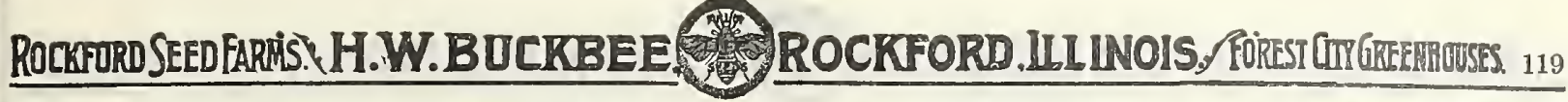

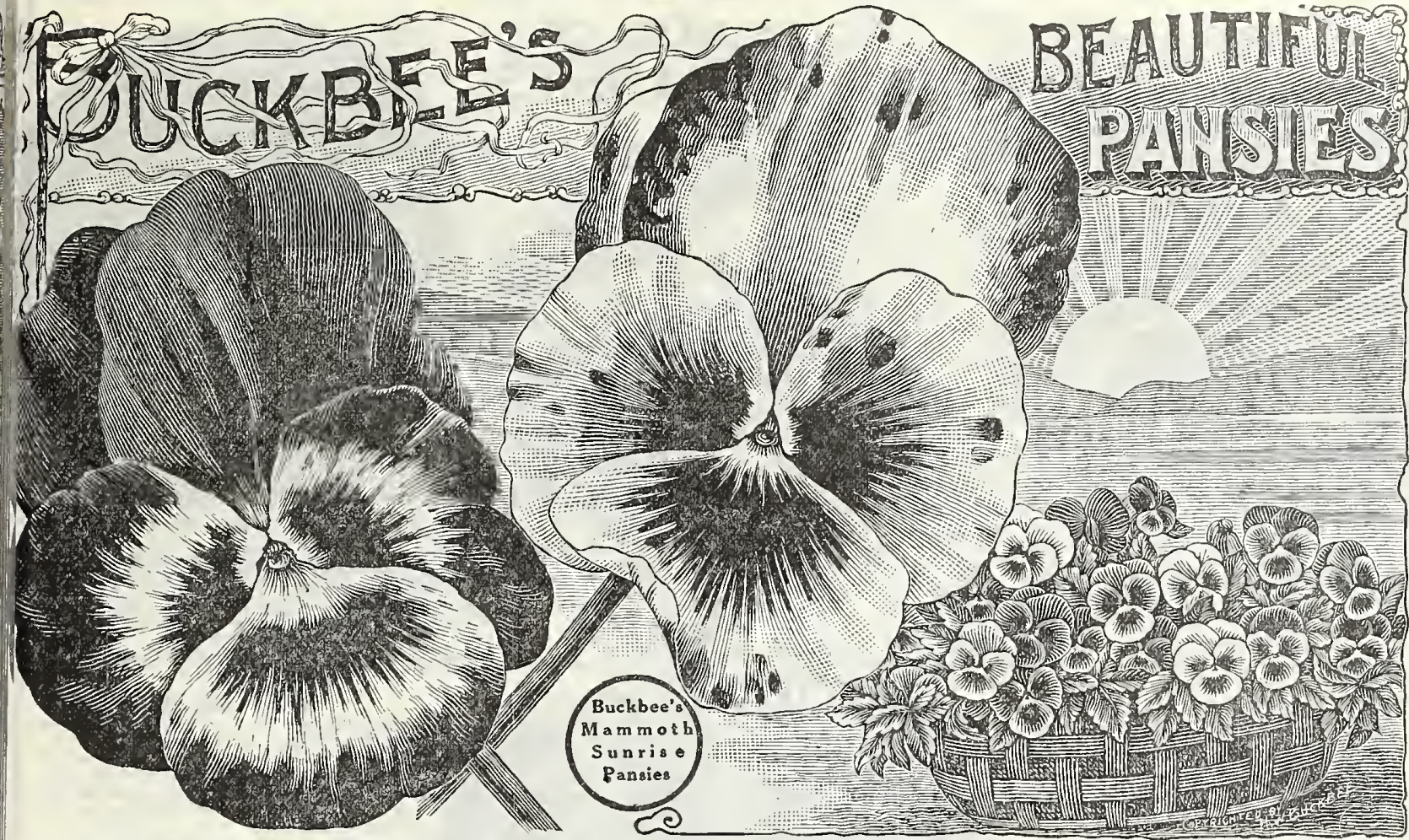

\section{WORLD RENOWNED -- OF HIGHEST PERFECTION}

A universal favorite with young and old. Every child sees the face in the Pansy, and, aside from its great beauty, we all treasure

\section{PANSY SEED MIXTURES}

Buckbee's Giant Flowering Mixed

In this magnificent mixture of giant flowering Pansies the colorings are wonderfully rich and varied; every shade and tint of rose, canary-yellow, black, white, cream, lavvariations and striking combinations, while others have silvery grounds heavily blotched at the base of each petal with a dark rich shade. The enormous fowers are stems well above the foliage. The compact rounded plant are of sturdy habit and fep rooted, so that they bea the gigantic flowers profusely and continuously. Pkt. $8 \mathrm{c}$; $1 / 8$ oz. $75 \mathrm{c}$.

Buckbee's Mammoth Sunrise Mixture This splendid mixture is a blended combination of mam moth flowering Pansies. It contains all colors and will prove a delightful surprise in regard to the great size lar. Pkt. 6c; $1 / 8$ oz, 50c.

Buckbee's World's Fair Prize Mixed This mixture was awarded Grand Prize Medal at the World's Fair. It is an exceedingly fine mixture, producPkt. 5c; $1 / 2$ oz. 60c; 0z. \$1.00.

\section{Buckbee's Everblooming Mixture} This high-grade mixture will give you a profusion of fail to include it in your order. Plkt. 4c; $1 / 2$ oz. 40c; oz. 75c.

\section{Buckbee's Mixed Hybrids}

This Hybrid Mixture is a truly exquisite mixture of the

\section{Buckbee's Sweet Scented Mixture}

The Perfume of the Violet. The Beanty of the Pansy. Thls new class is the result of crossing the Pansy (viola tri-color) with the Sweet Violet (viola cornuta); the resulting hybrids, in addition to retaining the delightful Violet perfume, produce the most beautiful Pangy-like of an endless variety of colors. Mixed. Pkt. 4c; 1/ 0z. 500.

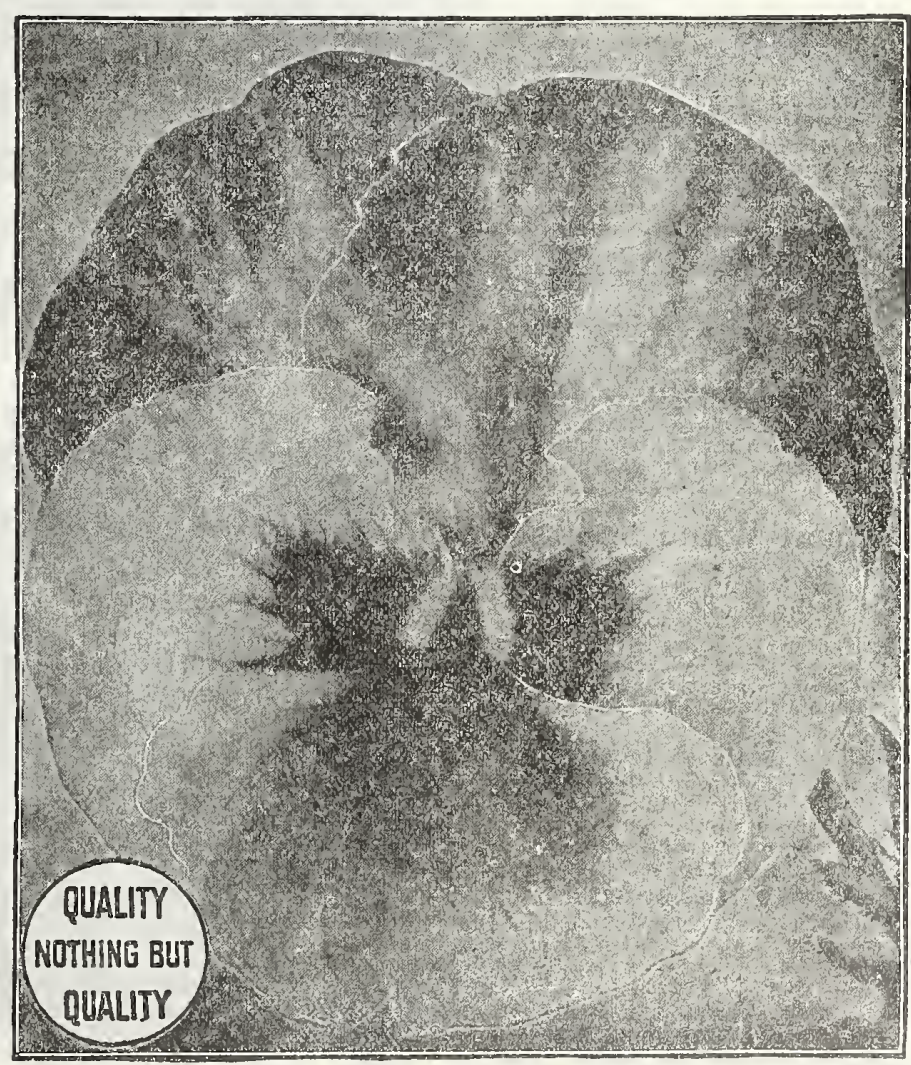

Bgckbe日'g Glant Flowerlng Raner. 


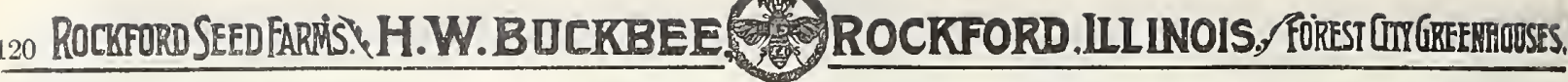

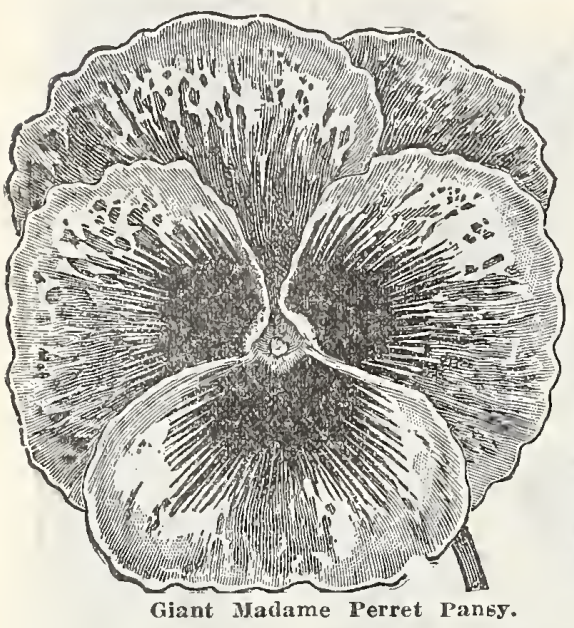

Giant Madame Perret A superb new strain, large flowers and beautiful colors, blossoms ranging through deep purple, with an intermediate bright red, edged with white. The face of the while in others it is lined and striped. The extraordinary size of the flowers, which reach as much as 3 to $31 \%$ inches in diameter, makes it a novelty of the first rank. Pkt. 7c.

\section{Giant Black Prince}

sterling merit. The rich glossy black has a peculiarly cent large flowers are of fine circular form, and fowers so profusely that a bed of the Black Prince makes a sight

\section{Giant Snow Queen} The largest pure white Pansy without bloteh
Pkt. 6c.

Giant "Masterpiece" This magniflcent new Pansy comes thing ever introduced under that name. The border of every petal being conspicuously crimped and curled in such ble, and the color combinations and variations are very odd and striking, and contain some very lovely tints of color that cannot be found in any other strain of Pansies. Plt. 8c.

\section{Giant Yellow Prince}

The color is pure golden yellow, shaded canary, sometimes with the three lower petals marked with purplish or red blotches and hair lines. Pkt. 6c.

Giant White Spotted The flowers are very large, pure white, with a violet blotch
three lower petals. Plkt. 6c.

\section{Giant Striped}

The flowers are striped and mottled in various tints. Pkt. 4c.

\section{Giant Adonis}

Color a magnificent light blue with a white center, which sets off the striking manner. Plkt. 6e.

\section{Giant Beaconsfield} This is a great favorite on account of the rich combination of purple and the top. Plit.

\section{Giant Psyche}

Velvety violet-blue with a broad white age, petals undulated and
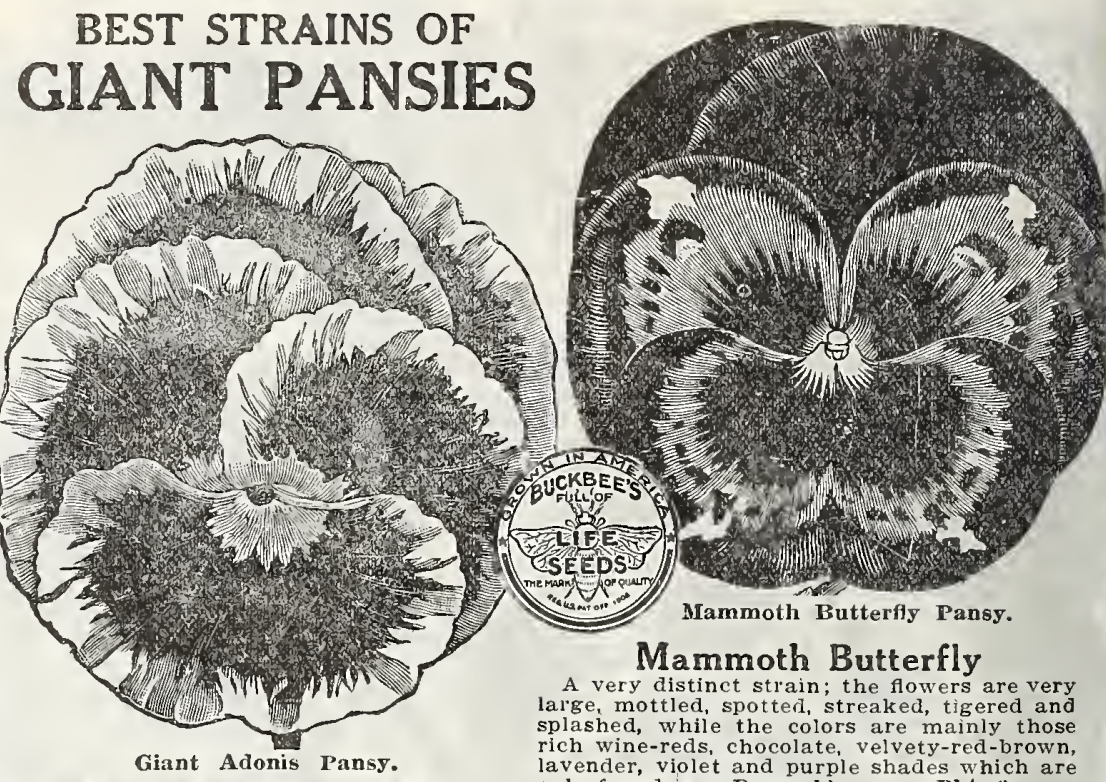

Mammoth Butterfly

are very ine, mottled, spotted, streaked, tigered and plah wine whe lavender, violet and purple shades which are only found in a Pansy blossom. Pkt. be.

\section{Bridesmaid}

interesting variety are very Its ground color is a Rosy White, rivaling in delicacy and beauty the finest Apple-blossom, and most strikingly sets off the dark blotches of the

\section{Emperor William}

The finest blue variety. The flowers are the true splendid ultramarine blue Plkt. 4c.

Emperor Frederick Velvety brown, shaded into a narrow band of deep golden yellow, which

\section{Fire King}

The three large blotch of deep brown-red or magenta margined with yellow, while the upper petals are of a bright reddishing the name Fire King. Pkt. 4c.

\section{Peacock}

A beautiful variety of ultramarine blue in the upper petals of the flower, which is a space of purplish-crimson, passing into a rich central blotch of deep blue, shading to black, named resemble the feathers of a Peacors

\section{Plst. 4c. Rosy Morn}

The color of this Giant Flowered Pansy is a bright purplish crimson margined with a clear white edge; color gradually turns a pleasing rosy carmine and the silver edge becomes wider. Plit. 50

\section{Volcano}

Color, bright dark red, each petal being marked with a very large dark blotch. The flowers are of large size and good substance and the edges of the petals are curled like those of " from which it is a seNew Red Mixed

The New Red Mixed mixture ver offered brillant Pansy mixture of all the best red and fiery shades which have been produced up to date by the expert Pansy growers of Europe and America, If you want red Pansies Imperial German Mixed For Pansy over fifty colors and markings, and is planis hee guaranteed to equal any strain offered page 148 as Imperial $G$ 


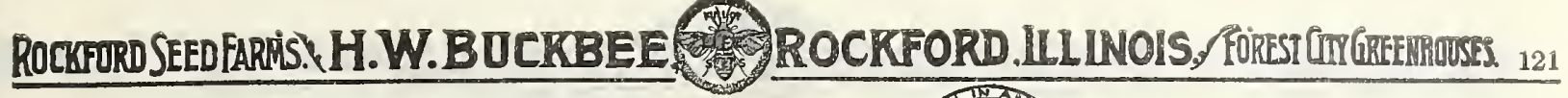

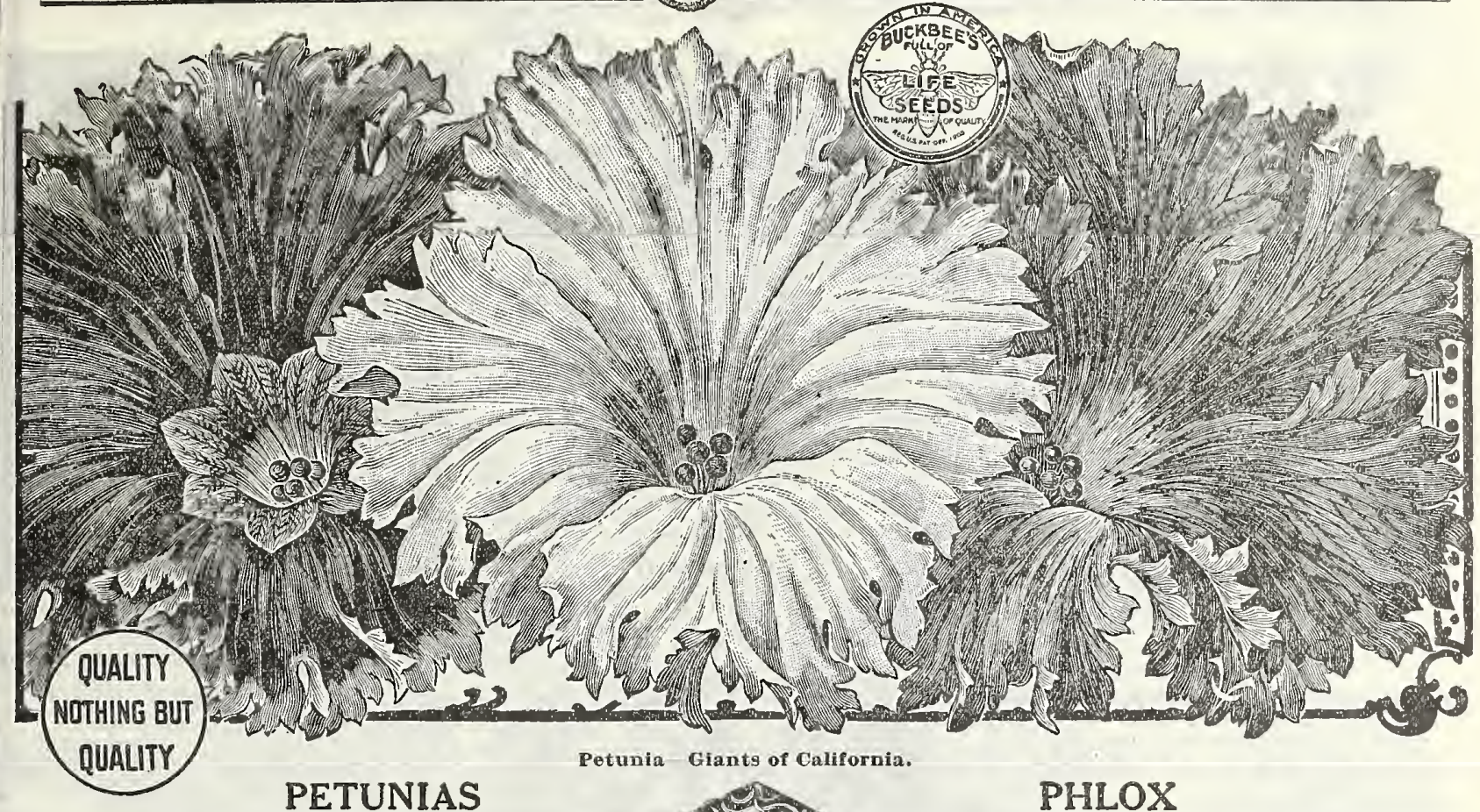

GIANS OF CALIFORNIA-A California strain of great

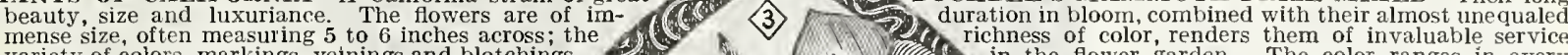
variety of colors, markings, veinings and blotchings 3 as distinguish them from ail others. They are
usually ruffled and fringed on the edges, and
present a great variety of beautiful colors.
Pkt. 10c.

DEFIANCE, Large Flowering Single-Flow ers unequaled in size, mixture is remarkson, maroon and violet shades. Pkt. 8c. GRANDIFLORA, Single Largo Flowering-One of the richest colored in cultivation, beautifully veined with der, yellow and crimson. Mixed. Pkt. 6e.

HYBRIDA, Single Mixed - A splendid mixture, embracing all colors, including striped and blotched varities. Are excellent for tire Summer, Pkt. 4c; $1 / 4$ oz. 20c. BUCKBEE'S NEW DOURLE FANCY FRINGED - They embrace a wide range of colors and show finer combinations than we have heretorore found

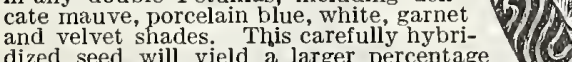
dized seed will yield a larger percentage
of double flowers than any other Petunia in
cultivation Mixed. Pkt. 15c.
FornHooK-Fancy Fringed Double-Mixof double flowers than any other Petunia in
cultivation Mixed. Pkt. 15c.
FoRDHooK-Fancy Fringed Double-Mixture of the best large-flowering and fringed double
Petunias. Yields 20 to 30 per cent. of doubles. Phlox-Mammoth Prize Mixed. Mixed. Pkt. 10c.

\section{Phlox, New Double} Double Phlox is one of the most desirable annuals for cut flowers. whaty yne exrain of ot the couble trom

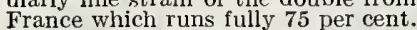
pure white and cream color and perwhite is especially valuable as a cutflower. We are sure our customers will be greatly pleased with these.
Select Mixed. Pkt. 6c; 1/8 oz. zoc.

\section{$\underset{\text { A MIOST }}{\operatorname{MiOSO}} \mathrm{BOOK}$} HOW TO GROW FLOWERS AND SEEDS. It tells the whole story in a practical way. Price only $50 \mathrm{c}$., or
FREE with an order for $\$ 1.50$ or upwards, if requested on the order.

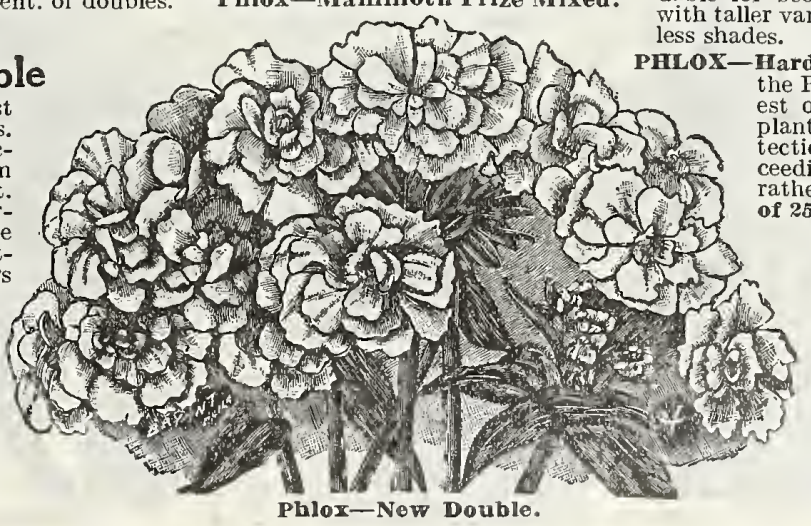
est of flowers for bedding and border tection; will flourish in any soil, suc-

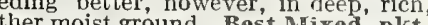
25 seeds, $7 \mathrm{c}$.

SPECIAL CHILDREN'S COLLECTION OF CHOICE FLOWER SEEDS 15 Varieties of the Best and Most Popular and Easily Grown Sorts. of the 15 Varieties 95 for 


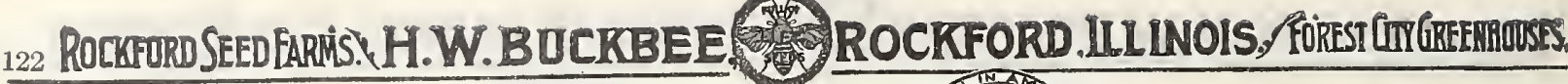

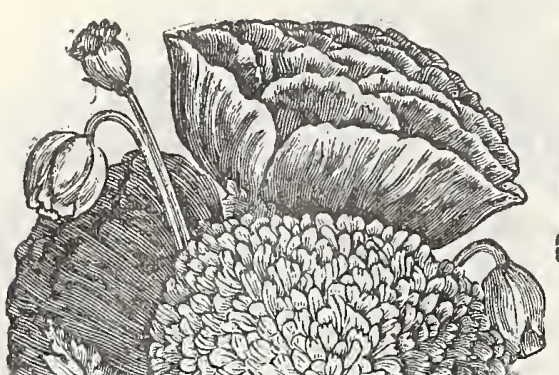

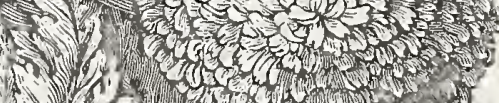
ivel. a $3.1 \%$.

Buckbee's Giant Double Poppies.

\section{Poppies}

BUCKBEE'S GIANT GRANDEST DOUBLE MIXED-A dazzling mixture of beautiful double Poppies, giant-flowering kinds of the richest and brightest colors as well as the 15c; OZ. 25c. Fine Mixed. Pkt. 3c; oz. 12c. PERENNIAL POPPIES, CHOICEST MIXED - Although hardy perennia
these Poppies bloom the first season, from Spring-sown seed. Finest

For Hardy Poppy Plants see age 165.

\section{Ricinus}

(Castor Oil Bean) ZANZIBARIENSIS GIANT MIX ED-From seeds sown in the open foliag arly in July and attain height of twelve to fourteen feet lobed, measure two and a half to nearly four feet across. Pkt. 4 c GOOD MIXED-Many choice vari-

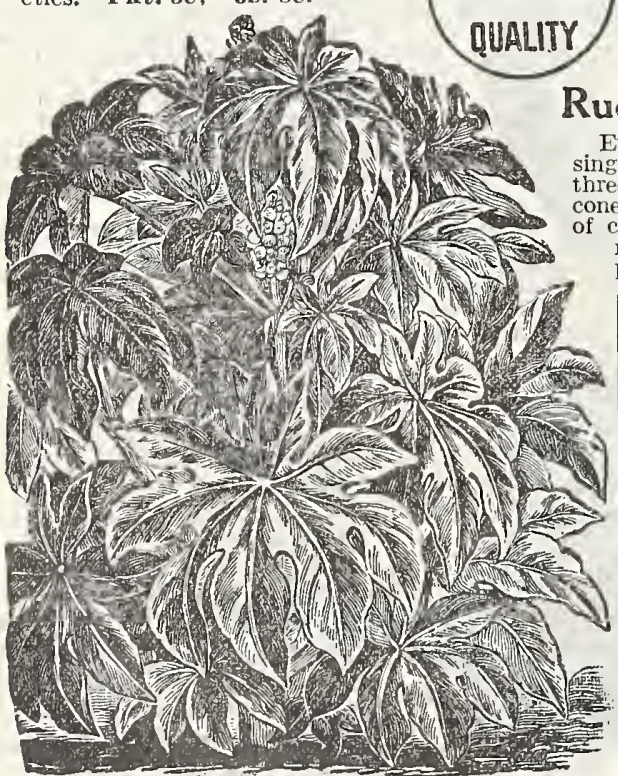

Giant Caster oil Bean (Ricinus, Zanzibariensis).

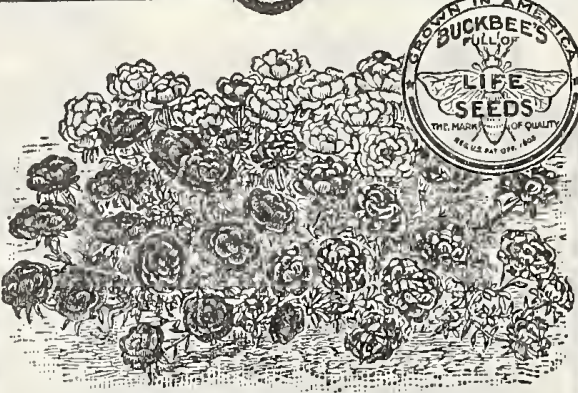

Double Portulaca, or Moss IRose.

Portulaca (Moss Rose) DOUBLE GIANT FLOWERED MIXED

the most showy and beautiful annuals. With beds, masses or edging it is invaluable. Pkt. 6c; INGLE MIXED-A great variety of colors. Penstemon

The most showy of perennials, and as a bedding takes rank with the Petunia Phlox, etc. Colors, rose, red, carmine, cherry, pink, lilac, urple, etc. Choicest Mixed. Pkt. 4c; 1/8 oz. 15c. Burbank's SANTA Giant Shirley Poppy

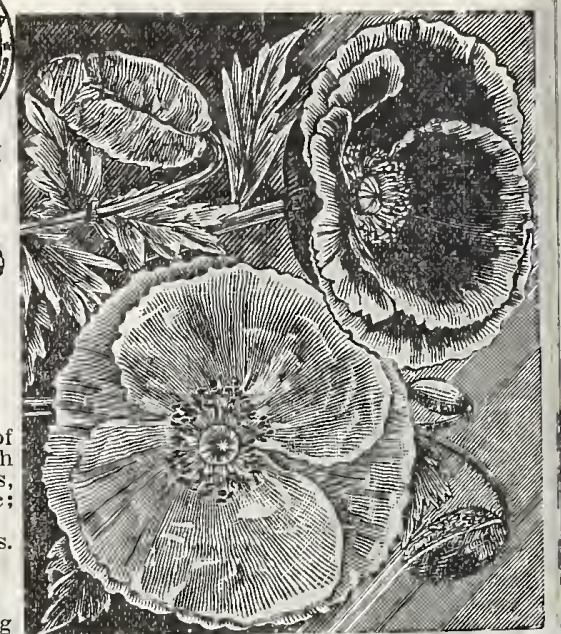
A great advance in single-flowering annual Popples. The flowers are immense, of ten meas-
uring 3 to 4 inches across, the petals are fluted and crinkled and in the sunlight appear like sloom in continuous succession por weeks. Flowers white, white veiled pink, white-splashed crimson, rose bandTofors blush, scarlet, and many splashtstriped, dotted $5 \mathbf{c}$;

\section{Primula Sinensis}

\section{(Chinese Primrose)} our most beautiful and indispensable plants for Winter or conservatory. They are un-
equalled as Winter bloomers,

CHINESE PRIMROSE-Buckbee's Superb Mixed-An elegant mixture embracing all the and also including the fringed sorts. Pkt. 10c.

CHINESE PRIMIROSE-Finest Double Mixed. A splendid strain of the finest large-flowering fringed varieties. liant colors. Pkt. 18c.

Primula

Primrose) Primula, Obconica Grandiflora

The Baby Primrose.

Primula Obconica is as near an everblooming plant as is possible to obtain. Eighteen inches in height. Flowers produced It has been known to flower for over ingly on stiff stems about six inches in length, two to twelve months without a break. Pkt.8c

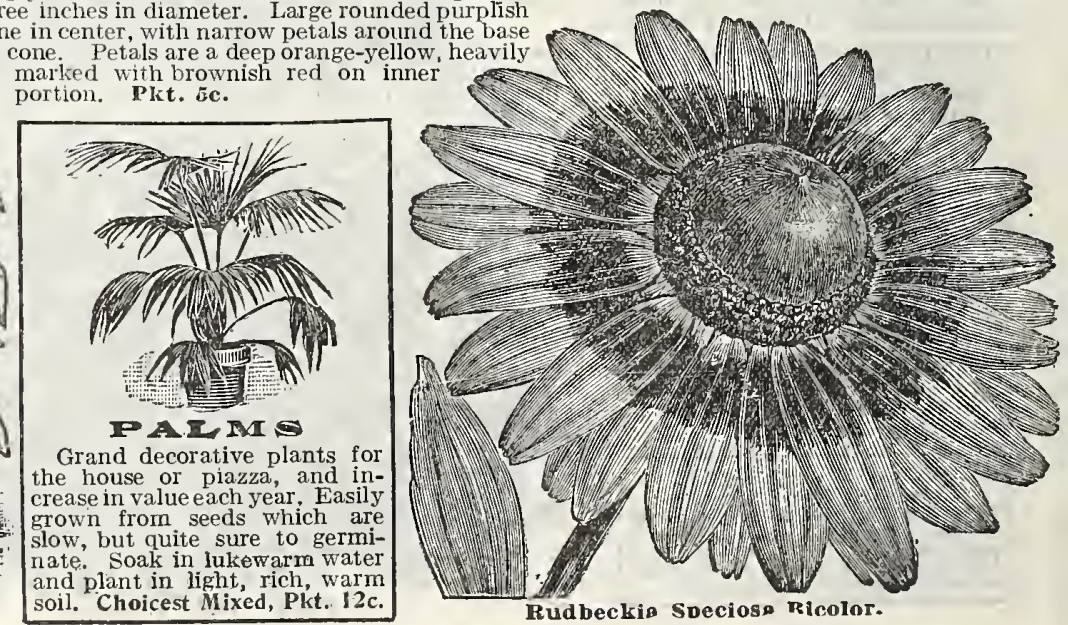




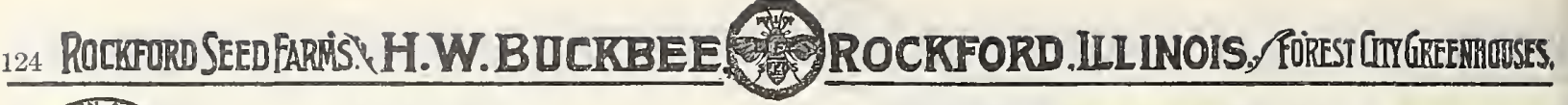

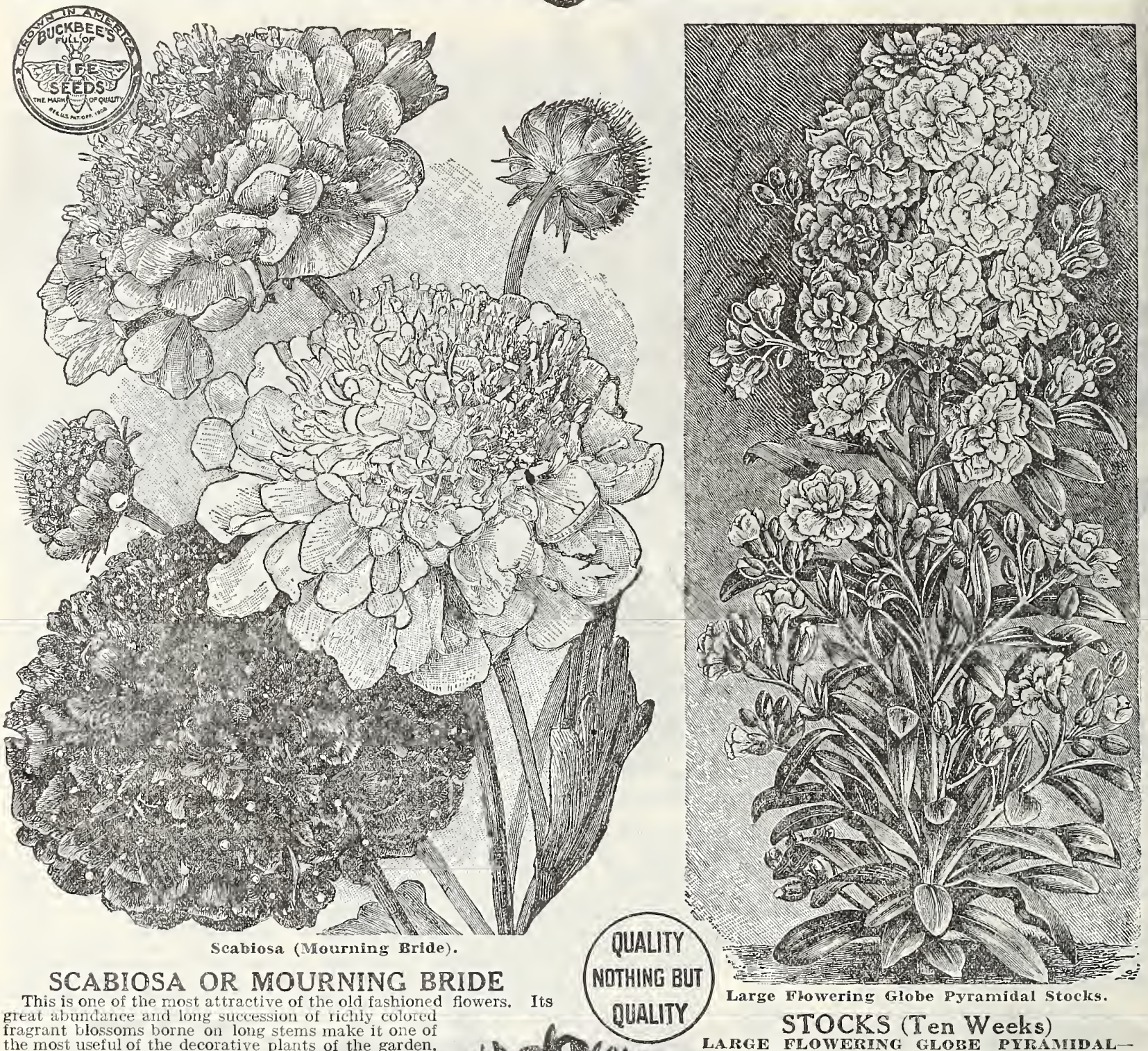

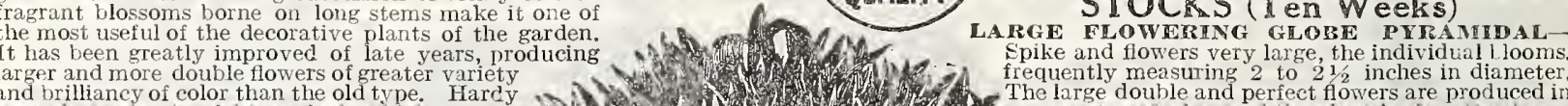
The large double and perfect fowers are produced in
a DWART DOURLE MIXED-

TALL DOUBLE MIXED-Pkt.

\section{SUNFLOWERS}

NEW CHRYSANTREMUM FLOW ERED - Fine, perfectly bling Japanese ChrysantheNEW DOUELE MIULTIFLORA The plant is pyramidal in flowers a the haced at base o

STELLA - Flowers star-shaped

of brightest golden yellow, with

stems, and are suitable for cutting. Pkt. 4c; 9 Z. 20c. FINEST MIXED-For backsightly places. Pkt. 4e; oz. 10e. SWEET ROCKET

Hardy perennials, bearing purple or white flowers. Plants 2 to 3 feet high. Flowers fragrant. An old4c; 122 oz. 10c.

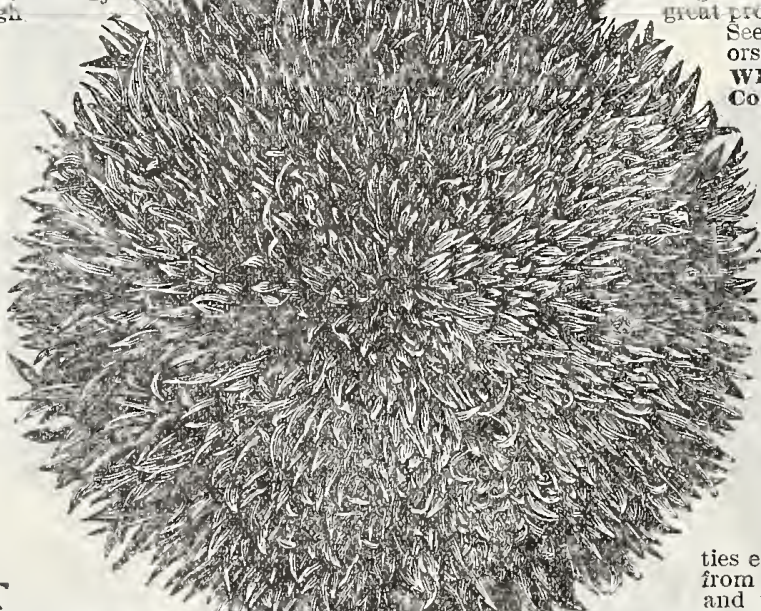
WHITE PERPETUAT - cut and white double variety about 2 feet high, producing endless numbers of side branches. Every branch bears a cluster of delightfully fragrant flowers, and new ones are are removed Place ac; $1 / 53.25 \mathbf{c}$. EVENING SCENTED STOCKS(The Wonderful Perfume Plant.)this in delicate perfume of its flowers Pkt. 4c.

DWARF GERMAN-Fine Mixed Pkt. 4c; $1 / 8$ oz. 15e.

\section{BUCKBEE'S}

NEW SNOWBALL STOCKS

Each Plant a Fouquet in Itself.

One of the finest flower seed novelintroduced Bloons very quickly

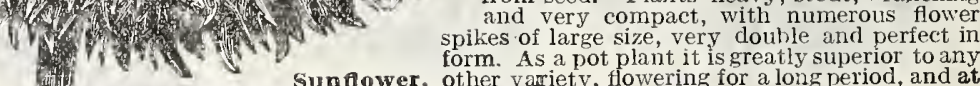

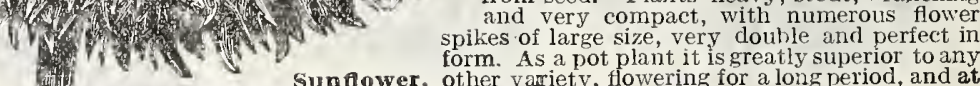
Chrysan the mu wow Flowed. any time. of the year. Pkt. 7c; 1/8 oz. 35c. 


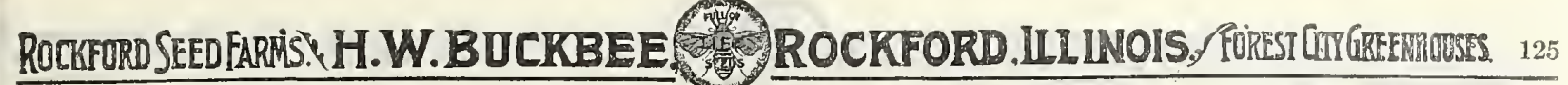
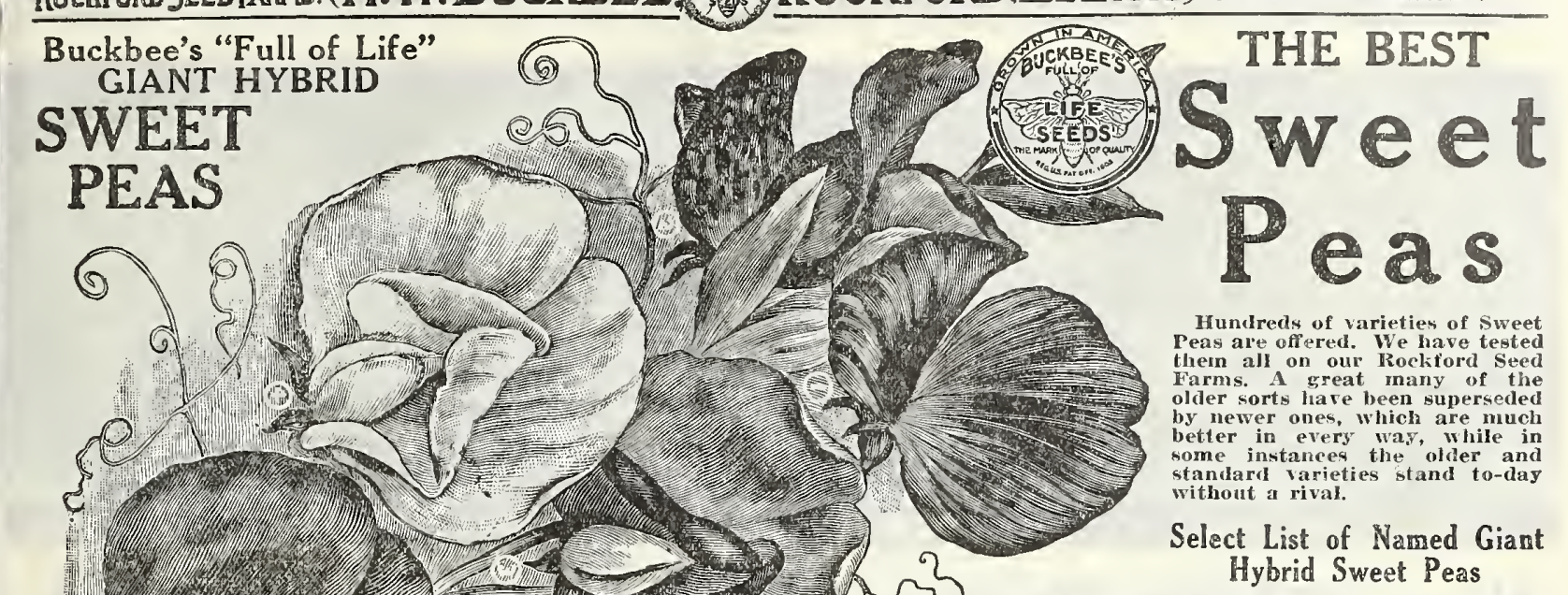

Hundreds of varieties of sweet Peas are offered. We have tested thein all on our Rockford Seed Farms. A great many of the older sorts liare been superseded by newer ones, which are much better in every was, while in standard varieties stand to-day without a rival.

Select List of Named Giant Hybrid Sweet Peas

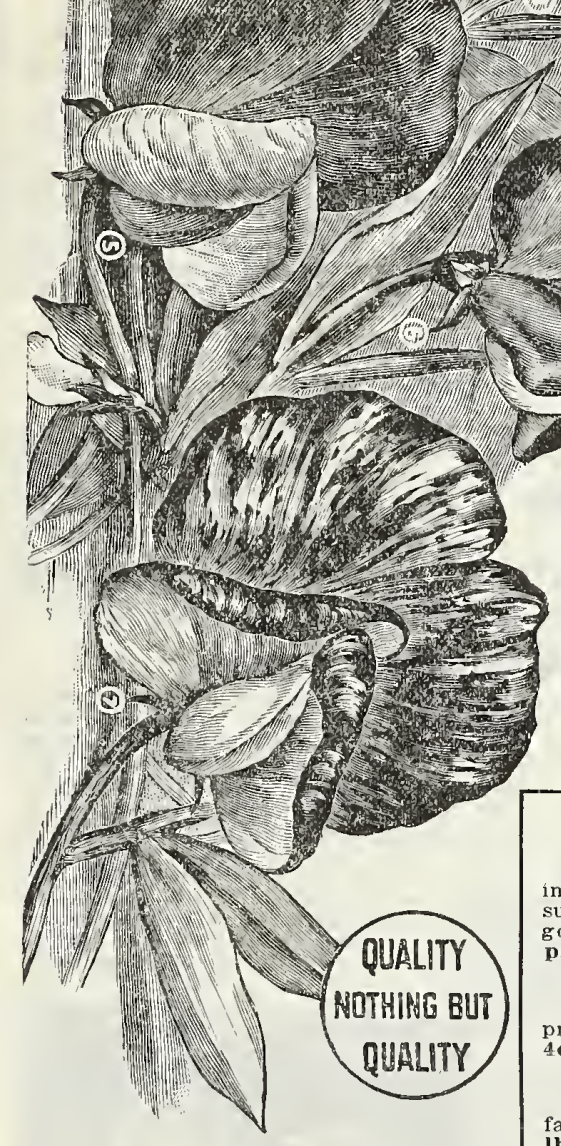

ADMIRATION-A grand large fiower of beauti-
ful form, self-cololed in a delicate shade of AMERICA-Striped

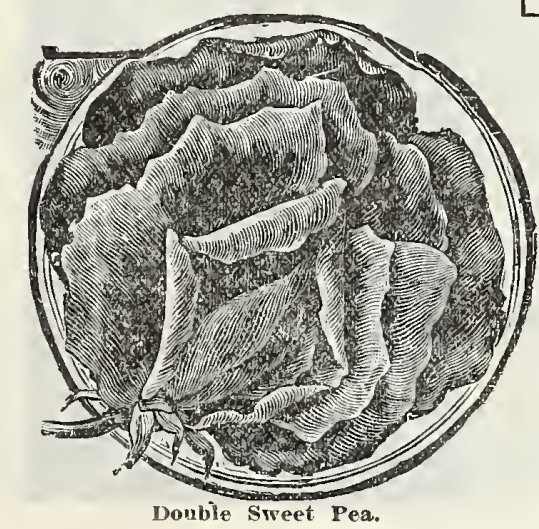

MISS WILIMOTT

LOTTIE ECK blue wings.

BLACK KNIGHT-Very rich dar
HLANCIIE FERRY-Rose-red,
COUNTESS OF CADOGAN-A

IRS. DLGALGing crimson-rose, with markings of primro

NAYY ISLUE-Dark indigo-blue and violet, the best deep

OTHELLO-Very dark maroon with blackish veins. Rich and

PRIMA DONNA-Gxquisite rose-pink, large and profuse a

PRINCE IEDWARD OF YORK - Standard scarlet, bordering on salmon

QUEEN ALEXANDRA-Brilliant scarlet. A bold

STELLA MIORSE-Has a faint tinge of pink underlying the cream, a true apricot shade

Prices for any of the above 25 Named Varieties, Pkt. 4c; oz. 8c; $20 z .15 c$; $\frac{1}{4}$ lb. 25c; postpaid.

\section{Buckbee's Pedigreed Gilt Edge Mixture} Best Colors, Largest Size, Very Fragrant.

This mixture is carefully blended by ourse n the right proportion for the most beautiful show and without question

good sed for gorgeousness of colors and brilliancy of effect, embracing every known

packet 5c; oz. 8c; 2 oz. 15c. 1/1b. 25c; 1/2 lb. 40c; bb. 75c, postpaid.

\section{Eckford's Choicest Mixed}

This blend or mixture embraces a cholce selection of the Eckford varieties of $1 \mathrm{~m}$ proved type, with a fair proport 4 ; oz. 7c; 2 oz. 12c; $1 / 4$ lb. 20c; $1 \%$ lb. 35c; ll, 60c, postpaid.

Fine Mixed

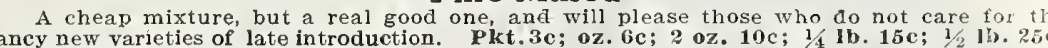
lb. $45 \mathrm{c}$, postpaid,

\section{DOUBLE FLOWERING SWEET PEAS NEW YELLOW IN FINE MIXTUR.}

Under favorable conditions they will pro- $/$
uce a large percentage of double flowers. Usually the double and single flowers are borne about half-and-half They are regular tall-growing Sweet Peas. Our mixture includes every desirable shade and color.
Pkt. 5c; oz. 10c; 2 oz. I8e; 1/2 Ib. 35c; $1 / 2$ ib. $65 \mathrm{c}: 1 \mathrm{t}, \$ 1.25$.

\section{NEW YELLOW SWEET PEAS}

A Wonderful Everblooming Variety. One of the most beautiful, interesting and ing, profusely branching plant, every long. of beautiful, large Sweet Pea-like flowers. These flowers are of a thick substance, fragrant and of a golden yellow color (except the keel in the center, which by clusters of short, smooth pods. A gold. Pkt. 5c.

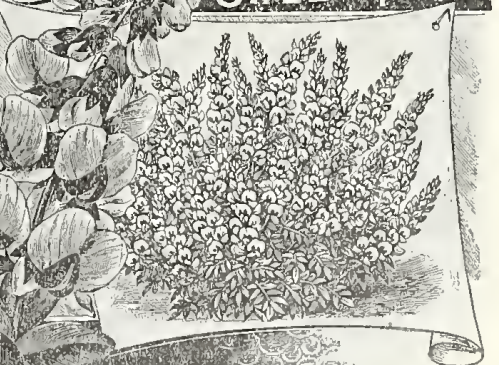

Double Sweet Pea. 


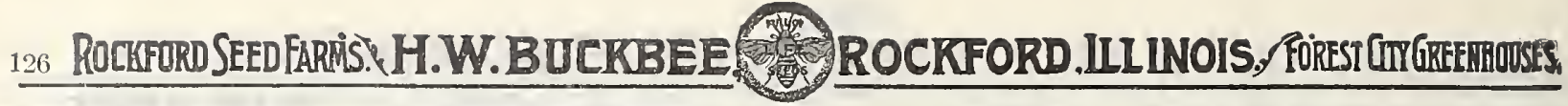

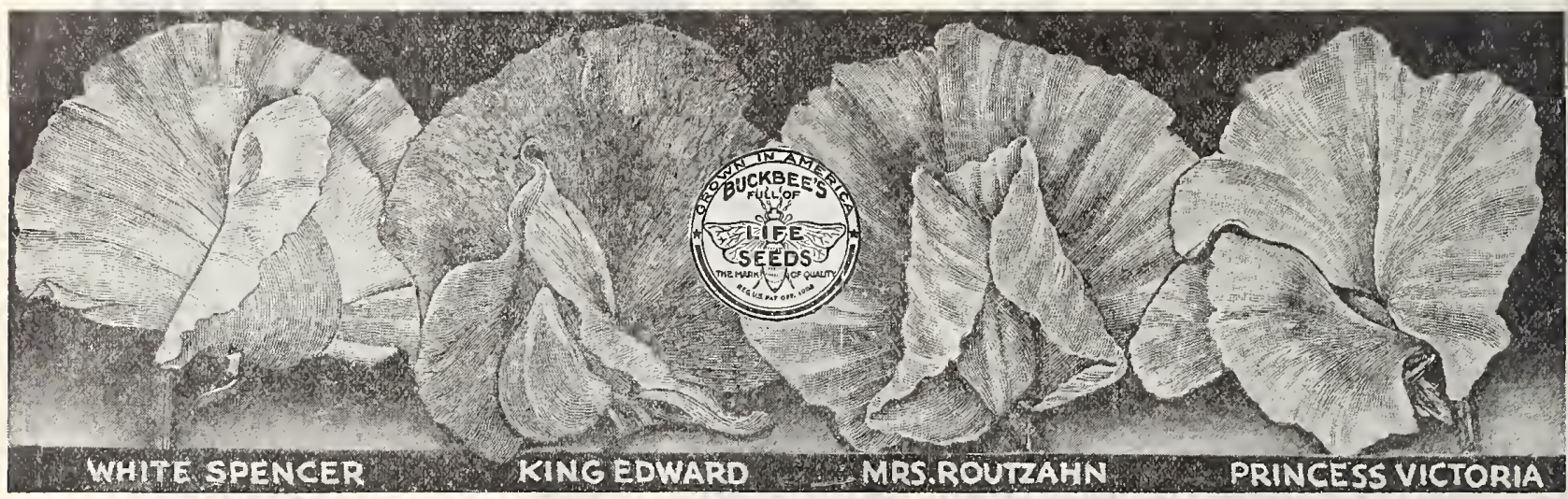

\section{New Giant Spencer}

APPLE BLOSSOM SPENCER--Bright rose wings. Very large; true spencer form. Pkt. 5c: oz. 20c. form

AURORA SPENCER-Flowers large, brilliant orange rose, CAPTAIN OF TIE BLUES SPENCER-Purple, with blue wings, CAPTAIN OF THE BLUES SPENCER-Purple, with blue wings, COUNTESS SPENCER-Bright clear pink; very large, open form; long stems. Pkt. 5c; oz, 15c.

DAINTY SPENCER-White suffused and edged with pink; large and of spencer form Pkt. 5e; oz, 20c.

E. J. CASTLE (Unwin type)-The color is a rich carmine-rose with salmon shading in the standard. Plt, 5c: oz, 10e.

FLORENCE MORSE SPENCER-A very large, delicate blush with pink margin. Plkt. 5c; oz, 25c.

GEORGE IERBERT-A bright, rose carmine, spencer variety of large size. Both standard and wings beautifully waved. 5c; oz. 20c.

GLADYS UNWIN-Clear light bright pink with deeper shade a edge of standard. Pkt. 5e; oz. 15e.

IIELEN LWWIS-A rich crimson orange, with wings of orange Pkt. 5c; 0z. 25c.

JOHN INGMAN (Unwin type)-Standards large, rich salmonrose, with the vavy appearance of the true Countess spencer wings rose. Pkt. 5c; oz. 15c.

JOSEPHINE BARNARD (SPENCER)-Both the large fluted colored deep rose tint. Pkt. 5e; oz, 15c.

KING EDWARD SPENCER-Brilliant crimson searlet; very large size, The best of the bright red Spencers, Pkt.5e; oz. 20c.
IRS. JOS. CIMAMRRLAIN (SPINCER)-Heavily flaked and splashed with a bright rose on white ground. Plt. 5c; oz. 20c. MRS. ROUTZAHN-Primrose and buff, shaded light rose at Pkt. 5e; oz, 25c.

NORA UNWIN-Flowers very large, pure white, Spencer type with very broad standard, beautifully frilled. Plat. 5c; oz. 15c. THELLO SPINCER-A beautiful, deep, pure maroon of the

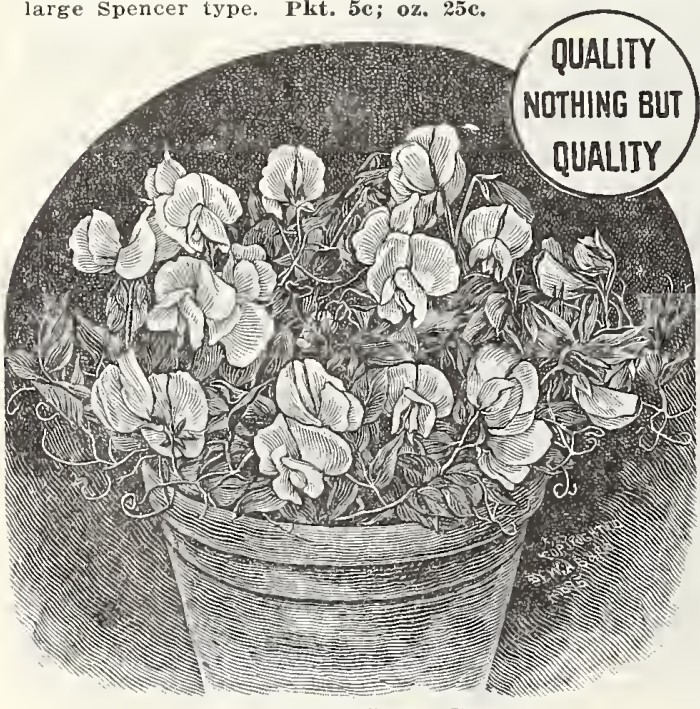

Dwari Cupid Swect Peas.

\section{Sweet $\mathrm{P}$ eas Wavy Petaled Orchid Flowered}

PRIMROSE SPENCER-The best primrose sweet pea yet developed. True Spencer type, large wavy pe
clear, distinct color. Plit. 5c; oz. 20c.

PRINCESS AIICE (SPENCER)-A lovely shade of lavender, possessing every characteristic of the true Spencer. Extra large, wavy flowers. Pkt. 5c; oz, 20c.

PRINCESS VICTORIA (SPENCER) - This beautiful wavy new "Spencer" was named for the Princess Victoria by royal re-
quest. It might be described briefly as a lighter pink CoUNTESS SPENCER. Pkt. 5e; oz. 20c.

PIIYLIS UNWIN-The flowers are of a beautiful rose color throughout. Pkt. 5e; oz. 15c.

TENNANT SPENCER-A light rosy purple or purplish mauve. Pkt. 5e; oz. 25c

WHITE SPENCER-Standard and wings of pure white, beauPlit. 5c; oz. 20c.

SPECIAL OFFER One Plkt. each of the 2t Spencer 98c Buckbee's Grand Mixture of Spencer Hybrids or Orchid Flowered SWEET PEAS

This in for most brilliant effect. It contains some most superb seedlings that have not yet been introduced. New and exquisite colors and shades, such as apricot, lavender, light and dark blue, several shades of pinks and scarlets from light shades to deep rose. Also striped and mottled varieties, with purple and deep maroons, all of the waved and fluted spencer Without exception this is the very flnest mixture it is possible to make, and we recommend our patrons to grow them lib erally, a packet or so is not a satisfactory test. Plant at least ance; a quarter of a pound is better, and you will have the finest display of Sweet Peas ever seen in your neighborhood. Price, large Plit. 7c; oz. 15c; $20 z$. 28c; 1/4 lb. 55c, postpaid.

Cupid or Dwarf Sweet Peas In Fine Mixture.

Therv five o six inches high, and excite wonder wherever seen; are very fragrant; bea full-sized lowers of fine substance, fuse bloomers; excellent for beds, borders and pot culture. A.s they cover the ground so closely they are not so likely to suffer from droughtes all tall sorts. Our mixture includes all 4c; oz. 12c;2 oz. 220; $1 / 1 / 2$ lb. 40c.

\section{Hardy or Everlasting Sweet Peas (Lathyrus) \\ ties Mixed.} Perfectly hardy perennial, handsome ree-blooming climbers. with clusters of elegant sweet-pea-like blossoms, profusion. They come up year aftcr year, and also bloom earlier than other Sweet Peas. Especially suitable mixture contains all colors. Pkt, 5c 行 oz. 1ธ̃c; oz. 25̄c.

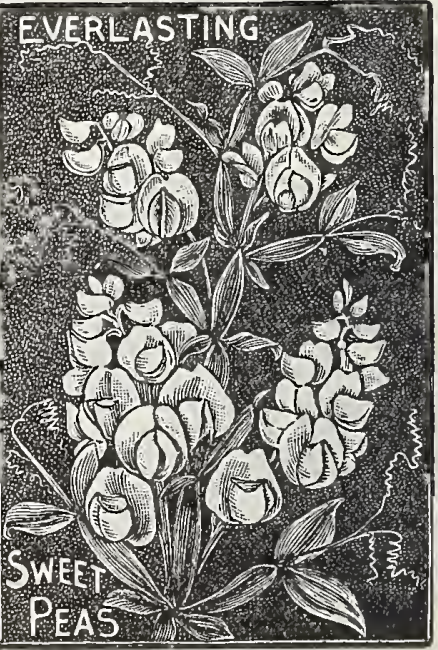




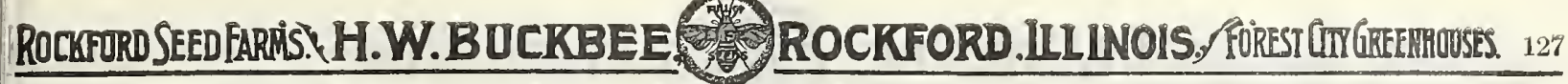

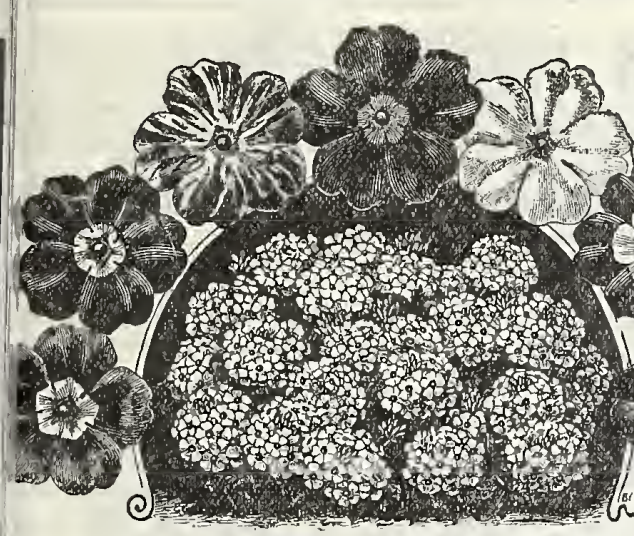

VERBENAS

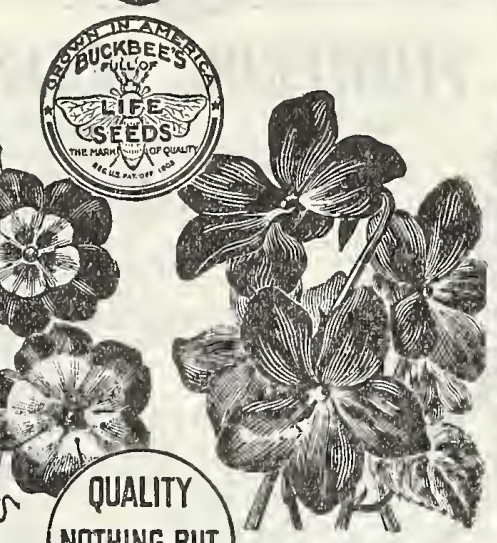

(NOTHING BUT

violet.
BUCKBEE'S GIANT COSMOPOLITAN MIXED

This selection and mixture embrace all the choice and most desirable colors in the Giant Flowering Verbenas, the shades are mostl very delicate and dainty, in fact, perfectly exquisite, there being ver little of the common blue and purple colors among them, but instead they have beautiful pinks, la venders, whites, dazzling scarlet, mottled striped blushes, variegated, and all the auricula-flowered varietie with white eyes. It is truly the best Giant, or Mammoth Strain, yet introduced for mammoth size of flowers', perfect form of trusses, rich and most velvety colors. Some of the individual florets are nearly as large as a silver half dollar. Pkt. 10c; $1 / 4$ oz. 50c.

\section{Mammoth Verbenas}

In Separate Colors.

BLUE KING-Showy and distinct, best blue. Pkt. 5c;1/4 oz. 25c. BURBANK'S MA YFLOWER-Lovely pink. Pkt. 8c; 1/8 oz. 50c. GOLDEN BEDDER-Scarlet blossoms, yellow foliage. Pkt. 5c. ITALIAN STRIPED-Striped flowers. Pkt. 5c; $1 / 40 z .35 \mathrm{c}$. PURPLE. Dark purple. Very rich color. Pkt. 5c; 1/4 oz. 25c. SCARLET DEFIANCE-True, brightest searlet. Pkt. 5c; $1 / 4 \mathrm{oz}$. YELLOW-Soft, pale yellow or primrose. Pkt. $5 \mathrm{c} ; 1 / 8$ oz. 35c. MAMMOTH MIXED-The above and others. Pkt. 5c; 1/4 oz. 25c.

\section{Verbena, Choicest Prize Mixed}

From a most superb collection of named varieties. Very large in lower and corymbs, and of the richest and most brilliant colors. Pkt. 5c; 1/4 oz. 30c; 0z. 75c.

Verbena, Hybrida-Fine Mixed A very good strain, and fully equal to that offered by many dealers at a greatly advanced price. Pkt. 3c; $1 / 4$ 0z. 15c; oz. 50c.

\section{Lemon Verbena}

\section{This elegant, fragrant plant is easily} grown from seed and succeeds everywhere. Have a good bed of it in the cut its fragrant foliage and flowers
make up with bouquets. Pkt. 5c.

Verbena Odorata

\section{SWEET SCENTED.}

The blossoms, instead of being in clusters like ot her sorts, run up into spikes usually 3 or 4 inches
long. Very sweet scented; flower is pure white; comes true from seed Pkt. 5c; $1 / 8$ 0z. 35́c.

\section{Vinca}

(Madagascar Periwinkle.) Ornamental free-flowering, flowers the Arst season; glossy green foliage; han Pkt. 4c; $1 / 4$ oz. 25c.

\section{Violet (Viola)}

The Violet should not be wanting in any garden, on account of its fragrance and early appearance. Succeeds best in a shady, sheltered place, and can be easily increased

\section{WILD CUCUMBER VINE}

The Quickest Climber for Arbor

Iakes the most massive covering. people in the country, and it is undoubtedy the best climber for coverIng verandas, trellises, etc., never suffering from the heat, but retaining its fresh and lively green color, and, what is of prime importance, holding forth throughout the whole summer, whether hot or cold, wet sow itself and come up every year in the same place. Pkt. 5c; oz. 15c.

\section{WILD FLOWER GARDEN}

A mixture of many varieties of bealitiful, easy producing a constant and varied bloom the whole season, and is especially suited for those who wish only a few seeds each of the leading varieties, or a much more extensive collection than their means will permit. In no other manner can so many seeds be obtained for such a small cost. This mixture is especially prepared from Fresh Seeds, the colors and varieties being carefully proportioned and will be found superior to any mixture offered, and can-
not fail to give satisfaction. Large Pkt. 5c; oz. 10c; $1 / 4$ ib. 30c. WHITLAVIA

GRANIIFLORA-A plant with a delicate, handsome foliage, producing a constant succession of beautiful violet blue, bell-shaped

flowers about half an inch long. and borne in drooping clusters. WATER LILIES

Flowers of the most exquisite coloring, and so profuse blooming that a tub of them is never without flowers from early summer until frost. They grow so rapidly that they will bloom in ten weeks from them. Select Sccd, Mixcd Coiors, pkt. 10c.

\section{WALL FLOWER}

SINGLE PARISIAN - This mnnual variety will fower throughout summer and Fall from seed sown the same Spring. Pkt. 5c. DOUBLE MIXED-Spikes of deliciously fragrant flowers, comchocolate and orange-purple pr ZINNIAS

No flowers are more easily grown from seeds sown in the open ground. and few bloom so continuously hroughout the entire Summer.
BUCKBEE'S NEW GIANT F. TCKBEE'S NEW GIANT new class of Zinnias, giant in I nize, and perfectly double colors and shades; plants grow 3 feet high, blooming freely during long periods: particularly valuable for groups. Choicest Mixed. Pkt. 6c; $1 / 4$ oz. 30c.

BUCKBEE'S SUPERIOR DOUBLE MINED-The grandsize, brilliant colors. Pkt. $0 z .25 \mathrm{c}$.

FINE MIXED-All colors mixed. Pkt. 3c; $1 / 1$ oz. 15c.

MAMMOTH ZEBRA-This really the finest strain of Striped
or Zebra $Z$ innias in cultivation. Pkt. 5c: 1/4 oz. 20c. LILLIPU T MIXED - Half the heigh of ordinary Zinnias. Blossoms small

Buckbee's New Glant Zinnias. 


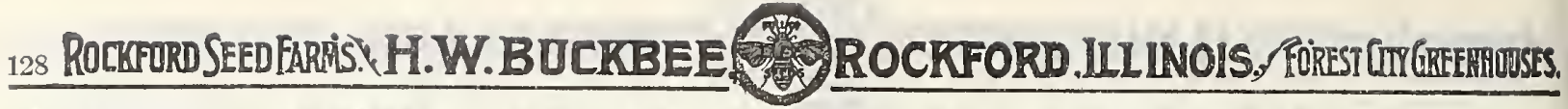
"Full of Life", SUMMER FLOWERING BULBS

REMEMBER, the bulbs offered are large,
sound and solid, with live center shoots and are far super.

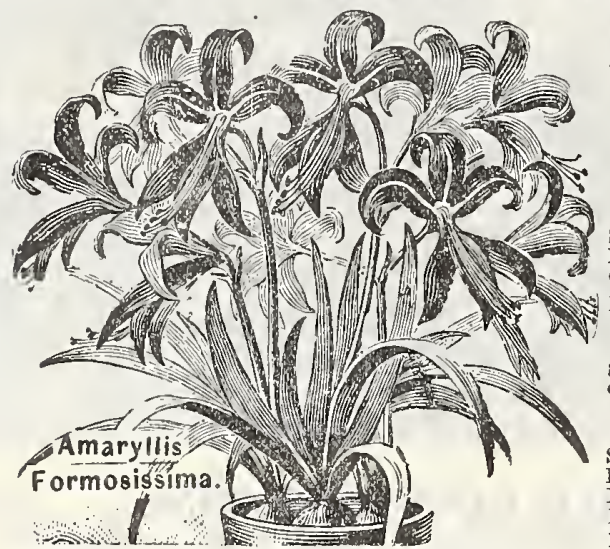

WE GROW AND OFFER ONLY TIE MOST POPULAR SORTS WITA ARE EASIL GROWN, REQUIRE SCARCELY ANY CARE, AND MAKE A SHOWY AND GOR. GEOUS DISPLAY. ALL OUR BULBS ARE SURE TO GROW AND BLOOM.

\section{BEGONIAS, TUBEROUS ROOTED, GIANT FLOWERED}

Tuberous Begonias are the handsomest of all Summer flowering tuberous rooted plants. They will succeed in any rich, well drained soil, and also make the very finest pot plants for the conseravtory or window garden.

New Single Varieties
Snow, snowy white. Moon, golden-yellow. Bride, soft pink. Fairy, rich rose.
Glow, scarlet. Price each, 10c; 3 for 25c; any 6 for $45 c$. Buckbee's "Full of Life" New Single. Glant Flowered Tuberous Begonias in doz. 48c, postpaid.

New Double Varieties

Silver, pure white. Sunset, rich yellow. Love, flesh pink. Oream, rose pink. Frice each, 12c; 3 for $30 \mathrm{c}$; any 6 for $54 \mathrm{c}$, postpaid.

Buckbee's "Full of Life" Double. Giant Flowered Tuberous Begonias, in
finest mixture. Each 10c; $\mathbf{3}$ for 25 ; doz. 75c, postpaid.

Thère is hardly a flower which has such intensely brilliant as this. It is a free bloomplanting. Few flowers can equal it in richevery year. $10 \mathrm{c}$ each; 3 for 20c.
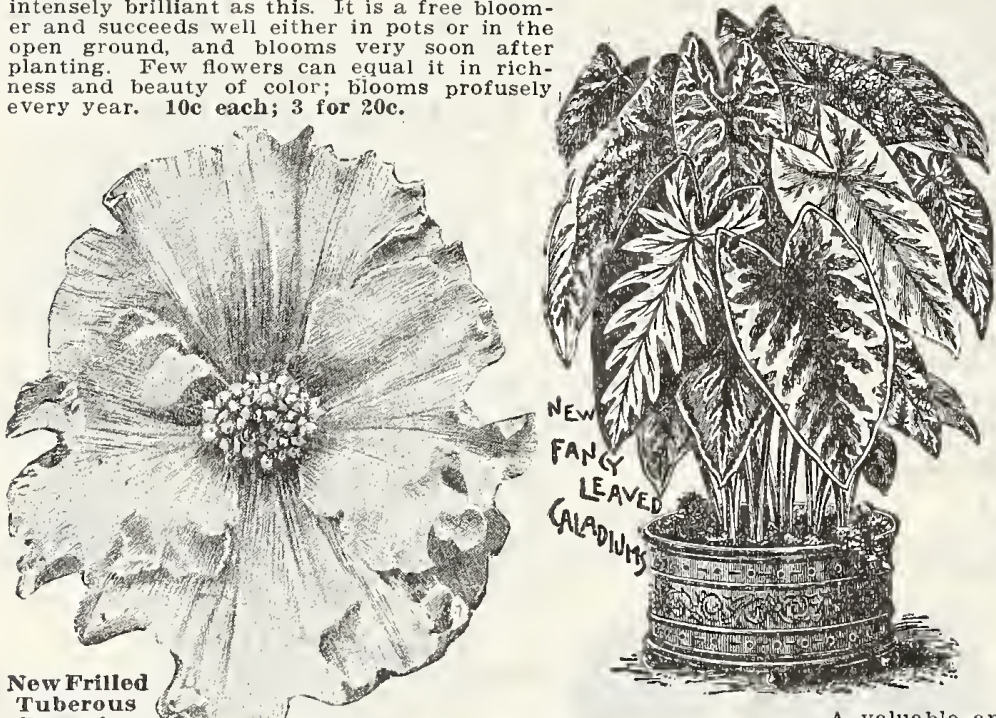

CALADIUM, New Fancy Leaved Varieties For window bores, house or greenhouse growing this is one of the most decorative plants. Their leaves, handsomer than Begonias, are spotted, marbled, veined and striped with white, pink and dark red. These Bulbs though comparatively rare, much admired. Bulbs should be started into grom th in a warm place. Selected Plants, $20 \mathrm{c}$ each; 3 for 50c; doz., \$1.75, postpaid.

\section{ELEPHANT'S EAR (Caladium Esculentum)}

A handsome plant of tropical aspect, bearing fective as a single plant on a lawn, or in groups; effect near streams or this splendid plant, and handle them in large lots. FIRST SIZE BULBS- $1 \frac{1}{2}$ to $21 / 2$ inches in diameter. Postpaid, 10c each; 3 for $26 \mathrm{c}$; 94e per doz.; By express, not prepaid, $\$ 3.40$ per 100 . SEIECT SIZE BULBS-2 $1 / 2$ to 3 inches in diameter. Postpaid, 15c each; 3 for $37 \mathrm{c} ; \$ 1.38$ per TT: 1 ing eter, Postpaid, 210 each; 3 for 65̃ doz. By express, not prepaid, $\$ 8.75$ per 100 . MATOTH SIZE-Bzeautiful Bulbs. 14 to 17

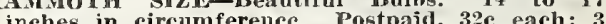
for 92c; $\$ 3.44$ per doz. By express, not prepaid, $\$ 14.65$ per 100 .

WISTARIA, HARDY TUBEROUS ROOTED A valuable and desirable tuberous-rooted twiner, resembling Wistaria in form of leaf and flower, but smalier. Grows to a height of 8 to 10 feet. Dies to the ground each Winter, deep purple root is perfectly hardy. The numer
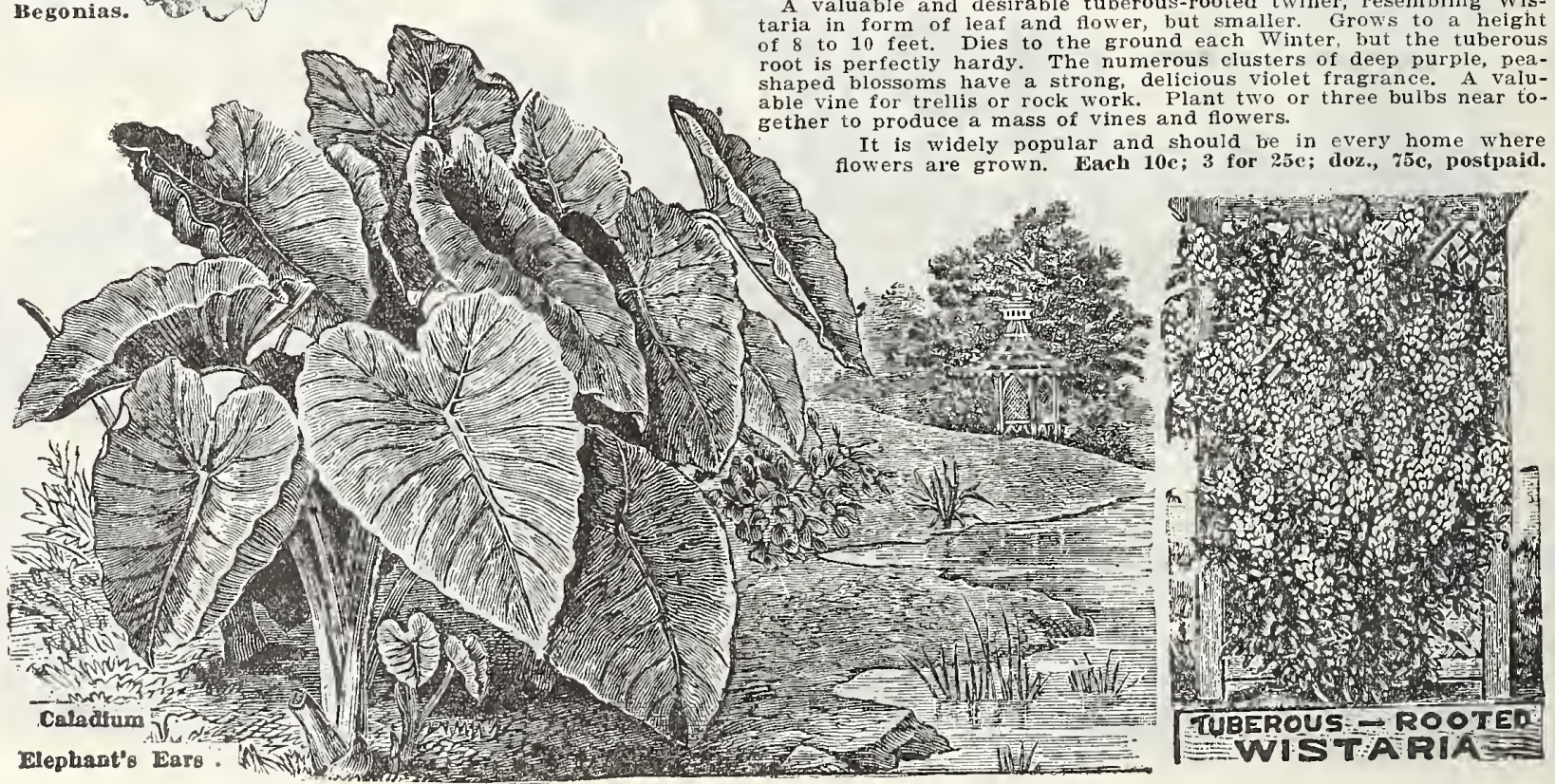


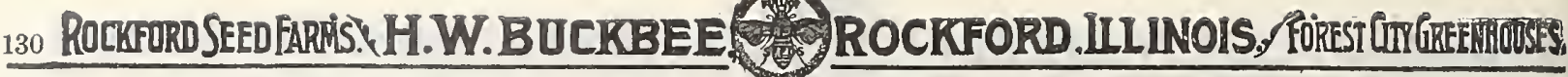

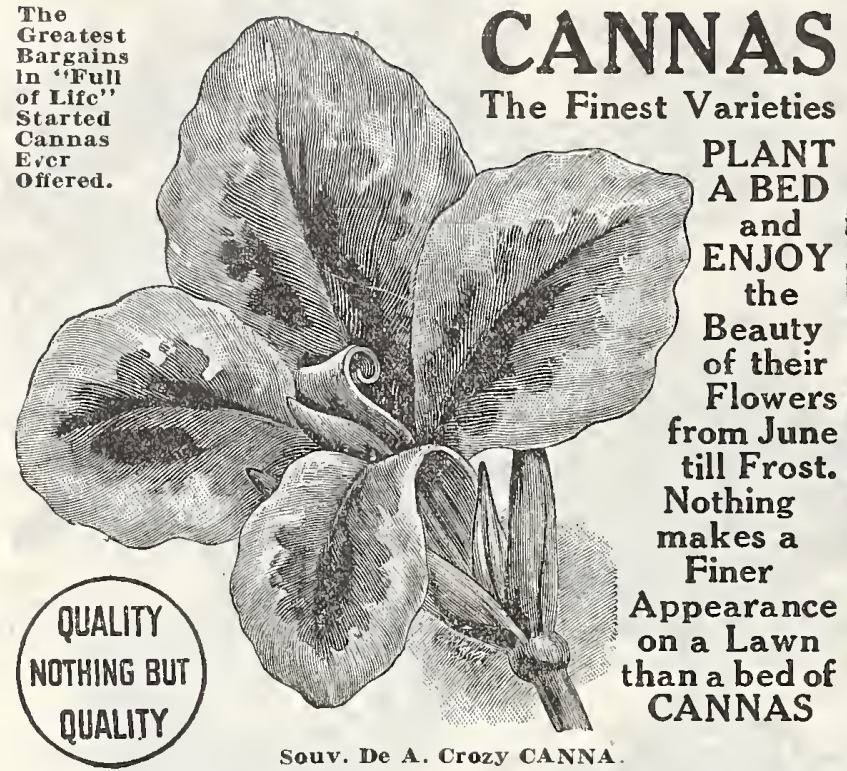

BUCKBEE'S BEST BEDDING CANNAS

These are all of the large flowering Crozy type. The choicest and best kinds, and embrace the entire range of colors known to this remarbable class of plants.

PRICE, each 15c; doz. $\$ 1.50$. The Sct of 20 for $\$ 2.25$, postpaid. ALPHONSE BOUVIER-5 ft. Crimson flowers. Green foliage. BEA UTE POITEVINE-3 $1 / 2 \mathrm{ft}$. Large crimson flowers. green foliage. BLACK BEA UTY $-5 \mathrm{ft}$. Darkest leaved Canna known; crimson flowers, BUTTERCUP-3 $1 / 2 \mathrm{ft}$. A true bright buttercup yellow; green foliage. CHAS, HENDERS ON-4 $\mathrm{ft}$. Crimson flowers; green foliage. DUKE OF MARLBOROUGH-4 1/2 ft.Color rich maroon; green foliage. DUKE OF NARLSB EGANDALE-4 ft. Bronze foliage, Color, currant red. FLORENCE VAUGHAN-5 $\mathrm{ft}$ Yellow, spotted red; green foliage.
KING HUNIBURT-5 ft. Rich orange and bright red; bronze foliage. KING HUNIBERT-5 ft. Rich orange and bright red; bronze foliage
MIAB. CROZX $-31 / 2 \mathrm{ft}$. Vermillion with gold border. Green foliage. MLLE. BER A T $-41 \% \mathrm{ft}$. A shade of rose carmine; green foliage. MLLE. BERAT-4 $1 / 2 \mathrm{ft}$. A shade of rose carmine; green foll
MONT BLANC-2 $1 / 2 \mathrm{ft}$. Pure white flowers; green foliage.

PAPA NARD Y - 4 1/2 ft. A beantiful purplish crimson; green foliage. QUEEN CHARLOTTE-4 ft. Orange scarlet, gilt edge; green foliage. SOUV. DE A. CROZY - $4 \mathrm{ft}$. Scarlet-crimson, border yellow; green SEC. CHABANNF-4 ft. Green foliage. Beautiful orange color. SHENA NDOAH-4 ft. Deep rosy pink; rich dark foliage.

WILLIAM SA UNDERS-4 ft. Flowers bright scarlet. Bronze leaved.

\section{New Giant Orchid-Flowered Cannas}

These Cannas are glants in every way. They are in a class by themsclves, because of thelr wonderful slze, and also the rare and bcautifu! formation of their flowers. whlch has given them the name of ORCHID-FLOWERING CANNAS. Of the many varietics introduced, the six offered bclow are the most distlnct and desirable.

PRICE, each 15c.; Doz. \$1.50. The set of 6 for only 75c. postpaid.

ALLEMANIA-Flowers enormous in size; outer petals scarlet, with a broad yellow border: inside scarlet and red. Six feet

AUSTRIA - The largest fowering Canna in the world. The flower when

extended measuring over 8 inches across; color a pure canary yellow
with the exception that two of the segments are slightly spotted with

B URBANK-Rich, clcar canary vellow, with crimson spots in the center.

Five feet. The flowers are truly gigantic in size.
ITALI -4 $1 / \mathrm{ft}$. Color brilliant red, the outer half of each petal a band of clear yellow. The flowers are producerl on massive stems, set well ahove the foliage, which is large and heavy.

MRS. KATE GRA Y - Color a rich dazzling scarlet orange. Four fcet. tense vermillion scarlet, overlaid with an orange sheen, foliage rich

green. Five feet.

\section{Mixed Large Flowering Cannas}

Every season we have a considerablc number of unnamed Large Flowering Cannas, including some very rare sorts mixed by accident and otherwise which we offer (our selection) at the vcry low price of 10c each, PLEASE NOTE E $\begin{gathered}\text { Wosend out Growing } \\ \text { canna }\end{gathered}$ Our prlces are low; in fact, we are only charging what most fims sell dormant roots at-AND oUR SPLENDIT STARTED PLANTS ARE EASILY WORTH twice as much as the dormant roots.

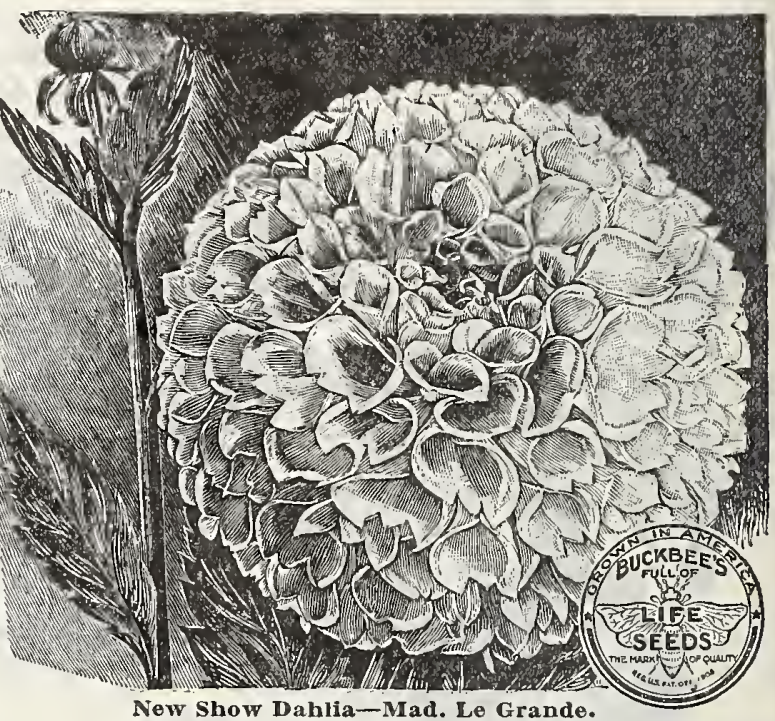

\section{BEST SHOW DAHLIAS}

\section{The Real Old Fashioned Type.}

The following are the very latest, newest and best varieties:

PRICE. Any of the following New Show Dahlias, Strong
PRI rooted pot plants 3 for $50 c$, or the entire set of 8 varleties for $\$ 1.25$, postpaid.

MI. BREURS-Lovely primrose shaded to peach. Fine

flower... . . . . . . . . . . . . . . MRS. E.H. HARRINIAN-Velvety maroon tipped white.20c eacr MAD. LE GRA NDE-Solferino rose of perfect form...25c each GOV. GUILD-Best large pure white. A strong grower, 20c cach CONSTELLATION-Old gold tipped shell pink, full to CHARLES iIAiBü-Rich golden yellow. Profuse $20 \mathrm{ceach}$ RED HUZZZAR - A rich, cardinal red. “ very large fine IoHN Limo

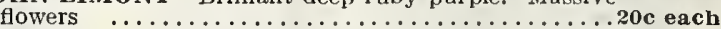

\section{BEST DECORATIVE DAHLIAS}

PRICE. Any of the following New Decoratlve Dahllas. Strong rooted pot plants, 3 for $50 \mathrm{c}$, or the entire set of 8 varieties for $\$ 1.25$, postpald.

COMMA NDA NT GUI NET-Rich purple, violet shad-

ings ... . . . . . e GEO. R. DRA KE-Bright coppery orange; attractive.20c each JACI ROSE-Brilliant crimson red, rich and glowing. $20 \mathrm{ceach}$ DON UA N-Extra large flowers of a rich golden yellow, 20c each GABRIEL DE LIEN-Deep velvety maroon, almost

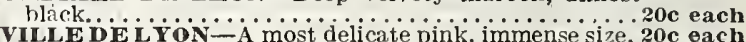
MIIE. F. MOLLARD-Best and largest pure white...20c each

\section{BEST CACTUS DAHLIAS}

SPECIAL PRICE. Any of the following New Cactus Dahlias, Strong rooted pot plants, 3 for 50c, or the entlre sct of 8 varieties for $\$ 1.25$, postpaid.

A. D. GOODRICH-A lovely tint of a rich plum color, quite velvety in texture, $20 \mathrm{c}$ each.

ETRURIA-Resembling autumn-oak foliage, a color most diffcult to descrihe, heautiful and effcctive, 20c each.

in

l'he color is a glowing crimson deepening to maroon in the center Very fine exhibition flower. One of the best. 20c each.
MRS. STA NACK GASKILL-Lovely clear deep rose pink. large magnificent flower. $20 \mathrm{c}$ each.

HAROLD PEERMAN-A deep pure yellow: very free and extremely reliable, the best exhibition flower. $20 \mathrm{c}$ each.

FLAG OF TRUCE-A pure white variety of the finest form, with long narrow florets, terminating in a point, stems are long and graceful. 20c each.

HARLEQ UIN-Bright scarlet tipped white. A most exquisite flower. 20c each.

HAS. H. CURTIS-Rich fiery scarlet. A large incurved flower. 20c each.

\section{DOUBLE DAHLIAS (Unnamed)}

When the purchaser is not particular about knowing the names, but desires fine colors only. we offer this superh assortment, including many of last season's high priced novelties, our selection of varieties. You will get your money's worth for the price we ask. PRICE. Strong rooted pot plants, $15 \mathrm{c}$ each, 6 for $60 \mathrm{c}$ or $\$ 1.00$ per doz. postpaid.

SPECIALNOTICE We send strong growing plants 
The Gladiolus deserves a place in every garden, large or small, being of easiest possible culture. They make grand beds and the bulbs can be planted any time during Spring and early Summer.

\section{Buckbee's Famous Rockford Mixed Gladioli}

\section{Gorgeous Colors and Marvelous Markings.}

We call spectal attention to our Famous Rockford Mixed Gladiol which have been constantly improved year after year by discarding all undesirable flowers and developing new shades and combinations of colors, including Childsi and Lemoinel kinds, with several other choice varieties of which we do not have sufficiently large quantities to offer separately. This mixture also contains a good many rich blue, purple and wine shades, with vivid tints and variations; all splendid flowering buibs that will make a grand show, and at such a low price that every 10c; 25e per doz.; 50 for $\$ 1.00 ; 100$ for $\$ 1.75$. By express, not prepaid, $\$ 1.25$ per 100 .

Buckbee's New Frilled and Ruffled Gladioli Apparently a new and quite distinct strain in form of flower, the
border of every petal being conspicuously frilled, crimped and ruffled (see illustration from photograph) which gives to the extra large expanded flower a most chaste and refined appearance. The colors so far noted in our special trial grounds at Rockford are very dainty and striking-rich, delicate cream white, flaked, suffused and blended with numerous shades and markings of lavender, violet and soft canary yellow, with deeper tints and reddish brown markings. While this new and lovely strain does not yet show as wide a range of colors and markings as our other mixtures, it is made up with all our new special select seedlings, giving an average of at least forty per cent. of the true type, and without question the finest and best mixture of delicate light markings and shades ever offered, Price,

\section{Kunderdi "Glory" Gladioli}

The color is a delicate cream pink, with stripe in the center of each lower petal, the shade of which is unigue in Gladiolus. The ruffling of the petals has attracted much attention the country over. It is claimed by the grower, who has worked ou this type that later on he will have a wide range of colors in this class. He claims distinctness of form, even as the "Spencer" types of sweet twos, all face the same. Price, postpaid, each 10c; 3 for $25 \mathrm{c}$; doz. $\$ 1.00$.

\section{Giant Orchid Flowering Gladioli}

\section{Tlowers Size of Tea Plates.}

This new race of extraordinary beautiful Gladiolus represents the perfection of this genus since its introduction. The flowers have reached enormous dimensions, often 7 to 9 inches across, far surpassing an others and much resembling Orchids of the brightest hues and most many having beautifully mottled and spotted throats, made up o white, crimson, pink, yellow, etc., of unsurpassed beauty. Finest Mixed. 8c. each; T5e per doz., postpaid.

Buckbee's Famous Grand Twelve Named Gladioli The following selections are the finest and most distinct sorts, giving
the widest range of colors. Price, each, 5c, or one each of the complete collection (12 varieties) for only 50c, postpaid

America-Color exquisite soft lavender pink. Brahma-Intense scarlet with white center. Chrysolora-Goiden yellow, pure and distinct. Dawn-Blush white, suffused with carmine rose.

Jean Valjean-Rich yellow tinged with rose Kaleidoscope-Slate, orange, white and violet La Candewr-White, suffused with carmine Mephisto-Coppery scarlet tG dark carmine.
Mrs. Beecher-Bright scarlet flamed vermil-

lion.

Proscrpine

Cherry red, white and lavender

Rosedale-Lilac rose, tinted slate blue.

Ruth Mercier-White, with crimson penciling.

\section{Bargain} Collection ONLY $50 \mathrm{c}$
A MOST

VALUABLE BOOK

How to Grow

Flowers and Seeds

T u 11 Cultural Directions for Vegetable Seeds, Field Seeds, Flower Seeds, Bulbs and Plants. Useful tables of Information. ProPrice. 50c, postpaid, or we will give a copy FREE with an order a mounting to $\$ 1.50$ or upwards, if asked for on the order.

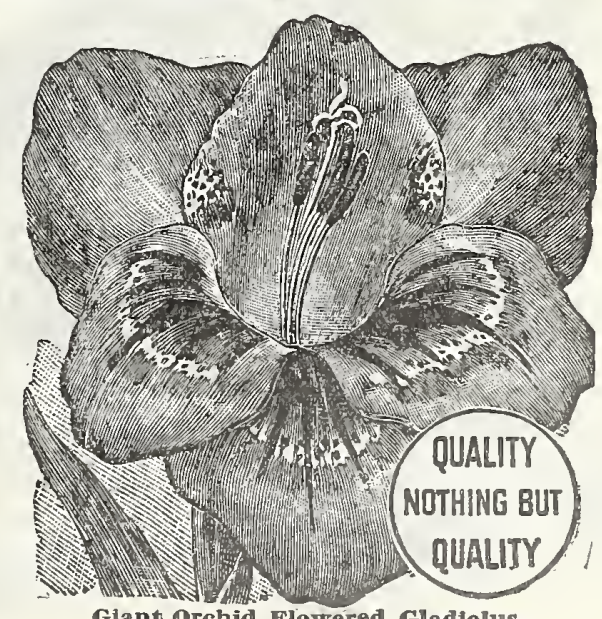




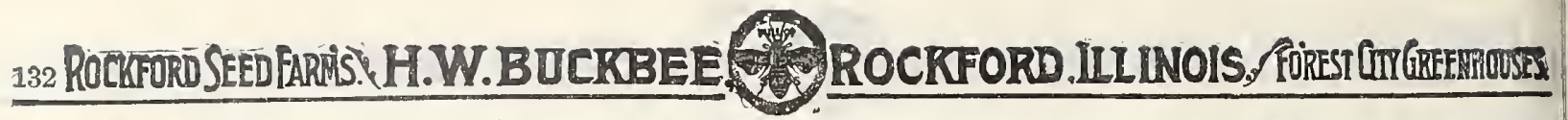
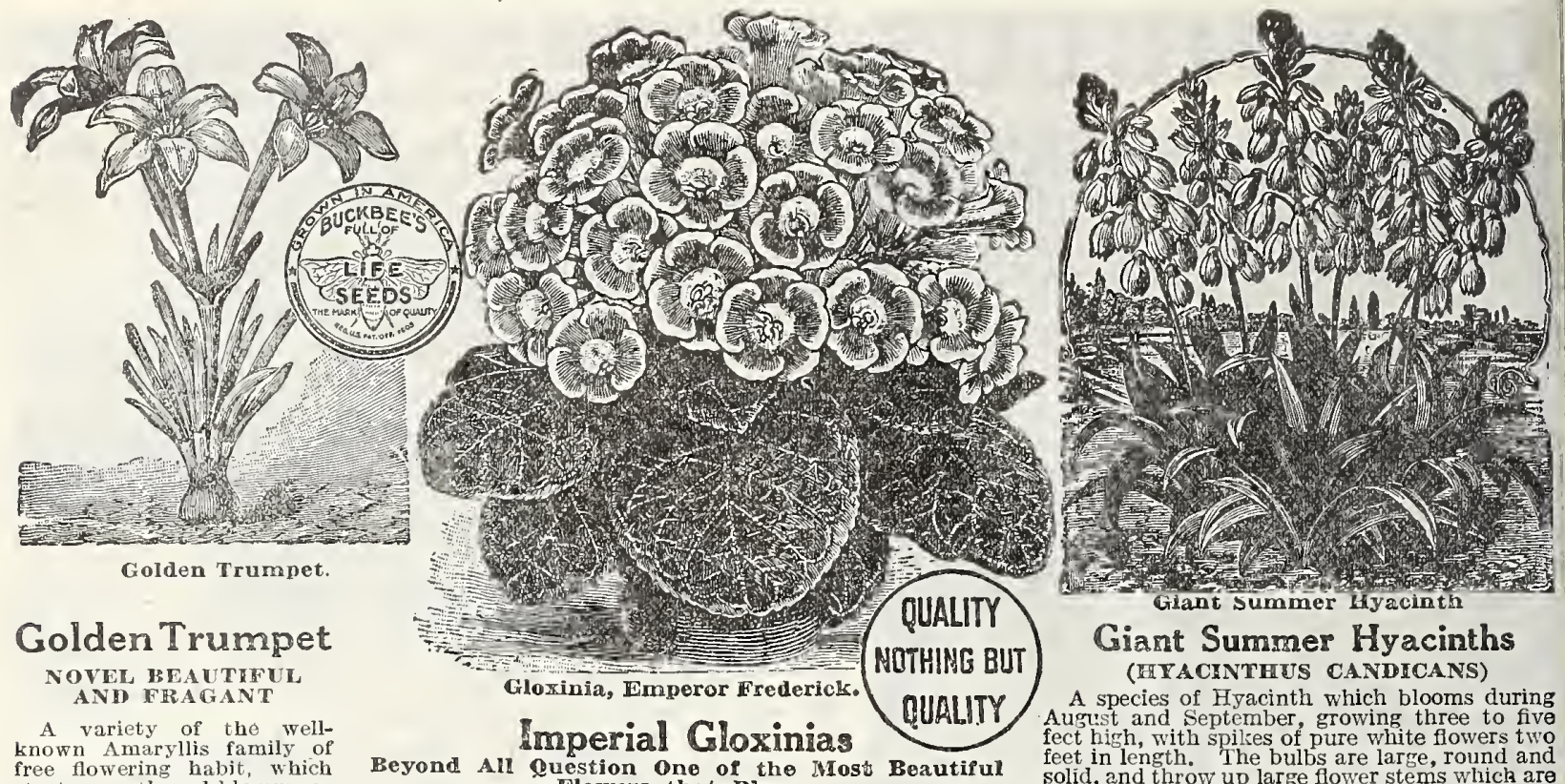

Giant Summer Hyacinths

(IITACINTHUS CANDICANS)

A species of Hyacinth which blooms during August and September, growing three to five feet in length. The bulbs are laree round and solid, and throw up larme flower stems whick are gigantic spikes of thimble-shaped white blossoms. Planted in the Spring they bloom in August, September and October; strong bulbs producing two, three and even four flower stems. A bed of a dozen or more bulbs produccs a grand effcct. A few planted in the center of a bed of Verbenas, Petunias or other flowers make a beautiful display, For a cemetery nothing can be more bcautirul or appropriate and nothing sure to bloom. $5 \mathrm{c}$ each; 6 for $25 \mathrm{c} ; 12$ for $45 \mathrm{c}$; postpaid.

bination between the Lilac

and the Tuberose. Two or

large y ellow blossoms are pro-

period. Pot the bulbs at any

they will be soon in bloom.

A truly magnificent plant. Strong bulbs, 5c each: 6

for $25 \mathrm{c}$; nostpaid.

The Gloxinia is a grand flower and makes a lovely pot plant as easily grown and cared for as many of the comtheir unrivaled beaut seering will bloom in six NMPELOR FREDERICK-Red, with white border, 150 MONT BLANC-Pure white, enormous size, 12c each. IDEFYANCE-Rich crimson scarlct. 12c each.

GMPEROR WILLIIM-Violet-blue, white throat, 120

LEOPARD-Beautifully tigered and spotted. 12c each PIICE FOR AEOVE NAMIED VARIETIES, READY

FOR MMMEDIATE GROWTH AND RLOOM: Any 3 for $35 \mathrm{c}$, doz. 81.15 , postpaid.

3 for $25 \mathrm{c}$

\section{Climbing Mignonette}
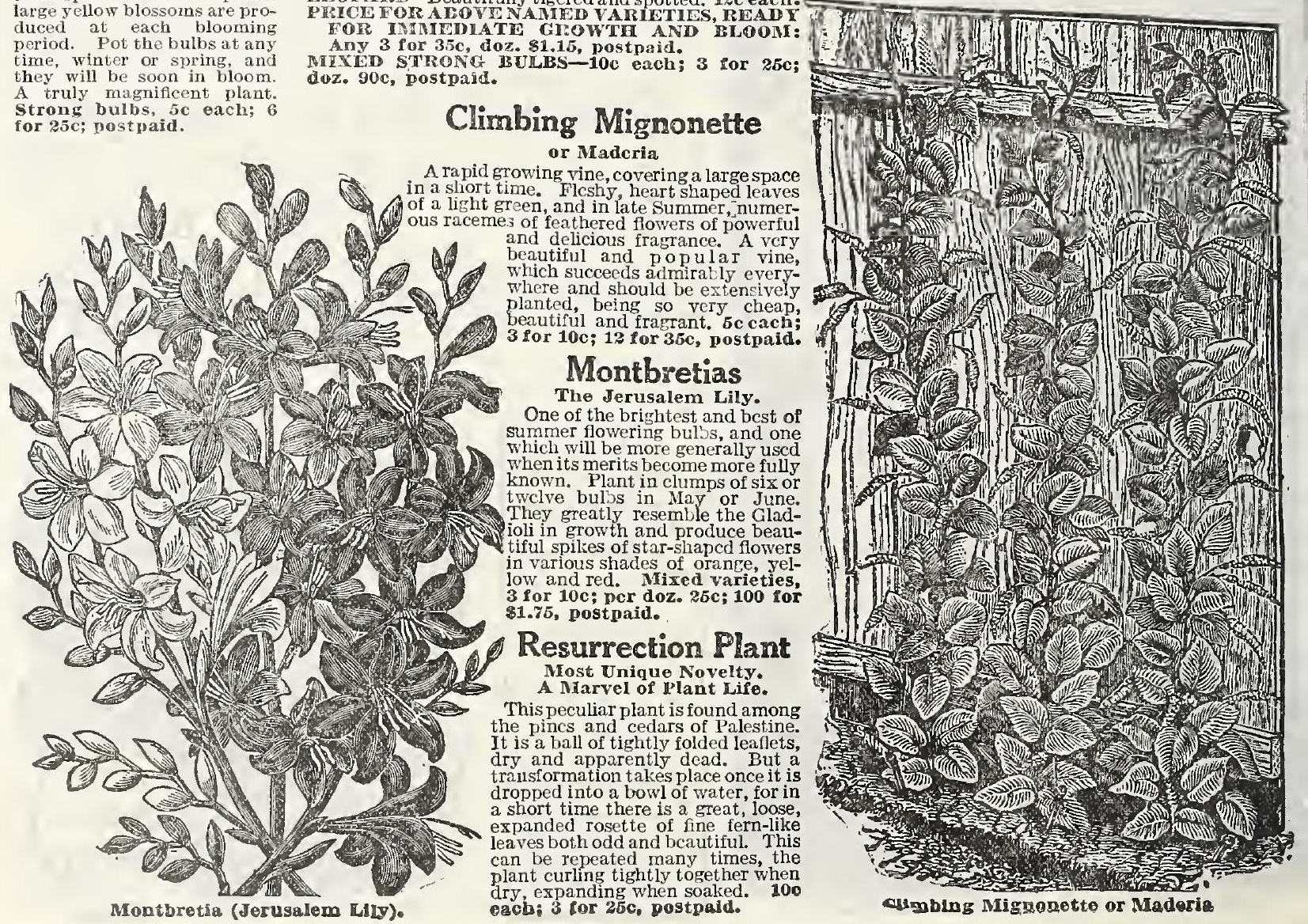

4

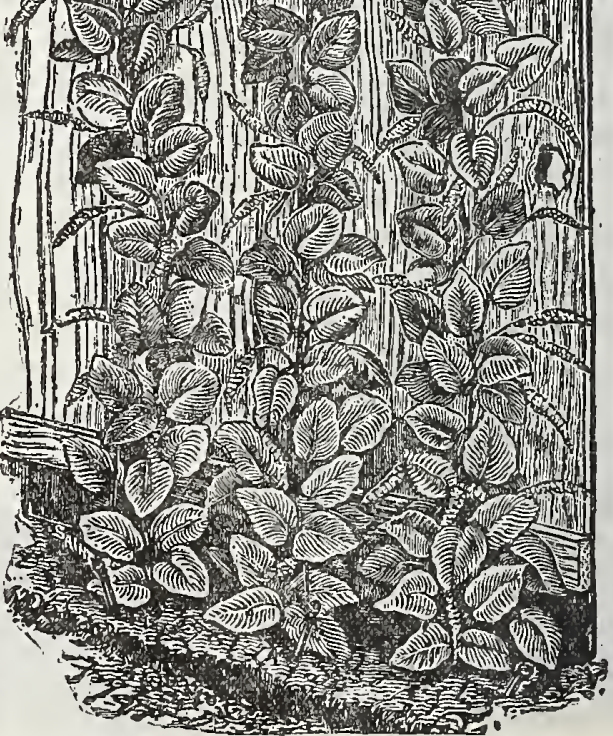

clumblng Mignenette or Maderia 


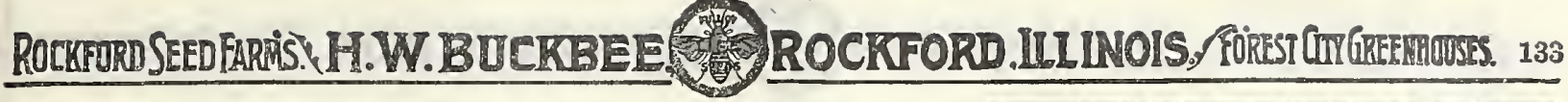

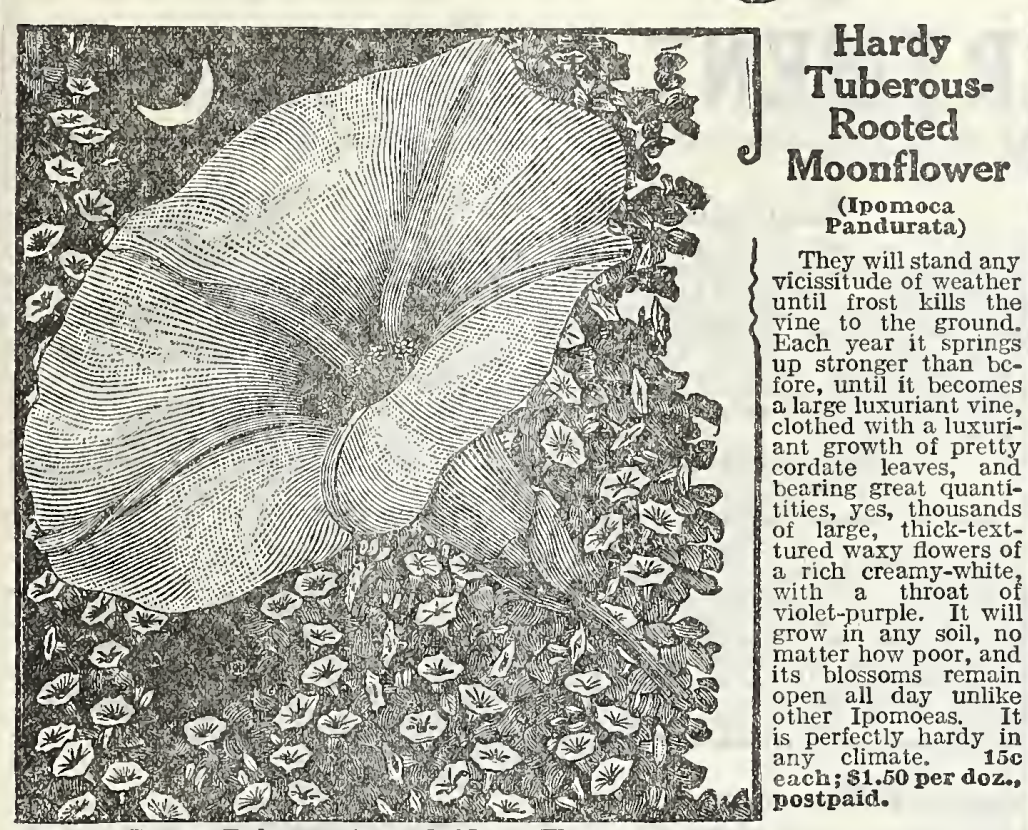

Hardy Tuberous-Rooted Moon Flower.
Summes Flowering Oralis No bulb is so valuable for edging the borfowering Oxalis.

Dicpp-Pure white: very fine.

Lasandria-Fine rosy-pink, beautiful cut foliage. and pink blossoms,

Irice of bulbs of the above pour va rieties, $10 \mathrm{c}$ per dozen: 25 for $15 \mathrm{c}$ : 100 Ior 40 ; postpaid.

Mammoth Brilbs-These bulbs are nearly as large as Gladiolus, and will produce a wonderful profusion of bloom.
each; 3 for 10c: 12 for 25 , postpard.

\section{Mexican Star Flower}

\section{Milla Biflora}

The flowers are pure waxy white, two inches in diameter, star-shaped and usually in pairs on long slencer stems, It is beaut. ful, especially for culting, as it lasts a long
time in water. Too much praise cannot be bcstowed upon this lovely fower. It pleases everyone, and should be grown largcly. The blossoms frequently last two weels when fect gem. 5 e each; 3 for $10 \mathrm{c}$; 12 for $35 \mathrm{c}$. poct geri.

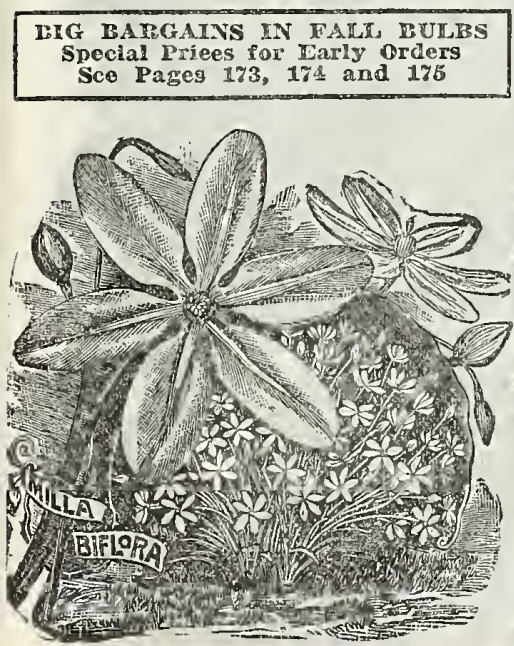

Mexcan star Flower.
14. (1.12) s. H.m My H.

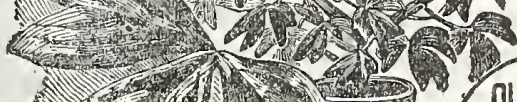
a

Shell Flowers (Tigridias) of the most showy of all Summer bulbs, and blooms from mid-summer until frost. growing two feet high, with large wide-open triangular blooms, four to six inches across. peculiarly odd and attractive. All Colors Mixed. bc eacb: $40 \mathrm{c}$ per doz., postpaid.

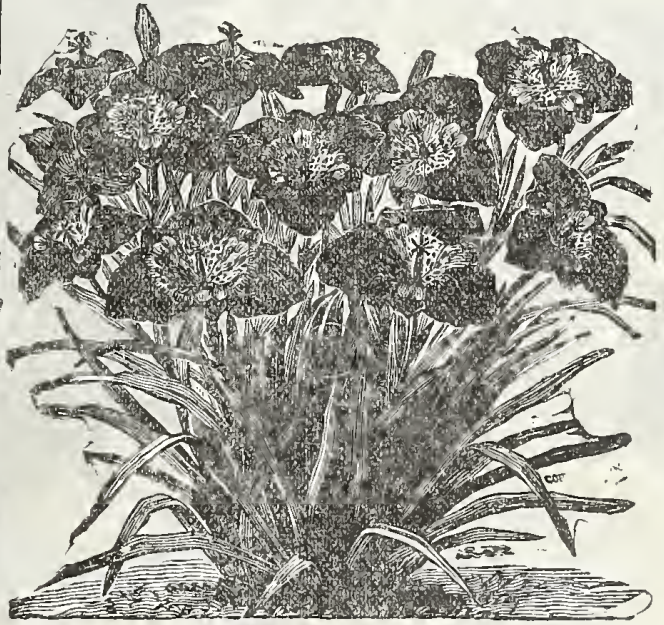

Shel Flower or Tigridis.

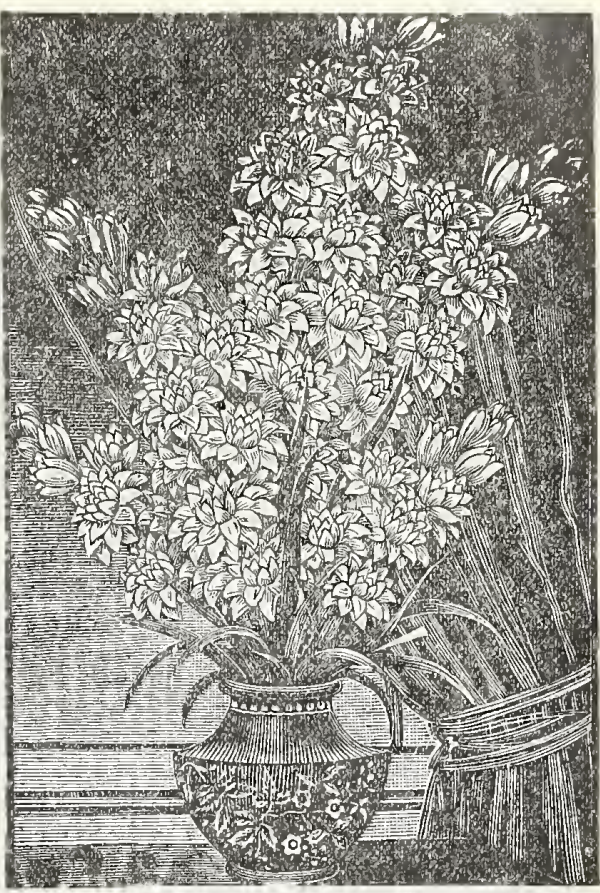

Buckbee's Monstrous Tuberoses. Tuberoses

BUCKBEE'S MONSTROUS FLOWERING

A most delightfully fragrant and beautiful summer-fowering bulb. For early flowhouse or hot bed, planting at intervals as late as August. For flowering in open border, plant about the middle of May. Our select strain of bulbs has no equal and will produce the best and sweetest scented each 5c; per doz. 40c; per 100, \$3.00, postpaid, second size, $25 \mathrm{c}$ doz: $\$ 1.25$ per 100, postpaid.

Mammoth Bulbs, blooms enormous in size and very double and fragrant. each, 10c; 3 for $25 \mathrm{c}$; per doz. 75c, postArmstrong's

Ever-Blooming Tuberose This variety blooms year after year and produces single pure white flowers of a fragmalies a splendid cut flower and should be in evcry one's garden. Each, '7c; 4 for 25c: doz. 60c, postpaid.

\section{Fairy Lilies}

(Zephyranthes.)

Pretty flowers, similar to the Amaryllis but of miniature plant several bulbs in a box or flower-pot. They can also be planted in the open ground colors mixed. Each, 5c; doz. 40c, posto paid.

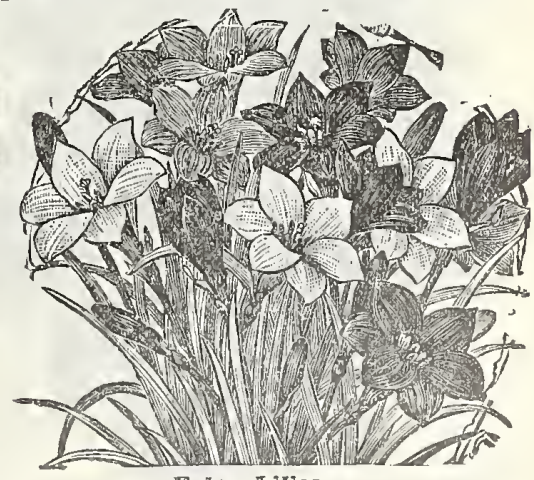

Falry Lilles. 


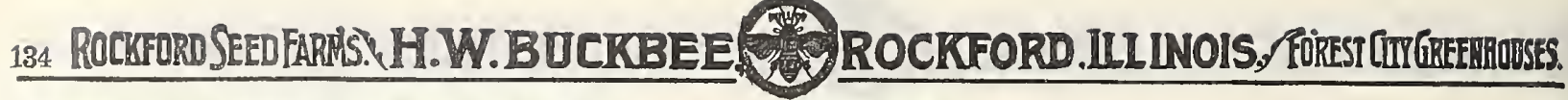

PLANT DEPARTMENT

Our List of Plants for House Culture, also for utdoors has been carefully revised and is p-to-date and we offer only the most valuOur Mammoth Greenhouges Contain over 250,000 square feet of Giass devoted to Growing Millions of Buckbee's Famous thes "Full or Life" Plants.

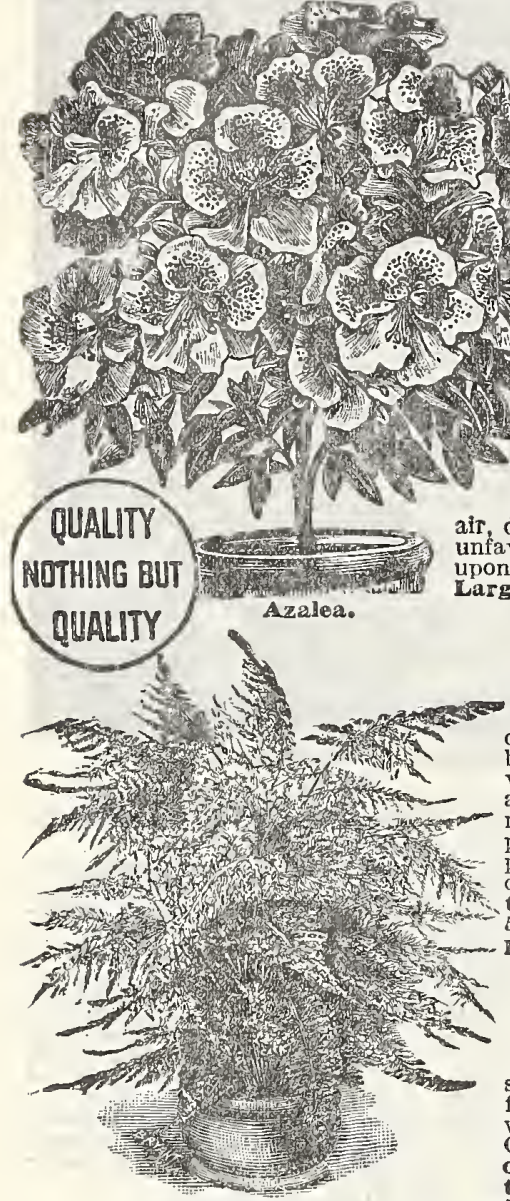

Azalea Indica

For late winter and spring flowering, and especially for

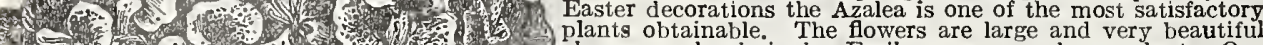
plants obtainable. The flowers are large and very beautiful plants are the finest new varieties, and are much superior to the older sorts, and the colors of all are greatly improved, as well as the flowering qualities. We can furnish beautiful and $\$ 1.50$ each. Must be sent by express at purchaser's expense.

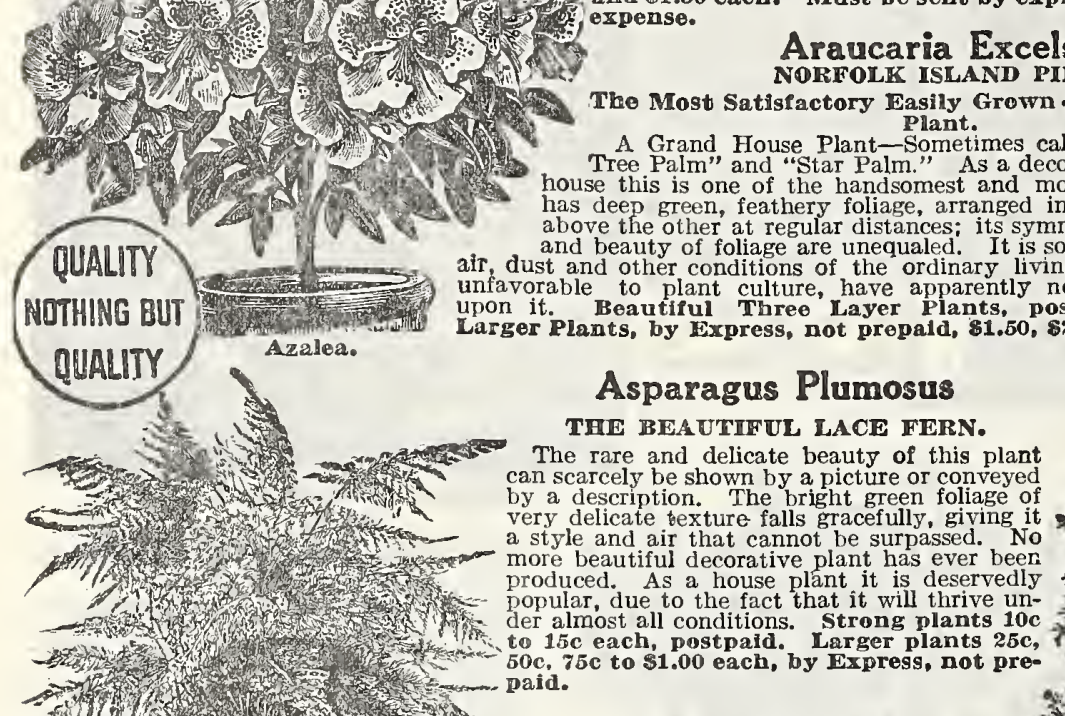
Araucaria Excelsa

The Most Satisfactory Easily Grown . Decorative House

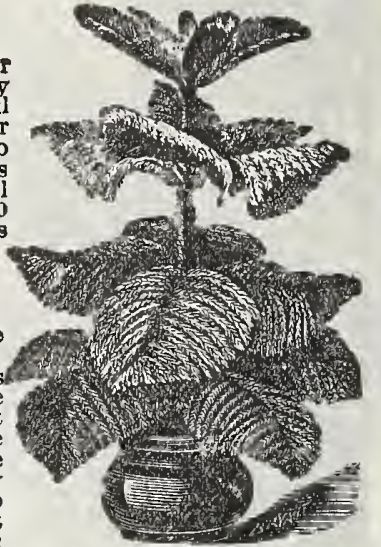
no deleterious ef so no deleterious effect postpaid, only 99c;

\section{Asparagus Plumosus}

THE BEAUTIFUL LACE FERN. The rare and delicate beauty of this plant cy 列 more beautiful decorative plant has ever been ppular, due to the fact that it will thrive unto $15 \mathrm{c}$ each, postpald. Larger plants 25c, paid.

\section{Asparagus Sprengeri}

The Charming Emerald Feather Fern. Grows free the whole year round, producing foliage. Valuable for cutting for fine cut flower work, more particularly in use with large Roses. Grown in suspended pots it makes a very pretty decorative house plant. Strong plants, 10c 50c to $\$ 1.00$ each, by Express, not prepaid.

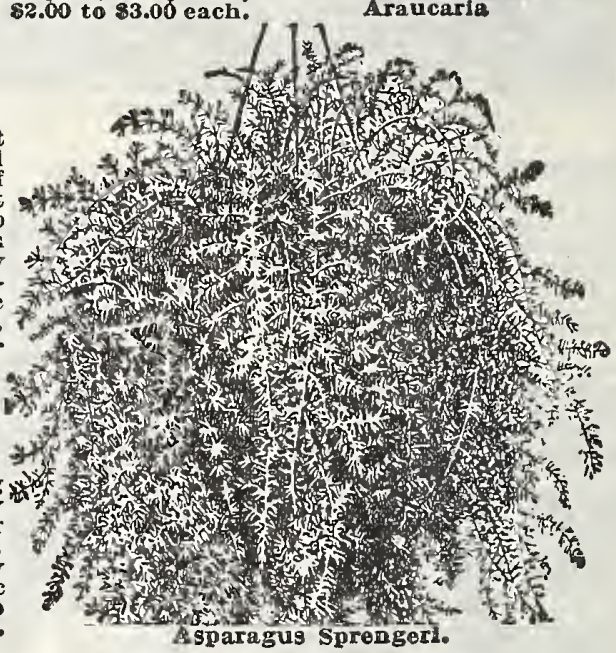

The Wonder Bedding Plant (Acalpha)

Rrighter and More Attractive than Coleus,
AUTUMN TINTS-(Acalpha Bicolor.) - A most wonderful plant, surpassing the finest Coleus or Begonia in the rich color of the leaves, which are beautifully marked with a bright green color margined with a wide irregular band of lemon yellow and having wide yellow bars running lengthwise of the leaf, and also thickly
dotted with yellow blotches. Its most important feature is its wonderful quali-

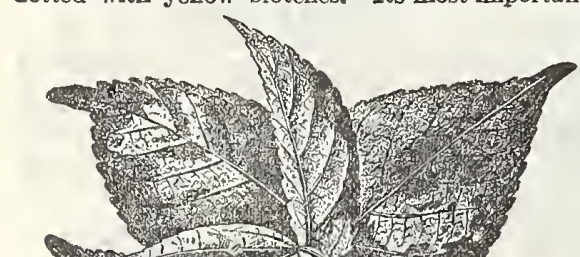
fication for bedding, as it will stand bedding out like a niest place it produces the 2 for $25 \mathrm{c}$.

\section{Brazilian Plume Plant}

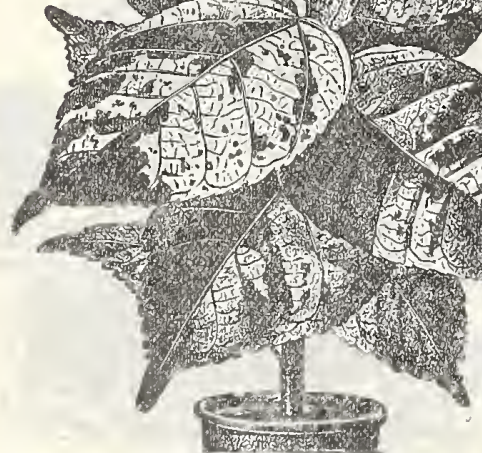

Wordertul Bedding Plant (Acalpha)

Novel and Beautifur This plant is a native of Brazil, and of the easiest possible culture, and seems to do equally well in all kinds of soil, and in any situation, retion: it is in fact, one of the few plants that grow successfully. It is a strong, rapid grower, and which is tipped with the beautiful pink, plume-like flowers, the ends of every petal drooping in a most charming manner. In appearance the blossoms but are three or four times as large, and the petals broader nd of different formation. It is a grand pot plant commencing to flower when the plants are very small, and $15 \mathrm{c}$ each. 2 tor $26 \mathrm{c}$.

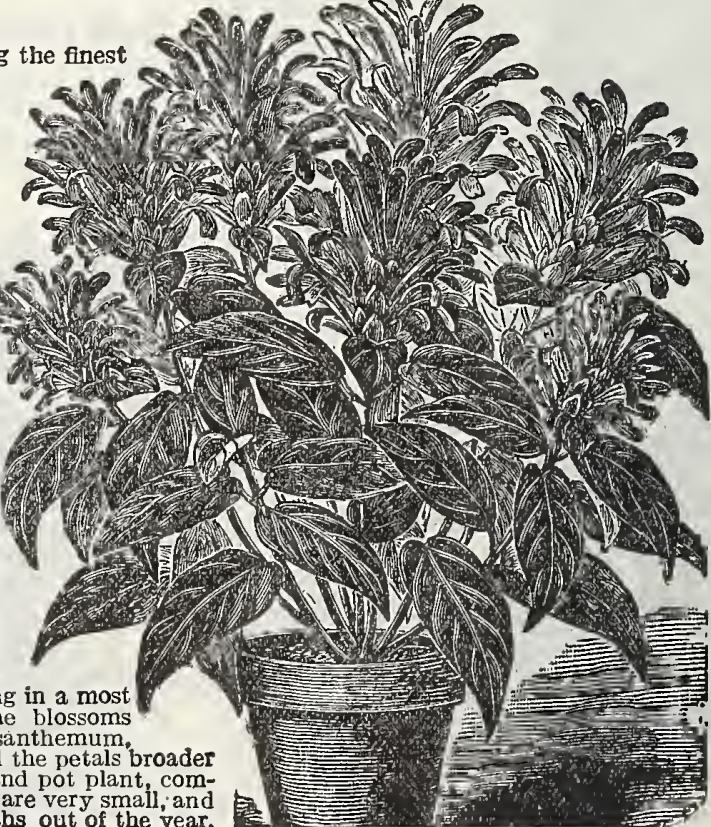

Brazillan Plume Plant. 


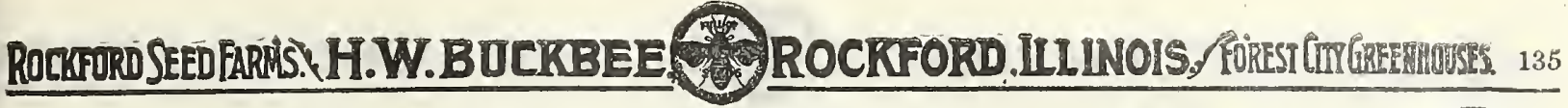

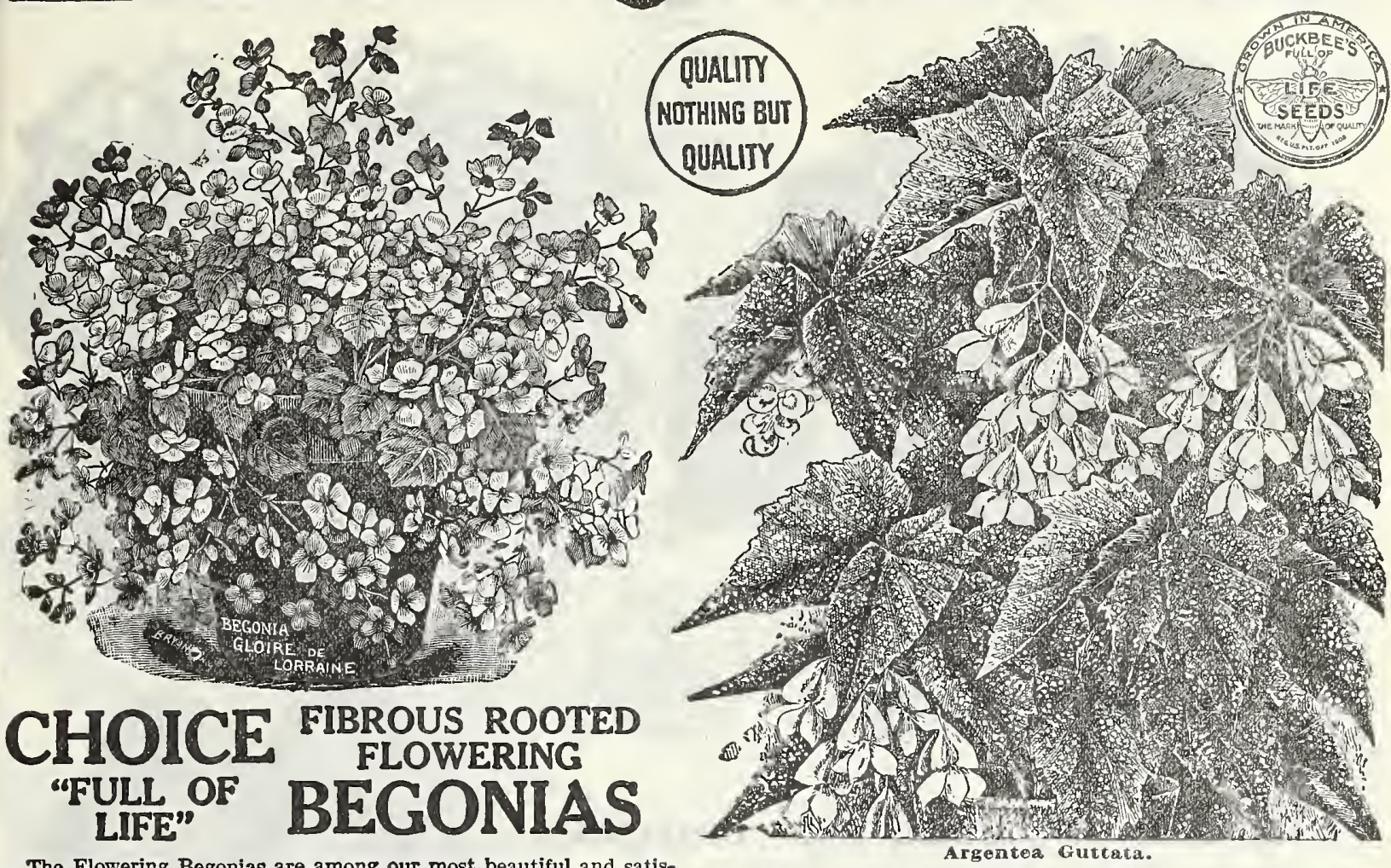

The Flowering Begonias are among our most beautiful and satisfactory flowers for house culture and bedding. They grow nicely. wax-like flowers and glossy bright-colored leaves and stems are always creatly admired.

\section{GLOIRE DE LORRAINE}

This beautiful new Begonia is the latest novelty in the Begonia tamily. Its foliage resembles a little that grand old variety, Vernon, rich glossy-green, often shaded deep bronze. It begins flowering durIng the Summer months, and is a mass of bloom all through the Wincoral-red. It thrives everywhere and is destined to become a leader among ail the Begonias. Each, 15c. Larger Plants, each, 25c.

\section{OTTO HACKER}

In a class by itself A strong, vigorous grower, of fine upright habit, with large shining deep green leaves eight to ten inches long. across. Each, 15c.

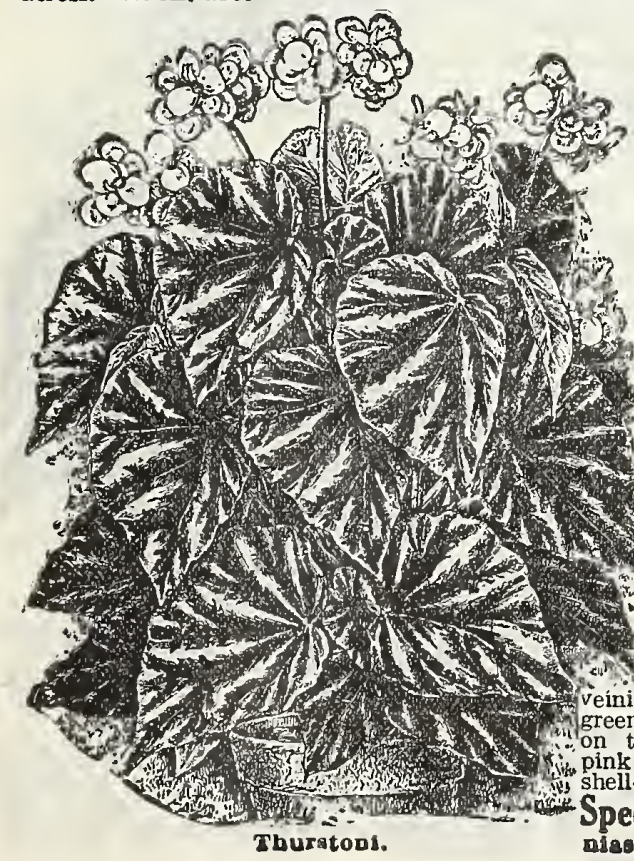

\section{ROBUSTA} This is one of the most pe-
culiar Begonias grown. The stock, stem and under side of the leaf are Indian-red; the olive-green. The petals are almost pure white, a distinct pink stripe in the center of each, enlivened with golden and with the coral red buds chaste appearance. Each chaste appearan 3 for $25 \mathrm{c}$.

\section{RUBRA}

One of the finest Begonias sy-green leaves, combined with its free-flowering habit,
make it one of the very best plants for house or conservatory decoration. The flowers 15c: 2 for $25 \mathrm{c}$.

\section{THURSTONI}

This Begonia is a cross between Metallic and Sanguinea

\section{ARGENTEA GUTTATA} Makes beautiful plants for pots or bedding; graceful drooping MULTIFLORA

pe, with silver markings and is in every way a most beautiful Begonia, It produces white METALICA

This elegant variety has very large glossy leaves shaded with Flowers large, rose or pinkish white. It is one of the most popular, esirable and showy varieties in cultivation, and should be in every

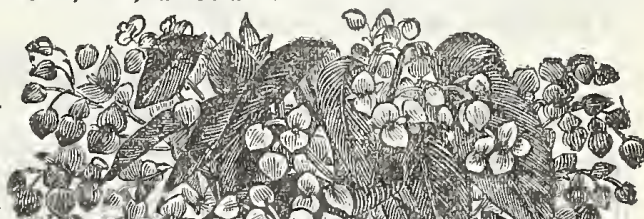
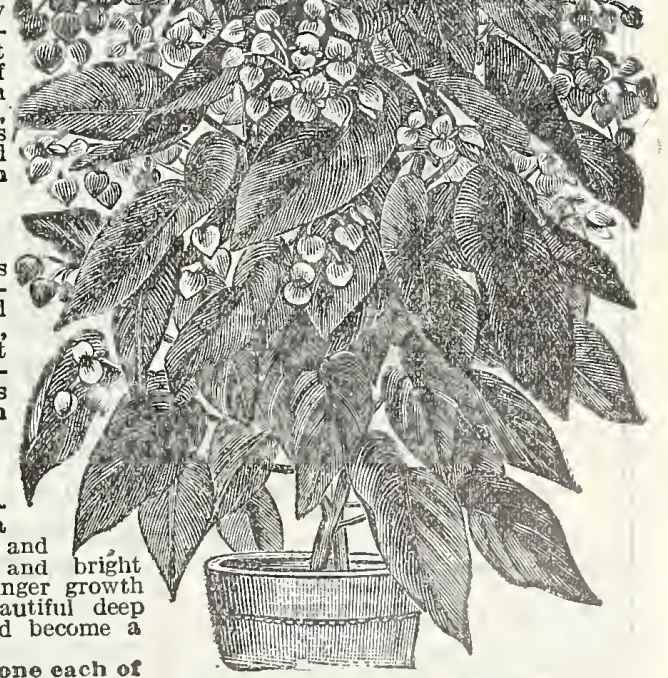
Thuratoni. pecial Offer the 8 wlowering Bogo aise on this page, for $\% 60$. Dostpald.

Eubre. 


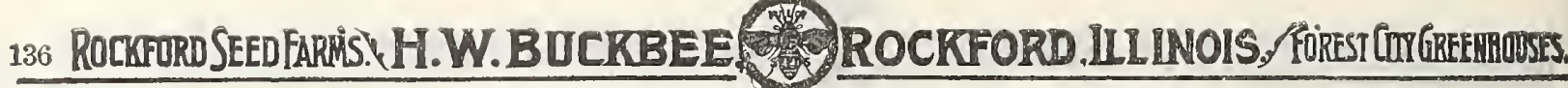

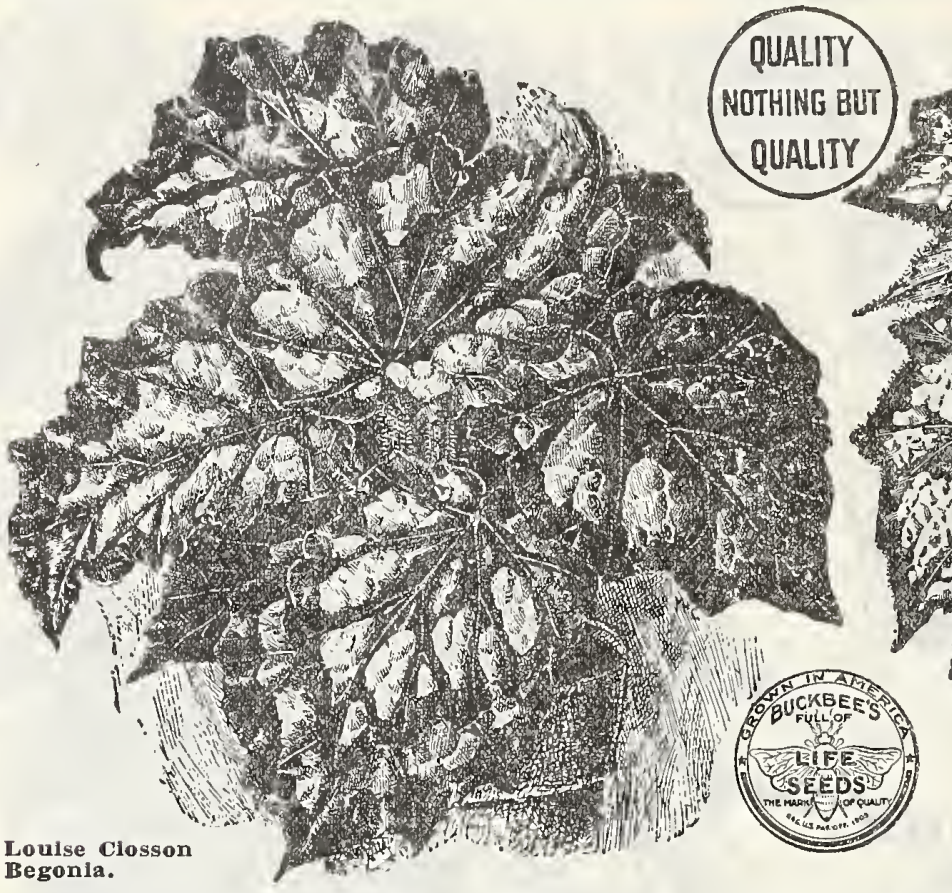

\section{The Rex or Painted Leaf Begonias}

Rex Begonias are the most beautiful and the most desirable of decorative foliage plants for house and conservatory culture; they are strong bushy growers and their them a soil composed of rich loam, woods earth and sharp sand, a warm, moist atmosphere and a shady situation. Do not allow the sun to strike the leaves while wet, and do not over-water.

\section{MIKADO}

This is the finest and largest of any of the Rex family. It is a cross between Begonia Diadema and a Rex variety, but rctains in a marked degree the Rex character.

\section{LORD PALMERSTON}

The leaves are extra large with a dark bronze center, silver band and irregular bronze border, blotched and specked into the silver. The edge of the leaf is fluted and irregular. Fine plants, each 20c; 3 for 50c.

\section{LOUISE CLOSSON}

Coloring of this variety is simply magnificent; center of leaf deep bronze with broad band of silvery rose, edge bronze, giving the whole leaf a purplish tint. The brightest

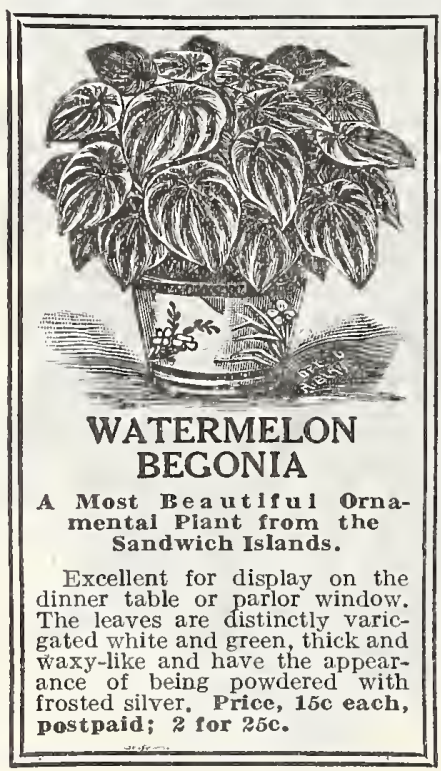
colored Rex yet introduced. The zone of rosy heliotrope is broad and very highly colored, the habit and freedom of growth exccptionally good, Fino plants, 20e each; 3 for $50 c$.

\section{ALFONSO}

A grand variety, leaves very large, soft rich velvety green splashed all over with silver

narkings, shaded and veined with rose and pink.
Fine plants, each 15c; 2 for $25 \mathrm{c}$.

\section{KING OF REX}

Extra large leaf of fine silver, small dark starry center, and edge embroidered in the Extra fine.

Select plants, each 20c; 3 ror $60 c$.

\section{EMPEROR WILLIAM}

A very short, bushy-growing variety. The most part of the leaf is of a silver color streaked with dark green on the edges. A very pointed leaf with a hairy growth on the edges.

\section{BUCKBEE'S PLANT FOOD}

A dressing mado expressly for plants grown in the house, garden or conservatory: clean, and producing early and abundant blossoms, healthy, luxuriant piants. One package is enough for 30 plants for three months.i 25c per package, postpaid.

\section{Lord Palmerston Begonia.}

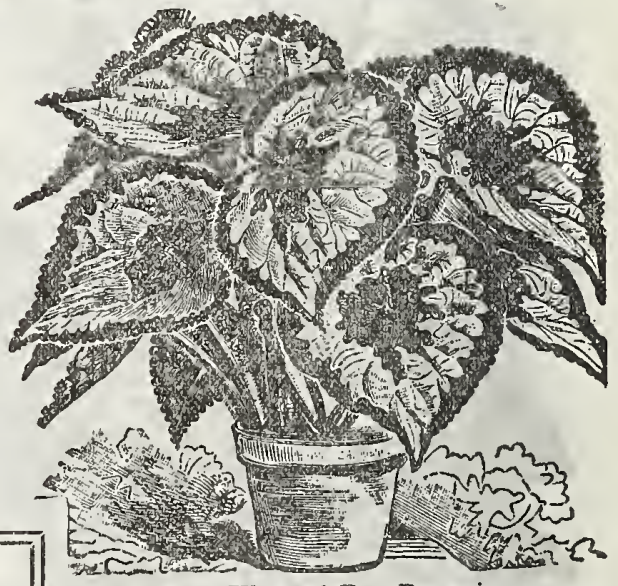

Now King of Rex Begonia.

STecil Offer ono cholco

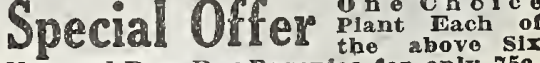
New and Rare Rez. Begonias for only 750, Postpafd. 


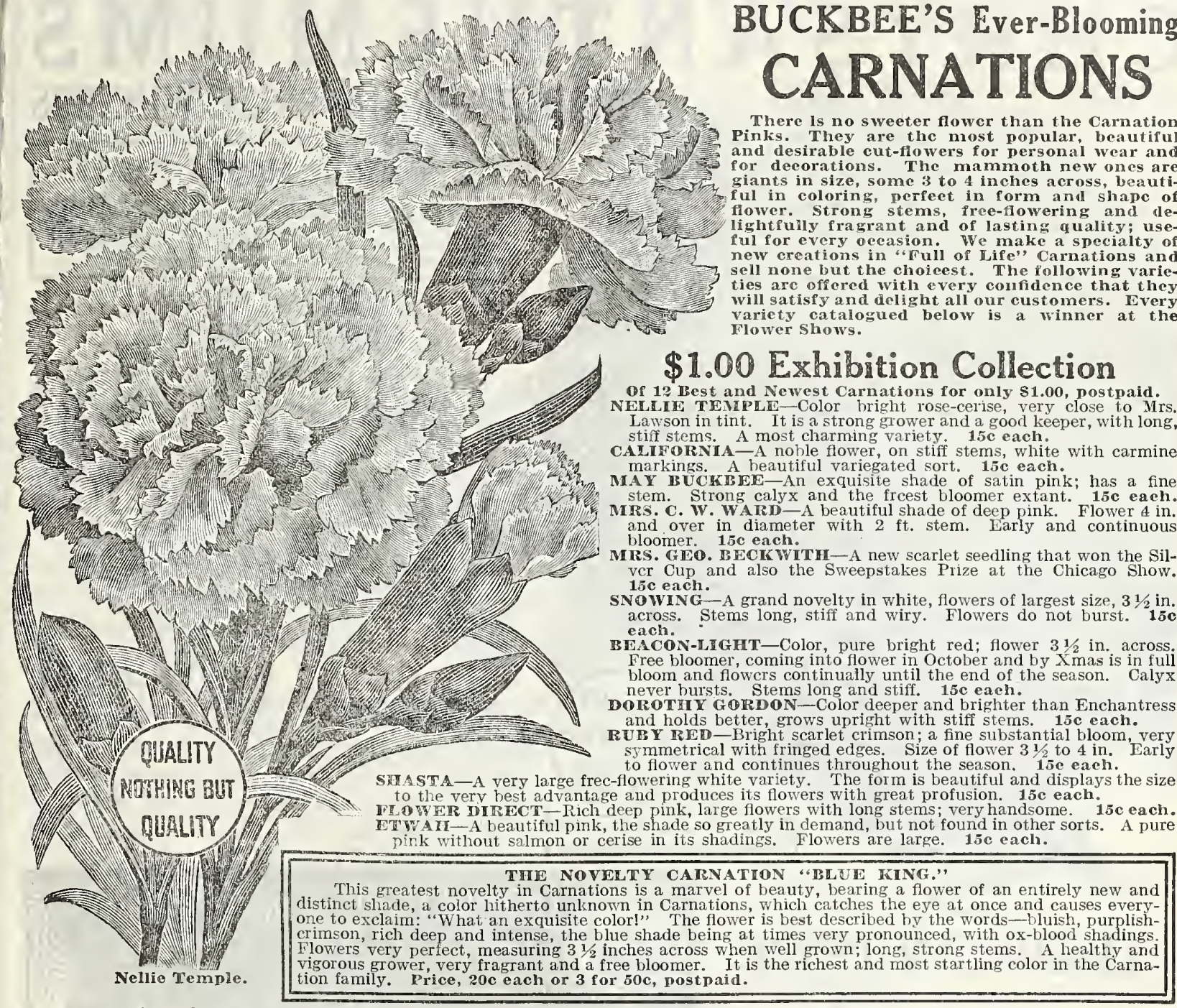

$50 c$ Surprise Collection

of 8 Beautiful Varieties for only 50c, postpaid.

AFTERGLG W-Deep pink; extra long stems and large flowers. A strikingly handsome and very valuable new sort. 10c each.

DOROTIIY GA - One of the finest variegated Carnations in cultivation, particularly in its prolific blooming. Flowers are not so large as some, but so many more. Color pink with a white stripe. $10 \mathrm{c}$ each.

SARAII HILL-A fine, strong growing white variety, a very free bloomer and fine keeper. 10 each.

ELDORADO-Light, clear vellow, petals edged with a narrow band of light pink. A strong vigorous grower with fine liealthy foliage, stems of good length, supporting large, finely formed flowers. $10 \mathrm{c}$ each.

ESTEILL-One of the most fragrant Carnations. Color, a clear bright glowing scarlet, a most continuous bloomer and distinet in color froin any other sort offered. $10 \mathrm{c}$ each.

MA Y DAY - A clear pink, a fine Carnation in size and form. 10c

o. P. PASSETT-One of the showiest varieties of Carnations. Nothing will equal it for large flowers, for quality and quantity. Color, a flaming scarlet. $10 \mathrm{e}$ each.

WHITE ENCHANTRESS-The purest white sport from the variety

\section{5c Bargain Collection}

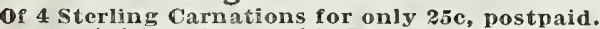

CARDINAL - A bright crimson with flowers of an enormous size.
This new Carnation has taken several prizes at the latest shows, This new Carnation has taken several prizes at the latest shows. and increases in quantity as late as July. $10 \mathrm{c}$ cach. G. H. CRANE-Color, a flaming scarlet; growth hardy; broad foliage,

FCORA HILL-One of the very choicest white varieties; of large size. 10c each.

VA. LAWSON-The famous "Lawson Pink." This is the most popular Camation of all, producing more flowers and of larger size than any other
oink Carnations. $\mathbf{1 0 c}$ each.

\section{$75 c$ Paradise Collection}

of 12 Lovely Carnations for only z5e, postpaid.

COLUMBIA FIRE-Delicate flesh pink, the largest and most beautiful Carnation ever raised. Not anything yet produced can approach it in size, color or freedom of growth. $10 \mathrm{c}$ each.

KISHWAUIGEE-Magnificent large scarlet flowers. Strong clove fragrance. $10 \mathrm{c}$ each.

FRANCES BUCKBEE-Brilliant crimson. A big advance over al others of this color. The plant is a free and easy grower, and always in bloom. A gem in every way. 10e each.

COL. GIEO. BAIN-A perfect wonder. Large white, with excellent calyx and stem. Strong, vigorous grower, very free bloomer. $10 \mathrm{c}$ each.

MISS ETHEL ROOSEVWLT-A beautiful silvery pink, darker to center; strong stem; free bloomer. 10 c each.

M. A. PATTEN-The newest striped Carnation. Color, white with red stripe. Blooms large and spreading, stiff stem and a fine grower. $10 \mathrm{c}$ each.

ROSE PIN HE FNCHA NTRESS-A true pink in color. Surpassingly beautiful. Largest of any and a prize winner over the strongest competition. Strong grower, free bloomer. $10 \mathrm{c}$ each.

SUNBEAMI-Strong grower and free-flowering; long stem; flower three inches in diameter and a deep golden yellow, with faint red stripes. $10 \mathrm{c}$ each.

THE BEACON-Ideal shade of scarlet; exquisitely fragrant. One of the most popular new Carnations. Plant is of strong growt and blooms freely. $10 \mathrm{c}$ each.

VICTOIR Y - Intense scarlet with a bright orange glow to the color ing. Very popular. The flowers are borne in great profusion. the plant

WHITE PRIBECTION-A great new white, verv fragrant. Longest and best stems of any white Calnation. Thoroughly up-todate in every respect. $10 \mathrm{c}$ each.

WINDSOR-A grand new variety; color pure medium pink; form. size and growth of the best. 10c each. 


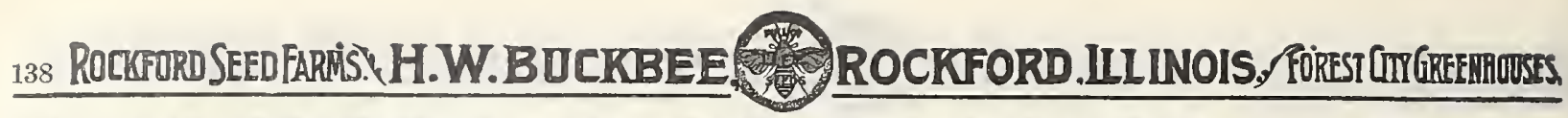
C HRYSA N T HEM UMS BUCKBEE'S GRAND PRIZE-WINNERS

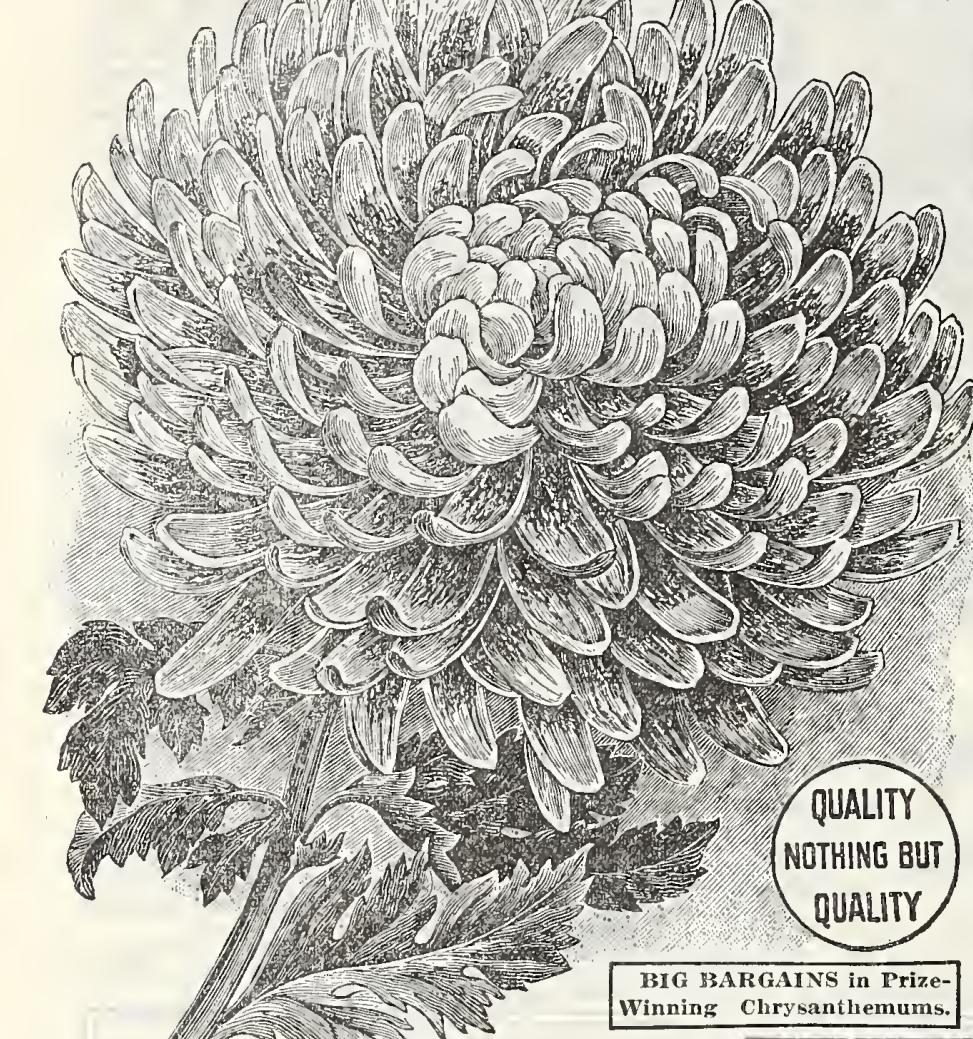

\begin{abstract}
THE QUEEN OF AUTUMN FLOWERS
For massive blooms, grandeur of color, ease of culture and certainty of flower, either in the open ground or in pots, there are no plants that will surpass them, and but few their equal. Every solt
grown, should prove a prize winner.
\end{abstract}

\section{GRAND DIAMOND MEDAL COLLECTION \\ RARE CHRYSANTHEMUMS.}

The set of 6 Rare Chrysanthemums only 73c, postpaid. RED BAND-Crimson amaranth: a novel color. Among very finest Japanese varieties; makes a beautiful plant.

15c each; 2 for 25c, postpaid.
GLITTER. The most striking introduction among yellows large flower; easy, free grower. 15 c each; 2 for $25 \mathrm{c}$, postpaid.

OOSEVELT-Best of all white Chrysanthemums. JANE DOStpaid. color; semi-dwarf with stiff stem and elegant foliage.
15c each; f for $25 c$, postpaid. PINK LA IY A beautiful soft rose-pink. 15c each; 2 for TETRAZZ1N1-A very fine example of crimson and gold. TETRAZZ1N1-A very fine examp
20c each; 3 for 50c, post paid.

\section{THE GIANT FLOWERING}

The set of 4 Mammoth Flowering Varieties, postpaid, ALICE BYRON-Pure white, handsome large, spreading H. Hower. 10e each. I0c each. WU. DUCK1IAM-Handsome, large yellow, reS. A. NACUER FEY-Color yellow, intermingled with red and bronze petals. $15 \mathrm{c}$ each.

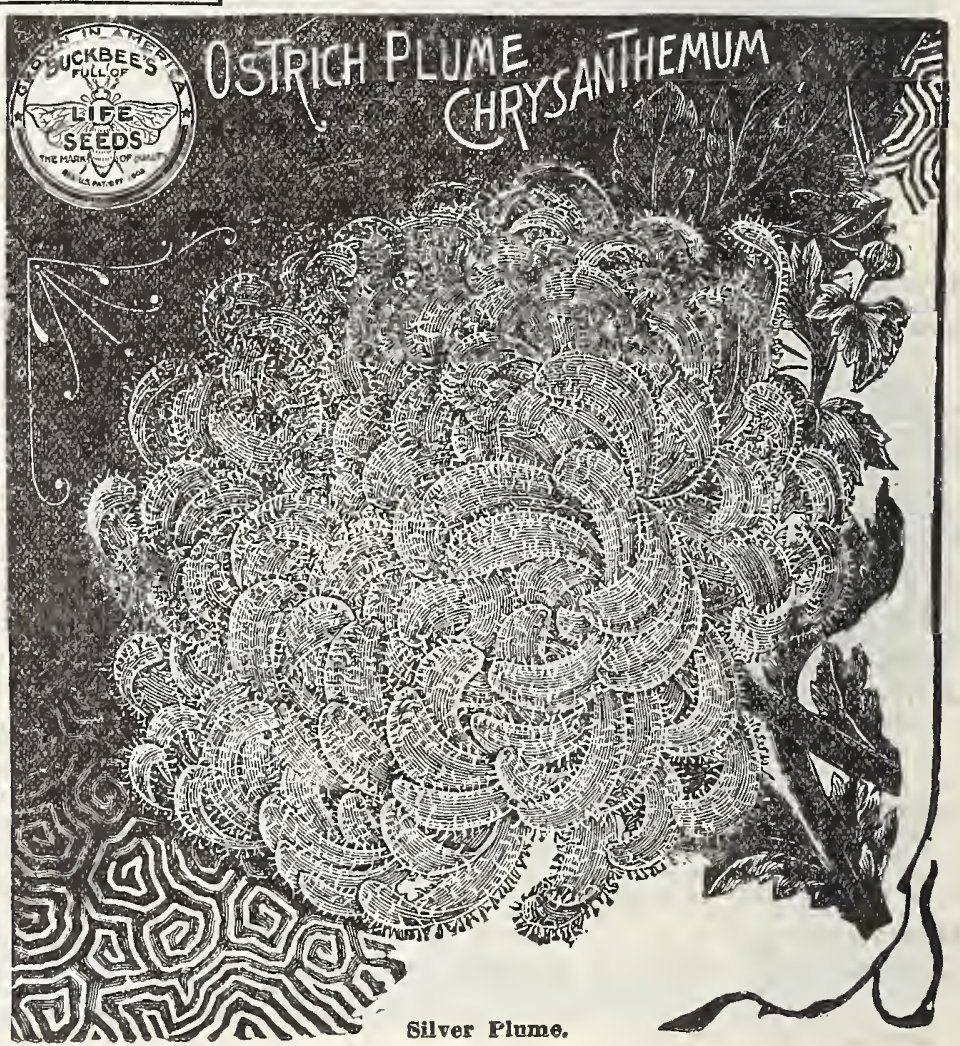




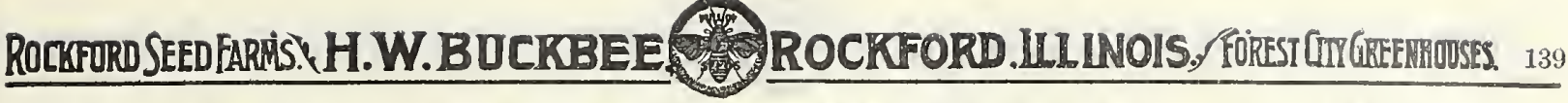 CHR YSANT HEM UMS ${ }_{\text {PRIZE WINNERS }}^{\text {BUCRE' GRAND }}$}

\section{The Wonderful Everblooming Chrysanthemum MAZEPPA \\ The first of a new race of Chrysanthemums that we have developed to bloom the year round. Without question the largest, handsomest hardiest, most desilable variety ever grown. Flowers of immense size; borne in profusion on long, strong stems almost continuously. Beautiful deep, rosy-pink flowers. Strong plants 20 e each; 3 for soc, postpaid.}

\section{Buckbee's Big Six}

Chrysanthemum Collection

The World's Newest and Best Varieties for 1916.

Grand Special Offer P140 For only $\$ 1.50$ we will plant eacli of the following 6 best of all easily grown Chrysantliemums.

KARA DOW-A wonderful flower, largest size, color a mar-

velous combination of golden yellow and red, long reflexing petals, easy to grow. 30c cach, postpaid.

TENARA-Flower of largest size, beautiful light pink color a strikingly handsome variety. 35c each, postpaid. THE PRESIDENT-A monster flower, true yellow of beautiful texture; the best and easiest to grow, 30c each, postpaid. ing petals. 30c cach, postpaid.

OROBA - The Grand Prize Winner, mammoth flowers, pure white with very wide overlapping petals; an exquisitely beautiful Toviravi rasily

TONKAWA-A glorious crimson and gold reflexed variety of the largest size; unquestionably the finest variety ever introduced. $30 \mathrm{ceach}$ postpaid.

\section{The Gold Medal Chrysanthemum Collection}

The sct of four Gold Medal Varieties, postpaid, for only 2ác. RALPH EMIERSON - One of the handsomest pinks, 10c each.

MRS. STANTON BURPEE-Mammoth gold bronze, Broad strap petals, First prize at every show, $10 \mathrm{c}$ each.

15c W. T. ROBERTSON-One of the most beautiful of all pink varieties. Very early ioc each.

\section{New Perpetual Blooming Chrysanthemum "GLORY OF SEVEN OAKS"}

Blooms profusely bedded out from June to December. Perfectly hardy in the open ground. Flowers 4 to 5 inches across on stems 2 to 3 feet. Begins blooming in thumb pots. Flowers of the brightest golden yellow, double to the very center and of large size and borne in clusters of 3 to 6 on strong upright stems. Fine plants, 20c each; 3 for 50c.

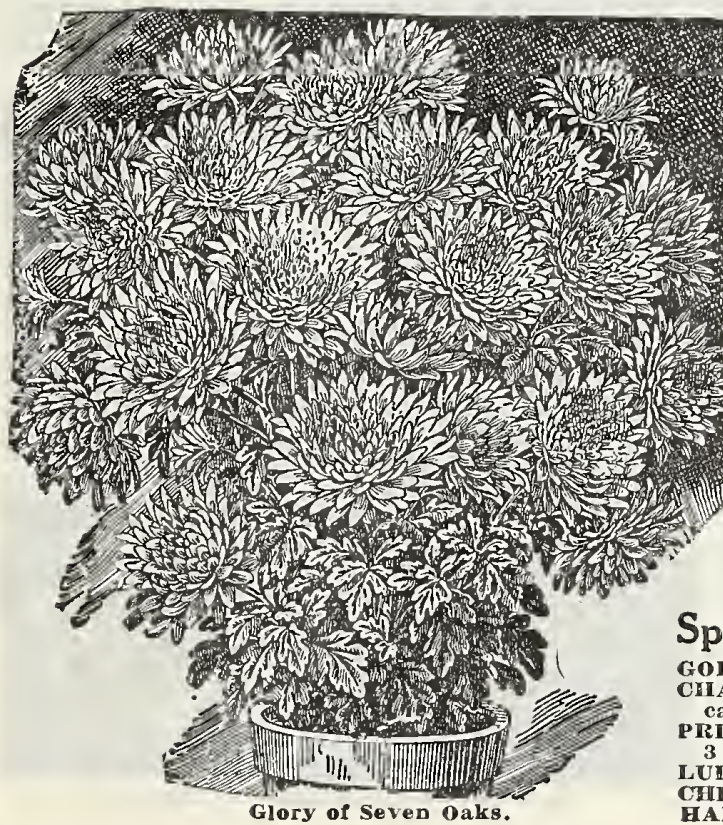

\section{Grand Sweepstakes Collection of Prize Winning Chrysanthemums}

one carefully grown selceted plant of each of the six varieties de scribed below for only $50 \mathrm{c}$, postpaid.

G. W. POOK-Extra large incurved petals; salmon bronze red, good grower. $15 \mathrm{c}$ each; 2 for $25 \mathrm{c}$, postpaid.

RUTH CARROLL HAINES-Rosy pink shading to liohter pink on outside

$15 \mathrm{c}$ cach; 2 for $25 \mathrm{c}$, postpaid.

Mrs. L. 'THOR - Very large, bright, deep yellow incurved petals, $10 \mathrm{c}$ each; 3 for $2 \bar{c}$, postpaid.

beautiful bronze with mahorany shading, that lights up beautifully. $10 \mathrm{c}$ each, 3 for $25 \mathrm{c}$, postvaid.

WINTER OHEER - A massive fower of deep violet rose, shaded silver. $10 \mathrm{c}$ each; 3 for $25 \mathrm{c}$, postpaid.

IRGINIA POEHILMANN-The great prizc-wínner.
largest possible size. 10e cach; 3 for 25 , postpaid.

Giant Flowering Japanese Chrysanthemums THE LATEST INTRODUCTIONS TROM THE FLOWER Y KHGDONA

The Set of four Mammoth Varieties only 25c, postpaid.

DUBLIN LADY - A changeable glistening purplish bronze. $10 \mathrm{c}$ each, postpaid.

M RS. W. F, BA RNES-Magnificent large glistening white. Strong grower. 10c each, postpaid.

COL. FRED STERLING-An extremely handsome yellow, Color is bright and pure. 10c cach, postpaid.

W. F WOODRUFF-Color varies from yellow to bronze A handsome and striking variety. $10 \mathrm{c}$ cach, postpaid.

\section{Hardy Garden Chrysanthemum Collection}

Easily grown, perfectly hardy; will live outside during the Winter month without protection. There is a delichtful charm about them in contrast with the indoor varieties.

Special Offer F8 The Set of 6 Newest Varieties.

作 RINCESS LOUISE-Orange brown. Exquisitely beautiful color 10c each 3 for 25 c.

LULU-White. One of the most beautiful, 10e each; 3 for $25 \mathrm{c}$. HALO-Golden bronze. One of the best in the family. 10c each; 3 for $25 \mathrm{c}$. 


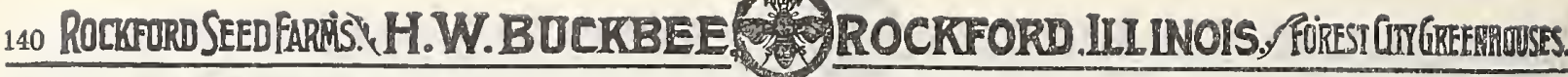

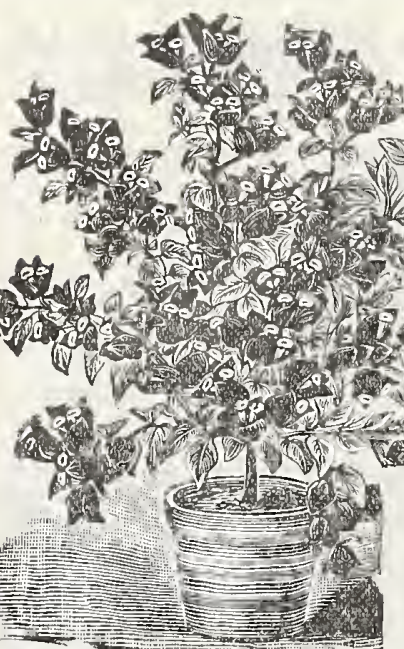

Chinese Paper Plant.

\section{Coleus}

Beautiful Fancy Varieties.

These beautiful new Coleus are much used for planting in beds and borders; also for pots, window boxes, vases, ctc.,
where their bright and striking colors are where their bright and stri

SPECIAL OFFER F8-Each $8 \mathrm{c}$, or the full set of Six new Coleus for 35c; postpaid. Price per 100, by express at buyer's expense, $\$ 3.50$.

BECKWITH'S GEM-A beautiful fancy variety with large leaves of heavy texture and flnely velvety-maroon. The center of leaf is dark edge is green, changing to creamy-yellow at the point of leaf.

DUNERIA - The grandest Coleus of recent years: has a deep velvety texture. Color, crimson-maroon center; beautifully scalloped edge of light red.

GOLDEN BEDDER-Clear yellow when well de veloped, enter rib of lighter yellow.

MISS RETTA KIRKPATRICK - Large white center, shaded with yellow, broad green lobed

QUEEN OF THE WIST-Large leaf, and slightly serrated; outer band of bright oxide-green with

margin of bright yellow, and ccnter creamy-white; covered with SPOTTEID GEM-Yellow, blotehed crimson and green.

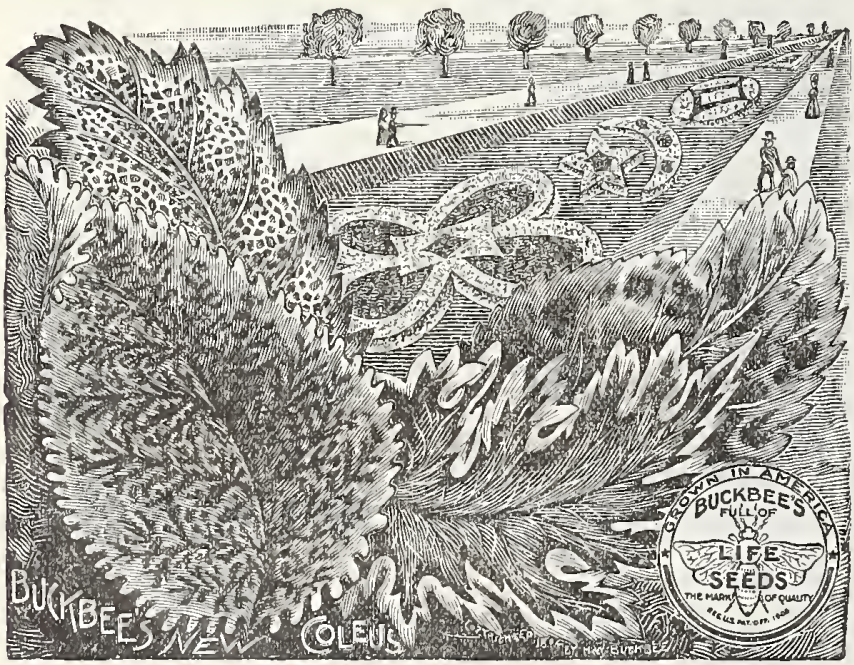

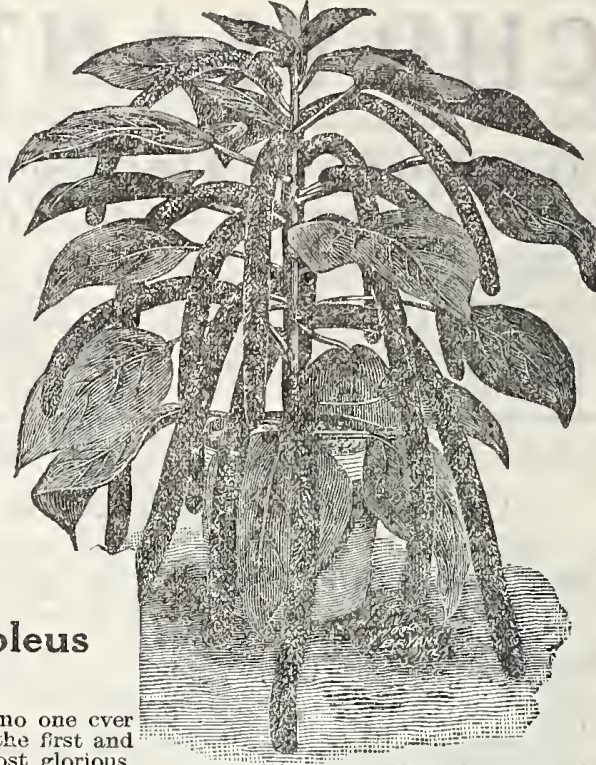

Now Comet Plant.

\section{Dragon Plant}

(Dracena Indivisa.)

The Charming Decorative Plant.

A very bcautiful house plant, also desirable for vase or garden, with slender.

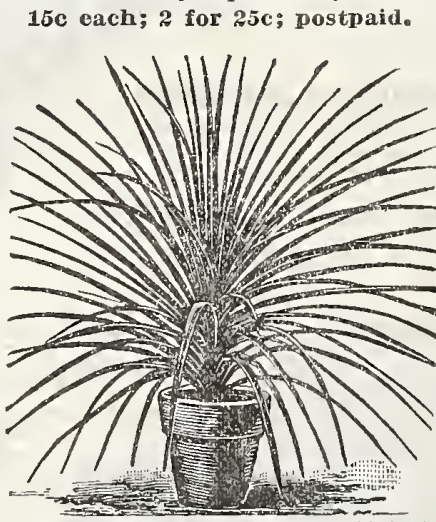

drooping leaves often called "Fountain Plant." The leaves are of several shades of grecn, with delicate stripings of yello marked as the plant grows older. Price, postpaid, men plants by express, not prepaid, $\$ 1.00$ each.

\section{Daisies}

IIRS. F, SANDERS-The flowrers are of the most listening white throughout, frequently mcasuring flve inches across. The center of the flowe is a mass of closely arranged fringed florets, surrounded or edged by broad shining petals, produced on long stems. 15c each; 2 10r 25 . BLUSF QUEEN ALEXANDRA-The new Mammoth White Paris Daisy. Single, semi-doublc and often fully double blooms appcar on the same plant. $10 \mathrm{c}$ each; 3 for $25 \mathrm{c}$; postpaid.

WLLOW DAIS Y - (Etoile d'Or)-The Ncw Yel3 for $25 \mathrm{c}$; posta ric

BLUE DAISY-(Agathea Coelestis) - A beautifui bedding plant and an excellent indoor bloomer The flowers are daisy-shaped, of a delicate light blue, with a yellow disc. Flowers all the

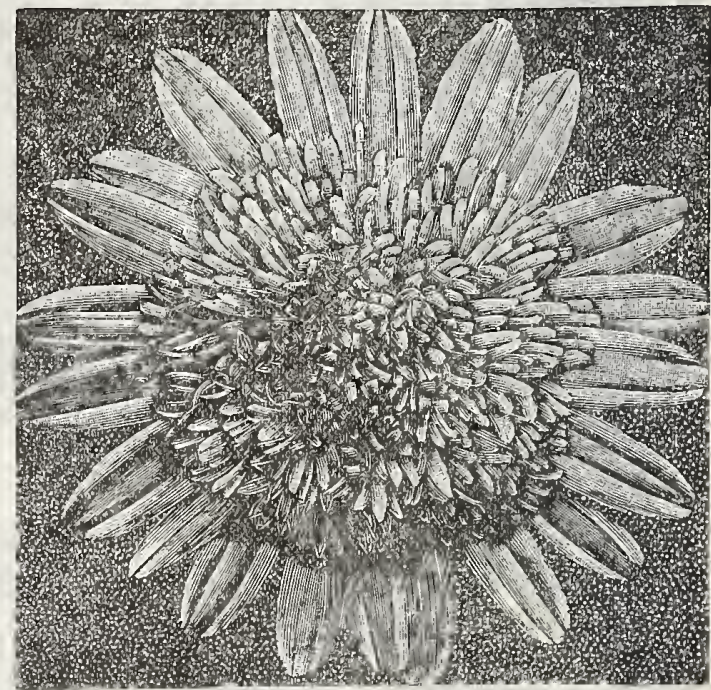

New Double Daisy, Mrs. F. Samders. 


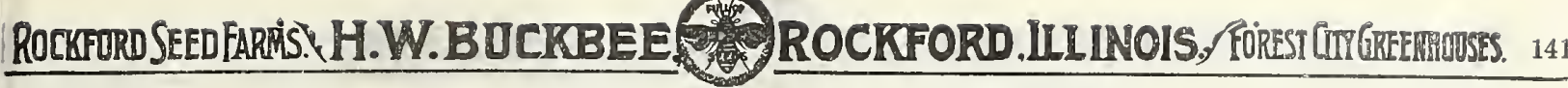

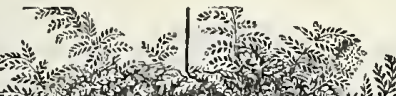
3.t.

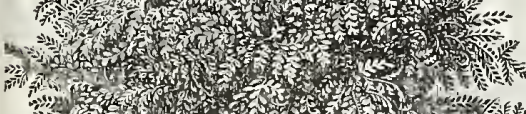
m.

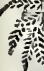

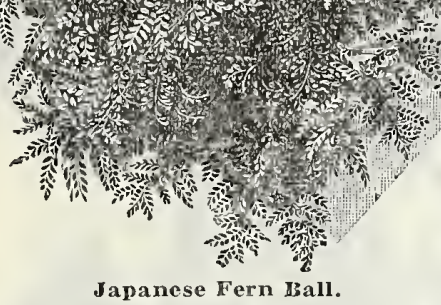

Japanese Fern Ball

This exquisite Fern is rooted in moss. and requires no earth. It is simply necessary to hang it up and supply it with water once a day. In full growth the beautiful foliage extends outward live for years under proper treatment, alternately growing and resting. They need no earth, dish or pot. Simply soak well with tepid water for 50c; 12 for $\$ 5.00$; larger size, $75 \mathrm{c}$ each; 12 for \$7.50, postpaid.

The Ostrich Plume Fern (Nephrolepis Piersonii)

A strong, vigorous grower, resembling the Boston Fern somewhat, but the fronds are
much heavier and more feathery, and arch over in a most graceful manner, showing two shades of green an producing a lovely mossy effect, Fine young plants 10e, 15c and 25e each, postpaid. Largeach,

Newport Parlor Fern

(Nephrolepis Scot tif)

Resembles the Boston in some respects, but grows more elect, has and makes three times as man nicely in parlor or living room, requires very little plants $10 \mathrm{c}, 15 \mathrm{c}$ to $25 \mathrm{c}$ each, postpaid. Larger plants $50 \mathrm{e}, 81.00$ to not each, by

$$
\text { ris }
$$

420

-4.4.

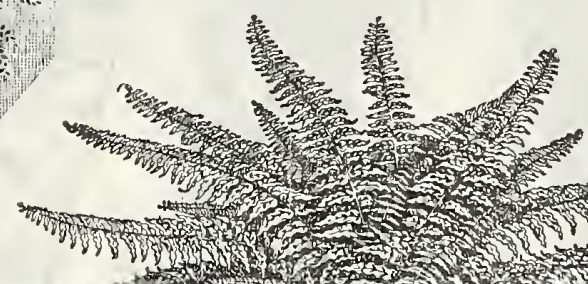

FERNS

BUCKBEE'S BEST

FOR HOUSE CULTURE

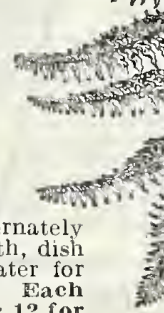

13

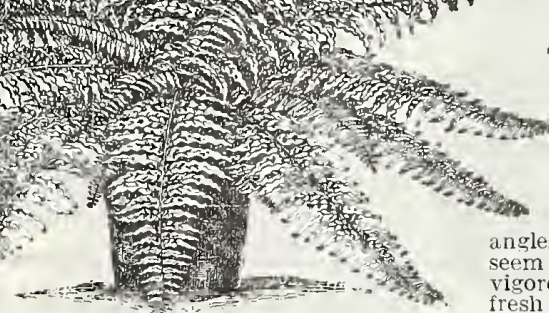

New Roosevelt Fern.

\section{e}
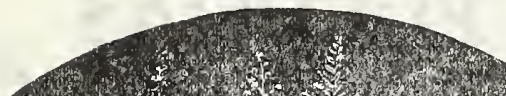

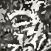

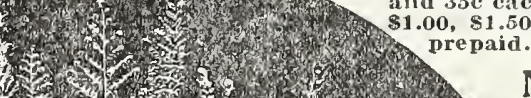
exquisitely with the deep green of the
older fronds. It is somewhat like Bar-
New Crested Fern.

The New Crested Fern (Whitmanii)
We think this the most popular Fern, $R$ ather dwarf in
rowth, but graceful, very com-

pact, dense and feathery. Each of perfect little fronds set at light. the mid-rib, and so thick they mous grotver, constently a rowsi, but and beautiful. Fine young plants $15 \mathrm{c}$, 25c \$1.00, $\$ 1.50$, to $\$ 2.00$ each, by tixpress, not New Roosevelt Fern

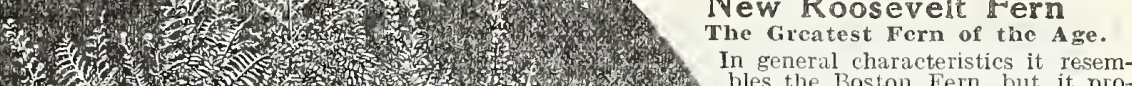

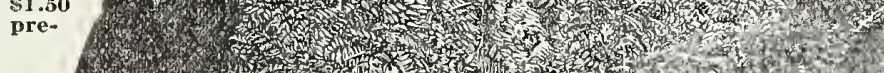

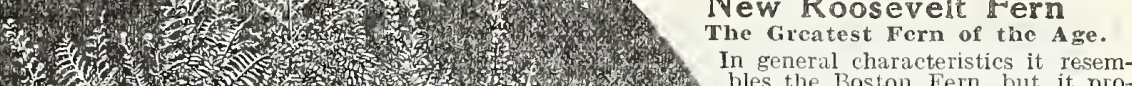




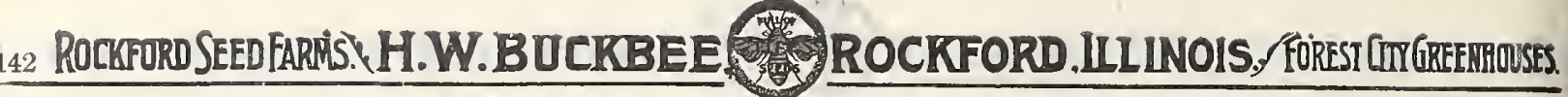

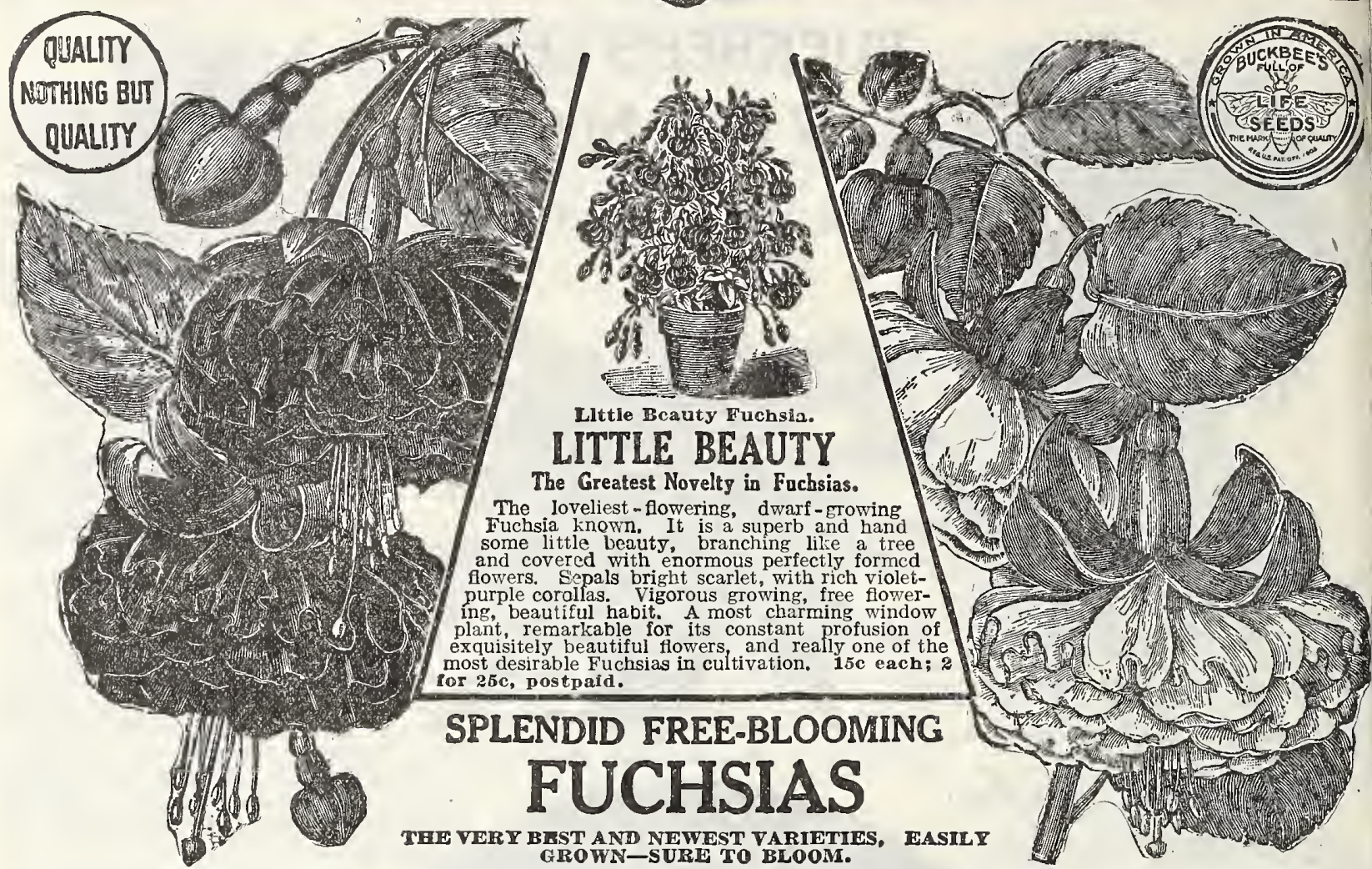

Phenomenal Fuchsia.

PHENOMENAL- The largest flowering Fuchsia in cultivation. The plant is a tall grower, branching like a tree; the leaves are dark, glossy green, with veins of dark crimson, giving the foliage a rich (ante single flower measuring $31 / 2$ inches across; sepals bright scarlet, with rich, violet purple corollas, very double, 15e each, 2 for $25 c$, postpaid.

SPECIOSA-(The True Winter Blooming Fuchsia.)-This lovely Fuchsia blooms with greatest profusion during Winter, is scarcely ever without flowers from September till June; the flowers are large and of the most graceful form; color, rich carmine and rose; a most charming window plant, remarkable for its bright glossy green leaves and constant profusion

TROPHEE- (Double) - Violet blue corolla; very dark rich red sepals,

waxy lustre. Plant of fine form, easy to grow, continually in bloom. 3 for 25 c one of the

LOVEL $\mathbf{Y}$-Large semi-double flowers; color rosy mauve with rich scarlet sepals. Exquisite, 10c each, 3 for 25c, postpaid.

A Valuable $\mathrm{BOOK}$ of Practical HOW TO GROW SEEDS AND FLOWERS A complete guide for the house and garden, profusely illustrated. Price $50 \mathrm{c}$, an order amounting to $\$ 1.50$ or upwards, if requested on the order.

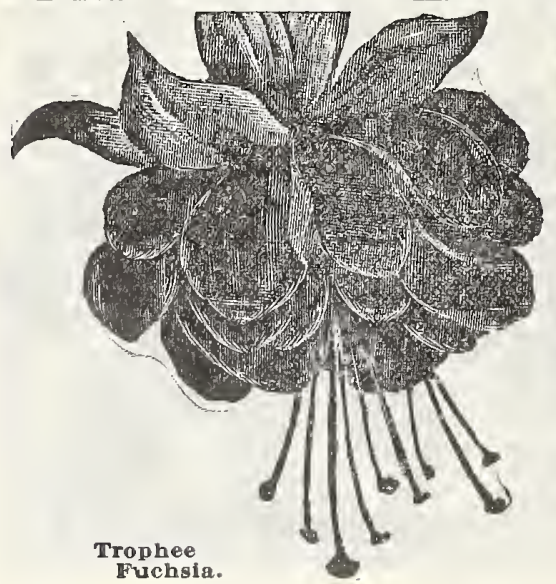

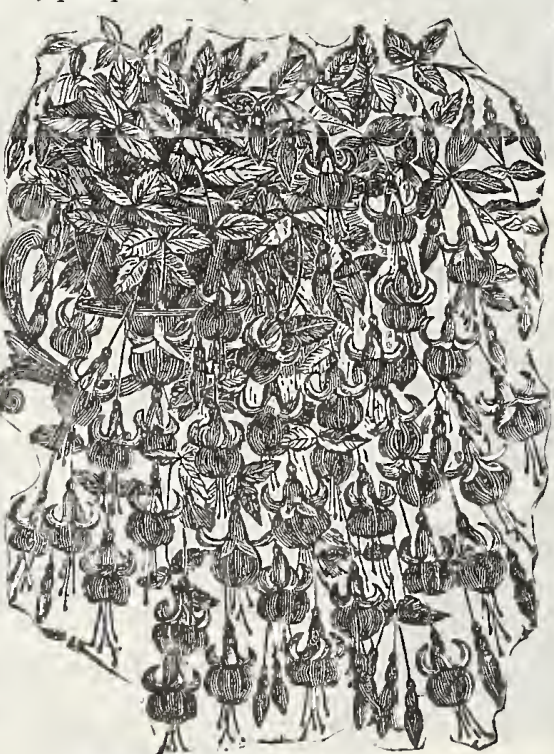

Tralling Queen Fuchsia.
Gloire Des Marches Fuchsia.

GLOIRE DES MARCHES-Undoubtedly the finest Double White Fuchsia ever sent out; makes a neat compact plant, branches freely and is covered nearly all the time with exquisite double flowers of postpaid.

BLACK PRINCE-This is, without question, the very finest Fuchsia grown for the amateur to cultivate. It makes a shapely bush is robust in growth, free from disease and insects, and is probably the freest in blooming. Blossoms of a beautiful waxy-carmine or pink color. Certainly a plant for easy culture. $10 \mathrm{c}$ each, 3 for $25 \mathrm{c}$, postpaid

RAILING QUEEN-This Fuchsia is an entirely new departure, different from other large-flowering varieties in its habit of growth, as it is a trailing vine. The young plants, as they commence growth, creep out to the edge of the pot, and then go trailing downward. It continues growing and branching in this way until the vines are a solid wavy mass of the most elegant foliage and perfect
flowers. The flowers are borne in large, drooping clusters; very large, long, graceful. 15c each, 2 for $25 \mathrm{c}$, postpaid. "Ix"

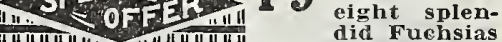
"illill" "escribed on thill" page for only $65 \mathrm{c}$, postpaid.

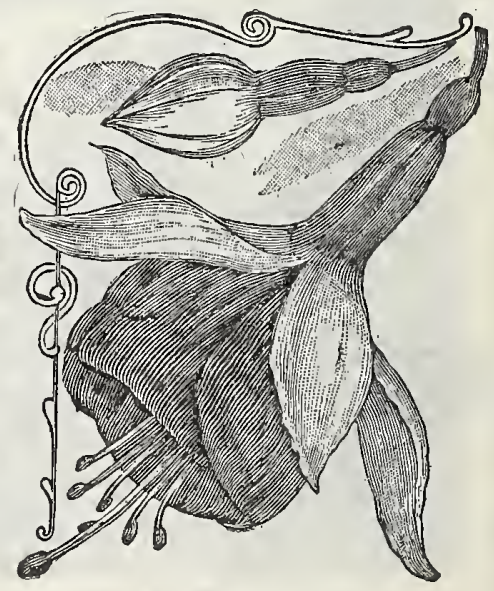

Lovely Fuchsia. 


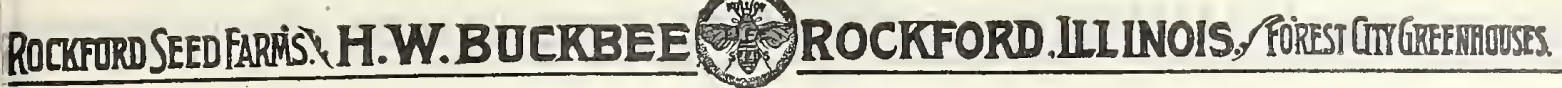

Buckbee's New Large Flowering Brilliant

Best

Single Geraniums

The Sunshine Set of 6

For Only 75c, Postpaid.

EURIPIDE-Pure snow white without a

t. $15 \mathrm{c}$ each.

and effective. 150 each.

OOL. DARDE-An attractive tint of warm sy cerise. $20 \mathrm{c}$ each.

cer Salmon,

blooming. $15 \mathrm{c}$ cach.
MONAIGNE-Fiery scarlet, splendid truss $15 \mathrm{c}$ each.

OLYMPI A A splendid pink, good grower nd free bloomer. $15 \mathrm{c}$ each

The Rainbow Set of Six only 70c, Postpaid.

VILLA STELCA-Carmine, purple, shaded

SIMONE CORDAY-A brilliant shade of

sset orange. 15c cach.
SACHA GUITRY-Soft red with large

THAIS-Rosy pink, clear and bright. 15c
THE.

RABELAIS-Pure scarlet, a most effective RABELAIS-Pu

MAD. ACCOLAS-A pleasing shade of very light pink. $15 \mathrm{c}$ each.
| II II II II ".
SPECALPR:
64. $\begin{aligned} & \text { The } 2 \text { sets of } \\ & \text { Geraniums }\end{aligned}$
"IIIIIा..
Rainbow for only $\$ 1.20$ postpaid.

The Best Large Flowering New Geraniums

The Paris Set

Six for Only $77 \mathrm{c}$, Postpaid.

AID A-Pure snow white, a grand bedder.

ARTHUR CHUQUET-Pure rose pink in
ARTH any sections. $15 \mathrm{c}$ each.

CONCHITA-Rich scarlet, very large TANGARA - Richest crimson, profuse omer. $20 \mathrm{c}$ each.

VALD A-Picotee, a ureole, pure snow white. cach.

GERTRUDE ZILLE - Beautiful and rare, fresh salmon pink. $15 \mathrm{c}$ each.

The London Set of Six only 72c, Postpaid.

COLIBRI-Bright silvery rose pink. 15c DR. LANNE-Beautiful rose mauve. $15 \mathrm{c}$

HENRI ARDEL-Cerise-red, grand trusses. bloomer. $15 \mathrm{c}$ each.

KR YLOR-A soft, salmon; very strong rower. $15 \mathrm{c}$ each.

IONTE ROSA-Violet stained rose; a rand effect. $15 \mathrm{c}$ each.

SUZETTE-Daybreak pink painted rose. $15 \mathrm{c}$ each.

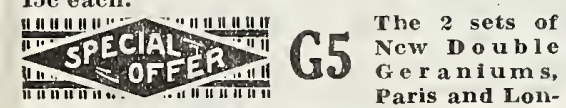
don, for only $\$ 1.25$, postpaid.

Buckbee's Beautiful

Hanging Basket Collection

Especially adapted for growing in baskets in the house or on the porch.

1 BOSTON OR SWORD FERN.... 15c

1 ENGLISH IV Y....................

1 IV $\mathbf{Y}$ GER ANIUM. . . . . . . . .

1 LANTANA … $\ldots \ldots \ldots \ldots \ldots$

1 MARGUERITE DAIS $Y \ldots \ldots \ldots$. . .

1 TORPEDO PLANT $\ldots \ldots \ldots \ldots 10 \mathrm{c}$

Eight leading and popular varieties,

all of easy culture and sure of growth.

Regular Catalog Price, 95c.

The Complete Collection, 8 Choice

Plants, only 73c, Postpaid.
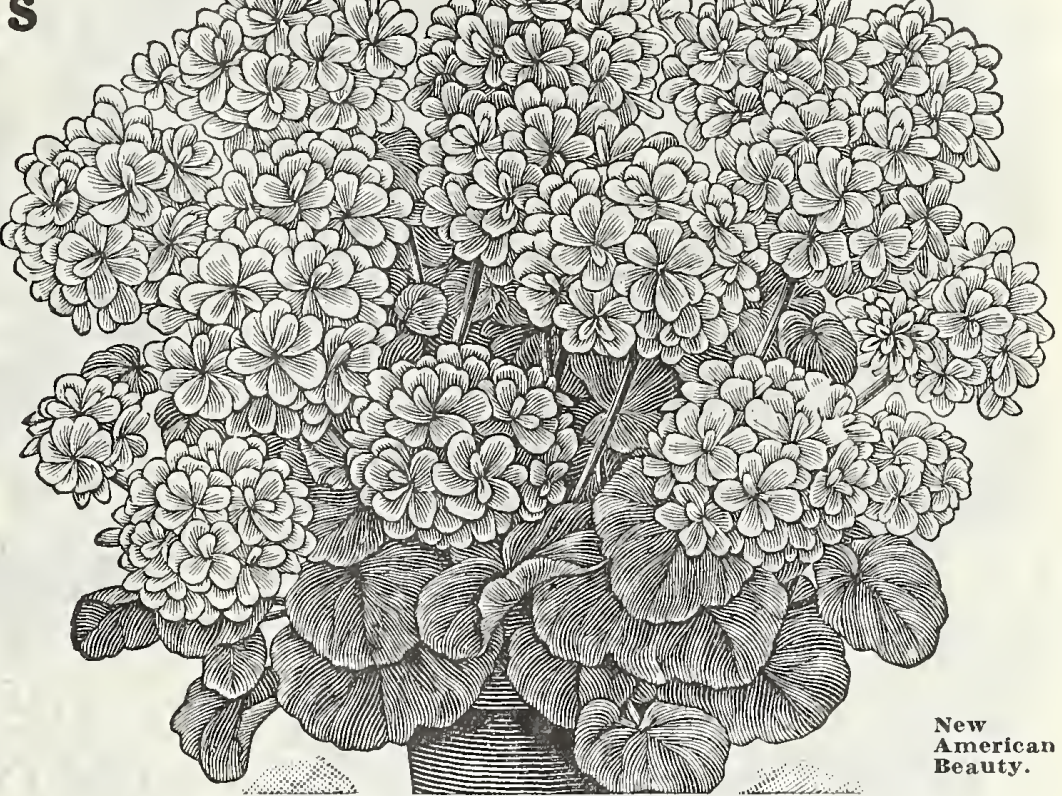

\section{NEW AMERICAN BEAUTY GERANIUM}

A Scmi-Double of the Purest American Beauty Color.

The only Geranium or its color ever introduced. It flowers freely the entire season. It grows compact, medium dwarf, of stately shape with lustrous green foliage, slightly corrugated, with a brownish circle. The flower heads are gigantic individual blooms measseveral half open, and more in bud. It surpasses all other Geraniums-in brilliancy of color; in size of its large blossoms; in earliness of bloom; in constancy of bloom; in vigor. strength and stocky plants; in propagating quality; in numbers of large clusters of bloom; in a wonderful ability to retain its color in cool or the hottest weather. Fine, strong plants. $20 \mathrm{c}$ each, 3 for $50 \mathrm{c}$, post aid.

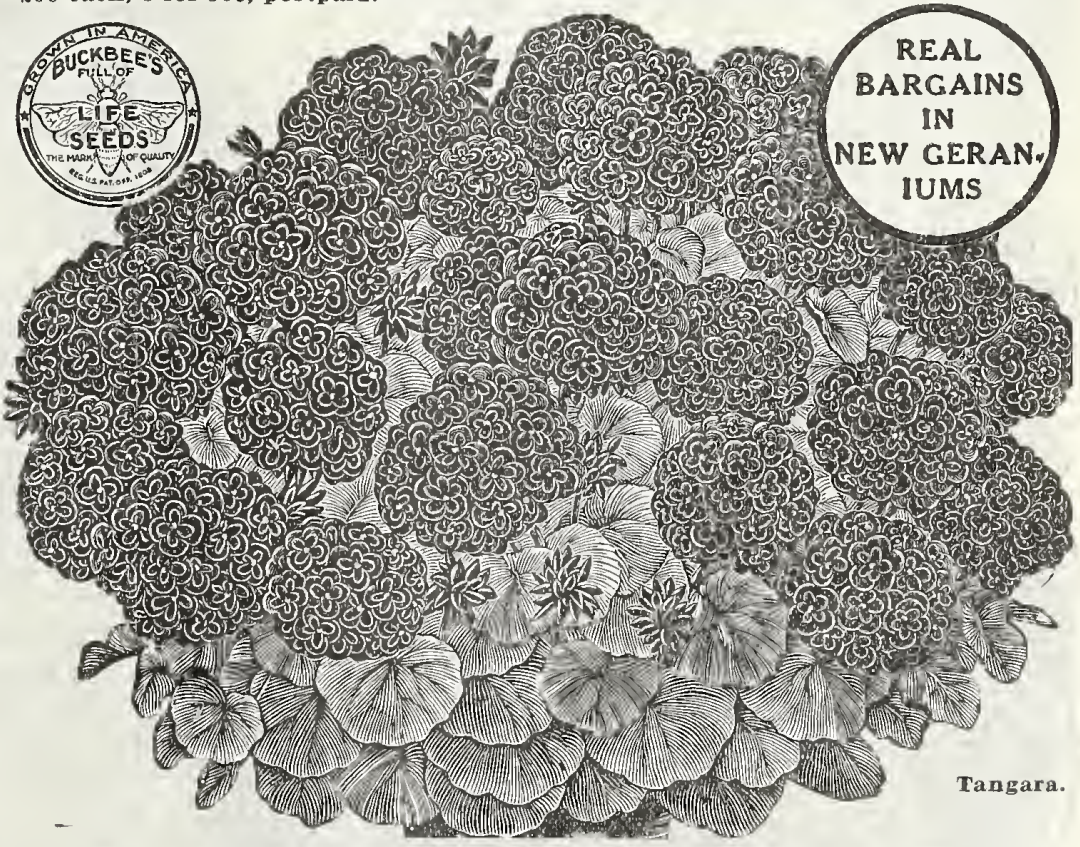

DOUBLE NEW LIFE GERANIUM

A Curious and Beautfil Novelty.

This is a remarkable novelty. Always scarce and difficult to obtain. The florets are dark red and in the center of each there appears a small pure white floret, giving the flowers a novel and curious appearance. Very beautiful when flowers are perfect but variable and best for house culture. This is one of the most easily grown and satisfactory of all flower plants, and only the Rose can vie wlth them in popularity. postpaid. 


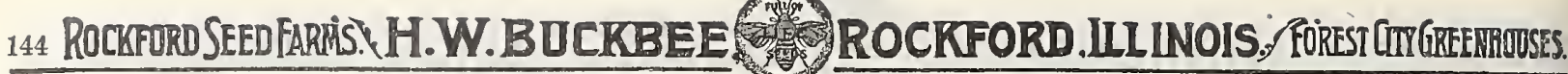
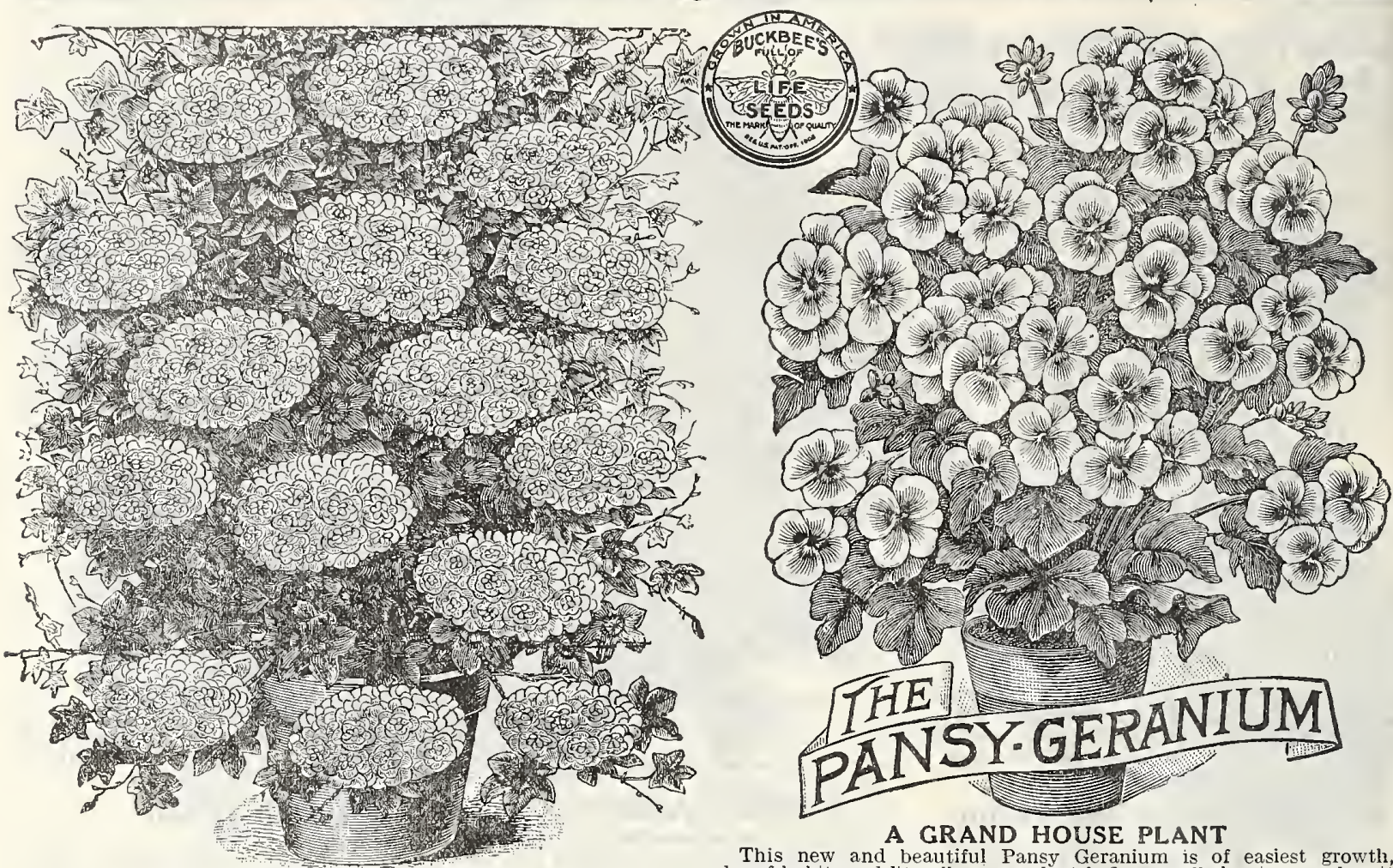

A GRAND HOUSE PLANT

Ivy Leaf Geranium, Duke of Edinburgh. This new and beautiful Pansy Geranium is of easiest growth
dwarf habit, and literally covered with flowers all the time, and as it dwarf habit, and literally covered with flowers all the time, and as it
requires little or no attention it is invaluable as a window plant. The coloring and markings of the flowers are most extraordinary-light
pink, white, dark purple, black, etc, almost rivaling the Pansy in uniqueness of flower. It is this combination of coloring which obtained for it the popular name of Pansy Geranium. Strong plants, ready to bloon, $20 \mathrm{c}$ each; 3 for $50 \mathrm{c}$, postpaid.

Variegated or Silver Leaved Geraniums Very pretty and attractive for bedding and edgings and particularly valuable for pots and window culture.

HAPPY THOUGHT-Foliage beautiful green and yellow, magenta MAD. SALLEROI-Foliage green, edged with white. 10c each.
MOUNTAIN OF SNOW-Center of leaves bright green, edged with white. PARKER-

white. $20 \mathrm{coach}$

MRS. POLLOCK-Bronze crimson edged yellow, pink flowers. 15c each.

WM. CANGGUTI-Beautiful scarlet flowers, silver leaf. $\mathbf{1 5 c}$ each. THE SET OF SIX FOR ONLY 64c, POSTPAID.

\section{Sweet-Scented Geraniums}

$10 \mathrm{c}$ each; 3 for $25 \mathrm{c}$. The set of 6 for only $40 \mathrm{c}$, postpaid. LARGE LEAF ROSE-Indispensable in the formation of MRS. TAYLoR - Fragrant foliage. Flowers s carlet magenta.
NUTMEG:

OAK KEAVED-O scented. A valuable variety.

SHRUBLAND PET - Deliciously fragrant. A splendid

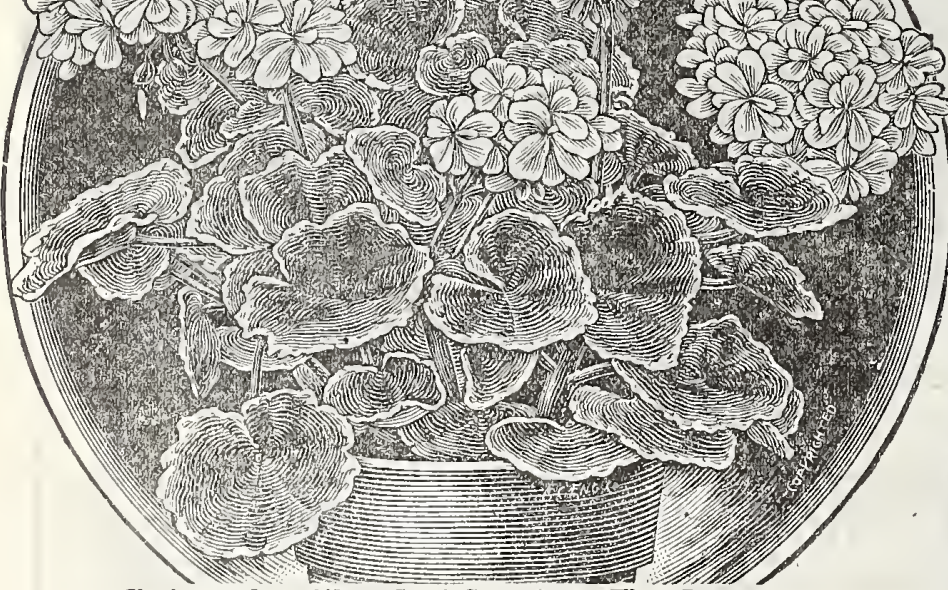

LEMON-Lemon scented. A grand variety.

\section{Crown of}

Thorns

The Great Biblical Plant. Hills of Judea this jof

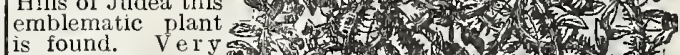
is found. very with a few bright an abundance of Easy to grow, can be trained to asshape. Fin e plants 20c each: 3 for
pald.

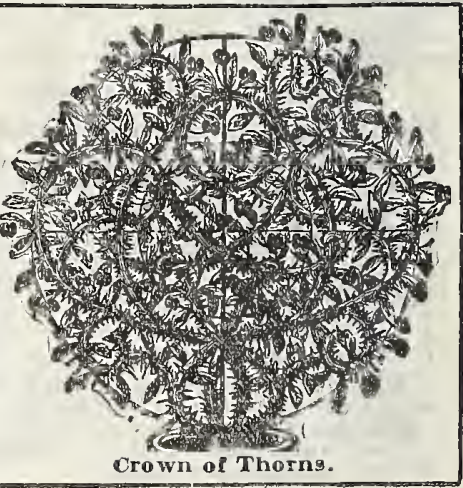




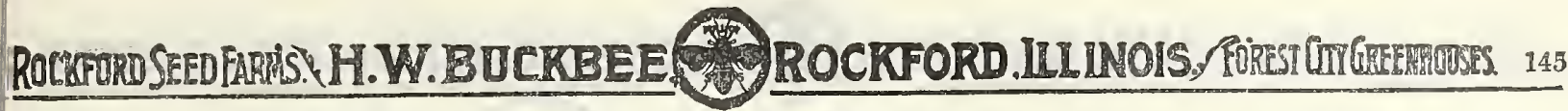

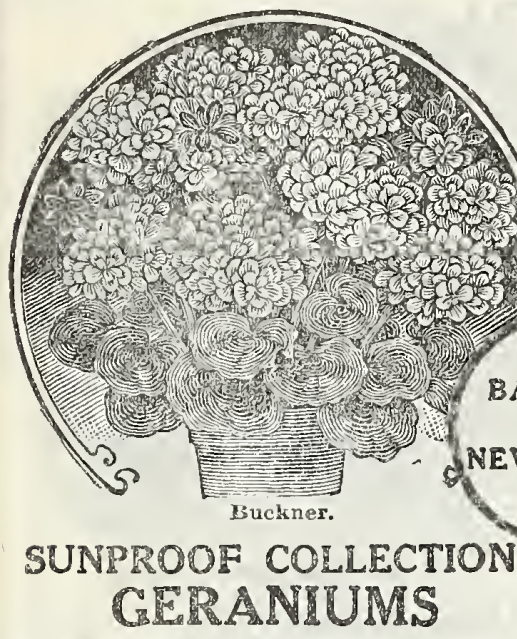

9. A. NUTT-Double rich rosy crimson. The best bedding variety, and as a pot plant it cannot be excelled. 10c.

BEAUTE POITEVIN - Double salmon pink, shading to clear salmon in cen-

JWAN VIAUD-Double deep rich pink blooms borne in large trusses well above the foliage; individual florets large. 10e. BUCKNER-Double purest white. A proIuse and constani bloomer, splendid habit of growth. 15c.

THE SET OF 4 ONLY 25 CENTS.

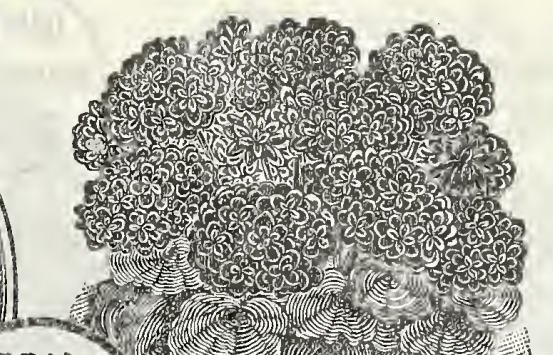

REAL

BARGAINS

IN

IUMS

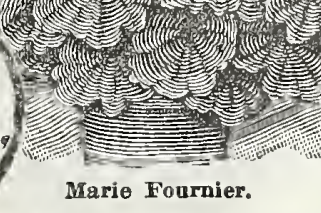

IDEAL COLLECTION GERANIUMS

T. T. HARRISON-Double brilliant scarlet, trusses are large often 8 inches in diameter, very showy. I0c.

MAD. LANDRY-Double rich salmon red. Splendid flower and fine large trusses,

MARIE TOURNIER-Double deep pink. Florets borne in enormous trusses held well above the foliage. 15c.

WHITE SWAN-Double pure white. A good healthy grower and free bloomer tine bedder. 10c.

THE SET OF' 4 ONLX 25 CENTS.

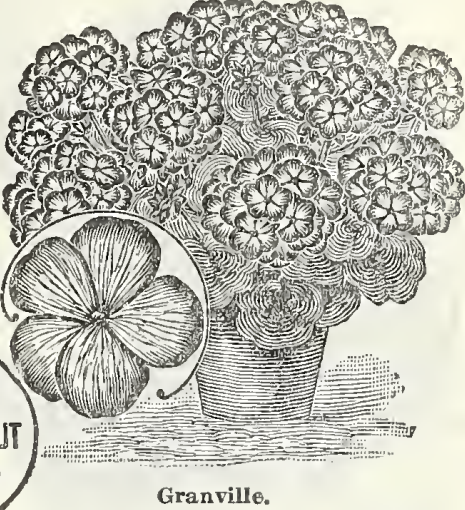

NONE SUCH COLLECTION GERANIUMS

MRS. F. G. HILL-New and fine, trusses of mime: color, oright salmon with pure white center, probably the best and most beautiful salmon-colored Geranium

GRANVILLE-Single clear rosy pink. Immense bloomer, covered with flowers the LAUBE-Single large snow white. One of the finest varietles in existence. I0c. Immense trusses on very long stems; flne 'THE SET OF 4 ONLY 25 CENTS.

\section{PELARGONIUMS (Lady Washington Geraniums)}

Pelargoniums or "Lady Washington Geraniums" as they are commonly called are among the most beautiful of our Summer and Fall flowering plants; they offer a rich and varied assortment of colors, and do not resemble the common Geranium in any particular, neither in foliage nor flower; more beautiful in every way and the ease with which they may be grown should recommend

them to everyone.
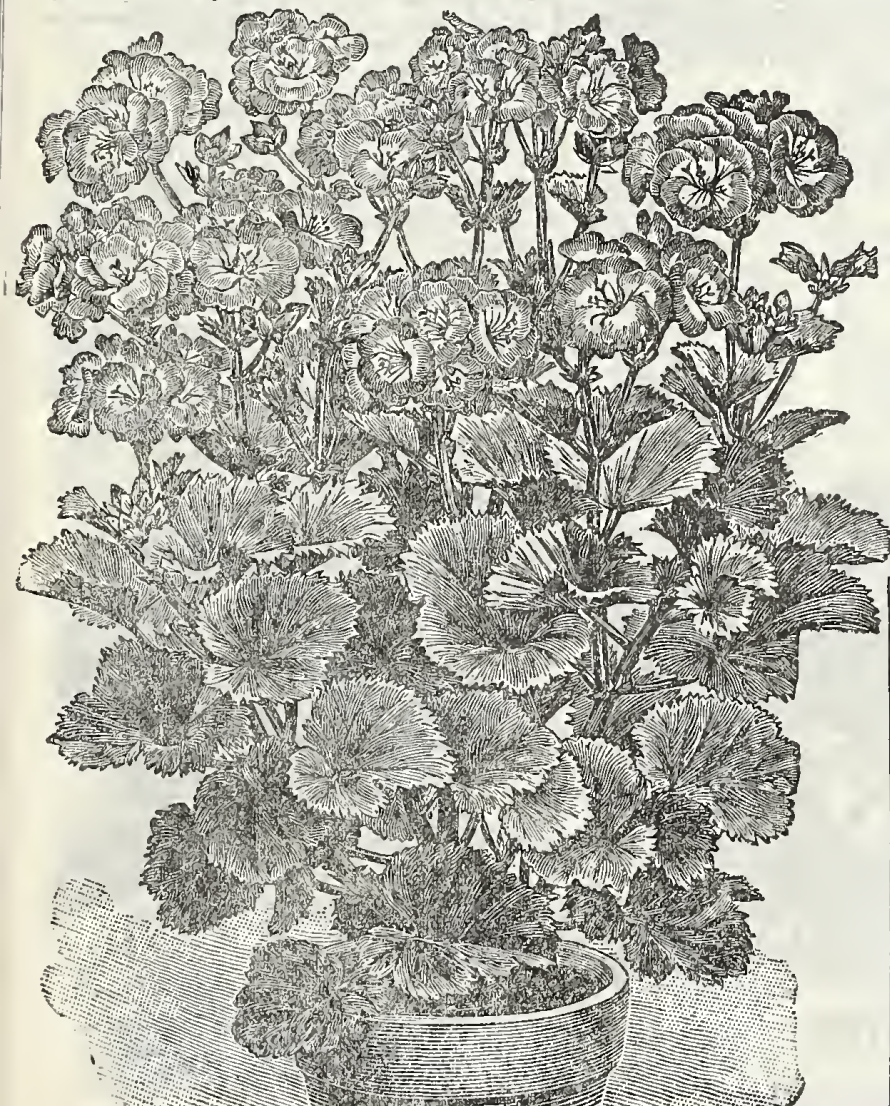

Lady Washington Geranlums-Easter Greetlogs.

\section{Easter Greetings \\ A New Everblooming Varietv.}

Flowers large and free; bright amaranth red, each petal marked with a large black blotch. This variety is distinct from the rest, and remarkable on account of its long bloomspring, but ordinarily continuing throughout the summer and fall. 20c each.

\section{CRIMSON KING}

Intense rich crimson; single. Flowers extra size and well rounded. 15e each.

\section{KINGSTON BEAUTY}

single silvery white crimped. Full rounded petals and the MRS. ROBERT SANDIFORD

This is a grand double white variety; the flowers are extra large perfectly double and beautifully laced and ruffled. The color is glistening snow white, exceedingly beautiful, 20c each.

\section{MAD. THIBAUT}

White, richly marke and blotched with rose; the upper petals marked crimson maroon with large white center; petals heavily ruffled, giving it a double appearance. 15e each. The Set of 5 for only \%0c, postpaid.

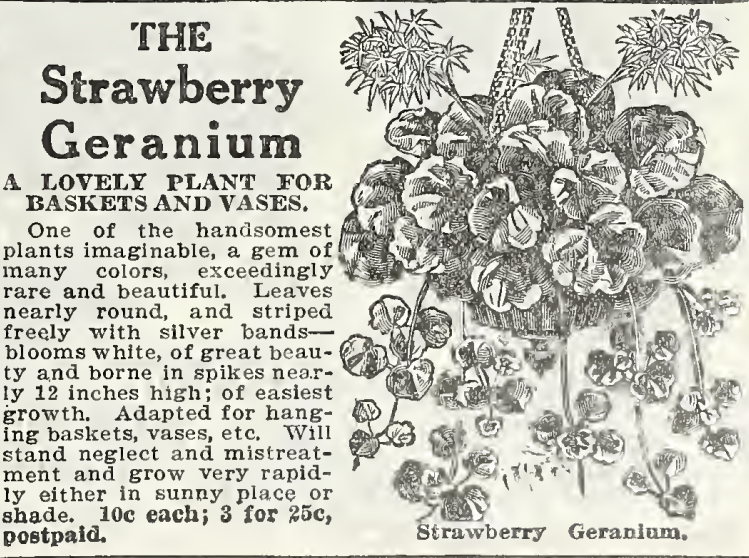




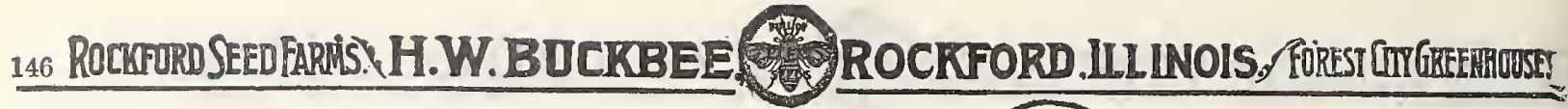

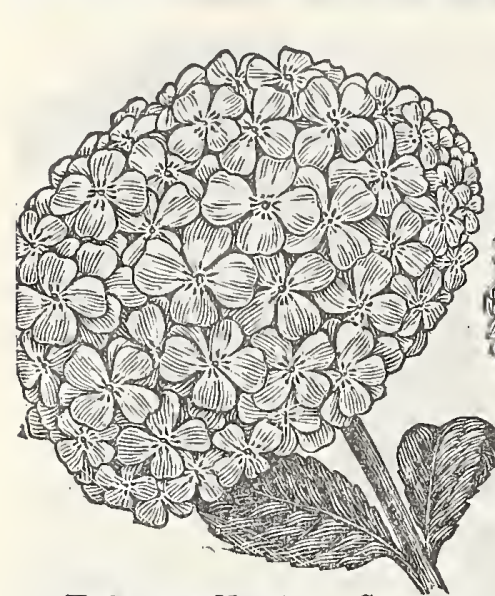

Hydrangea Monstrosa Compacta.

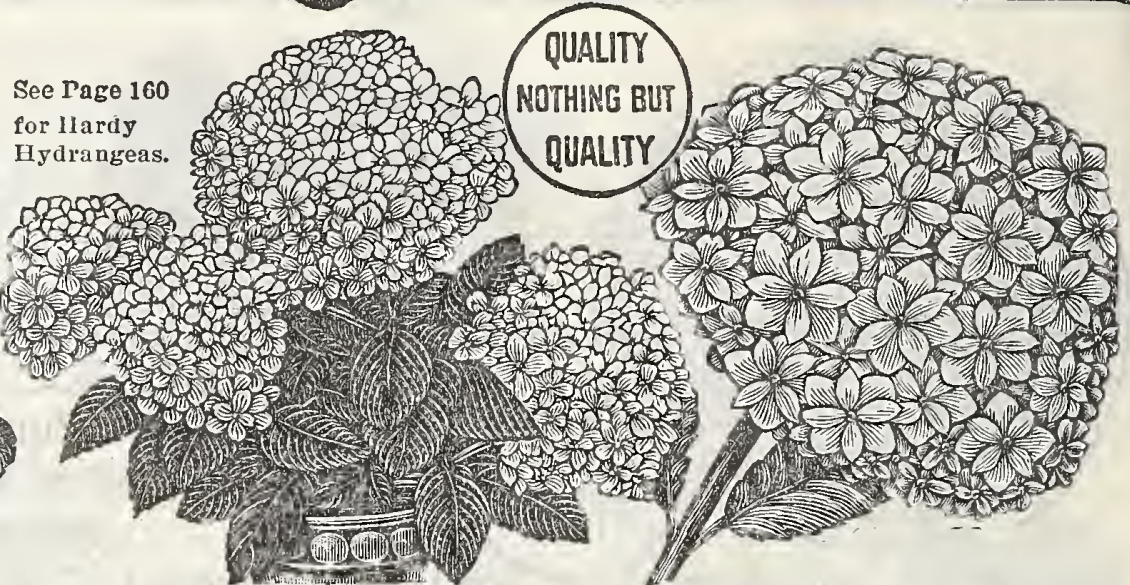

IIIdrangea Blue King.

\section{Hydrangeas for Pot Culture}

These are orand low orowlng bushy shrubs: much used for decorating lawns and porches during Summer; thcy bear enormous heads of flowers, often more than a foot in diameter, and not being entirely hardy are usually kept in tubs or boxes; set out in summer and taken to cellar over Winter.

JEANNE D'ARC-A new variety of exceptionally good merlts.

It is a variation of the old favorite Thomas Hogg, with dark

reddish brown stems. The flower is pure white and very

effective. Pxice, 15c each, 2 for $25 \mathrm{c}$, postpaid. Larger plant $25 \mathrm{c}$ to $50 \mathrm{c}$ each.

distinct color of its sterile flowers, which are fully 3 inches across, of a light plnk color tinted with mauve. Price, 20e each, 3 for 50c, postpaid. Larger plants, 35c to $75 \mathrm{c}$ each. MONSTROSA COMPACTA-The flowers are something enormous, trusses 18 inches in diameter being a common occureter, and the individual forets measure brintestiny pink. $15 \mathrm{c}$ each, 2 for $25 \mathrm{c}$, postpaid. Larger plants, $25 \mathrm{c}$ to $50 \mathrm{c}$ each. RED BRANCHED-This variety, with heads of blooms as

large as a water pail commences to bear its enormous

trusses of deep rose pink blooms while very small, increasing constantly in size and profusion. The stems and postpaid. Larger plants, 25c to $50 \mathrm{c}$ each.

THOMAS HOGG-Splendid variety; has all the characteristics so valuable in a plant of this kind. When fully grown attains a height and width of over 6 feet, and is fairly covered with immense trusses of cleamy white flowers, often measurLarger plants, 25c to 50c each.

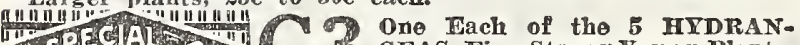

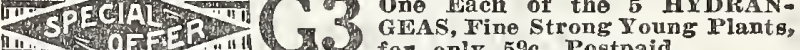
111. English Ivy

QUEEN VICTORLA-This is a hardy evergreen climbing vine, with dark glossy green leaves. Much used for covering walls rreen: retains its bright green leares all ivinter and always looks alive, also one of the very best plants for house culture. 10e each, 3 for $25 \mathrm{c}$, postpaid.

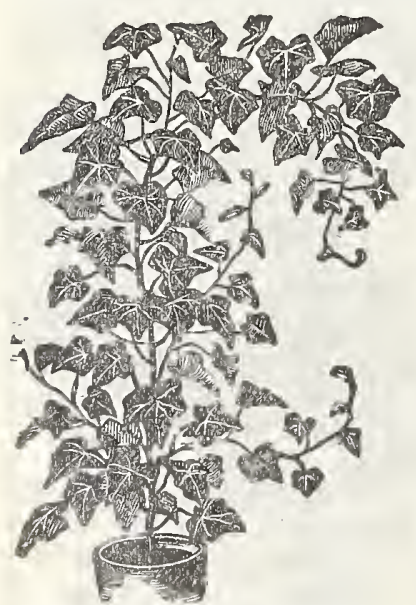

Qpesn Victeria Wnglish Iv

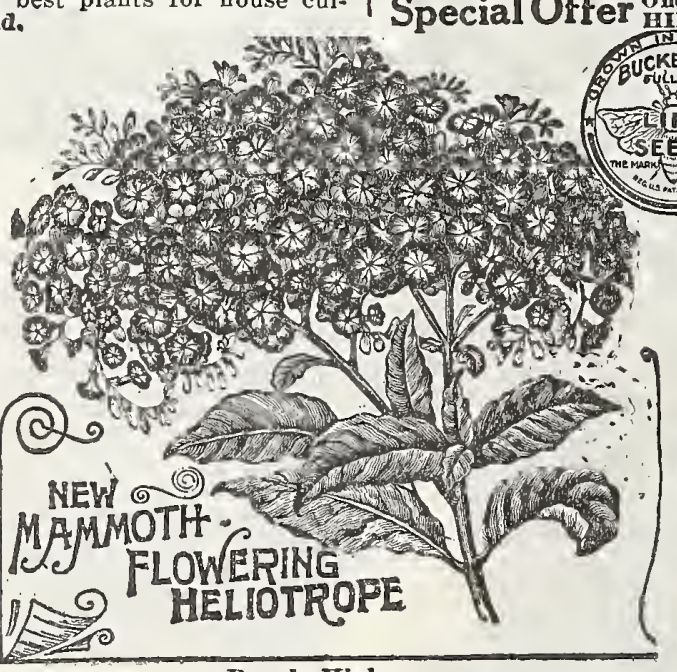

Rozal Highness.
Hydrangea Jeanne D'Arc.

\section{Heliotropes}

These are universal favorites on account of their delightfur fragrance. Flowers equally well as bedding plants in Summer, or as pot plants in the house during Winter.

ALBERT DELEAUX-Foliage is a bright golden-yellow, marked slightly with a delicate green, Each 10c, 3 for 25c, post paid.

CCIOLA-Rosy-violet, indeed, almost red, with a distinct, white

center showing upright growth, producing immense heads of

PRINCE CII TRANT-A Pariety with handsome foliage: ex-

tremely free in bloom; color a lorely tint of bluish-maure.

Like all of the Bruant type, this variety has panicles of bloom

of enormous size, is dwarf and compact in growth. Wach 10c, 3 for 25c, postpaid.

ROYAL IIIGRNESS-Deep blue flowers clustered into great globe-shaped trusses. Wach 15c, 2 for $25 \mathrm{c}$, postpaid.

NOW STORM-Blooms in large trusses of fragrant whlte flowers. An excellent sort. Each 10c, 3 for 25c, postpaid.

CZAR-Strong, stocky growth, heavily corrugated dark foliage; immense clusters of semi-double flowers, rich purple. Each $10 \mathrm{c}, 3$ for $25 \mathrm{c}$, postpaid.

"III" 페... The Full Set, One Fach of the

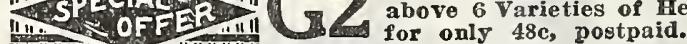

\section{Hibiscus}

The Nost Satisfactory Honse Plant.

ORANGE QUEEN-Large, double orange-colored flowers. Vers nopel and attractive. 15c each, 2 for $25 c$, postpaid.

BRILLIANT KING-Semi-double flowers of a bright vermillion-scarlet; petals wared and recurved; the flowers notice. able for the absence of formality, but are very handsome, $15 \mathrm{c}$ each, 2 for 25c, postpaid.

APPLE BLOSSOM-This is a truly surprising house plant, the flowers are so immense and yet so beautiful that you can scarcely belleve that they are not artiflcial in some way. It is a rapid, erect grower, with bright glossy green leaves and immense double flowers like Roses, 4 to 5 inches in dlameter. Color rich brlght pink, with deep crimson center; likes heat cor

F lor above 3 Magnifleent eclal Orer HIBISCUS for only 35e, postpaid. 


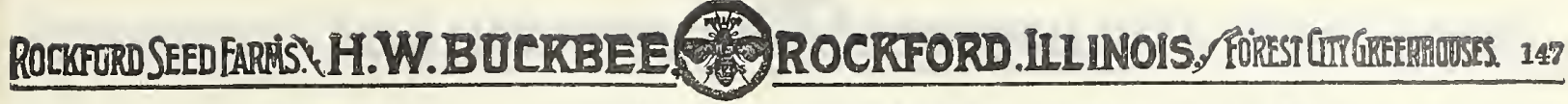

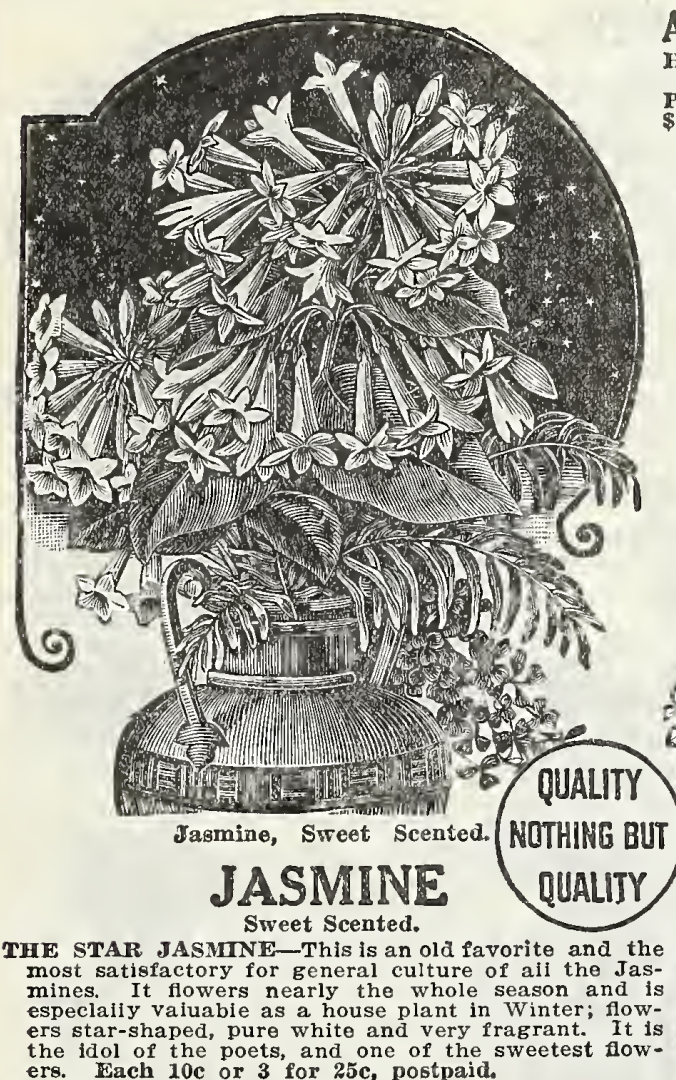

\section{WEEPING LANTANA}

MURS. MeKINLEY - This Lantana is a fine plant, of gracefui, drooping habit, producing flowers at each leaf. The nowers are a brililant rosy lilac, borne in elegant clusters, and hundreds and thousands of them are in bloom of the best varieties for hanging baskets. Entireiy We make the price very low so as to meet the large popular demand. Each 10c or 3 for 25c, postpaid.

Mrs. Isaac Yates, Arabia, Lawrence County, Ohio, writes: I never had Seeds or Piants that have done as weil as
Buckbee's "Fuil of Life," as I have tried them for several years, and think there are none better.

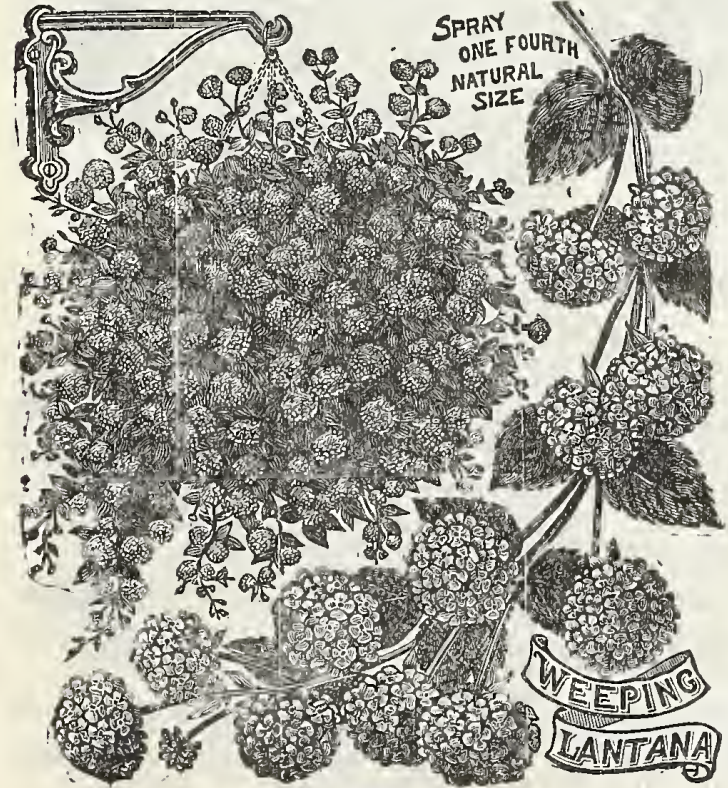

Mrs. Makinley.

A MOST VALUABLE BOOK

HOW TO GROW TLOWERS AND SEEDS.

It tells the whole story in a practical way.
Price only $50 \mathrm{c}$, or $\mathrm{FREE}$ with an order for

1.50 or upwards, if requested on the order.
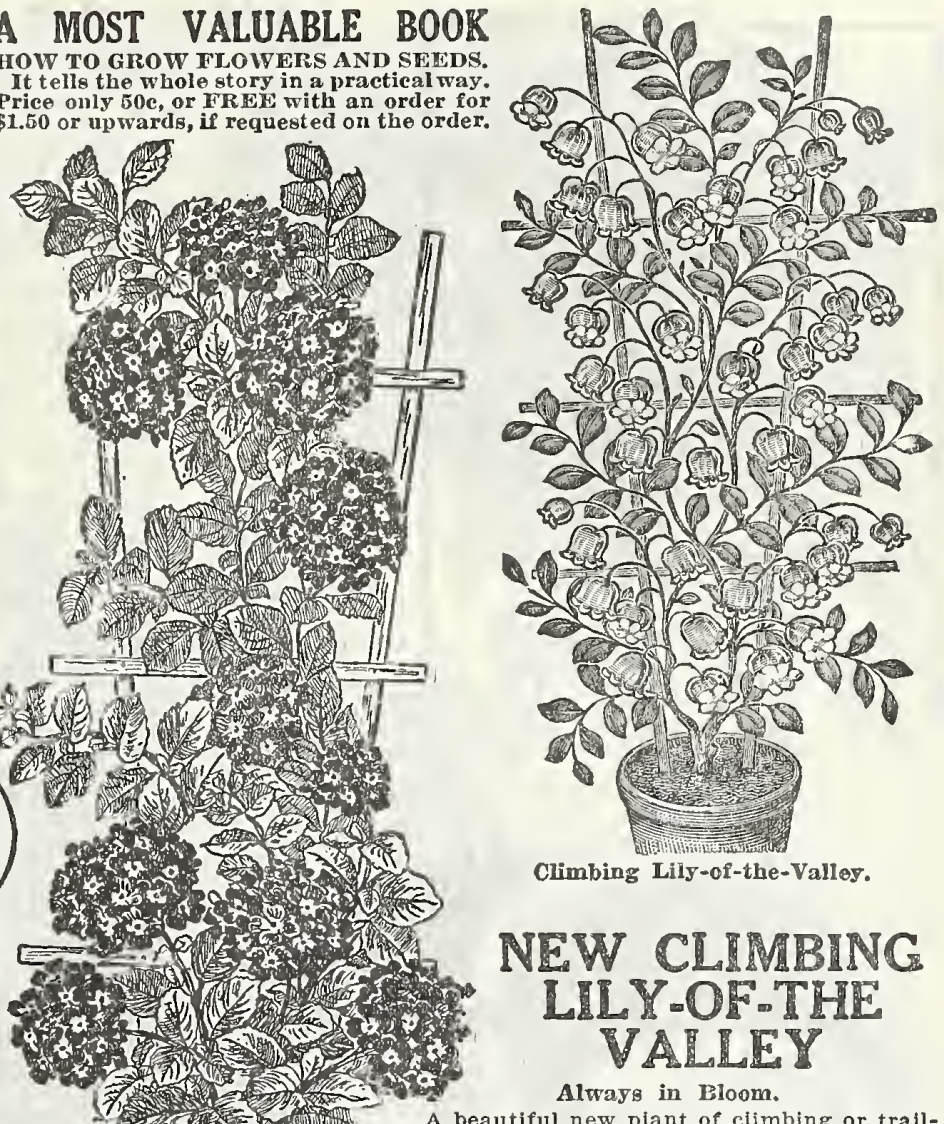

Climbing Lily-of-the-Valley.

\section{NEW CLIMBING LILY Y OF-THE VALLEY}

Always in Bloom.

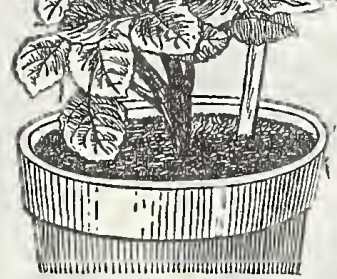

New Climbing Lantana.

\section{NEW CLIMBING}

\section{LANTANA}

Evergreen and Everblooming. It $1 \mathrm{~s}$ at all times graceful pretty and evergreen. It has a great weaith or bloom, the large, of growth and all the year round, and as its growth is easiyy conmade to fit any space where a It is one of the most charming pot vines for windows we ever is a spiendid garden of bioom. Fine Plants, 15c each, 2 for $25 \mathrm{c}$, postpaid.

\section{MANETTIA VINE}

One of the handsomest little vines, easiiy and quickly grown and biooms continuously. Adapted for hanging baskets, pot cuiflower is of the size and shape shown in our lilustration and brillant scarlet, tipped with cleat golden yeliow, making it most 100 os \& for $25 \mathrm{c}$, postpeld.
FOR HARDY LILY OF THE VALLEY STE PAGE 166

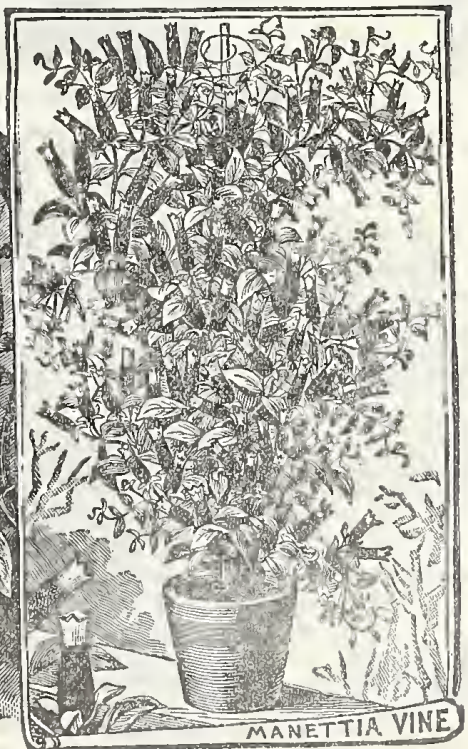




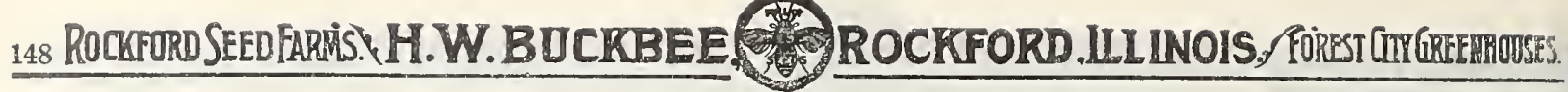

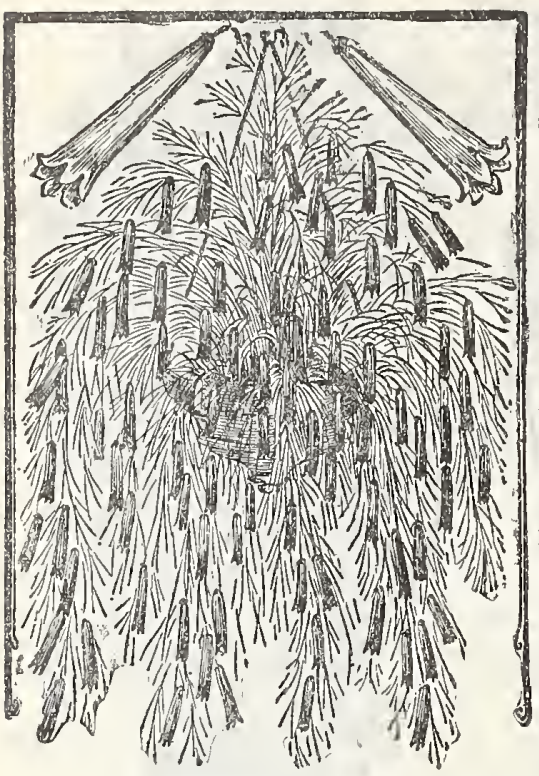

Scarlet Fountain Plant

(RUSSELLIA) A Charming basket or Vase

A novel and beautiful plant, suitable either for bedding or pot culture. Has long, wiry, leafless tubular blooms of the most vivid scarlet color. Blooms almost incessantly as a pot plant. The of coral, scarlet and green. In the South it is perfcctly hardy and a superb garden flower. In any climate it is one of the very easiest of plants to persistent of bloomers. Price, $10 \mathrm{c}$ each, or 3 for $25 \mathrm{c}$.

\section{OLEANDERS}

These old-fashioned shrubs are becoming immensely popular again, They are very attractive plants that can be grown in almost any soil or in tself neat and pleasing. A, Yellow-Large and very beautiful Each $15 \mathrm{c}$, postpaid

LILLI AN WDNDERSQN, White-Magnificent
large snow-white double blossoms, Each 15c, postpaid.

ROS M MORN, Pink-Large blossoms of fine rosy pink. Each, 15e, postpaid.

VARIEGATA-Leaves bordered

white; fowers pink, very double. A magnificent plant, the contrast of follage and delicate $20 \mathrm{c}$, postpaid.

SPECIAL OFFER, G1. The full set, one each of the 4 varieties of Oleanders for $65 \mathrm{c}$ Scarlet Fountain plant. castpaid
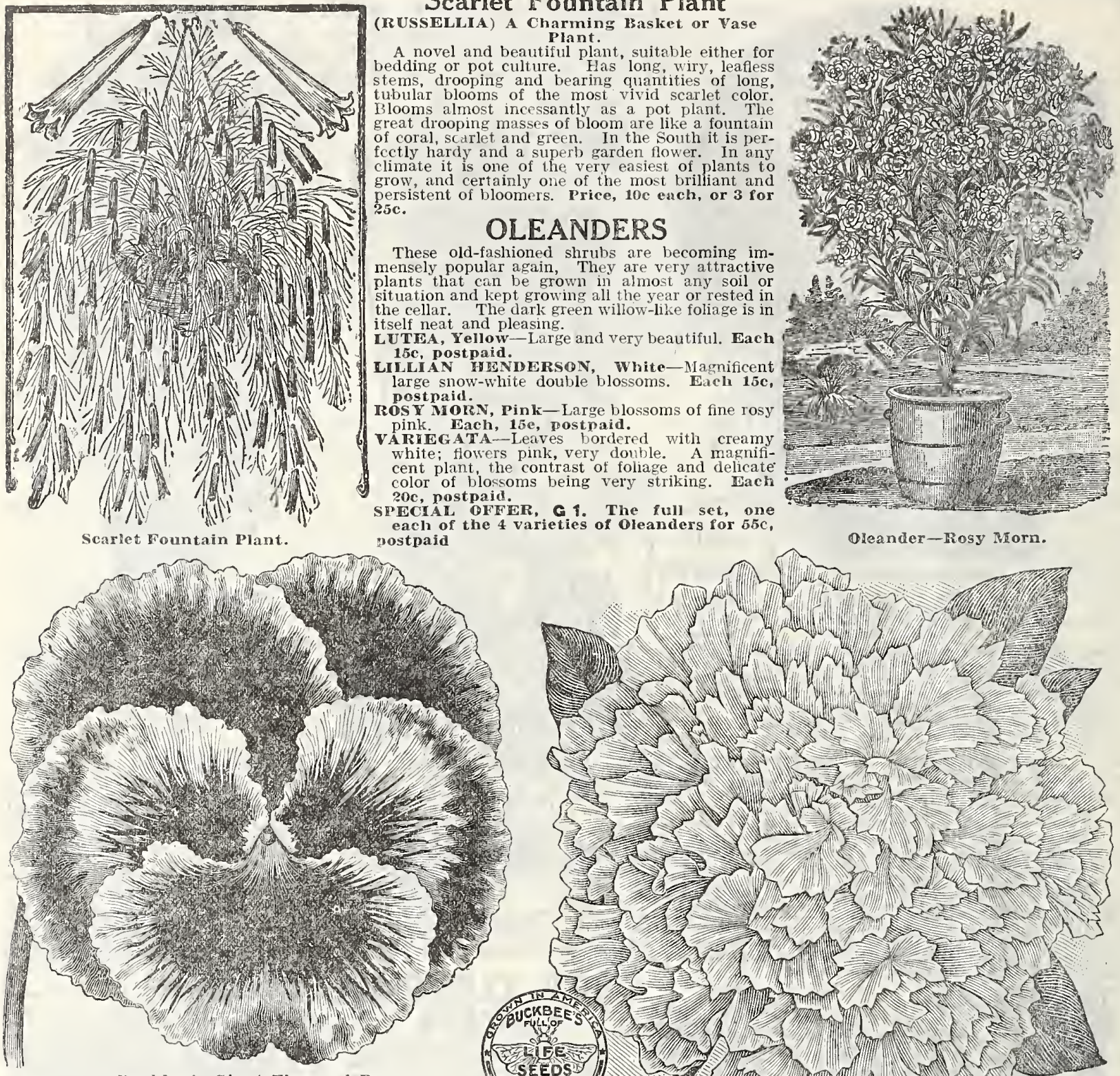

Buckbee's Giant Flowered Pansy.

\section{BUCKBEE'S GIANT FLOWERED} PANSY PLANTS

or Wondrous Beauty:

WTI GROVV BND STOCFY.

For Immediate Planting that will Come Into Flower at once.

Transplanted in october. Wintered in Coid Fr
500,000 Choice plants. Ready for Farly shipment.

Absolutely the fimest stock we have ever grown. None but the choicest. Magnificent colors. Infmite varion of all those who see it, or if you want to make a friend a beautiful gift, there is nothing RIADY FOR SIIPMENT MARCH 15th UNTIL JUNE 1st. WESHIP THEM POSTPAID AT THE FOLLOWING PRICES. HERE IS A GREAT BARGAIN. LOOK AT THE PRICES.

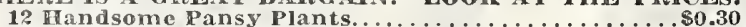
1.5 Handsome Pansy Plants.

50 Fandsomie Pansy plants.

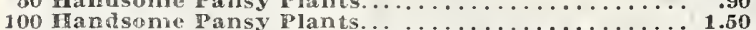

LARGE ROOTS. ALI TRANSPLANTï. WW GUARANTEE THEN TO PLEASE YOU.

A MOST BOOK TOWTOGROW FLOWERS AND VALUABLE BOCK. SEEUS. It tells the whole story in a practieal way. Price only $50 \mathrm{c}$, or FREF with an
Oleander-Rosy Morn.

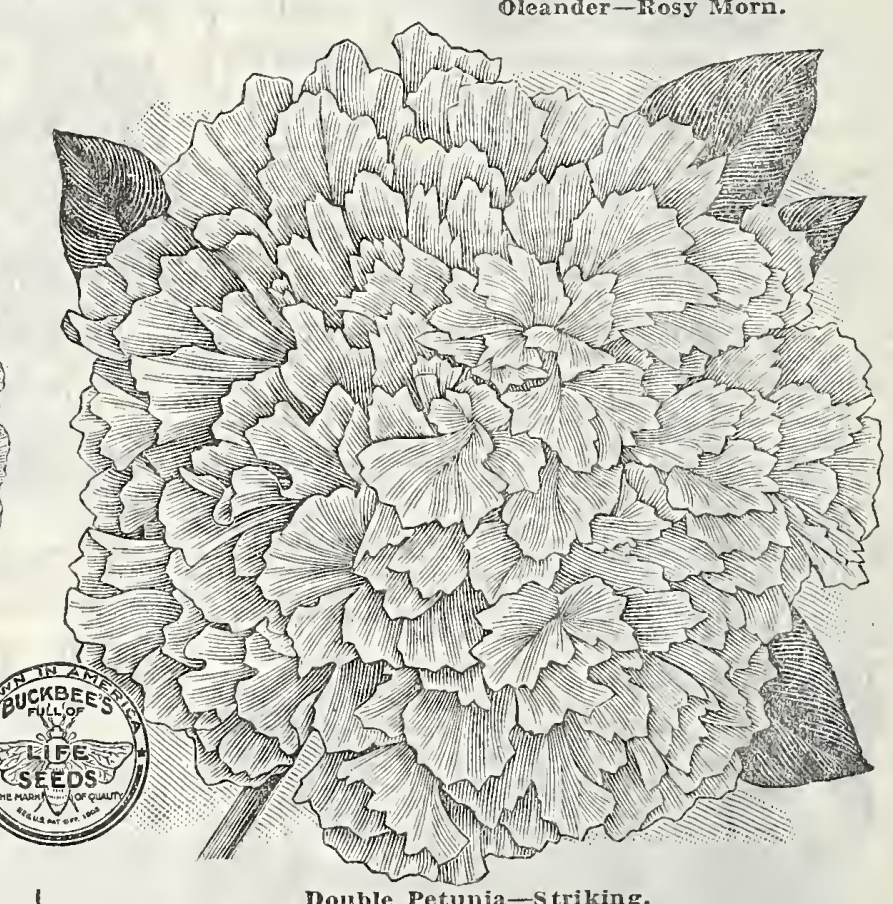

\section{BUCKBEE'S LARGE FLOWERING DOUBLE PETUNIAS}

The Double Petunia is one of the finest bedding plants for massing, mixed combined with the duration of its blooming period, render it invaluable for garden decoration. It is the flower for every body the smallest yard and the finest park is not complete without these butterfties among flowers, that mind neither heat, drouth or rain, but bloom in profusion
the whole season. Our collection is unsurpassed for brilliancy of color and size of bloom.

Rich, deep purple, shaded crimson. $10 \mathrm{c}$ each.

PINK RTAUTY

A very handsome shade of pink, the only pink variety known. $15 \mathbf{c}$ each.

The finest Petunia grown; color a sea-foam white; flowers of the largest size and beautifully frilled. $10 \mathrm{c}$ cach.

STRIKING

Rich purple, mottled and edged white A mosi beautiful combination of colors fully meriting the rame Striking. $10 \mathrm{c}$ each.

SPECIAL OFFER G 6 . FOR ONLI 30C. WE WILL SEND PQSTPAID TAE FOUR LOVELY PEIUNIAS LISTED AROVE. 


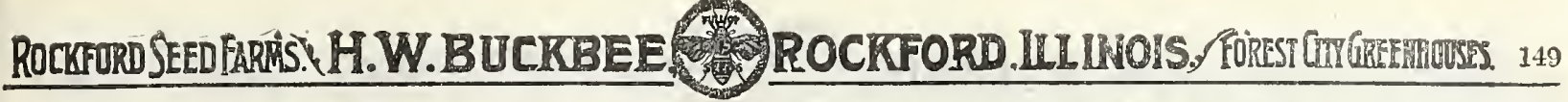
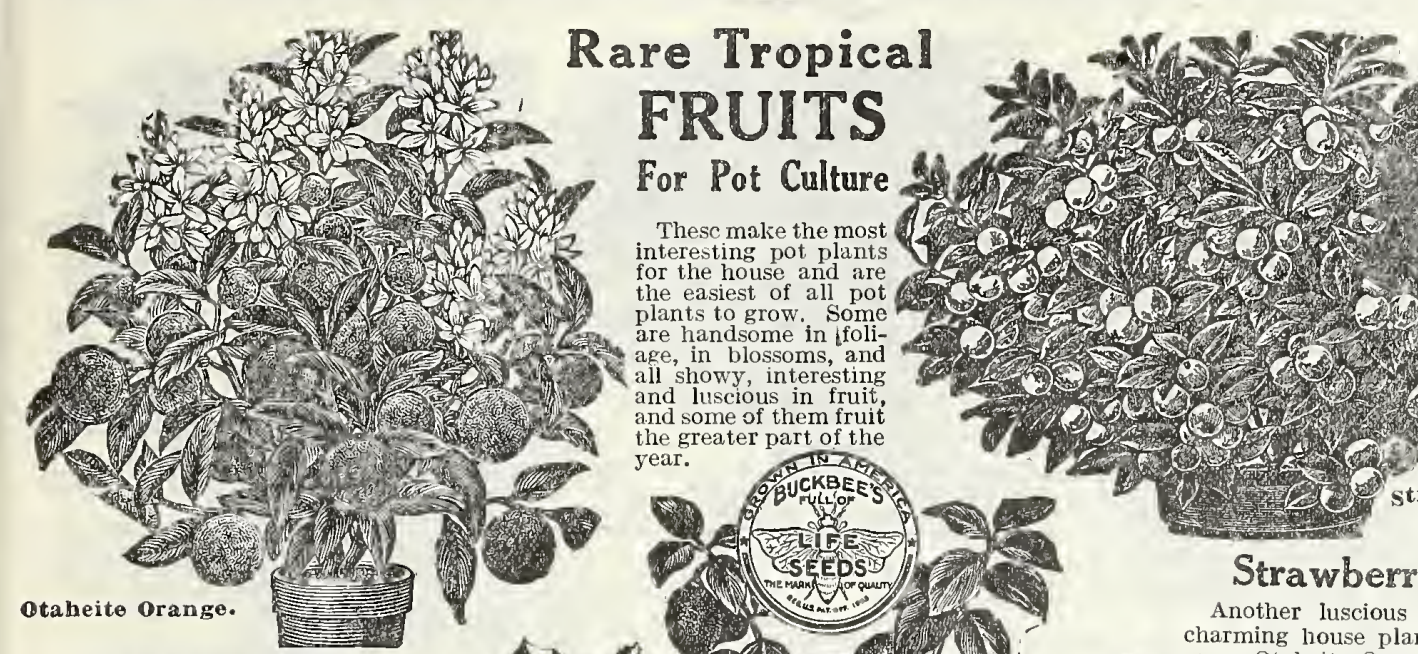

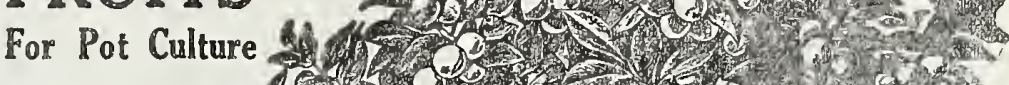

Thesc make the most 400 .

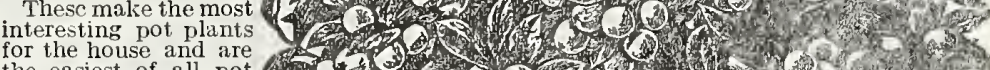

plants to grow. Some

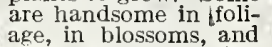
all showy, interesting and luscious in fruit, and some of them fruit
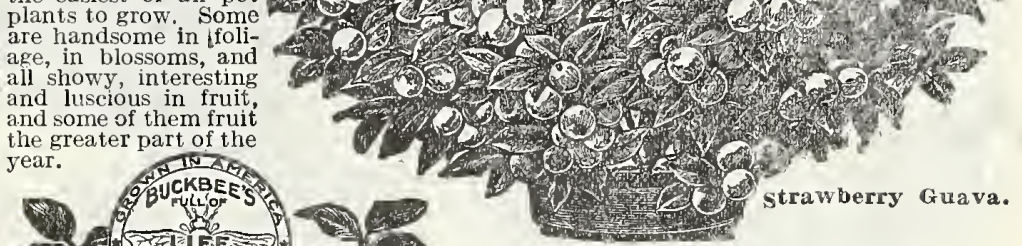

\section{Strawberry Guava}

Another luscious tropical fruit and

\section{Otaheite Orange}

An extra fine pot plant, with glossy leaves, the true fragrant Orange blooms and abundant little bright Oranges that gold for six months after they are ripe. They will bloom and fruit in a two-inch mon window, that was but 15 inches high and had 23 oranges on it. With good sunlight they are never out of fruit least two-thirds of the time are in flower also. The fruit is very sweet and handthere is nothing like it. Fine plants for blooming and fruiting at once, our Sclect, each, postpald 25c. Nice, young thrifty plants, postpaid $10 \mathrm{c}$ to $1 \tilde{5} \mathrm{c}$ each. Fine 2-year old plants Por immedlate effect by express $50 \mathrm{c}$ $\$ 1.00$ to $\$ 2.00$ each.

\section{Surinam Dwarf Cherry}

Ornamental as well as useful, both in flower and fruit; and on account of its dwarf growth can be grown in pots if fruits are rich bright red in color and most delicious flavor. A most desirable plant that will interest the "Shutins" for house culture. Price, strong plants, each $30 \mathrm{c} ; 2$ for $50 c_{\text {。 }}$ postpaid.

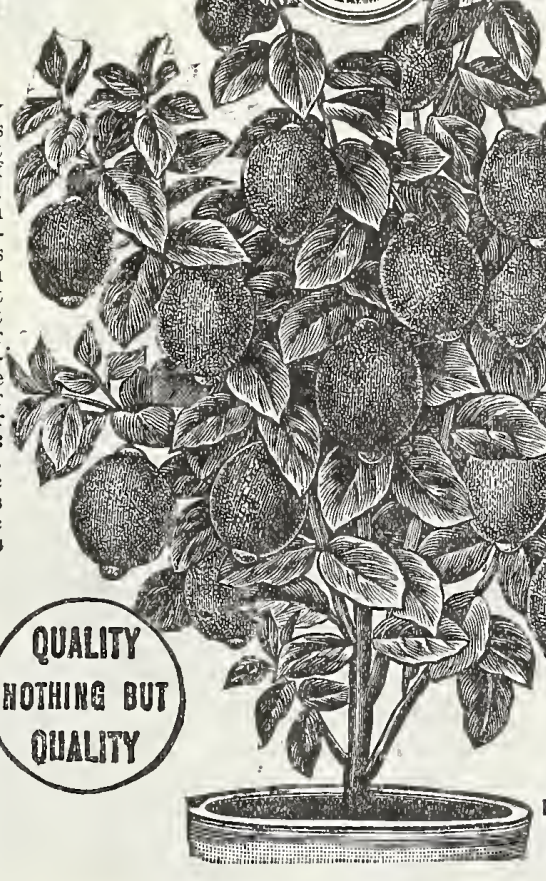

Buckbee's New

Everbearing Ponderosa Lemon

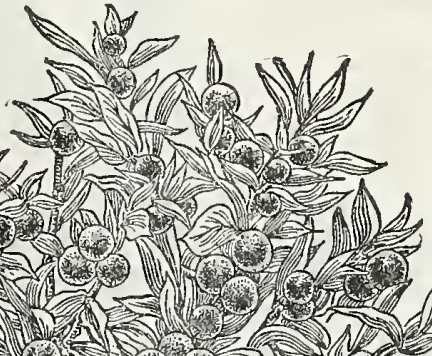

A Lemon that can be as easily grown

a pot as a Geranium and which proA Lemon that can be as easily grown
in a pot as a Geranium and which pro-
duces fruit weighing from one to three
pounds each These enormous fruits
are borne on plants one to two feet high,
growing in pots. It is everbearing and culinary purposes. The enormous Lemons have a thin rind BUCKBEE's variety of MEW in a season. The ideal Fig for pot culture Verbeanug in the North, and it is one of the rare plants PONDER that you should not miss getting. Strong LEMOH plants on own roots, growing from fruiting LEMOH. wood which will commence to bear soon.

Price, strong plants, each 30c; 2 for 60c, postpaid.

$$
\text { iㅔ }
$$

Now

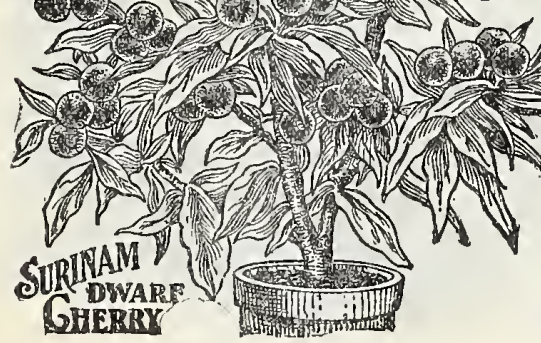
indoors or out. One of the very finest plants for house culture. our price is for the very best

plants: Select, each, postpaid, 25c. Smaller, thrifty plants, postpaid, 10c to 15c each. for immediate effect by express, 50c. Extra large plants,

\section{Special Offer A-1}

We will send by mail, postpatd, one cach of the fove rare troplcal Frults illustrated on this page. Strong Sclected Plants. Safo Arrival Guaranteed.

\section{Smyrma Fig}




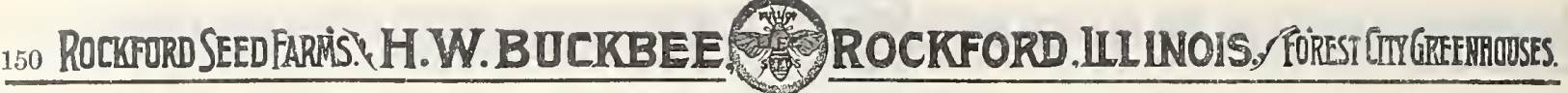

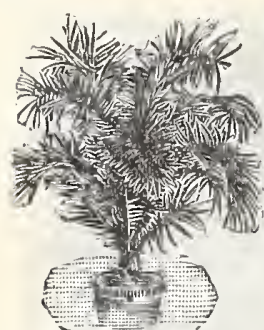

\section{Palms and Choice}

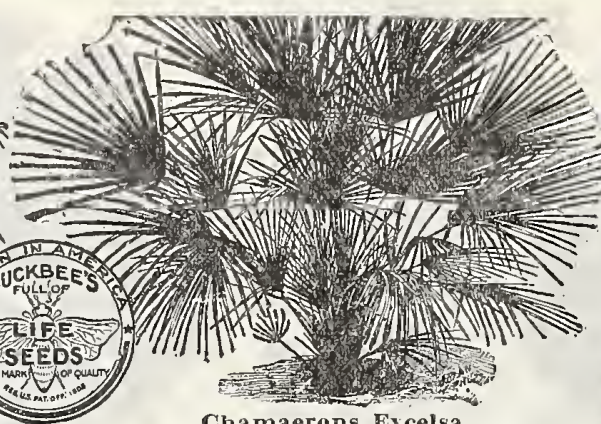

Chamaerons Excelsa.

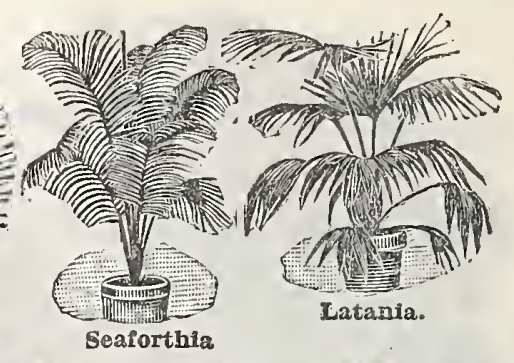

Decorative Plants

CHAMAEROPS EXCELSA (Japanese Fan Palm)-One of the hardiest of the Fan Palms. Foliage dark green; the segments of the fan-shapcd leaves deeply cut, the edges covered with tooth-like decoration. Fine plants $20 \mathrm{c}$ each, postpaid.

KENTIA BAIMORRANA Exceedingly popular parlor Palm. Decidely rugged under all kinds of treatment. Fine plants $20 \mathrm{ceach}$,

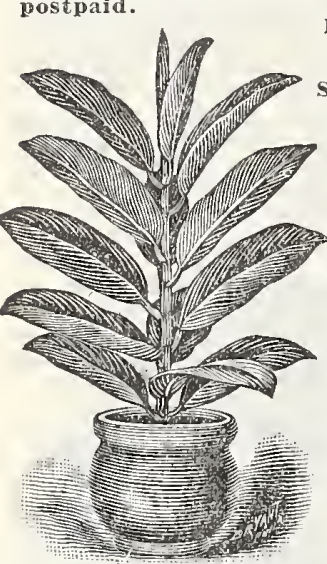

Rubber Plant. PHOFNIX CANARIENSIS-Beautiful, strong-growing Palm with glossy,
dark green foliage. Sure to please and easily grown. Fine plants 15 . each, post paid.

SEAFOR'THIA ELEGANS-A magnificent plant for jardinieres or center of tropical bed. Most graceful. Leaves of rare beautiful formation. Fine plants 20c each, postpaid.

"11.3P "iाiाiा แ

Larger palms by Express at buyer's expense 50c, 75c to $\$ 1.50$ to \$2.50 each. Excellent Specimen Palms by Express at buyer's expense $\$ 3.00$ to $\$ 5.00$ each.

\section{INDIA RUBBER PLANT (Ficus Belgica.)}

The India Rubber Tree is well known as one of the finest plants for table and parlor decoration. Its large, thick olive green leaves and graceful polished stems malie it one of the very finest ornamental plants for the house and conservatory. Will stand much more neglect than most plants. Fine plants soc $\$ 1.00, \$ 1.50$ and $\$ 2.00$

\section{UMBRELLA PLANT}

As decorative as a palm. Hardy, useful and beautiful window plant for all seasons, always presenting a fresh, green, attractive appearance. Invaluable as
an aquatic plant. Throws up stems 2 to 3 feet high, surmounted by whorls of

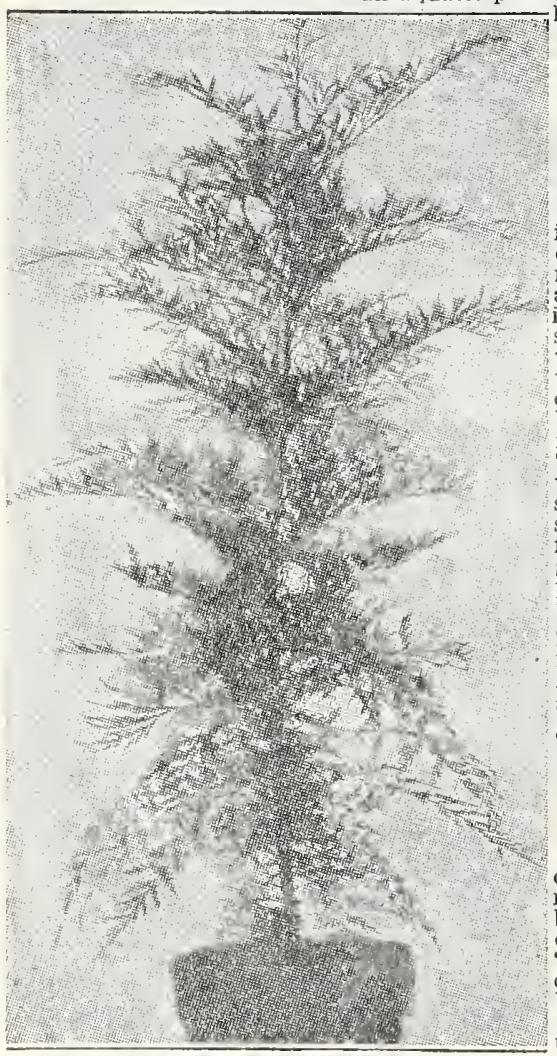

\section{THE BEAUTIFUL TIGER HOUSE PLANT}

Sanseveria Zealanica.

New Decorative Plant of Great Value.

There is scarcely a decorative plant listed that is more striking in foliage and habit than this, and certainly none other that will stand as much downright neglect and hardship. Nothing but frost or a continual drenching with water has terrors for t. It will grow in a dark hall, a cool bedroom, or will stand gas and dust, and will go for months ill ever. Singularly beautiful, as well as easily grown. , sword-like leaves, in some old speciThe leaves are thick and fleshy, a dark green color. with clouded bars of white. In May and Jume it sends up long plumy flower spikes, which, in their soft, feathery whiteness, remind one of an Agave's flower. The splendid outlines of this plant, toperb plant for jardinieres, centers of vases, etc. It will also grow splendidly out of doors in summer. Just the plant for sunless windows or halls, where nothing else will grow. It is new and little known to cultivation, but a plant which all will delight to possess. Fine plants, postpaid, each 15e, for $50 \mathrm{c}$ to $\$ 1.00$ each.

\section{THE AUSTRALIAN SILK TREE}

Irgnifucent Decorative House Plant.

A magnificent plant for decorative purposes, of rapid easy, growth, finely cut foliage, rivaling a rare fern. The young, growing leaves are a light brown color, the tips being covered with a soft down, closely resembling raw silk, hence the name "Silk Oak." In its native place it attains magnificent proportions and produces

Few plants are bettcr adapted to withstand $15 \mathrm{c}$ each; 2 for $25 \mathrm{c}$

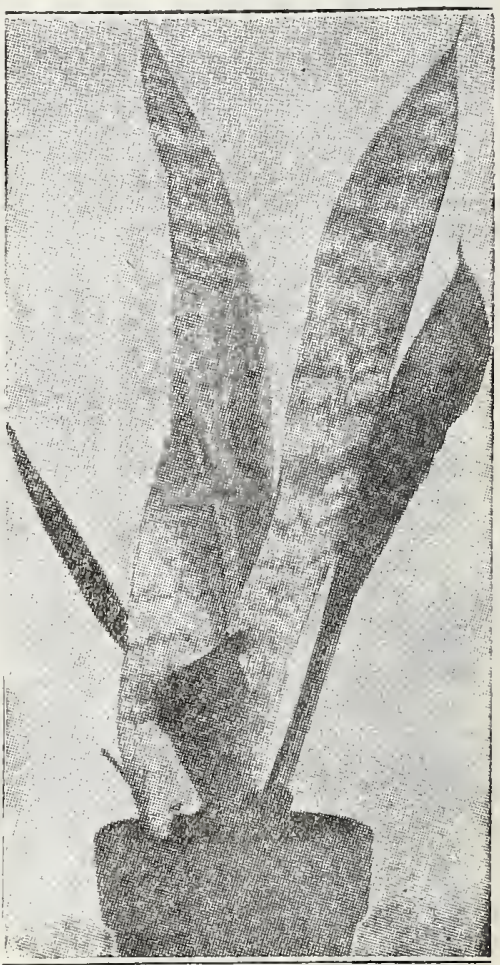

The Bcautiful Tiger House Plant. Sanseveria Zcalanica. 


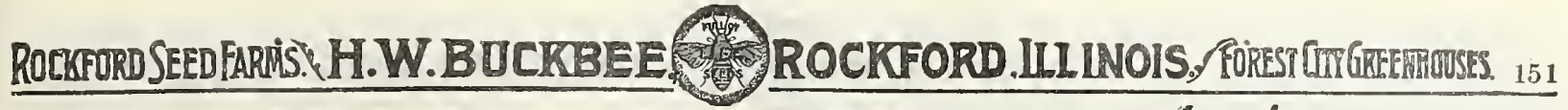

\section{4.}

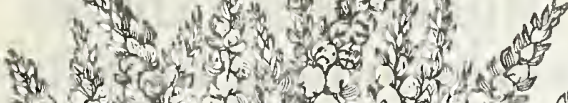

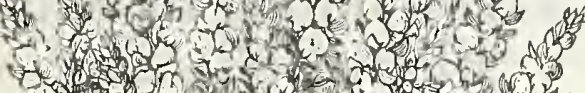

2. on

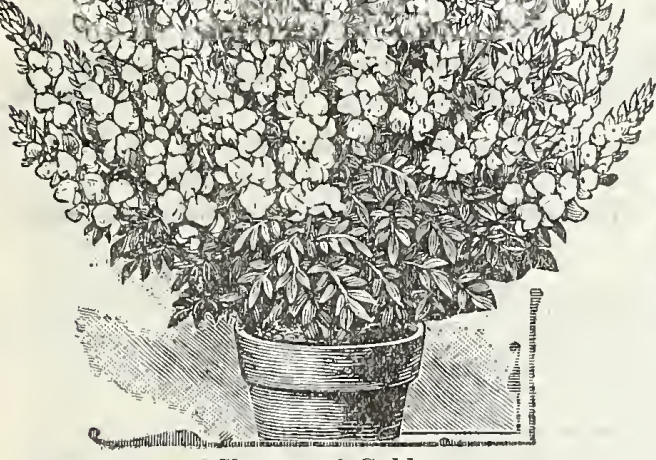

Shower of Gold.

\section{Shower of Gold (Genista)}

A beautiful yellow flowering plant that grows and flowers freely with ordinary care, flowering so freely as to literally cover the plant with its rich goldeu-yellow blooms when well grown. A very popular plant for Easter decorations, 2 for 25 c, postpaid.

\section{SWEET VIOLETS}

ROYALT Y -The new double Violet. Bcautiful azure blue, of rare fragrance. Each, 15c; 2 for $25 \mathrm{c}$.

THE CALIFORNIA - Flowers single, of immense size; color, clear dclightful. Each 10e; 3 ror 25c.

GOVERNOR HERRICK - Rich. dark purple; single flowers of lovely fragrance. Each 10c; 3 for $25 \mathrm{c}$.

IMPROVED MARIE LOUISE One of the finest double blue Violets grown. Very fragrant and a for $25 \mathrm{c}$.

THE BRIDE-A grand pure white variety. Flowers are double and immense in size, extra early and for $25 \mathrm{c}$.

SPECIA , OFFER E For only 45c we will fno plant of each of the five Grand violets listed above.

HARDY VIOLETS-See page 165.

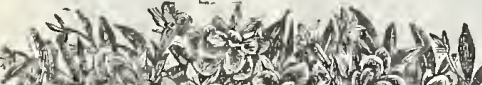
v.

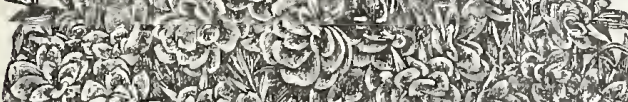

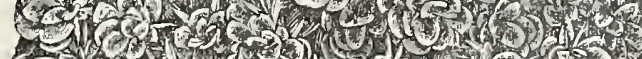
G. (n)

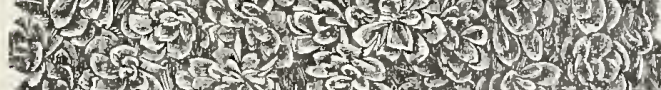
(1) r.

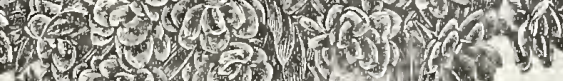
(4)

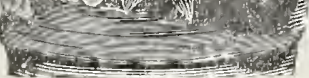

New Blue Star Flower.

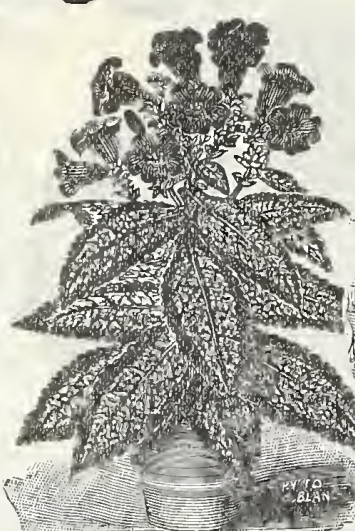

Royal Purple Plant.

Royal Purple Plant

The leaves are bcautifully variegated, with a deep metal lic purple, shaded with dark rose and margined light green. and border and is entirely disinet from any other beddin plant. Grown as a pot plaut and effective. for 25c; postiaid.

\section{M.}

(

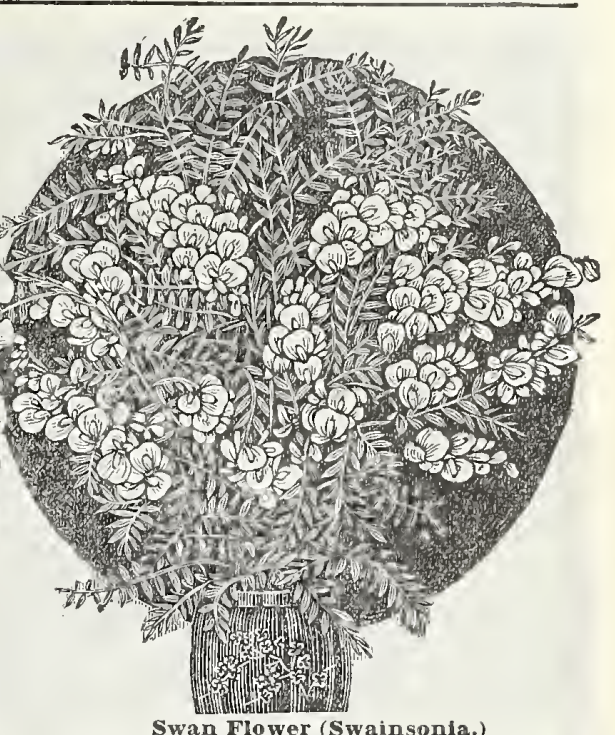

Swan Flower (Swainsonia)

ALBA-This is a very beautiful plant, both for flower bed and house culture; flowers are pure snowy white, and borne in pretty sprays all over paid.

ROSEA-Same as Alba cxcept in color, which is bright rich rosy red. Price, $10 \mathrm{c}$ each; 3 for $25 \mathrm{c}$ postpaid. Lemon Verbena
A universal favorite and invaluable for its Lemon Verbena
a universal favorite and invaluable for its
fragrant leaves, so graceful when mixed with
bouquets. They will retain their fragrance

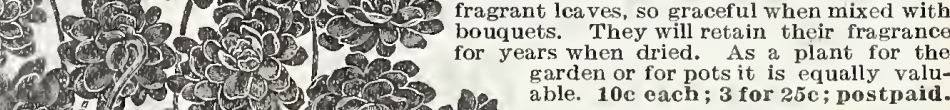

Wandering Jew

(Tradescantia Multicolor.) Fine variegated leaves, striped crimson, green and silver, with a beautiful silvery sheen on them. A very rapid grower and excellent for boxes, etc. Price, 10c each; 3 for $25 \mathrm{c} ; \$ 1.00$ per dozen; post paid.

Zrabor Christmas Cactus (Also Known as Lobster Cactus.) An early flowering crimson scarlet lariety, with long drooping flowers, branching and hanging in bunches. ires absolutely no care, living for month without water, increasing in val ue yearly. Fin plants, 20c each; 3 for 50c; postpaid. 3 as

A Wonderful Novelty-

Actually a good sized plant is one solid bouquct of the most
elegant blue blossoms we ever saw, as many as 300 showing at one time. As a pot plant for very flnest things ever introQ

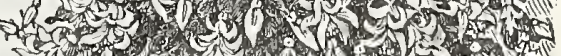
both summer and winter. As a
bedding plant it is equally valu-

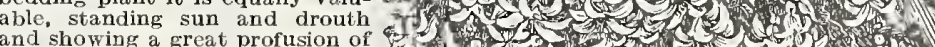

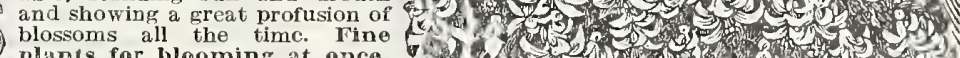

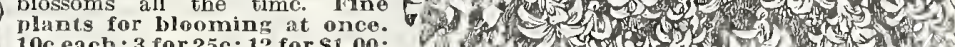
$10 c$ each; 3 for $25 \mathrm{c} ; 12$ for $\$ 1.00$; -4 .
postpaid.

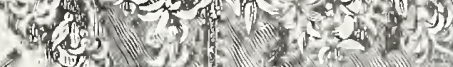

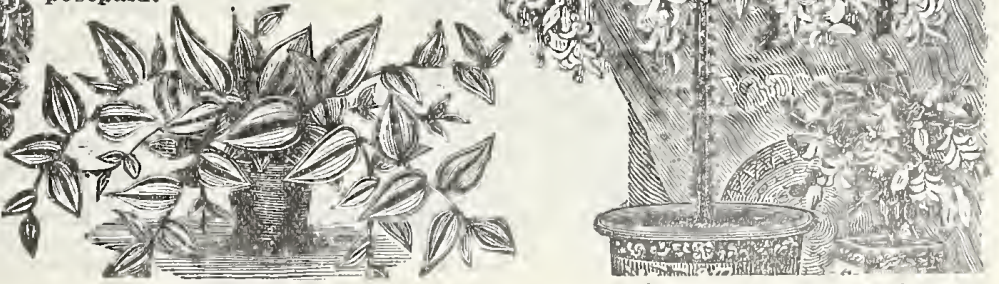




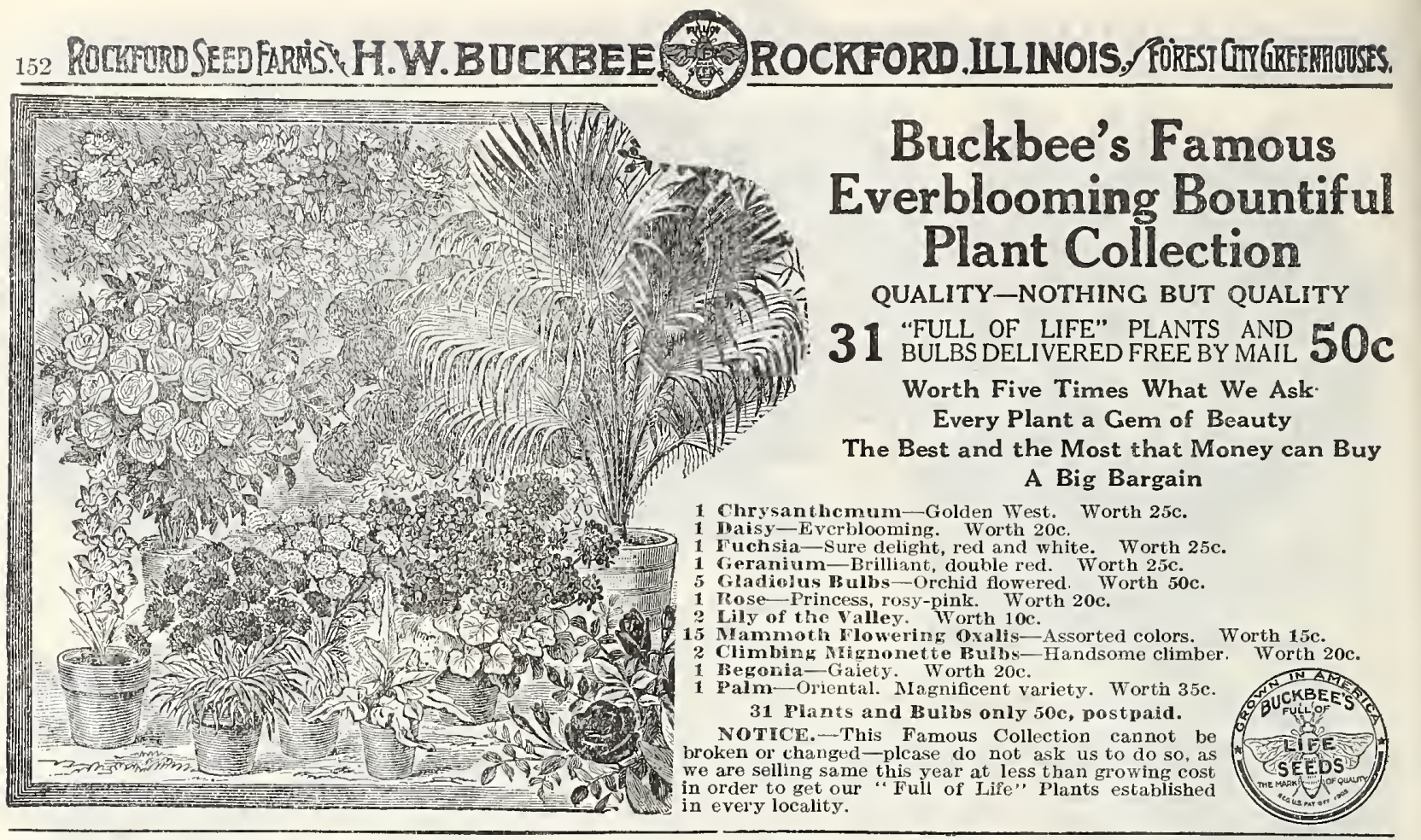

Buckbee's Everblooming Monthly Tea Roses Special Offer

Your Selection one Each of Any Three Varieties, Postpaid, only 25c. Large Two-year old Plants one each of any thrce varieties for $75 \mathrm{c}$

ALLIANCE FIRANCO-RUSSE-Flowers are large, double and of the best substance, beautifully formed; color rich Beilow without a blemish. 10e each; 3 for 25c.

ERIged tender rose. $10 \mathrm{c}$ each: 3 for $25 \mathrm{c}$. regular full form, delightfully tea-scented; color, clearrose pink. 10c each; 3 for $25 \mathrm{c}$. stance and durability 10\% each: 3 for $25 \mathrm{c}$

TRLD-Blossoms are deep, rosy pink - a shade of delicate richness that is seldom seen. ETOILE DE FEANCE-The gold medal Rose of France. The flowers are very large and borno on good, long, stiff stems; color a lovely shade of clear, red crimson velvet: very fragrant. $10 c$ earh; 3 for $25 e$.
MELEN GoULD-Beautiful, long, pointed buds and immense, full, perfectly double flowers. Color warm, rosy pink. $10 \mathrm{c}$ each; 3 for $25 \mathrm{c}$.

ETOILE DE LON-One of the fnest yellow bedding Roses for outside planting; it is moreover one of the hardiest. $10 \mathrm{c}$ each; 3 for $25 \mathrm{c}$

GENERAL MICARTHUR-One of the most vixid crimsonscarlet Roses in existence. The bushes arc of vigorous, healthy growth and very hardy. The large, double well-
formed flowers are very fragrant. 10c each; 3 for 25 c.

GENERAL, ROPERT F. LEE-Lovely canary yellow, delicately tinged with rose, full deep flowers, very sweet. $10 \mathrm{c}$ each; 3 for $\mathbf{2 5 c}$ KAISERIN AURUSTA VICTORIA-A beantiful Rose with clegant large pointed buds and very large, full double flowers: cclor delicate creamy white; deliciously fragrant. $10 \mathrm{c}$ each; 3 for $25 \mathrm{c}$.

MAMAN COCIET-A valuable pink bedding or pot Rose, with rich, healthy foliage and large flowers on long, straight stems; color, deep ros, pink, the inner side of petals silvery rose. $10 \mathrm{c}$ ach: 3 for $25 \mathrm{c}$

MAGNAFRANO-Splendid crimson scarlet color and magniflcent buds. The flowers are large, very regular, full and double, and deliciously sweet. $10 \mathrm{c}$ each; 3 for $25 \mathrm{c}$.

MY MARYLAND-Large. full double flowers, a pleasing shade of clear pink. $10 \mathrm{c}$ each; 3 for $25 \mathrm{c}$.

NEW DOUREE KILEARNEY-The color is brilliant sparkling pink: the flowers aro extra large and full, with broad, thick petals and delightâl tea frag! ance. $15 \mathrm{c}$ each; 2 for $25 \mathrm{c}$

PERLE DES JAUNES-Buds long and pointed, of a deep tawny yellow on first opening, changing to almost clear yellow. 15c each; 2 for $25 \mathrm{c}$.

Fuchsia-Sure delight, red and white. Worth 25

reranitum-Brilliant, double red. Worth $25 \mathrm{c}$.

Rose-Princess, rosy-pink. Worth 20c.

NOTCT-This Tallous only 50c, postpan.

are lhanged-plcase do not ask us to do so, every locality.

The color is a lovely shade of deep coral pink, elegantly striped and mottled with intensc shining crimson, fnely

SAFRANO-Color, bright apricot yellow changing to orange and fawn; sometimes tinted with rose. Very fragrant.

$10 \mathrm{c}$ each; 3 for $25 \mathrm{c}$

SOUV. DE LA MALMAISON-One of the choicest Roses we offer; color, a creamy flesh, bright and clear. $15 \mathrm{c}$ each; 2 for $25 \mathrm{c}$.

SOUV. DE WOOTTON-Flowers as large and full as the American Beauty. Deliciously fragrant. Color, rich bright cerise in summer and dark red in winter. Very free blooming.

$15 \mathrm{c}$ each; 2 for $25 \mathrm{c}$

THE B RIDE-Pure white, delightfully scented. $10 \mathrm{c}$ each; 3 for $25 \mathrm{c}$

WHITE COCHET-Beautiful pure white sport from Maman Cochet; large, full and beautifully scented. $10 \mathrm{c}$ oach; 3 for $2 \overline{\mathrm{sc}}$.

WM. R. SMITR-Flowers creamy white, with pink shadings, of heavy texture and great durability. $10 \mathrm{c}$ each; 3 for $25 \mathrm{c}$.

YELLOW COCHET-Deep sulphur yellow. True Cochet type; most desirable of all yellow Roses for outdoor planting. 10c each; 3 for $25 \mathrm{c}$. 


\section{Buckbee's Everblooming Monthly Tea Roses}

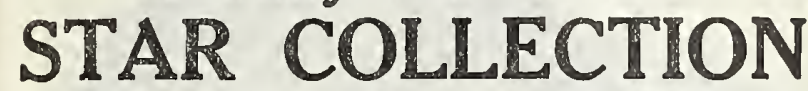
4 Choice Varieties, one of $25 \mathrm{C}$
Each, postpaid, for only 25 . 41.00
or 4 Large 2 yr. old Plants for $\$ 1.00$

FRANCES E. WILLARD-It is of strong, vigorous growth and everblooming, producing snow-white buds and large flowers of perfect form; very fragrant. $15 \mathrm{c}$ each; 2 for $25 \mathrm{c}$.

RICHMIOND-Unquestionably one of the handsomest varieties of late introduction. A real Resi Rose, shading to velvety scarlet or crimson as the flowers mature. Flowers full and flnely formed, very fragrant; a free, strong grower and a profuse bloomer. $10 \mathrm{c}$ each; 3 for $25 \mathrm{c}$.

SUNBURST-Beautiful old gold, shaded coppery crimson, with

sunset tints. $10 \mathrm{c}$ cach; 3 for $25 \mathrm{c}$.
WELLESLEY-(New)-A rich shade of pink. Obtained by crossing Liberty and Bridesmaid, form and habit being influenced advautageously by both parents. 15c each; 2 for $25 c$.

\section{Buckbee's World Beating} ROSE

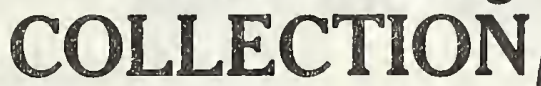

4. Grand and Superb Varieties $35 \mathrm{C}$ or 4 Large $2 \mathrm{yr}$. old Plants for $\$ 1.15$

CLIMBING METEOR, (Monthly Everbloming)

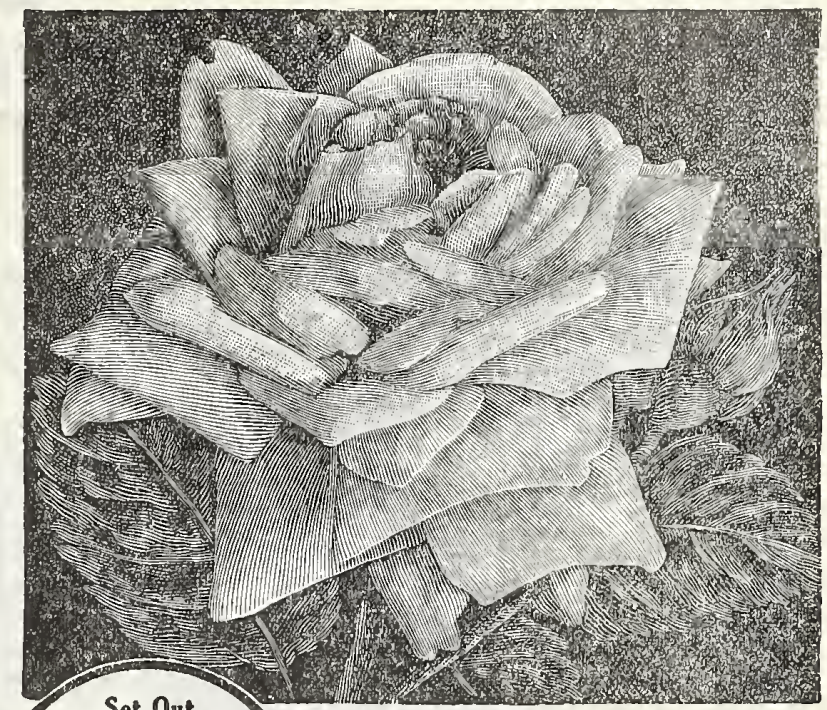

Set Out

2 YEAR OLD ROSES FOR

IMMEDIATE EFFECT

Our Prices are

Bargains. Choice Plants Growa On

Their Own

Roots

A sport from Meteor, famous for its magnificent flowers. True climbing habit, attaining a height of 10 to 15 feet in a single season. Free, persistent bloomer, with magnificently formed buds and flowers. Dark, volvety crimson, the equal of any
Rose in cultivation. Hardy with protection, and will givo absolute satisfaction. $15 \mathrm{c}$ cach; 2 for $25 \mathrm{c}$. Large 2 yr. old plants $35 \mathrm{c}$ each.

\section{LADY GAY, (climber)}

Deep, rich, rosy pink. The plants are hardy and vigorous; foliage dark glossy green. It forms large, loose trusses, containing from fifty to one hundred brilliant green. It forms large, loose trusses, containing from fifty to one hundred brilliant cover the plants. 16c eaeh; 2 for $25 \mathrm{c}$. Largc 2 yr. old plants $35 \mathrm{c}$ each. RADIANCE, (Monthly Everblooming)

Lovely rosy pink color, and has wonderful lasting qualities, keeping crisp and fresh even in very hot weather. The color is extremely high and clear in all its tones. 15c each; 2 for $25 \mathrm{c}$. Large 2 yr. old plants $35 \mathrm{c}$ each.

\section{SILVER CLOUD, ( $\left.\begin{array}{c}\text { Hardy } \\ \text { Memorial }\end{array}\right)$}

Beautiful foliage and elegant clusters of lovely satiny white flowers produced in wonderful abundance. One of the kinds of Roses the more you see of it the better you like it. $15 \mathrm{c}$ each; 2 for $25 \mathrm{c}$. Large $2 \mathrm{yr}$. old plants $35 \mathrm{c}$ each.

Buclsbee's Everblooming Monthly Tea Roses MOTHER'S COLLECTION 9 RARE VARIETIES

The full Set, One Each, $50 \mathrm{C}$ or 9 Large 2 yr. old Plants for $\$ 2.25$

BESSIE BROWN-A strong, vigorous grower of erect, branching habit, flowering in great profusion almost continuously; flowers of perfect form, large size, of good substance and highly fragrant; color creamy white. 10c each; 3 ror 25c. blossoms, which are beautiful in buds or open flowers. The color is a flne shade of soft. rosy pink, which deepens to bright rose. 10c each; 3 for $25 \mathrm{c}$.

LIBERTY-Magniflcently formed flowers, full, deep and double. Deep crimsonLIBERT Y - Magniflcently formed
scarlet. $15 \mathrm{ceach} ; 2$ for $2 \bar{c}$.

MAD. JOSEPH SCHWARTZ-A lovely Rose, extra large, globular flowers, very full and sweet, pure white, tinged and shaded with pale yellow and rosy blush: very fragrant. 10c each; 3 for $25 \mathrm{c}$

MARIE GUILLOT-A pure snow $\mathrm{y}$-white Rose; large and full flowers; a constant bloomer. 10c each; 3 for $25 \mathrm{c}$

MARIE VAN HOUTTE-The color is a lovely canary yellow, passing to creamy white, and beautifully shaded with rich pink. $10 \mathrm{ceach} ; 3$ for $25 \mathrm{c}$.

MIRS. DEGRAW-Bright coral pink; flowers are borne in clusters; very handsome: noted as a free and continuous bloomer. $10 \mathrm{c}$ each: 3 for $25 \bar{c}$.

PRINCESS DE SAGAN-The flowers are of the most rich velvety crimson color, surpassingly brilliant. $10 \mathrm{c}$ each; 3 for $25 \mathrm{c}$.

A A beautiful Rose of shining, silvery pink, recommended for bedding. Very large and double. $15 \mathrm{c}$ each; 2 for $25 \mathrm{c}$.

Large 2-yr.-old Plants of the above 9 varieties 30c Each

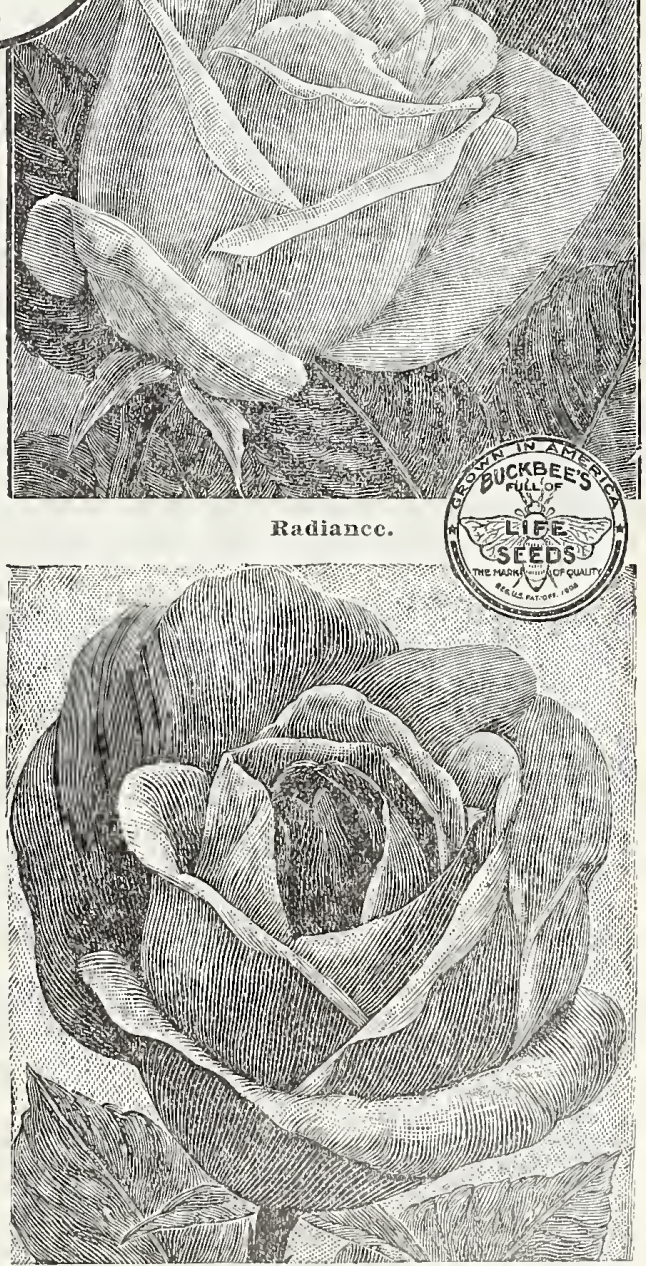

Liberty 


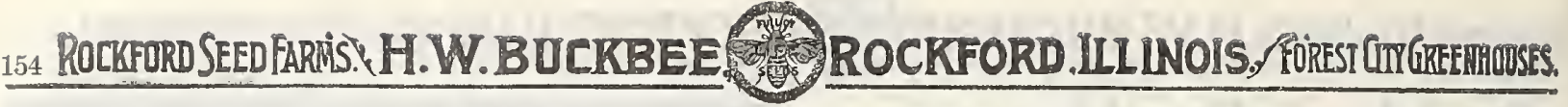

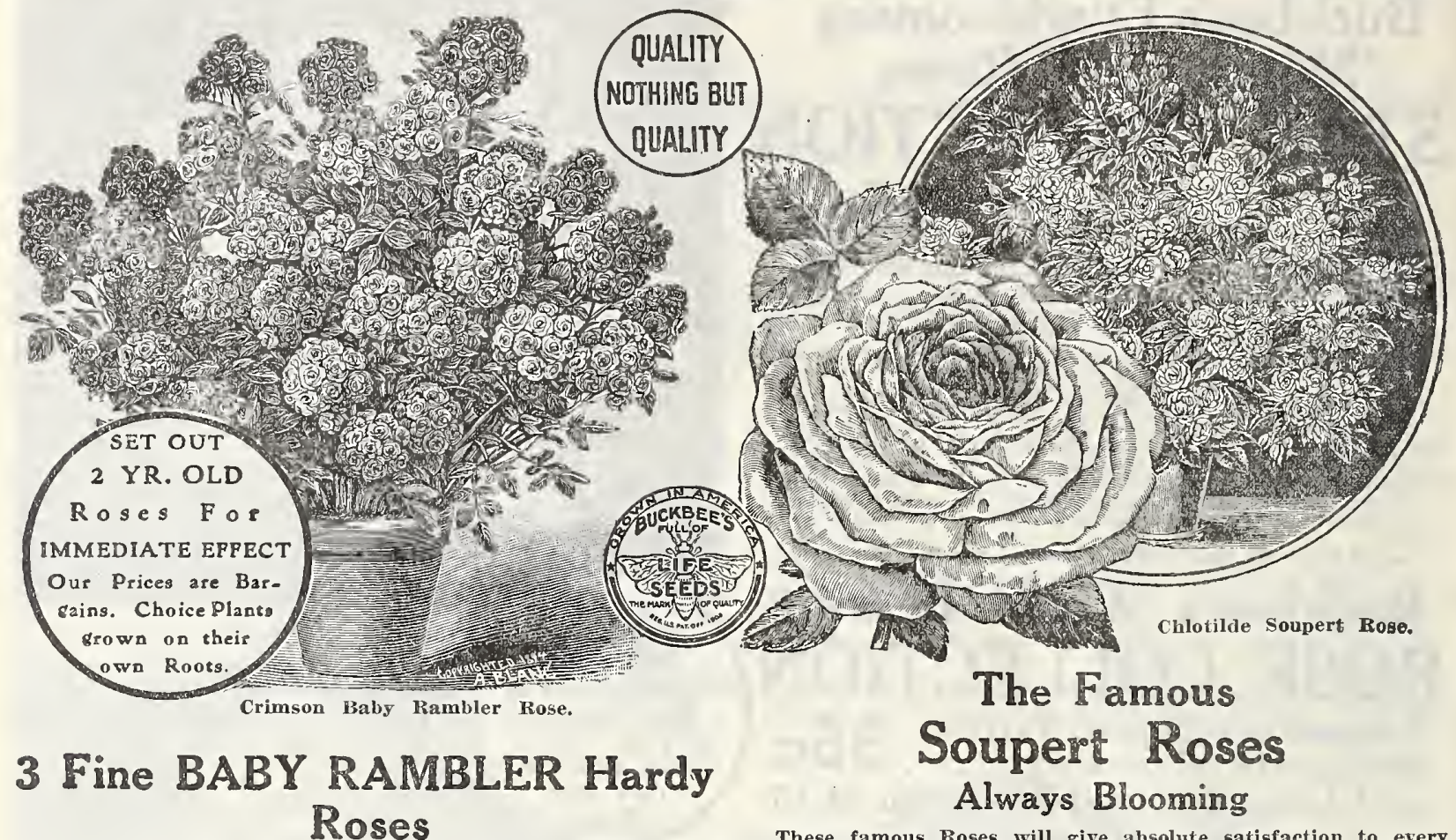

Baby Rambler, or Dwarf Crimson Rambler

A dwarf Bush (not climbing) form of Crimson Rambler, and, furthermore, everblooming. It forms compact bushes about two itet high when fully grown, and is fully covered with clusters hardy, with good culture. The coloring is brighter than "Crimson Rambler" of which it is a seeding. The size of the clusters and the number of flowers in each are the marvel of all beholders. variety to make a low, attractive hedge, to border a walk, for planting, in cemeteries, or for growing in pots in the house, it stands alone and must find its way everywhere. Remember it is 2 for $25 \mathrm{e}$. Large 2 yr. old plants, 35e each.

Baby Dorothy, The Pink Baby Rambler

The freely branching plants attain a height of about 24 inches, somewhat similar to the Rea Baby Rambler, the numerous flower stalks contaning fifty to sixty flowers and buds at one time Fowers cerise pink, measuring 2 inches in diameter, with a hardy. Fine plants, postpaid, 15c each, 2 for $25 c$. Large 2 yr. old plants, 35c each.

The White Baby Rambler (Catherine Zeimet)

This is surely a beauty and a great addition to the Baby Ramblers. It grows to a height of twenty triches, and produces double pure white flowers in abundance. Of free compact growth postpaid, $15 \mathrm{c}$ each, 2 for $25 \mathrm{c}$. Large $2 \mathrm{yr}$. old plants, $35 \mathrm{c}$ each. Special Offer C.6. The set of 3 Baby Rambler Roses, 2 yr. old plants, one each of the 3 varieties, for only $90 \mathrm{c}$

\section{The Unexcelled LA FRANCE ROSES}

The La France Roses are of the highest merit, and each member of the family has particularly strong points; they are splendidly adapted for general

PINK IA FRANCE-The color of this is an exquisite shade of silvery pink tinged with crimson. The buds are large beautifully formed and the open flower exceedingly handsome, with a delightful fragrance. In continuous bloom all summer and late into fall until stopped by frost. $10 \mathrm{c}$ each, 3 for $25 \mathrm{c}$. Large 2 y . old, $25 \mathrm{c}$ each.

RED IA FRANCE-It is much deeper in color than its pink sister the center 10c each, 3 for 25c. Large $2 \mathbf{y r}$, old, $30 \mathrm{c}$ each.

STRIPED I,A FTANCE-In all respects the same as the pink, except that its petals are beautifnlly striped with a deeper shade of rose pink. $15 \mathrm{c}$ each, for 250 . Large 2 . old, $35 \mathrm{c}$ each.

WWITT IA FRANCE-Silvery white, with the faintest tinge of Rose blush. Buds and flowers are extra large and of splendid shape and
exquisitely perfumed. 10c each, 3 for $25 \mathrm{c}$. Large $2 . \mathbf{y r}$. old, 30e each. Special Offer. The Set of 4 La France for $25 \mathrm{c}$, postpaid, or

These famous Roses will give absolute satisfaction to every They bloom the first year and will be in bloom nicely indoors during the Winter months. There are no Roses them; certainly none better. If you try them, take our Special Price. Fine plants of the 3 Soupert Roses, postLarge 2 yr. old plants, $30 \mathrm{c}$ each or the set of 3 for only $75 c$.

\section{Chlotilde Soupert}

Known the world over and is one of the very best of all Roses. strong, dwarf grower and a truly wonderful bloomer, produccluster after cluster of the finest formed flowers. In form, cerfecty full and double and delicious sweet. The the center to silvery rose. Has no superior in the open ground. Hardy everywhere.

\section{White Soupert}

The genuine White Soupert. Identical in every way with ChloThe gentert $\mathrm{ng}$ and hardy, a new and valuable addition to this family.

\section{Yellow Soupert}

Everybody's Rose. The flowers are very double and of the same Camellia-like form as Chlotilde Soupert, and are produced in immense clusters; buds exceedingly dainty. A strong upright,
bushy grower. Color, white on beautiful light yellow ground; enter chrome yellow.

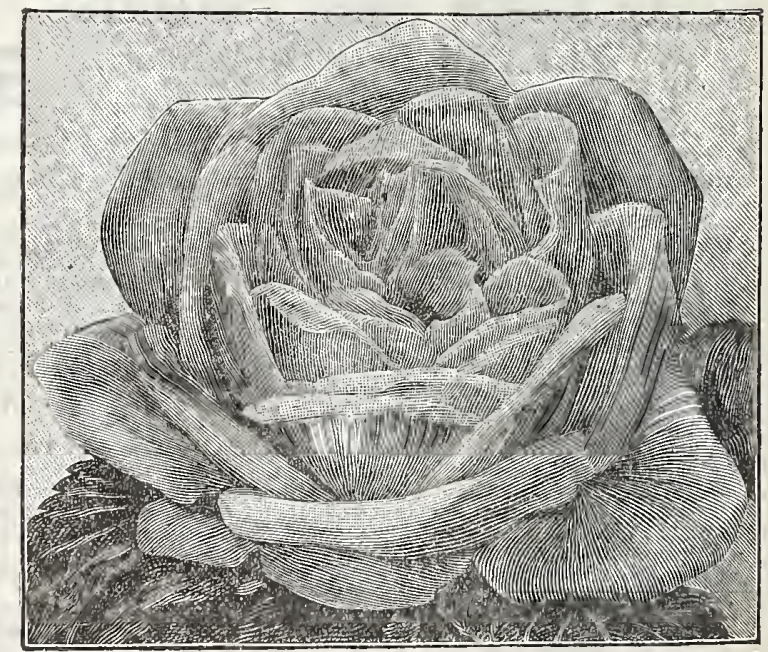

La France Rose. 


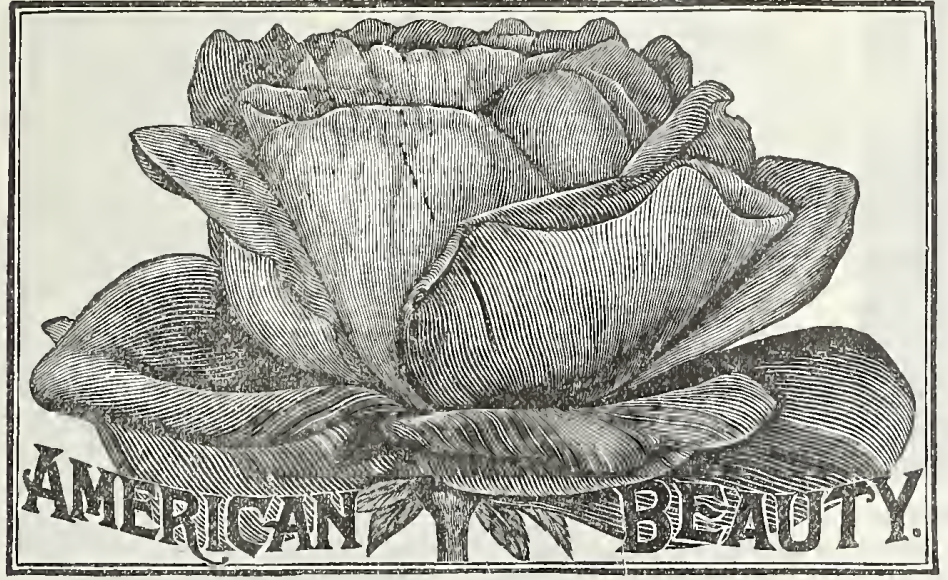

\section{Perpetual Roses}

The National
Rose of Americat

The Largest, Sweetest and Best of All Ilardy Roses.

Mole plants are grown and more flower's are sold of cultivation, and deservedly so, for it is one of the grandest and most beautiful Roses now known. It is a genuine Hardy, Ever-Blooming Rose. For immensity grance, it stands without equal. It is a quick and bushy grower, with splendid foliage, producing upo buds and large, deep, double flowers. Is valuable both Roses for and garden culture. $I$ is the peer of all thes for lorcing porposes, the flowers selling during rich. charming fashion. strong plants, postpaid, 20c each, for 50c. Large $2 \mathrm{yr}$. old plants, toc each.

\section{Prince Camille De Rohan}

This is a magnificent rese Hardy for its large, handsome, fragrant flowers and the free

The Magrificent Hardy Rose FRAU KARL DRUSKY The Best Hardy Whise Rose in Existence.

This magnificent fiose is the owly absolutely pure paid, $20 \mathrm{c}$ each, 3 for $50 \mathrm{c}$. Large $2 \mathrm{y}$, old plants, paid, each.

\section{CLIO}

A Beautiful Pink Hybrid Perpetual Garden Rose. One of the most beoutiful hardy Roses grown awarded two first-class certificates by the Roya Horticultural Society of England. Flowers very large, color flesh shaded in center to rosy-pink. Stroug plants, post paid, $15 \mathrm{c}$ each, 2 for $25 \mathrm{c}$. Large 2 yr. old plants, $35 \mathrm{c}$ eácli.

\section{MAD. CHAS. WOOD}

Bright fiery-scarlet, passing to a fire rosy-crimson Free bloomer. Strong plants, postpaid, 15e each, 2 for $25 \mathrm{c}$. Large 2 yr. old phints, $35 \mathrm{c}$ each. PAUL NEYRON

Probably the largest Rose in cultivation ald one of the best bloomers. Color a bright sining pink, each, 2 for $25 \mathrm{c}$. Large $2 \mathrm{yr}$. old plants, $35 \mathrm{c}$ eatreh. ULRICH BRUNNER, Crimson Beauty The color a rich velvety crimson, brilliant arid showy. Strong plants, postpaid,
Large 2 yr. old plants, 35 e each.

\section{GEN. JACQUEMINOT}

Famous the world over as one of the most mag. nificent Hardy Crimson Roses ever introduced Every one wants a "Teneral Jack"." St rong plants, postpaid, $15 \mathrm{c}$ each, 2 for $25 \mathrm{c}$. Large 2 yr. old plants, $35 \mathrm{c}$ each.
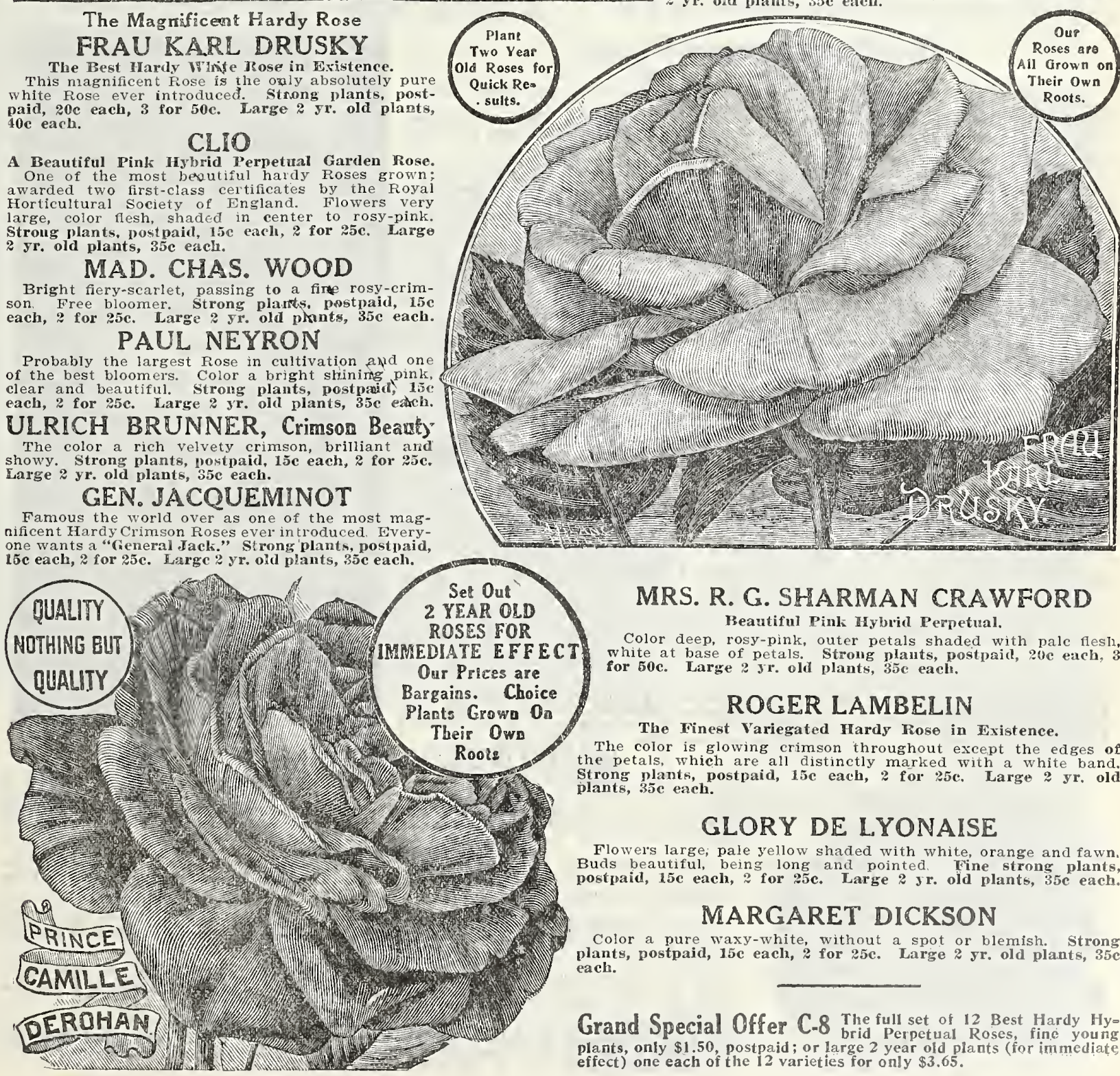

MRS. R. G. SHARMAN CRAWFORD

Beautiful Pinl Hrbrid Perpetual.

Color deep, rosy-pink, outer petals shaded with palc flest White at base of petals, Strong plauts, p
for 50c. Large 2 yr. old plants, $35 \mathrm{c}$ each.

\section{ROGER LAMBELIN}

The Finest Variegated Hardy Rose in Existence. The color is glowing crimson throughout except the edges of the petals, which are all distinctly marked with a white band. Strong plants, postpaid, $15 \mathrm{c}$ each, 2 for $25 \mathrm{c}$. Large $2 \mathrm{yr}$, old plants, 35c each.

\section{GLORY DE LYYONAISE}

Tare, pale yellow shaded with white, orange and fawn. Buds beautiful being long and pointed Fine stre and plants, postpaid, $15 \mathrm{c}$ each, 2 for $25 \mathrm{c}$. Large $2 \mathrm{yr}$. old plants, $35 \mathrm{c}$ each.

\section{MARGARET DICKSON}

Color a pure waxy-white, without a spot or blemish. Stron Conts, postpaid, $15 \mathrm{c}$ each, 2 for $25 \mathrm{c}$. Large $2 \mathrm{yr}$. old plants, $35 \mathrm{c}$

Grand Special Offer C-8 The full set of 12 Best Hardy Hy= plants, only $\$ 1.50$, postpaid or large 2 year old plants (for imuediate ffect) one each of the 12 varieties for only $\$ 3.65$. 


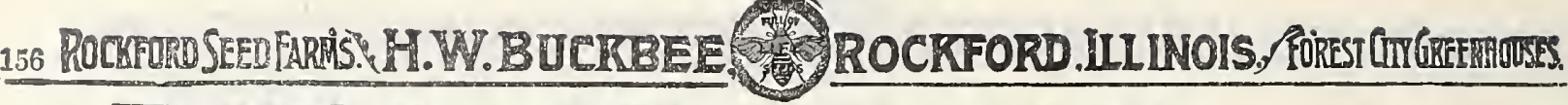

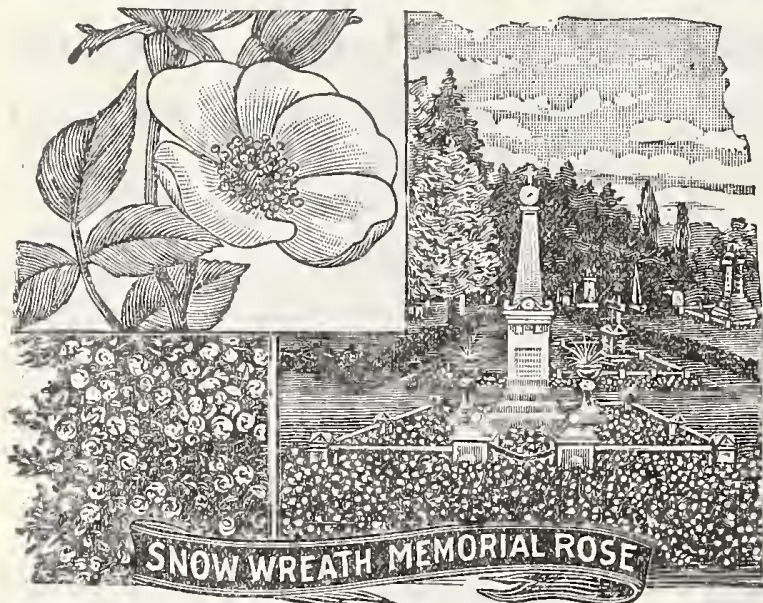

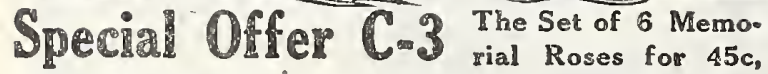

postpaid, or the set of 6 large 2 year old plants, for $\$ 1.50$

\section{Hardy Climbing Roses \\ Sure to Grow and Sure to Bloom.}

\section{The Hardy Memorial Roses}

\section{Especially Recommended for Cemetery Planting.}

Sometlmes called the Wichuriana Roses but approprlately classed as "Memorials" because everywhere acknowledged to be the most suitable and satisfactory Roses one can get for cemetery planting. They will climb when trained, or if let alone they creep along the green foliage. The leaves remain green on the plants nearly all Winter. They bloom in profusion during June and July, and the slngle ones bear red berries in the Autumn. Entirely hardy, and When planted take care of themselves. ers; bright and effective. One of the best in this section. Wach $15 \mathrm{c} ; 2$ for $25 \mathrm{c}$, postpaid. Large 2 yr. old plants, each 35c. JERSEY BEAUTY - Elegant single flowers, 3 inches in dlameter, pale yellow, very fragrant. Wach 10c; 3 for 25c, postpaid. Large 2 yr. old plants, each 35c. double to the center, pure white and very fragrant. Fach 10c, 3 for 25c, postpaid. Large 2 vr. old plants, each 25c. SWELTHART-Bright riomens. Flowers single, of good size and very fragrant. Each 10c, 3 for 25c, postpaid. Large 2 yr. old plants, each 35c. Hardy as grass, will grow in sun or shade, poor cround or rich. Makes a beautiful display of blossoms, very laree (often five or six inches around) pure satiny white with bright golden center. Each 10c, 3 for 25 , postpaid. Large 2 yr. old plants, each $30 \mathrm{c}$ UNIVERSAI. FAVORITW-Double bright pink, equally as beautiful as the double white and a charming companion for it. Each
$10 c, 3$ for $25 c$, postpaid. Large 2 y. old plants, each 25 .

Desirable for covering trellises, walls and porches, as they succeed under almost

ALBERIC BARBIER-Creamy-white with canary-yellow center; buds of orange-

yellow. Semi-double flowers in immense clusters. Each 15e, 2 for 25c, postpald. AMERICAN PILLAR-A new single flowering Rose with blooms three to five inches across, borne in immense clusters. Color lovely apple-blossom pink with bright
golden stamens. Wach 15e, 2 for 25 , postpaid. Large 2 \% r. old plants, each 35c. Flowers in beautiful clusters. Each 10c, 8 for 25c, postpaid. Large 2 yr. old plants, each 25c.
ARY WASHINGTON-A pure white, hardy constant blooming Rose of strong upright growth; blooms in clusters. Each 10e, 3 for 25c, postpaid. Large 2 yr. PRAIRIE QUEEN $\rightarrow$ Bright rosy pink, large, compact and globular flower. Blooms in clusters. One of the best. Each 10c, 3 for 25e, postpaid. Large 2 yr, old RUNNENG GENERAL JACQUEMINOT-Velvet-red, ever-blooming in clusters of decidedly fragrant flowers. Each 15c, 2 for 25e, postpaid. Large 2 yr. old plants, TRIER-Soft rosy-blush, becoming almost whlte, large clusters, full and double. Special Offer C.4 One strong plant each of the abovel $y$ Hardy Climbing Roseg for Climbing Everblooming Monthly Tea Roses

We have many inquiries for Roses that are both hardy and everblooming. The

following varieties combine both qualities if protected in Winter. In Southern or warm climates is a profuse bloomer, well grown specimens being loaded with thousands of blooms the entire season. A rapid grower, often plants, postpaid, $15 \mathrm{c}$ each, 2 for $25 \mathrm{c}$. Large $2 \mathrm{yr}$. old plants, 35e each. EMIRESS OF CHINA-A strong growing Rose, growing to a height of 15 to 25 feet in a single season. Produces throughout the season hundreds of handsome formed buds and flowers, of a soft dark red, changing to a lighter red or pink. Fine plants, postpaid, 15c eaeh, 2 for 25c. Large 2 yr. old plants, 30c eaeli.
CLIMISING NAPIE GUILLOT-Pure whlte, slightly tinted primrose at base of petals. A vigorous grower and free, continuous bloomer. Buds, beautiful, very Large 2 yr. cld plants, $35 \mathrm{c}$ each.

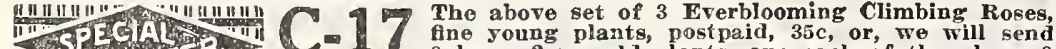

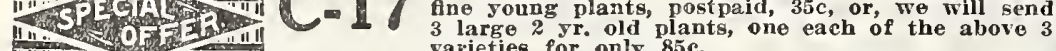

\section{BEAUTIFUL HARDY MOSS ROSES}

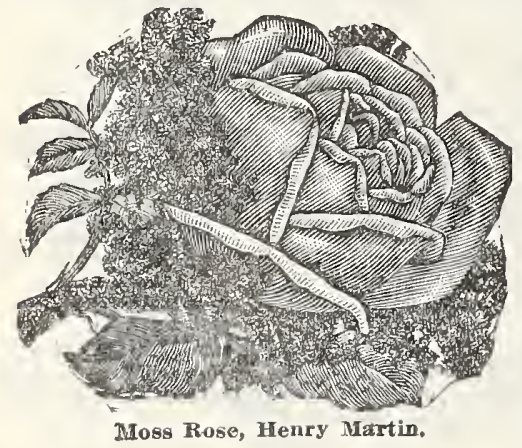

A class of Roses which are much admired. The beauty of the flower consists of the delicate mossy covering which surrounds the bud, and which gives the openlng flower a unique appearance. They are strong, vigorous growers, perfectly hardy and suitable for planting singly or in beds or clumps with other shrubbery. They bloom but once in the season. The moss is seen best on the buds before the flowers open.

Rich glossy light red, tinged with crimson; large globular flowers, very full and sweet; finely mossed. Price, strong'plants, postpaid, 20e each, 3 for 50c. Large 2 yr. old plants $40 \mathrm{c}$, each.

MOUSSELINE. fully postpaid, 15e each, 2 for 25c. Large 2 yr. old plants, 35c each.

PRINCESS ADELAIDE.

Rich, glossy plnk, tinged with crimson; large globular flowers, very full and sweet; finely mossed; one of the finest. Price, strong plants, postpaid, 15c each, 2 for $25 c$ Large 2 yr. old plants, 35c each.

"1" Ninis -9 -9 One each of these three beautiful Moss Roses in strong one3 , large $2 \mathbf{5 r}$. old plants for $\$ 1.00$. 


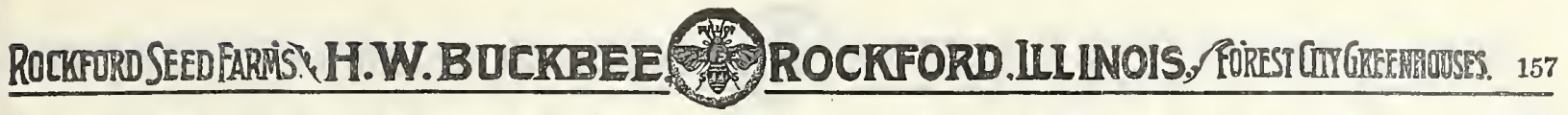
THREE GRAND NEW CLIMBING ROSES
FIOWET of FaIr Feld 1. THE EVER BLOOMING CRIMSON RAMBLER

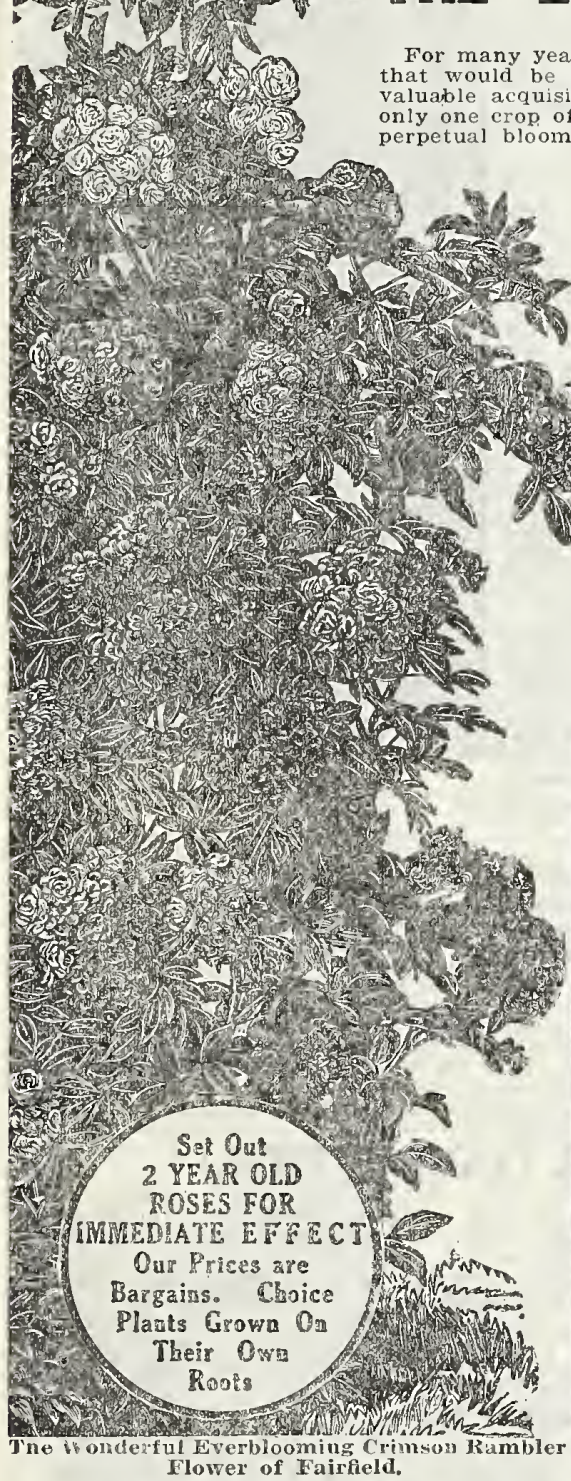

The Most Wonderful Garden Rose Introduced for Years.

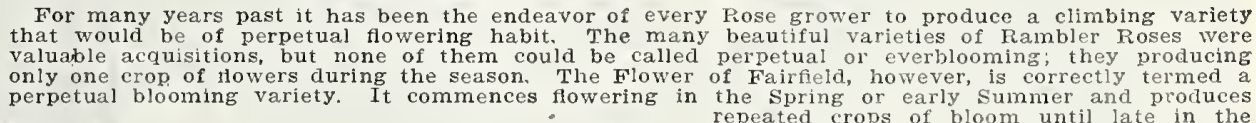

New Hardy Climbing Baby Rambler

\section{THE BLUE ROSE}

VEILCHENBLAU, or VIOLET BLUE NEWEST CLIMBING ROSE

"THE SHNSATION ON THE CENTURE.

After years of effort rosarians have been rewarded by the production of a blue Rose which will be welcomed with the greatest interest by all lovers of the garden. This color. The flowers appear in large clusters after the manner of the Crimson Rambler, and partly bright rose, turning soon to a steel blue. The color is best described by shining green foliage and few thorns. It has not been troubled by mildew and is fully. Be th first in your neighborhood to githstaing the Winters very successgenuine blue Rose; the true stock. of which is very limited. We urge that you place supply. Strong plants 15 e each; 2 for $25 \mathrm{c}$, postpaid. Large, 2 5r. old Plants, $30 \mathrm{c}$ each.

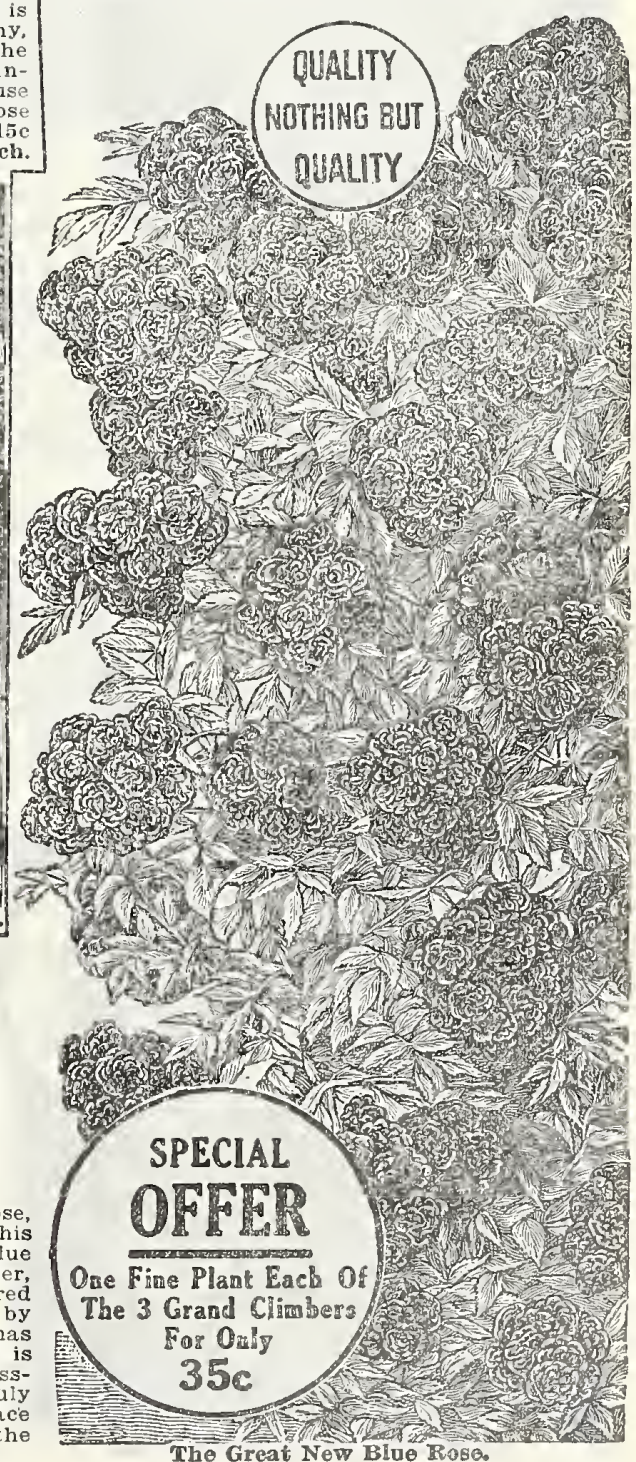



The Famous Climbing Rambler Hardy Roses

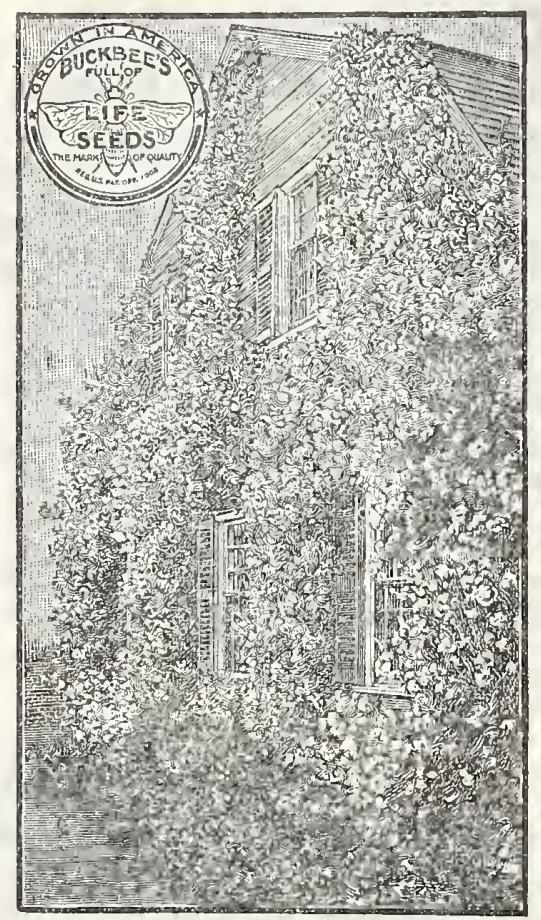

Tausendschon (Thousand Beautics)

Beautiful, Ornamental, Quick Growing

IMPROVED CRIMSON RAMBLER-The most is absolutely hardy in all localities, a most vigorous grower, a most prolific bloomer, fine for growing on trellises, unexcelled for covering porches, walls, etc., producing a gorgeous mass of crimson blossoms which remain 12 to 15 fect in song time. Often grows from postpaid, $10 \mathrm{c}$ each, 3 for $25 \mathrm{c}$. Large $2 \mathrm{yr}$. old plants, 25c each.

DOROTIIY PERKINS RAMBLER-As hardy as Crimson Rambler. Flowers about $1 \frac{1}{1 / 2}$ inches double. and crinkled. Color is a most beautiful shell pink and holds a long time without fading. Wine plants, postpaid, $10 \mathrm{c}$ each, 3 for $25 \mathrm{c}$. PHLAOELPHA RAIISLER-Pure "Crimson Rambler," and less subject to mil"Crim. Blooms two weeks earlier than the individual flower being larger. Fine plants. postpaid, 15e each, 2 for 25c. Large 2 yr. old PINK RAMBLER-(Euphrosyne)-Deep pink flowers borne in large clusters, 60 being frequently found in a cluster, Of vigorous growth, rarely attacked by disease. Fine
plants, postpaid, 10 ceach, 3 for 25c. Large 2 yr. old plants, 25c cach.

EATIBLER-We believe this Rose to be the very besit hardy, climbing Rose yet introduced. Color is a
beautiful cherry-pink; foljage a beautiful glossy green. Trusses containing nearly 100 buds and blossoms have been counted on merous, breaking out from the base to the summit, so that a most beautiful mass of bloom for 25c. Large 2 yr. old plants, 30c each.

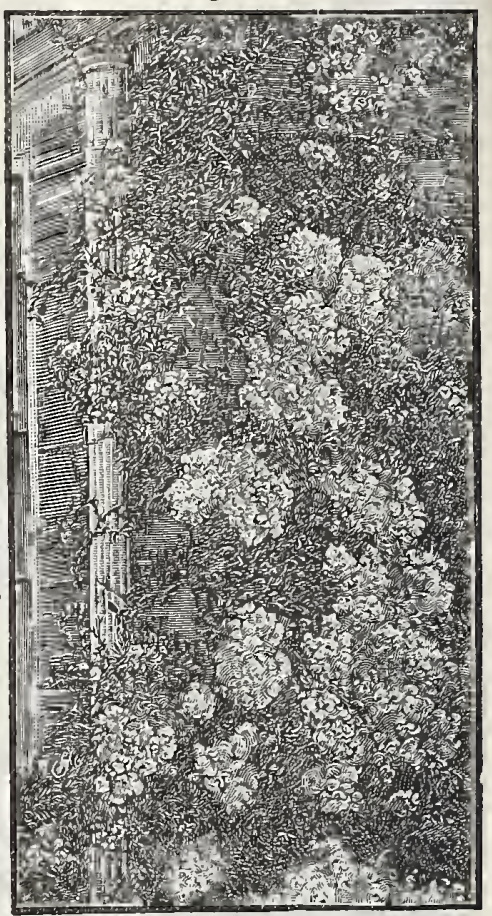

Dorothy Perkins

\section{JAPANESE ROSES}

NEW VELLOW RAMBLER-The flowers are borne in clusters, after the same manner as the Crimson Rambler. The color is Large 2 yr. old plants, 30c each.

NEW KAMBLER ROSE, TAUSENDSCHON OR 1000 BEAUTIES - It bears its flowers in immense clusters; in color a soft pink as they fully expand. Fine plants, postpaid, 15e each, 2 for 25c. Large 2 yr. old plants, $30 \mathrm{c}$ each.

NEW WHITE RAIBLER-Flowers of the White Rambler have the charm of being sweetly scented. Color a pure white, with-
out a blemish. Ihey remain on the bush from three to five out a blemish. They remain on the bush from three to five beauty. The habit of growth is vigorous, young plants throwing up shoots eight to ten feet in height in a single season.
Fine plants, postpaid, 10e each, 3 for 25c. Largo 2 yr. old plants, 30c each.

\section{wavin

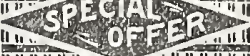

C.5 The Set of 8 Rambler Roses. postpaid, $75 \mathrm{c}$ or we will send 8 large? yr. ofd plants, one each of the 8 varieYr. ofd plants, one
ties. for only $\$ 1.85$.

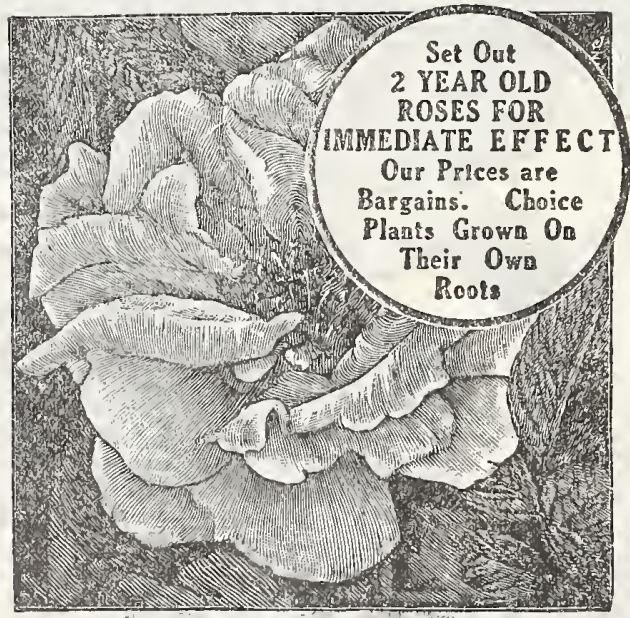

Sir Thomas Lipton-Kegota Rose.
Hardy Hybrid Sweet Brier Roses These lovely hybrids are crosses between the common sweet brier and variousinother Roses, and, like theix, parent, the foliage is delarge and produced in great profusion, and the plants are perfectly hardy, strong, vigorous brawers, throwing long, graceful

\section{Annie of Geierstein}

Large handsome, deep crimson fowers, graceful branching habit; delightfully fragrant. Price, 15e
each, f for 25c, postpaid. Large each, 2 for $25 \mathrm{c}$, postp. old, $35 \mathrm{c}$ each.
$2 \mathrm{rr}$.

\section{Amy Robsart}

Robust grower ond free bloomer. Beautiful deep rose-cotored
flowers. Price, 15c each, 25e. Large 2 yr. old, 35c each.

\section{(HARDY REGOSA ROSES)}

apanese Roses make dense, sturdy, compact

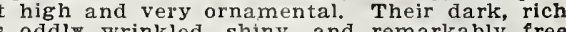
the large fragrant double and semi-double in profusion throughout the Summer, and Ath a profusion of beautiful orange Excellent for making hedges or planting on the bery or in isolated groups. If you want someThe best two varieties are the following:

\section{SIR THOMAS LIPTON}

\section{AGNES EMILY CARMEN}

It ls semi-double, and flowers in clusters; a beautiful crimson shade like General Jacqueminot; a free and continuous bloomer. A rampant grower, handsome foliage. Price 15c each, 2 por 25c, 2 yr. old, $35 \mathrm{c}$ each.

\section{BUCKBEE'S XX INSECT SOAP}

\section{For House and Garden Plants.}

A wonderful insect pest exterminator and unsurpassed for use on ail plants and flowers in and out of doors. It is harmless and noninjurious to the tenderest rrowth and can be uscd with perfect safety on all plants. It also acts as valuable fertilizer in reviving and giving ncw life to partly diseased plants, prevents leavcs from cropping and foliage turning yellow. It is odorless, clean and easy to handle-a small piece dissolved in luke-warm water and stirred well until it suds-then applied to plants, either with spray, or washed well with a soft sponge is sufficient for two gallons prepared solu. tion, mailed, postpaid, for $25 \mathrm{c}$.

\section{Tobacco Dust}

One of the best remedies for green and black ayhis, fleas, beetles, etc. Lb., 26c.. postraid. 


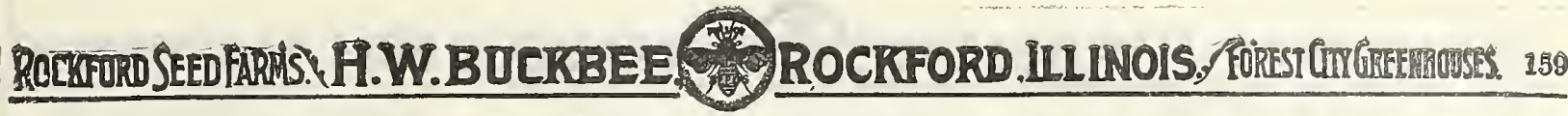

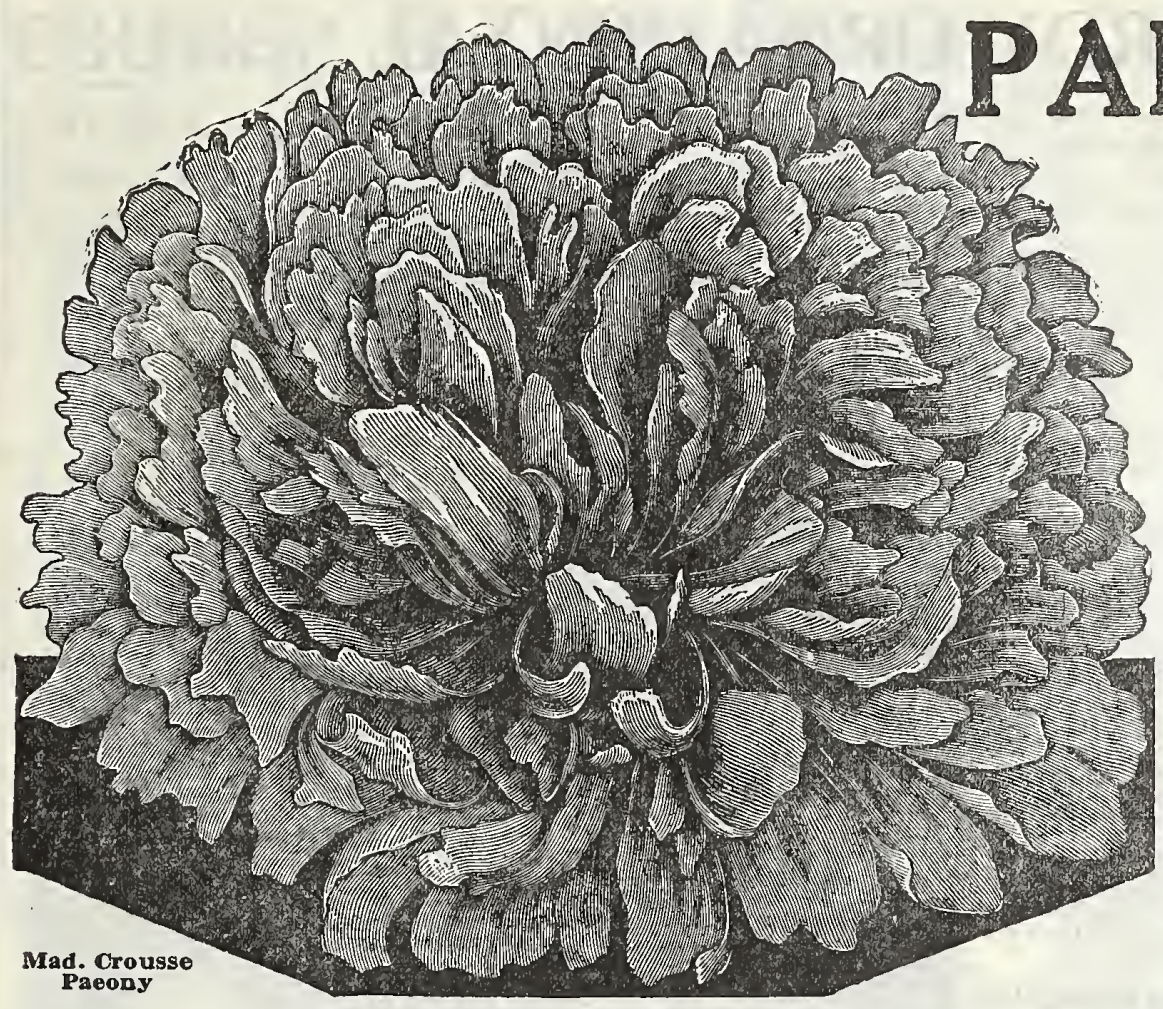

GERMAN IRIS (FLEUR-DE-LIS)

The German Iris is one of the most desirable eariy Spring-flowering plants. No garden is complete without a collection of these beautiful fags. We especialiy wlsh to call attention to the vaiue of this Irls for groups for planting in masses on the lawn or among shrubbery, or for naturalizlng in wild or uncultivated piaces. It is

BLACK PRINCT Each, 20c, postpaid.

CELESTE-Bright satiny blue. Each, 15c, postpaid.

DAWr-Lemon yeliow, purple edge. Wach, $15 \mathrm{c}$, postpaid. HER MAJESTY-Beautiful rosy liiac. Fach,
20c, postpaid.

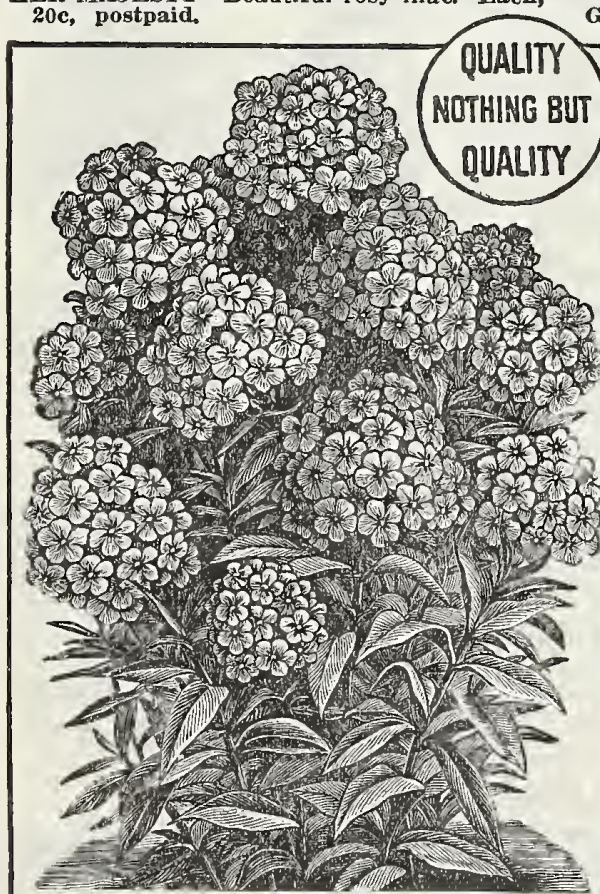

Hardy Perennial Phlox Coquelicot.
MADANE CHEREAC-White frilled violet. Each, 20c, postpaid. postpaid.

Special Offer E6. The set, one each of German Iris, postpaid, for only....75c.

\section{HARDY PHI_OX}

No ciass of Hardy Perennials is of more importance than the from the end of June untll late in the Fall; and while they wlll continue in good condition and flower freely for many years without attention, still they are much lmproved by ilberai cultlvation. Although there are qute a number or different vafined ourselves to six of the newest and rarest sorts, which are, wlthout doubt, the cholcest that has ever been offered. CHATEAUBRTAND - Pu r white with crimson, carm COQUELICOT-Orange red and F. G. VON LASSBURG-The purest whit

INSPTCTOR PIETER-Purplish mauve.

PANTHEON-The peorless pink. Extra large.

BELMA-Light salmon, with

Price, any of the above choice varietics $15 \mathrm{c}$ each, postpaid. SPECIAL OFFER E9. The Set of Six Best Hardy $60 \mathrm{c}$.
Phlox, postpaid, ONLY most any conditions and flower

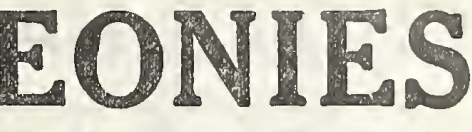

No flower exceeds them in popularIty, and none are more easily grown. "Pveryone lnows the old-fashioned There is no other flower that will give you sueh an attraetive display of fowers and supply of cut llowers. take care of themselves, and are well adapted for planting in the border bed or in solid beds. "They are among the showiest and most nseful of ail hardy plants.

Wach Deliction a deep rich Dorchester-Shell pink plnk......3 Duehess de Nemours-Pure white.35e Duchess of Wellington - SuiphurLmily Lemoine - splendid rich red.30e Festiva Maxima Pure white.....35c Jules Calot-Bright pink........30 Jouis Van IIoutti-Bright red...30c Louis Van llouttil-Bright red....30c Modele de Perfection-Large, flesh

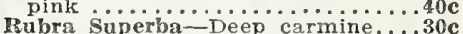
Rubra superbant double white..30 Zada-A delicate soft pink......25e Special Offer E7. 3 best Paeonies, Festiva Maxima, Delieatissima and Rubra superba for 80c postSpecial Offer E8. one each of Yenus and rada paeon hi ef $t$ a in, fenus and zada Paeozies 50 c. Post-
paid.

\section{JAPANESE IRIS}

\section{(Iris Kaempferii)}

These magniflcent Iris are among the most beautiful of our Summer-flowering plants, and are becoming more popular every season. They commence continue for five or six weeks. Many of these flowers measure from 10 to 12 in. in dlameter, and rlval the Orchids in their rich colorings and markings. colors, each 15c; $\$ 1.50$ per dozen.

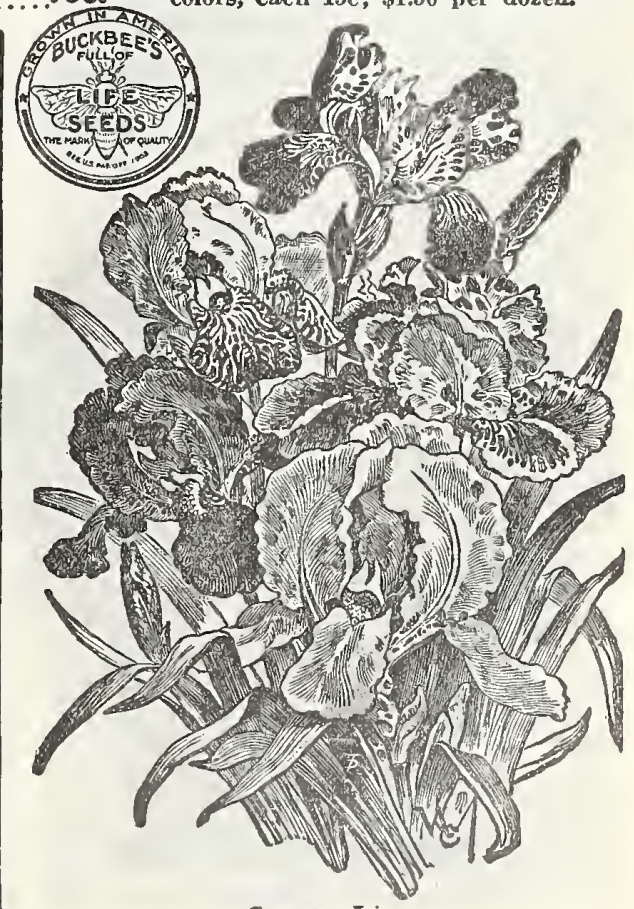

Gepman Irio. 


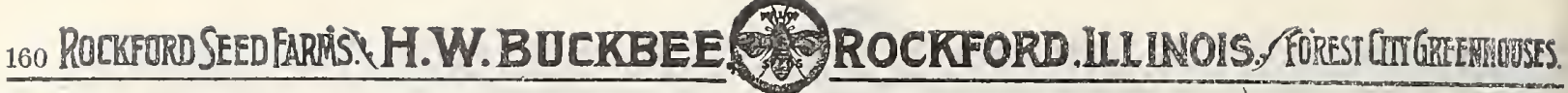

\section{CHOICE HARDY ORNAMENTAL SHRUBS}

No flowering plants are more worthy of cultivation than shrubs and none can be cultivated more easily.

Shrubbery is indispensable for it has all the artistic advantages and all the practical ones as well. The first cost is the only cost, and the plants greatly increasing in size and beauty year after year, make an investment which yields an annual dividend of loveliness not to be computed in any ordinary way.

\section{MAGNIFICENT NEW HYDRANGEA}

\section{"HILLS OF SNOW"}

Immense snow white panicles of blooms, literally covering the bush; absolutely hardy, standing 20 degrees below zer@ without the least injury.

This magnificent, hardy American shrub is the finest addition to this class of plants found in many a sear. The heads of blooms, which are of large size and pure snowthe color are produced in marvelous profusion covering flowers. The foliage is finely finished, lacking entirely that coarseness found in so many of our best known shrubs. One of the most valuable characteristics is its coming into bloom just after the passing of all the early Spring shruhs While its long season, from early June, through September, renders it doubly valuable, not only to the florist for cutflowers, but also to the owner of a garden-as there is no shrub so grandly decorative. The large heads of bloom are superbly attractive, and the habit of the plant is excellent. This splendid hardy shrub is b most widely grown just as soon as its great value becomes growing and can offer them to you at the following ver reasonable prices: Strong Plants, postpaid, each 15c 2 for 25̌c; doz. \$1.35. By Express, not prepaid, Larger Plants, each, 35e: doz. \$3.50; or, Extra Large Plants, each, 50c; doz., \$5.00.

HYDRANGEA-Paniculata Grandiflora THE MOST POPULAR OF ALL HARDY SHRUBS.

Hundreds of thousands of them are sold every year and the demand is constantly increasing. Unsurpassed for the lawn, a hedge, or for cemetery planting. It readily attains a height of 5 to 7 feet; hardy in all localities, needs no protection in Winter; blooms the first and every season in July and August and continues to bloom for two or times ten inches in length, and changing from the original pure white to pink, and finally to a beautiful rich coppery Larger Plants, by Hispess, not prepaid, each, 20̃c; doz. \$2.50. IItra Large Plants, each, 35c; doz.\$3.50

\section{Snowberry}

A well-known dwarf shrub with small pink flowers and large white berries that hang on the plant the greater part of the winter. Highly valued for use in densely shaded situations where little else will grow and for the striking beauty of their bright,
Plants, each $15 \mathrm{c} ; 2$ for $25 \mathrm{c}$, post paid.

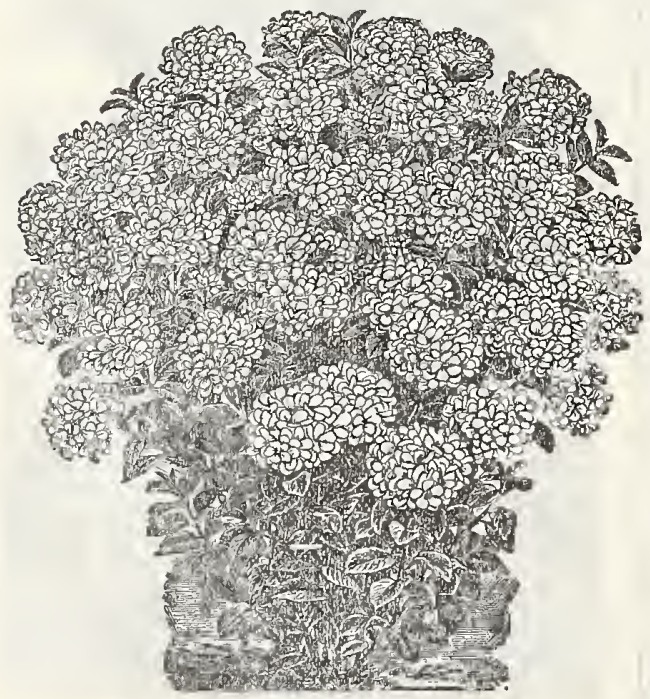
a to 8 feet in helght, blooms in June and for a lonetine the plant ethereal whitenesslite striking of all hardy decorative plants. Price, $15 \mathrm{c}$ each; 2 for $25 \mathrm{c}$, postpaid. Larger Plants, 35c to $50 \mathrm{c}$ to $75 \mathrm{c}$ each, shipped by express, not prepaid.

\section{Spirea, Bridal Wreath}

This lovely old-fashioned shrub is always popular, and justly so, because of its real beauty; bears large spirals of densely crowded double white flowers, each blossom like a miniature rose, the entire length of the branches-and they appear
by the million-hence the common title of "Bridal Wreath." A beautiful floral wreath is made at once by bending and tying the ends of the branch together. One of the most beautiful hardy shrubs in existence. Fine Plants, 1 5e each; 2 for $25 \mathrm{c}$, postpaid.

\section{Spirea, Anthony Waterer}

Makes a dwarf bush A PHRPTUAL BLoOMER. Fall with large heads of lovely crimson fowers, covered from spring until latc in the peculiar feathery appearance, which is beantiful. Flowering profusely when only a or whercver a low bush is required. Fine Plants, $15 \mathrm{c}$ each; 2 for 25c, postpaid.

\section{Sweet Scented Shrub}

Of spreading growth Spicy Fragrant Flowers. dull brownish purple flowers of exquisite aromatic strawberry-like fragrance. The wood and leaves are also sweet scented, which causes it to be known as SweetScented Shrub and Strawberry Shrub. Each 15c; 2 10r 25c, postpaid.

\section{Sweet Pepper Bush (Clethra Alnifolia)}

A low-growing shrub with dense, pale green foliage covered with spikes of delightfully fragrant white flowers, producivit frotth July to October, whinen fiowers are of such value. A hedge of it fully equals the wonderful Jessamine hedges of
the South, both in beauty and fragrance. Strong Plants, each 15c; 2 for 260 . 


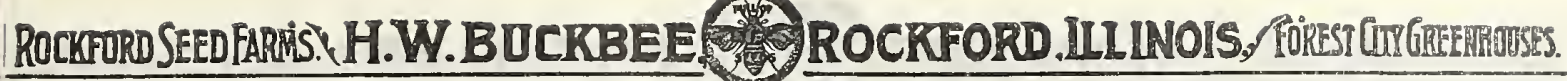

\section{Persian Tree Lilac}

Popular Favorites for Thoir Beauty and Perfume.

A neat, handsome little tree, growing seven to eight feet high, with slender branches and long narrow foliage; the flowers grow in immense clusters, delightfully and deliciously sweet and fragrant. It is perfectly hardy, a vigorous grower and flowers bloom with a fragrance and beauty that is surpassed by no other shrub. Nearly every one is fond of Lilac blossoms and with the revival of the old-fashioned garden their popularity increases. A general favorite for planting in the dooryard and lawn. Wo offer nice, strong plants.

Persian Blue, $15 \mathrm{c}$ each; 2 for $25 \mathrm{c}$ : postuaid.

Persian White, 15c each; 2 for 25c; postpaid.

\section{Deutzia Lemoinei}

One of the best of hardy shrubs. Magnificent broad dense heads of bloom, opening very full, pure snowy white, each panicle forming a veritable bouquet and completely covering the brush. A great improvemeing upon larger and more enduring and the bush a stronger grower. Strong plants, eacl 15c; 2 for 25c; postpaid.

Mrs. E. B. Hibbard, Rochester, Wis., writcs: We had very fine luck with your plants. I purchased your 50 cent collection last spring, have a vase of the "Chrysanthmany flowers on one plant as the Fuchsia had.

\section{Everblooming Fragrant Butterfly Bush \\ A Show Plant for Every Garden, Perfectly Hardy}

This shrub, from a young plant, will grow to its full size and maturity in less than three months, giving the grower the opportunity to admire all its features the very first year. Its growth is instantaneous, branching directly above the ground into many long, graceful flowering stems, which attain a height of $41 / \mathrm{ft}$. and terminate with long tapering panicles of claret colored flowers. The individual flowers, which are of miniature size resemble that of are borne by the lut \begin{tabular}{l|l} 
axtends from 6 to $8 \mathrm{in}$. long. A single plant will bear at one time from \\
12 to 18 of these flowering stems, and the most remarkable feature is
\end{tabular} \begin{tabular}{l|l} 
axtends from 6 to $8 \mathrm{in}$. long. A single plant will bear at one time from \\
12 to 18 of these flowering stems, and the most remarkable feature is
\end{tabular} \begin{tabular}{l|l} 
axtends from 6 to $8 \mathrm{in}$. long. A single plant will bear at one time from \\
12 to 18 of these flowering stems, and the most remarkable feature is
\end{tabular}

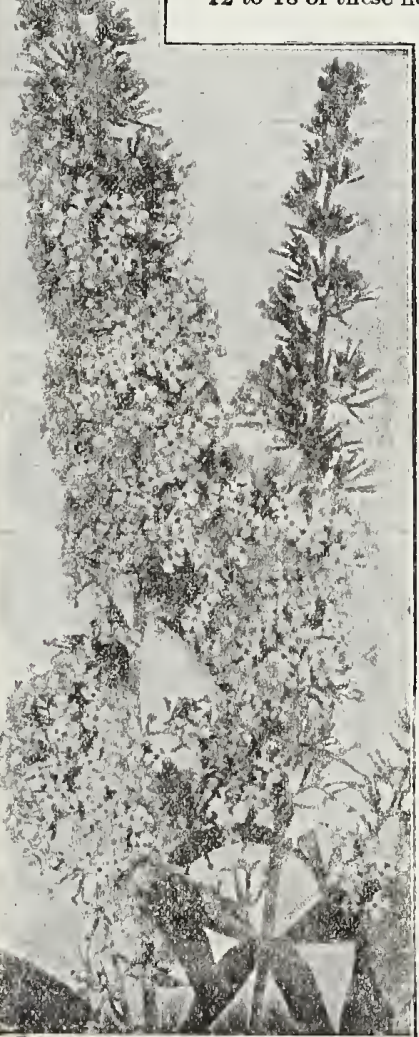

Euttertly Bush. early June till the snow flies. A remarkable attribute is the incomparable fragrance, of which its like we know no other. The fragance of a single plant will perfume the air of a large garden the entire season. The foliage is not less attractive, being decp green on the surface and silvery gray underneath, of elongated form and dis the stem from the ground to crown. butterfies, fitting to and fro, giving animation to an otherwise dead garden, and it is for this reason alone it is namcd the "Butterfiy Bush." Price, strong, thrifty plants, 20c each; 3 for 50c: postpaid.

\section{OUR GRAND Special Offer E5}

\section{Best Hardy Shrubs}

\section{HYDRANGEA.}

1 SWEET PEPPER B USH.

1 DEUTZIA LEMOINEL.

1 JAPANESE SNOWBALL

1 MOCK ORANGE OR S YRINGA.

1 PERSEAN TREE LILAC.

1 SPIREA.

1 SNOWIERR

1 SWEET SCENTED SHRUB.

For $\$ 1.00$ Wo will send one plant ties by express, not prepaid. Or for $\$ 1.25$ we will send the by mail, postpaid.

\section{This Is A Real Bargain}

They are all perfectly hardy and when established will bloom on and on. year after year, with little or no attention and make a handsome display of brilliant flowers every season.
Syringa, Philadelphus

Coronarius, a well-known, indispens able hardy shrub of vigorous habit, with large handsome foliage and beautiful creamy white flowers, deliciously fragrant and borne sirable. Strong, thrifty plants, $15 \mathrm{c}$ each 2 for $25 \mathrm{c}$; postpaid.

Weigela, Eva Rathire A remarkably frco bloomer, flowering continuously throughout the summer and a rich ruby-carminely distinct color, being along the branches. One of the finest all around flowering shrubs. Strong plants, 5c oach; 2 for $25 \mathrm{c}$; postpaid.

\section{New Hardy Climbing}

\section{Hydrangea From Japan.}

In this beautiful new climbcr we have a trum magnincent adidition to the line mates. The foliage is a bright green and the flowers which grow in numerous umbels are or a creamy white and last a long time. It is a very rapid grower, and in a short time covers any object it is planted around on to dense mantle of greenery. It holds and twines around any object it is intended should give it a trial. Extra strong grown Rot Plants, sure to grow on without check when planted, $35 \mathrm{c}$ each, postpaid. 


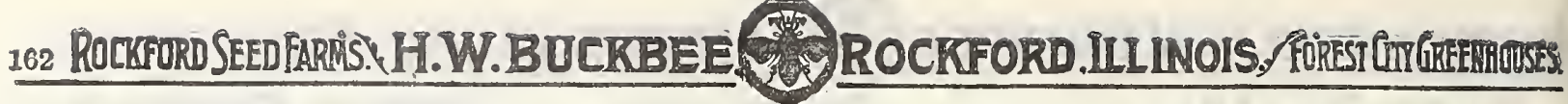

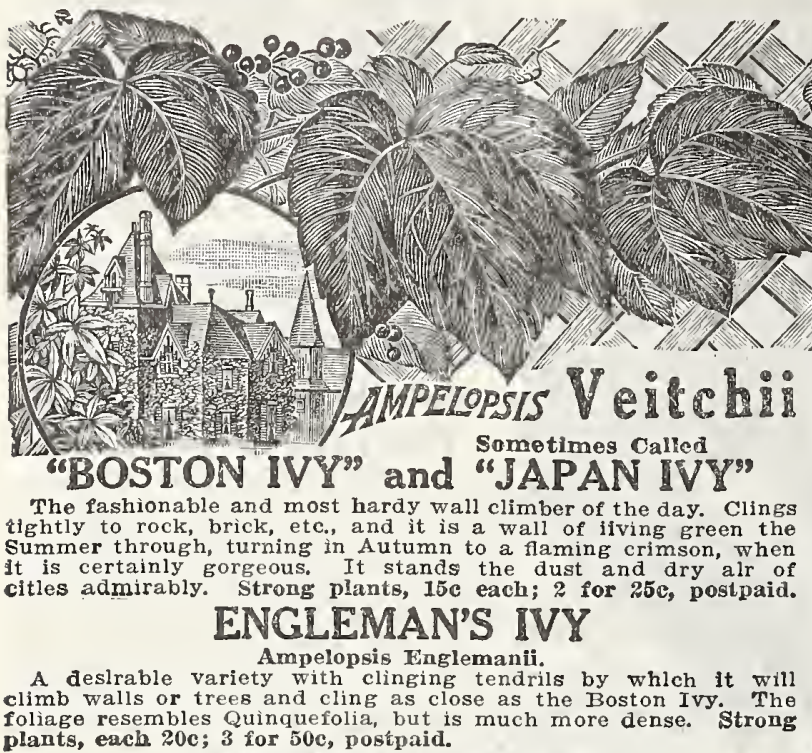

\section{VIRGINIA CREEPER}

Ampelonsis Quinquefolia.

A native vine of rapid growth, with large, luxurlant follage which in the Autumn takes on the most gorgeous coloring. Strong plants, each $15 \mathrm{c}$; i for $25 \mathrm{c}$, postpaid.

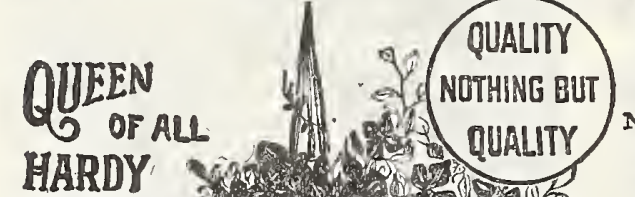
[LIMERS

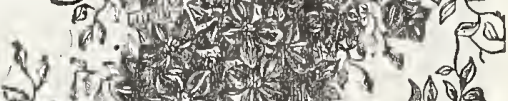

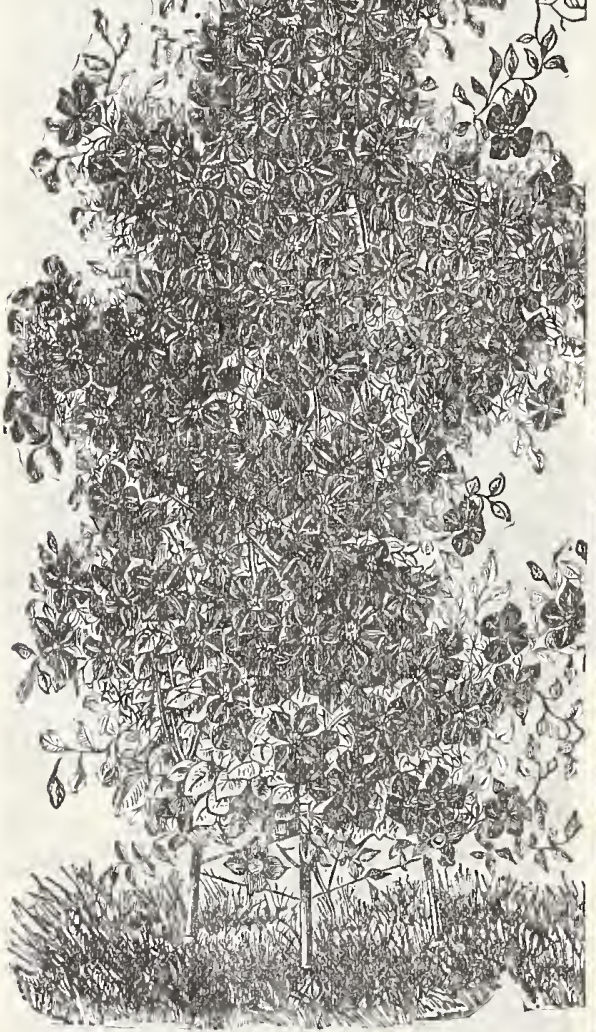

Beautiful Jackmanii Clematio each, postpaid.

BEST HARDY

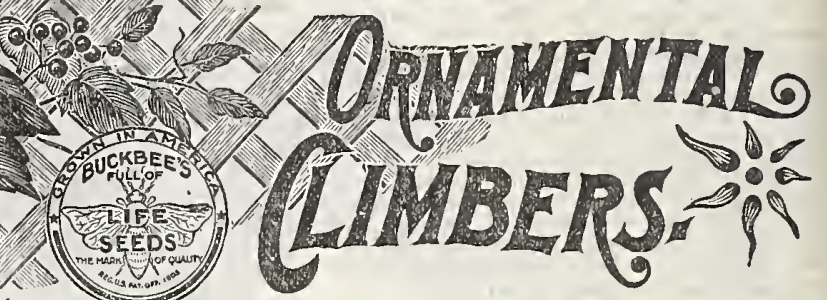

ClEMATIS-Hardy Perpetual Flowering Of all the vines used either for shade or decoration, none can ducing hundreds and thousands of picturesque and strikingly beautiful blossoms.

BEAUTIFUL JACKMANT-A perfect beauty, 5,000 blossoms have been counted on a sinsle specimen plant. Jackmanii is of rapid growth, early, abundant and continuous bloomer. Per fectly hardy and adapted to all klnds of culture. In fower from midale of June to middle of October. The blossoms aire of large size, intense royai velvety-purple when in full bloom, varying through all the exquisite shades of vlolet; 6 inches across, richly velned and handsomely shaded. The most striking and picturesque variety known. Strong field-grown, 3-yearold roots, price 50e each, postpaid.

CLEMATIS, PANICULATA-(Japanese Virgin's Bower)-One of the most beautiful of our hardy flowering vines. The flowers of pure white, three-fourths of an inch in diameter, starshaped, and are borne in great panicles or clusters of bloom fairly covering the plant These clusters are borne on long, slender stems, which stand out boldly from between the glossygreen leaves. The fragrance is delicious, resembling the EngIt berins to blom in Aupu t a of blom of bloom-an inestimable advantage. It is a strong, rapidgrower, quickly reachstrings. It is perfectly hardy in all sections of the country, and it is, in our opinion, the most valuable among hardy climbing vines. A grand porch cllmber 1-year-old, $15 \mathrm{c}$ each; large, strong $2-y$ ear-old roots, $25 \mathrm{c}$ each; 5 for $\$ 1.00$, postpaid. NEW RED CLEMATIS-(Mad. Edouard Andre)-An entirely distinct, and most novel variety, and the nearest approach to a red ever sent out. Thousands of flowers produced on a single specimen plant. Large 3-year-old roots, price, 50c

CLEMATIS, HENRY IT-Fine, large, creamy white flowers. The very best of the white varietles; a perpetuai bloomer. Large field-grown roots, 3 years old, only 50c each, postpaid.

STANDISHE-One of the most striking beautles ever offered. In color it is a most exquisite lavendtr-blue of large size, often measuring 6 inches across. Thousands beauty. It is a perpetual bloomer. Large roots, 3 years old, 50c each, postpaid.

SE. If In all instances we would advise that Clematis plants be shipped

\section{MOUNTAIN BEAUTY VINE}

\section{(ANTIGONON LPPTOPUS)}

A beautiful New Climbln Vine not quite hardy here but specially recommended A but 作

shaped. Price, fine strong plants, $15 \mathrm{c}$ each; or 2 for $25 \mathrm{c}$, postpaid.

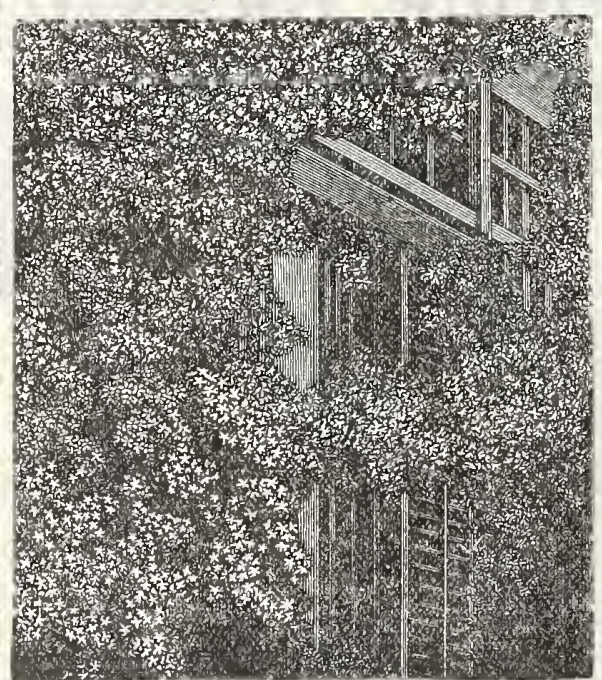

Clematis Panículata.

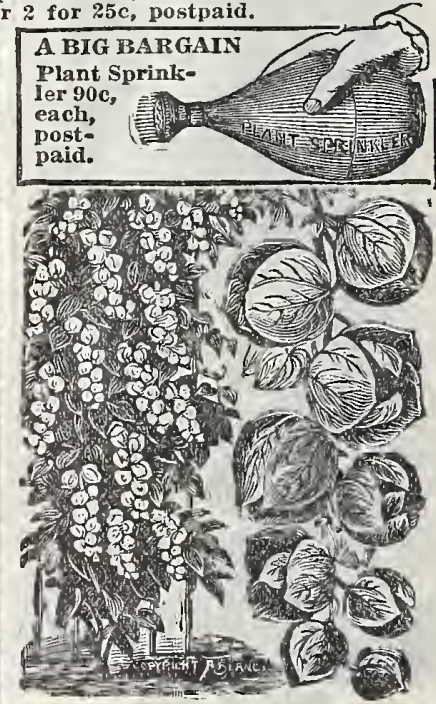

Mountain Beauty Vine. 


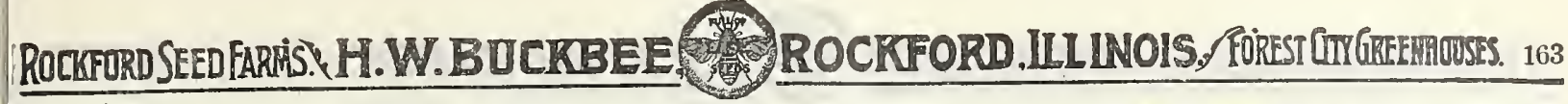

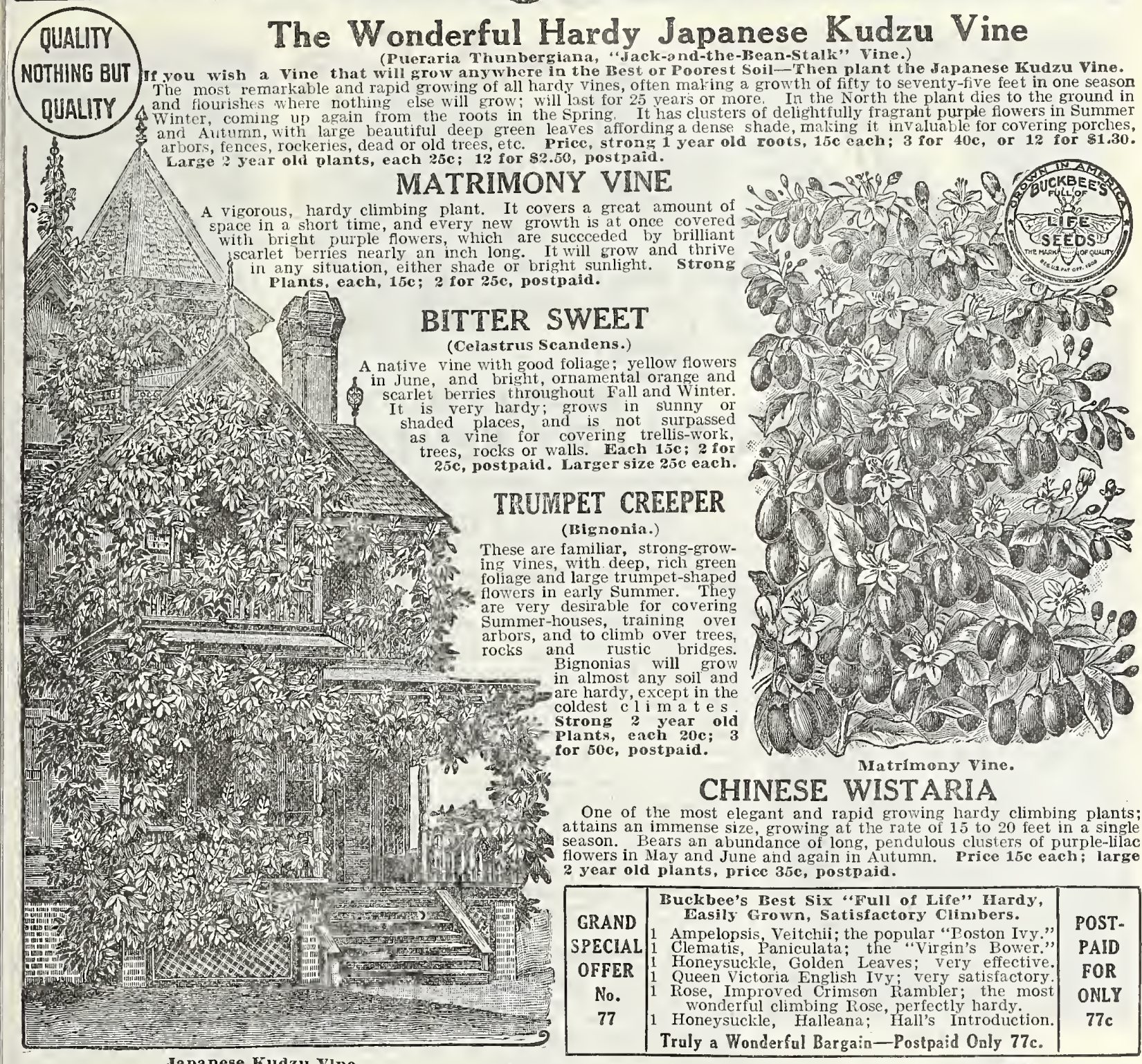

Japanese Kudzu Vlne.

HONEYSUCKLES

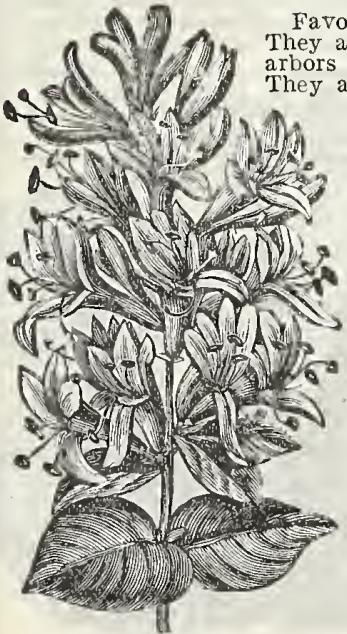

them for creeping over dumps and unsightly places as well as for retaining purposes on slopes and banks. places where grass will not grow.

HALLEANA - (IJall's Japan)-For real home vines to climb over your windows and doorways there is Halleana is considered by many the sweetest and most beautiful of all. It is a strong, rapid grower, perfectly hardy. Blooms constantly and profusely from June to November. Flowers are pure White fragrance. Fine for trellises or piliars. Foliage bright, glossy green; makes dense shade. Strong plants, $15 \mathrm{c}$ each; or 2 for $25 \mathrm{c}$, postpaid.

GOLDEN LIEA VES-MIarvelously effective. It bears innumerable sprays of the most perfect little leaves, that are covered with a network of gold and green white blosedoms. A unique vine. Strong plants, 150 each, or 2 for $25 \mathrm{c}$, postpaid.

SPECIAL OFEER:- For only 25c I will send

SPECIAL, OFLER:- For only $25 \mathrm{c}$ will send
postpaid one fne plant each of the two varieties Beautiful Boneysuckles. postpaid one fine
of Homeysuckles.

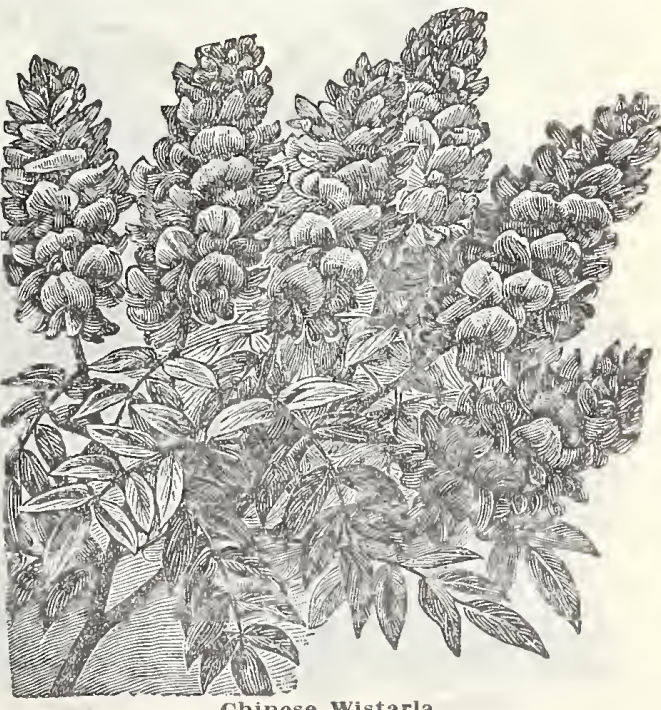

Chinese Wistarla. 


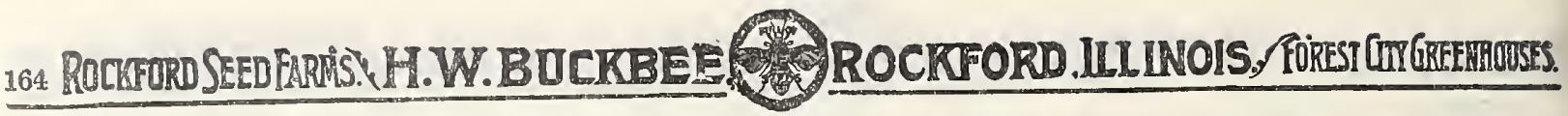
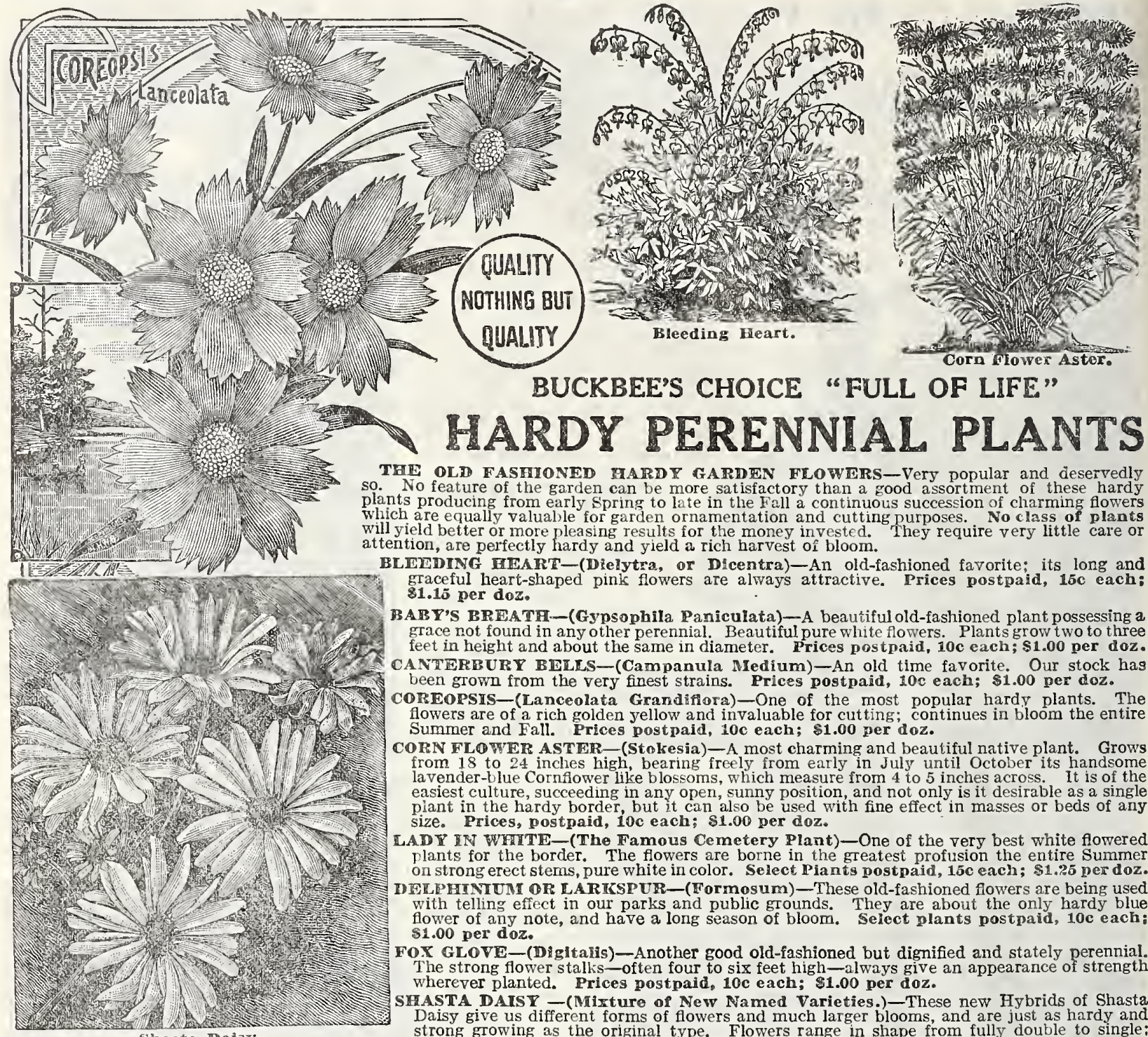

\section{BUCKBEE'S CHOICE "FULL OF LIFE"}

\section{HARDY PERENNIAL PLANTS}

THE OLD FASTIONED GARDT GARDEN FLOWTRS-Very popular and deservedly No feature of the garden can be more satisfactory than a good assortment of these hardy plants producing from early spring to late in the Fall a continuous succession of charming flowers whill yield better or valualle for garden ornamentation and cutting purposes. No class of plants attention, are perfectly hardy and yield a rich harvest of bloom.

BLERDING HEART-(Dielytra, or Dicentra)-An old-fashioned favorite; its long and graceful heart-shaped pink flowers are always attractive. Prices postpaid, 15c each:

BABY'S BREATH-(Gypsophila Paniculata)-A beautiful old-fashioned plant possessing a grace not found in any other perennial. Beautiful pure white flowers. Plants grow two to three CANTRRBURT BILLS-(Campanula Medium)-An old time favorite. Our stock has been grown from the very finest strains. Prices postpaid, 10c each; $\$ 1.00$ per doz.

COREOPSIS-(Lanceolata Grandifiora)-One of the most popular hardy plants. The flowers are of a rich golden yellow and invaluable for cutting; contin
Summer and Fall. Prices postpaid, 10c each; $\$ 1.00$ per doz.

CORN FLOWER ASTER-(Stokesia)-A most charming and beautiful native plant. Grows from 18 to 24 inches high, bearing freely from early in July until October its handsome lavender-blue Cornflower like blossoms, which measure from 4 to 5 inches across. It is of the plant in the hardy border, but it can also be used with fine effect in masses or beds of any size. Prices, postpaid, ioc each; $\$ 1.00$ per doz.

LADT IN WhTTE-(The Famous Cemetery Plant)-One of the very best white flowered plants for the border. The flowers are borne in the greatest profusion the entire Summer on strong erect stems, pure white in color. Select Piants postpaid, 15c each; \$1.25 per doz.

IFIPHINIUM OR IARIKSPR-(Formosum)-These old-fashioned fiowers are being used with telling effect in our parks and public grounds. They are about the only hardy blue $\$ 1.00$ per doz.

FOX GLOVE-(Digitalis)-Another good old-fashioned but dignified and stately perennial. The strong flower stalks-often four to six feet high-always give an appearance of strength wherever planted. Prices postpaid, 10c each; $\$ 1.00$ per doz.

SFASTA DAIST -(Mixture of New Named Varieties.)-These new Hybrids of Shasta (low and in color, from pure white to pale lemon yellow - some solid color, some prettily variegated with yellow dises. The plants are extremely productive of bloom, which continues through-

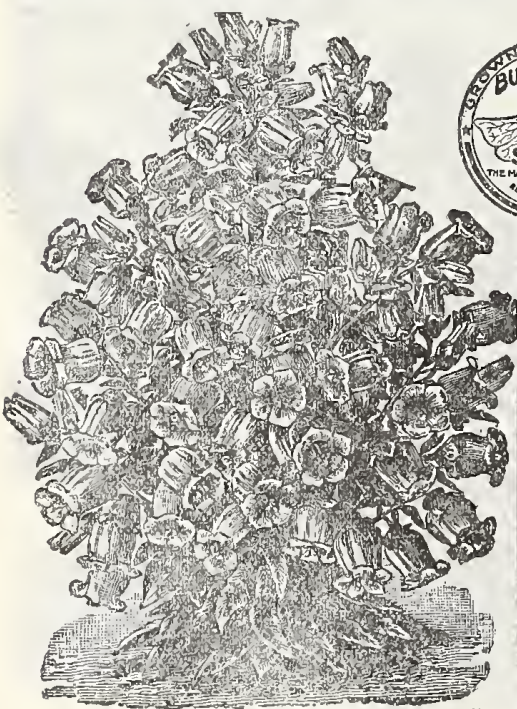

Canterbury Hells.

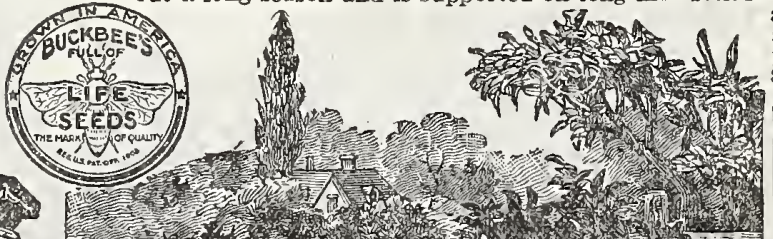
and as profitable a cut flower supply plants, prices postpaid, $10 \mathrm{c}$ each: per doz.

Hardy Perennials Last for are especially useful as cut flowers

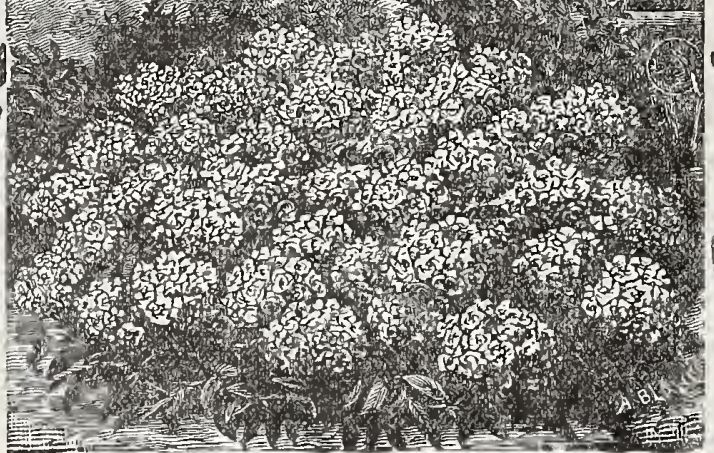

Lady in White-The Famous Cemetery Planb.

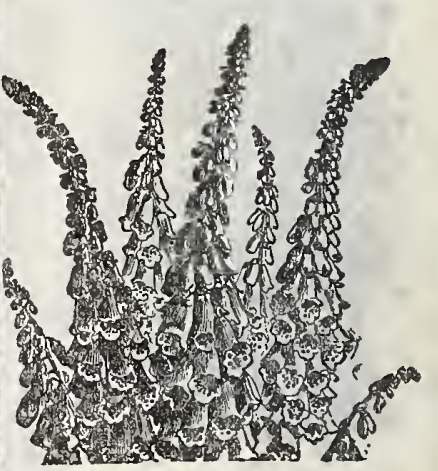

For Glove. 
1.

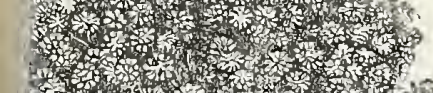

1.7.

8.

8.7. W

5.

3.

2.

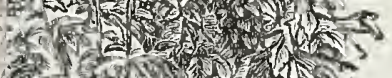

C.

monton.

aty

1.

(1)

(20)

Golden Glow.

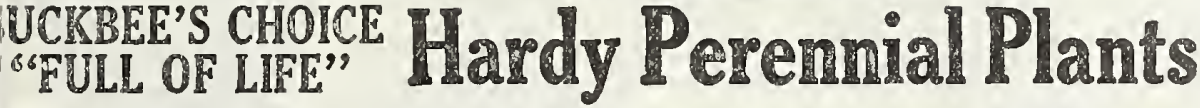
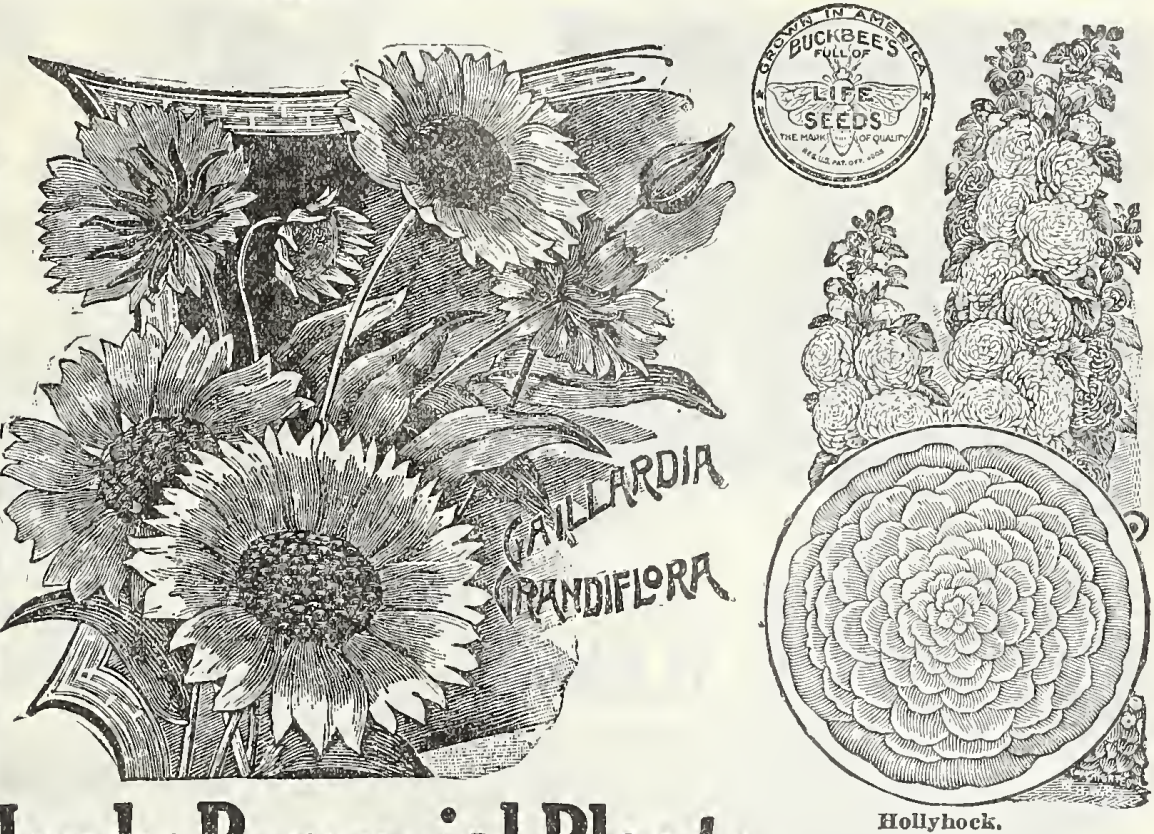

2. T2.

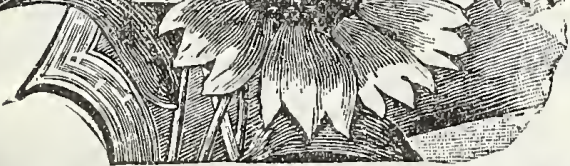

AILLARDIA GRANDIFLORA-One of the showiest and most effective hardy plants, about two feet

high, and continuous bloomers from June till cut down by the frost. The flowers are of gorgeous coloring; the center is of dark red-brown with petals marked with rings of brillia
and vermilion, Excellent for cutting. Priccs postpaid, 10c. each; $\$ 1.00$ per doz.

OLDEN GLOW-(Rudbeclia)-It is a question

Whether any other hardy percnnial has ever

strong robust grower, of five to six feet, and

produces masses of double golden yellow cactus

dahlia-like flowers from July to September.

Prices, postpaid, $10 \mathrm{c}$ each; $\$ 1.00$ per doz.

ARDY ENGLISH VIOLET-This Violet is enmost deliciously fragrant and perfectly double. It surpasses the well-known "Marie Louise" Violet in richness of color, being many shades darker and far excells it in its delightful odor, which is one of its greatest merits Will grow and bloom in any garcen and in any situation. plots than i Prices, postpaid, 15e each; \$1.50 per doz.

IOLLViroch- Few hardy plants combine as hony good qualities as the Holly hock. The ly shades of color. It requires a ricl. deep soil, well drained, and will repay in quantity and elegance of bloom any extra care. A slight protection during the Winter will be beneficial. Prices postpaid, Choicest Varieties IARDY GARDEN PINIS-Old favorites bearing their sweet clove-scented flowers in the Greatest profusion during the Summer months, $\$ 1.00$ per doz.
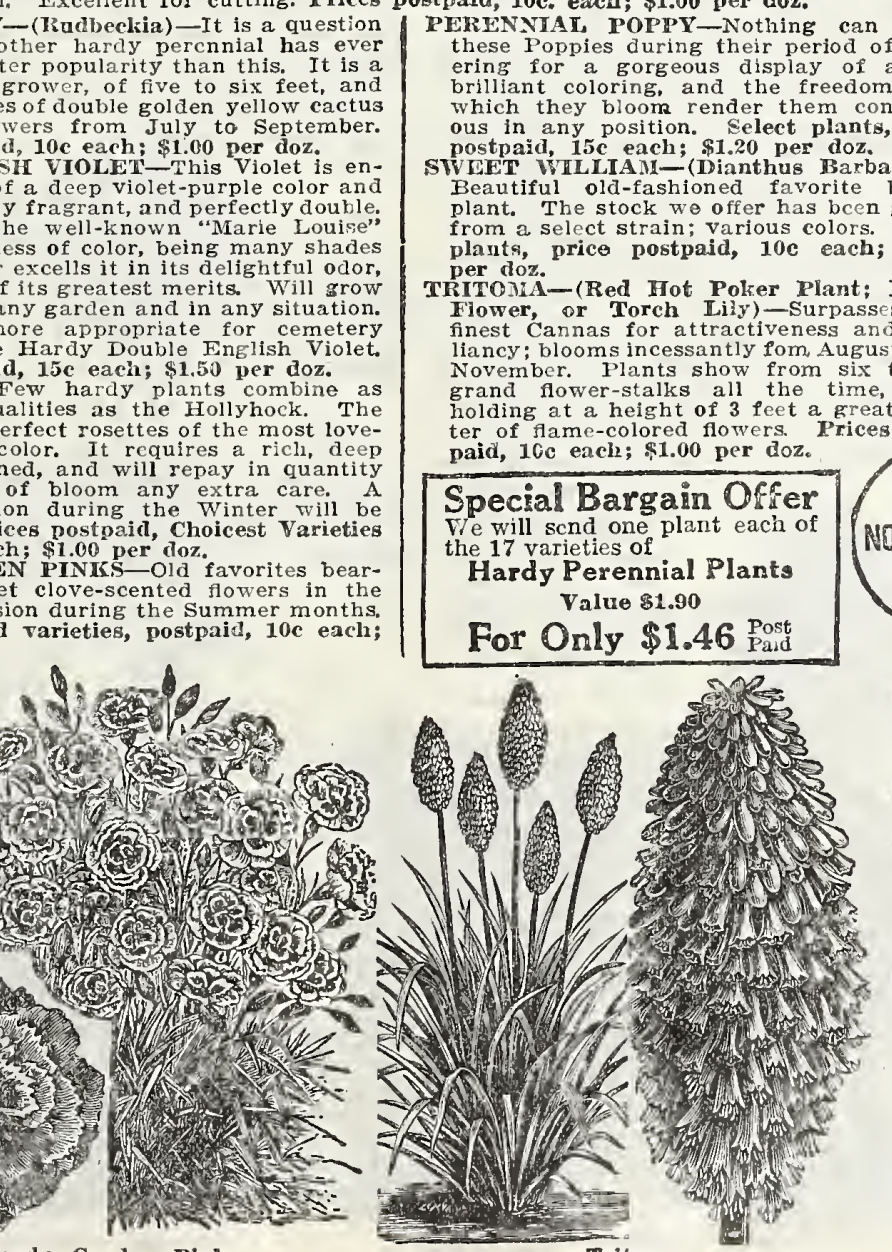

Me 30 ,

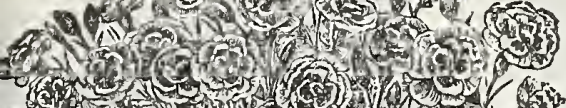
is

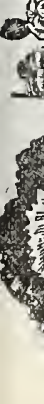
in

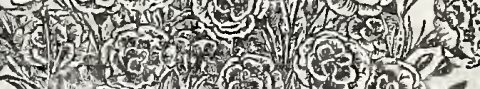
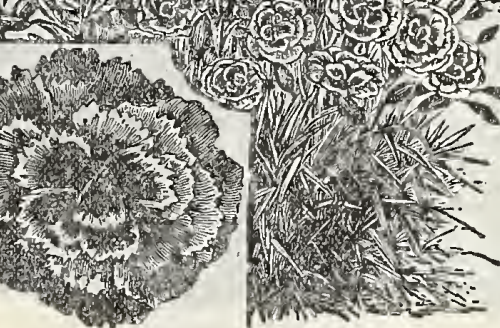

Hardy Garden Pinks.

Tritoma.

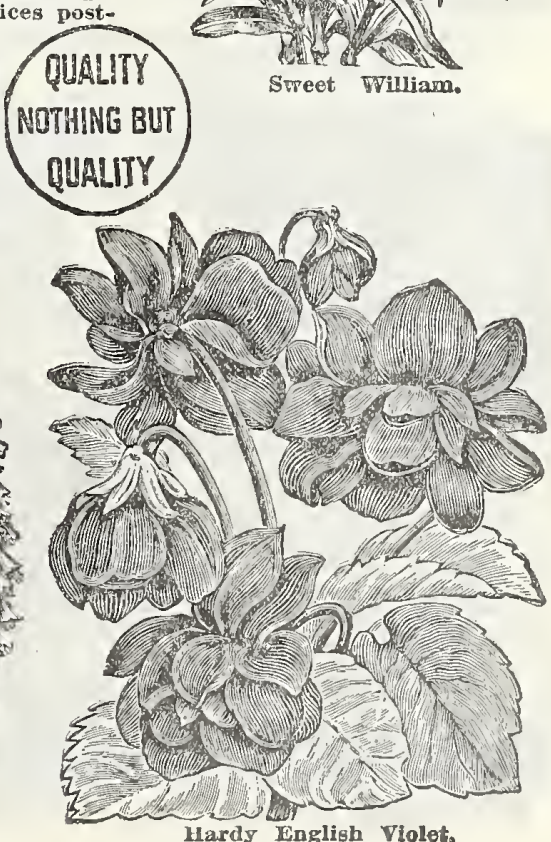




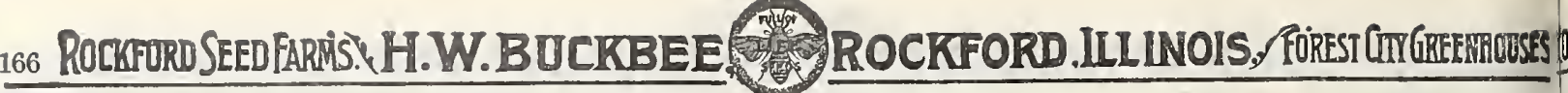

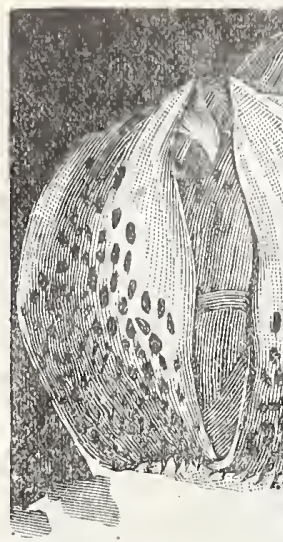

OUALITY NOTHNG BUT) QUALITY
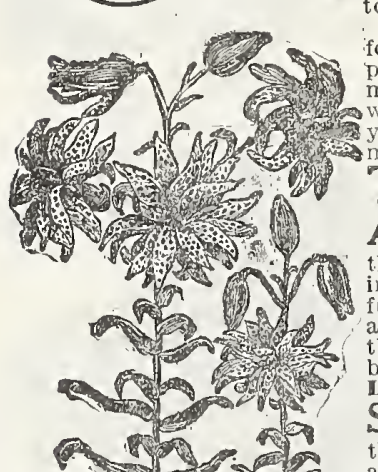
popular Three Popular Japan Lilies Auratum (The Goiden-Banded Lily of (This is justly entily to immense blooms measuring nearly a foot in width when expanded-are produced in the greatest profusion filly exp deliciously fragrant. The large thite petals are thickly spotted with chocolate-crimson, and have Large Bulbs Each 15e; doz. 81.25 , postpaid. Speciosum Album. Pure white flowers with the center of each petal. They are of great substance
and very fragrant. One of the best for general culture. a Prom Miammoth Bulb. Each 20c; doz. S2.00, postpaid. (enlisum fospeciosum Rubrum. State the brilliant G TRIMUM

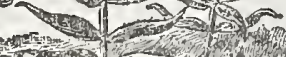

Double Tiger Lily.

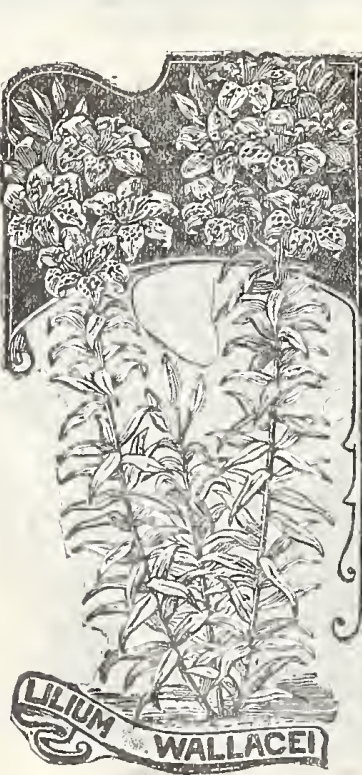

White or pink petals are thickly dotted with rose or make them very effective and desirable. Especially Earge Bulbs Each 15e; doz. \$1.25, postpaid. Special Offer $\mathrm{Cl}$ three varieties postpaid 0 nly $40 \mathrm{c}$.

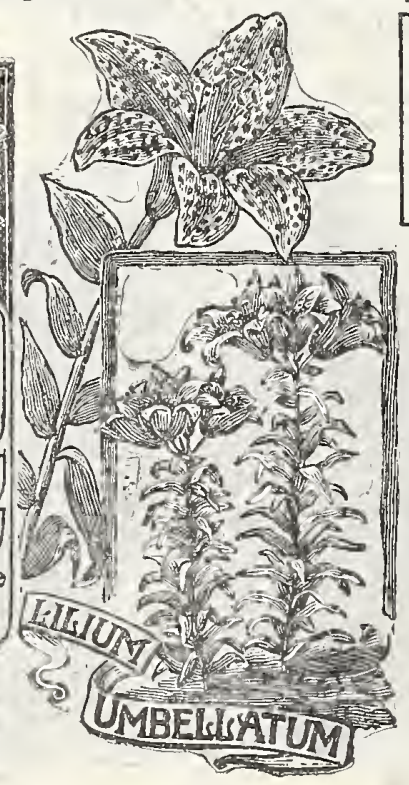

SpecialOfferC2 one fine bulb each of 8 splenon this page paid, only $84 c$.

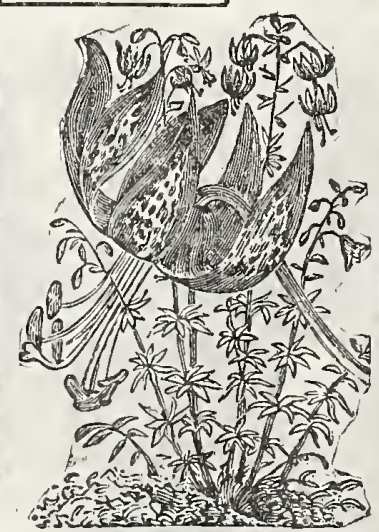

Leopard Lilly.

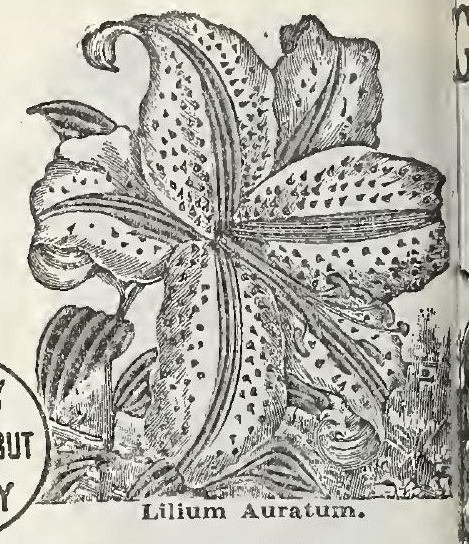

Double Tiger Lily

(Tiorlnum Flore Pleno.

This is a plant of stately habit, growing from 4 to 1 feet high bearing an immense number of doubl bright orance red flowers, spotted with black. Bloom in August. Splendid Eulbs. Each 10e; doz.\$1.00 postpaid.

\section{The Leopard Lily \\ (Lillum Pardallnum.}

An elegant and very beautiful Lily from California rich scarlet and yellow flowers, spotted with purplis brown. This is a superb lily and always gives satis faction, does well everywhere, blooms finely in th It is one of the Lilies you want. Splendid Bulbs Each 10e; doz. $\$ 1.00$, postpaid.

\section{Lilium Umbellatum}

One of the very best classes of the hardy gardel Lilies, strong sturdy habit, growing from 2 to 3 fee high, having large showy flowers held upright and is clusters at the simmit. They are of easy culture thing under ordinary garden conditions, flowerin June and July. The colors range through all th buff, apricot, orange, etc. Splendid Bulbs. 10 each; doz. $\$ 1.00$, postpaid.

\section{Lilum Wallacei}

This Lily is very floriferous, each bulb throwing from 4 to 6 flower stems, each one of which is crown with 8 to 10 beautiful, upright blossoms, of a delicate bright a pricot color. It is very perfect in form, anı a most desirable sort. Splendid Bulbs. Eaeh 10e Buckbee's Mammoth Flowering Lily of the Valley

No garden is eomplete witheut a bed of thes Fragrant Flowers.

The sweetest the loveliest Spring blooming plant producing delightfully fragrant blooms. Will thrivi in any common soil and do well in shady places wher many other plants fail. Large flowering roots, for 15e; 12 for 30c; 100 for $\$ 2.00$, postpaid.

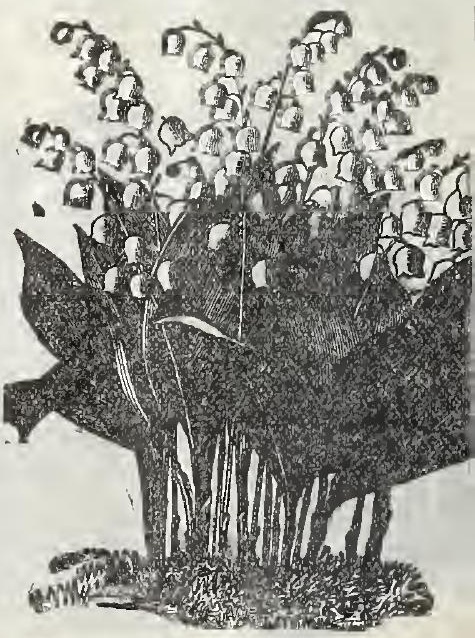

Lilly of the Valley. 


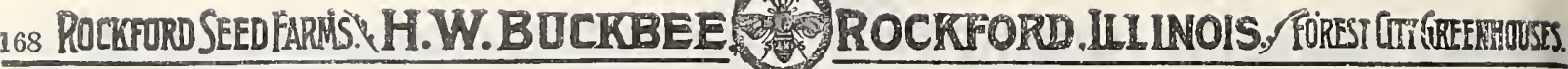

\section{BLACKBERRIES}

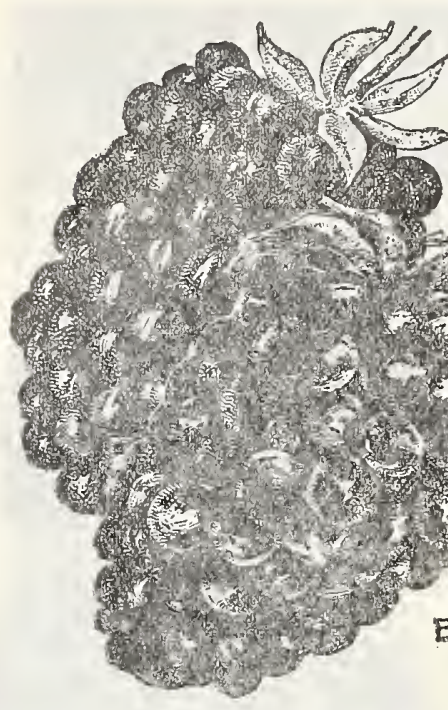

CURRANTS

The Cream of the Best Varieties

PERFECTION-The la fêst introduction, crented by crossin Fay's Prolific with White Grape, and combines the best qualities of both parents. In color it is a beautifui bright red and of size larger than the Fay, the clusters average longer and the size or the berres is mainthe most productive Currants, and in quallty it is superior to anything in the market today, being of a rich, mild, sub-acld fiavor and haveach, or \$1.75 doz., postpaid.

GIANT RUBY-The largest red Currant. Unusually hardy in habit of growth and bears profusely. The berries are beautiful light red and grow in immense clusters, more resemCurrants. Many fruit growers are now plant. ing largely of this variety in place of the older sorts on account of its enormous yield. Price, $15 \mathrm{c}$ each, $0 \mathrm{I}^{\mathrm{N}} \$ 1.25 \mathrm{doz}$, postpaid.

WIITE WINE-This is the hardiest white sort and is therefore especially desirable for the middie and northern states. It bears great bunches of pearly white Currants of the most cious flavor. Vigorous grower, very productive. The sweet and richest white Currant extant. Fruit larger and stems longer than White Grape. The fruit sugar best aci ar $\$ 1.25$ doz., postpaid.

BLACK CHAMPTON-The leading, tested black Currant. It is a vigorous grower and very productive.

cellent quality. Price, 15c each, or $\$ 1.25$ doz., postpaid.

Special Offer 44 The set of 4 of each variety, by mail, postpaid, only $40 \mathrm{C}$

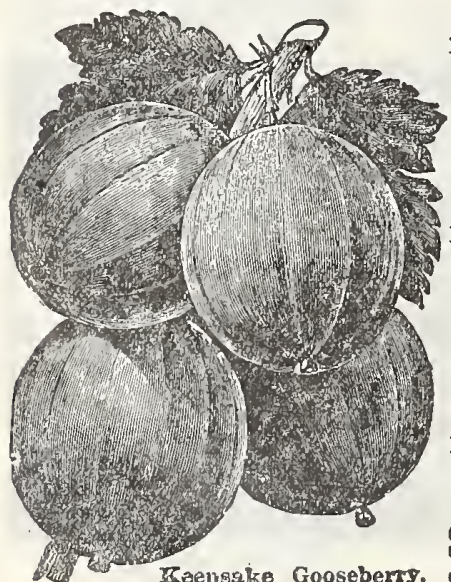

\section{Nothing But the Best.}

GOOSEBERRIES

KMEPSAKE-A new English variety, possessing unusual merlt. Plants grow in tree form, dwarf in habit, very productive, free from mildew and very hardy. The fruit is very large, straw colored, of exceilent fiavor blossom is well protected by early foilage, blossom is well protected by earice, strnng plants, 20c each, or $\$ 1.75$ doz., pnstpaid RED JACKET-Fruit large, a bright shiny red, a most beautiful and attractive perry. Flavor is most delicious and commands the very best market price. Plants and foilage are at all times vigorous, clean, heaithy and mlldew proof. Has been tested in many sectlons under most trying circum. stances and has proven at all times and in all places thoroughly hardy and enormously productive. Prices same as Keepsake. DOWNING-The berry is large, handsome, a pale green in color, of exceilent quallty. A favorite for home and market. Prices same as Keepsake.

Special Offer E5 Tho set of 3 GooseberIFoepsatice Gooseberty. of each variety, by mail, postpald, only $48 c$

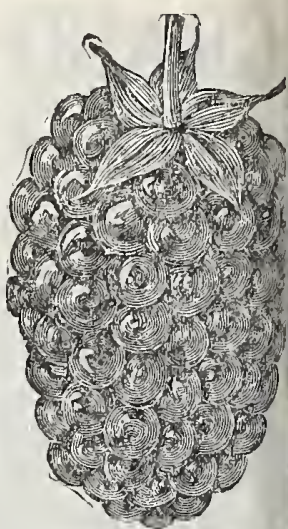

Austin's Improved Derberry.

\section{DEWBERRY}

ED-The berries are much larger than those of any nd of superior flavor. For productiveness it outrivals Price, 10c each, or 75c. doz,, postpaid.

\section{GRAPES}

\section{Choicest Hardy Varieties.}

CAMPBELL'S TARLY-The berries are large, of ten an inch or more in diameter, glossy biack with a purple bloom, sweet and juicy, with few seeds. As a keeper American Ger this variety is unequalled by any other A0c each, or $\$ 1.75$ doz., postpaid. 20c each, or $\$ 1.75$ doz., postpaid. hibited in al parts of the country fine favor and beauty creating a sensation It is a secdling of Worden. Ripens before Concord Prices same as Campbell's Warly.

WHTTE DIAMOND-Valuable for all sections of the United States Best white, healthy and perfectly hardy. Prices same as Campbell's Early.

IOORE'S EARLY-One of the best early ripening varieties. The bunch is large, round and with a biack-blue bloom. In quality surpassing the Concord. doz., postpaid.

CONCORD-The well-known standard black-blue varlety. It succeeds wherever Grapes are grown. Prices same as Moore's Early.

WORDEN-A large black Grape of the Concord type, but 5 to 10 days earlier. Price same as Moore's

Special Offer E3 The set of 6 ne of each variety, by mail, postpaid, only $90 \mathrm{c}$

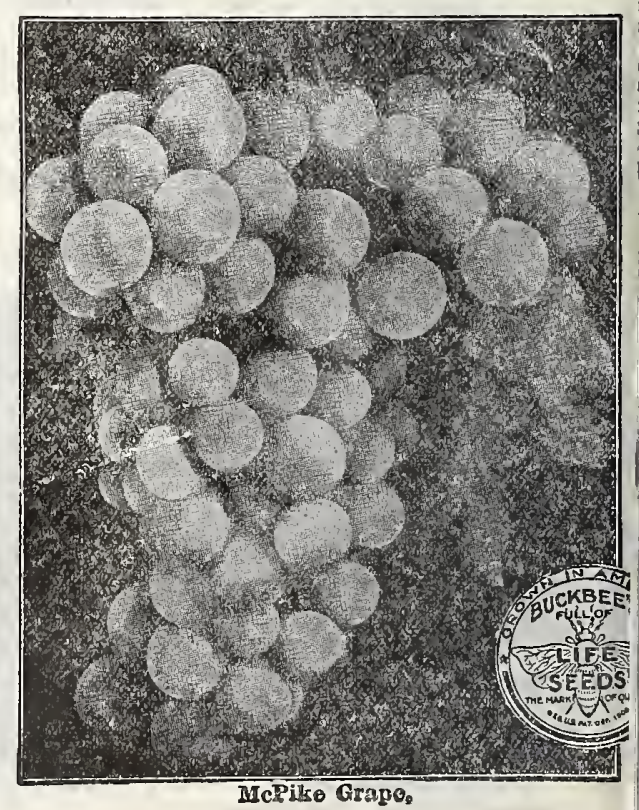




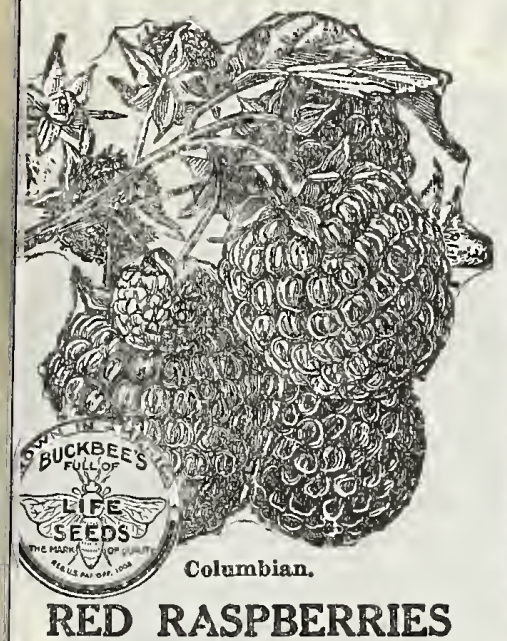

DLUMIBIAN-New, dark red color, rich flavor very large size. An excellent shipper, and the best for canning and dryir
Late. 10c each; 85c doz., postpaid.

JTHBERT-The most extensively planted red raspberry. Fruit bright red, good and very large, bush very vigorous, each: 50c doz., postpaid.

OLDEN QUEEN-New. Similar to Cuthbert (of which it is a seeding) except in Very, which is what its name implies. ivery large, hardy, vigorous and productive. No garden should be
i10c each; $\mathbf{8 0 0}$ doz., postpaid.

OUDON-A superior berry in every reispect. A vigorous grower, very hardy, healthy and productive. Its berries are Its color is a beautiful rich crimson. It 65e doz., postpaid.

PECIAL OFFER-The set of 4 Red Raspberries for 35c, postpaid.

Improved Russian MULBERRY

I An ornamental hardy fruit bearing trea Fruit larger than blacliberries and of delicious Havor

I Suitable for all sectiong of this country It is a very rapid grower, often reaching se height of 50 feet and from 3 to 5 feet 1 diameter, and is perfectly hardy. Comences to bear when two years old, and entirely hardy and impervious to heat and very prolific, the fruit being larger than drought. Berries are larger than the largest romatic flavor and sub-acid, sweet taste, Strawberries, bright shining scarlet with an nd is used for dessert as we use black- JWLLY, JAMS AND TARTS, having a delierries or raspberries. A beautiful, quick cious flavor entirely different from any ot her rowing tree for the lawn, and fruit is fruit. An immense yielder, producing regualuable for table use

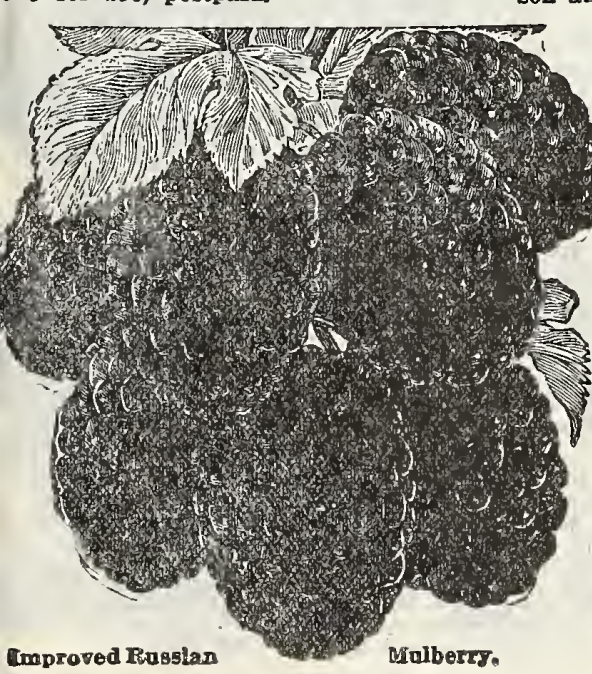

oon and gets stronger and larger each year. All lovers of fruit should give it a trial. It will both surprise and please $\$ 1.00$ pez doz., postpaid.
you.

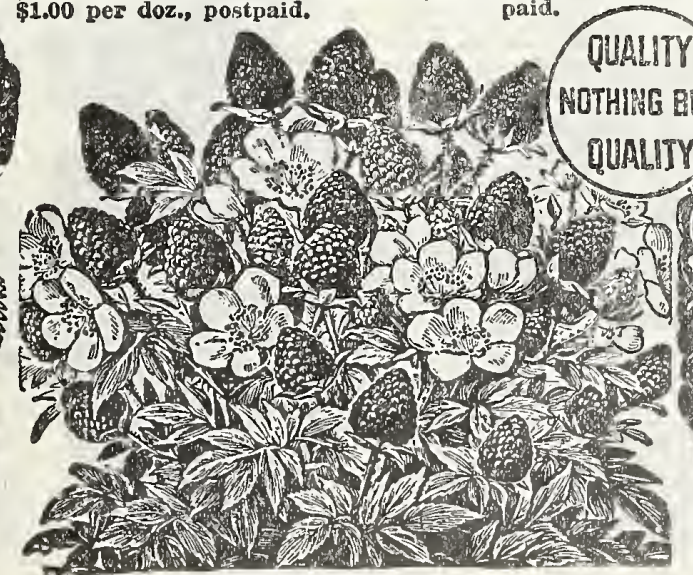

Stramberty Ragpberç;

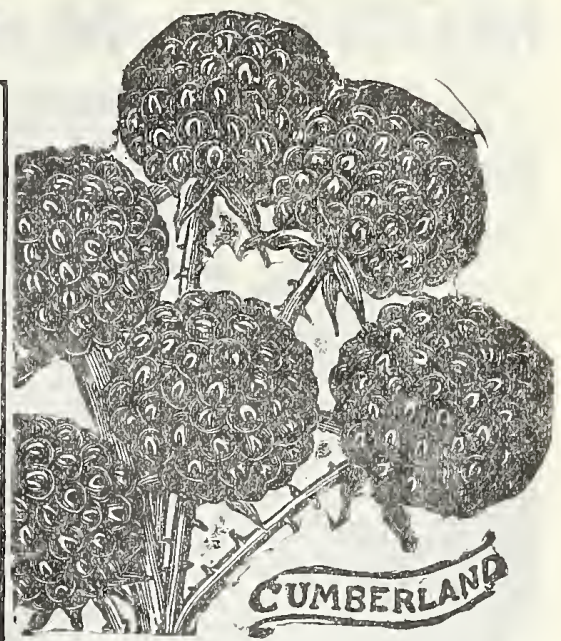

\section{BLACK RASPBERRIES}

CUMBURLAND-New, The largest black Raspberry known, averaging $7 /$ inch in diameter. Good and hrm as the Gregg. orous grower, and wonderfully product orous grower, and wonderfully productpostpaid.

GREGG-Very large and late. Bush strong upright grower, productive and very desirable for market and home use. 10c each; r0c doz., postpaid.

KANSAS-New. Originated in Kansas, Where it is prized as the best black. cap. Ripens early and is as large or large some and of best quality. 10c each; 650 doz., postpaic.

OHIO-Very productive and firm. Season medium to late. Bush a strong grower and drying. 10c each; 75c doz., postpaid.

\section{New Logan Berry}

(BLACKBERRY-RASPBURRY.)

This Thornless Raspberry Blackberty originated in California. It is an exceed. ingly strong grower, mak iarge as in one season. The fruit is as the same form and shape, and the color, When fully ripe, is a dark bright red. It berry and Raspberry, having a very mild, pleasant flavor. It is excellent for the the seeds are small and not very abundant. The fruit is extremeiy firm and the vines are enormous bearers. The fruit Bla a paid.

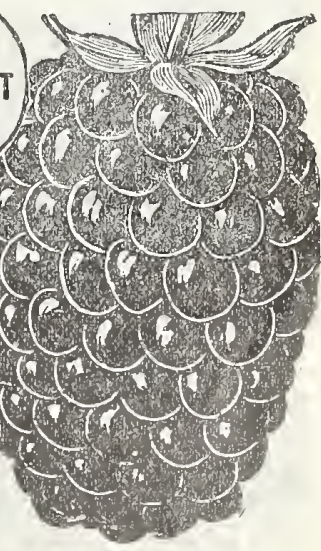

Now Logan Berro 


\section{MONEY MAKING STRAWBERRIES?}

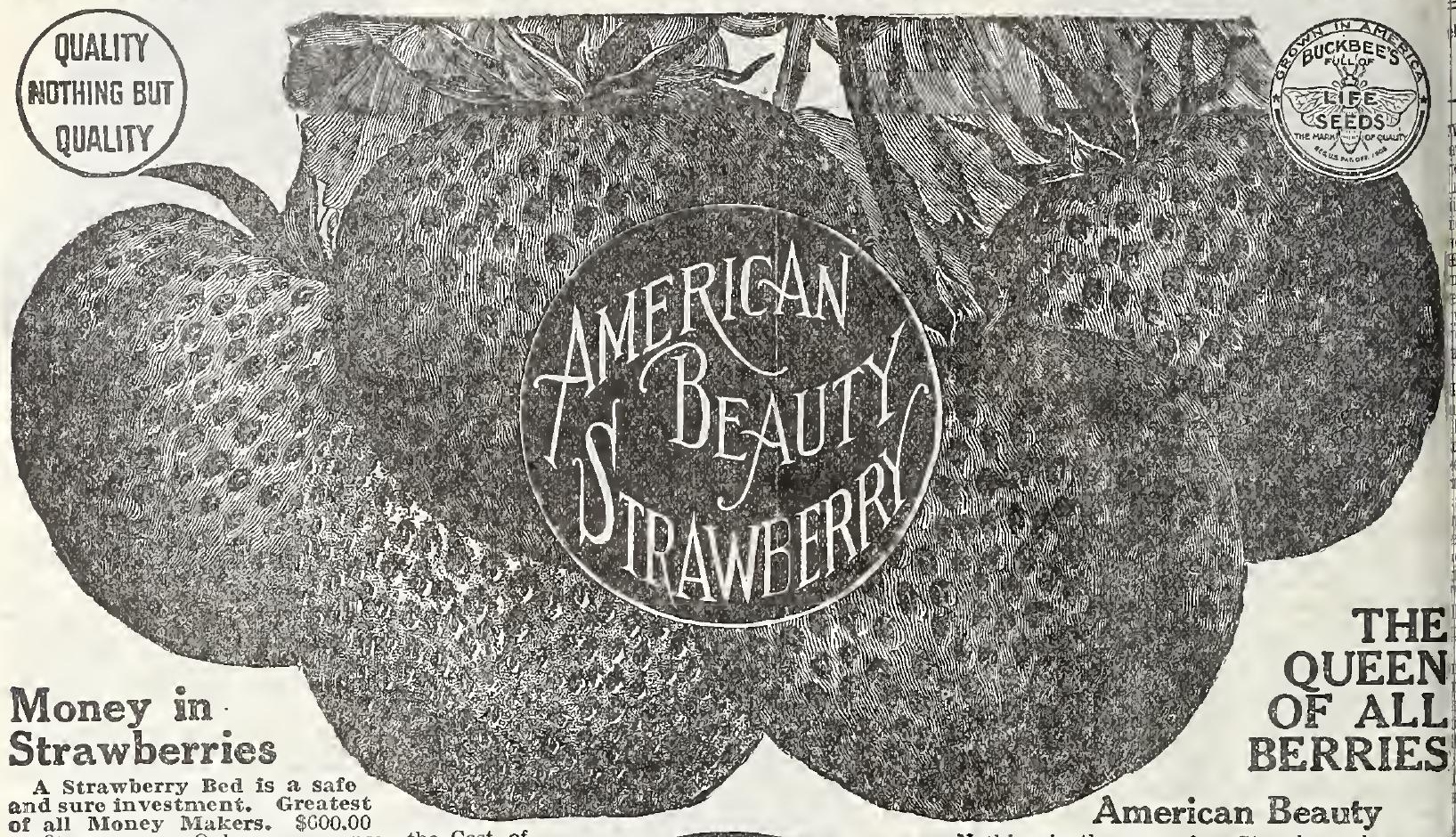

profit per acre. Only one expense-the Cost of Nothing in the way of a Strawberry has ever
Plants, which is merely nominal-lasts for Jears. Suited to all soils and climates. 100 Plants will
supply an ordinary family with frcsh, delicious truit all season. Start Right! Get the Best STRA WBERRY PLANTS. Order Farly. Pan American Everbearing TRULY AN EVERBEARING VARIETI Greatest Novelty Ever Introduced.

This new Strawberry bears a full crop in the spring and continues to bear berrics all thard freezing in the Fate novelty in Strawberries ever introduced. Think of a variety that you can pick ripe berrics from for three months, or until thcy are destroyed by the ter, smooth and colors up evenly all over, no green tips. In quality and flavor it is fine. It fruits on new runners and old plants, a (t) The ideal berry for the family garden.

\section{New Shuckless Wonder}

THE NEW SEEDLING STRA WBERRY

$$
\text { Đon't Overlook This. }
$$

A most valuable and distinct variety unlike any other, producing a berry parting freely from the calyx: and a berry that contains no acid; a berry that has very a berry that is mild and sweet. It ripen mid-season. plants short and stocky, very thrifty ( red with a long shaped neck, which is the unfailing per known.

\section{Great Ruby}

This large, brilliantly colored, deliciously flavored immensely productive variety holds its place as one of the few strictly fancy extra early varieties. Fruit As a shipper or home berry it can't be beat.

\section{Pride of Michigan}

One of the greatest ever introduced. In size the berTies surpass all other varieties, producing greater number of fancy berries than any other late variety which lie in wind-rows and are completely covered by its dense foliage. Excellent canner, fine shipper, always bringing top notch prices. Meat is firm, exceed. cious. Has long blooming season, therefore very valuable for market purposes.

SEE OPROSITE PAGF FOF RRICES

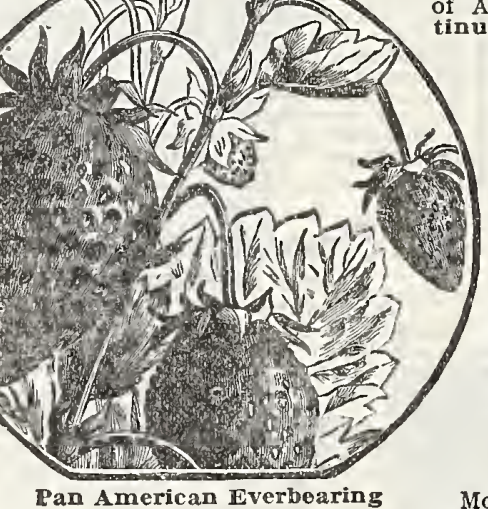
Enormously Produetive Vigorous Grower, Easy Picker, Best Keeper, Fine Shipper, Best Flavor, Best of all. For home use or market, without question it is the Ideal Strawberry grown for al! purposes. Be sure and give this best of all berries a trial; it will satisfy you.

\section{Great Northern}

Our own introduction. Unquestionably. one of the best Extra Earlies. Strong, age and perfect blossoms; heavy cropper. excellent for market or home consumption, fine canner. Berries large, beautiful glowing Ied in color, decidedly sweet.

\section{Senator Dunlap}

Pan American Everbearing

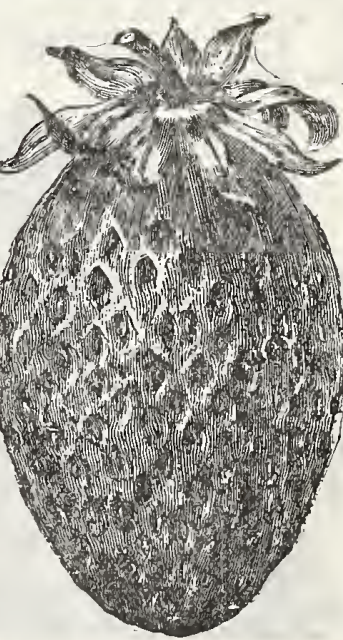

Most Popular of All. Grows immense quantities of large handsome berries that are a rich dark ed with glosșy finish, shading to deep scarlet on imbedded in highly colored wax Noted for uniformity of size and shape. The rich bright red of its meat and delicate favor make it really ideal. Recogtrade on this variety extends from coast to coast.

\section{Buster}

Derives its name because its chief characteristic its record breaking yield. Has won distinction for its vigor of growth and reliability under adverse conditions. Just the thing for new beginners. Stands more frosts than any other, consequently popular everywhere, particularly where late springs are common. BUSTER beats them all when it comes to yield, red, fine quality and excellent shipper.

\section{Early Ozark}

First in market. World wide reputation as one of the earliest varieties ever originated. Ranks with thes cross between Frcelsior and so pronounced in both; excellent maturing variety. strong in pollen, very productive, firm texture. As a Non Sbuckless Wender commercial variety it holds frout ranks. 


\section{Buckbee's "Full of Life" Strawberry Plants}

\begin{tabular}{|c|c|c|c|c|c|c|c|c|c|c|c|c|}
\hline \multirow{2}{*}{$\begin{array}{l}\text { lect List Buckbee's "ITull } \\
\text { of Life" Strawberry } \\
\text { Plants }\end{array}$} & \multicolumn{7}{|c|}{ FIELD GROWN PLANTS } & \multicolumn{5}{|c|}{ POTTED PLANTS } \\
\hline & \multicolumn{3}{|c|}{$\begin{array}{l}\text { Postpaid } \\
\text { By Mail }\end{array}$} & \multicolumn{4}{|c|}{$\begin{array}{l}\text { By Express } \\
\text { Not Prepaid }\end{array}$} & \multicolumn{5}{|c|}{$\begin{array}{l}\text { By Express } \\
\text { Not Prepaid }\end{array}$} \\
\hline $\begin{array}{l}\text { EARL Y VARIETI } \\
\text { riy Ozark (S) }\end{array}$ & Doz. & 50 & 100 & 50 & & 500 & 1000 & Doz. & 50 & 100 & & \\
\hline $\begin{array}{l}\text { riy Ozark (S) } \\
\text { eat Northern (S)...... }\end{array}$ & 27 & 60 & 95 & 40 & 75 & 2.50 & & & 1.65 & 2.65 & 11.50 & \\
\hline$\because$ & $\begin{array}{l}27 \\
22\end{array}$ & $\begin{array}{r}60 \\
40\end{array}$ & 95 & $\begin{array}{l}40 \\
30\end{array}$ & 75 & $\begin{array}{r}2.50 \\
1.50\end{array}$ & ${ }_{2}^{4}$. & $\begin{array}{l}56 \\
45\end{array}$ & 2.00 & $\begin{array}{r}3.75 \\
2.50\end{array}-1$ & $\begin{array}{l}17.00 \\
10.50\end{array}$ & \\
\hline & 22 & 40 & 70 & 30 & 50 & 1.60 & 3.00 & 45 & & & & \\
\hline S) & 21 & 40 & 65 & 30 & 45 & 1.50 & 2 . & 45 & 1.50 & 2.50 & 10 & \\
\hline Ärietries: & 27 & 60 & 95 & 40 & 75 & 2.50 & 4.75 & 56 & 2.00 & 3.75 & 17.00 & 32.50 \\
\hline & 40 & 65 & 1.20 & 60 & 1.00 & 4.00 & 7.50 & 75 & 2.75 & 5.00 & 22.50 & 40.00 \\
\hline & 21 & 40 & & 30 & 45 & & & 45 & & & & \\
\hline & 21 & 40 & 65 & 30 & 45 & 1.50 & & 45 & 1.50 & 2.50 & & \\
\hline & 2 & 40 & & $30]$ & & 1.50 & & 45 & 1.50 & 2.50 & & \\
\hline & 2 & 40 & 65 & 30 & 45 & 1.40 & 2. & 45 & 1.50 & & & \\
\hline & 2 & $4 c$ & 70 & 30 & 50 & 1.60 & 3.00 & 45 & 1.65 & 2.65 & 11.50 & 22.0 \\
\hline & 27 & 60 & 95 & 50 & 75 & 2.50 & 4.75 & 56 & 2.00 & 3.75 & 17. & \\
\hline & 22 & 40 & & 30 & & & & 45 & & & & \\
\hline & 24 & 50 & 85 & 40 & 65 & 2.0 & 3. & 45 & & & & \\
\hline & 4 & 85 & 1.50 & 80 & 1.25 & 6.5 & & 90 & & & & \\
\hline & 2 & 50 & 85 & 35 & 60 & 1. & & 45 & & & & \\
\hline & 21 & 40. & 6 & 30 & 45 & 1. & & & & & & \\
\hline & 22 & 40 & 7 & 30 & 5 & 1. & & 45 & & & & \\
\hline & 22 & 40 & 7 & 30 & 5 & 1. & & & & & & \\
\hline & 27 & 60 & 9 & 40 & 7 & 2.5 & & & & & & \\
\hline & 22 & 40 & 7 & 30 & & & 3. & 45 & & & & \\
\hline & 2 & 40 & & 30 & & & & & & & & \\
\hline & 21 & 40 & & & & & & & & & & \\
\hline & 21 & 40 & 65 & 30 & 45 & 1.50 & 2.75 & 45 & 1.50 & 2.50 & 10.50 & 20.0 \\
\hline & & 40 & & 30 & 50 & & 3.00 & & & & & \\
\hline & 22 & 40 & 7 & 30 & 50 & & 3. & 45 & 1. & & & 22 \\
\hline & 21 & 40 & 65 & 30 & 4 & 1.5 & & 45 & & & & \\
\hline & 2 & 40 & 70 & 30 & 5 & 1. & & 45 & & & & \\
\hline & 2 & 50 & 8. & 35 & 6 & 1. & & 45 & & & & \\
\hline & 2 & 40 & 7 & 30 & 5 & 1. & & 45 & & & & \\
\hline & 2 & 50 & 8 & 35 & 60 & & & 45 & & & & \\
\hline & & 40 & 70 & 30 & 50 & 1.60 & 3.00 & 45 & 1.65 & 2.65 & 11.50 & 22.00 \\
\hline E & 75 & 2.50 & & 2.00 & 3.50 & & & & & & & \\
\hline & & & & & & & & & & & & \\
\hline & 65 & 2.00 & & 1.75 & & & & 1.50 & 4.00 & 7.50 & & \\
\hline
\end{tabular}

WHEN WE SHIP STRAWBERRY PLANTS-In this locality Field Grown Strawberry Plants are ready for shipment in April. We can also make Fall Shipments in October of each year if desired. Pot ted strawberries are shipped in August and September. Be sure to state th
your plants shipped when ordering. Otherwise we will use our best judgment.

\section{$75 c$ \\ GILT EDGE COLLECTION \\ STRAWBERRY PLANTS}

American Beauty, 12 selected plants, value.........40c R uster, 12 selected plants, value $.27 \mathrm{c}$ In all, 36 plants, value $94 \mathrm{c}$, for only $7 \mathrm{se}$, postpaid.
We Warrant all shipStrawberiy Plan ts to reach purchaser's hands in guod wlen so a cepted, no orders will be duplicated or replaced for any cause.

Strawberry Plant Orders Will be shipped direct from our Strawberry Farms and goods. Send your orders in early and they will be filled in rotation just as early in the Spring as possible. (In you want them shipped,

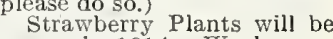
scarce in 1914. We have a splendid supply.

ORDER EARLY.

NOTICE-All varieties marked. (S) are Staminate Sexual varieties. All varieties marked ( $(P)$ of Stamens.

Therefore when planting varieties marked $(\mathrm{P})$ it will third row a Perfect Flowering or (S) variety to properly fertilize the bed; much finer fruit will be obtained For example-If your order calls for 200 Great Ruby Great Northern (S) to properly fertilize the bed. Plant Ruby (P) and the third row with Great Northern (S) and so on; or you can use any the same manner.

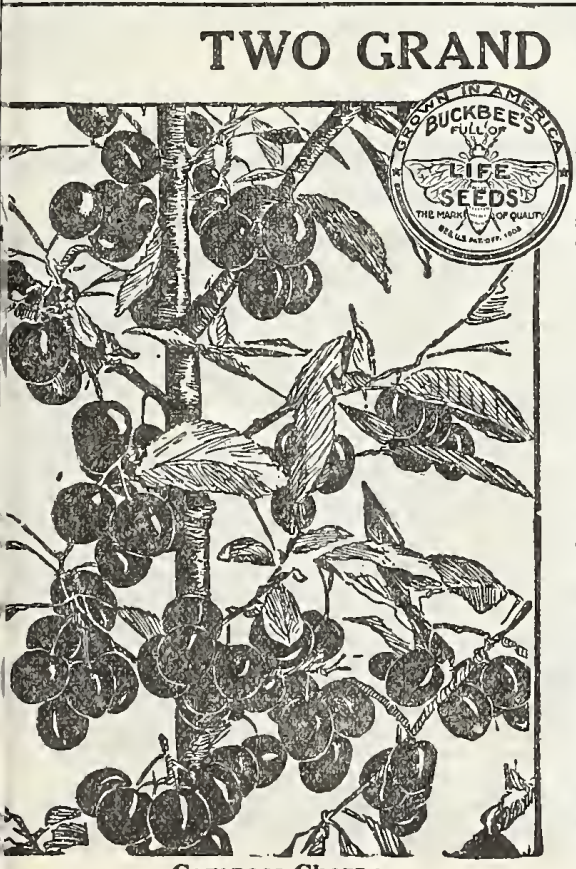

\section{$\$ 1.25$ \\ BARGAIN COLLECTION}

STRAWBEREY PLANT

Buster, 50 selected 50 selected plants, value

Early ozark, 50 selected plants, value

in all, 150 plants, value $\$ 1.50$, for oniy $\$ 1.25$

ints, value $\$ 1.50$, for only

\section{TWO GRAND AND MAGNIFICENT CERRRIES}

Rocky Mountain Cherry

ONE OF THE GREATEST NOYELTIES IN THE FRUTT IINE EVRR INTT ONDCED It bears fruit every year and is as prolific as a curent bush. 16 quarts having

The fruit is a rich red and changes to almost black wheu ripe, of good size, fine flavor and unsurpassed for preserves or eating from the hand; season of ripening being after all others are gone. In freserves or eating from the hand; season of ripening being ater all pitted fruits. Price, $15 e$, cach, or 3 for $35 \mathrm{c}$, postpaid.

\section{Compass Cherry} Absolutely Hardy Everywhere
Originator's description: "This cherry
was originated at Springfield, Minn. It is a cross between the sand Cherry and the Miner Plum. Nearly an inch in diameter, a bright red, sweet and juic and of very fine flavor. the third year from the seed and has borne a full crop every year since. The tree is a regular and duces fruit the next year after setting out. For exposed situations and for the North and West it is the "Cherry." Requires no every particular as Hiardy as an oak. Mail size, postpaid, each $35 c^{2} 4$ for $\$ 1.00$. NoTICE-Our Full of Life Small fruits are Acclimated and well adapted to Every Section of the United States.

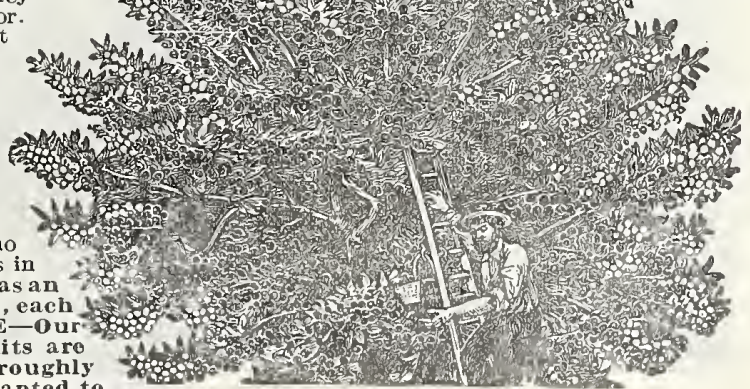

Rocky Mountain Cherry. 


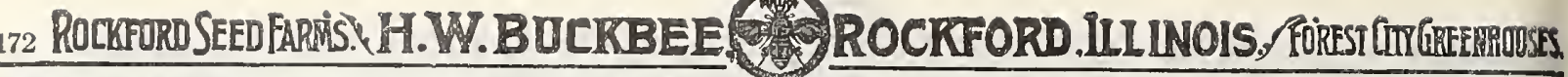

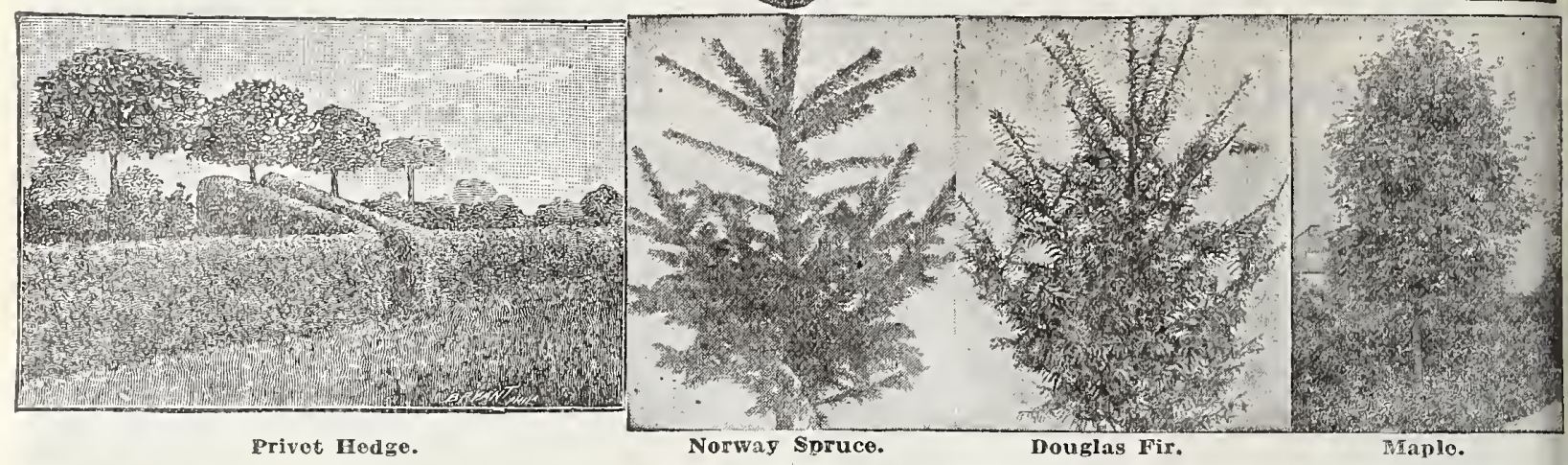

\section{Hardy Ornamental Hedge Plants}

\section{Japanese Barberry (Berberis Thunbergii)}

This is the most valuable for making a low dwarf heage. It is of low, regular and compact growth and requires very littlo oruning It has fne thorns aud smal, round rich green leaves that chang tootor in the Autumn to a fery crimson. The hedge is made scill moro beautiful by grcat numbers of pretty drooping yellow flower which are followed by bright red berries. It is frequently planted ngly plants, postpaid, each lde; doz. \$1.00. Prices by express, not prenaid, select plants 12 to 15 inches high, $\$ 1.25$ per doz. $\$ 6.00$ per $100 ; 15$ to 20 inches high, $\$ 1,30$ por doz.; $\$ 7.50$ per 100 .

\section{California Privet (Ligustram Ovalifolium)}

This is one of the most popular hedge plants grows very fast, bushy, compact and very hardy. For group and specimens it is terracc decoration when grown in standard form. Oan bo sheared o any desired shape. Price, good strong plants, postpaid, each $10 \mathrm{c}$; doz. \$1.00. Prices by express, not prepaid, zelect plants 15 to 18 inches ligh, $\$ 3.00$ per $100 ; 18$ to 24 inches wigh, $\$ 4.00$ per 100 .

\section{JAPANESE ROSE HEDGES ( $\left.\begin{array}{c}\text { Rezosa } \\ \text { Rose }\end{array}\right)$}

Roses are coming to be more and more popular for hedges. They are perfectly hardy in the coldest Winters and are especially valuable Price, by express, not prepaid, $35 \mathrm{c}$ each; $\$ 3.00$ per doz. for strong 3 year old plants. Extra fine 5 yr. old, $50 \mathrm{c}$ each; $\$ 5.00$ per doz.

\section{Catalpa Speciosa (The Tree for Profit)}

Excels for building material-makes good fence postsnothing botter for telograph poles-good plow beams and handles, superior to oak for furnituro-lighter than pinestronger than oak-tougher than bickory-neither shrinks Hor SWoils. of all our common trees. Any soil that will grow farm crops wil giow Catalpa trees. An acre of Catalpa trees properly cultivated and cared for, will take no more labor than an acre of corn, ane after three years this acre is growing into more value each year than an acre of corn, with no labor at all. Start a grove of Catalpa trees 作

SPECIAL PRECE Catalpa speciosa trees 8 to 10 WARNING The True Catalpa Speciosa is scarce. 函ven genuine stock and not "Catalpa Bignonioides" and other common varieties, which are only scrub trees and worthless for almost any 153

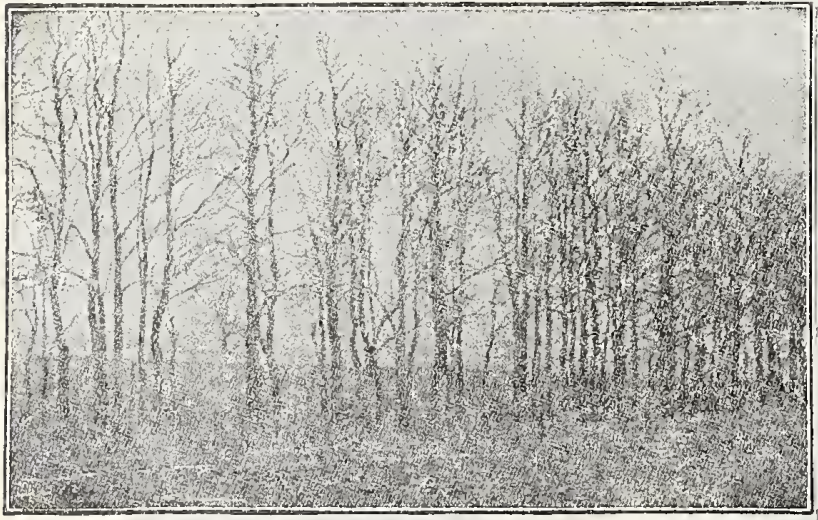

Catalpa Speciosa.

\section{Hardy Evergreen Seedlings}

For Hedges, Windbreaks and Ornamental Lawn Planting

An Evergreen Windbreak will keep your stock warmer, bealthier and allow them to fatten quicker and with less food. It will give you larger and bettcr crops. It will make your garden and pastures one or two weeks earlier every spring. It will raise the selling value of every acre you own by beautifying it and making it more productive.

There is unquestionably no botter way of beautifying your grounds than surrounding it with beautiful Evergreens. Evergreens are permanent asset. They are everlasting and add to the beauty of the home winter and summer. Plant some Evergrcens around your garden, and just see how much difference there is in the temperature and moisture. You will find that you can grow flowers, fruits and
vegetables that you never could beforc. Groups of spruces, Pincs, Firs and individual trees here and there about the yard, and along driveways, change a dreary house into a comfortable homc. Remarkable effects are produced by Evergreens, with color and foliage blending harmoniously - full of mystery at dawn or dusk. In summer they are cooling and refreshing. In winter they add color, warmth and checrfulness.

These varieties have been thoroughly tested and proven absolutely hardy and reliable, and will grow successfully in all parts of the country Complete planting instructions and cultural directions will be furnished with each order sent. Send in your orders as early as possible to avoid disappointment, as stock is limited. Shipment vill be made in March, April or May, You cannot afford to overlook these wonderful collcctions of Hardy Evergreen Secdlings at REAL B.1RGAIN prices.

100 Norway Spruce

Each of these 12 Varieties tied up in bunches of 50 or 100 as noted, PRICE, \$1.00 Per Package.

Any 6 packages for

\$5.00, Postpaid. Safe arrival guaranteod.

$\left\{\begin{array}{l}100 \text { Scotch Pine } \\ 100 \text { Douglas Fir } \\ 50 \text { Colo. Blue Spruce } \\ 100 \text { White Pine } \\ 50 \text { Black Hill Spruce } \\ 100 \text { American Arbor Vita } \\ 100 \text { Dwarf Mount. Pine } \\ 100 \text { Jack Pine } \\ 100 \text { Concolor Silver Fir } \\ 100 \text { Ponderosa Pine } \\ 100 \text { White Spruce }\end{array}\right.$

yr. Seedlings 2 yr. Seedlings 2 yr. Seedlings $2 \mathrm{yr}$. Seedlings yr. Seedlings yr. scedlings 3 yr. Seedlings 2 yr. Seedlings 3 yr. Seedlings 3 yr. Seedlings

Please Rememiber, These Packages Cannot be Broken.

\section{TREE SEEDLINGS (Deciduous Varieties)}

\section{Well Rooted, Nursery Grow.}

They are intended for planting groves, tree claims, wind breaks, tc. Lumber and posts are becoming more expensive every year, and oeople could save a great deal of this expense by planting some of the juick-growing forest trces. Nearly every farm has some twaste land hat could be used for this purpose. The profit that can be realized rom a single acre for fence posts will in a few years liquidate the original investment many times over.

At prices quoted, sent by express at purchaser's expense. If wanted by mail postage must be added $35 \mathrm{c}$ extra per 100

Ash, White.

Box Elder.

Cottonwood

CIm, American

Locust, Black.

Poplar, Carolina.

Walnut, Black.

Size

Per 100
$\$ 0.50$
.75
.50
.90
.50
.75
2.85
1.25
2.00

Per 1000

8 to 12 in.

12 to $18 \mathrm{in}$.

12 to $18 \mathrm{in}$.

8 to 12 in.

8 to 12 in.

12 to 18 in.

2 to 3 feet

2.00

$\$ 3.00$

5.25

5.50

2.50

5.50

20.00

16.00

SPECIAL NOTICF All Tree Seedlings and Evergrcen SPECIA Seedlings will be ready for shipcen be sent after tiat as early as possible, so that we can reserve shipment at proper tine.

Mrs. C. L. Hewitt, Pierre, S. Dak., writes: Have just received the specimen trees. I am well satisfled. 


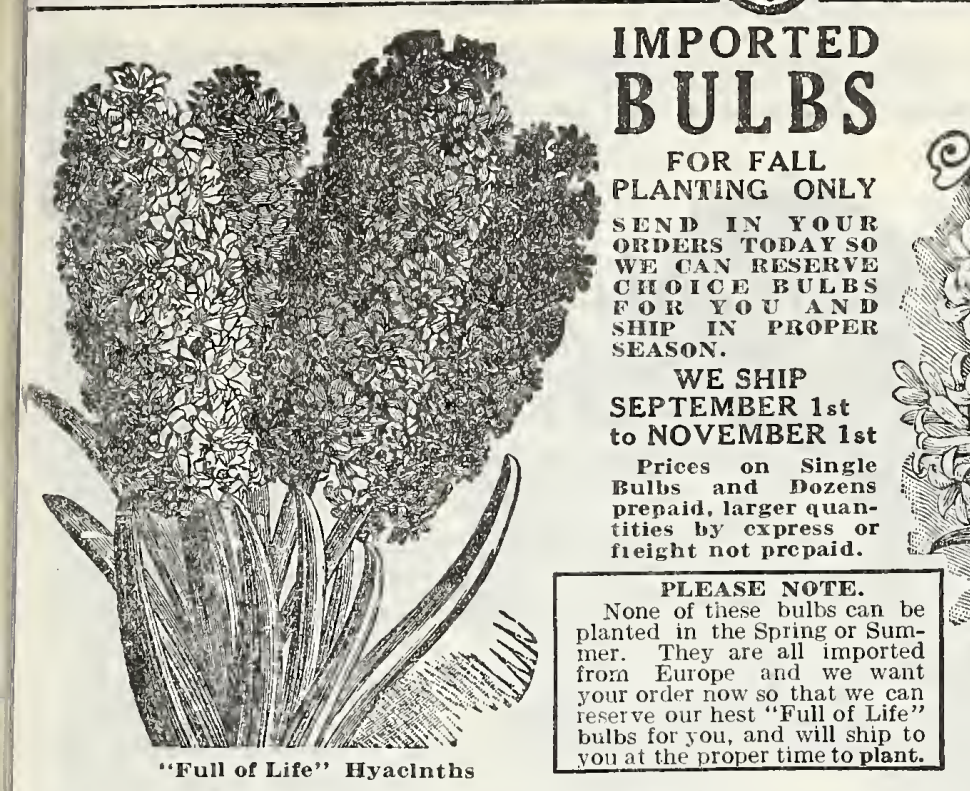

HYACINTHS

Best Named Single.

Garihaldi-Bright scarlet.

Czar Peter-Light Blue.

Grand Vainqueur-White rose.

Homerus-Delicate rose color

Jacques-Light pink color

Hont Blane-Pure white.

Menelik-Rich dark blue.

Obelisque-Deep orange.

price any of the above.

each, 88c doz.; \$6.84 per 100.

HY A CINTHS, Single.

Buckbec's Full of Life Mixed

- The very best colors selected

Price, 8c each; 88c doz.;

MYACINHS, Single.

Special MIxcd-Sclect Colors.

Price, 6e each; 63e doz: 4.67 per 100 .

H YACINTHS, Single.

Fine Mixed-Splendid assort-

ment.

Price, 5c each, 48c doz.; $\$ 3.00$

\section{Snow Drops}

\section{HYACINTHS}

Best Named Double. Envoyc-Porcelain blue. La Grandessc-Pure white, ksabella-Flesh pink.

Van Speyk-Golden yellow. Dagnar-Rich dark red. Ophir D'or-Reddish orange. vilton-Bright crimson Noblc Par Merite-Deep rose. Distinction-Rich indigo blue. Hayden-Lilac tinted mauve. each, 90e doz.; $\$ 7.31$ per 100

HYACINTHS, Double.

Buckbce's Full of Life Mllxed - Select bulbs and richest colper 100.

HYACINTHS, Double. 7e each, 77e doz.; \$6.44 per

HY Y AINTHS, Double.

Good Mixed-All colors. 5e each, 54c doz.; 83.25 per 100 .
Superb Mixed - Select Colors.

The earliest spring flower. Pure white flowers of great beauty. GIANT FLOWERING SINGLE-2 for $5 \mathrm{c} ; 18 \mathrm{c}$ doz.; 51.19 per 100 GIANT FLOWERING DOUBLE-3 for $10 \mathrm{c} ; 22 \mathrm{cdoz} ; \$ 1.65$ per 100 . GIAN' ELWELSII-2 for 5c; $17 \mathrm{c}$ doz.; \$1.10 per 100 .

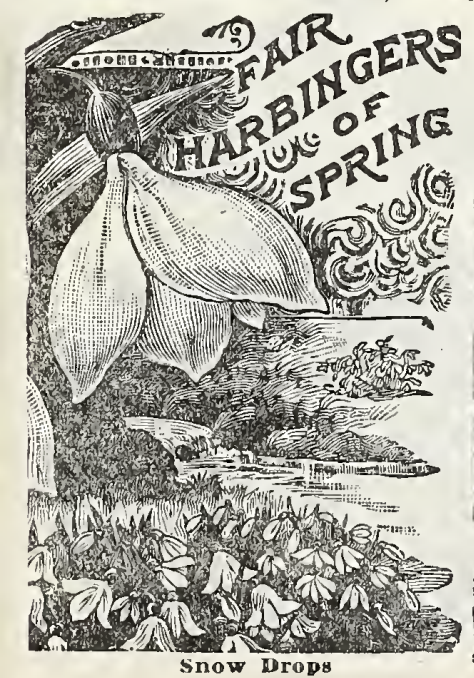

\section{Cockade Hyacinth}

A real curiosity. First, a frizzed cockade-like spike, an inch or two in length, appears above the soil, and as it slowly rises on its long stalks it becomes five or six times as large as at first, developing into a long feathery blue plume, and lasting for weeks in that condition. Perfectly hardy in the
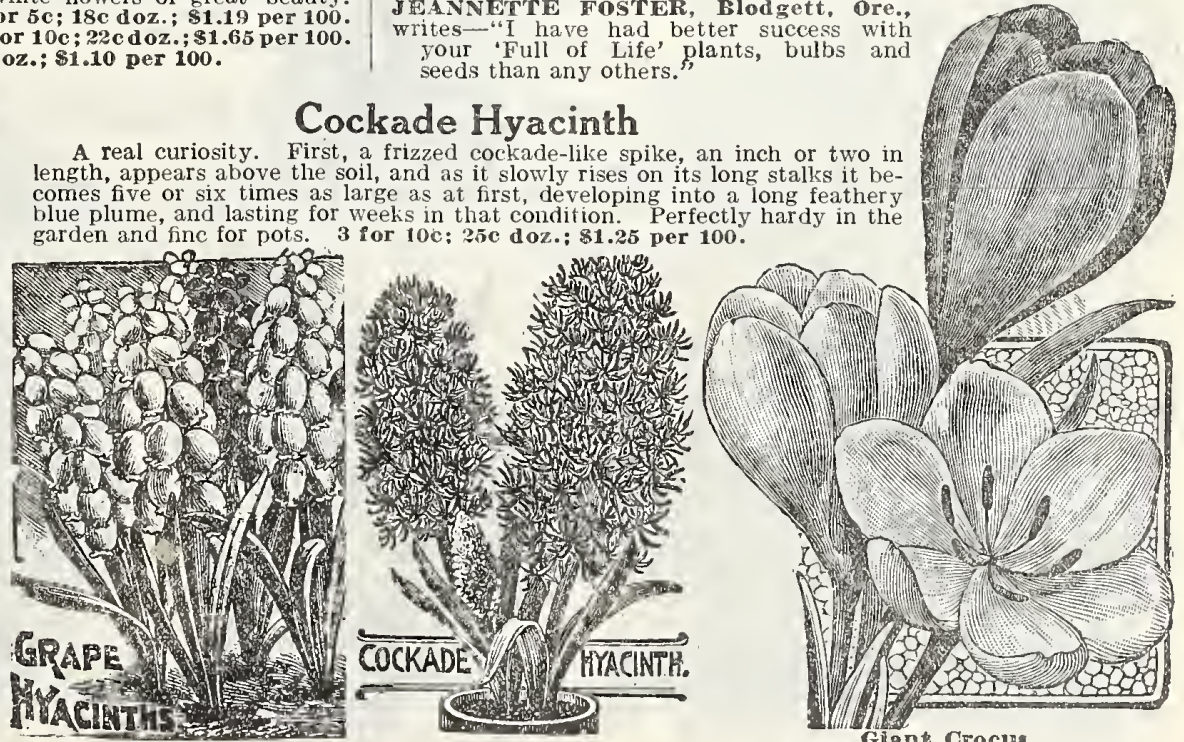

Giant Crocus
QUALITY MOTHNG BUT QUARTY
French Roman Hyacinths

The earliest bloomers of all the Hyacinths. While the flower August and September, will flower in November and December. Beautiful for Christmas flowering. 6e each; 60c doz.; \$4.50 per

\section{Giant Named Crocus}

are remarkable for Albert-Dark blue.

Cloth of Silver-White striped

Mont Blanc-Large white.

striped purple.

Prlces of the above, $18 \mathrm{cdoz}$; Grape Hyacinth

"Full of Life" best colors and shades in per 1000. less than 100 sold.)-Owing to cannot afford to put up packages containing less than 100 Ber 1000, $\$ 3.97$. greater abundance. Each bulb bearing several graceful, richness of color and size of their flovers, and are the best to use for doz.; $\$ 1.00$ per $100 ; 57.50$

Perfectly hardy, in the arden, also adapted for Winter flowering in the house. The spikes advantage in bouquets. The best colors in finest mixture. $3 \mathbf{c}$ each. $14 \mathrm{c}$ doz,; $72 \mathrm{c}$ per 100 .

EANNETTE FOSTER, Blodgett, Ore. ites-"I have had better success with
your "Full of Life' plants, bulbs and 


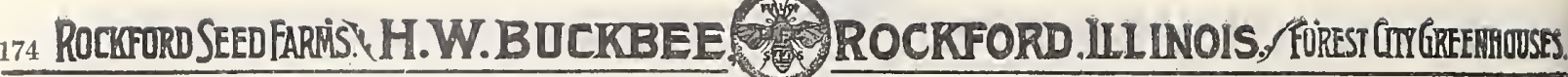

DTT DC FOR FALL Send in your order today so we can rescrve choice Bulbs for you and ship in proper season. DU DU PLANTHNG WE SHIP SEPTEMBER 1st TO NOVEMBER Ist.
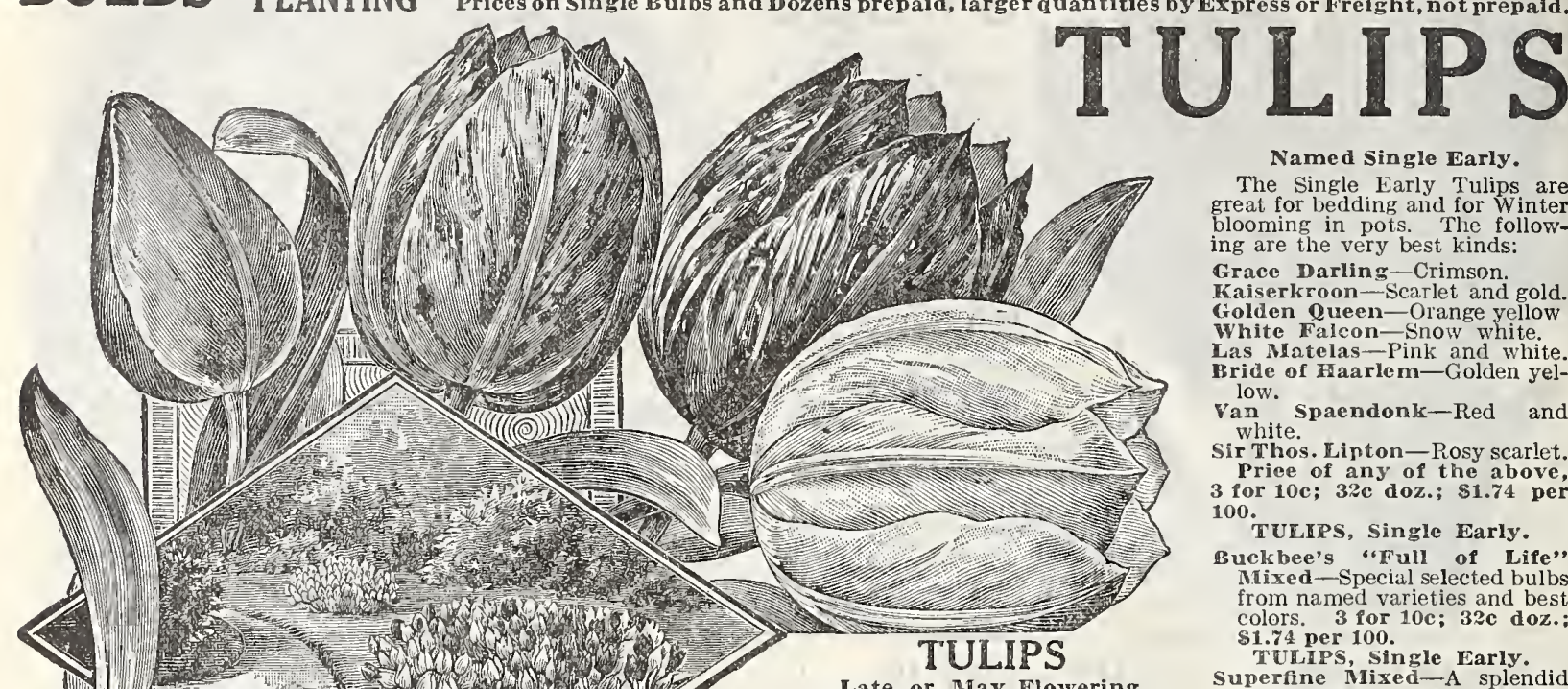

Named Single Early.

The Single Early Tulips are bleat for bedding and for Winter ing are the very best kinds:

Grace Darling-Crimson.

Kaiserkroon-Scarlet and gold. Golden Queen-Orange yellow White Falcon-Snow white. Bride of Haarlem-Golden yellow.

Van Spaendonk-Red and

Sir Thos. Linton-Rosy scarlet. Priee of any of the above, 3 for 10c; 32c doz.; $\$ 1.74$ per 100 .

TuLrPs, Single Early.

Buckbee's "Full of Iife" Mixed-Special selected bulbs from named varieties and best colors. 3 for 10c; $32 \mathrm{c}$ doz.: $\$ 1.74$ per 100.

TULIPS, Single Early.

Late or May Flowering. Superfine Mixed-A splendid For Out-door planting only. Bizarres-Yellow ground, feathered crimson, purple or white.
3 for $10 \mathrm{c} ; 32 \mathrm{c}$ doz.; $\$ 1.46$ per 100.
TULIPS

Named Double Early.

COCHINEAL-Bright scarlet. DUKE OF YORK-Carmine. BOULE DE NEIGE - White. MIANLUS-Scarlet and yellow. RAPHAEL-Blush white. SAFRANO-Golden yellow.

TOREADOR-Crimson gold.

TOREABOR-Crimson gold.
UNURBACK-Crimson Scarlet.

Price of any of the above.

3 for $10 \mathrm{c} ; 34 \mathrm{c}$ doz.; $\$ 1.78$ per 100.

THE GIANT TULIP (Tulip Gregi)

Tallest and showiest of Tulips; flowers of enormous size, brilliant scarlet color with blue center, foliage spotted maroon. It comes into bloom about Decoration Day. Fe each; 72c per doz.

FREESIAS (New Purity)

One of the very finest of recent Bulb Novelties. Flowers of enormous size, with thick, heavy, waxy petals that last nearly two weeks, even when cut. Flower pure snow-white, save one tiny yellow spot in throat, and of wonderfully beautiful shape, petals being large, rounded winter-blooming in pots. Large bulbs, $4 \mathrm{c}$ each; 3 for $10 c ; 12$ for $35 \mathrm{e} ; \$ 2.75$ per 100 White fowers in splendid sprays. 3 for 10c; $32 \mathrm{c}$ doz.; $\$ 2.40$ per 100 .

FREESIA, REFRACTA ALBA-3 for $5 c$; 19c doz,

CHIONODOXA (Glory of the Snow)

These are among the most beautiful of our Springgone. 2 for be; 19c. doz.; $\$ 1.12$ per 100.
FREESIA-SNOW STORM, Large size pure snow $\$ 1.18$ per 100. do\%.; $\$ 1.15$ per 100.

TULIPS, Single Early.

Good Mixed-Choice bulbs, all olors. $15 \mathrm{c}$ doz.; $80 \mathrm{c}$ per 100 .

\section{PARROT TULIPS}

yboems-Brilliantly varielitac white. 3 for 10c: 32 doz.; \$1.45 per 100 .

Darwin - Flowers are large, most varied and beautiful of all the late tulips. Choieest mixed, 2 for 5c; 28c doz.: $\$ 1.54$ ner 100.

TULIPS, Late or May Flowinuckbee's "Truli of Mife" Mixed. All the richest colors. 3c each, 24c doz.; $\$ 1.48$ per 100 .

\section{STAR OF BETHLEHEM \\ (Ornithogalum Arabicum.)}

A beautiful variety, throwing up a tall spike bearing numerous arge milk-white star-shaped flowers, with a black center, an having a distinet aromatic perfume. They are decidedly pretty and interesting when grown in the garden, but are more largely

\section{IXIAS}

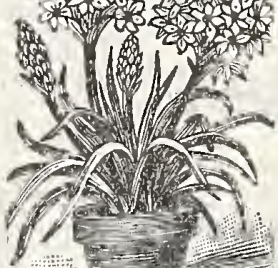

These beautiful flowers for pot culture in the house give great satisfaction. Flowers in spikes of the most dazzling 100, $90 \mathrm{c}$.

\section{SPARAXIS}

The same as Ixias, in fact, we recommend growing bulbs of each in the

\section{SCILLA SIBERICA}

This is the best Scilla for forcing indoors, coming into bloom with Roman Hyacinths. The flowers are true ultra-marine blue, and are borne on graceful spikes of six
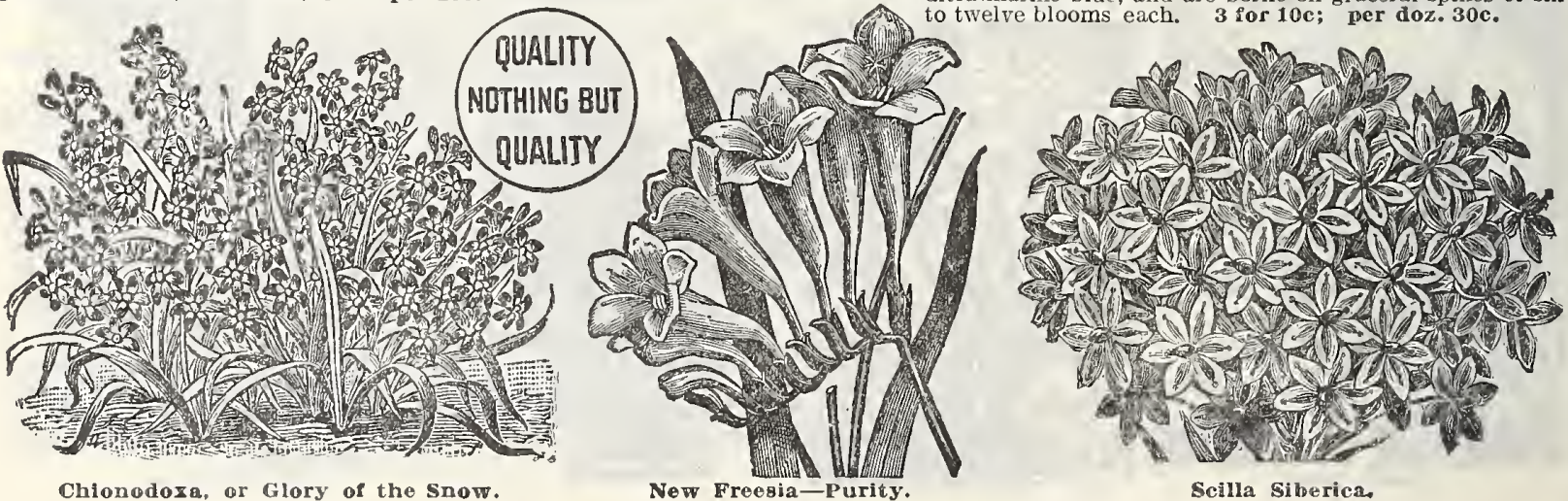

Seilla Siberica. 


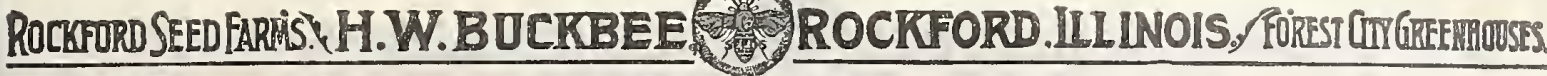

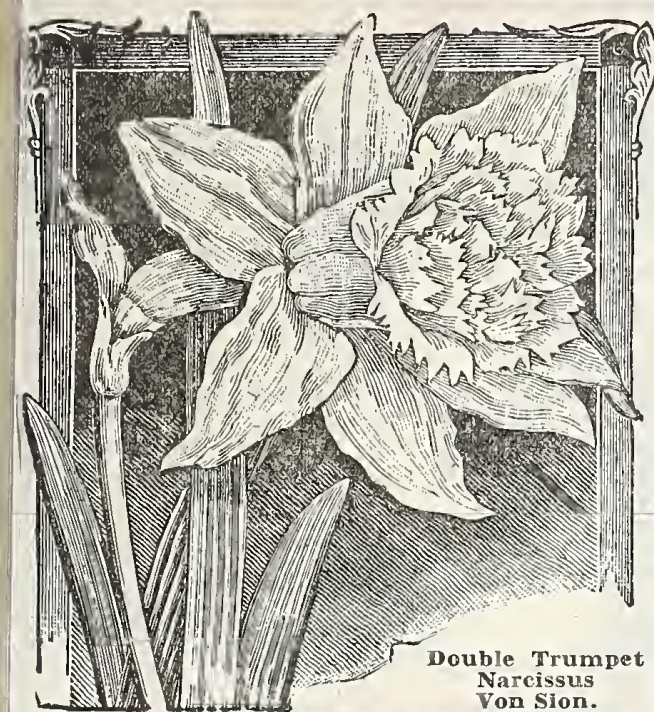

IMPORTED "Full
of Life" BULBS FOR FALL PLANTING SEND IN YOUR ORDERS TODAY SO WE CAN RESERVE CHOICE BUULBS FOR YOU AND SHIP
PROPER SEASON.

WE SHIP SEPTEMBER 1 st TO NOVEMBER 1 st

Prices on $\mathbf{S}$ ing $\mathbf{l}$ e Bulbs and Dozens prepaid, larger quantities by express or frcight not prepaid.

Narcissus or Daffodils Selected Bulbs Either for Garden or House

Culture

The airy grace and refined beauty of the Nar-

cissus has no superior and few equals among fowers. The beautiful Von Sion.
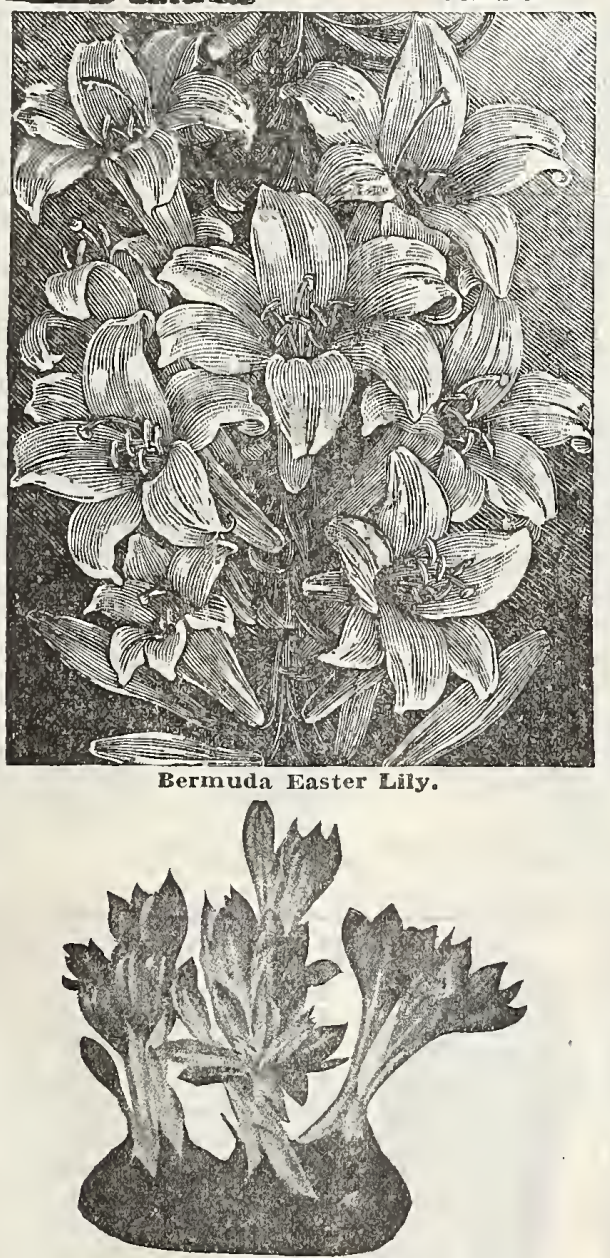

Byzantine Wonder Lilies

This truly wonderful bulb throws up its many rosy hued, exquisite flowers without need of either in any receptacle, or merely in sunshine or warmth. in any receptacle, or merely in sunshine or warmth, ready for shipment in September. Send in your order ready for shipment in September. Send in your order at once as the demand for this wonderful flower exceeds the supply and your order will be booked for prompt delivery in September. Large bulbs 16c each, or 3 for $25 \mathrm{c}$; Tonster bulbs, 20c eaeh, or 3 for $50 c$; Jumbo Bulbs, 20c each; 6 for $\$ 1.00$.
The larger the bulbs, the more fowers.

floral beauty, and the colors harmonious and refined.
DouBLE VoN SION-The well-known popular Double Yellow Daffodil. Extra Select Bulbs, 4c each; $36 \mathrm{c}$ doz.; $\$ 1.71$ per 100.

DOUBLE WHTTE-Sweet scented, 3c each; $29 \mathrm{c}$ doz.; $\$ 1.35$ per 100.

DOUBLE FINEST MIXED-Made up from the finest of the double sorts. 3 for 10c $25 \mathrm{c} \mathrm{doz} ; 99 \mathrm{c}$ рет 100

EMPEROR, Single Rich Yellow. 2 for 5c; 24c doz.; \$1.15 per 100.

SINGLE WHITE-AIl white. 3c each; $22 \mathrm{c} \mathrm{doz;} 81.10$ per 100

SING LICINEST MIXED - The best assortment ever offered. All colors and varieties 4 for 10c; $22 \mathrm{c}$ doz., $92 \mathrm{c}$ per 100.

PRE THEAST'S EYE-Single pure white, orange cup, 2 for $5 \mathrm{c} ; 19 \mathrm{c}$ POETICUS ORNATUS-Earlier than above. 2 for $5 \mathrm{e} ; 20 \mathrm{c}$ doz; ; $7 \mathrm{c}$ per 100.

\section{Giant "Paper White" Narcissus}

These beautiful, graceful Narcissus are the best of all the European bulbs for growing in water. Also fine for growing in pots or pans. Extra Sclected Bulbs, fc each $37 \mathrm{c}$ doz.; $\$ 1.72$ per 100.

\section{Polyanthus Narcissus}

Yll Narcissus for pot culture, and by many esteemed the most beautiful. Very fragrant, Choicest mixed colors, 3c each; 29c doz. $\$ 1.48$ per 100 .

\section{Jonquils}

Highly prized for their graceful, fragrant harge yellow blossoms. SINGLE SWEET SCENTED-17c doz.; 83c per 100. DOUBLE SWEET SCENTED-29c doz.; \$1.74 per 100

\section{Anemone}

(WIND FLOWERE)

These beautiful hardy Spring flowers are well worthy of a place in every garden and are unsurpassed for their bright colors. MIXED-Double Assorted. 3 for $10 \mathrm{c} ; 25 \mathrm{c}$ doz.; $\$ 1.65$ per 100 ,

Genuine Bermuda Easter Lily

The Grandest Winter F

plant in Cultivation.

Our stock of this most popular flower is unsurpassed. Extra Seleeted Bulb l5e each; 4 for $50 c$ Mam
Eulbs, $23 \mathrm{c}$ cach; 5 for $\$ 1.00$.

\section{Japanese Easter Lilies} A beautiful flower. True type. About two weeks later than the Bermuda.

\section{Lilium Candidum}

The peerless white Lily, queen of the garden. Also called Annunciation or Madonna Lily. Although old and common, this is still one of the finest single clear white lilies in cultivation and no garden, however small, should be without at least one plant of this variety. It should be planted in the Fall. Perfectly Hardy, Extra Sclect Bulbs. 1 ac each; \$1.25 per doz.

\section{Chinese Sacred Lilies}

The most easily grown and satisfactory bulb for house or window culture eacb: 2 know of

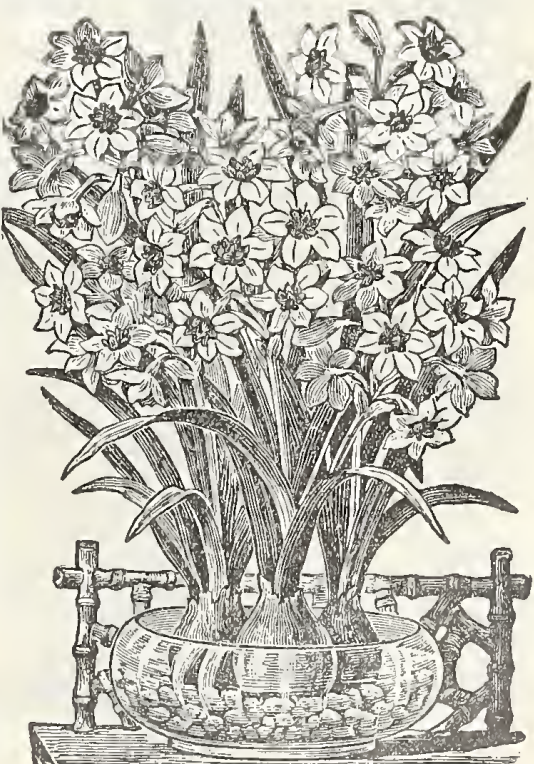

Chinese Sacred bily 


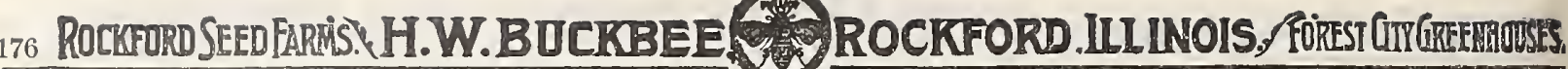

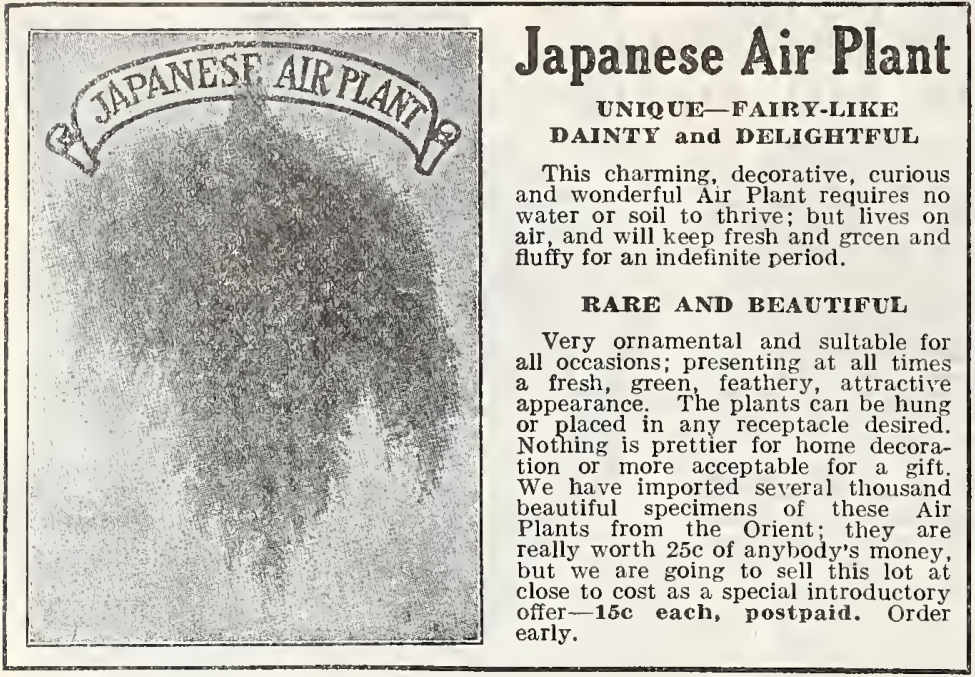

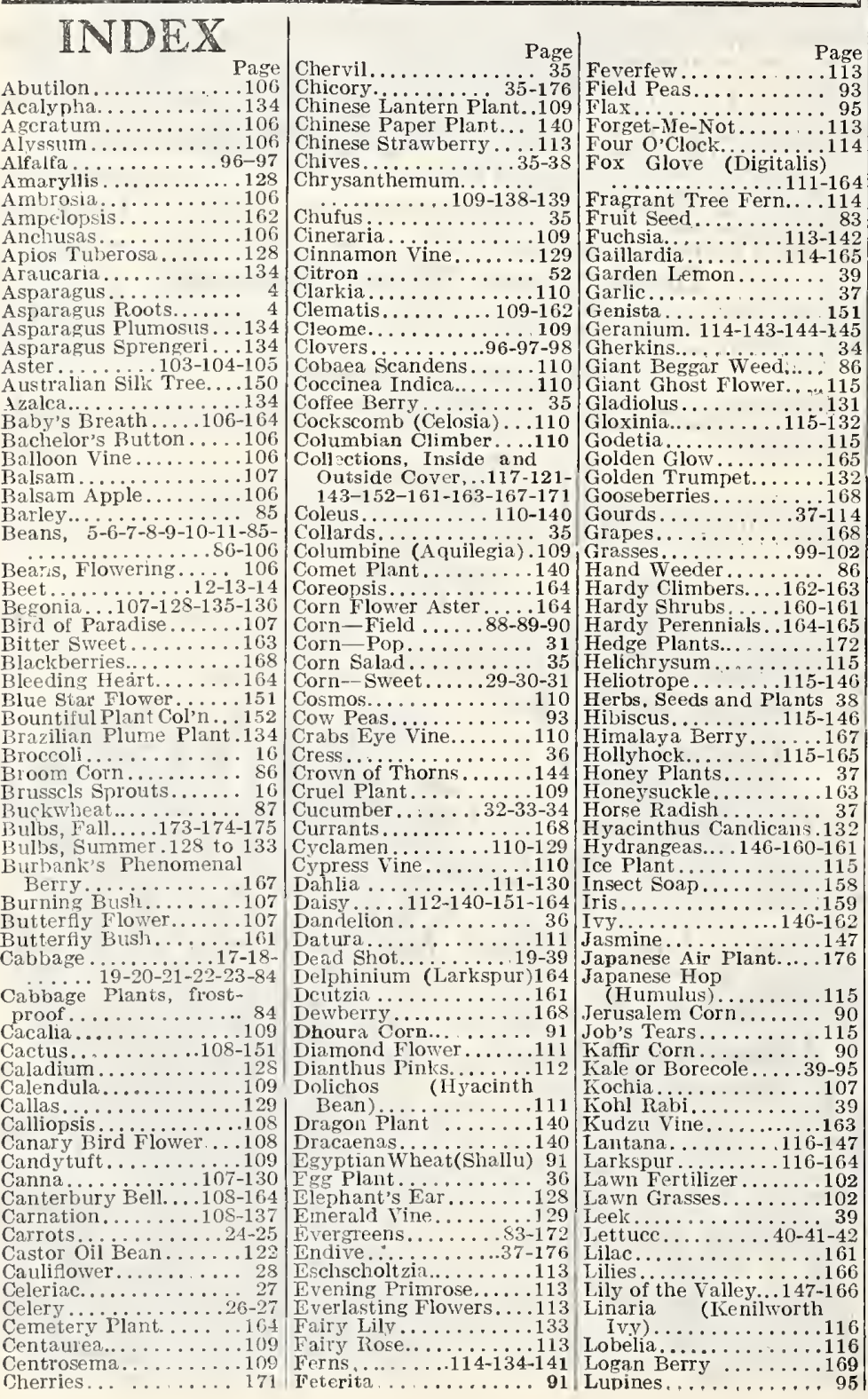

Page $\left.\right|_{\text {Madeira Vine }}$ Page

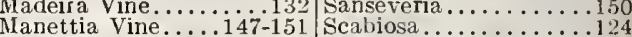
Mangels.............. 15 5 Scarlet Fouitain........148 Marigold............116 1 , Senecio Elegans.......123

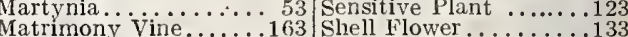

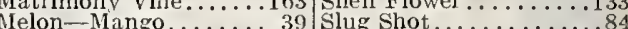

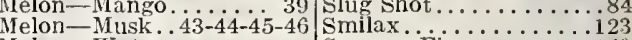
Melon-Water 1 Smyrna Fig............. M......47-48-49-50-51-52 2 Snap Dragon.............

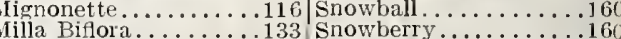
Millets............ 91 Soja Beans.......... 85 Milo Maize .......... 91 Sorrel............ 74 Moon Flower......116-133 Spelts or Emmer...... 94 Monkey Flower......116 Spinach $\ldots \ldots \ldots \ldots \ldots \ldots$. ${ }^{74}$ Morning Glory.........117 $\mid$ Spurry, Giant.............. 93 Mountain Bcauty vine.162 Squash............72-73 Iushroom Spawn..... 5 5 3 Stocks.................

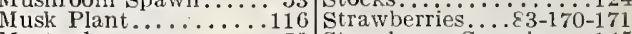
Mustard .............116 5 Strawberry Geranium..145 Nasturtium................. Nicotina..............117 $\mid$ Strawberry Raspberry...169

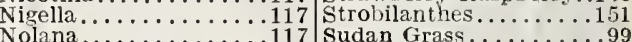
Nolana............

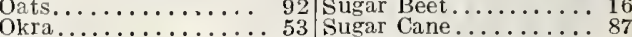

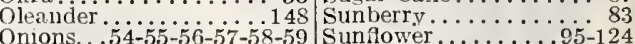
Onions...54-55-56-57-58-59 Sunfower .......... Otaheite Orange........ 149 Swainsonia ............

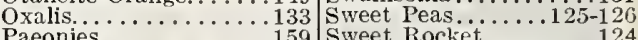
Paeonies......... 159 $\begin{aligned} & \text { Sweet Rocket.......124 } \\ & \text { Sweet Scented Shirub..160 }\end{aligned}$ Pansies...........119-120-148 Sweet Pepper Busl ...160 Parsley............... 60 Sweet William.....123-165 Parsnip...............6. 61 Swiss Chard..........74 Peanuts............ 60 60 Syringa............... Peas...63-64-65-66-67-93 Tigridias ...............

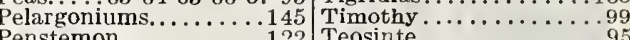
Pepper..............6. 62 Tepary Beans ....... 86

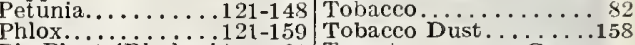

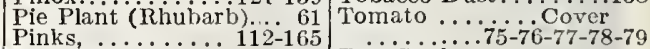

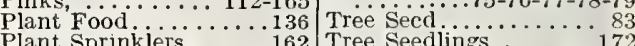
Plant Sprinklers.......162
Ponderosa Lemon $\ldots \ldots 149$ Tree Seedlings.........17 Poppy ..............22-165 Trumpet Creeper......163

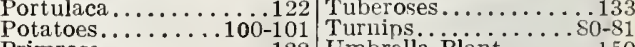
Primrose..............122 Umbrella Plant.........150 Rampkins...........69-7 68 68 Vegetable Collection (See Rainbow Corn.........110 Vegetable Plants...... 84 Rape............... 94 $\mid \begin{aligned} & \text { Velvet Bean........... } 85 \\ & \text { Velvet }\end{aligned}$ Raspberry.........169 Verbena ............127-151 Ricinus............122 12 Vinca ..............127

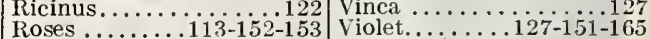
Roses $154-155-156-157-158-153$ Virginia Creeper $\ldots \ldots \ldots 162$ Rubber Plant.......150 Wall Flower............ Rudbeckia.......122-165 Wandering Jew.......151

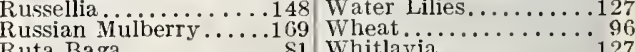
Ruta Baga........... \&1 Whitlavia............... 127 Rve .................. 94 94 Weigelia ............ Salsify................ 74 Wild Flower Garden...127 Salvia (Scarlet Sage $\ldots 123$ Wonderberry........... 83 sand Vetch......... 93 Zinnia...............127

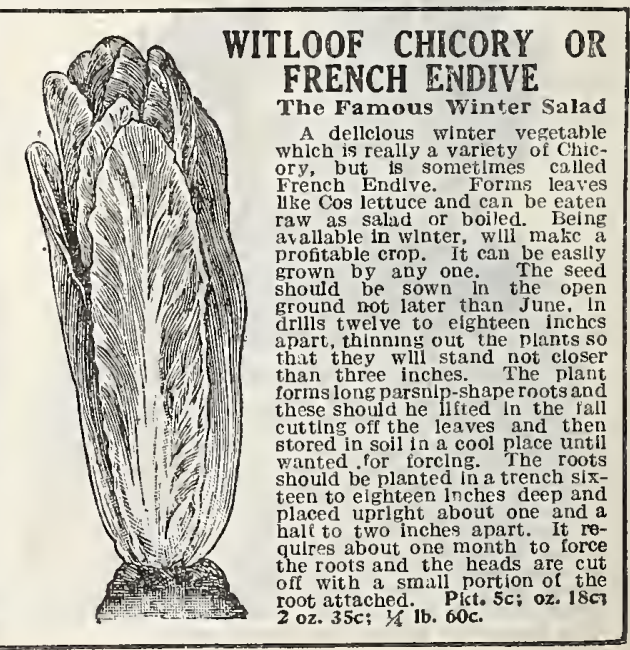




\section{Buckbee's famous Everiblooming Bountiful Plant COLlection}

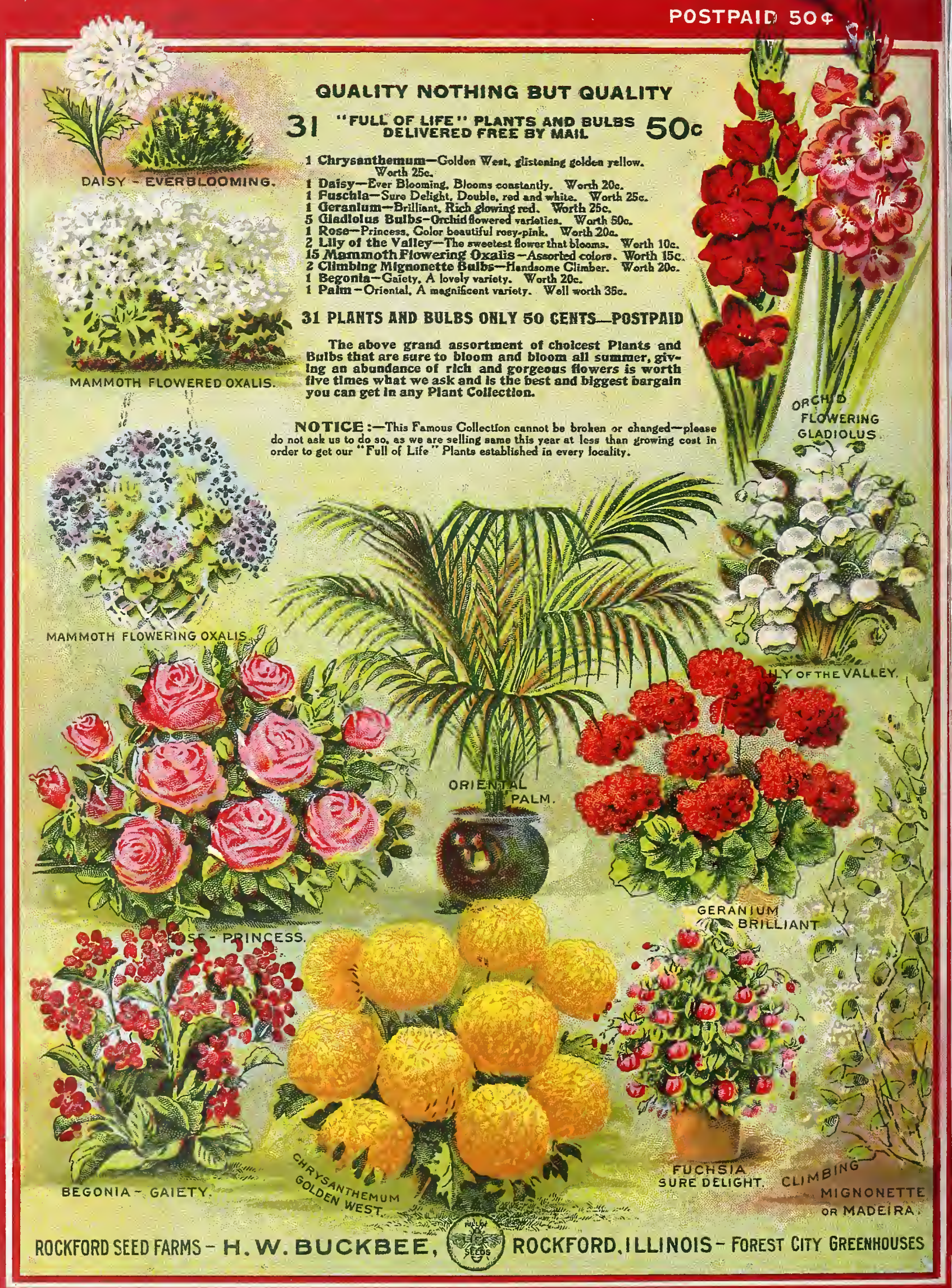

